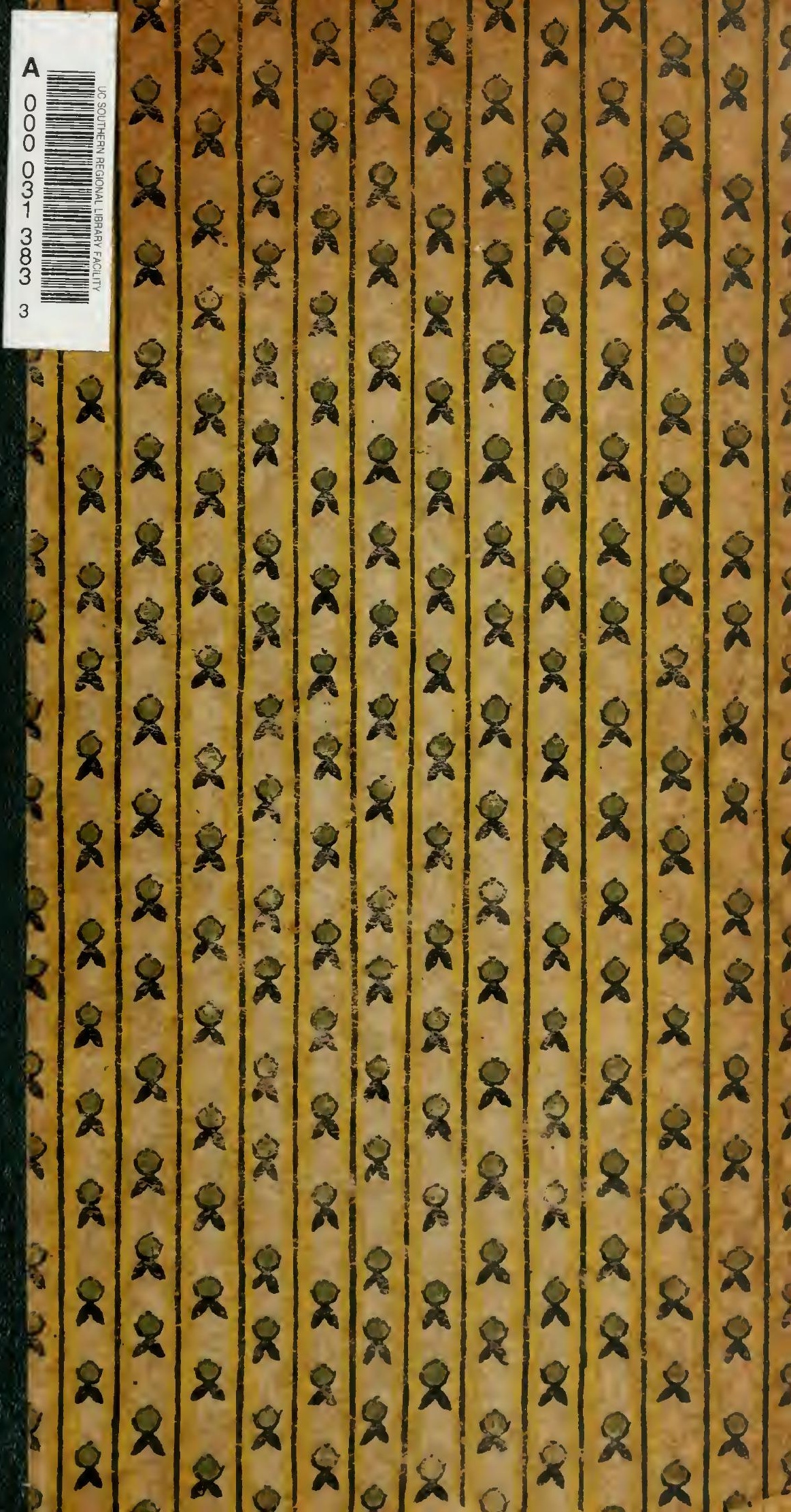




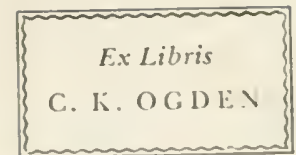







\title{
GENERAL VIEW
}

$$
\text { OF THE }
$$

$A \mathbb{G} \mathbb{R} \mathbb{C} \mathbb{U} \mathbb{T} \mathbb{U} \mathbb{R}$

\author{
OF THE
}

COUNTY OF NORFOLK. 



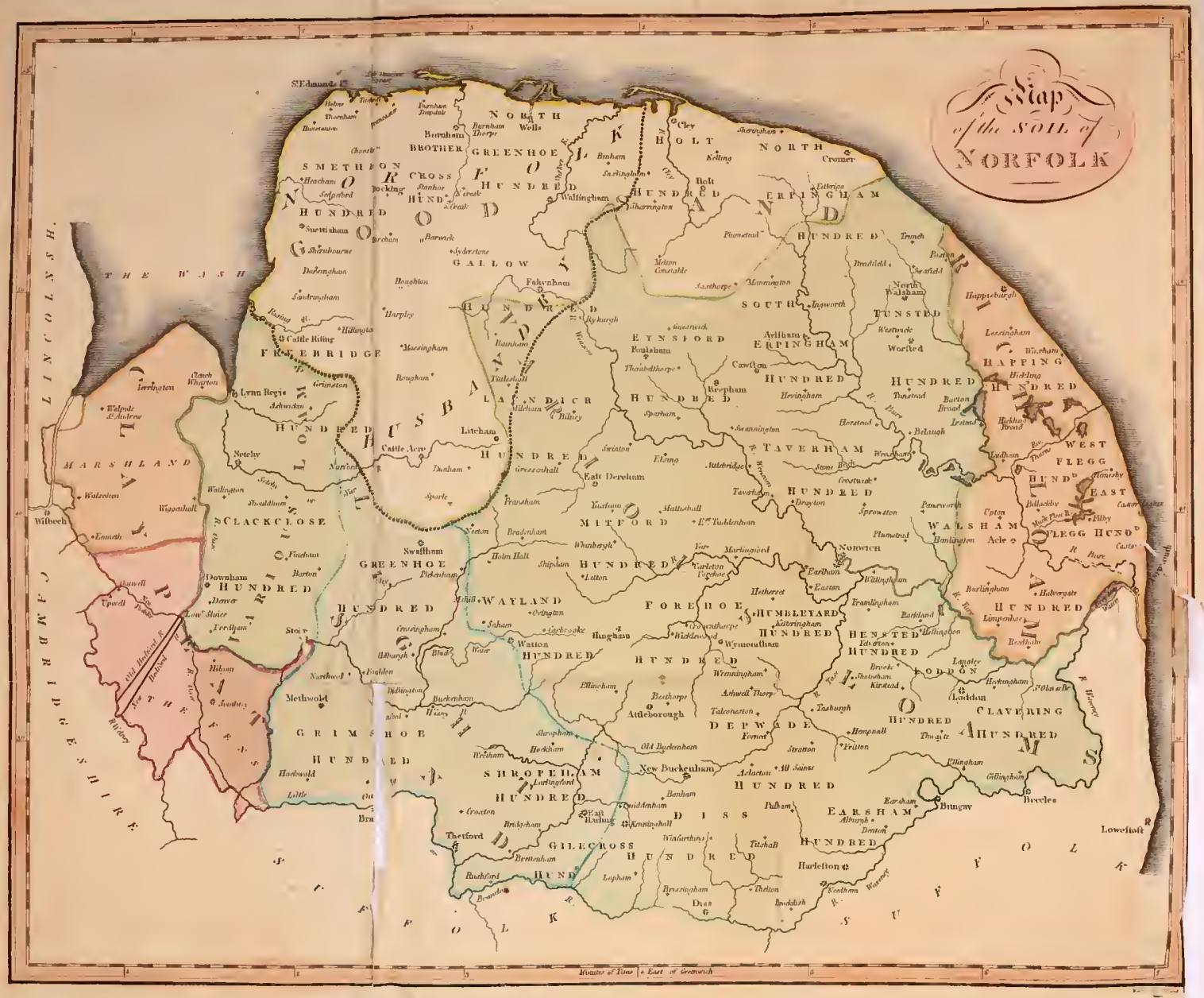

\section{0}




\title{
GENERAL VIEW
}

OF THE

\section{$A \mathbb{G} \mathbb{R} \mathbb{C} U{ }^{\top} \mathbb{T} U \mathbb{R} \mathbb{E}$}

OF THE

\section{COUNTY OF NORFOLK.}

\author{
DRAWN UP FOR THE CONSIDERATION OF
}

THE BOARD OF AGRICULTURE AND INTERNAL IMPROVEMENT.

BY

THE SECRETARY OF THE BOARD.

\section{I, O N D O N :}

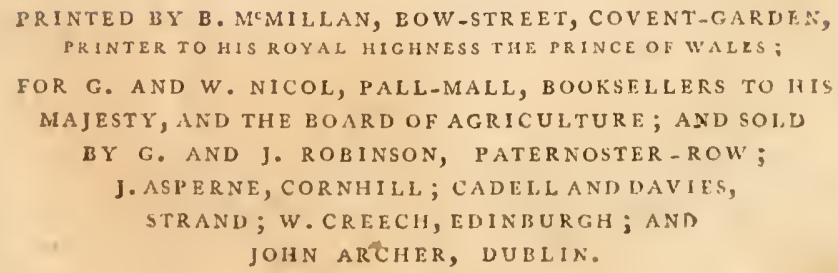

1804. 
1

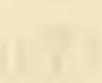




\section{ADVERTISEMENT.}

THE great desire that has been very generally expressed, for having the Agricultural SurreYs of the KINGDOir reprinted, with the additional Communications which have been received since the Original Reports were circulated, has induced the Board of Agriculture to come to a resolution of reprinting such as may appear on the whole fit for publication. It is proper at the same time to add, that the Board does not consider itself responsible for any fact or observation contained in the Reports thus reprinted, as it is impossible to consider them yet in a perfect state; and that it will thankfully acknowledge any additional information which may still be communicated: an invitation, of which, it is hoped, many will avail themselves, as there is no circumstance from which any one can derive more real satisfaction, than that of contributing, by every possible means, to promote the improvement of his Country.

N. B. Letters to the Board, may le nddressed to Lord Suerfield, the President, No. 32, Sachille-Street, Piccadilly, London.
NORFOLK.]
b)
PI. N 


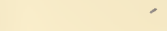

, 


\section{$\mathbb{P}$ I A N}

FOR RE-PRINTING THE

AGRICULTURAL SURVEYS.

BY THE PRESIDENT OF THE BOARD OF AGRICULTURE.

A BOARD established for the purpose of making every essential inquiry into the Agricultural State, and the means of promoting the internal improvement of a powerful Empire, will necessarily have it in view to examine the sources of public prosperity, in regard to various important particulars. Perhaps the following is the most natural order for carrying on such important investigations; namely, to ascertain,

I. The riches to be obtained from the surface of the national territory.

2. The mineral or subtertaneous treasures of which the country is possessed.

3. The wealth to be derived from its streams, rivers, canals, inland navigations, coasts, and fisheries;and

4. The means of promoting the improvement of the people, in regard to their health, industry, and morals, founded on a statistical survey, or a minutc and careful inquiry into the actual state of every parochial district in the kingdom, and the circumstariccs of its inhabitanis. 
Unicr one or other of these lieads, every point of real importance that can tesd to promote the general happiness of a great nation, seems to be included.

Investigations of so cxtensive and so complicated a naturc, must require, it is evident, a considerable space of time before they can be completed. Differing indeed in many respects from each other, it is better perhaps that they should be undertaken at different periods, and separately considered. Under that impression, the Board of Agriculture has hitherto direeted its attention to the first point only, namely, the culrivation of the surface, and the resources to be derived from it.

That the facts essential for such an investigation might be collested with more celerity and advantage, a number of intelligent and respectable individuals were appointed, to furnish the Board with accounts of the state of luusbandry, and the menns of impraving the different districts of the kingdom. The returns they sent were printed, and circulated by cvery means the Board of Agriculture could devise, in the districts to which they respectivcly related; and in consequence of that circulation, a great mass of additional valuable information has been obtained. For the purpose of communicating that information to the Public in general, but more especially to those Counties the most interested therein, the Board has resolved to re-print the Survey of each County, as soon as it seemed to be fit for publication; and, among several equally advanced, the Counties of Norfolk and Lancaster were pitched upon for the commencement of the proposed publication; it being rhought most advisabte to begin with one County on the Fasten, and another on the Western Coast of the island. When all these Surveys shall have been thus reprinted, it will be atcended with little difficulty to draw up 


\section{( is )}

an abstract of the whole (which will not probably exceed two or three volumes quarto) to be laid before His MAJESTY, and both Houses of. Parliament; and afterwards, a General Report on the present state of the country, and the means of its improvement, may be systematically arranged, according to the various subjects connected with Agriculture. Thus every individual in the kingdom may have,

I. An account of the husbandry of his own particular county ; or,

2. A general view of the agricultural state of the kingdom at large, according to the counties, or districts, into which it is divided; or,

3. An arranged system of information on agricultural subjects, whether accumulated by the Board since its establishment, or previously known:

And thus information respecting the state of the kingdom, and agricultural knowledge in general, will be attainable with every possible advantage.

In re-printing these Reports, it was judged necessary, that they should be drawn up according to one uniform model; and after fully considering the subject, the following form was pitclied upon, as one that would include in it all the particulars which it was necessary to notice in an Agricultural Survey. As the other Reports will be reprinted in the same manucr, the reader will thus be enabled to find out at once where any point is treated of, to which he may wish to direct his attention. 


\section{PLAN OF THE RE-PRINTED REPORTS.}

\section{Preliminary Olservations.}

Chap. I. Geographical State and Circumstances.

SECT. I Situation and Extent.

2. Divisions.

3. Climate.

4. Soil and Surface.

5. Minerals.

6. Water.

Chap. II. State of Property.

SECT. I. Estates, and their Management.

2. Tenures.

Chap. III. Buildings.

SEct. I. Houses of Proprietors.

2. Farm Houses and Offices, and Repairs.

3. Cottages.

Criap. IV. Mode of Occupation.

SECr. I. Size of Farms. Character of the Farmers.

2. Rent-in Money-in Kind-in Personal Services.

3. Tithes.

4. Poor Kates.

5. Leases.

6. Expense and Profit.

Chap. V. Implements.

Chap. VI. Enclosing-Fences-Gates.

Chap. 


\section{( $\mathrm{xi}$ )}

Chap. VII. Arable Land.

Sect. I. Tillage.

2. Fallowing.

3. Rotation of Crops.

4. Crops commonly cultivated, such as Corn. Pulse, Artificial Grasses; their Seed, Culture, Produce, \&c**

5. Crops not commonly cultivated.

\section{Chap. VIII. Grass.}

SEct. 1. Natural Meadows and Pastures.

2. Hay Harvest.

3. Feeding.

Chap. IX. Gardens and Orchards.

Chap. X. Woods and Plantations.

\section{Chap. XI. Wastes.}

* Where the quantity is considesable, the information respecting the crops commonly cultivated may be arranged under the following heads-for exam. ple, WhEAт :

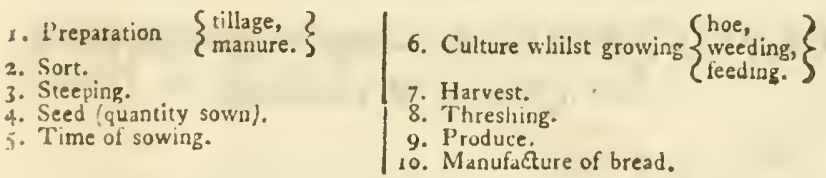

In general, the same heads will suit the following grains :

Barley. Oats. Beans. Rye. Pease. Buck-wheat.

$$
\begin{aligned}
& \text { Vetches - Application. } \\
& \text { Cole-seed - } \begin{array}{l}
\text { Feeding, } \\
\text { Seed. }
\end{array} \\
& \text { Turnip: - }-\left\{\begin{array}{l}
\text { Drawn, } \\
\text { Fed, on grass, } \\
\text { Fed in houses. }
\end{array}\right\}
\end{aligned}
$$

$\mathrm{b} \cdot \mathrm{d}$ 


\section{( xii)}

Chap. XII. Improvements。

SECT. I. Draining.

2. Paring and Burning.

3. Manuring.

4. W'ceding.

5. Watering.

Chap. XIII. Live Stock.

Sect. I. Cattle.

2. Sheep.

3. Horses, and their Use in Husbandry, compared to Oxen.

4. Hogs.

5. Rabbits.

6. Poultry.

7. Pigeons.

8. Bees.

Chap. XIV. Rutal Economy.

Sect. I. Labour-Servants - Labourers-Hours of Labour.

2. Provisions.

3. Fuel.

Chap. XV. Political Economy, as connected with or affecting Agriculture.

SECT. I. Roalds.

2. Canils.

3. Fairs.

4. Weekly Markets.

5. Commerce.

6. Manufactures.

7. Poor.

§. Population. 


\section{( (iii)}

Chap. XVI. Obstacles to Improvement; including General Olservations on Agricultural Legislation and Police.

\section{Chap. XVII. Miscellaneous Observations.}

SEct. I. Agricultural Societies.

2. Weights and Measures.

3. Supply of London.

4. Experimental Farm.

Conclusion. Means of Improvement, and the Measures calculated for that Purpose.

Appendix.

PERFECTION in such inquiries is not in the power of any body of men to obtain at once, whatever may be the extent of their views or the vigour of their exertions. If LoUIs XIV. eager to have his kingdom known, and possessed of boundless power to effeet it, failed so much in the attempt, that of all the provinces in his kingdom, only one was so described as to secure the approbation of posterity*, it will not be thought strange that a Board, pos-

* See Voltaire's Age of Louis XIV. vol.ii. p. 127, 128, edit. 1752. The following extract from that work will explain the circumstance above alluded to :

"Louss had no Colisert, nor Louvois, when, about the year $16 \mathrm{~g} 8$, for the instruction of the Duke of BURCUNDY, he ordered each of the intendants to draw up a particular description of his province. By this ineans an exact account of the kingdom might lave been obtained, and a just enumeration of the inhabitants. It was an useful work, thoug! all the intendauts had not the capacity and attention of Monsieur DE LAMOIGNON DE BAVILL5. Had what the King directed been as well excuted, in regard to 


\section{( $\operatorname{xiv})$}

sesecd of means so extremely limited, should find it difficule to reach even that degree of perfection which perhaps might have been attainable with more extensive powers. The cantlid reader camnot expeet in these Reports more thats a certain portion of useful information, so arranged as to render them a basis for further and more detailed inquiries. The attention of the intelligent cultivators of the kingdon, however, will doubtless be excited, and the minds of men in general gradually brougist to consider favourably of an undertaking which will enable all to contribute to the rational stores of hnowledge, upon topics so truly interesting as those which concern the agricultural interests of their country; interests which, on just principles, never can be improved, intil the present state of the kingdom is fully known, and the means of its future improvement ascertained with minuteness and accuracy.

every province, as it was by this magistrate in the account of Languedoc, the collection would have been one of the most valuable monuments of the age. Some of thein are well done; but the plan was irregular and imperfect, because all the intendants were not restrained to one and the same. It were to be wished thateach of them had given, in columns, the number of inhabitants in each election; the nobles, the citizens, the labourers, the artisans, the mechanss; the cantle of every kind; the good, the indifierent, and the bad lands; all the clergy, regular and secular; their revenues, those of the towns, and those of the communities.

"All these heads, in most of their accounts, are confused and imperfect; and it is Irequently necessary to search with great care and pains, to find what is wanted. The design was excellent, and would have been of the greatest use, had it been exccuted whth judgment and uniformity." 


\section{IN TRODUCTION.}

A second Report for the County of Norfolk, by a different Writer from the Gentleman who executed the first, demands a short explanation, to obviate any idea tending to lower the estimation in which the Original Report is justly held. There have been various instances of second, and even third Reports of the same County, all by different hands; but in the case of Norfolk a new Report was demanded, for a local reason. The introduction of a new breed of Sheep, and the rapidity with which the practice of Drilling spread in the County, had effected so great a change in the state of Norfolk Husbandry, that all former works on the Agriculture of that celebrated County must necessarily be deficient, however excellent in other respects. The present Report does not appear to the exclusion of the former, but merely in assistance of it; that such objects as were unnoticed, or but 
xvi INTRODUCTION.

little attended to, from their being at that moment in their infancy, should now be registered, for the ușe of such other Counties as may not yet have made similar exertions.

July 14, 1804 .

\section{ERRATA.}

In p. 527 , third line from the bottom, after Rent 35 , read per cent.

P. $\$ 29$, in the col. of Uninhabited Houses in the Hunored of liynesford, for $39 \mathrm{rad} 32$. 


\section{CONTENTS.}

CHAPTER I. GEOGRAPHICAL STATE.

SECT. 1. Extent, ....................

2. Climate, ................... 2

3. Soil, ...................... ilid.

District of various Loams, ......... 5

Light Sand, .............. 12

Light Loam, . . . . . . . . . . . . . itid.

Marshland Clay, ............. 14

4. Water, .................. itid.

CHAP. H. PROPERTY, ...... 17

CHAP. III. BUILDINGS, ....... 19

Cottages, .................... 24

Farm-yard, ................... itid.

CHAP. IV. OCCUPATION.

BEст. 1. Farms, .................. 26

2. Rent, ................. 36

3. Tithes, ................... 40

4. Poor-rates, .................. 41

5. Leases, .....................47

CHAP. V. IMPLEMENTS, ......52

Ploughs, .................... itid.

Hatrows, ................... 55

Roller, ........................56

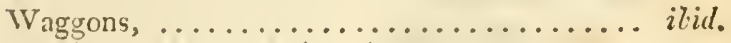

Drill-roller, .................. $5 s$

Drill Machine, .............. ibid.

lixed Harrow, ................... 59

Horse-hoes, ..................... ilid. 


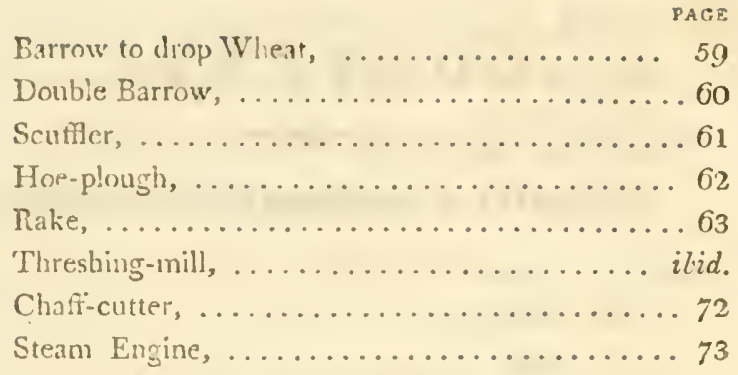

CHAP. VI. ENCLOSING, ......75

Fences,........................ 185

CHAP. VII. ARABLE LAND.

Sест. 1. Tillage, ................... 187

2. Fallowing $\ldots \ldots \ldots \ldots \ldots \ldots . \ldots \ldots 2$

3. Course of Crops, .............. 193

4. Turnips, .................. 219

5. Barley, .................... 238

6. Clover, ....................... 256

Ray-grass, ............. 267

Buriet, .....................26s

Cock's-fnot, ...............269

Chicory, ................ 270

7. Wheat,................. 271

8. Rye, ...................... 304

9. Oats, ..................... itid.

10. Pease, ........................ 30s

11. Beans, ..................... 311

12. Buck-wheat, ............... 317

13. Tares, .............................. 318

14. Cabbages, .................. 320

Cole-seed, ................... 323

15. Carrots, ........................

16. Mirstard, ................. 325

17. Hemp and Flax, ........... 326

18. Sainfoin, ................. 338

SECT. 


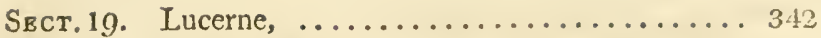

20. Mangel Wurzel, .............. 347

21. Potatoes, ................... ilid.

22. Drill Husbandry, .............. 348

23. Norfolk Arable System, ........... 3022

CHAP. VIII. GRASS, ....... 370

Rouen, ..................... 376

CHAP. IX. WOODS AND PLANTATIONS, 3S1 CHAP. X. WASTES, ....... 355

CHAP. XI. , IMPROVEMENTS.

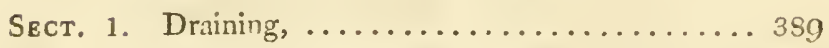

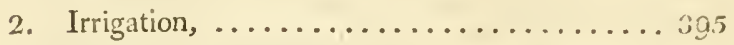

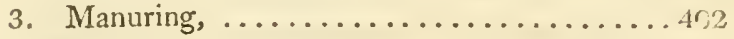

Marle, .................... ilid.

Lime, ................... 412

Gypsum, ................. 413

Oyster-shells, ................ $i ! n$,

Sea-Ouze, ................... $41 \cdot t$

Sea-weed, .................... itud.

Pond-weed, ................... 45

Burnt earth, ................ ihr.

Sticklebacks, .................417

Oil-cake, ................... itivl.

Ashes, ......................4 41

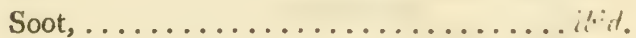

Malt-dust, ................ it.

Buck-wheat, ................. ilid.

Yard-dung, ................ 422

Littering, ...................4 432

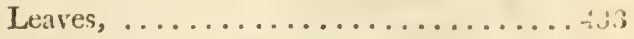

Burning Stubbles, ............. icul.

River Mud, ................. ilicl.

Town Manure, ............... 1;4 
Sect. 4. Paring and Furning, ............ 434

5. Embankingr ................. 435

CHAP. XII. LIVE STOCK.

SECT. 1. Cattle, .................. 44.

2. Shcep, .................. 447

Breeds, Crosses, \&c. ...........4 49

Food, Wool, .............. 470

Fold . . . . . . . . . . . . 473

Distempers, ...............4 470

3. Hogs, $\ldots \ldots \ldots \ldots \ldots \ldots \ldots \ldots \ldots . \ldots 48$

4. Horses and Oxen, ............ 479

CHAP. XIII, IURAL, ECONOMY.

5ECr. 1. Labour, ............... 483

CHAP. XIV. POLITICAL ECONOMY.

SEст. 1. Roads, .................4 459

2. Canals, ................ ibid.

3. Fairs and Markets, ........... 490

4. The Poor, ................... 492

Houses of Industry, . . . . . . . . 49-1

House of Correction, .......... 503

5. Comparison of Times, ............ 504

Day-work, ............... 505

Wages, ............... 506

Piece-work, ............... 507

Blacksmith, .............. 508

Artisans, ............... 509

Rent, Tithe, and Parish Taxes, ...... 510

Cultivation, ............... 511

Manure, ..................... 511

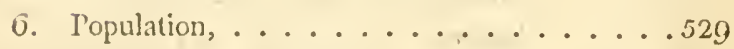

CHAP. XV. OBSTACLES TO IMPROVEMENT.

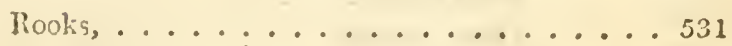




\title{
AGRICULTURAL SURVEY
}

\author{
OF
}

\section{NORFOLK.}

\section{CHAPTER I.}

GEOGRAPHICAL STATE.

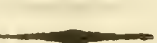

SECT. I. - EXTENT.

A CCORDING to Tempieman's Survey of the
Globe, Norfolk is 57 miles in length and 35 in breadth, and contains 1426 square geographic miles. Mr. KENT makes the greatest length, from east to west, 59 miles, and its greatest breadth, from north to south, 38 ; containing 1710 squate miles, and $1,094,400$ statute acres. It contains 33 hundreds, one city, four sea-port towns, 25 other market-towns, and $75^{6}$ parishes; a greater number than any other county in the kingdom. Mr. Howlet contends that Norfolk is larger than Essex, which is estimated at $1,240,000$ acres. As this point was therefore doubtful, I had the area of the county on the new and very accurate map, measured carefully by the map-engraver to the Buard, whose measurenent gives I 830 square miles. 
SECT. II.-CLIMATE.

THERE are several points of the compass from which lie north and north-east winds blow more directly on this county than on any other in the kingdom: we feel these winds severely in Suffolk; but Norfolk is still more exposed to them, and the climate consequently colder, and more backward in the Spring. Another circumstance which must have some effect on the climate, is the whole western boundary being the fens and marshes of Lincolnsisire and Cambridgeshire, to the amount of 5 or 600,000 acres; but this is more likely to affect the salubrity of the air relative to the human body, than to the products of the earth.

SECT, III.-SOIL.

THE annexed Map will best explain the great divisions of the soil of Norfolk. I travelled many miles, in order to give it as much accuracy as such a shetch admits, short of an attention that would demand years rather than months, perfectly to ascertain.

Entering the county from the south-west, the district of sand exterds from Garboldsham to the fens of Hockwold and Methwold; contracting its breadth between Stoke and Pickenham, continues to Congham and South Rainham; and then diverging both to the east and west, fills up the whole north-eastern part of the county to Hindringham, and then taking a south-easterly direction, bends again to the north to Barningham, and strikes the sea at Overstrand. But this sandy district is again divisible into light and good sand; the former to the south of the line from Winch to Swaffham, and the latter to the north. The southern part comprehends by far the poorest part of the county, a considerable portion of which is occupied by rabbit- 
rabbit-warrens and sheep-walk heaths, and has a most desolate and dreary aspect. It is, however, highly improveable by the marle and chalk, or cork, which is almost cvery where found under the surface. Much has been broken up in the last 20 years; but much remains to be done. The improvement of this district has been long impeded, from an idea that the white chalky marle would not answer carrying; and what they call good clay is scarce; but modern experiments have, or rather are, at present, working out these erroneous icieas; and under the article of Manures, will be found some satisfactory trials, which speak a different language.

The north-eastern angle, of better sand, contains large tracts of excellent land, intermixed with a good deal of an inferior quality. Here is found the agriculture to which the general epichet of Norfolk husbandry peculiarly belongs. The improvements wrought here from 60 to 70 years ago, first gave rise to, and afterwards established, the celcbrity of the county: rents have risen from is. to to 15 s. and from $15.6 \%$. and 2 s. to 203 . A country of rabbits and sheep-walk has been covered with some of the finest corn in the world; and, by dint of management, what was thus gained, has been preserved and in. proved, even to the present moment.

T'o the west of the light sand district is a small tract of various soils, between the Stoke and the Sechy rivers, and bounded on the west by the river Ouze. Here is much good sand, some strong wet clayey loams, and on the Ouze a line of rich marsh.

Still more to the west, and cut off by the Ouze from the rest of the county, lies the rich district of marshland; the larger part of which is a marine silt on a clay basis, at various deptlis. In some traets the clay mixes with the silt to the surface, and forms the richer grazing lands.

The district of various loams comprehends the larger 
part of the county, and includes soils of a very differene description. In the southern part of it, in Diss hundred, and some adjoining ones towards Norwich, there is much strong wet loan, where sumuncr fallow and beans are found; and similar land is scattered in other parts; but the general feature is a good sandy loan, upon which turnips come in regular course : it is an old enclosed woodland country, which would not be noted as very famous for management; nor had Norfolk attained any great cclebrity for her farming, from the practices (though, upon the whole, meritorious) which are found in this district. The natural fertility is considerable. Marle is found alınost in cvery part.

- It only remains to speak of the district of rich loam, which is certainly, in point of soil, onc of the finest tracts of lanó that is any where to be seen : broads and marshes occupy too much of it; but the land, under the plough, is a fine, deep, mellow, purrid, sandy loam, adhesire enough to fear no drought, and friable enough to strain off superfluous moisture; so that all seasons suit it: from texture, free to work, and from chemical qualities, sure to produce in luxuriance whatever the industry of man commits to its friendly bosom. The husbandry is goot, hut by no incans perfect.

The relative contents of these districts are found by measurement to be:

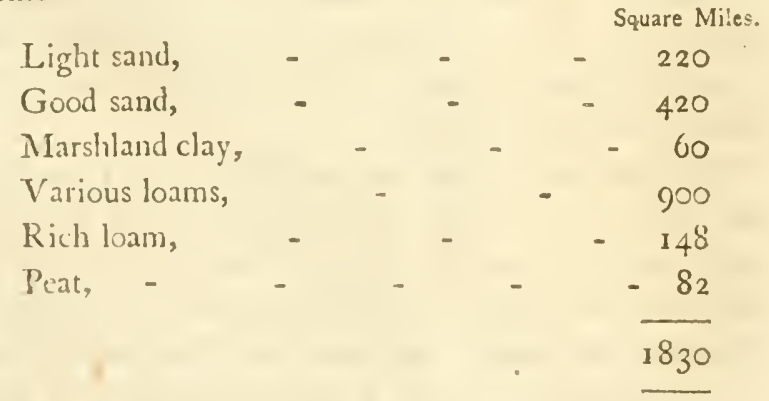


Or, in acres:

Acres.

\begin{tabular}{|c|c|c|c|c|}
\hline Light sand, & - & - & - & 140,800 \\
\hline Good sand, & - & - & - & 268,800 \\
\hline Marshland clay, & & - & - & $3^{8,400}$ \\
\hline Various !oams, & - & - & - & 576,000 \\
\hline Rich loam, & - & - & - & 94.720 \\
\hline Peat, & - & - & - & 52,480 \\
\hline & & & & 1,171 \\
\hline
\end{tabular}

LOCAL NOTES.

DISTRICT OF VARIOUS LOAMS.

In passing through the county, and discriminating the great divisions of the soils, some exceptions occurred, which were noted, and other circumstances not coinciding direelly with the general features of the distriet.

Around Watton are various loams, some of them sandy ; and some hcavy, on a clay marle bottom: much land that is improved by draining.

Some of the black sand and gravel at Billingfold has proved very ungenial in cultivation; part of it broken up from tỉe heath, and marled with 80 loads an acre, gave only blind ears; that is, the ears had chaff only, withous grain; after this it was marled again; and cultivation has brought it to be profitable.

From Dereham to Wymoniham, by Winhorough, Yaxham, Garveston, and Kinderly, much of the country, especially towards Wymondham, is a thickly enclosed woodland; the soil is strong loam on clay marle, and very fine: I saw great crops of ail sorts, and many laid. Around W ymondham, some light but good land. 'The two Morleys contain some vety light, and some heavy. Deepham, heavy; and Wickle-wood, inclining to it. Fundenham, Ashwell, and Wramplingham, a strong loam.

From Wyndham, by Hcthel, Wrenningham, and 
Flordon, very fune rich land, being a strong loam on marle; Mr. DAwEs, of Wrenningliam, has an immense crop of wheat, dibbled on clover lev. At Flordon, some land of the finest quality, decp, friable, and putrid. All good and strong land to Stratton; thence to near Harling (about which town there is some lighter land), by Wacton and the Pulhams, all strong land on clay marle: clover sown alone, a regular plant, and good; and a scattcring of beans from Wymondham to Harleston, sufficient to shew (if this proof were wanted) what the soil is.

I met with few farmers in Norfolk who admitted that fern was a sign of good land; as I have an entire conviotion that it is an excellent sign, I was pleased to hear Mr. BLOOMFIELD, the brother of the gentleman who lives at Billingford, observe, in riding over a heath in that parish, on my asking why they did not plough it-" this part, where there are brakes, would pay well; but some of it is poor."

Thelton, Rushel, Billingford, and to the back of Needham, are very wet and strong, as much so as any parts of Norfolk.

Earsham hundred has much mixed good land, some sharp gravel, and much heavy wet clay.

Diss hundred, good, though strong and wet. Rent $x$ s. to 20 .

Depwade has much strong land, but little meadow; nearly equal, however, to Diss.

The Pulhams are wet and heavy, and contain much pasture. Mr. Donne's farm is broken up.

In Loddon liundred, Langley, Mendham, and Seetling, strong land, but good; greatly improved by hollowdraining. At Langley, all I viewed, except the marshes, is a very fine and fertile sandy and gravelly loam; in vari- 
ous tracts on a fine clay marle, well worth jos. an acre ; equally good for turnips and wheat. Twaite, strong. Hedingham, half strong, half mixed soil, none light. Broom has some heavy, but much gravel. Loddon, a little strong, but all good.

Chedgrave and Hardy, mixed; average rent, 20 .

Carleton and Ashby on loam; and a little clay. Hillington, Claxton, and Houlston, better; all good.

Brook divides the soils; on one side the land is as fine as in Fleg.

Kirstead has a good soil. Stoke has some heavy land. '

There is a remarkable vein of strong clay soil, eight miles long, and two wide, extending from Brook to Tasborough turnpike at the Bird-in.Hand; taking in a little of Fladdon, and ending at Mulbarton; this is all a strong clay land, with many beans cultivated; it was not worth above 8 s. an acre ; but by draining, and other improvements, is now brought to be good land.

To the north of this line, towards Norwich, it is a country of good mixed soil ; the worst of it is at Dunstonhills, near Hartford bridges. To the south there lies also a range of mixed soil, till it meets the strong land of Thelton, Thorpe, Albots, \&c.

Clavering hundred, all good land.

Horsted and Belough, light. Wroxham, light.

The soil at Coltishal is various, but much a light sandy loam on a red running sand, three or four fect deep; then a bed of flints, then more sand; another bed of flints, and then marle; but little gravel.

About North Walsham a mixed soil, that is, a sandy loam; some sand; and the sub-soil sand: at the distance of three or four miles, much on brick earth, and some on clay marle. 
The saine at Scotter; a fine sandy loam opposite Mr. DYBLE's house, and much of it in the country.

At Oxnead, \&c. a mixed sandy loam on a red sand, under which a layer of flints; then strong brick earth, and then white chalky marle, at the depth of 10 to 15 feet.

From Aylsham to North Walsham good land; better than to Holt. Around Wolterton good; and the first four miles to Cromer. It is bad to Causton; and much of it indifferent to Norwich. From St. Faith to Norwich enclosed within 30 years, and good.

From Causton to Reepham and Foulsham, a tract of good soil, but much wet, on which draining is a great improvement.

At Heveringland much sandy land, on a hard cold sand bottom.

Excellent sandy loam at Hackford and Reepham ; much of it on a marley botton.

Spixworth, Crostwick, W ickmer, and Wolterton, have very good land.

At Thurning there are sands of various qualities; some good ; but much on a cold clung gravel; some stiff, even on the surface; so that water stands in the horses' foot-steps in turnip-feeding. Mr. Jounson remarks, as a general rule, that if the sand does not wash in the furrows, the land is bad, good neither for barley nor turnips. On many soils a thickish mud washes, which keeps the plat, the breast of the plough, from scouring. There is some good mixed soil on gravel, and some on clay; good strong land, with the sand washed in the furrows.

Gistick, as good land as any in this neighbourhood. Dawling better than Thurning. Briston part good, and part bad.

Croxton, 
Croxton, Fulmerston, and Stibbard, good; also Wood Nowton, and Riborough.

The trast to the east of the Ouze, comprized in Downham, Winsbotsham, Stow, Crumplesham, Bexwell, Ruston, \&c. is a mixed soil; sand, and sandy loam; some clayey, and a little moory; generally good land, upon a white clay marle.

At Watlington much sandy gravel, on a yellow clay; also strong silt clay, on a gault bottom, wet.

There is much very poor sand, gravel, and poor moory heaths, from Lynn to Swaffham; and poor shallow sand, on hard chalk, at Narborough.

The soil at Besthorpe is strong, and much wants draining; but some very fine brown sandy loam is found. A hedge thrown down many years ago in Mr. Priest's turnip-ficld, and the rankness of the crop there, striking.

Hookering, and North and West Tuddenham, are a strong enclosure; mixed soil, being good turnip-land.

Part of Weston is sandy, and part good.

At Siwanton Morley, Mr. Emms's farm, 1000 acres, mixed land; but part of the parish heavy. Lyng is light, and Dillington various.

At Gressenhall there are three or four farms, of I 200 acres, to be sold, some of which might be watered. An advowson of 4 or 5001 . a year, and manors; the price $50,00 \mathrm{cl}$.

Kempston is a fine mixed loam; no light land, but some heavy.

- To Fakenham, all good.

Beccles to Loddon, a fine sandy loam, 20s. an acre in 1792.

Loddon to Norwich, and Norwich to Dereham, a fine sandy loam. 


\section{GOOD SAND.}

At Great Dunham the soil is very fine land, and produces great crops. But in Little Dunlan is some of the finest land I have any where seen: the crops immense; yet, if possible, inferior to the texture and appearance of the land. The herbage of the leys of a deep hue, that speaks their nourishment.

Along the coast, from Holkham, westward, towards Hunston, there is a tract between the marshes and the sand, from half a mile to a mile broad, of a singularly fertile sandy loam: it has tenacity sufficient to adhere into clods easily broken, and to produce great crops of vegetables demanding the richest soils; at the same time it has that dryness and friability which renders it excellent turnip-land. It may let at about 20s. an acre; whoever views it will not think the rent high.

At Burnham Westgate, some poorer sands, and chalk slopes. Choseley, middling sand. Summerfield, good mixed soil and sand. Thornham very grod sandy loam. Holm equal, and part of it superior to Thornham. Tichwell is good, but has some light. Brancaster the same; and Hunston, very good.

Fring has some light, and some middling. All these parishes class as sand in general; the basis marle or chalk.

Snettisham, much good sand on chalk and marle, and some low and strong land. Hexham nearly the same.

At Ringstead a quarry of marble; the colour and veins something like that of Sienna. At Snettisham, a quarry belonging to Mr. StyLeman, of red sand-stone, 20 feet deep : it rises soft, but hardens in the air. The stables at Houghton are built of it.

Upon the sea-shore at Snettisham, Mr. STyLeman has

a large 
i large tract of sea-shingle, which bears little more than eringo: he sowed some chicory seed on it for experiment, but it never vegetated.

The soil of Houghton, is sand on chalk and marle: that of Harpley better ; the Rudhams good; Bagthorpe light; the Birchams ordinary; Anmer is better, but all sand.

At Hillingdon there is some black sand and gravel; a poor soil, but the hills are chalk: the sands all apt to be more foul than the chalk.

Much blowing sand at Riseing; and the evil of some of the soil there is, its being free from stones, and for that reason burns much; on which account Mr. BECK disapproves of picking stones. The remark is very judicious. To deep sands he thinks twitch so natural, that it is impossible to free them from it: if the field is made ever so clean, and lays two years, there will be some.

There is some sand that burns, at Grimstone. The soil of Massingha:n is much better, and never burns.

At Guyton the soil has a mixture of stones, and is the better for it.

At Morston, near the sea, there is so:ne land so covered with stones, as to appear to the eye to contain little besides; but excellent for corn; I I combs an acre of white vetches have been gained on it. Much good land is found at Cley.

Sarsingham, Dawling, Binhan, are good sand; the loam on white clay marle.

Wighton, sandy loam; good mixed soil, on clay marle; but some is inferior.

In Sherrington, Hindringham, and Kilderston, there is much strong land, upon which hollow-draining is practised. 


\section{LIGHT SAND.}

From Riddlesworth, by West Harling, there are poor thin sands on marle. At Quiddenliam it improves, and continues better through Eccles to Snetterton. The crops in Harling-field, in this wet seasom, miserably poor, hardly yickling the seed again; yet a most luxuriant growth of spontaneous chicory and mellilot, which shews the profit to which the tract might be applicl, if the hints offered by the beneficence of the Almighty were pursued.

From Attleborough to Euston, by Rowdham and Bretenham, a dicary country, beginning wish rich, but sombre commons, and then crossing poor open heaths and sheep-walks, and open arable, that cries aloud for chicory: poor sand, on chalk and marle.

\section{RICH LOAM.}

One of the most interesting circumstances in the liusbandry of Norfolk, is the soil of Fleg liundred; and much in Blowficld and Walsham hundreds is of the same quality: it is a sandy loam, from two to three fcet deep, and much of it as good at bottom as on the surface; of so happy a texture, that almost any season suits ir; sulject neither to burn in drougints, nor to be wet with incessant rains. The basis most general, is a clay marle; but in several districts sand, both ycllow and white. So fertile a soil I have very rarely seen of so pale a colour; it is a very light whitish brown in dry weather. The products are great: wheat from 6 to I 4 combs; barley 9 to 16 ; oats 10 to 24 ; pease to 15 . Yet these products do not altogether announce the merits of the soil, which perhaps is marked more by paucity of failures than by extraordinary crops. Ashby and Burgh were named to me as having extraordinary land, and at the latter I found it 
excellent. Mr. James WIGG's is famous land, and his whent this year great.

Mr. Brown, of Thrigby, remarked to me a circumstance which well deserves noting ; that at Ashby, Billaby, and Burgh, is land that, before marling, ran uncommonly to white clover; but after being marled from Thorpe and Wightlingham, will do it no longer, none coming at present without sowing.

At the Burlinghams and Linwood there is capital land.

Some of the finest land in Norfolk is at Acle, Moulton, Tunstal, and South Walsham; the crops of wheat were, in 1789 , estimated, on an average of years, at ten combs an acre on their good land; they have, however, some that does not produce above six. At Mawby, near Castor, the average of the parish, for ten years together, ten comlss: twelve, and even fifteen, have been had; but in 1802 , they did not admit crops equal to these.

I examined with pleasure the fine loums near the respective houses of Mr. Everitt, of Caistor, and Mr. FERRABY, of Hemsby, which class amongst the finest soils in Fleg; it ought to be termed a rich sandy loam; dry enough for feeding turnips, and rich enough for five or six quarters of wheat; equal to great crops of cabbage, beans, or any other production.

Southwood, Moulton, Lippenhoe, and Rudham, class high among the fertile parishes.

At Martham, much of the land is on a sand bottom, and some gravelly spots subjeet to scald, but towards the fens, brick earth.

At Catfield, \&rc. a pale, fine, sandy, loam, upon a sand bottom, esteemed thin skinned, but I found it to the eye the same, at a foot and eighteen inches deep. 
At Waxham the soil is very fine.

No clay for an under-stratum in Happing hundred, except at Happsborough, Walcot, and Bacton; generally sand or brick earth. Here are some of the finest lands in the county-equal to Fleg, but stiffer; yet the surface a fine friable sandy loam, and the bottom not too retentive of water. The best land in the Catfield district is at Stalham and East Ruston.

Happsborough, Walcot, and Bacton, again noted to me as the finest soils, perhaps, in the county; a rich, deep, mellow, friable loam, on a clay loam buttom, some on brick-earth and sand; all good. East Ruston, very good, deep, on brick-earth.

Mr. CUBıt, at Honing, has some very fine palc coloured sandy loam, resembling the Fleg soils, and worth 26s. an acre; yet, intermised, he has some hills of sand and gravel of much inferior value.

\section{MARSHLAND CLAY.}

The whole district of marshlaud is probably a relict of deposition of the sea; it is a silt, or warp clay of great fertility, upon a sandy silt at various depths, but usually eighteen inches or two feet. The stiffer clays are the worst arable: the more mild and temperate ones, the best and easiest worked of course; but the strongest clay is the best for grass.

\section{SECT. IV, - WATER.}

NORFOLK is advantageously situated respecting mavigation; for of its great circumference of 200 miles, there are but something more than thirty, from Thetford 
to Bungay, which do not consist of the sea, or of navigable rivers: to the north, the ocean; to the west, the great Ouze; to the east, thesea; to the south, the lesser Ouze, and the Waveney; and, exclusive of this beneficial bonndary, the Yare and the Wensum penetrate from Yarmouth to Norwich, and the Bure and Thyrn, from the same port to Aylesham. With the last named river the Broads, and thcir communicating channels in the hundreds of Fieg and Happing, unite and connef the rich district with the sea and with Norwich, and the advantage is much felt in the conveyance of marle, \&xc. The navigation of the Nar reaches Naborough, and connects with the Ouze.

Smaller stieams abound in every part of the county, and offer such opportunities of irrigation, as must excite the amazement of every farming traveller, at the utter neglect in which they have been suffered to run to waste for so many ages. At last, this important application has begun to receive a little attention; so that we may hope, that, in half a century more, these valuable treasures will be accepted.

Ponds, artificial.-Mr. COKE makes these ponds at Holkham to serve each four enclosures; they are set out 42 feet square; at botton twelve, and seven deep. A bottom is worked with good clay, free from all stones, nor the least soil or sand in it, beating it as close as possible three inches thick; then three inches more are beaten in, and so on till a foot thick; then sand over it, to keep the drought out. The sides are made in the same manner as the bortom : within a yard of the top, the clay should be two feet thick. It is then paved with bricks set on edge. These ponds wese made by men from Gloucestershire, who were paid 2s. Gol. per superficial yard, costing 281. each, 
besides the bricks. To divide the ponds for four fields, a large stone with a hole wrought in it to receive a post, is necessary at the centre, with mortices to receive the rails. 
CHAP. II.

PROPERTY.

ESTATES are of all sizes in Norfolk, from nearly the largest scale to the little freehold: cne of 25,0001 , a year ; one of 14,0001 ; one of 13,0001 ,; two of 10,0001 ; many of about joool.; and an increasing number of all sinalier proportions. When the larger properties are dedusted, the remainder of the county will be found divided inso moderace estates, and in the hands of gentlemer who pay a considerable attention to the prablice of agriculture.

Seventy years ago, there was not, I belicre, a great rental in the county, so that these considerable properties rave been accumulated, first, by the most excellent of all canses, agricultural improvements, and, seccondly; by additional purchases.

Estates seli now (1802) pretiy currently at thirty yoars purchise.

In the Ovington and Sayham enclosure, the land solil by the commissioners to defray the expense of the mea. sure, brought 43l. per acre, as it was assigned, waste and unenclosed. The aicrage of all sales near TVatton, 4ol. all acre.

An estate lately sold at Fishley, near Yatnouth, contained

Arable bancl, good, - $\quad$ - 250 acres.

Cars and marshes, worth 12s. an acre, 100

Maroh, worth 20s. au acse, - 50

RORFOLK.]

c

Rent, 
Rent, 400l. a year, wortl 500 . fairly, hut 6ool. a yeas offerẹd for it ; sold for 17,500 . to Sir LDMOND LACON, and $1500 l$. offered for the bargain.

Price of the estates sold at and near Happshorough, $3 \mathrm{C}$, 40, and 5ol. an acre; much sold lately; and at this time, the best land would all sell at from fol. to 5ol. an acre.

Land worth not above 20s. an acre, between Coltishal and Norwich, has been sold at 50 . an acre.

In Marshland Sineeth, newly cnclosed, at jo, 60, and gol. an acre.

In Downhan Westside, Denver, Welney, \&xc. fen farms, 10l. to 12l. an acre: to the cast of Downliam, at 24 years purchase.

In Upwell, some, not fen, to 50l. an acre, but the average 201 .

Mr. BAGGE, of Lynn, has land in Marshland which would now sell at $70 l$ an acre, which Mr. Dixos bought, 6o years ago, at 12l. sos. 


\section{CHAP. III.}

\section{BUILDINGS,}

SOME of the houses belonging to the proprietors of large estates in this county, have long been famous as objects of the attention of travellers, and deservedly so; for there are very few counties that rival it in this respect: the circumstance, however, is not interesting in an agricultural inquiry. The well-cultivated domain is here of much more consequence than the well-decorated palace.

In the species of building properly appropriated to an Agricultural Report, greater exertions have, I bclieve, been made in Norfolk than in any other county of the kingdom. One landed proprietor, Mr. Coke, has expended above ONE HUNDRED THOUSAND POUNDS in farm-houses and offices; very many of them erected in a style much superior to the houses usually assigned for the residence of tenants; and it gave me pleasure to find all that I viewed, furnished by his farmers in a manner somewhat proportioned to the costliness of the edifices. When men can wcll afford such exertions, they are certainly commendable.

One of Mr. CokE's barns at Holkham is built in a supcrior style; 120 feet long, 30 broal, and 30 high, and surrounded with sheds for 60 head of cattle: it is capitally executed in white brick, and covered with fine blue slate.

At Syderstone, he has built another cnormous barn, with stables, cattle-sheds, hog-stics, shcpherd's and bailiff's houses, surrounding a large quadrangular yard, likcwise 
in a style of expense rarely met with. In discoutse witly the men at work in this barm, they informed us, that to one man who unpitiche the waggon at harvest, seven others were necessary on the goff to receive and dispose of the corn, after it was raised to soine height; a great expense at a time of the year when labour is the most valuable. The farmers are, however, very generally advocates not only for barns, bur for great balns. Another inconvenience is their not daring to tread, except lightly, in large barns: and the men complained that the corn threshed the worse for want of more treading. I 40 acres were in ellis barn of Mr. SAyaRY's. Floor, eleven yards; barn, nine wide.

In all Mr. Coke's new barns, and other offices, Tre has sulistituted milted leal for ridge tiles to the roofs, which is far more lasting, and the means of escaping the common accidents, in raising a heavy lalder on tiling, in order to replace a ridge-tile blown off.

For all locks, particularly in stables and other offices, Mr. Coke has found those with cepper wards muels more durable than any others.

The front edge of his own mangers are rollers coveret with tin; the mangers themselves are plated with iron:; and the bottons of the stall fences are of slate. All these circumstances are found very economical in duration.

In building the wails around a new farm-yasd for $M r$. Coke, Mr. Overman, after a certain height, draws them in to a brick's length at the top, a saring in these ereetions which merits notice.

MH. CokE's Mhthod of making up and applying Lime-wask as a Preservative and Covering to Boarding, Walls, Ec.

In a tub of six or cight gallons, put of water a quantrity. sufficien: 
Stificient to half fill the same; add thereto of clean sharp sand, and of line fiesh burnt, in about equal quantities, as nuch as will make, when well stirred up, a wash of mot̉erate consistence. With this wash, as soon as made, pay over the boarding of any barns or buildings, keeping the sand constantly stirred up, so that the brush may take up the sand as well as the lime. As the quantity in the tub decreases, add by degrees, in small quantities, more lime ard more sand, taking carc to make up no more than will be imnediately used. The quicker the lime the lratter, which, if good, will make the wash hot; and if it be required to make this wash particularly hard and durable, the same will be effected by making use of boiling water instead of cold, taking care to make it in such quantities that it can be laid hot on the boards.

Mr. Coke has, at Holkham, a brick manufactory, which ranks very high among the first in the kingdom; bricks in all sorts of forms are made, șo that in raising an edifice, there is never a nccessity for breaking a whole brick to have a smaller of a very imperfect shape, which takes time, and creates waste; connice, round column, corner, arch brirks, \&c. are made in great perfection.

Account in 1792

E. s. ..

Raising earth, making and burning per 1000

(white bricks I 2s.),

$\circ 80$

[The brick-maker finds mou'ds, pails, barrows, rakes, boards, \&xc.]

Duty, - $\quad$ - $\quad$ - $\quad$ - 026

A chaldrun of coals, at 26 s. burns $7000, \quad 038 \frac{1}{2}$

$A$ kiln, 32,000, - - $\quad 00148 \frac{7}{2}$

Red are burnt with coals; white with wood: the lattcr

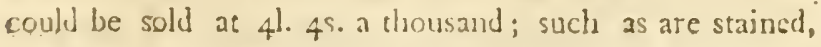


at $3^{1 .} 3^{5}$. 8000 of the white are burned in the centre of a kiln of 32,000 red.

1802. - All now are burnt with wood.

Mr. SALTER, at Winborough, built a cart-lorige, and granary over it, in which are three circumstances that deserve noting: the main-posts that support the granary rest on brick-work syuare foundations, about two feet high, and these he has guarded by oak plank let into the ground; the posts are ticd to the beams at top by knees, which add inuch strength.- [See Plate 1. Fig. I.] The stairs are without the building, at the end; and for the conveniency of loading waggons, there are two rollers fixed, over which sacks are slid down easily into the waggon.

Mr. Robinson, at Carbrook, sanded his cornice, window and door frames, and window soles. The method is, to paint white, and dash it imnsediately with sea sand from a dredging box: the effeet, as I saw, is that of an exceeding good imitation of stone. It is said to be very durable.

Mr. Collison, of Dereham, has built at Bilney a very capital barn of brick, the walls i 8 inches thick, and for three feet from the ground, 22 ; and 23 fect high: no cross beams to impede the filling.-- [See Plate I. Fig. 2.] The porch, by being something lower at the point of the roof than the barn wall, and forming no junction in the roof, has no gutters. The lean-to sherls are joined to the walls by lead worked into the brick-work. No ridgetiles to any of his buildings, but milled lead. Stables, harness, and straw and hay houses, with two sheds, one on each side the barn porch: the whole covered with pantiles. A granary and cart-shed, and a clouble cottage, very good indeed, but with the universal error of the housc-door opening into the kesping-room. Good gar- 
Plate 1

for fares Payge ?"

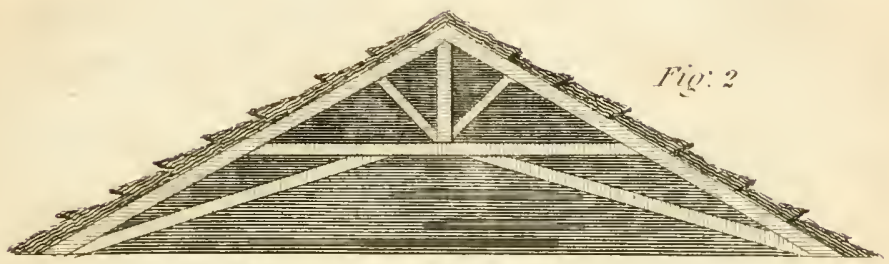

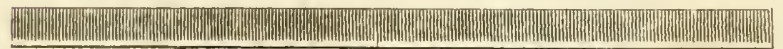

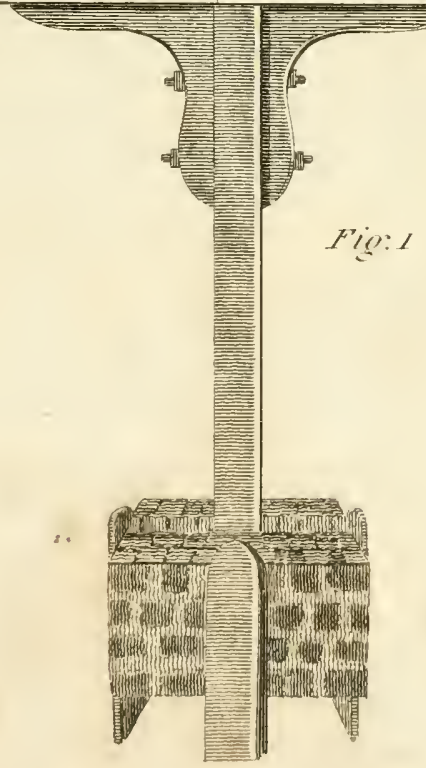



dens; and the people seemingly more comfortable than cornmon in Norfolk.

Mr. Drake, of Billingfold, near Scole, washes a fine white clay from a mixed soil, in order to nake white bricks-lumps, as they are called-for barn-floors, \&c. He has a boarded cistern, into which the earth is put, and water ladled or pumped from a contiguous pond: the earth is well stirred, and the sand, stones, \&er.. sinking, the suspended clay is let off into a broad shallow tank, and as soon as it is subsided, the water is lec off into the same pond. But the clay thus gained is too strong to make brick alone-fying in the fire; it is therefore mixed with a yellowish loam.

At Thelton, to dig, turn over, water, make, and burn bricks, 9s. per 1000 : every thing, as tahles, boards, sand-barrorvs, \&c. found. Some give 10s. $6 \mathrm{~d}$.

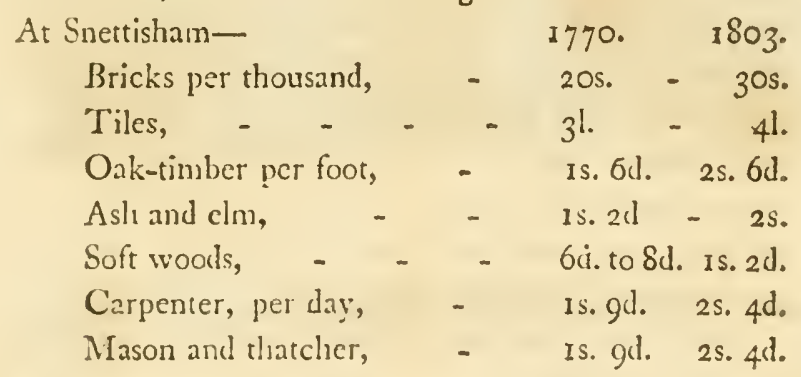

Building a tolerable cottage at Hillingdon, costs 501 . $60 l$. and to 801 . ; yet line is burnt for fll. a bushel; but it is bad, and the mortar decal's.

An observation Mr. MarLaxil made, in shewing me a sluice in Governor BENTINCK's embankment, merits noting. By the flooring of the arch being laid against the brick-work without due precaution, the water got shrough, and boiled up under the apron: he laid it afresh in Koman cement, stopt the watcr, and the evil ceased. 


\section{COTTAGES.}

Mr. Robinson, at Carbrook, has built a double cots tage of fint-work; the walls 18 inches thick, the workmanship of them 1s. the square yard. 'The rougl-cast within is all of clay white-washed, which answers very well. The covering is pan-tiles. Cost 1301 ; but finished neatly, and with Gothic windorws, perhaps may add 201 . or 301 . extra: good gardens, and very well cultivated.

The two bed-rooms and wood-roons are in a lean-to: a bed-chamber over each.- [Sec Plate Il.]

Cottages are much wanted at Snetterton and the neighbouring parishes; if built, they would presently be filled with inhabitants. I wish they were erefed, for the poor people are there very neat in their well-cultivatel gardens; the land fully cropt, and in high order, and the hedges neatly clipt; but their gardens are much too small: they well deserve additions. All to Attleborough, \&ce. the same; and at Hingham, Mr. HEATH was certain that, if 20 or 30 were built, they would be all inhabited in three months. It is the same in the surrounding parishes.

It is a new praclice in West Norfolk, to let cottages on leases of lives.

My guide into Marshland Smeeth, knows but three cottages built in consequence of cultivating 8000 acres: one by Mr. BAgge, one by Mr. Silverwood, and one by Lady TrAFForD.

Rent of a cortage and a bit of garden at Walpole, ${ }_{3} l$.

FARM-YARD.

The farm-yard of Mr. Purdis, at Houghton in the Hole, lics on a sloge, and runs into a dicch which conreyed 
Hate II.
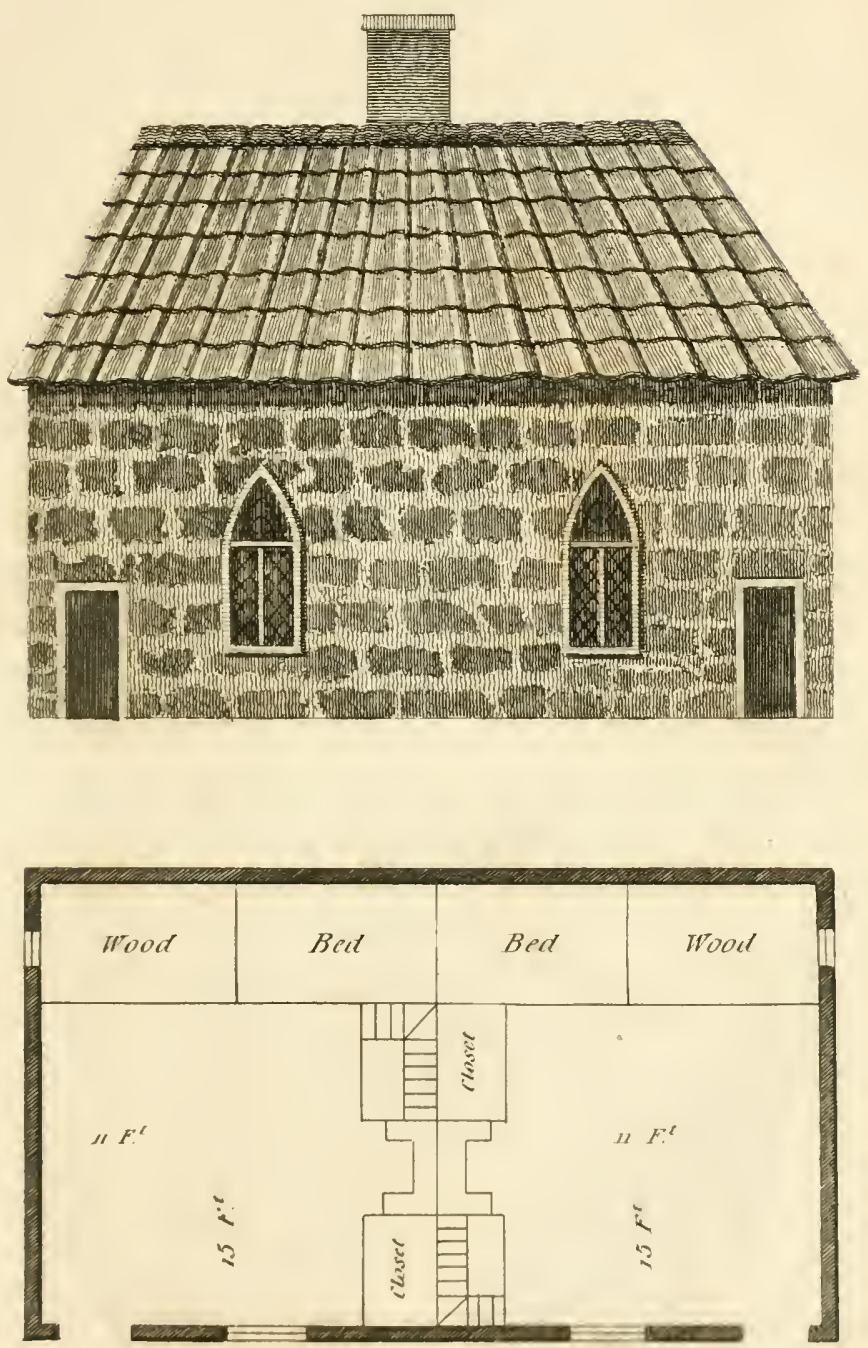




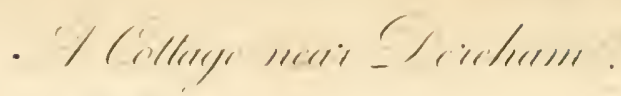
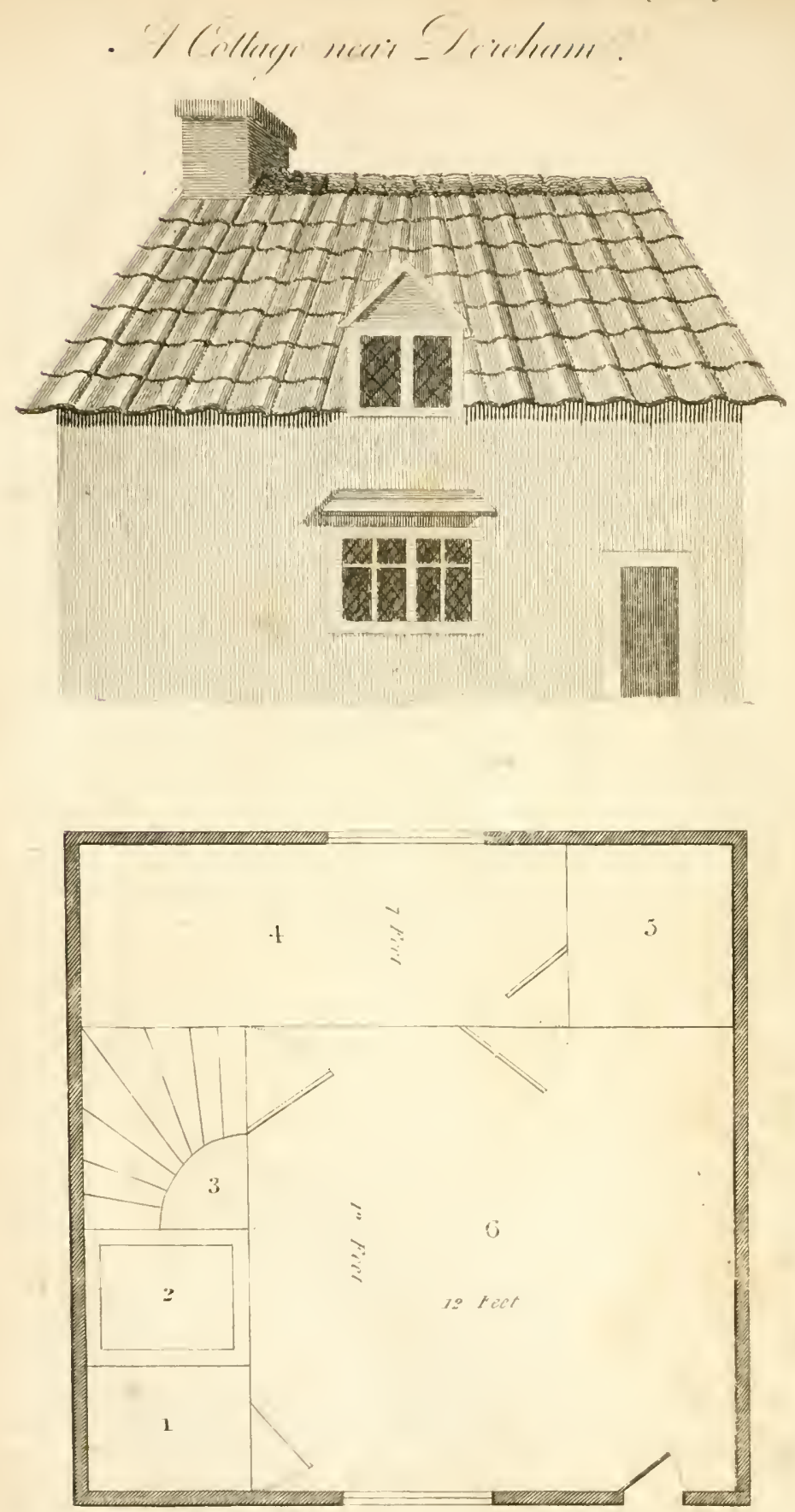

MIPTAYATIOA

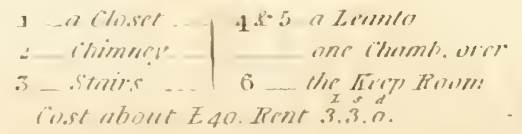


veyed the drainings of it to the river: this ditch was cleaned out, and a great row of road-side mould raised; the declivity admitted the execution of a thought, beautifully, simple and useful. A rench is cut along the top of this row of earth, to receive the drainings of the yard; stops are made at a small distance from each other, to keep the liquor till the earth absorbs it; and thus the whole is impregnated. As the watered meadow is just below, Mr. Purdis intends, "when the earth is removed, to convey the drainings into his main carrier, for enriching his swater of irrigation. When once men are led to think, nothing is lost: the mind is awakcned to every hint; and circumstances which, in a leeping age, would be passed by, are tumed by active exerion into profit. In such a state of progressive improvement, cvery object becomes interesting, and all the faculties of the human mind are on the stretch to draw advantage, where our ancestors drawled on inactive and torpid.

I wisl I had it in my power to add, that I saw a good farm-vard in the county, manifesting contrivance, and in which no building could be moved to any other scite without doing mischicf. Where is stich an one to be seen ? 


\section{CHAP. IV.}

\section{OCCUPATION:}

SECT.I.-FARMS.

UPON this subject we inust divide the county gene rally into two parts-the dry soils and the wet ones. Upon the former the farms are large, and upon the latter much smaller.

The rich districts which, though dry enough for turnips, are strong enough for yiclding great crops of wheat, possess some inoderately-sized farms, such as from 400 to 600 acres; but many smaller. The wet land is more commonly held in simall occupations. The poorer sands are usually in very extensive farms.

One near Holkhain, I 792, 1000 acres, 450l. rent. 50 acres wheat, $\quad 400$ acres sheep-ivalk,

$$
\begin{aligned}
& \text { I5O - spring com, Io harvest-men, } \\
& 120 \text { - turnips, } \quad 500 \text { sheep-Norfolks, } \\
& 240 \text { - layer, I4 farm-liorses, } \\
& 40 \text { - sundries, } 40 \text { cattle. }
\end{aligned}
$$

Mr. Purdis, at Egmore, i 802.

$$
\begin{aligned}
& 300 \text { acres of turnips, } \\
& 300-\text { barley, } \\
& 600-\text { seeds, } \\
& 300-\text { tares, } \\
& 300-\text { wheat, } \\
& 100-\text { sundries. }
\end{aligned}
$$

1900 
A finer farm is rarely to be seen, than Mr. MirDRED's at Earsham, belonging to the Duke of NORFoLK; as compact as a table; without a foot-path, near a town and a navigation: a good soil, and a beautiful situation.

In the hundreds of Diss, Earshain, and Depwade, more under than above iool. per ann.

Average farm of Fleg under 200 acres; none very large.

Mr. Heath's, at Hemlington, of 500 acres, is one of the largest farms, if not the largest, in South Walsham hundred.

In Happing hundred, farms are very much in the hands of the proprietors, the yeomanry being numerous; hardly any so large as 4 or 500 acres, and not many under 50 ; from 50 to 300.

About North Walsham, few more than 2 or 300 acres. Mr. Petre's, at Westwick, 600 acres:

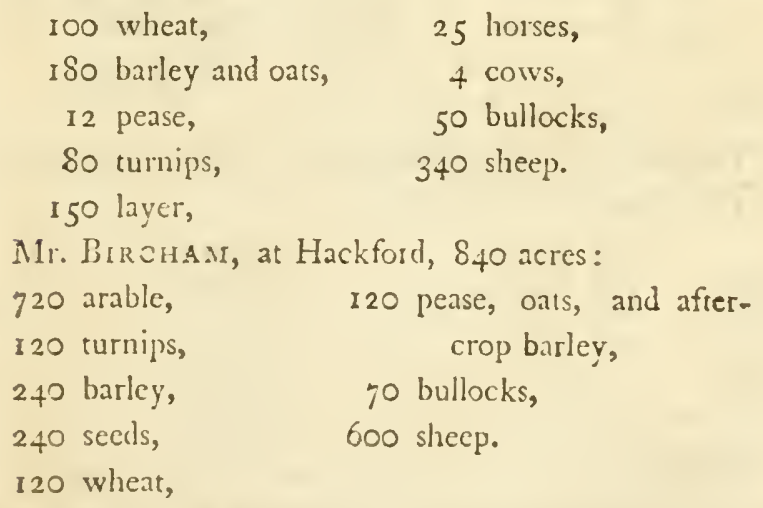

120 wheat,

His system is, to keep the greatest quantity of stock he can ; to keep his land clean, and then not to doubt of great crops of corn.

Mr. Jouxson, at Thurving, SSo acres: 200 grass, 
32 horses,

70 score sheep of all sorts,

95 beasts at turnips last year.

Mr. Keeve, at Wighton, 700 acres:

600 arable,

22 horses, and therefore not four to the hundred acres; all drilled.

Mr. Styledran's, at Snettisham, 2000 acres: .

1400 arable,

boo grass,

700 ewes, and their produce, or about $2000 \mathrm{in}$ all He has arranged his Ringstead farm in such a manner, in five divisions, each of six fields, like five distinct farms, that every sort of crop is scattered over the whole, which he considers as a great convenience.

Earl of Cholmondeley:

$$
\begin{array}{ll}
650 \text { acres arable, } & 120 \text { turnips, } \\
350 \text { grass, } & 120 \text { barley, } \\
560 \text { plantations, of which } & 240 \text { seeds, } \\
120 \text { addled by the } & 120 \text { wheat. } \\
\text { present Earl; } &
\end{array}
$$

The size of farms in Marshland, will be seen by certain of Governor BENTINCK's:

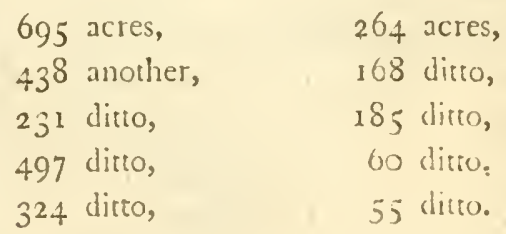

About Downham, most are small; a few to 4 or 500 acres. About W ymondham, chicfy small : 200l. a year a large one; many 40l. 70l. and to rool. per ann.

Around Hingham, and to At:leborough, farms are all small: Mr. Giss, at Hingham, has one of the largest.

In the richer lands of Aitleborough, Hingham, and Watton, 
ivaton, the farms are generally small: about the latter place, 200l. is a common size, and some of $100 \mathrm{l}$ and even 6ol. and 5ol. Mr. Bougen, of Sayham, 7001. the largest in the neighbourhood.

Entering.-Mr. JoHnson, of Thurning, entering 500 acres in sad order, he ploughed up and fallowed the seeds, for which he had given 30 . an acre.

Mr. Overman, at Burnham, entered his new farm hired of Mr. Coke, with a most decisive energy. He paid per acre for liberty to fallow land, from which his predecessor had liberty to take a crop : he fallowed other lands left under seeds, and for sowing which he had also paid. He brought a ship-load of turdles from Sussex, for defending his young setts: he marled such part of the farm as wanted it, the first year' remarking to me the great difference between enjoying the return from improvements for 19 or 20 years, rather than, by delay, possessing them oniy 14 or 16 .

Stock. - The Rcv. Mr. Priest, on 85 acres of very good land at Scarning, near Dereham, and 5 other acres at some distancc, keeps 100 excellent South Down sheep, 6 cows, 5 horses, and lras had a larger stock; yet 75 acres of it are arable.

Size.-In discourse with Mr. ThURTELr, on the size of farms, he remarked that nothing could, in his opinion, be more absurd, than the prejudice against large farms. Wherever he has made: any observation, large farms produce much more for the public consumption than small ones: that all improvements, if they arise at all, must be from large farmers, who are able, and ins a-days willing, to make experiments. And he further observed, that whatever crop would produce most money, was of snost public benefir; an obseryation perfeclly coinciding

with 
with that of a celebrated writer, but whom this gentleman had not read, Mr. Harte, in his Essays on Husbandry.

The size of farms is a subject upon which so mucl has been written, that to enter into a discussion on the subject in the Report of a single county, would be to swell a book with general suljeets, which ought to be appropriated to local and particular ones. I sliall only observe, that the vast improvements which have been madc in Norfolk, by converting boundless heaths, sheepwalis and warrens, into well-cultivated districts, by $\mathrm{en}$ closing and marling, are such as were never yet made by small farmers. Great farmers have converted in this county three or four hundred thousand acres of wastes into gardens: can any thing therefore he so grossly absurd, as to find fault with such divisions of the earth as have produced these effects? Little farmers have never, in any county that I am acquainted with, produced equal effeets : it they have, let the Reporters of such countics explain it; it is my business to state what has taken place in Norfolk. In the eastern district of rich land, farms are moderate or small, ret the country is well cultivated ; but natural fertility does the great business; upon such land, it is of much less consequence what the size of a farm may be.

When poorer tracts become highly improved, and very great cxertions are not equally necessary, farms of extraordinary size may be proftally divided, since the invention of threshing-mills, which supersede the necessity of barns: as in this case, the interest of the money expended in new buildings, added to their repairs, may not be cqual to the superior rent of a moderate farm over one of a great extent. 'The private interests of individuals may safely be rusted with all such arrangements, as much 
more likely to produce a result nationally beneficial, than any of the laws which have been stupidly and absurdly called for.

Farmers.-The Norfolk farmers are famous for their great improvements, the excellency of their management, and the bospitable manner in which they live and receive their friends, and all strangers that visit the county. I have on various occasions found how well they merit their reputation.

In respect to their husbandry, the farming mind in this county has undergone two pretty considerable revolutions. For 30 years, from 1730 to 1760 , the great improvements in the north western part of the county took place, and which rendered the county in general famous. For the next 30 years, to about I 790, I think they nearly stood still; they reposed upon their laurcls. About that period a second revolution was working: they seemed then to awaken to new ideas: an experimental spirit began to spread, much owing, it is said, to the introduction of drilling; and as so new a practice set men to thinking, it is not unlikely: nothing can be done till men think, and they certainly lad not thought for 30 years preceding. About that time also, Mr. Coke (who has done more for the husbandry of this county than any man since the turnip Lord Tow NSHEND, or any other man in any other county), began his sheepshearing meetings. These causes combined (for what I know, the former sprung partly from the latter) to raise a spirit which lias not subsided. The scarcities, and consequent high prices, brought immense sums into the county, and enabled the farmers to excrt themselves with uncommon vigour. Experiments in drilling shewed that farmers night step out of the common road, without any danger of a gaol. South Down sheep came in about the same timc. Folding was by many gradually given up. 
These new pradices operated upon the farming mind: ideas rook a larger range; a disposition was established. that would not readily reje? a proposal merely because it was new-the sleep of so many countries. Every thing is to be expected from this spirit. Irrigation is gaining ground, in spite of the dreams that have been ventured against it. And if the men who occupy, or rather disgrace so large a part of the light sand district, by steadily adhering to those good old maxims which have preserved it so long in a desart state, shall once imbile a portion of this ardour, we shall see new plants introduced, and new practices pursued, to carry the county in gencral to the perfection of which jts lusbandry is capable.

Those who have visitel Holkham as farmers, will not accuse me of flattery, if I assert of Mr. CokE, that he is fairest where many are fair. To name particulars, would be to detail the whole farm.

Mr. Purdis, of Ecgmore, is in the first class of cxcelient cultivators: his farm has many unequivocal signis of spirited exertion: 300 acres of tares; 3000 South Down sheep; and a watere! neaklow, are objects that speak for themselves.

The late Mr. Maldet, of Bunton, lanving, on coming to his farm of 2500 acres, nothing more than the stock, valued at 7000 . in thity-four vears acquired a fortune of 70,0001 .

Mr. SABTER, of Wialurumgh, is sne of the most spirited improvers in the county: he hired 800 acres, in a state not far removed from a waste; and by ditching; draining. marling, and good husbandry of various kinds, las brought it to be one of the most productive farms in Norfuik.

The Rev. Mr. MUNings, near Dereham, invented a method of preserving turnips; which be described in a 
itte publication of merit. He drills successfully, and has various and useful implements.

Mrs. Collison, of Dereham, has made considerable improvements at East Bilney; drills successfully, and has built a capital barn, \&zc.

Mr. Moneyhill keeps a farm of near i 300 acres, with a degree of neatness and attention which classes him among the first farmers of the county: the whole drilled. Fine South Down Sheep.

The Rev. DixOn Hoste drills upon a very stiff and difficult soil, wirh success. Drains effectually.

Mr. JoHnson, of Kempston, has the best threshingmill I have seen in the county; Leicester sheep; and is a very good and attentive farmer.

Mr. Farrow, at Shipdan, $35^{\circ}$ acres at Sayham; 200 new enclosure; very great and expensive new brick barn and a threshing-mill. Sranton of Weybread's drill: mucls drilling, and great crops.

Mr. Robinson, of Watton, has erefed new cottages, with improved and economical circumstances in building: South Down sheep.

Mr. HEATH, of Hingham, aficr breaking up grassland, has great crops.

Mir. Fowel, of Snetterton, drills his whole farm: Incerne; soiling. An excellent farmer.

The Rev. Mr. Priest, at Scarning, drills all his arable land with harrow-drills, and horse-hces the whole; three rows, at nine inches, on three-feet ridges: fine crops. Various implements; and a beautiful little Rock of South Downs.

Mr. Draxe, of Billingord, paring and burning; dritling and dibbling.

Mr. Havers, of Thelton, Devon cattie; piggery ; beans; oxen.

$$
\text { SiOKFOLK.] D Mr. }
$$


Mrr. PITts, of 'Thorpe Alshots, dilling ; beans.

Mr. KERRICH, of Halleston, manuring for bearis.

Mr. Mirdred, at. Farsliam, beautiful farm.

Mr. Burton, at Largley, general information; extensive knowledge, and excellent management: enclosures:

Mr. THURTELL, near Yarmouth, manuring; tillage; building.

Mr. Everit, at Caistor, fine land, and good management.

Mr. Ferrier, at Hemsby, fine land, and great crops.

Mr. Brown, at Thrigby, clay; marle; yard-dung; pease.

Mir. SYBLE, of South Walsham, intelligent; course ; drilling; oil-cake feeding.

Mr. FrANCrs, at Martham, tillage; dibbling; manures; ploughs; products.

Mr. HornarD, of Ludham, double ploughs; teathing wheat; manuring.

Mr. Cubit, of Catfiekl, teathing wheat; potatoes; mixing elung; marte.

Mr. WISEMAN, of Happsborough, beans; pease for jigs; white clover.

Mr. CUBIT, of Honing, plougling in buck-wheat : marle.

Mir. Margateson, of North Walsham, feeding and moring clover; dibbling; marle.

Mir. Petre, of Westwick, Soulh Down sheep; bealtiful improvements.

Mr. DYBLE, of Scotter, tillage; ploughing in green crops; good managुement.

Mr. PALGRAve, of Coltishal, improvement of meadows; manuring; drilling.

Mr. Repron, of Oxnead, courses of crops; products ; Jrilling; steaming roots; Lcicester sheep. 
Mr. ReEves, of Heverland, Norwich muck; improvement of wastes; drilling; threshing-mill; South Down sheep.

Mr. Bircham, of Hackford, excellent management in the old school.

Colonel BUlLER, of Haydon, steam-engine; drilled barley; enclosing.

Mr. JoHnson, of 'Thurning, draining; improvement of meadows; drilling; tillage; South Down sheep.

Mr. ENGLAND, of Binham, drilling; South Downs.

Mr. REEvE, of Wighton, irrigation; draining ; drilling; Leicester sheep.

Mr. H. Blythe, of Burnham, drilling; South Down sheep; sainfoin; white marle.

Mr. Dursgate, of Summerfield, drilling; course of crops; manuring; South Down sheep.

Mr. Rishton, of Thornham, drilling; South Down sheep; sea-weed.

Mr. Styleman, at Snettisham, drilling; improvements; threshing-mill.

Mr. Goddison (for Lord Cholmondeley), manuring for wheat; marling.

Captain BEACHER, drilling; Wiltshire sheep.

Mr. BEck, of Riseing, South Down Sheep; drilling; marling; manuring; threshing-mill.

Mr. BENTINCK, a noble embankment.

Mr. SAFFoRY, of Downham, fen-management.

Mr. Portek, of Watlington, drilling; beans; manuring; course; Leicester sheep.

Mr. MARTIN, of Totterhill, drilling.

Mr. ROgERSON, of Narborough, drilling; manuring.

Mr. BURRoughs, of Wymondham, good management. Mr. PRIEsT, of Besthorpe, drilling; lucerne; chaffcutting.

Mr. Twss', of Bretenham, drilling; Norfolk sheep. 
Mr. GalwaY, of 'Toffts, irrigation.

Mr. BEvAN, of Riddlesworth, considerable efforts in irrigation; marling; and various improvements; South Down sheep, \&c.

\section{SECT.II.-RENT.}

THE circumstance which makes the rent of a county an object of any interest in an Agricultural Report, is its being a confirmation of the descriptions which are given of soils; the terms used in defining land, rich, poor, mixed, strong, light, \&c. must in many cases be vaguc; but when sand is noted at $2 \mathrm{~s}$. $6 \mathrm{~d}$. an acre, or rich or strong at 20s. to 3 os. the reader has more explicit information. When a man is told that sand produces six or seven quartcrs an acre of beans, the fact docs not convey any knowledge; but if it be added, that the rent is 30 . an acre, it becomes easy to guess what the soil is. The minutes, however, of rent, are not numerous: on many occasions it is an inquiry prudently shunned, and on some, it is not an ohject of consequence.

Hundred of Shropham.- Two-thirds of Shropham hundred, containing 20 parishes, are sand, at $5^{\text {s. an acre. }}$ The other thitd better land, at I2s.; average of the whole, 7s. 4 d.

Around Attleborough, 20s. to $35^{\mathrm{s}}$. Besthorpe, $23^{\mathrm{s}}$.

Shropham, 2.0s. but high let.

If ayland.-About Watton, small enclosures, up to 40 s. and 5 os. an acre: all the country round, that is not light, 20s.

Gilcross.-Snare-hill, June 20, I734. Valuation of stock : 15 neat beasts, 3 cart mares, 8 acres of grass, and all the other grass, and all the corn of the farm, rorl. 4 s. 
In 1802 , this estate sold for 15,000 . Memorandum with which I was favoured by Mr. SALTER, of Winborough.

Grimshoe and Sonth Grcenhoe.-Thetford to Swaffhan, 75. 6d. Some 3s. 6d. and 5s. Warrens, 5s. Lands that have been clayed, 7 s.; if not clayed, $5^{\text {s. }}$

Laundich.--One of the most extraordinary instances of advance, is that of the farm at Rougham. Within the memory of many persons, it has been advanced from $500 l$. a year to 25001 .

Diss.-The whole of this hundred is good land, and much of it strong. At Thelton, in general, about 20s.; some higher. Rents in this hundred not raised more than 15 per cent. of late yenrs.

Earsham and Depuade. - The former of these 20s. and not dear at that rent. Defwade equally good; but being further from navigation, is in reality worth 2s. or 2s. 6d, an acre less on that account. Rents have not been raised more than from 15 to 20 per cent. of late years.

Clavering.- The whole consists of rich land, rented at 20s. and cheap. Gillingham, r8s.; Stocton, 20s.; Alderby, 20s.; Whitacre better still.

Hensted and Loddon.-Both gond, and let at near zos. All the country for many miles around Langley, raised one-third in 25 years; and a great deal cioubled. In that parish, 600 acres newly enclosed, at 12 s. The river Y.re bounds both these hundreds to the north; on its bank a line of marshes. At Wightlingham these are neglected, and do not let for more than 20s. an acre. At Surlingliam and Rockland they are boggy, and let at about 8s.; but to Rudham-ferry at 20s.; thence, to Yarmouth, 23 s. and to 3 os.

Forchor, Humbleynd and Mifford-These are in the 1) 3 disuiat 
district of various loams, and let on an average at from I5s. to 20s, an acre.

For five miles around Wymondham, five years ago, the rents were not more than 20 s.; now from 18 s. to $25^{\text {s. }}$

From Attleborough to Hingham, 20s. to $35^{\text {s. an acre. }}$ Two miles around Hingham, 18s. to 20s. Three miles around, $15^{\mathrm{s}}$. or $16 \mathrm{~s}$.; hut, if clayed and drained, 20s. to $25^{\mathrm{s}}$.

East and West Fleg. - These hundreds are fainous for their excellent soil; and let on an average from 25. to 27s. an acre; some up to 42s.; at which rate Mrs. MAPEs, of Rolleshy, has let some.

In the opinion of Mr. Fforrier, they have doubled in 20 years.

Happing.-Great tracts let at from 25s. to 30 s. ; and the whole at above 20s. on an average. The northern part of the hundred contains some of the firest soil in the county. But there is in other parts of it much low land, fen and commons cnclosed, and some let in 1802, for the first time; the worst worth 12s. an acre, the better sort, 20s. The Bishop of Norwich has let some as bigh as $26 \mathrm{~s}$.

Happsborough, Waicot, and Bacton, I have heard in conversations, valued too high to note: much lers at 30 ., and well worth that rent. Sandy loam on a clayey-loam bottom; but sound.

Tunsted.--About North Walsham, raised one-third in 20 years. Westwick and its vicinity, 20s. to 25 s. ; but there is some much poorer. Scotto, 20s. 1025 s. ; some

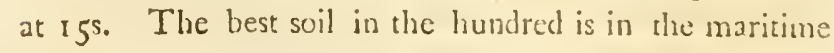
part.

North and South Erpingham.-Much of North Erpinglam is in the better sand district. In the southern part of it, much at 20s. In South Erpingham great tracts very sich, and as high in ront. Around Coltishal, i6s. 
Taverham-Consists of various soils, and varies much in rent: some up to 20s.; and some as low as 5 s.

Horsted, Belough and Wroxham, Ios. Raised onefourth, and some one-third, through most of this hundred in 20 years.

Blowficld and Tralsham.-These hundreds are in the sich district of East Norfolk, and are in general let (with local exceptions) from 20s. to 25 s. an acre.

Eynsford.-The whole of this hundred is included in the district of various loams.

For some miles around Reepham, Hackford, \&rc. rents 2OS.; they have been raised one-fourth in 20 years.

Much grazing land at Gestwick lets at 30 s. to $3^{6 \mathrm{~s}}$; some at 20 s.

Holt, North Grcenhoe, Gallow, Brothercross, Smeethder, Frecbridge.-These hundreds are in the distriot of g0o: sand, except only the marshland part of Freebridge.

From Holt to Burnhain, IOs. to 20s. an acre.

Thirty-five years ago, I registered the rent from Holkham westward to Snetrisham, and soudhward to Sivaffham, at 2s. 6d. to 6s. per acre; some farms then newly let, at xos.

Chosely, IOs. to 17 s. tithe and rate free. Thornham, 2 Is. Some from Thorniam to Snetisham, 8s. 10s. 12s. ; much at the latter place, 2os. Five miles round Houghton, s's. to 15 s. Hillingdon, \&c. 8s. to $16 \mathrm{~s}$; average 10s. The rich level of marshes to the south of Lymn, and east of the Ouse, 2 guineas an acre; the acre something more shan three roods.

The new intakes from the sea, in Marshand, by Gorernor BENTINCK, 2l. 2s. to 2l. 12s. 6d. an acre. The old lands 30 s. Marslaland in general, 28s. the statute acre; tut much, near 30 s. the short acre. It let 120 years ago at $15^{\text {s. }}$

Clackclosc. $-\mathrm{A}$ considerable part of this hundred is fen : 
inuch of it poor sand; but the rest is good, and lets at 175. ; some at 2 os.

East of the Ouze, at Downham, Stow, Wimshotsham, Cruiuplesham, Bexwell, Ruston, \&c. I 8s. Rise in seven years, one-fourch.

Recapitulation.-.The light sand distrint, as marked on the Mity, I conceive, lets, on an average, at 6s. an acre.

The various ioms at 16 s.

The better sand, I 2 s.

The rich loam, 26 s.

The Marshland clay, $2 \delta$ s.

\section{SECT. III, - TITHES.}

So much has been written on the great national ques. tion of tithes, and thcir commutation, that any general observations are unnecessary. All that can with propriety be inserted here, are the notes taken of the compositions per acre.

At Harleston, 5s. an acre. In the hundreds of Loddon and Clavering, 5s.; some 6.; ; and even 7s. an acre. Average of Fleg hundreds, 6s. marsh excluded. At Hemsby, taken in kind. Martham, \&c. 7s. Happing hundred, 4.5. . to 6s. In Ludham, great tithe, 4 s. 6d.; small, Is. 6d. At Catfield, 6s. At Sutton, 5s. Sorne parishes more, few iess. At Honing, great, 45. 6d. ; small, 15. 6d. Äbout North Walsham, 4s. to 6s. East Ruston and Happshorough, 7 s. Around Westwick, 5s. At Oxnead, 4s. Hevcringland free. At Causton, arable, 4s.; ordinary meadows and pastures, 1s. 6d. At Reepham, grcat and small, 4s. At 'Thurning, 3.. At Briston, sold by aution; and the 
buyer gathers. At Dawling, 3s. Binham, \&ic. $3^{\text {s. to }}$ 45. an acre. Snettisham, and the parishes around, average 4s. an acre. Houghton, \&cc. 4s. Gathered at Hillingdon: $2 \mathrm{~s}$. $6 \mathrm{~d}$. to $5^{\mathrm{s}}$. the common payment in the vicinity. At Snetterton, and the neightouring parishes in general, about $3^{\text {s. to }}$ 4s. an acre. At Attleborough all gathered; and they gave this as a reason for not enclosing their immense commons. At Hingham, 4s. an acre. At Watton taken in kind. At Carbrook 5s. an acre. At Gurs-

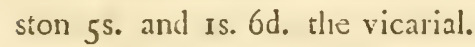

Waterden something under $3^{\text {s. }}$ per acre, grass included: in some parishes, $3^{\text {s. }} 6 \mathrm{~d}$.

In the parishes around East Bilney, $3^{\text {s. and }} 3^{\text {s. }} 3^{\mathrm{d}}$. an acre, on an average. At Goodwick, \&c. 3s. and 3s. 6d. Some so high as 6s. said to be known near Holt.

At Terrington 43. 6d. At Walpole 6s. arable; is.6d. grass. Parishes around Downham 3s. At Wymondham 4s. 6d. Carleton 4s. Bunwell 4s.

North Walsham, 1782, reetorial 2s. gd. and vicarial is. an acre, all round. North and South Reps about $3^{\text {s. an }}$ acre for both. I770, at Runcton, 20d. an acre round.

General Average of 37 minutes, 4s. gd. per acre.

SECT. IV.-POOR RATES.

IT is to be regretted that returns similar to those made pursuant to an act passed in the 16 th year of His present Majesty, have not been lately calied for by Parlianent. If the amount of the rates throughout the kingdom, during the late scarcity, were known, the necessity of some new system of provision for the poor would appear in a light so important, that measures wuuld probably be had re- 
coursc to, for preventing in future a return of simils burthens: not by way of lessening the comforts of the poor, but for increasing then; the grand objection to the present support being its insufficiency to answer the purposes for which it is given: the burden laas been enormous, and the poor not provided for, by means which xwould produce in them industry and economy.

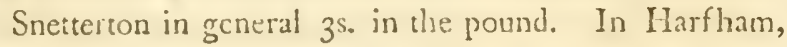
Wilby, Larling, and Eccles, in about the same proportion. The scarcity was met by different exertions. At Attleborough $3^{\text {s. }} 4$ di. for all parochial. At Hingham, in an incorporated hundred, 8s. 10 Ios.; once in the scarcity I 4 s. in the

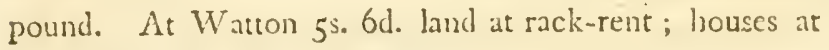
3-4ths. In North Barsham, 4s. in the pound.

Al Goodwick, in 1802 , 2s. in the pound. At Rep-

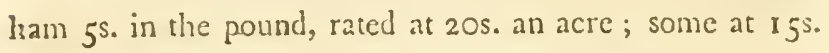
or 16 s.

The hundreds of Loddon and Clavering are incorporated; their house of industry at Heckingham, which has answered greatly. Five years ago, Mr. BuRTon, of Langley, paid I6l. a year: the scarcity doubled, and even trebled it; but now it is reduced to 2.1. and will come down again to 261 .

At Foncet and Tackleston, rates were 145 . in the pound, and now are 9s. to ros. Edgefield 24s. in the pound, for wwo ycars running, now I 6s. and the land not worth 20 s. an acre.

The Fleg hundreds incorporated! rates no where high : about $3^{s}$. in the pound. Marthain, \& c. 2s. to $3^{\text {s. an acre. }}$ Happing and Tunsted hundrcdis incorporated; 4 I parishes: income above 4000 . a year; rates in the scarcity rose, but they are now down again to $2 \mathrm{~s}$. in the pound; but not at full rent; about 2s. an acre: in winter between 3 and 400 in the house; in summer between 2 and 300 . 
At North Walsham, not included in the incorporated nundred, 49. in the pound; Westwick is. At Scotto, last year, 16s. in the pound, rack-rent: now Ios. Coltishal ss. $6 \mathrm{~d}$. in the pound.

Hevingham-
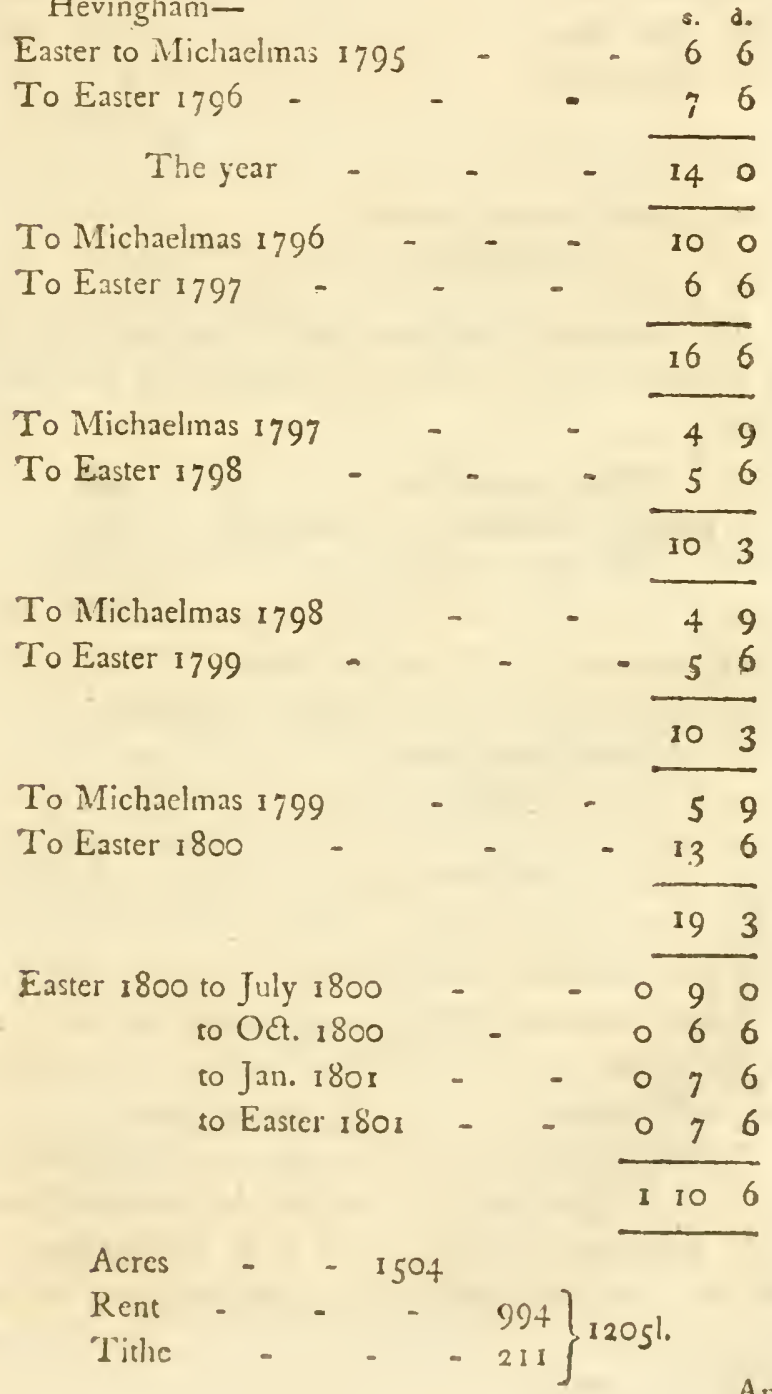
And this enormous rate on a new assessment, including tithe: the addition in the whole 350 .

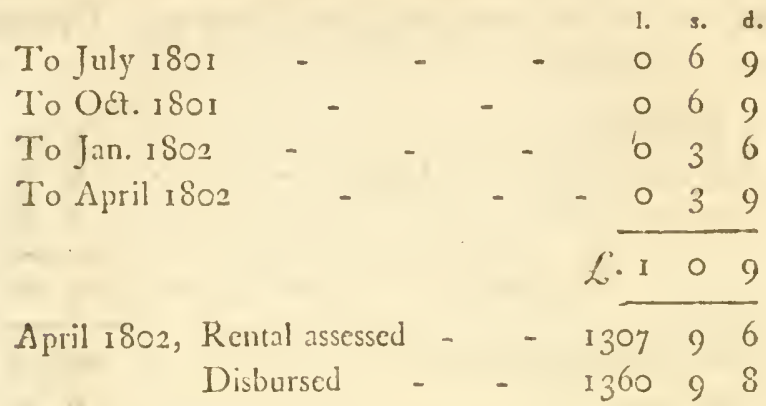

The common enclosed was I000 acres; it fed the cows of the poor, but they were greatly distressed to get winter food.

\section{Total population - $\quad 598$}

Deduct, not belonging to the parish, 83

515

Disbursements $13^{h o l}$. or 52 s. a head.

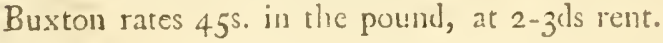

Maslıam, one quarter -
another
half year -

A new valuation, including tithe.

Bcfore the scarcitics, the rates at Causton were 4 s. or 5 \% in the pound. In the scarcity, 11s. or 12s. From Ladyday to Midsummer I SO2, Is. 6d. at rack-reut.

At Reepham and Hackford, 5s. an acre. At Thurning 5s. 64. At Holt ios. in the pound. At Burnhan $W^{\prime}$ estgate, from I 790 to $1800,2 s .6 d$. to 3 s. in the pound fot the year. In 1801 they were 8 s.; and this year (1802) 


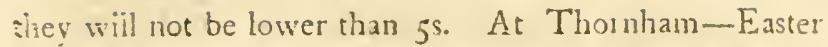
1797 to Easter I 798 , 6s. 61. in the pound, on half rent.

To Easter I 799, 4s. 6d.

To Easter 3800 , Ios. ol.

To Easter isoi, 17s. 6 d.

To Easter I 802,17 s. $6 \mathrm{~d}$.

Rental $126 ;$.

At Holm, last year (1801), 9s. 61. in the pound: this year $5^{\text {s. }} 6 \mathrm{~d}$.

Rates, exclusive of scarcity, at Snettisham, Sxc. 4 s. in the pound, rack-rent. In the scarcicy, some were $\eta^{s}$.

In the parishes around Houghron, 2s. 6d. in the pound, on the average. At Hillington, 2s, in the pound on real rent. At Castle Riseing is. 6d. to 2 s. in the pound; they were higher. At Lynn, they are now Ios. in the pound, and were hately I2s. and laid on stock; they would be near 20s. if on rent only: in the scarcity were 16s. besides great subscriptions. A gentleman in this town has paid 2l. $12 \mathrm{~s}$. in a year for poor-rates, and now (inlahiting the same house) 1001 . At Terrington, in Marshland, 2s. in the pound: were in the scarcity 5s. to 6s. At Walpole, poor 2s. church 6d. surveyor Is. in the pound. Dyke reeve 6d. Land-tax is. 4 d. per acre.

Parishes around Downhain 5: in the pound. Besthorpe, last year, 10s. in the pound, rack-rent: now 5s. to 6s. Carleton 8s. last year.

\section{RECAPITULATION.}

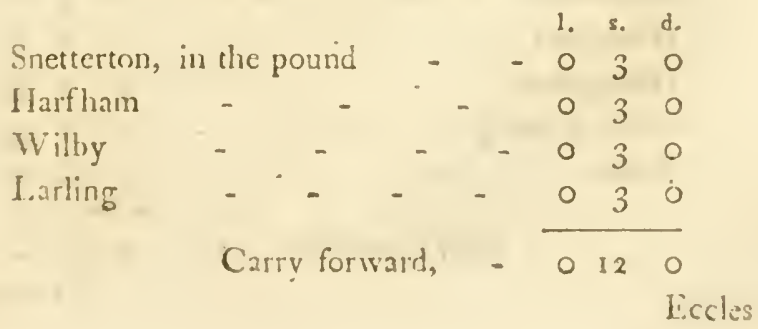




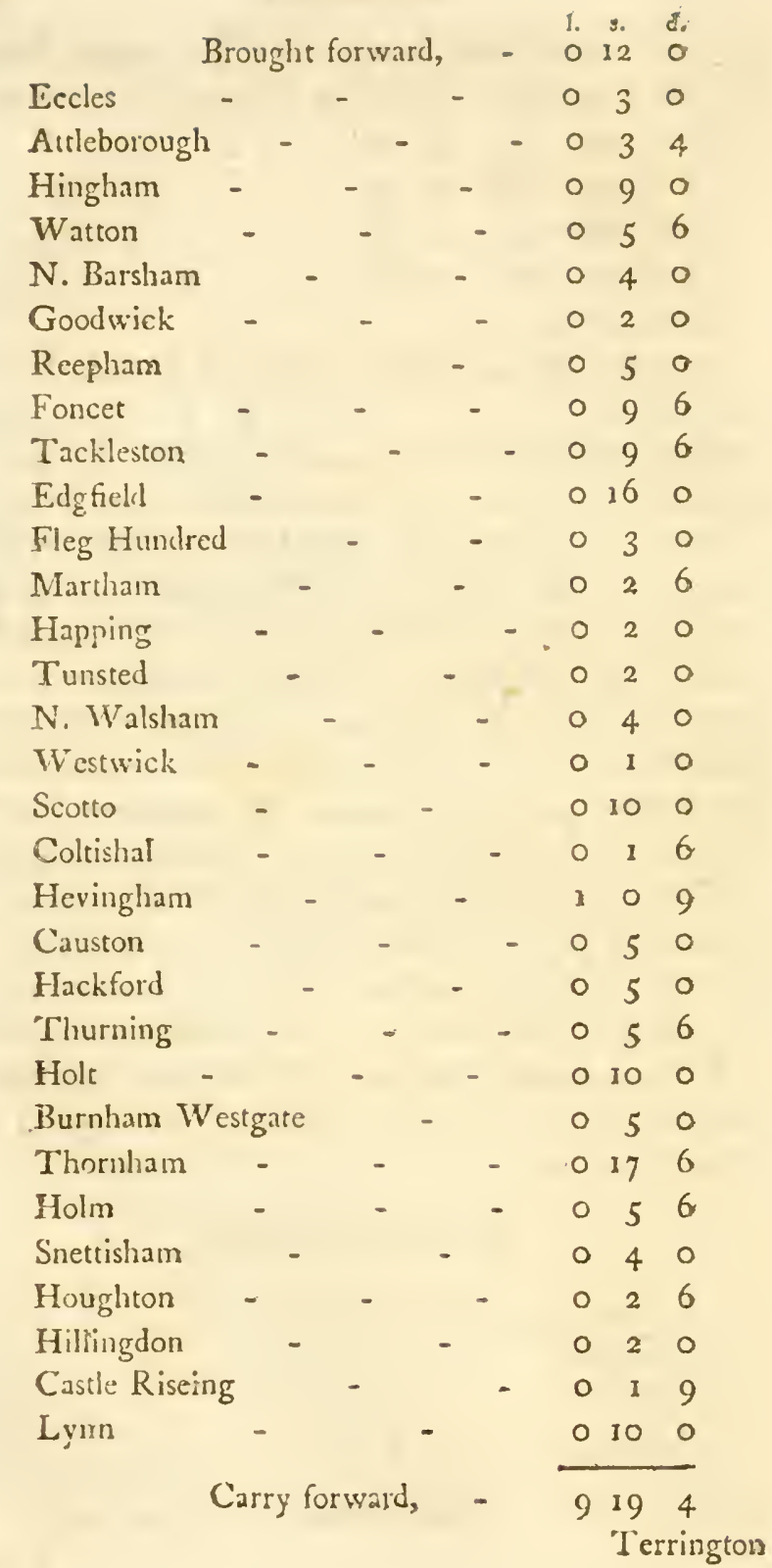




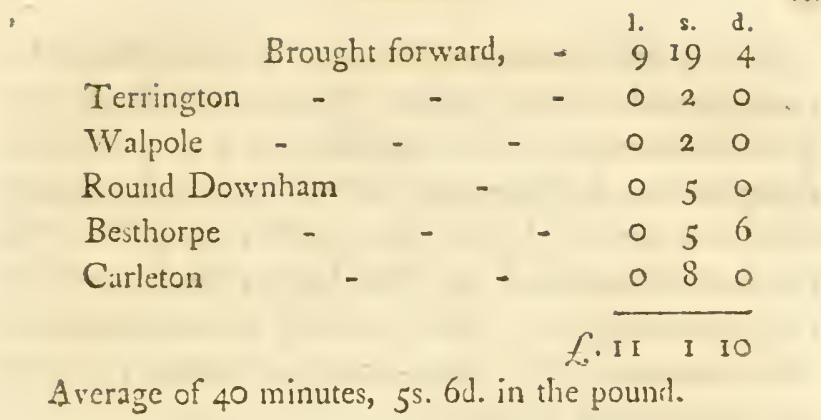

SECT. V.-LEASES.

THE great improvements which for 70 years past have rendered Norfolk famous for its husbandry, were effected by means of 21 years leases; a circumstance which very fortunatcly took place on the first attempt to break up the heaths and warrens in the north-west part of the county. These leases established themselves generally; and were, more than any other cause, powerfully operative in working those great ameliorations of wastes which converted that part of the county into a garden.

To explain gencrally the necessity of long leases, would at this time of day be an idle disquisition. I ncver heard any arguments against them which carried the least weight. Exceptions may, and will occur : in lands which are immediately around the mansion, it may be prudent to grant short tenures; and when a landlord is willing to take upon himself all those expenses which a tenant submits to merely because he has a term of $2 \mathrm{I}$ years, it is obvious that there is no necessity for a long lease; but, in general, it may be held for sound doetrine in Norfolk, that an estate can neither be improved, nor cven held to its formar state of improvement, without long leases. 
Sorry I am to perceive, that contrary ideas scem to be gaining ground in this county; that some landlords will give no leascs, and others only for 7 or 9 years. That the agricultuse of the courtry will suffer in proportion as these ideas prevail, I have not a doubt; and it is a very fortunate circumstance, that Mr. CokE, the possessor of the largest estate in it, adheres steadily to those principles which improved his noble property, never giving a shorter term than 2 I years.

The views of landlords who an otherwise may easily be conceived ; they have a quicker return of those opportunities for advancing their rents than occur with longer terms; and the late scarcities, among their other evils, have added much to this. 'The tenunts' profits (supposed to be greater than in fact they were), glittered in the eves of landlords, who were apt to think they had not a fair proportion of the product. But if such temporary fuctuations are to have weight in regulating the rent of land, the medium short of a corn rent will be difficult to find; and no leases at all are likely to be the consequence: what such maxims would prorluce in Norfolk, are easily conceiver.

But in the main objech of raising rents, confining inyself to the county I treat of, I have great doubts whether an estate, in 43 years, will not be let for much more afrer two leases, than after six. Every sort of improvement, and what is of as much consequence, the common course of the husbandry, in points which no covenants can touch, will tend to improve the land in one case; while, in the other, the tenant will look to the duration of his term before he spends a shilling, or gives an order for a cart or a plough to move. The silent operation of such a constantly influencing motive, will gradually affcet the farm in a manner that must be severely felt; and is a 
perfect contrast to the spirit of animated exertion which pervades every part of the farmer's business, when he looks forward to a long period for his renuneration. The particular notes I made on the subject are few, but merit insertion.

There are more seven years leases about Holt than of any orher term.

Mr. StYLEMAN, at Snettisham, gives leases of 10 or I5 years, of lands in the five-shift husbandry; that is, for two or three courses; and for 12 years, in the four or sis-shift course.

Mr. M. Hizl occupics two farms, one (Waterden) under Mr. CoKE, on a 2 I years lease, and another (Barsham) from a relation, on a 7 years tenure; the former land a lightish sand or gravel; sandy and gravelly light loans: the latter, a deep rich friable sandy loam, on marle, very fine land, and far superior to the Waterden soil ; but he has upon it crops at least equal to the soil; fine corn, that is in its appearance to his credit as a farmer. I was much surprized to find the crops on the Barsham land very inferior; by no means equal to the soil: some very good barley; but some inferior, and no wheat comparable to the crops at $W$ aterden. In such cases, I always expect to find some cross-ctopping has been tampered with; and it turncd out just so-wheat after barley; barley after wheat, \&rc. The circumstance is applicable not so much to the subject of courses of crops as to leases: it deserves the at:ention of landlords; for they never refuse 2 I years leases without their farms suffering. It is true, the farmers suffer also, and nine times in ten lose by their calculation. 
The New Couenants in Letting the Farms of T. W. CokE, Esq. M.P.

Supposing a farm to contain 540 acres arable land:

Shall, and will at all times, keep ard leave ninety acres, part of the arable land, iuid to grass of one or more years laying. $\Lambda$ so ninety acres grass of two or nuore years laying - each to be laid down with a crop of corn, after turnips, and to continue laid two years at least; the time of laying to be computed from the larvest next after sowing the said seeds; and upon breaking up the same*, after January Ist, 1804 , inly be permitted to sow forty-five acres (part theie of annually) with pease, or tares, for seed, to be twice well hoed: other part thereof with tares, for green food, buck-wheat, or any leguminous or other vegetable plant, for ploughing in as manure, or sumınertilling any portion of the remainder.

Shall not sow any of the lands with two successive crops of corn, grain, pulse, rape, or turnips, for sect, (except the above-mentioned pea and tare stubble), without the leave or consent of the said _- , his heirs, or assigns, being first lads ant obtained in writing.

Lands for turnips, four clean earths at least.

The turnips covenanted to be left in the last year, ninety acres to be mucked, so far as the same will extend, and to be paid for by valuation; at the same time a duc regard to be had to the cleanness of the land upon which they grow:

Sheep, cattle, and all other live stock, to be lodged

* The Land intended to be sown with fease should not be till tà years afier the commencement of lease, upon supposition that kerv terant may not be so situated as to have the tirnips (covenarted to be lsit by old lease) completely cleas. 
upon some part of the premises, when consuming the produce of the farm.

Straw, chaff, and colder, to be left without allowance.

Incoming tenant to carry out the crop of corn, not exceeding the distance of ten miles, gratis.

Rent payable forty days before St. Michaelmas (whereever a threshing machine is, or shall be erected), if demanded, by notice in writing being left at the farm-house - to that purpose. 


\section{CHAP. V.}

\section{IMPLEMENTS.}

FOR more than half a century, the implements of Norfolk remained without alteration or addition.; but of late years many and great improvements have been intro duced.

\section{PLOUGHS.}

"The common Norfolk wheel-plough varics from other wheel-ploughs in three circumstances: I. By the high pitch of the beam. 2. By the wheels being, when in work, brought so near to the point of the sharc. 3. By the general lightness of the tool, when compared with some others.

The Hertfordslire plough has a very long beam, with a low pitcls, a circumstance thought in that county to bo essential to stealiness of draught; and when Mir. AR ruthNOT made a wheei-plough for gaining 13 inches depth for the culture of malder, he adopted a long heam, as es. sential to a great power.

Whether the second circumstance in the Norfolk plough; that of the points in the periphery of the wheels which touch the ground, heing so near to the share point, is really a benefit, remains a question, and greatly merits experiment to ascertain.

The general lightness of the plough is probably a merit, when the work is easy; but when we find it not an uncommon practice to load the hody of the tool with a great 
store, to keep it steady, doubts will suggest themselves, that the inathematical construction is erroneous.

But let me recur to the notes.

I fousul wheel-ploughs common through Earsham, Loddon and Clavering heudreds, but a sprinkling of short swing ones, such as are in gencral use, ahout 'Thetford, Brandon, \&xc.

In discourse with Messrs. ThURTELL and Everit, near Yarmouth, they both insisted on the propriety of having the share point and the whcels as near together as possible, as the ease of draught depended much upon it; but admitted that a greater distance would make the plough go steadier, in case of difficulties.

Examining the ploughs of Mi. Francis, at Marthan; from perceiving the beams not mounted so high as in common, he remarked, that the wheelwright made his upon his own plan: he has ploughed much with his own hands, and knows that when they are very high, the plough is apt not to cut a flat furrow, nor to go close at heel, he therefore lowers the beam, and the share is wo feet from the points where the wheels touch the earth; and the beam-ring being in the centre hole, the plough will then go alone without holding.

Mr. JoHNSON, of Thurming, has his beans lower than conmon, and rather further from the share point to the wheel points af contad with the ground; nor does he find that his ploughs are at all jess easy in the draft.

Mr. ENGLAND, of Binkin, thinks that the nearer the share is to the draft, the easicr for the horses; the reason for mounting the bcam.

Mr. ReEves, of Wighton, is of the same opinion, and that the points of wheels and share being near, does not make the plough go unsteady. When he wants to whlim a layer well, he uses ploughs with the tilat rather longer, 
and the heam a littic longer, as well as the share point a little farther from the wheels.

Mr. Hil. remarks, that there are three sorts of ploughwheels used in West Norfolk; first, all of cust-iron; second, wooden hoxes, spokes, and fellies shod with iron; thiru, wooden boxes and spokes, with rims of hammered iron. The first are good and safe while at work, but very apt to break as they move through stony lancs; the third are light, and do well in dry weather; but the second are the most durable; he thinks they last out ten sets of the cast-iron, and two sets of the iron-rims. He uses the cast shares of Miessrs. Gurney and Co.; No. 6 of these he much approves. Cast-iron wheels are ros. $6 \mathrm{~d}$. a pair; wooden ones zos.

They do nor use wheels of unequal height in Norfoik, common in Hertfordshire, \&c. because in one-furrow work (a species of half-ploughing), the whecls would be reversed, the high one run on the land, and the low one in the furrow, as the plough turus the contrary way.

The line of traction, from the tuck of the collar to the heel of the plough, passes through the axletree.

The ploughs are a foot wide at the heel.

In the south-west angle of the county, and from $W y$ mondham, swing-ploughs only are used. On different farms I followed several of them, most of which were j!] construeted; they ride on the nose, to use the farming term, not going close at heel, a defect arising from the shortness of the beam.

It would be improper to omit noticing the high opinion which the great agriculturist, Mr. CoKE, has of the Norfolk wheel-plough; which goes so far as to induce him to be always ready to bet it against any other, on any soil; and he has in several trials been successful. But for want of minutes being kept of such trials, and, above all, 
for want of the force exerted being accurately ascertained, these experiments have not been attended with the conviction which might have been the consequence.

From the preceding minutes it appears, that some doubts have astually been entertained, by very able and practical farmers, on the usual structure of this plourgh; and Mr. REEvE, varying the form in the length of beam and the mould-board, when he wants to sihelm the furrow well (that is, turn it completeiy over), confirms the propriety of our considering the structure of this plough as not well ascertained.

In addition to this observation I have to remark, that in passing through aimost every past of the county, I never omitted any opportunity of following ploughs at work, and noticing their steadiness and other circumstances; and I remarked two very deficient points-they do not ginerally go close at heel; and when $I$ desired the men to quit their hold, and let the plough go alone, not one in twenty woukd do it, even for a single rod; now, a wheelplough must he badly construeted that will not siand this trial, which, for a short distance, is perhaps the best criterion of a swing-plough.

I have an high opinion of the Norfolk plough, when well constructed, and offer these semarks merely to instigate the gentlemen of the county who take any pleasure in rural mechanics, to ascertain these circumstances by experiments which are not diffcult to make, and would rend powerfully to give the wheelurights and blacksmiths more certain rules to work by, than they possess at present.

\section{HARROWS.}

Mr. Jonnson, of Thurning, thinks that it is common to gut too many teeth in harrows: he clusses to have his 
harrows snatch in moving; and always trots the horses when finishing turnips.

Mr. M. Hill, of Waterden, has improved the light harrows of the country, by making them three fourbaulked (or rows of teeth), instead of two six-baulked; the division fits them better to the lands. The teeth all round, as he thinks that square tceth gather more as they move, and impede the work. He inclines the position of the teeth to the iron hooks, by which the whipple-trees are tastencd. .

\section{ROLLER.}

Mi. Priest, at Besthorpe, uses a roller divided in two parts, rising and falling in the centre, for rolling the slopes of ridges. I have seen the same uscful tool at the Rev. Mr. Hill's, in Suffolk.

Mr. CoKE has the inost powerful roller for grass-lands I have seen : it was cast at the Carron foundery; it is 5 feet 6 inches high, and 5 feet 6 inches long; weighs $3^{\frac{1}{2}}$ tons, drawn by 4 horses, and cost 601 . It leaves the surface of grass-land in the order it ought always to be in.

\section{WAGGONS.}

Mr. Denton, of Brandon, has found a consicierable saving by the use of light caravan waggons for two horses abreast, with which he carries a chaldron and half of coals, and other loads proportioned. Every man who reduces the teams of any country, will be sure to do this till he arrives at perfeetion in a one-horse carriage.

Very few waggons are used in Flég, except for road. work; chiefly carts and wizzards. 


\section{CARTS.}

Mr. Overman, of Burnham, made an improvement in his carts, of beautiful simplicity: instead of the toestick, as in the common, drawing out to let the buck tilt up, and deliver the load, it turns in the centre on a pivot, and the hooks which confine it at the ends, being each in a position the reverse of the other,

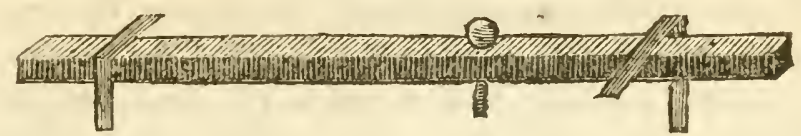

the least motion laterally, frees it, and permits the buck to rise.

A thought of no small value also, is that of chaining the tail-board to the cart. It is not uncommon elsewhere to see the carter, in unfoading, leave his board, and have to go many steps for it; not to mention carelessness in mislaying, and time lost in searching.

Yarmouth, from the singular arrangement of the streets, will not admit common carriages for the domestic purposes of the town. It consists of two large streets, but all the cross-ones (called rows) are so narrow, that a cart more than 3 feet or $3 \frac{1}{2}$ broad, cannot enter them. Necessity, therefore, has happily driven the inhabitants to the best of all vehicles fur carriage, those of a single horse or ass; they are not well construeted, as too great a weight rests on the back of the aninal, from the load being all before the axletree: howcver, the loads they carry are considerablc; seven coombs of whicat are a common load; a hogshead of sugar the same; one man and cart have moved ten score of corn in a day. 


\section{DRILL ROLLER.}

I have at different periods made many inquiries for the inventor of this tool, but could not ascertain it thirteen years ago. Mr. Sillis, of Hartford Bridge, near Norwich, was mentioned to me as a person who had improved it. It is a cylinder of iron, about seven feet long, around which are cutting wheels of cast-jron, that turn, each independenily of the others, around the common cylinder, weighing from a ton to $I \frac{I}{2}$, drawn by four horses, and heavy work. The cutting wheels, being moveable, may be fixed by washers, at any distance, commonly at four inches. By passing over a freshploughed layer, the soil is cut into little channels, four inches asunder; the seed is then sown broad-cast, and the land bush-harrowed in the direction of the drills; thus the seed is deposited at an equal depth. George Earl of ORFORD gave the Writer of this Report one, but the soil was too heavy for it: for breaking clods in a dry season, no tool l ever beheld comes near to it.

They are nuch in use in Loddon hundred. Mr. BurTon, of Langley, put in a great deal of corn thus, and approves the methol so much, that hitherto he has drilled little; but thinks dibbling a vast improvement.

The implement was more commonly used in the county ten or twelve ycars ago than it is at present, for the drill machine has been adopted by many who formerly had a good opinion of this tool.

\section{DRILL MACHINE.}

Mr. CoOKE's drill is very generally used in Norfolk, and I found it every where highly approved. 



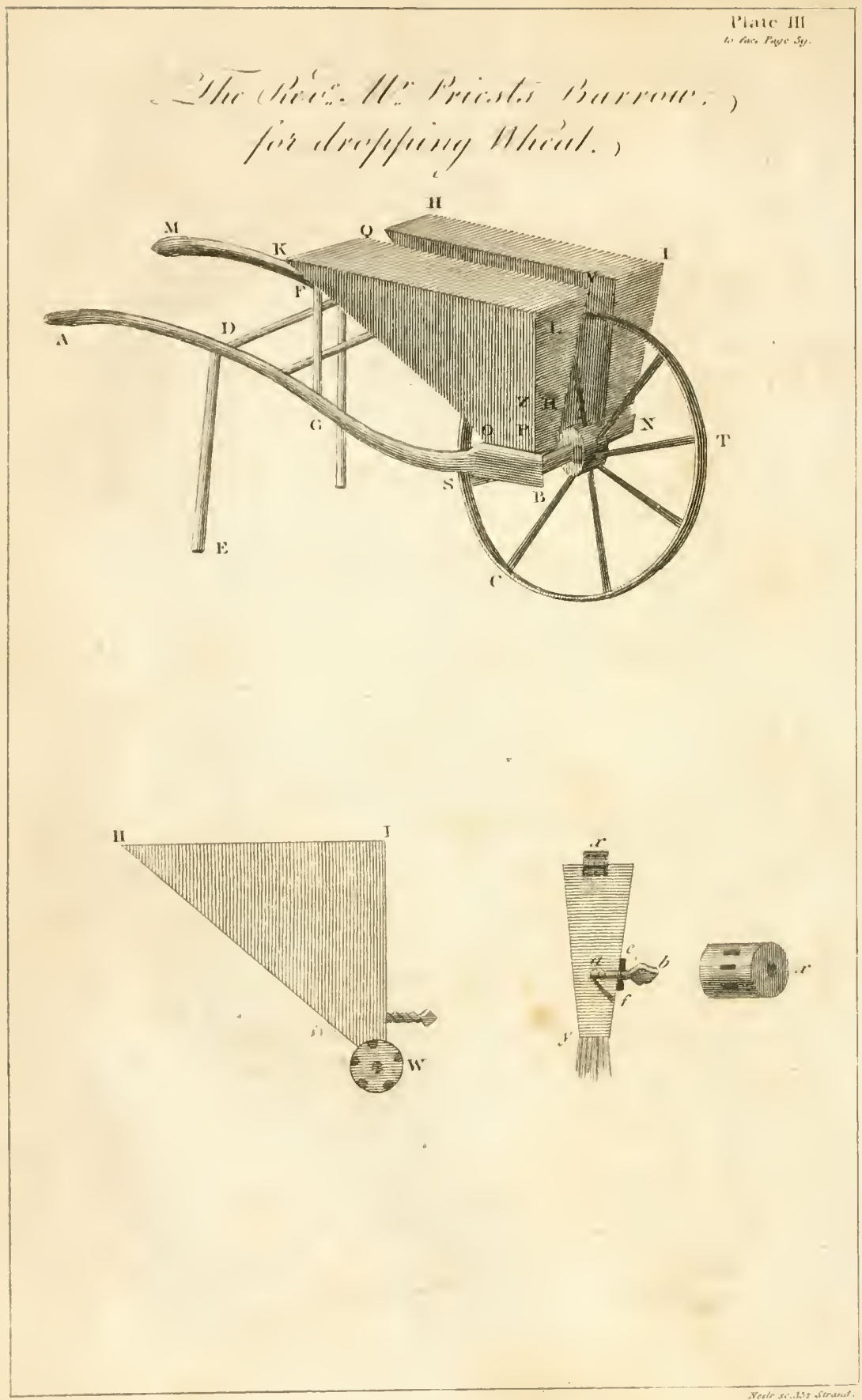


Mr. Farrow, of Shipdam, uses the drill of Mr. STANTON, of Weybread, the shares of which swing separately; but on his land it executes very badly; chokes at $5 \frac{1}{2}$ inches, and the delivery very unequal.

Mr. REEvEs, of Heverland, has a drill machine made by Mr. Ashis, of Blyborough, in Suffolk, which executes to his satisfaction: he has had it three years; price $51.5^{s}$.

The: Rev. Mr. Munnungs, at Gorget, near Derehain, uses only the barrow-drill, which he had originally from the Rev. Mr. LindseY, of Lincolnshire, at present Lord Bishop of KiLlatioe. He finds it excellent for all purposes, and especially adapted for little farmers, who are weak in horses. He has himself only 48 acres of arable land, and 14 of grass; by means of it, on this poor land, he gets 5 comb of wheat, 7 of barley, and 5 of pease; and once had 12.

\section{IIXED HARROW.}

This implement, newly invented by Mr. Cooke, for attaching to his drill machine, has been used this year (1802) by Mr. REEves, of Wighton, who thinks it the best tool he ever saw of the kind.

HORSE-HOES, \&ic.

The following tools, invented or improved by the Rev. Mr. PRIEST, of Scarning, merit the attention of the reader.

No. I.

Is an attempt to delineate the Barrow I used to drop my wheat. [See Plate III.]

$\left.\begin{array}{l}\text { A B } \\ \text { MN }\end{array}\right\}$ the two handles are 4 feet long.

$D E$, one 
$D E$, one of the feet 13 inches.

The diameter of the whecl, viz. $S$ ', 22 inclies.

The dimensions of each hopper:

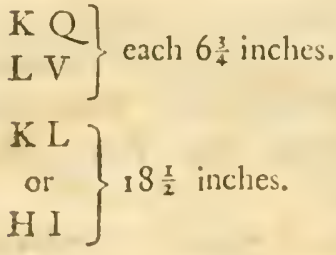

L P 72 inclics of which, $x y$, makes 4 inches;

or and the length of the hairs of the brush is one I W inch.

$\mathrm{XY}$, is the form of the brush, nade noveable upon a hinge at $Z$, so that the hairs of the brush may aet by pressing against a cylinder at the bottom of the hopper, and suffer more or less seed to drop from it, according as it is pressed against the cylinder by the screw a b. This screw is 3 inclies long, fastened to the brush $x y$, and by acting through a female screw $e f$, fixed at the end of the handle $A B$, viz. at $c$, presses the brush against the cylinder.

The cylinder $\mathrm{x}$ is in length two inches; its diameter $2 \frac{3}{4}$ inches. It has twelve cups indented in its surface: each cup $\frac{x}{4}$ of an inch in diameter. The cylinder is fixed upon the axis of the wheel, and revolves with it at the bottom of the hopper, so as to carry' the wheat out of it by the cups on its surface.

The hopper is supported upon the handle A B, at PO, and by the stay $F \mathrm{G}$.

No. II.

Is an attempt to delineate my. Double Barrow- [Sec Plate IV.] It is only the Barrow No. I: with two wheels instead of one; the two wheels and the axle-tree 


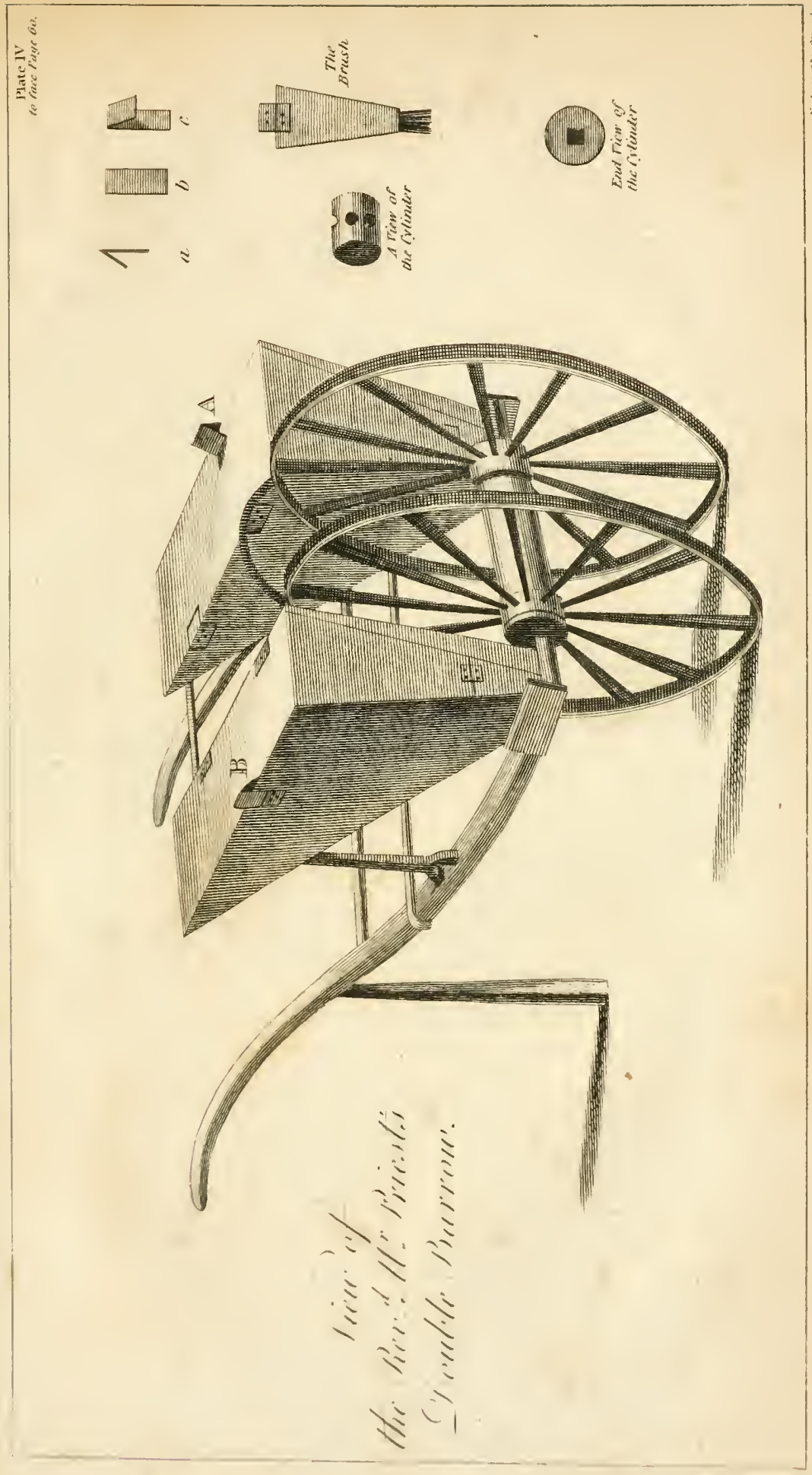






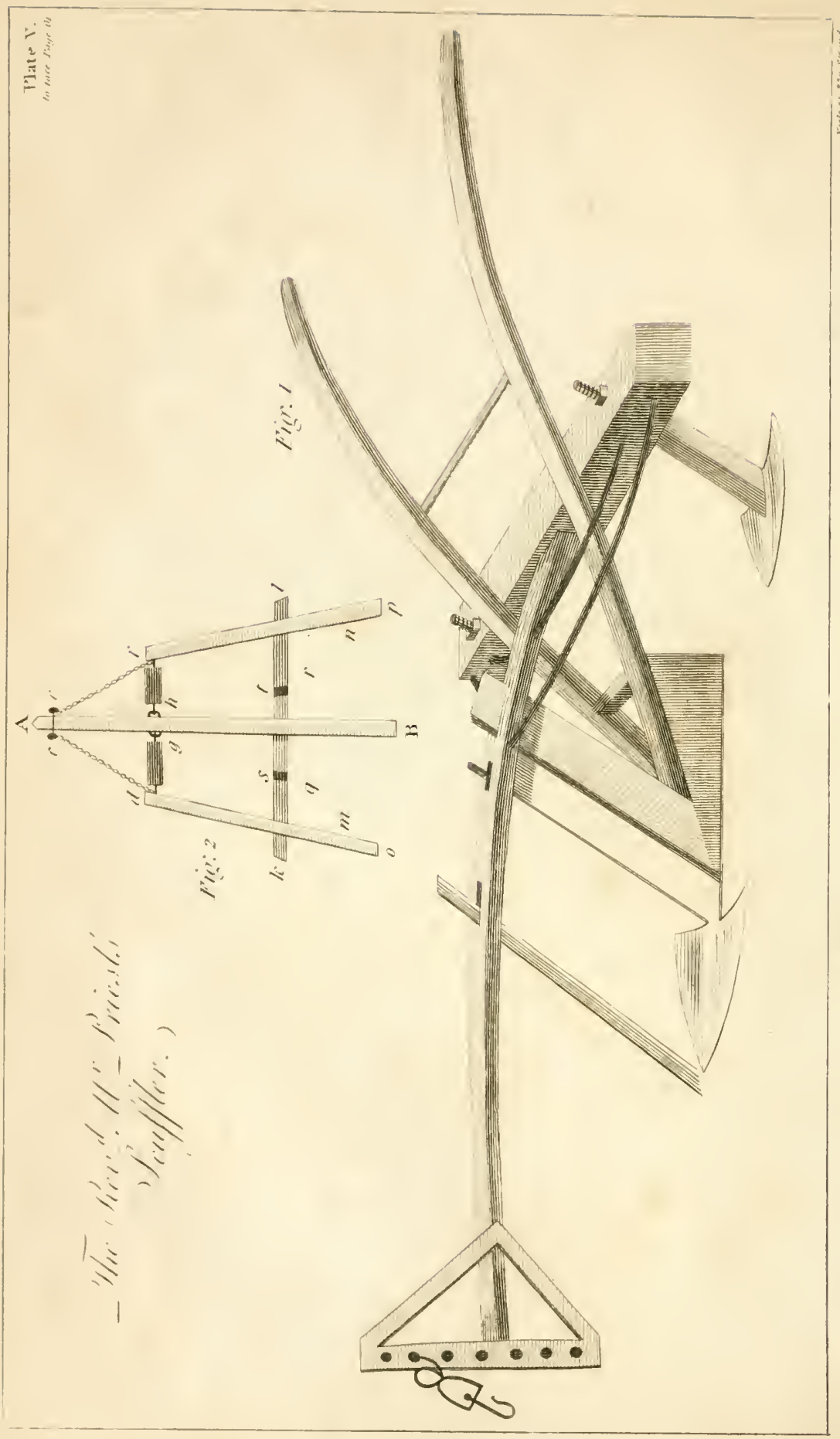


zre united like the wheels of what are called Yarmouth carts.

$a b c$ are different views of the springs $A B$, against which the lids of the hoppers fall, and are fastened; a is a side view, $b$ the back, and $c$ a front view. This barrow, and No. I. I formed myself from a single barrow, which I saw when I accompanied my friend MUNNings into Lincolnshire, to visit the Rev. and Hon. Mr. LindSEY.

Noti.-The flat piece of iron $k 1$, lies parallel, and the plates $d g, f h$, perpendicular, to the horizon.

No. III.

My Scufler [See Plate V. Fig. 1.] is an instrument formed from a double-breasted foot-plough : thus-I took off the breasts of the plough, and had a share larger and flatter than the original share made. I then fastened, at the end of the beam of the plough, a cross heam of wood, 3 feet long, 4 inches broad, 4 inches thick, and at the distance of $12 \frac{1}{2}$ inches each way from the centre of this cross-beam, inserted two coulters, each 12 inches long, 3 inches broad, and $\frac{3}{4}$ of an inch thick on the back, but reduced to 3 -8ths in front; and into these coulters, at the bottom, I rivetted two shares, of nearly the same size as the first share, which was 9 inches broad, but these two only 8 inches. The cross-beam 1 strengthened by two iron reins, or bars, fixed to the cross-beam, and also to the beam of the plough, thus:

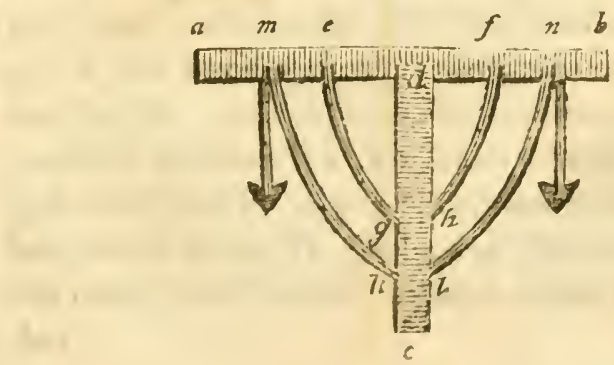


c d, a part of the beam of the plough.

$a \mathrm{~b}$, the cross-beam.

$\left.\begin{array}{l}e g \\ m k \\ n l\end{array}\right\}$ iron reins, or bars to strengthen the cross-bean?.

The coulters which are fixed into the cross-bean, do not stand perpendicularly, but inclining, as the coulter at the head of the plough, thus they are fixed into the cross-beam by a screw, a b, and a nut, $\mathrm{c}$ d.

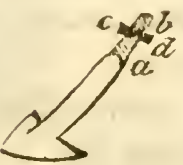

The acivantage of this scufler above any that 1 have seen is, that it is used with two horses only. It does the work of more than two ploughs, as the three shares cut nearly the width of 30 inches, whereas two ploughs would cut only 24 inches. My farm consists of heavy land, as well as land of a mixed soil.

\section{No. IV.}

Next I am to describe my Hoe-Plough, which I formed purposely to scarify and hoe wheat on four-furrow work. At the time when I visited Mr. LrNDSEY, I saw a double inould board foot-plough, which he sent to $\mathrm{Mr}$. MUNNings, and from it I had one made like it. Upon the beam of this hoc-plough I have fixed two scarifiers (or hoes, as I want them), [See Plate V. Fig. 2.]

$A B$ represents a part of the back of the bean of the plough; $A$ the head, and $B$ the tail.- $c$ e is a small iron bolt, with a nut and screw at one end, fixed into a cap upon the beam, to be taken out at pleasure. At each end of this bolt is fixed a chain, $\mathrm{c} d$, e f, each two feet long, and hooked to plates of iron, $\mathrm{d} g, f h_{1}$. These plates, $d g$, $f$ h, are flat, and $8 \frac{1}{2}$ incheslong, $2 \frac{\pi}{2}$ inches broad, and moveable upon staples fastened into the beam: upon the ends 
cnds of these fiat plates of iron are fixed two pieces of wood, d o, f p, parallelopipeds, 2 feet 3 inches long, $2 \frac{\mathrm{T}}{2}$ inches broad, and $2 \frac{I}{2}$ thick; moveable at $d$ and $f$ by hooks (upon the wool of the same breadth as the iron plates), and eyes (upon the iron plates). The points $q$ and $I$ mark the distances to which the expanding mould-hoards are opened, viz. ahcur 10 inches from one to the other.

At $\mathrm{m}$ and $\mathrm{n}$, distances beyond the points $\mathrm{q}$ and $\mathrm{r}$, are cu: grooves through the woolen paralielopipeds, for the scarifiers and hoes to be fixed in.

$k l$, is a flat piece of iron, 3 feet long, and 2 inches broad, $\frac{1}{2}$ an inch thick, passing through grooves in each parallelopiped, and in the grooves through which it passes are screws to fasten it. This iron does not communicate with the beam of the plough. At s and t, points on each side the beam, are hung weights, such as may he necessary to make the scarificrs or hoes do their work properly.

I do not describe my scarifiers and hoes, because they are nearly the same as are used upon all instruments of this kind.

RAKE.

The hand-wheel rake of Fleg is an excellent implement for both hay and corn: it is to answer the purpose of the common hav-rake.; about fout feet long in the rake, and the two wheels of nine inches dianeter, so fixed that the seeth are kept in any position, at the will of the holder.

\section{THRESHING MILL.}

Mr. Johnson, at Kempston, was so obliging as to order horses into his mill, that I might view it. To me it appears to be one of the best I have seen; if not the very best of the larger machines. The movements are 
uncommonly smooth. It requires from six to eight horses, six men, and one woman; threshes, without any question, much cleaner than the flail, and, without any doubt, cheaper. To bring it to its present perfection cost Mr. Johnso.s much tinse, attention, and expense ; but as he was determined to carry his point, he never stopped till it worked to his mind; and having completed it, the repairs have been quite trifling. He auributes the common complaints of their being always out of order, to original errots or inattention in the construction. The arrangement is cxcellent, for disposing of the chaff, colder, straw, and corn, at once, in their respective places, without any confusion or removals; and it takes up a very sinall part of a barn. It was built by Mr. Wigful, of Lynn.

Mrr. Drozler's, of Rudham ; built by Messrs. WICsUL, 1799:

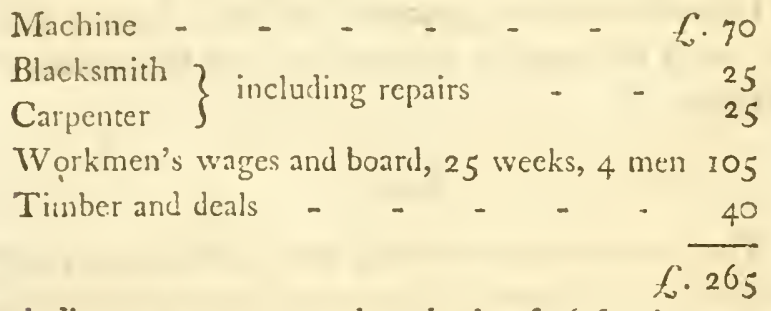

Including a granary over the wheel, of 26 feet by 24 .

The threshing-mill, with dressing addition, would have cost about $120 l$.

A repair now in hand will cost rol. at least.

$$
\text { EXPENSE OF THRESHING. } \quad f \cdot s . d \text {. }
$$

Four strong horses, at $5^{\text {s. }} \quad$ - $\quad$ - I 00 One boy 10 drive - $\quad$ - $\quad 0 \quad 10$

Carry forward - $\mathcal{L}_{\overline{1}}$ I 0 Three 


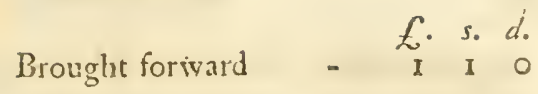

Three women, to hand and untie

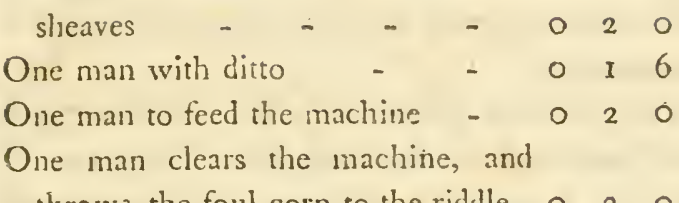

throws the foul corn to the riddle 020

One man to carry away straw - $\quad 0$ I 6

Repairs and oil, calculated at ro per

cent. on 120l. 121.

At 60 days work - _ _ _ $\quad 040$

f.I I4

The mill will thresh 40 comb of wheat in eight hours, 50 conih of barley, 60 of oats and pease, and threshes pease better than any thing. The same men, while the horses bait, dress the corn with the winnowing machine.

40 comb of wheat, 34 s. at Iod. a comb.

50 comb of barley, $3 f^{\text {s. }}$. at $8 \mathrm{~d}$.

60 comb of oxts and pease, 34 s. at $6 \frac{\pi}{4} \mathrm{~d}$.

$\mathrm{He}$ is confident that the machine threshes much clearier than any flails. Every man that has examined the straw, admits this without a shadow of doubt; and barley equalIy with any other sort. One objection however, is, breaking the straw for thatching; but this is none for cattle. It makes the chaff good; but leaves no corn in the colder-not a grain. He has not tried threshing with the mill any straw from flails; but that there is a saving, he has no doubt.

Common threshing was never less than Is. per comb ; may be reckoned for wheat, on an average $1 \mathrm{~s} .3 \mathrm{~d}$. for this NORFOLK.] 
neiglıbourhood; for barley, 6d. the general price, but $\%$ d. the average now; onts and pease, 6d. On an emergency, there is a power of getting corn out much quicker than withuut a machine.

Mr. Whiting, of Fring, has a large threshing-mill, built by an engincer from Scotand, Mr. Fordyce. It cost him 200l.; is worked by 6 horses; threshes 24 comb of wheat in the day, 55 of barley, and from 63 to 84 of oats. It has five beaters on the drum-wheel, and the fluted segment of a cylinder which covers the drum in two pasts, with an unfluted plate between them, which is raised or sunk by a short lever; this as a guard against stones getting in. In znother circumstance also it is singular; there is a long platform, with a rolling cloth bottom; the whole raised or sunk at pleasure, for delivering the corn, across the floor space of the barn, from the goff in which the corn is stacked, to the other end in which the mill is built; which saves much libour, and works to his satisfaction.

$$
\text { EXPENSE OF THRESHENG. } \quad f . s . d \text {. }
$$

Four men; one to feed, one to hand the corn,

swo at the straw, and one to drive - 070

One boy at the straw - $\quad \ldots \quad-0010$

One woman - - - - - 008

Six horses - - - - -0120

I 06

Repairs have been considerable, but 10 per cent.

a large estimate, or 20l.: if it works 80 days, this is

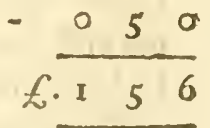

This may be called Is. a comb for wheat, $5 \frac{\mathrm{T}}{2} \mathrm{~d}$. for barley, and 4 d. for pease and oats. As to its performance, 
Mr. WhITING is well satisfied with it; no flails in conmon management equal it for cleanness, and with barley as well as all other sorts of corn.

The horse-wheel is upon a different construction from the common ones, working by a cogged-wheel of small diameter below, instead of above the horses; and the communicating spindle under their path; but $\mathrm{Mr}$. W HitiNG says it is hard work.

Mr. Styleman, of Snettisham, has a very capital mill, which cost $300 \mathrm{l}$. It is worked by 8 horses, and threshes in a day of 8 hours 120 comb of barley, pease, or oats, and 80 of wheat. It is afterwards dressed in the hand machine.

EXPENSES. $\quad$ f. s. $d$.

Two men to feed, alternately _ _ - 040

One at the chaff - $\quad$ - $\quad$ - 020

One at the stravy $\quad$ - $\quad$ - $\quad \ldots \quad 0$ I 6

Four women - $\quad$ - $\quad$ - 040

Two drivers - $\quad$ - $\quad$ - $\quad 020$

0 I3 6

Eight horses - $\quad$ - $\quad$ - $\quad$ - 140

Repairs, ro per cent. 301. : if So days work, it

is, per diem,

$$
\frac{070}{2.246}
$$

The wheat is therefore threshed at $6 \mathrm{~d}$. per comb, and the other sorts of corn at $4 \frac{\mathrm{I}}{4} \mathrm{~d}$. As to clean work, it does every sort of corn far cleaner than the generality of tasking, and barley equally with the rest.

Mr. Coke, of Holkham, has a very large machine, which cost about 600 . Besides thresling, it grinds corn, works two chaff-cutters, and breaks oil-cake. 


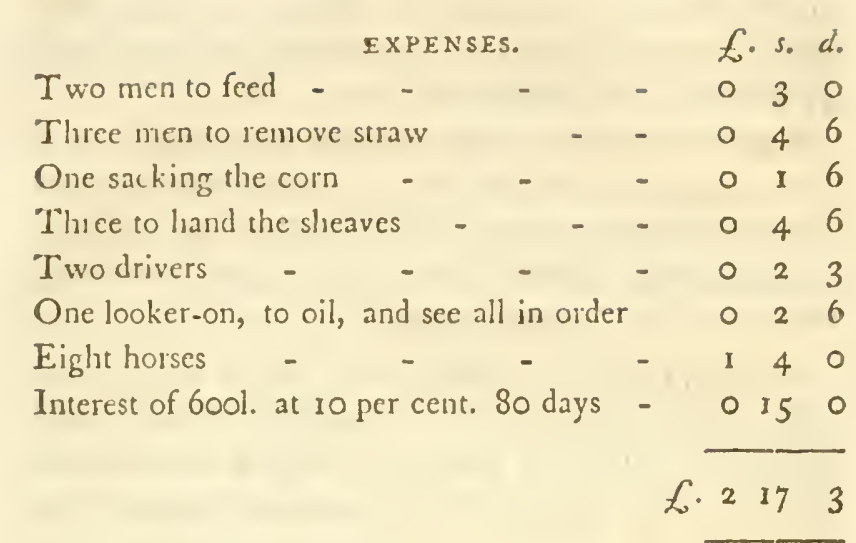

Its work has not been tried with sufficient accuracy with any thing but wheat, of which it threshes 64 combs a-day: it has sacked I 3 combs in an hour; but no rule, as it was a mere exertion: 64 combs, at 52s. $3 d$. is $9 \frac{3}{4} d$. per comb. The common price is Is.; here, therefore, is a saving; no fails equal it for cleanness in every sort of corn; and it dresses better than any method whatever that has been yet tried. It occupies too great a space in one of the finest barns in England: it prevents the stowing of near 300 quarters of barley. The more of these machines I see, the inore I am convincel of the saving that would attend the moveable stacks 1 proposed in the Annals.

Mir. BEvan, of Riddlesworth, built one by a person from I,eith, in Scotland: it cost rool The following is Mr. DAY, the bailiff's, calculation of its work, compared with common flails. 
TO THRESHING BY FI:AILS.

E. S. d.

Forty combs barley, at $7 \mathrm{~d}$. come to - I 34 To dressing of ditto

E. 54

Fifty combs oats, at $6 \mathrm{~d}$.

Dressing ditto, at is. per score

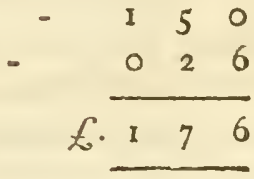

Forty combs rye, at gd.

- I 100

Dressing ditto, at Is. per score

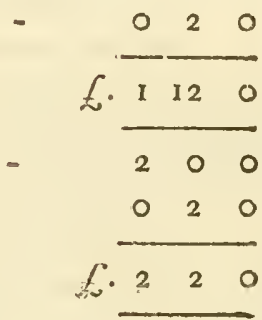

Forty combs wheat, at is. Dressing ditio

f. \begin{tabular}{llll}
0 & 2 & 0 \\
\hline
\end{tabular}

THRESHING BY MILL:

Forty combs barley take eight horses, at

2s. 6d. - - - - \$ 00

Ten men, at is. 6d. each - - o is 0

To dressing ditto, five men one day 076

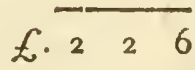

Barley costs more by I 7 s. 2 d.

Fifty combs oats take eight horses, at 2s.6d. I $0 \circ$

Ten men, at Is. 6d. each - 0150

To dressing ditto

$$
-\frac{076}{2.226}
$$

Oats cost more by 15 . 
Forty combs rye take eight horses, at 2s. $6 \mathrm{~d}$. $\begin{array}{ccc}\text { I } & \text { s. } & \text { d. } \\ & 0 & 0\end{array}$ Ten men, at Is. 6d, each - - o r 50 To five ditto, at 1s.6d. one day dressing $0 \quad 7 \quad 6$

£. 226

Rye costs more by ros. $6 \mathrm{~d}$.

Forty combs wheat take eight horses - I 0 ?

Ten men, at is.6il. each - - O I5

Five ditto to dressing - $\quad-076$

£. 226

Whear costs more by $6 \mathrm{~d}$.

The flails thresh much cleaner, as the thatching of the stacks proves; so that if this article were brought to account, it would go much further against the mill. Nor is here any thing reckoned for repairs, which have always amounted to from 61. to 81. a year: to which add 5 l. interest of capital, and the worthlessness of bad threshing mills will be sufficiently obvious.

1802.-Mr. BEVAN has had the machine eight or ten years; and thinks the material object is the power of getting out a crop to sell for seed, or to employ the men and horses in a wet lay; but is clear that if he had it not, he would not build one, unless he was certain of its threshing barley cleaner than his does.

MIr. FARRow, of Shipdam, has built one of these mills on his new farm at Sayham: Mr. WIGFUL, of Lynn, was the enginecr: it is worked by four, five, or six horses, requiring also three men and three women and a boy. It threshes with that strength 40 combs of pease in a day; 40 of oats; 30 of barley; and 20 of wheat; but the dressing is not more than half effected, so that the com- 
mon machine is necessary to finish it, by which a man and woman will dress 60 combs a day. It threshes all grain very clean; barley as well as the rest; and in a year and quarter's nearly constant work, has not demanded any repairs. Yet upon the whole Mr. F. is not well satisfied with it. On examination, I found it very aukwardly placed: the delivery of the corn is in too confined a space, close to a wall, so that men must attend to take it away; the straw is thrown out against a door into a yard, when it cannot all be wanted, and no sufficient receptacle for the chaff: the appearance is as if the machine was hooked into a building, and not the building raised for the machine. One is never to see an end to ill adapted farm buildings.

Mr. Goocr, of Quidkenham, has a threshing-mil built by BURREL, of Thetford. It works with two horses; and threshes all sorts of grain to his satisfaction. barley includeu.

Mr. REEvEs, of Heverland, has a threshing-mill, which is, I think, nearer to perfection than any other I have seen: it is made by Mr. AssBy, of Blyborough, in Suffolk; works with two or three horses, and cost 100 guineas. I found it at work, threshing oats: it does for barley, as well as for any other grain, threshing 32 combs in a day, of $7 \frac{1}{2}$ loours; more of oats; 40 of pease, and 30 of wheat: its day's work of wheat, threshed the day lyefore I was there, was 3 I combs, standing sacked in the barn. It varies considerably in the beating-drum cylinder from the others I have seen, it being of a much larger diameter, and has I I beaters. Mr. ReEves is perfectly well satisfied with it; and the men all agreed that it does the work much better than the flail. It has had no repairs in the threshing one crop; nor does he, from the simpli-

$$
\text { F } 4
$$$$
\text { city }
$$ 
city of the movements, expeet that it will be in that respect the least expensive.

Mr. BECK, of Castle Riseing, has a threshing-mill built by Mr. WIGFUL, of Lynn; he works it with four, five, or six horses, three men and three womell. It threshes 32 combs of wheat, 64 of barley, or 80 of pease, in a day; cost 200 guineas, and has had very trifling repairs in three years, not $3^{1}$. and threshes barley as clean as any other grain. I saw it at its work, and clean done.

\section{CHAFF-CUTTER.}

Mr. BuRtor, of Langley, has so high an opinion of cutting hay into chaff, that he gives his horses nothing else; and finds that a bushel weighing $14 \mathrm{lb}$. will go as far as 3016 . given in the comınon way.

Mr. KERRICH, of Harleston, has attached one of SALMon's cliaff-cutters, which cost him twenty-two guincas, to his malt mill; and as he had to fix it in a chamber near to the stable, for the chaff to fall at once into the chaff-room, which joins it, and the whoie building detached from the mill, he very ingeniously contrived a communication of the power, under the pavement of the yard, by a universal joint. The engine cuts 40 bushels an hour, with no other expense than feeding; and the addition of labour to the horse so small, that a man's force will take the whole pressure off. He finds the saving, by giving hay in chaff only, to amount, at the lowest computation, to one-fourth. He also applies the engine to cutting green rye, mixed with an equal quantity of hay, which makes a most fragrantly sweet food, with attention not tokeep it after cutting more than six or seven hours. Two acres of rye thus used in soiling, last twenty

horses 
fhorses three weeks: succeeded by winter tares, and these by summer tares.

\section{STEAM-ENGINE.}

Mr. Gooch, of Quidjenham, in Norfolk, having a water-mill which was sometimes unemployed for want of water, erected a steam-engine contiguous, at the expense of about 500 . The stove which heats the boiler, is so contrived as to burn coal to coke for his malt-house. One man attends both the engine and the cinder oven. It was, in the drought of 1800 , of singular use to the whole country, for wind and water having both failed in a great measure, corn was brought from ten miles distance, to be grourd by this engine: he has two pair of stones to the water-wheel, and two pair to the engine. The power, that of twelve horses.

The first steam-engine erected in Norfolk for merely agricultural purposes, and, for what I know, in England, is one now erecting at Haydon, by Colonel BuLLER. He has contraeted for the sum of 600 . It is to dio the work of ten horses; to work a threshing-mill that slıall thresh and dress six lasts a day: it is to grind corn also, and cut straw; to grind nine bushels of wheat with one bushel of good Newcastle coals, of $\delta_{4} l \mathrm{lb}$. weight, and this with all the other works going on at the same time: the Colonel to find timber. Last year his hay and straw cutting cost above 7 ol. therefore liute doubt can be entertained of the plan answering.

Under the head Implements, I must not conclude without mentioning a person of most extraordinary mechanical talents. Mr. JEx, a young blacksmith at Billingford, at 16 years of age, having heard that there was such a machine as a way-measurer, he refeded by what machinery the result could be prodticed, and set to work to con- 
trive one: the whole was his own invention. It was done, as might be expected, in a round about way, a motion too accelerated, curredted by addirional wheels; but throughour the complexity such accurate calculations were the basis of his work, that when finished and iried, it was perfecily correct without alteration. His inventive talents are unquestionable. He has snade a machine for cutting watch pinnons; a depthening tool; a machine for cutting and finishing watch-wheel teeth, of his own invention; a clock barrel and fuzec engine, made without ever sceing any thing of the kind. He male a clock; the teeth of the wheels cut with a hack saw, and the balance with a half round file. He has made an electrical machine, and a powerful horse-shoe magnet.

Upon being shewn by Mr. MUNNINGS a common barsow-drill, the dejivery by a notched cylinder, he invented and wrought an absolutely new delivery; a brass cylinder, with holes, having moveable plugs govcrued by springs, which clear the holes or cups, throwing out the seed of any size with great accuracy; and not liking the application of the springs on the outside of the cylinder, reversed she wholc; and in a second, now making, placed them most ingeniously within it. He has not yet failed in any thing he has undertaken: he makes every thing himself: he models, and casts them in iron and brass, having a powerful wind-furnace of his own invention. It is melancholy to see such a genius employed in all the work of a common blacksmith. However, he is only 23 years of age, and 1 am mistaken greatly, if he does not ere long move in a much higher sphere. This is not a country in which such talents can long be buried: a mind so occupied has had no time for vicious habits; he is a very sober honest young man, and bears an excellent character.

CHAP. 


\section{CHAP. VI.}

ENCLOSING.

THE number of parliamentary enclosures that have raken place of late years in Norfolk, and the remarkable improvements which were known to have flowed from them, made it an object of considerable importance to ascertain the result, as far as it could be procured by visiting the respective places, or obtaining information from the Commissioners, or other persons interested in the work thus effected. With this view I visited many of them, and gained the best intelligence to be procured concerning the rest. The following alphabetical table contains the result of these inquiries, with such additions, not immediately relative to enclosing, as circumstances induced my attending to.

\section{ACLE, I 797 .}

2uantity.-About 350 acres of common, 300 of it grass ; the great object laying lands together: no half-year land.

Rent.-Now 20s. and upwards.

Corn.-Increased.

Sheep.-None before, nor at present: not 100 in the parish.

Corws.-The same; but few; they might kecp more: perhaps more bullocks.

Course.-Now, 1. Turnips; 2. Barley; 3. Seeds, one year; 4. Wheat; 5. Barley or oats; a middling crop of barley, 
barley, Io comb an acre; wheat, average 9 comb; oats 20 comb sometimes, average 14 ; turnips, all for bullocks, and generally in stalls.

Improvement. - The chief improvement is the bringing malle from Thorpe, near Norwich, by water; notwithstanding which conveyance it costs 4 s. 6d. a cart-load, and

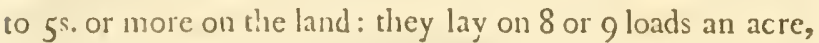
which has more effect than 40 or 50 of what they call clay, though that has a good effervescence with acids. The marle works sooner, and mixes better. The marshes are very extensive, and have for centuries yielded much stuff, as rushes, \&c. for making dung, and thus contributed to the great fertility of much of this country. More than 8 or 9 loads of marle is prejudicial for a time; a farmer in the neighbourhoud tried 12 loads, and did mischief at first.

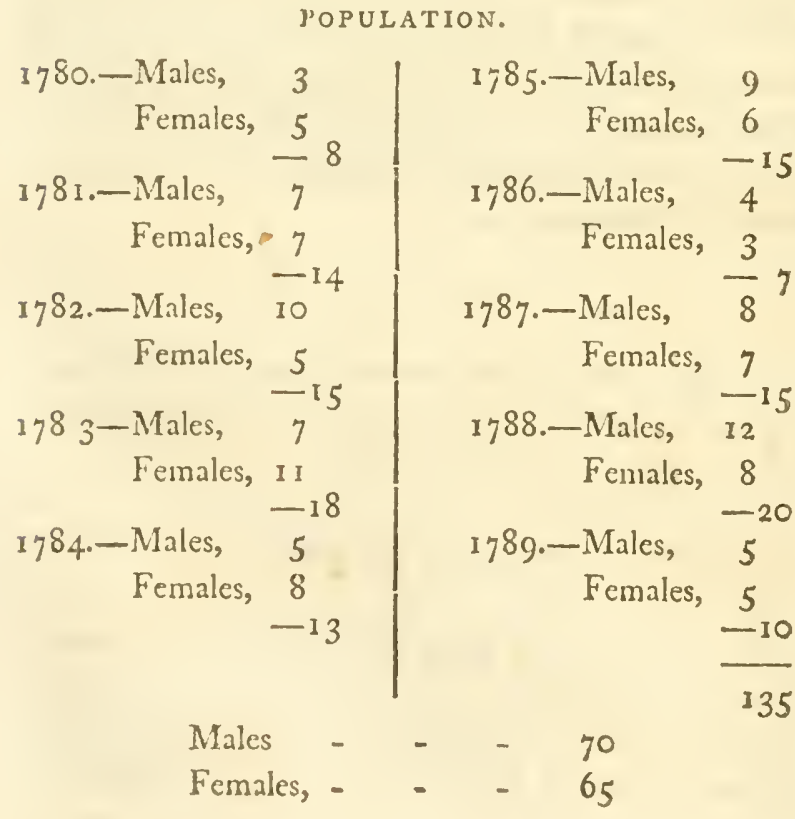




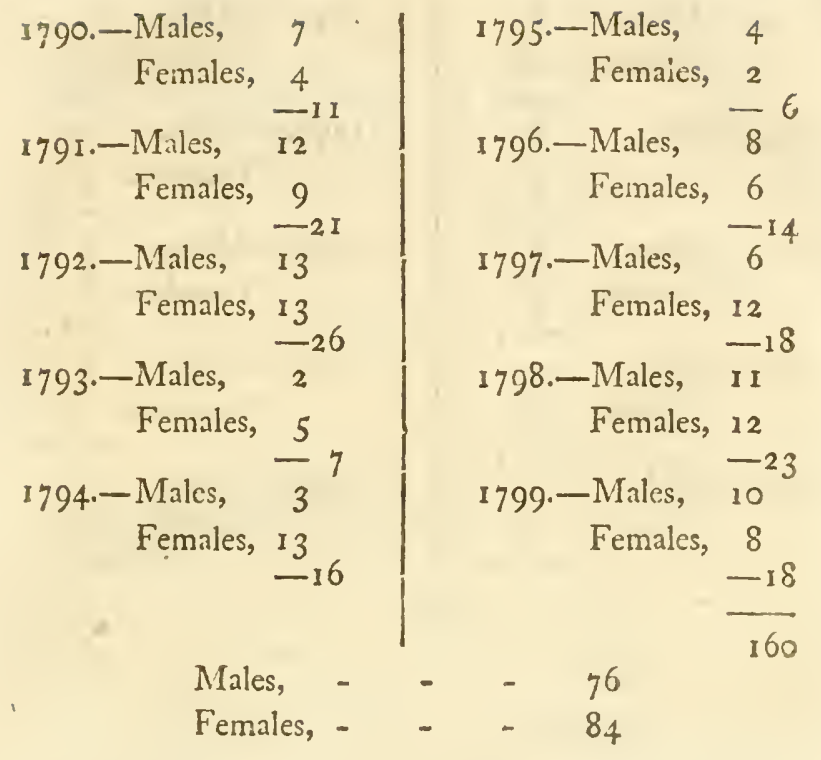

BURIALS.

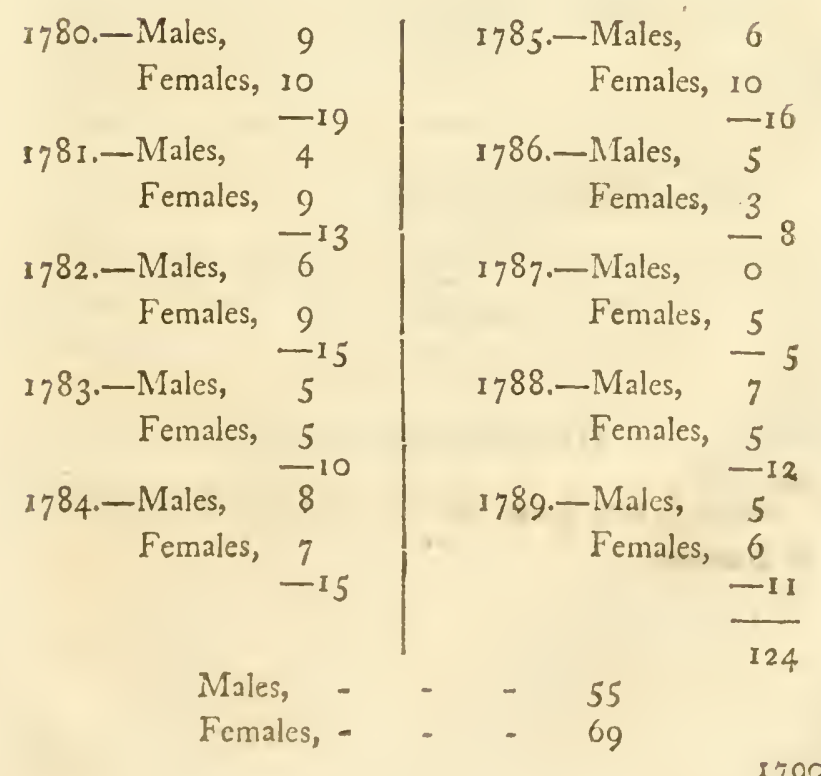




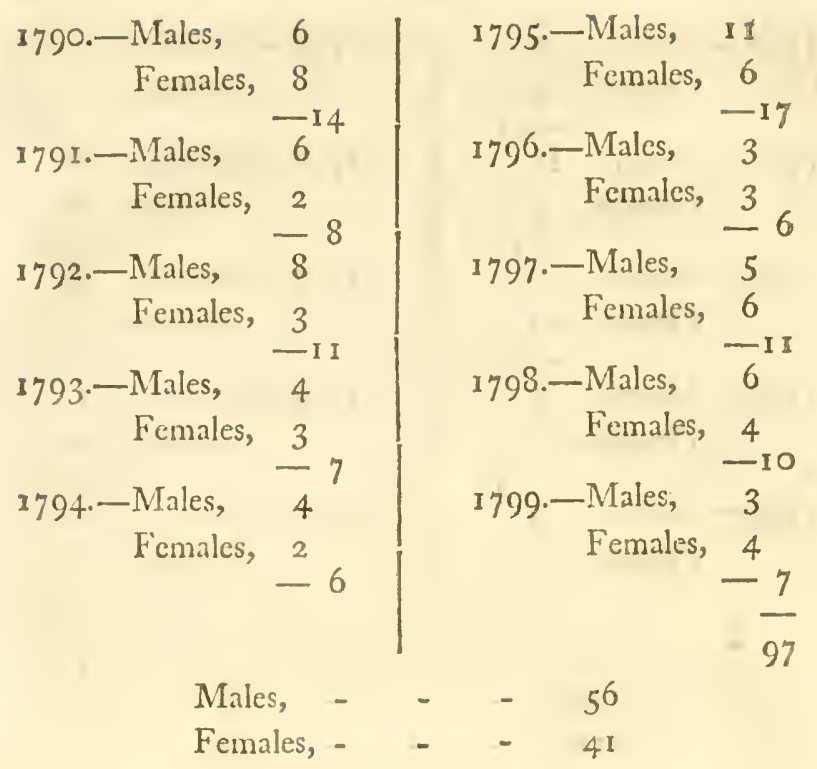

First period. Baptisms, - - $\quad$ - I35

$$
\begin{array}{lll}
\text { Burials, } & - & - \\
\text { Increase, } & - & -
\end{array}
$$

Second period. Baptisms, - - $\quad-\overline{160}$

Burials, -
Increase, -

ASHILL.-ENCLOSED I 785 .

Soil.-A very good mixt soil; scarcely better corn-land in Norfolk. 
Acres. Value.

2yanity - Whole yearland - $893 \quad$ L. 610

Half year ditto $\quad-819 \quad 468$

Land in dispute $\quad 329 \quad$ Igo

Commons $\quad-933 \quad 550$

$2974 \quad 1818$

Roads

20

2994

Rent.-Quality price 581. I8s.

Fifty-four Proprietors.

Course-Now, r. Turnips; 2. Barley; 3. Clover, one year; 4. Wheat; 5. Sometimes Barley.

Cows.-Have diminished.

Poor.-39 acres of common for the poor; fed by all whose occupation is under 51 . a year; and 32 let, and applied in coals. The former of no benefit, from abuses. They rake in stock, and call it their own, but none of the real poor enjoy the benefits.

Tithe.-Remains subject, and pays 5s. and 5s. 6d. an acre.

Corn.-The produce of corn has increased to an extraordinary degree. They raise upon the best land wheat of 8 combs an acre; oats 20 combs; and barley 14.

Improvement.- Has been in general great: the land, which before enclosing was worth but little, has been sold so high as 401 . an acre. 


\begin{tabular}{|c|c|c|c|c|c|c|}
\hline & & Baptisins & Burials. & & Baptisms. & Burials. \\
\hline 1770 & - & I 5 & - & 1785 & 23 & $-\quad 14$ \\
\hline 1771 & - & 14 & 4 & 1786 & 13 & 14 \\
\hline 1772 & - & 7 & - & 1787 & 18 & - \\
\hline 1773 & - & 12 & - & 1788 & 14 & - \\
\hline 1774 & - & I 2 & - & 1789 & 16 & - \\
\hline 1775 & - & 15 & 9 & 1790 & I 8 & - \\
\hline 1776 & - & 13 & 5 & 1791 & 11 & 12 \\
\hline 1777 & $\therefore$ & 19 & - & 1792 & 14 & - \\
\hline 1778 & - & 10 & $-\quad 16$ & 1793 & 26 & II \\
\hline 1779 & - & T6 & $-\quad$ I 5 & I 794 & 11 & - \\
\hline 1780 & - & 15 & - & 1795 & 19. & - \\
\hline 1781 & - & 14 & - & $179^{6}$ & 23 & - \\
\hline 1782 & - & IO & - I7 & 1797 & 17 & - \\
\hline 1783 & - & 15 & $-\quad 14$ & 1798 & 16 & - \\
\hline 1784 & 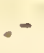 & 8 & $-\quad 13$ & 1799 & 18 & $-\quad 10$ \\
\hline & & 195 & 148 & & 257 & 129 \\
\hline
\end{tabular}

First period, is years before the enclosure,

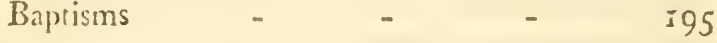

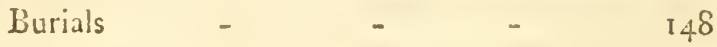

$$
\begin{aligned}
& \text { Increase - - } 47
\end{aligned}
$$

Second period, I5 ycars since the enclosure,

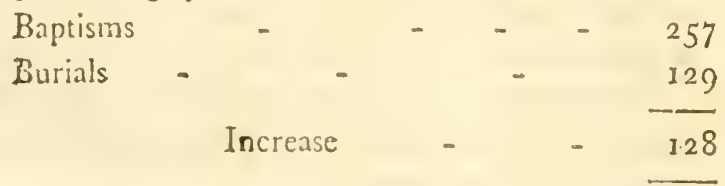

$$
\text { BANHAM-ACT I }\rceil S q \text {. }
$$

Quntity. - About 1000 acres: 600 of heath and common; no open arable.

Soil.-Very goid strong land; clay bottom. 
Rent.-Quality price from I $5^{\text {s. }}$ to $25^{\text {s. }}$

Corn.-All turned to arable.

Shccp.-6 or 700 sheep were kept; now not more than 300 ; but much better: soine farmers breed, and some graze. The common was much subject to the rot.

Corus.-Nearly the same as before.

Tithe.-Remains subject.

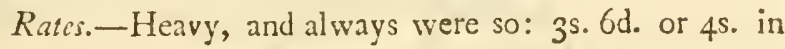
the pound.

Expenses.-There was much road to make, and cost above 2000 l.

Pcor.-An allotment of $3^{\mathrm{c}}$ acres of turf fen, for fuel. No complaints of any injury. The herbage of the 30 acres is given among them.

Improvement.-All clayed; and where wet, hollow. drained.

\section{POPULATION.}

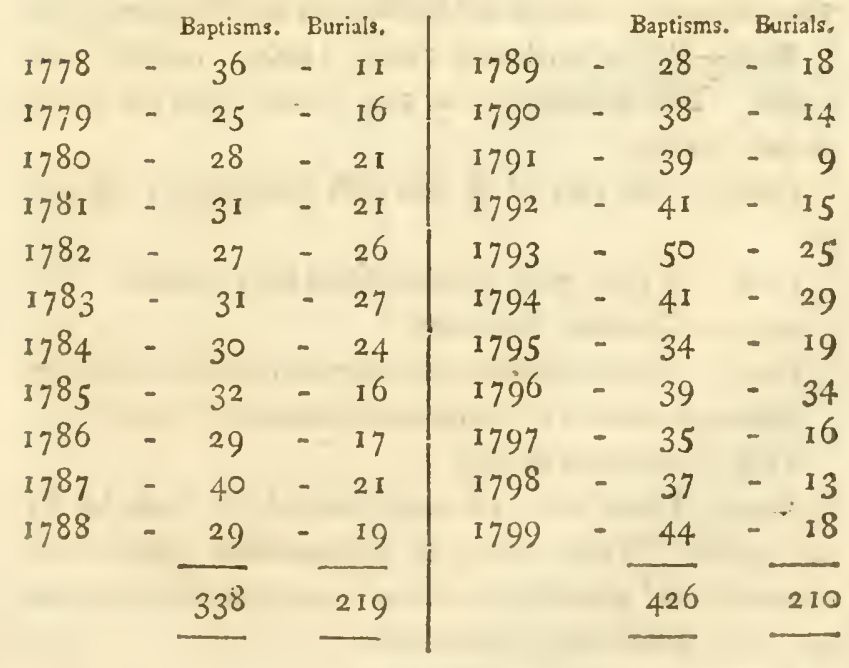




\begin{tabular}{|c|c|c|c|c|}
\hline First period. & Births & - & - & $33^{8}$ \\
\hline & Burials & - & . & 219 \\
\hline & Increase & - & - & II \\
\hline Second period. & Births & - & - & 426 \\
\hline & Burials & - & - & 210 \\
\hline & Increase & - & - & \\
\hline
\end{tabular}

BARTON.-ENCLOSED 1774.

(5) zantity.-Open fields, 2626 acres; commons and wastes, 784 ; total, 4087 .

Soil.-Much of it strong land; but some on chalk.

Rent.-Now about 2000 .

Tithe.-Land assigned, about one-seventh.

Corn.-Increased much.

BINTREY AND TWIFORD.-FNCLOSED $1795^{\circ}$

Soil.-Mixed soil ; turnip and wheat land.

2uantity.-About 1950 acres; open fields 661 acres; 309 cominons; the rest old enclosures, or whole year land.

Rent.-Before enclosing ahout I 200l.; quality rent, I 5601 . The commons let at 20s. which were not worth 2s. 6d, before.

Course.-On part of it five shift husbandry; on part six.

Corn.-A very great increase from the common.

Shecp.-Certainly increased.

Cows.-Not diminished; as some part remains in pasture.

Improvement.- The commons drained and clayed.

Tithe.-Remains subject.

Poor.-There were 26 acres allotted for fuel, let by she parish. There were 46 commonable rights; the whole divided according to value: very few litile proprietors; but small occupicrs suffered.

Exprnses. - r gocol. : paid by rate. 


\section{BIRCHAM (GREAT).-ENCLOSED I740.}

I attempted to procure information here, but every body was dead who lived at the time, except the old ParishClerk, who remembered nothing more than working at the fences. Corn must be increased.

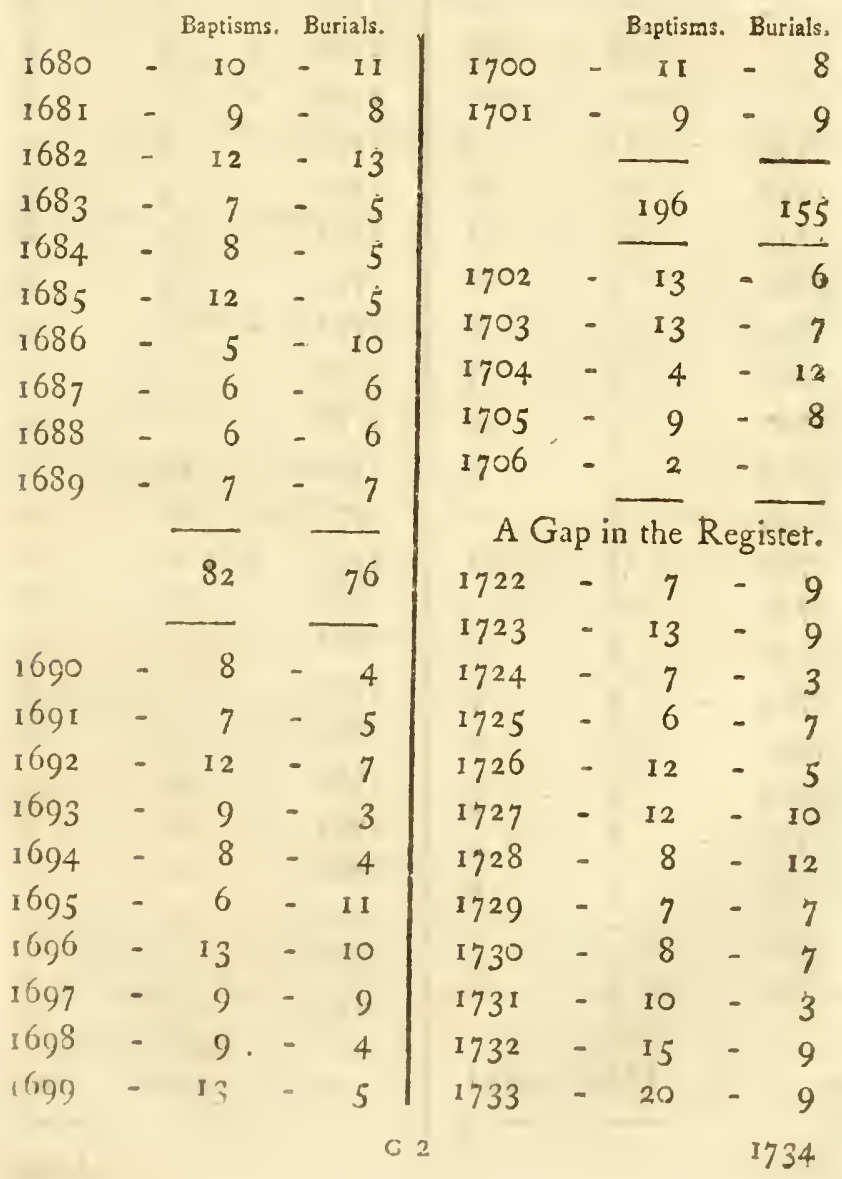




\begin{tabular}{|c|c|c|c|c|c|}
\hline & Baptisms. & Burials. & & Baptisms. & Burials. \\
\hline 1734 & 8 & 7 & 1760 & 4 & 4 \\
\hline 5735 & 17 & -10 & 1761 & - & 8 \\
\hline 736 & 9 & $-\quad 11$ & 1762 & - & 6 \\
\hline 1737 & 15 & -9 & $176_{3}$ & 6 & $-\quad 1 I$ \\
\hline $173^{8}$ & 12 & -2 & 1764 & 4 & I \\
\hline 1739 & 19 & -5 & 1765 & 3 & 6 \\
\hline 1740 & 9 & -14 & I766 & 7 & - \\
\hline an & 214 & $\overline{148}$ & $\begin{array}{l}1707 \\
1768\end{array}$ & $\begin{array}{l}8 \\
6\end{array}$ & - \\
\hline 1741 & & & $\begin{array}{l}1769 \\
1770\end{array}$ & $\begin{array}{l}6 \\
8\end{array}$ & - \\
\hline $174^{2}$ & - $\quad$ I3 & $-\delta$ & $177 \mathrm{I}$ & - & - \\
\hline $17 \div 3$ & - $\quad 17$ & 7 & I 772 & 7 & - \\
\hline 1744 & 9 & 2 & 1773 & 5 & - \\
\hline 1745 & 5 & -8 & 1774 & 5 & - \\
\hline 1746 & 8 & 5 & 1775 & - & 5 \\
\hline $17+?$ & 9 & 2 & 1776 & 12 & 6 \\
\hline 1748 & - & 7 & 1777 & I5 & 8 \\
\hline 1749 & - & -2 & 1778 & - & 6 \\
\hline 1750 & 12 & $-\quad I I$ & 1779 & - & 6 \\
\hline $175^{1}$ & 6 & & 1780 & 15 & 7 \\
\hline $175^{2}$ & 8 & $-\quad I$ & 1781 & $\sim$ & 12 \\
\hline 1753 & - & -6 & 1782 & - & 8 \\
\hline 3754 & 12 & -7 & 1783 & I5 & 8 \\
\hline 1755 & 2 & -5 & 1784 & 14 & 9 \\
\hline $175^{6}$ & 8 & -4 & 1785 & 16 & - \\
\hline 1757 & 6 & $-\quad 9$ & I 786 & 12 & 7 \\
\hline $175^{8}$ & - & -7 & 1787 & 12 & 7 \\
\hline 1759 & - & 0 & I 788 & - & - \\
\hline & & 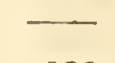 & I 789 & 34 & \\
\hline & 173 & 101 & & $25^{I}$ & 203 \\
\hline
\end{tabular}




\begin{tabular}{|c|c|c|c|c|c|c|c|}
\hline & & aptisms. & Eurials. & & & Baptisms. & Burials. \\
\hline 1790 & - & 5 & 6 & I 797 & - & 9 & - \\
\hline I 79I & - & I3 & I I & $179^{8}$ & - & 9 & - \\
\hline I 792 & - & 11 & 5 & 1799 & - & II & - \\
\hline 1793 & - & 13 & 6 & & & - & \\
\hline 1794 & - & 10 & $-\quad I 2$ & & & 102 & 6 \\
\hline 1795 & - & 12 & - & & & & \\
\hline 1796 & - & 9 & 5 & & & & \\
\hline
\end{tabular}

Baptisms in 19 years immediately preceding

the enclosure

Burials

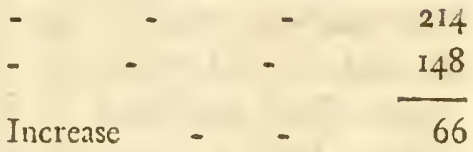

Baptisms in 19 years immediately following

the enclosure

Burials

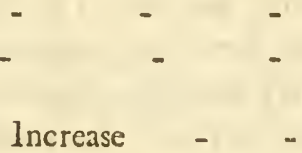

175

iot

74

Ten years from 1780 to 1789 :

Baptisms

Burials

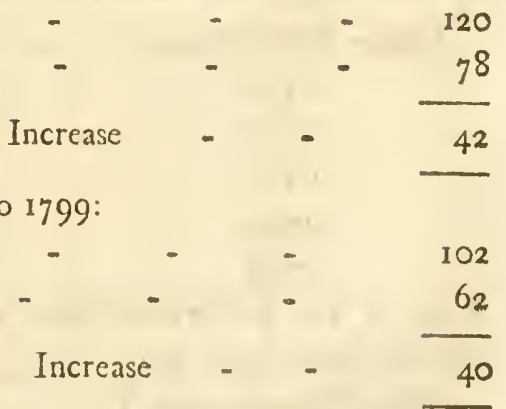

The whole of this account is unfavourable: the enclosure lessened Baptisms so far as these data extend ; and in the last 10 years there are 18 fewer baptisms than in the to preceding. These are circumstances not uncommon ○ 3 
in this part of Norfolk, and they deserve an attentive investigation. I know knothing to which to attribute it, except the parishes being occupied by one farmer; or perlaaps by two, or at most three, who unite and prevent the settlement of poor, by employing hands only from more populous places. In such a case the local deficiency is made up elsewhere.

BRANCASTER.-ENCLOSED $1755^{\circ}$

2uantity. - About 2350 acres, beșides salt-marshes, of which 960 were breals; 1020 common field; 210 halfyear land, 160 old enclosures.

Soil.-Good sandy ioam.

Rent.-What it was before the enclosure is unknown; now about 2500 . a year. In 1792 , there were 1570 acres sold, containing 940 arable, 75 fiesh marsh, and 555 salt marsh, which were then rented at 500 . a year.

Poor.-Very well off; Barrow-hills, a common of 65 acres, allotted to them; and each Jwelling-house has a right to keep two cows or heifers; or a mare and foal; or two horses; and also to cut furze.

Rates.-Disbursements for the poor :

\begin{tabular}{|c|c|c|c|c|}
\hline 1760 & & & 6.91 & 0 \\
\hline 1770 & - & - & II9 & 0 \\
\hline$I_{7} \delta_{7}$ & - & - & ISo & 0 \\
\hline 794 & - & - & 203 & 0 \\
\hline 100 & - & - & 337 & 0 \\
\hline
\end{tabular}

A rate of $2 \mathrm{~s}$. in 11. raises 2011 ; this last year the rates therefore were above 3 s.

Tithe-_Remains subjeot.

Corn.-Before the enclosure it was in an open, rude, bad state; now in five or six regular shifts. 
POPUX.ATION.

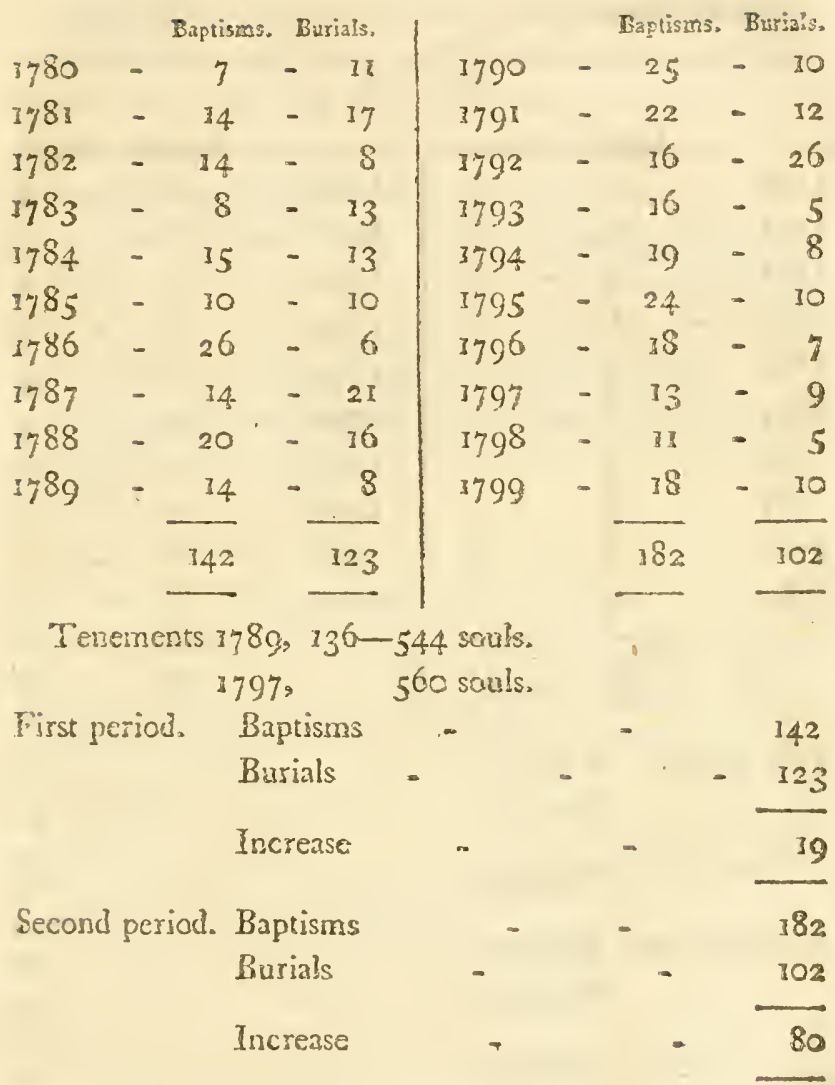

In the last ien years, I in $3^{I}$ born; I in $5^{6}$ died.

BRESSINGHAM AND FERSPIELD.-179S.

2uantity. - $A$ bout 800 acres of common.

Rent.-Will be 18s. some worth 3 os.

Corn.-All corn.

Sliccp.-Will lessen.

Corss.-More will be kept.

G 4

$P_{\text {col: }}$ 
Poor- Never cut any fucl on the common: no ailotnent.

Kates.-About $5^{\text {s. }}$

BRINTON.

\begin{tabular}{|c|c|c|c|c|c|}
\hline & Eaptisn & ms. Burials. & & Eaptisms & Burials. \\
\hline 1780 & - & -3 & 1790 & I 3 & 3 \\
\hline $178 I$ & 10 & 3 & 1791 & - & 7 \\
\hline 1782 & - & 3 & 1792 & - & 2 \\
\hline 1783 & - & 7 & 1793 & - & 3 \\
\hline 1784 & - & 8 & 1794 & - & - \\
\hline 1785 & - & 5 & 1795 & - & 4 \\
\hline \pm 786 & - & 7 & 1796 & - & - \\
\hline 1787 & - & 2 & I 797 & - & - \\
\hline 1788 & - & -8 & I 798 & - & - \\
\hline 1789 & - & -6 & 1799 & - & - \\
\hline & 70 & $5^{2}$ & & 79 & 39 \\
\hline \multirow{3}{*}{\multicolumn{2}{|c|}{ First period. }} & Baptisms & - & - & 70 \\
\hline & & Burials & - & - & $5^{2}$ \\
\hline & & Increase & - & - & I 8 \\
\hline \multirow{3}{*}{\multicolumn{2}{|c|}{ Second period. }} & Baptisms & - & - & 79 \\
\hline & & Burials & - & - & 39 \\
\hline & & Increase & - & - & 40 \\
\hline
\end{tabular}

B ROOK.- 1800 .

2uantity. -200 acres of common; no open field ; all will be ploughed, except 40 acres; the value will be above 20 . ; quality price, I5s.; never paid any thing but to jobbers and idle fellows. 
OLD BUCKENGAM.-ACT I790.

Guartity. - Near goo acres of poor comınon, some wet, the rest sandy and gravel; a little good, that the aA operated upon. No open field arable.

Rint.-Quality, price 5s. to $25^{\text {s. }}$. Now I 5s. and much raised since enclosing. All now, $15^{5}$.

Corn.-All, except 100 acres, converted to arable.

Shecp.-Very few kept before; certainly increased.

Cows, \&c.-Lessened, perinaps two-thirds; but as much butter as before; other kinds of cattle increased.

Improvements. - The soil not adapted to the common ones.

Tithe.-Free before.

Rates.-About 2s. except in a year of scarcity.

Expenses.-Roads included, above I 500 l.

Poor.-Had Ico acres of fen allotted for fuel; the herbage lets for 12l. a year; had, as at Carleton, a double portion, and set out near their houses; nobody suffered or complained; very few under $5^{l}$. a year kept cows; they have not been injured in any degree whatever : for fuel, are better off than before; as no draining was done to the fen, it is not under any regulations.

\section{BURNHAM NORTON.}

This parish was instanced to me, as a proof that the nominal number of cows kept before enclosing, was a mere fallacy. There is a salt-marsh common, of 15 acres, which, if embanked, would not let at $5_{5}$. There are 24 cows kept on it by the common-right cottagers; they have no other land; no hay; no turnips; no means of winter support; no enclosures belonging to them. It is not known that they do, or can buy liay or turnips. How the cowș are supported is an enigma; bur, as in summer, there 
is not fecl harilly for a sheep, it may easily be supposed what the 2.4 cows yichld.

Such was the account I received in the ncighbourhood; but the circumstances seeming extraordinary, I went to the place itsclf for further information, and there I was told a rather diffesent account: that the number of cows was 17 ; that they had another stnall common besides that alluded to; that Mr. FOLEY, the farmer of the parish, sold them hay and straw for their cows; that he did not disapprove their keeping cows, and that the poor were better contented, and better off here, and at Brancaster, than in any parish near them. This the second attempt; I shall make a third, by seeing Mr. Fole y himself.

Called; but not at home.

$$
\text { CANTLEY AND HASSINGHAM. - } 1800 .
$$

2uantity.-600 acres of common; no open fields; 100 acres of it to till; the rest marsh.

Rent.-Increased from $5^{\text {s. to }} 16 \mathrm{~s}$.

Shecp.-No sheep; but will have some.

Corvs.-Will be increased; and grazing also.

Corn._-Will be greatly increased.

\section{CARLETON.-ENCLOSED $1777^{\circ}$}

2uantity.-About 3000 acres in all: enclosed about 1200 , chiefly common.

Soil.-Sandy loam; good mixt soil, upon a clay bottom. Rent._Old enclosed land, 15 s. to 20 s. before the enclosure; very little open field; new rent of enclosed conmon, $x 5^{\text {s. to }} 20$. quality price.

Corn.-Greatly more corn produced since than before; it is the best corn parish in the neighbourhood: the 1200 acres all converted to corn, and very little has been laid down: neariy half more corn than before. 
Sheep. - About 1000 sheep were kept on the common before; now not above half; they buy lambs and fatten them, having changed their system to grazing: the sheep before were much subject to rot, and were very ordinary ; now very good.

Corws. - As many as ever, or rather more, and have a considerable return of fat beasto, as turnips are now largely cultivated.

Horses. - Are increased a third, in consequence of the increase of tillage.

Improvement. - The whole 1200 acres have been marled, and all the parts that were too wet, have been hollowdrained. In general procuce, it may fairly be estimated that the parish produces louble what it did before. It gave me very great satisfaction to view this parish, with Mr. Gooch, of Quiddenhan, who was a Commissioner in the enclosure, and to whom I am obliged for these particulars. The crops, very generally, great, and the whole face of the parish bore every appearance of a most prosperous cultivation.

Tithe.-Remains subjed to tithe; they would not take land.

Rates. - The rental increased one-third; and till the last year, not inore than 2 s. in the pound.

Expenses. - The whole about 25001.

Poor.-40 acres allorted for tuel; not turf, but flag: and, therefore, the land let at I 5 s. an acre, and the money applied to buying fuel. In the allotment for commonrights, every poor man who had a 5 l. or 61. a year tene. ment, had equal to tol. given him, in case lie was a poor owner; but not for the tenement, if belonging to a large proprietor. Several poor owners, received for Iol. occupancy, two acres. Almost all kept them ; and several kept cows, others turned thacir attention to hemp, turnip secd, 
\&cc. and have acknowledged that they are better off than hefore. And very few indeed who had received an advantage from the common before, but what had some thing better, and to their content, in the enclosure.

\section{POPULATION.}

Twenty-thrce years before and 23 after the enclosure.

\begin{tabular}{|c|c|c|c|c|c|}
\hline & Baptisıns. & Burials. & & Baptisms. & Burials. \\
\hline 1754 & 30 & -30 & 1777 & 28 & $-\quad 16$ \\
\hline 1755 & I 4 & $-\quad 16$ & 1778 & 20 & - \\
\hline $175^{6}$ & 25 & 6 & 1779 & $-\quad 26$ & 20 \\
\hline 1757 & 14 & $-\quad 23$ & 1780 & 19 & 19 \\
\hline $175^{3}$ & 28 & $-\quad I I$ & $178 \mathrm{r}$ & 19 & II \\
\hline 1759 & 15 & $-\quad 16$ & 1782 & 17 & 20 \\
\hline 1760 & 27 & $-\quad 18$ & 1783 & 20 & 14 \\
\hline $176 !$ & 25 & - 19 & 1784 & 17 & 13 \\
\hline 1762 & 17 & $-\quad 33$ & 1785 & 16 & 9 \\
\hline 1763 & 26 & $-\quad 18$ & 1786 & I 8 & 5 \\
\hline 1764 & 27 & $-\quad 29$ & 1787 & 16 & - II \\
\hline 1765 & 19 & $-\quad 17$ & 1788 & 17 & 12 \\
\hline 1766 & 27 & $-2 I$ & 1789 & I 2 & 6 \\
\hline 1767 & 26 & $-\quad 14$ & I790。 & 19 & $-\quad 14$ \\
\hline 1768 & 25 & $-\quad 17$. & I79I" & 8 & $-\quad 24$ \\
\hline 1769 & 26 & -28 & 1792 & I 4 & $-\quad 12$ \\
\hline 1770 & 21 & -23 & I793 & 14 & - \\
\hline 1771 & 22 & $-\quad 21$ & 1794 & I 8 & $-\quad 10$ \\
\hline 1772 & 24 & $-\quad 18$ & 1795 & 11 & -10 \\
\hline 1773 & 26 & - 22 & $179^{6}$ & $2 \mathrm{I}$ & $-\quad 12$ \\
\hline 1774 & 24 & -15 & 1797 & 12 & -15 \\
\hline 1775 & 27 & -6 & 1798 & 17 & - \\
\hline 1776 & 22 & $\begin{array}{r}-\quad 19 \\
\end{array}$ & 1799 & 10 & $-\quad 13$ \\
\hline & 537 & 440 & & $3^{89}$ & 287 \\
\hline
\end{tabular}


First period, If years before the enclosure:

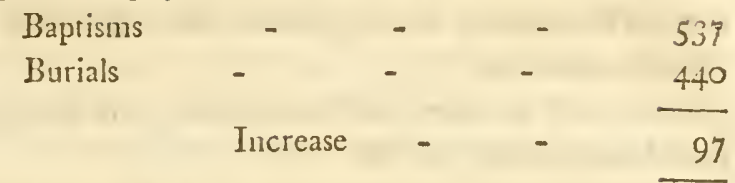

Second period, I5 years since the enclosure:

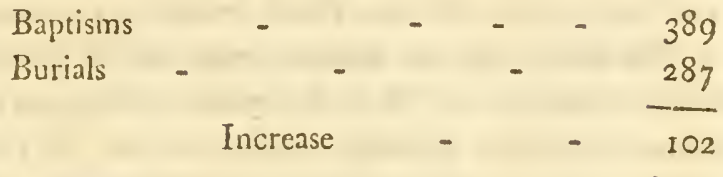

The difference marked in this account is far inferior to the fact; for the number of Anabaptists have multiplied so of late years, as to form a considerable proportion of the whole population. The parish is crowded with inhabitants, who have increased uncommonly since the enclosure.

CALSTON.-ENCLOSED I BOI.

Thirteen hundred acres of common and warren; the warren subject to sheep-walk, and the rent only 20 guineas 2 year, to Colonel-Buller.

Remains subject to tithe.

The mode of improving has been, to plough it up, and leave it for a year, then coleseed sown, for sheep to mamure and tread it; then marle, by lease 25 loads an acre for the first course; and in every after course 10 loads, mixed with dung.

Colonel BUlLer has arranged the divisions in such a manner, that the roads open into all the pieces.

The act, roads, commons, \&c. cost Colonel Buller I 3001. : probably the other proprictors' shares might have inade the total 2000 . 
By means of small allotments let by him to the poor, cows will increase, as they exceed the rights that were aetually exercised.

Sheep will increase after seven years; but during that period exclurled by the act.

The whole parish above 4000 acres; and the valuatiors two years ago for the rate, $2800 \mathrm{l}$. besides $400 \mathrm{l}$. tithe.

The rent of the new enclosed lands, on 2 I years leases, for 10 years, 7 s. to 8 s.; the tenants doing every thing cxcept raising the buildings; but at the end of 10 years, 2s. an acre more.

The Colonel reserved between 70 and So acres for sinall occupiers, to enable them to keep cows; and he has planted 321 acres of the parts where the common had been most pared for fuel, with all sorts of trees.

CRANWORTH, REMIRSTON, SOUTHBOROUGH.-ENCLOSED I 796.

2uantity.-Commons to four parishes, Cranworth and Letton, Remirston and Southborough; the two latter the largest. 743 acres in all. Remirston 306, Cranworth 17 I, Southborough 272 acres.

Rent._Will be 20 s. an acre.

Corn.-Greatly increased: the whole under it.

Cous.-Few or none were kept by the poor. Now more cattle of all sorts.

Shecp.- None to be kept for seven years in the new enclosures, by the act: they will be lessened; but very often used to be rotten.

Poor.-They kept geese on the commons, of which they are deprived. But in fuel they are benefited: an allotment nor to exceed $\frac{1}{20}$ let, and the rent applied in coals for all not occupying above 5 l. a year : this is to the advantage of those at Southborough, laving enough allowed 
Sor their consumption; at Cranworth the poor are more numerous, and the coals of little use. The allotment for the poor at Letton, is 17 acres. Ten are left as a pasture for the cows' of those who rent under 5 l. per annum. Seven are let to the higliest bidder, and the money is applied to the purchase of fuel. The number of those who keep cows, is five.

All encroachments within thirty years to be divided as common; but to be allotted to persons in possession, if entitled to any.

Tithe. - The commons to pay Is. 6d. an acre the first year; 2s. the second; 2 s. 6 d. the third ; 3 s. $6 \mathrm{~d}$. the fourth; and after that remain subject.

Rates. - Fous shillings to five shillings in the pound.

CRANWORTH AND LETTON.

POPULATION.

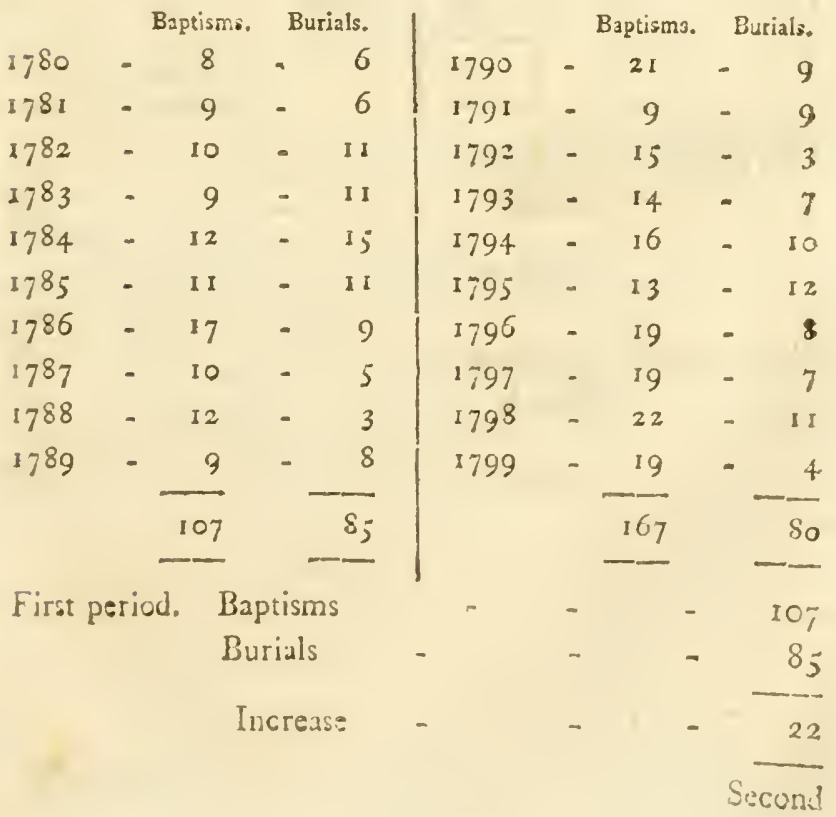




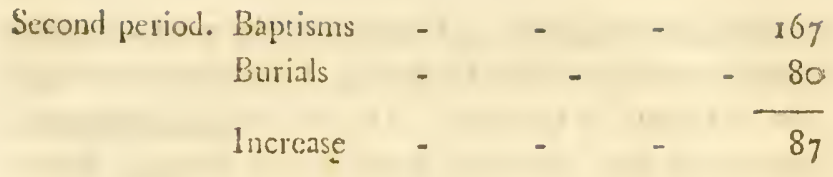

SOUTHBOROUGH.

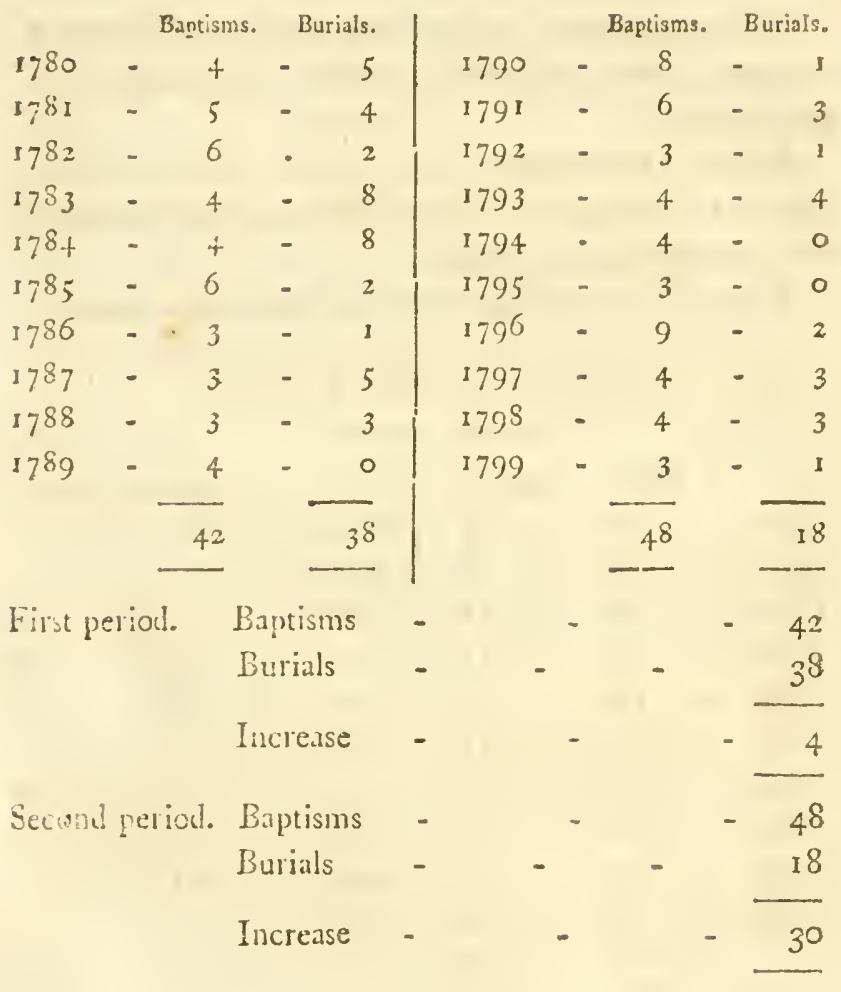


RIMERSTONE, ENCLOSED.

\begin{tabular}{|c|c|c|c|c|c|}
\hline & Baptisms. & Burials. & & Baptisms. & Burials. \\
\hline 1.780 & 6 & 5 & 1791 & $-\quad I I$ & 2 \\
\hline $17^{81}$ & 11 & 5 & 1792 & -5 & 3 \\
\hline 1782 & 4 & 4 & 1793 & -6 & - \\
\hline $17^{8} 3$ & 4 & - & 1794 & 7 & - \\
\hline 1784 & 6 & 5 & I 795 & -5 & - \\
\hline 1785 & 10 & 8 & 1796 & -6 & - \\
\hline 1786 & - & 7 & I 797 & $-\quad 7$ & - \\
\hline $17^{8} 7$ & 6 & I & 1798 & I & - \\
\hline 1788 & 8 & -6 & I 799 & 6 & - \\
\hline 1789 & $\dot{5}$ & - & 1800 & $\overline{7}$ & - \\
\hline 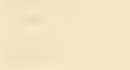 & 63 & 47 & & $6 I$ & 29 \\
\hline Increase & 16 & & Inerease & $3^{2}$ & \\
\hline
\end{tabular}

DERSINGHAM.

Rent.-Doubled.

Corn.-At least twice as much corn raised as before the enclosure.

Shccp.-Increased.

Cows. - $A$ bout the same number as before.

Tithe.-Remains suljeet.

Poor.-The poor are not affected, except by the increase of employment. 'The common remains common, but stinted by the Commissioners. 
DOCKING.

\begin{tabular}{|c|c|c|c|c|c|c|}
\hline & Baptism & ns. Burials. & & & aptisms. & Buria's. \\
\hline 17 So & -24 & $-\quad 18$ & 1790 & - & 20 & II \\
\hline 1781 & 22 & 12 & 1791 & - & 17 & 8 \\
\hline $17 S_{2}$ & 20 & $2 I$ & 1792 & - & 24 & 16 \\
\hline $17 \delta_{3}$ & 19 & 14 & 1793 & - & 20 & 14 \\
\hline $17 S_{+}$ & 12 & $-\quad 22$ & 1794 & - & 23 & 17 \\
\hline 3785 & 23 & II & 1795 & - & 16 & - \\
\hline 1786 & 20 & I 5 & 1796 & - & .15 & 16 \\
\hline $17^{87}$ & 29 & 12 & 1797 & - & 18 & 10 \\
\hline 1788 & 13 & -9 & $179^{8}$ & - & 19 & 17 \\
\hline 1789 & -24 & -10 & I 799 & - & 22 & 15 \\
\hline & 206 & $1+4$ & & & 194 & 131 \\
\hline First 1 & eriod. & Baptisms & - & - & - & 206 \\
\hline & & Burials & - & - & - & 144 \\
\hline & & Increase & - & - & - & 62 \\
\hline Secon & I period. & Baptisms & - & - & - & 194 \\
\hline & & Burials & - & - & - & I 31 \\
\hline & & Increase & - & - & - & $6_{3}$ \\
\hline
\end{tabular}

DOWIHAM.

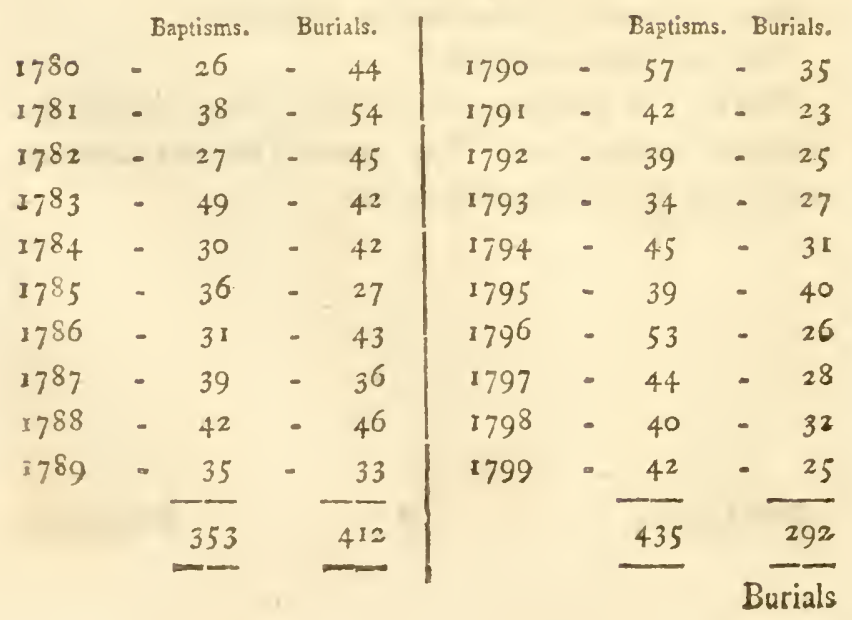


Burials in the first ten years Baptisms

Decrease

Baptisms in second ten years Burials

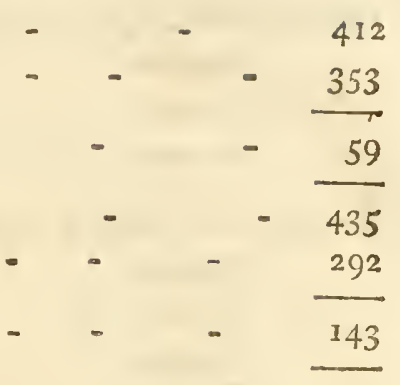

IITTLE DUNHAM.-ACT PASSED I794.

Quantity.-About I800 acres in the parish, of which 360 are common.

Improvement.-Had great effect on the common, and by exchanges; and half-year lands were much improved.

Poor.-Thirty-five acres of common let for 451 . a year, to be distributed in coals, instead of their cutting whins (not turf). Last winter each family had 22 bushels of coals. Very few kept cows.

Tithe.-Remains subject.

Expenses.-126ol.

POPULATION.

\begin{tabular}{|c|c|c|c|c|c|}
\hline & Baptism & Buriais. & & Baptisms & Burials. \\
\hline 1780 & 5 & 8 & $179^{\circ}$ & II & 5 \\
\hline 1781 & 8 & 6 & 1791 & 8 & 9 \\
\hline 1782 & - & - & 1792 & 10 & 3 \\
\hline $178_{3}$ & 6 & 2 & I 793 & 7 & 5 \\
\hline 1784 & 7 & 6 & I794 & 7 & 3 \\
\hline 1785 & 10 & 7 & 1795 & II & I \\
\hline 3786 & 9 & - & $x 796$ & - & - \\
\hline 1787 & 8 & - & I797 & II & - \\
\hline 1788 & 9 & - & $179^{8}$ & - & 3 \\
\hline 1789 & 12 & - & I 799 & - & 5 \\
\hline & 79 & $5^{1}$ & & 86 & 48 \\
\hline
\end{tabular}


Eighteen years, 1562 to 1579 :

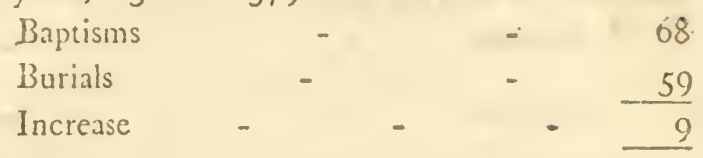

Twenty years, I 580 to I 599 :

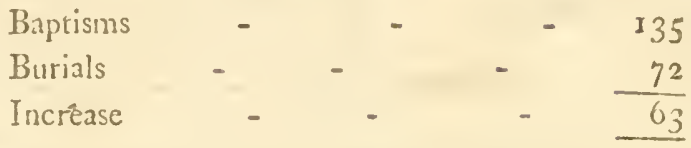

"Fwenty years, I 720 to I739:

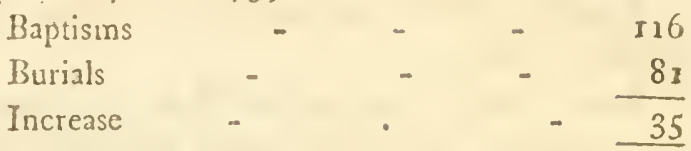

Twenty years, 1770 to 1759 :

Baptisms

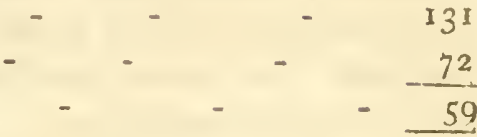

Twenty years, i 760 to 1770 :

Baptisms

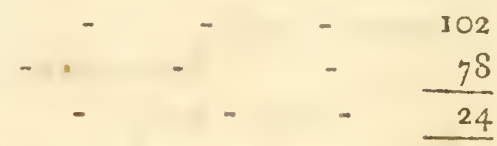

Burials

Increase

Twenty years, from I 780 to I 799 :

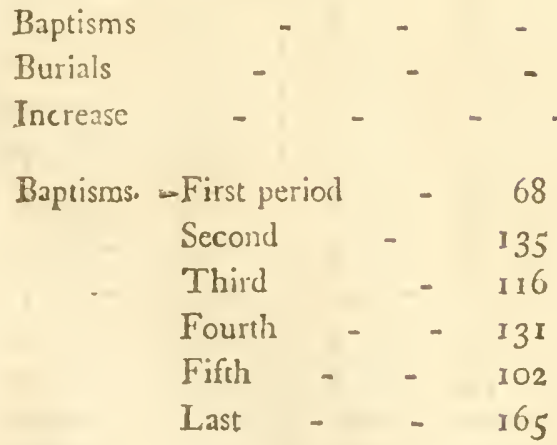

The account is remarkable; but in whatever light viewer, 
viewed, it proves the superior population of the present period.

Survey taken in 1792 :

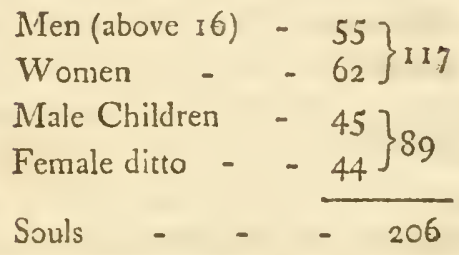

Forty-four families: 39 married couples.

Males 100.

Fernales 106.

Forty-one houses.

In $I 763$ there were $I 72$ souls.

If the average number be 190 , deaths will be $I$ in 38 ; births I in 21.-(Note in the Register.)

EATON.

\begin{tabular}{|c|c|c|c|c|c|}
\hline & Baptisms. & Burials. & & Baptisms. & Burials. \\
\hline 1780 & 6 & 6 & 1790 & $x I$ & - \\
\hline $178 \mathrm{I}$ & I6 & 8 & 1791 & 6 & - \\
\hline 1782 & 9 & 5 & 1792 & II & - \\
\hline 1783 & 5 & 6 & I 793 & 7 & 4 \\
\hline I 784 & 9 & 8 & 1794 & 3 & 4 \\
\hline $17^{8} 5$ & 9 & 6 & 1795 & 7 & 3 \\
\hline 1786 & 6 & 6 & 1796 & 8 & 5 \\
\hline 1787 & 13 & 4 & 1797 & 10 & 5 \\
\hline 1788 & 6 & 8 & 1798 & 14 & $I$ \\
\hline 1789 & - & 4 & 1799 & 6 & - \\
\hline & 87 & $6 I$ & & 93 & 40 \\
\hline
\end{tabular}




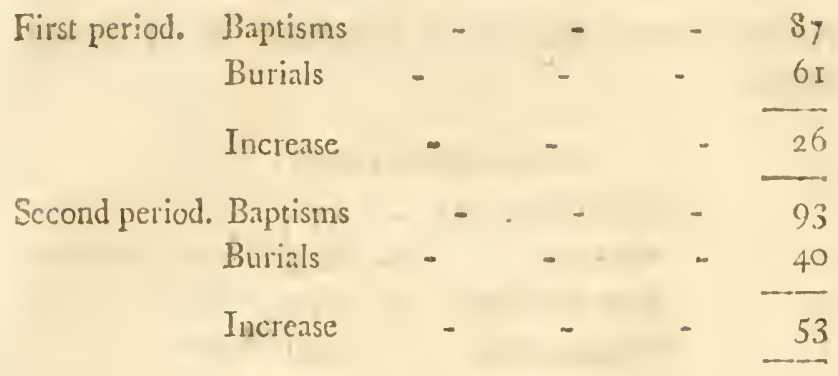

ELLINGHAM.-ENCLOSED I 798.

จ) uantity.-About 2000 acres, old enclosed land. .

Soo common divicied by the act.

2800

Rent. - A bout I 4 s. or I 5 s. old rent: quality price, I 5 s. to 17 s.

Soil.--A loam on clay; some light soils.

Poor.-The allotment for fuel by the ad, as the Commissioners shal! appoint. There are 64 common-rights; they have allozted 60: there were scarcely any cows kiept by the poor, as they would have been starved by the sheep.

Cows. -Mcre will be kept in consequence of the enclosure.

Steep.-Will be decreased.

Corn.-All will be in course under corn, and the increase very great.

Tithe-For five years from the award, Is. an acre, if not broken up; and 2 s. on such as is ploughed: then to remain titheable.

Rates. - Are about 4 s. in the pound.

$$
\text { FELTHORPE.-ENCLOSED I779. }
$$

Quantity-About I 500 acres; old enclosure, about one. third, or two-fiths; common, thee-fifths. 
Soil.-Old enclosures, red sand; the new, a grey sind on red and white sand.

Rent.-Before enclosing, 600l. ; at present not 800 .

$P$ por:- The common was so valuable to the poor, or thought to be, that the farmers could not get their wark done; they cut fuel, whins, Scc. for sale, and the place harhoured pachers, \&c. - T'wenty-five small occupiers; only four ahove 401 . a year: many very small, and genesally owners. They are comfurtable, though they work harder than iny labourers; they were not well treated respeching pusture; bat they have a cominon of $5^{\circ}$ acres for fuel, which they feed.

Com-There us be a little increase; but guestionable: perinaps nowe at all.

Cous. - Perhaps more cows; but doubtful: the poo: kept beiore, and do so now.

Shcop.-Little difference; for several years fewer.

Tithe.--Remains subjest to tithe.

Exponses. - The enclosure did not pay them.

Rates. - This year abour G.s.; in general atont 4 s.

Improvement.--Mr. WRIGHT, on a summer tallow, drilled an acre with sainfoin, July 1799 ; in 1800 it did nothing: soil, a red wand bottom. In 3 i $x$, six acres carrots of his did well, though a bad seison for hoeing; these were on red but good sind, workis $12 \mathrm{~s}$. an acre. He had lived at Sutton, near Wouthridge, where carrots are a common article of culture, sno did uot observe the husbandry in vain: I hope he wil !ully cstablish is on these sands, some of which are well adapted to it.

The husbandry which should be adopted, is to pare and burn for turnip., fol with sheep; then plough well for buckwheat (of which there is nuch in the parish), and with it hy down to grass for a sheep-walk; sowing burnet, chicory, cocks- 
cocks-foot, yarrow, \&rc.: this would be a great and lasting improvement, and would, hereafter, give good corn.-I do not know any where, after an enclosure, a parish that carries so unimproved a countenance as this, untess it he the heatis at Kelling Littie or no use is made of the allotments of common : they generally lie in their waste statc: they say, for want of marle or clay, without which turnips are anburicd; and yet some small pieces have been pared and hurnt, bur being exhausted by repeated crops of corn, the land and the husbandry both are abandoned. Some pieces have been sold since the act passed, at 40 s. an acre; at 20s. and even at 14 s. as it is said: yet these poor grev sanls do exceedingly well for potatoes; many are cultivated, and in I799, as many were produced on one acre, as would have paid the fee simple of 10 .

Population.-The register most irreguiarly kept, and births and burials so jumbled together, that even for the last eight or ten years (all $\mathfrak{l}$ could get at) they are not casily pscertained:

$\begin{array}{llccc} & & \text { Baplisms. } & & \text { Burials. } \\ 1792 & - & 8 & - & 4 \\ 1793 & - & 8 & - & 10 \\ 1794 & - & 11 & - & 5 \\ 1795 & - & 11 & - & 4 \\ 1796 & - & 9 & - & 5 \\ 1797- & -20 & - & 1 \\ 1798- & - & 10 & - & 2 \\ 1799- & 6 & - & 1\end{array}$

1 have little faith in the account: no resident clergyman; the case of half the county. 
FINCHAM.-ENCLOSED 1772.

Quantity.-2953 acres; by the award, divided amongst 29 proprietors, viz.

No.

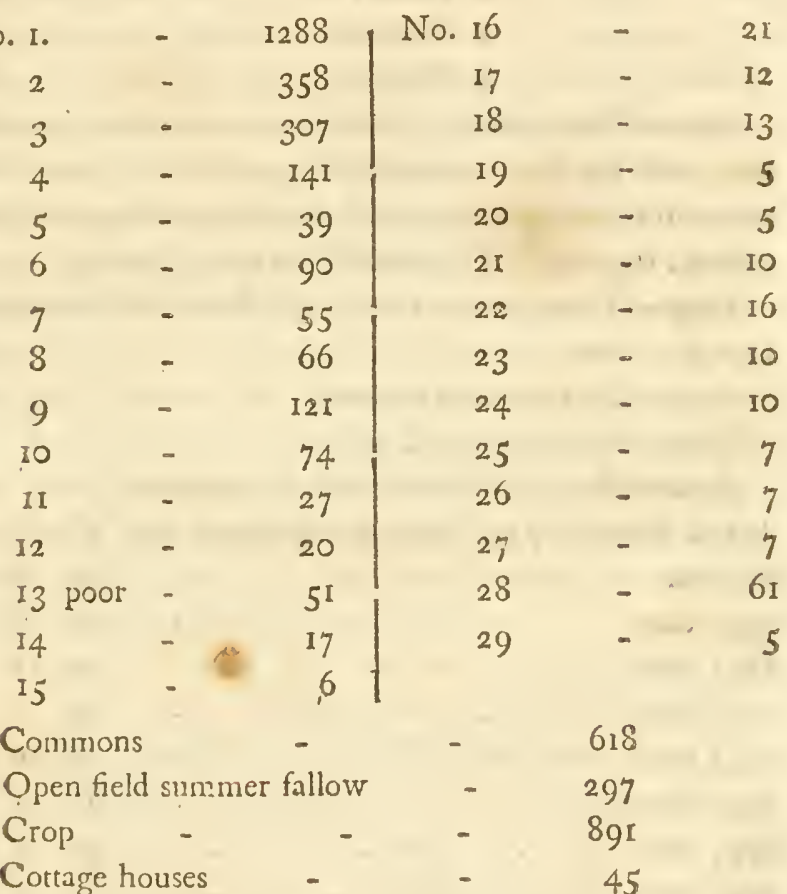

Valuation of the common houses - 26rl. I8s.

Soil.-Strong good land; some wet, and tenacious.

Rent.-Com, inissioners' valuation, 10.40!.

Course. 
Course-Before, 1. Fallow.

$$
\begin{aligned}
& \text { 2. Wheat. } \\
& \text { 3. Barley. } \\
& \text { 4. Pease or oats. } \\
& \text { Now, r. Turnips. } \\
& \text { 2. Barley. } \\
& \text { 3. Clover. } \\
& \text { 4. Whear. }
\end{aligned}
$$

Corm.-The common, except 30 or 40 acres, is under corn, and has been uncommonly productive; though for two or three years at first it did not weli, as they ploughed without burning. The product far more than ever.

Sheep.-There were two large flocks; not so many kept at prosent.

Cosws - Dairies much lessened.

Tithe.-Remains subject to it.

Ralcs.-By an old rate-hook it appears,

that at Easter, I729, there was disbursed for $\mathcal{E}$. s. $d$. the poor

1730 ditto

1731 ditto

1742 ditto

1747 ditto

$175^{\circ}$ ditto

$\mathbf{1 7 5 3}$ ditto

1754 ditto
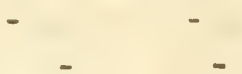

$-\quad 3965$

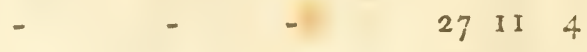

$175^{8}$ ditto, collected for it 1s. $6 \frac{\pi}{2} \mathrm{~d}$. on 913 l. 96 I 0

3762 ditto, rate 1s. 9 d. on 9201 . rent -78 1 7

1767 ditto, rate 1s. 1od. on $733^{1}$. sent -6762

1769 ditto, rate 2 s. $6 \mathrm{~d}$.

177 I ditto, rate 3 s. $3^{\text {d. }}$

1782 ditto, 3 s. 4 d.

1783 ditto, $\quad 3.9$ d.

1784 ditto,

2s. 7 d.
- 89184

- 119159

- 198180

- 200106

- I76 I8 II 1785 
1785 ditto, on a rental of $225^{81}$. Is. 11d. 1791 ditto, on 2.2521.

1794 ditto, 23. $3^{\text {d. }}$

1795 ditto, on 2303 !. at 3 s. 7 d.

I796 ditto, 3.6d.

1798 ditto, $2: 7$ d.

2141010

1799 ditto, on 2340 . at 2 s.

d.

- $\quad 159183$

- 259210

$412 \quad 1310$

- 40870

- 30406

$240 \circ 5$

Poor.-As much land allotted for their use by the act, as should produce 361 . a year, to be distributed to poor perscns nor receiving relief or alms; which has been apphied in the purchase of coals : the land is now worth 50 . a year. In fuel, they are not deficicat; but not quite equal to the former privilege.. As to cottage cow-keepers they are all over: many before the enclosure, but the allotments all thrown to the farms, and in this respeet they are much worse situated, though nany had no right, and paid when the common was driven. Stredgit has a common, and better. But take the poor lsere in general, employment has multiplied; so much, that they are in a better condition; better fed, and better clothed.

\section{POPULATION.}

Twenty-eight years before the enclosure.

\begin{tabular}{|c|c|c|c|c|c|c|c|}
\hline & & Baptisms. & Burials. & & & aptisms. & Burials. \\
\hline 1744 & - & 15 & -6 & 1754 & - & 14 & ${ }^{3} 3$ \\
\hline 1745 & - & 16 & -10 & 1755 & - & II & 10 \\
\hline 1746 & - & II & -23 & $175^{6}$ & - & II & - \\
\hline 1747 & - & I I & -13 & 1757 & - & 14 & I 3 \\
\hline 17.8 & - & 10 & -26 & $175^{8}$ & - & II & II \\
\hline 1749 & - & 10 & $-\quad 17$ & 1759 & - & 14 & 10 \\
\hline $175^{\circ}$ & - & II & 9 & 1760 & - & 9 & - \\
\hline 1751 & - & -15 & 5 & $176 I$ & - & 12 & $-\quad 2 I$ \\
\hline $175^{2}$ & - & 16 & 3 & 1762 & - & 15 & 12 \\
\hline 1753 & 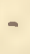 & II & 9 & 1.7 .63 & - & 12 & -10 \\
\hline
\end{tabular}




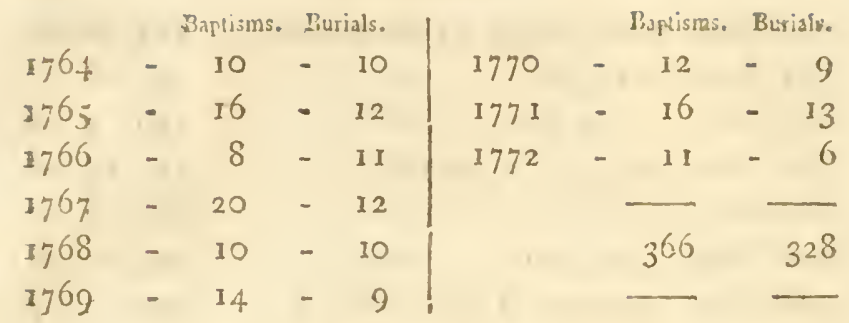

Twenty-eight years since the enclosure.

\begin{tabular}{|c|c|c|c|c|c|c|c|}
\hline & Bapti & isms. & Burials. & & & Baptisms. & Burials. \\
\hline 1773 & - & & - II & 1788 & - & 16 & 10 \\
\hline 1774 & - & 3 & $-\quad I I$ & 1789 & - & 10 & - \\
\hline 1775 & - & & 9 & 1790 & - & I 5 & - \\
\hline 1776 & - & 3 & 3 & 1791 & - & 17 & - \\
\hline 1777 & - & & 5 & 1792 & - & II & - \\
\hline 1778 & $-\quad 18$ & & 8 & 1793 & - & It & - \\
\hline$\$ 779$ & - & & $-\quad 10$ & 1794 & - & 16 & - \\
\hline 1780 & I & & $-\quad 16$ & 1795 & - & 16 & - \\
\hline $.778 I$ & - & & $-\quad 9$ & 1796 & - & 24 & - \\
\hline 1782 & 12 & & $-\quad 13$ & 1797 & - & 9 & - \\
\hline $7_{7} 8_{3}$ & 16 & & $-\quad 23$ & $179^{8}$ & - & 12 & - \\
\hline$I_{7} 8_{4}$ & - & 9 & -8 & I 799 & - & 16 & - \\
\hline 585 & - Is & & - I3 & & & - & 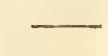 \\
\hline 1786 & $-\quad 13$ & & $-\quad$ II & & & 396 & 242 \\
\hline 37.87 & -22 & 2 & -7 & & & - & \\
\hline \multirow[t]{3}{*}{ First per } & ericd. & Bapti & isms & - & - & - & 366 \\
\hline & & Buri: & & - & - & - & 328 \\
\hline & 1 & Incr & rease & - & - & - & $3^{S}$ \\
\hline \multirow[t]{3}{*}{ Second p } & perioci. & Bapt & tisms & - & - & - & 396 \\
\hline & & Buri & rials & - & - & & -242 \\
\hline & & Inct & tcase & - & - & - & 154 \\
\hline
\end{tabular}

SOULDEN: 


\section{FOULDEN.}

Baptisms and Burials for twenty years.

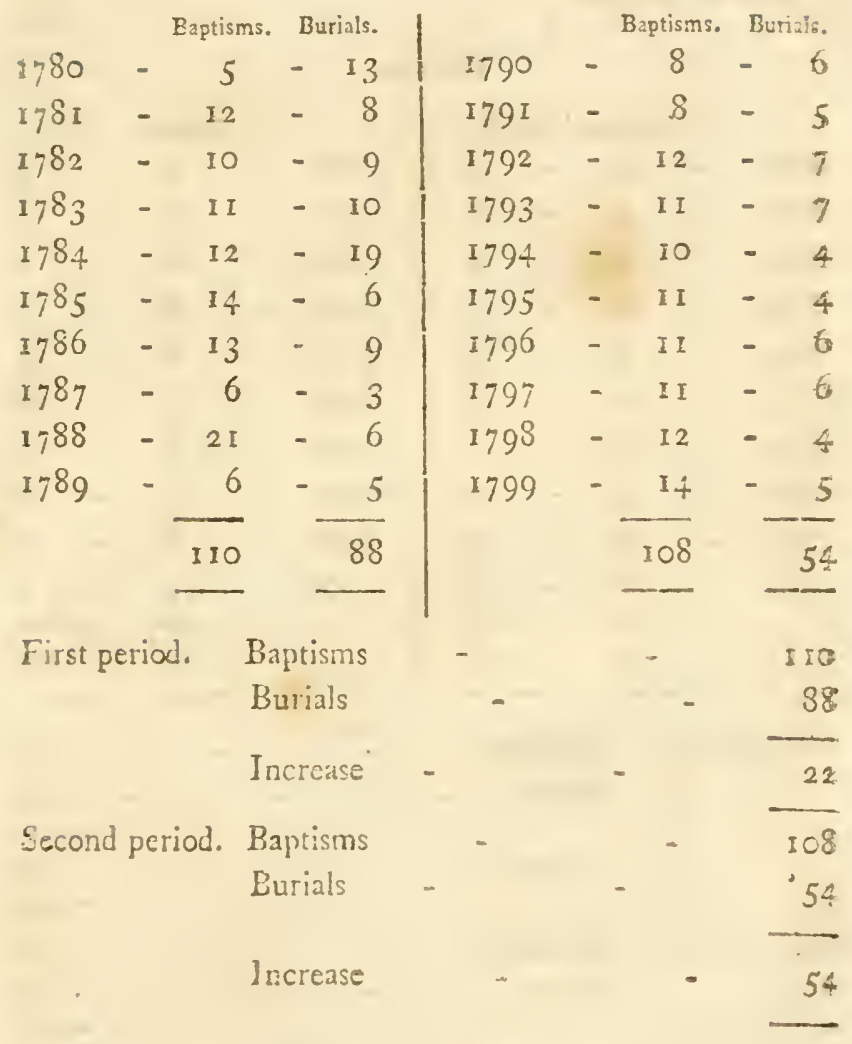

$$
\text { Enumeration-I782. }
$$

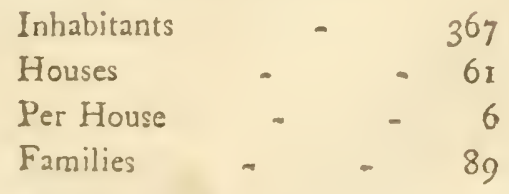

Baptistms 
Baptisms and Burials for seven years, from I 780 to 1786
Average
- $77-74$
One in 33 born.

One in 36 dies.

FRING.

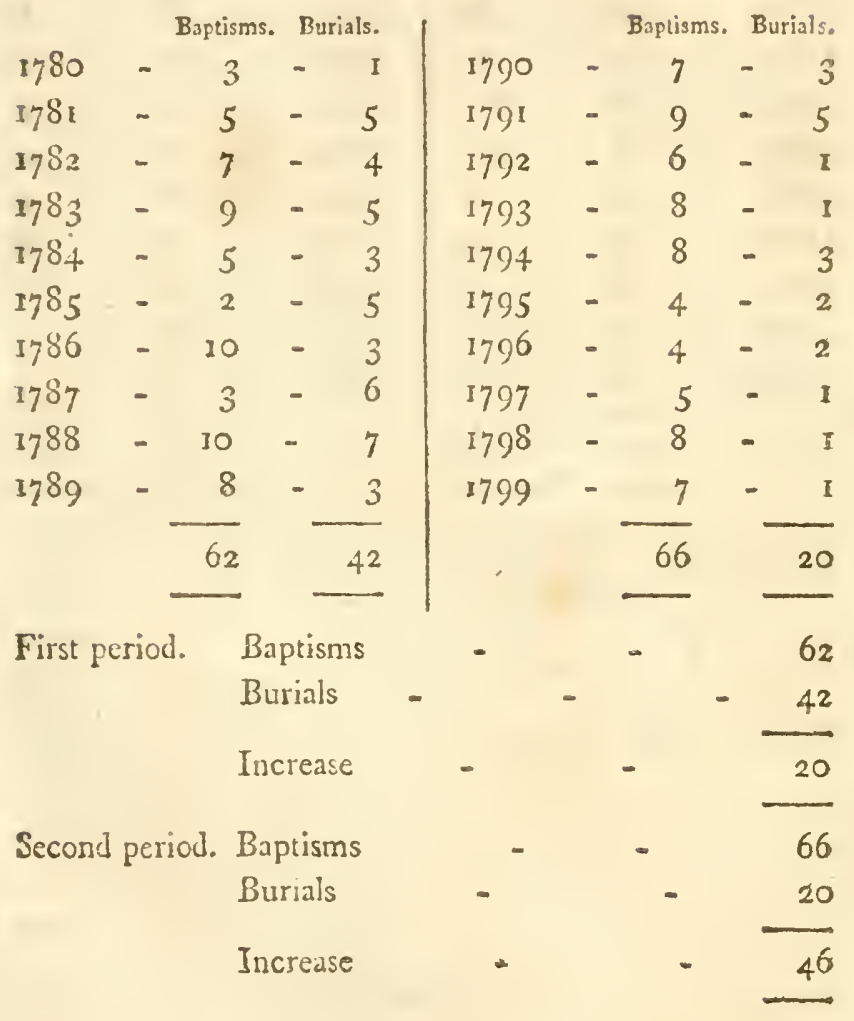


IARDINGHAM.

The register so kept, or rather so rotted with damp; and the entries made in such a scattcred topsy-turvy manncr, that the authority not too good.

\begin{tabular}{|c|c|c|c|c|c|}
\hline & Baptisms & Eurials. & & Baptisms. & Burials. \\
\hline $17 \delta_{3}$ & 2 & 4 & I 791 & 10 & 10 \\
\hline 1784 & 12 & 2 & 1792 & II & - \\
\hline 1785 & - & - & I 793 & 10 & - \\
\hline I 786 & I 7 & - & I 794 & I6 & - \\
\hline 1787 & - & - & 1795 & 10 & - \\
\hline 1788 & 14 & - & I 796 & I 2 & - \\
\hline 789 & 10 & - & I797 & 14 & - \\
\hline 90 & IO & - & I $79^{8}$ & I 6 & - \\
\hline & 80 & $3^{6}$ & & 99 & 48 \\
\hline
\end{tabular}

HARLESTON AND REDENHALL, I 89 .

$\begin{array}{ccr}\text { Enumeration.-Widowers } & - & \text { I4 } \\ \text { Married } & - & 357 \\ \text { Unmarried } & - & 25 \\ \text { Widows } & - & 4 \mathrm{t} \\ \text { Children } & - & 499 \\ \text { Servants - } & - & 185 \\ \text { Lodgers - } & - & 223 \\ \text { Total } & - & 1344 \\ \text { Families } & - & 240\end{array}$

Deduct, as living in separate apartments

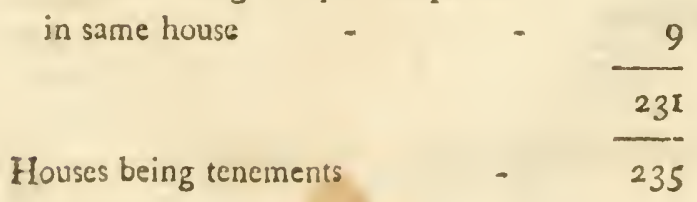

Nearly 
Nearly six to a family, consisting of

\begin{tabular}{|c|c|c|c|c|c|}
\hline Husbandmen & - & $3^{8}$ & Mason & - & 2 \\
\hline Spinners & - & 26 & Surgcons & - & \\
\hline Carpenters & - & 8 & Grocers & - & \\
\hline Fiarmers & - & 12 & Barbers & & - \\
\hline Painter & - & $\mathbf{I}$ & Knitter & - & \\
\hline Shoemakers & - & 15 & Thatchers & - & - \\
\hline Tailors & - & 3 & Heelmaker & & - \\
\hline Millwrights & - & 2 & Brickmaker & - & \\
\hline Blacksiniths & - & 5 & Brewer & & - \\
\hline Butchers & $-\cdot$ & 5 & Ditto Servants & & - \\
\hline Bakers & - & 6 & Midwife & - & \\
\hline $\begin{array}{c}\text { Schoolmasters } \\
\text { Mistresses }\end{array}$ & and - ? & 3 & $\begin{array}{l}\text { Currier } \\
\text { Glaziers }\end{array}$ & - & - \\
\hline $\begin{array}{c}\text { Gentlemen an } \\
\text { tlewomen }\end{array}$ & d Gen-? & 3 & $\begin{array}{l}\text { Shop general } \\
\text { Sawyer }\end{array}$ & & - \\
\hline Fruiterers & - & 2 & Erazier & - & \\
\hline Chaise-driver & - & 1 & Gelder & & - \\
\hline Sadlers & - & 3 & Woolcombers & & - \\
\hline Warchmaker & - & I & Milkwoman & & - \\
\hline Drapers & - & 2 & Nurse - & & - \\
\hline Gardener & - & I & Ironer & - & \\
\hline Coopers & - & 2 & Bookseller & - & - \\
\hline Weavers & - & 6 & Millincr & - & \\
\hline China and ear & thenware & 2 & Wheelwright & & - \\
\hline Altornies & - & 3 & Mole-catcher & & - \\
\hline Publicans & - & 12 & Rector & - & \\
\hline Ostlers & - & 2 & Clerk & - & \\
\hline Whitesmith & - & I & Sundries & - & \\
\hline Breeches-mak & ers & 2 & & & 23 \\
\hline Drovers & - & 2 & & & \\
\hline Hosier & - & 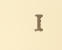 & & & \\
\hline
\end{tabular}

Wortwell, a hamlet, besides, not included. 
In I798-Men between 15 and $60 \quad-\quad 284$ Incapable of a气ive service - $\quad 27$

Men above 60; women and children II53

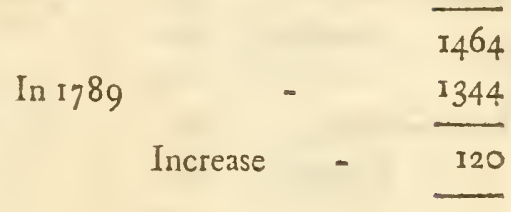

$\begin{array}{lr}\text { Cows - } & \text { II9 } \\ \text { Oxen - } & 63 \\ \text { Young cattle - } & 129 \\ \text { Sheep - } & 414 \\ \text { Pigs - } & 475 \\ \text { Riding horses } & 32 \\ \text { Cart ditto - } & 139\end{array}$

In Wortwell, in 1798-Men

Women

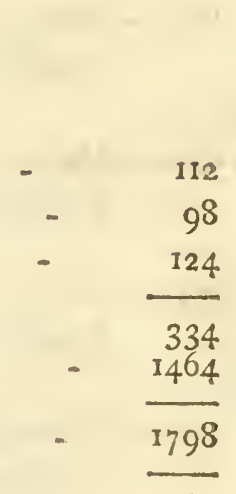

Harleston

Children

Rates.-Poor-rates, in Harleston, in $1780, \begin{array}{ccc}f . & s . & d . \\ 461 & 2 & 5\end{array}$

Ditto, in 1680 108510

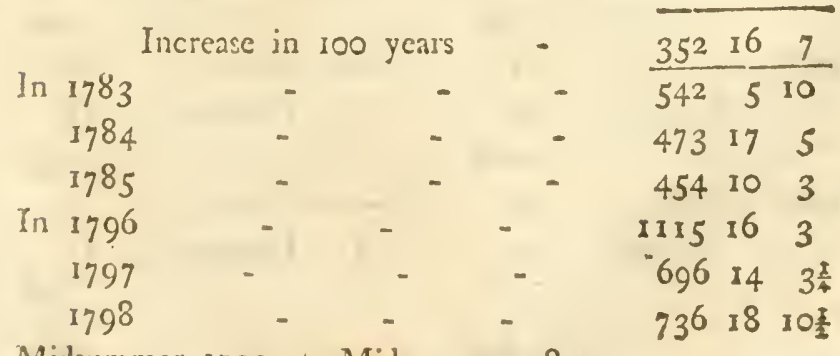

Midsummer 1799 , to Midsummer 1800 ,

8s. 5 l. in the pound.

NORFOLK.] 
REDENHALL, WITH HARLESTOR.

Baptisms.

Burials.

I780.-Males,

36

Females, 28

1780 Males,

Females,

24

$\begin{aligned} \text { 1781. - Males, } & -64 \\ \text { Eemales, } & 38\end{aligned}$

$-66$

1782.-Males, 19 Females, 28

- Males, Females,

23

- Males,

2 I

Fcmales,

25

$-47$

I783.-Males, $\quad 42$ Females, $\quad 46$

Mates, Females,

1784.-Males,

2 I Females,

2 I

$\begin{array}{ll}\text { Males, } & 24 \\ \text { Females, } & 26\end{array}$

$$
\text { 1785.-Males, } \quad 26
$$
Females, 29

$-55$ 17S6.-Males, $\quad 24$ Females, 34 I787.-Males, $\quad \frac{34}{31}$

20 I788.-Males, $\quad 4^{-51}$ Females, $\quad 27$

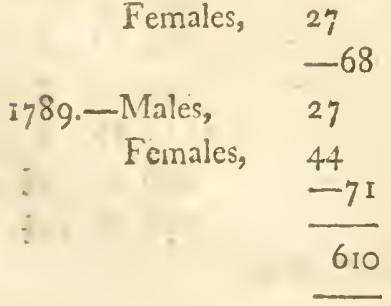

Males, Females,

Males, Females, $-50$

I 9 2 I $-40$ 22 25 $-47$ 24 13 $-37$ 14 10 $-24$ I6 Males, 17 $-33$ 13 2 I $-34$ 385 
Baptisms.

I790.-Males,
Females,
$3^{2}$

Burials,

1790 Males,

Females,

22

$-57$

I791.-Males, $\quad 3^{8}$

Females, 25

:792. - Malcs, $\quad-63$

Females, 33

Males,

Females,

_- Males,

Females,

17

$-39$

II

17

$-28$

23

27

$\begin{aligned} \text { r793. - Males, } & 48 \\ \text { Females, } & 30\end{aligned}$

$\begin{aligned} & -78 \\ \text { Females, } & 30\end{aligned}$

-.. Males,

$-50$

Females,

I4

10

$-24$

- Males, 20

- Females, 20

$-68 \quad-40$

1795- - Males, 39

Females, 35

Males,

24

Females, $\quad 23$

1796.-Males, $\quad 3^{-74}$

Females, 29

$-67$

597-Males, $\quad 32$ Females, $\quad 3^{6}$

$-68$

1798.-Males, $\quad 3^{6}$

Females, 49

49

1799.-Males, 33

Females, 30

${ }^{30}-63$

- Males,

$-47$

Females,

10

I3 .

$-23$

Males, 25

Females, $\quad 26$

- Males $\quad \frac{-51}{16}$

Females, 18

$\begin{array}{ll}\text { Males, } & -34 \\ \text { Females, } & 20 \\ & \\ & \\ & \\ & \\ & \end{array}$


First period.

Baptisms
Burials -
Increase

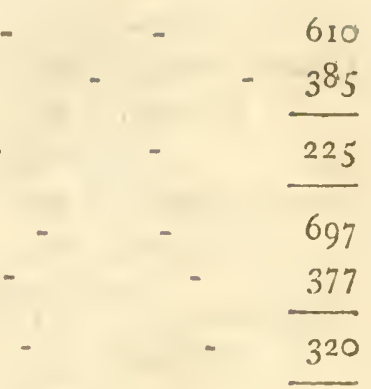

Second period. Baptisms Burials

Increase

THE SEXES.

\begin{tabular}{|c|c|c|c|c|c|}
\hline & Males born. & Males died. & & Males born. & Males died. \\
\hline 1780 & $-\quad 36$ & 24 & 1790 & 25 & 22 \\
\hline 1781 & 28 & 21 & 1791 & $3^{8}$ & 11 \\
\hline 1782 & 19 & 9 & 1792 & 41 & 23 \\
\hline 1783 & 42 & 24 & 1793 & $4^{8}$ & 14 \\
\hline 1784 & $2 I$ & 19 & 1794 & 38 & 20 \\
\hline $17 \$ 5$ & 26 & 22 & 1795 & 39 & 24 \\
\hline 1786 & 24 & 24 & 1796 & 38 & ro \\
\hline 1787 & $3 I$ & It & 1797 & 32 & 25 \\
\hline 1788 & 41 & 16 & I 798 & 36 & 16 \\
\hline \multirow[t]{5}{*}{$=789$} & 27 & 13 & 1799 & $-\quad 33$ & 20 \\
\hline & 295 & 186 & & 368 & 185 \\
\hline & Born & & - & $66_{3}$ & \\
\hline & Died & - & - & $37 x$ & \\
\hline & Died & sewhere & - & 292 & \\
\hline
\end{tabular}


Females born. Ditto buried.

\begin{tabular}{|c|c|c|c|c|c|c|}
\hline \multicolumn{4}{|c|}{ Females born. Ditto buried. } & \multicolumn{2}{|c|}{ Females born. } & Ditto buried. \\
\hline 1780 & - & 28 & 23 & I 790 & 32 & 17 \\
\hline$I 78 I$ & - & $3^{8}$ & 25 & 1791 & 25 & - \\
\hline 1782 & - & 28 & I 8 & 1792 & 33 & - \\
\hline 1783 & - & 46 & 26 & I 793. & 30 & - \\
\hline 1784 & - & 21 & $2 I$ & 1794 & 30 & - \\
\hline 1785 & - & 29 & 25 & 1795 & 35 & - \\
\hline I 786 & - & 34 & 13 & $179^{6}$ & 29 & - \\
\hline 1787 & - & 20 & 10 & 1797 & 36 & - \\
\hline 1788 & - & 27 & 17 & 1798 & 49 & - \\
\hline 1789 & - & 44 & $2 I$ & 1799 & 30 & - \\
\hline & & 315 & 199 & 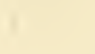 & 329 & 192 \\
\hline & & Born & - & - & 644 & \\
\hline & & Buried & - & - & 391 & \\
\hline & & Ditto & where & - & 253 & \\
\hline
\end{tabular}

\begin{tabular}{ll|l} 
Men born - - 663 Died elsewhere - 292
\end{tabular} Women ditto - 644 Women ditto - 253 \begin{tabular}{l|lll} 
Excess of men - 19 & Excess & -39 \\
\hline
\end{tabular}

The number of people in 1798 , being 1798 ; and the average of ten years baptisms 69 . There is born annually one in 26 ; and the average burials being 37 , there dies annually one in 47 . 
HARPLEY.

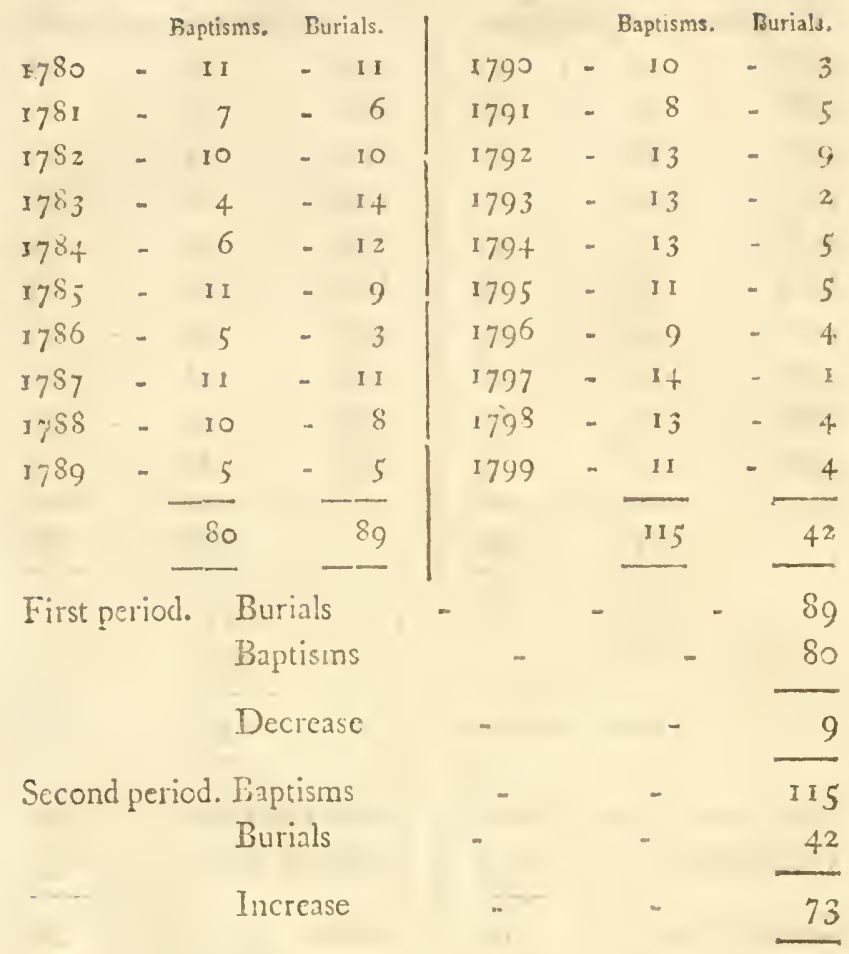

This parish joins Masșingham ; and offers in the last ten years a complete contrast to it.

HETHERSET, I 798.

Quantity.-About 480 acres of common; good land; and about 2 ?० of open field arable: let very high in small parcels.

Rent.-The whole parish, of 2100 acres, improved about $5^{5}$. an acre: the common is at 20 . and to $25^{\text {s. }}$

Shcep.-Decreased. Many werc kept; but many rotted.

Cows-And cattle will be increased: the common was so fed with sheep, that cows could get nothing. The poor now keep some.

Corn. 
Corn.-Immensely increased.

Course.-In I 800 broke up and dibbled with oats and pease; but moderate crops; and rurnips after oats; and wheat after pease. Thue who scaled shallow, had very bad crops: one who plonghed deeper, a very tolerable one.

Poor.-There were filty or sixty small allotments. Only one has been sold. Twenty guineas for halt an acre and so be at the expense of the measure. An allotments was made for the poor's feel, let at jo: an acre, 34l. Ios. a year, including a public-house at 14 l.

Experses.-These were very heavy; amounsing to 67. an acre, on the common allotments, free from all ex. changes (2700!.); which were numerous, aud for which the charge was $25^{5}$. For each piece, whethe yreat or sinall.

Rates. - Were on an average, befure the scarcity, $5^{s}$. in the pound. In the scarcity Ios.

Tithc.-Remains subject.

POPULATION.

\begin{tabular}{|c|c|c|c|c|c|}
\hline & Baptisms, & Burials. & & Baptisms. & - Burials. \\
\hline $1783 *-$ & 10 & $-\quad 15$ & 1790 & 20 & - \\
\hline 1784 & 28 & - & 1791 & 20 & - \\
\hline 1785 & 15 & $-\quad 14$ & 1792 & 19 & 14 \\
\hline 1786 & 24 & $-\quad 12$ & 3793 & 23 & 10 \\
\hline 787 & 25 & -14 & 1794 & I7 & $-\quad 11$ \\
\hline 1788 & 24 & $-\quad 17$ & 3795 & 18 & - II \\
\hline \multirow[t]{3}{*}{1789} & 24 & 7 & $179^{6}$ & 21 & - \\
\hline & 150 & 86 & 1797 & 22 & - \\
\hline & & & 1798 & 23 & $-\quad 12$ \\
\hline \multirow{3}{*}{ Average } & $2 I$ & 12 & 1799 & 17 & - \\
\hline & & & & 200 & 95 \\
\hline & & & Average & 20 & 9 \\
\hline
\end{tabular}

- I cou!d not see the preceding, Mr. FDWARDs being absent. 
First period, adding two years at the avcrage:

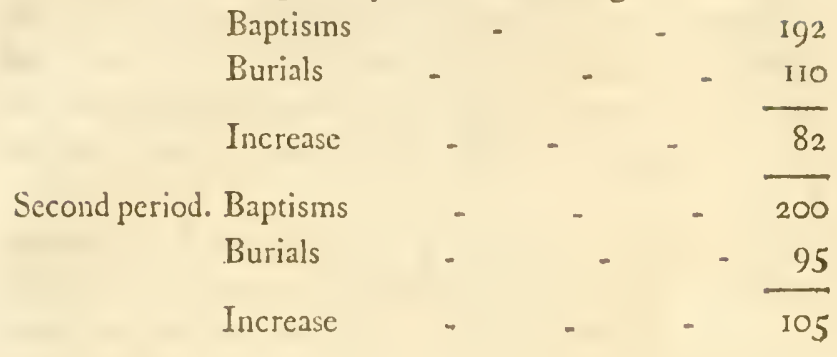

HEVENINGHAM, I 799.

Quantity.-In Heveningham 1553 acres of arable and meadow, and 1000 acres of common.

Rent.-Better than $\delta$ ool. on the old rate. Valuation 1024l. Tithes 2121 .

Corn.-Will be considerably increased. Four hundred acres will yield good barley and wheat.

Sheep. - Will be increascd considerably. Six hundred acres will be turned into sheep-ivalk. Some so light they would be otherwise unprofitable.

Cows. - Will not probably be increascd.

Poor.-They had allotments to common-right houses. The poor that had no rights, have no benefit. Others will be benefited in proporion to their properties. The common was the source of all sorts of immorality, paaching, smuggling, \&c. \&c.

Tithe.-Remains subject to tithe.

Rates.-The Norwich manufactories are here both spinning and weaving, and shawls. The poor complain that they are forced to lay out half their earnings with those at Norwich, who supply them with work.-For further particulars see the Chapter on Pcor Rates. 
Population.-In 1560 ,

Men -

Women

Under 16 yeais

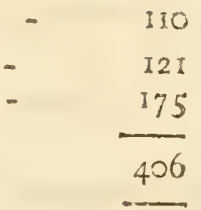

\begin{tabular}{|c|c|c|c|c|c|c|c|}
\hline In $t$ & ear & & & 1787 & 1791 & 1795 & 1796 \\
\hline Males & Married - & & . & & & & I I 2 \\
\hline Ficmales & $\begin{array}{l}\text { Married } \\
\text { Unmarried }\end{array}$ & 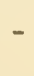 & & $\begin{array}{l}39 \\
90\end{array}$ & $\begin{array}{l}431 \\
93 \\
28\end{array}$ & $\begin{array}{r}30 \\
.101 \\
42\end{array}$ & $\begin{array}{r}32 \\
112 \\
36\end{array}$ \\
\hline Widowers & - & & & & 30 & $\begin{array}{l}43 \\
12\end{array}$ & \\
\hline Widows & - & - & 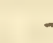 & 12 & 8 & 17 & 12 \\
\hline Male & r 20 ycars & & - & 128 & I I 3 & 121 & I 40 \\
\hline Fen & I 20 years & & & $9 \mathrm{I}$ & I 16 & I 26 & \\
\hline & & & & I & $5^{12}$ & 559 & \\
\hline
\end{tabular}

Increase from 60 to 85 , average increase

of nine years

Increase from 1787 to 1796

Additional increase in the last nine years

\begin{tabular}{|c|c|c|c|c|c|}
\hline & Baptism & Burials. & & Baptisms. & Burials. \\
\hline$\$ 790$ & 22 & $-\quad 18$ & 1790 & 10 & ${ }_{13}$ \\
\hline 1781 & $\begin{array}{l}-\quad 18 \\
-18\end{array}$ & 9 & $179 \mathrm{I}$ & 21 & - \\
\hline 1782 & - & 14 & 1792 & 21 & - \\
\hline $17^{8} 3$ & 16 & 6 & 1793 & 21 & - \\
\hline 1784 & 14 & 12 & $179+$ & 20 & - \\
\hline 1785 & 18 & 16 & 1795 & 19 & 34 \\
\hline 1786 & 24 & 11 & 1796 & 17 & 10 \\
\hline 5787 & 16 & 11 & 1797 & 23 & - \\
\hline 1788 & 17 & 6 & $179^{8}$ & 26 & 18 \\
\hline 1789 & 19 & - & 1799 & 18 & - \\
\hline & 173 & 110 & & 196 & $9^{8}$ \\
\hline
\end{tabular}


First period.

Baptisms
Burials

Increase

Second period. Baptisms

$$
\text { Burials }
$$

Increase
$-173$ 110

$-63$

- $\quad 19^{6}$

$9^{8}$

$9^{8}$

559

19

Average haptisms from I 790 to I 799

Ore in 29 therefore born annually.

Average burials in the same period, ten.

One in 55 dies annually.

The Rev. Mr. Alderson, the Rector, has great merit for the regular manner in which this register is kept, and the people numbered.

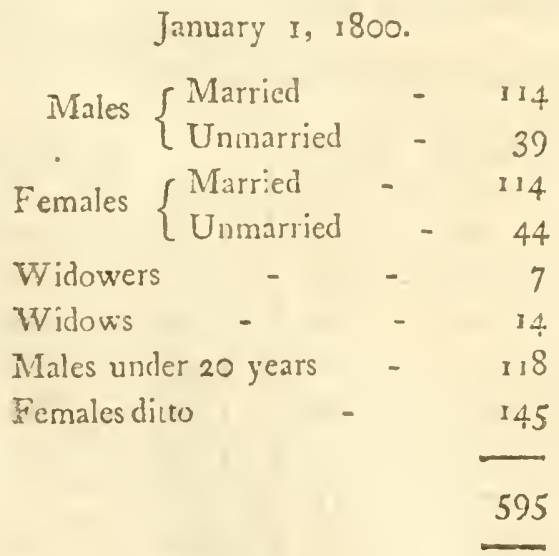




$$
\text { January 1, 1801. }
$$

\begin{tabular}{|c|c|c|c|}
\hline Males married & & - & 13 \\
\hline Females ditto & & - & 113 \\
\hline Males unmarric & cd, abo & ve 20 years & 3 \\
\hline Females dirto & - & - & 3 \\
\hline Males under 20 , & , and $a$ & bove $I_{4}$ & \\
\hline Females ditio & - & - & 3 \\
\hline Males under is & & - & 10. \\
\hline Females ditio & & - & 3 \\
\hline Widowers & - & - & \\
\hline Widows & - & - & \\
\hline
\end{tabular}

January I, I 802 .

$\begin{array}{lrr}\text { Males married } & - & 109 \\ \text { Females ditto } & \text { - } & 109 \\ \text { Males unmarried, above 20 years } & 40 \\ \text { Females ditto } & - & 48 \\ \text { Males between } 14 \text { and } 20 & 18 \\ \text { Females ditto } & - & 22 \\ \text { Males under 14 } & - & \text { II } 3 \\ \text { Females ditto, - } & \text { I2I } \\ \text { Widowers } & 7 \\ \text { Widows } & \\ & & \\ & \end{array}$

The decrease has been occasionel by the enclosure of the common, which bas lessened the temptation to getting settlements in the parish: poor-lates had risen to such a leight, that this parish, Buxton, and Marsham, have united 
united for building a work-house, under Mir. GilBERT's aet, which has carried off some to settle elscwlicre.

IFosd's. - Memorandun in possession of Rob. MarsFam, Esq. Of Stratton Strawless, wade by Mr. PlumbSTEAD, Rector of Heveniugham: it appears that the Spanish chesnut, now standing in the church-yard, was planted in 1610.

It girted in - $1742-12$ feet $\%$ inches.

$1778-14 \quad 8 \frac{x}{2}$

$1782-15 \quad C_{2}^{\frac{x}{2}}$

$I$ measured it in $1802-15$ II

All the measures were taken at the same place, four feet $11 \frac{1}{2}$ inches from the ground, on one side; and four feet four inches on the other. Tliere are knots at five fect.

HEACHAM.-ENCLOSED I 780.

Quanity.-Three thousand three hundred and twentynine acres, of which 400 salt-marsh; now worth about 5s.

Rent.-Now above 15s. (deducting marsh) an acre, which is more than double what it was before the enclosure.

Soil.-Fine loamy sand, on maric, or a chalky bottom.

Course.-Before the enclosure they were in no regular shifts, and the ficld baily managed; now in regular five shift Norfolk management.

Corn. The produce of com is increased by the enclosure very considerably.

Sheep.-More and larger sheep are kept, and the crop of wool more considcrable.

Cou's.-More cows aje kept; for the common was not divided, only.stinted by the act. 
Tithe.-Remains suljeet.

Rates. - Of late years 1s. gd. to 2s. in the pound.

Experises. -11741 .

Poor.-There are fifty-five commonable right-houses, of which none belonged to poor people; but many to litthe tradesmen and small occupiers. The really poor and distressed people had no stock on the fields or common, further than geese, and could suffer by the enclosure to no other amount; abundantly made up to them by an ampler and better paid empioyment. The common-rights themselves were worth very little before the enclosure, which gave two head of large cattle per right to feed on the common of 209 acres. As to fuel, the poor had no right to cut flag, \&c. on the common before, nor of course since: they burn coals, supplied by the parish. To the common. right houses were assigned for each right, two acres of middling land, or one and half of good, for open field shackage and feeding; the right to the stinted common, remaining: there are from twelve to fifteen little and very comfortable proprietors and renters of small plots, from two to ten acres; who have corvs and some corn, and what they like to cultivate. A remarkable instance, and I cordially wish it was universal. Most of them lave two cows; some more.

Population.-This register, like that of Snettislam, kept previous to 1784 so ill, with such 2 gap of years, as to be useless. 


\begin{tabular}{|c|c|c|c|c|c|c|}
\hline & Baptisms & 8. Burials. & \multicolumn{4}{|c|}{ Baptisms. Burials. . } \\
\hline 1780 & 19 & $-\quad 18$ & 1790 & - & 19 & 9 \\
\hline 1781 & 8 & 5 & 1791 & - & 19 & II \\
\hline $378 z$ & - $\quad 16$ & 21 & 1792 & - & 22 & 8 \\
\hline 3783 & 15 & 10 & 1793 & - & 28 & $x 6$ \\
\hline 2784 & $-\quad 17$ & 15 & 1794 & - & 19 & 16 \\
\hline 1785 & 14 & - 20 & 1795 & - & 19 & 23 \\
\hline 1786 & $-\quad 22$ & -14 & 1796 & - & 17 & 16 \\
\hline 5787 & 18 & 17 & 1797 & - & 17 & 9 \\
\hline 1788 & 17 & .. 12 & I 798 & - & 15 & 15 \\
\hline 1789 & $-\quad 18$ & $-\quad I I$ & I 799 & .. & 19 & 15 \\
\hline & 164 & 143 & & & 194 & I 39 \\
\hline First & iod. & Baptisms & - & - & & 164 \\
\hline & & Burials & $\sim$ & - & & 143 \\
\hline & & Increase & - & - & & 21 \\
\hline Secon & period. & Baptisms & - & - & & 194 \\
\hline & & Burials & - & & - & 139 \\
\hline & & Increase & - & - & 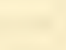 & 55 \\
\hline
\end{tabular}

MIILLBOROUGH.-ACT PASSED 1769.

Soil.-Sand: some mixed land.

Quantity.-The parish contains 3020 acres: of which 420 commons.

Rent.-In 1791 the parish was valued.

$\begin{array}{rr}\text { Farms-No 1. }-572 \text { Acres } & £ .272 \text { Rent } \\ 2 .-535 & 250 \\ 3 .-356 & 117 \\ 4 .-244 & 120 \\ 5 \cdot-407 & 190 \\ 6 .-199 & 80\end{array}$

Farms 


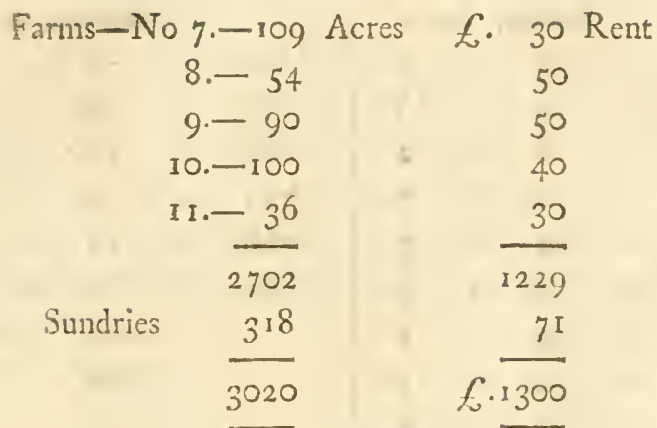

Tithe.-Glebes, \&c. 30ol.

Corn.-Produce greatly increased.

Shcep. - The number lessened: before the enclosure there was a large flock of ewes for folding; now they buy and sell for fatting; under 1000.

Cows.-Lessened; there are not above 60 at present; some few cottagers have ten or twelve anong them.

Rates.-For three or four years past, average 3 s. in the pound. In 1800 , 6s.

Poor. - Twenty acres were directed by the act to be sown with whins; and six others for turf and whins, and feeding their cows; but the crcip of whins was so badly sown or managed, that the produce is trifling; and the people suffered.

Population,-Baptisms, \&rc. for thirty years before the enclosure.

\begin{tabular}{|c|c|c|c|c|c|}
\hline & Baptism & Buria's. & & Baptisms. & Eurials. \\
\hline 1740 & 5 & - & 1747 & 7 & 4 \\
\hline $17+1$ & 5 & - & 1748 & 3 & 2 \\
\hline I 742 & 5 & 9 & 1749 & 6 & 4 \\
\hline 2743 & 10 & - & 1750 & 6 & - \\
\hline 744 & 8 & I & $175^{1}$ & 3 & 4 \\
\hline 745 & 7 & 7 & 1752 & 9 & 8 \\
\hline 746 & 6 & - & 1733 & - & $\begin{array}{r}-\quad 4 \\
1754\end{array}$ \\
\hline
\end{tabular}




\begin{tabular}{|c|c|c|c|c|c|c|c|}
\hline & & aptisms. & Burials. & & & Baptisms, & Eurials. \\
\hline 1754 & - & 5 & $-I$ & I 764 & - & 3 & - \\
\hline 1755 & - & 5 & 3 & 1765 & - & 7 & - \\
\hline $175^{6}$ & - & 9 & 4 & 1766 & - & II & - \\
\hline 1757 & - & 4 & 7 & 1767 & 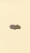 & 9 & - \\
\hline $175^{8}$ & - & 4 & - & 1768 & - & 12 & - \\
\hline 1759 & - & 5 & 3 & 1769 & - & 7 & - \\
\hline 1760 & - & 4 & 2 & & & - & - \\
\hline $176 \mathrm{I}$ & - & 4 & 4 & & & 186 & ${ }^{1} 3^{6}$ \\
\hline 1762 & - & 5 & 6 & & & - & \\
\hline $1 ; 6_{3}$ & - & 10 & 3 & & & & \\
\hline
\end{tabular}

Thirty years since the enclosure.

\begin{tabular}{|c|c|c|c|c|c|c|c|c|}
\hline & & ptisms. & Burials. & & & & Baptisms. & Burials. \\
\hline 1770 & - & $\delta$ & 6 & & 1786 & - & 6 & 2 \\
\hline 1771 & - & II & 4 & & 1787 & - & 12 & - \\
\hline 1772 & - & 18 & 6 & & 1788 & - & 10 & - \\
\hline 1773 & - & 10 & 6 & & 1789 & - & 10 & - \\
\hline 1774 & - & I 3 & 6 & & 1790 & - & 14 & - \\
\hline 1775 & - & I 3 & $-\quad 16$ & & I79I & - & 9 & -10 \\
\hline 1776 & - & 12 & 4 & & 1792 & - & 8 & - \\
\hline 1777 & - & 13 & 9 & & 1793 & - & 14 & - \\
\hline 1778 & - & 10 & 4 & & 1794 & - & 7 & 9 \\
\hline 1779 & - & 10 & 7 & & 1795 & - & 10 & - \\
\hline 1780 & - & 12 & 7 & & 1796 & - & 13 & - \\
\hline 1781 & - & 6 & $-\quad 15$ & & 1797 & - & 9 & I \\
\hline I 782 & - & 8 & -10 & & 1798 & - & I 4 & 7 \\
\hline $178_{3}$ & - & 10 & 6 & & 1799 & - & $i 3$ & 6 \\
\hline $178_{4}$ & - & 9 & 8 & & & & & \\
\hline 1785 & - & 8 & 4 & & & & 320 & 201 \\
\hline \multirow{3}{*}{\multicolumn{2}{|c|}{ First pericd. }} & \multicolumn{2}{|c|}{ Baptisms } & & . & 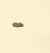 & - & 186 \\
\hline & & \multicolumn{2}{|c|}{ Burials } & - & . & - & - & 136 \\
\hline & & \multicolumn{2}{|c|}{ Increasc } & - & & - & - & $5^{\circ}$ \\
\hline
\end{tabular}




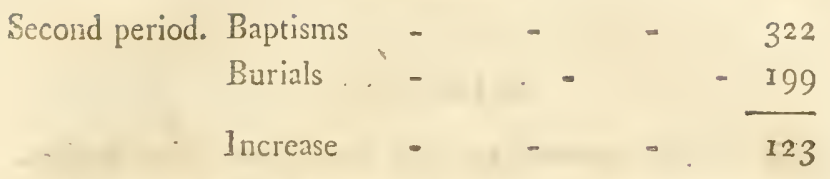

In 1792 the Rev. Mr. NeLson, the Rector (brother of the ever-celebrated Admiral Lord NeLson), numbered the inhabitants.

\begin{tabular}{|c|c|c|}
\hline Males & - & - \\
\hline Females & - & . \\
\hline
\end{tabular}

Baptisms and Burials in seven years,

from I786 to I793 - $\quad 83-49$

Average per annum - - _ 12- 7

One in 26 borm. One in 45 dies.

That year the parish was inoculated, and of 98 chil- , dien and 17 adults, not one died. Iin 1800 there was another inoculation, and of $9^{I}$, none died.

GREAT HOCKHAM.-ENCLOSED I 795.

Quantity.-About 1000 acres of common, and some open field arable.

Rent.-About $\eta$ s. valuation: some will let at 18 s.

Corn.-Much left in grass for sheep-walk, perhaps hals. But cơrn greatly increased.

Shecp.-Increased.

Cows. - Not increased; nor much decreased.

Poor.-Have an allotment of 40 acres; 20 acres of flags and 20 of furze. Some kept cows, and so they do now on their allotments.

Tithe.-Land allotred.

Rates.-About 5s. in the pound. 


\section{HOLM HALE,}

Has an inter-commonage with NeẼon and West Bradenhain; there are in the three commons 1000 acres: Hale has 300; Bradenham 200; and Necton 500. The soil in the low commons on a gravel bottom, with good loam surface, but for want of draining, is much injured by water in the winter. Hale has 36 comnon rights, which would sell now for 301 . cach. They turn on what horses and cows, and geese they please, but no stcers, sheep or hogs. There is not one cottager that has a right of his own; all farmers and tradesmen. Some so low as 5l. or 61. a year. All have a-right to cut flags. The same nearly occurs at Hale and Bradenham; it is a great injury to the common, and if it continues long, will renter it hardly worth enclosing. The cartlc are all turnal on by the proprietors, and not by the cottagers to whom the houses are let: they have no: a cow in the town; but keep geese, snd cut flags.

Shcep.-Very few sheep kept; many oullocks grazed.

Cows. - Not 200 coves in the parish.

Land.-About half grass and lialf arable.

IFETON.

The above unenclosed common of 1000 acres, with Bradenliam and Hale.

\begin{tabular}{|c|c|c|c|c|}
\hline Baptisms from $1 /$ So to & 1789 & - & - & 246 \\
\hline Butials & - & - & . & 158 \\
\hline Increase & - & - & . & 88 \\
\hline Baptisms from I 790 to & 1799 & - & - & 223 \\
\hline Burials. & - & - & - & 140 \\
\hline Increase &. & - & $=$ & 83 \\
\hline
\end{tabular}


Popilation of Holm Hale.

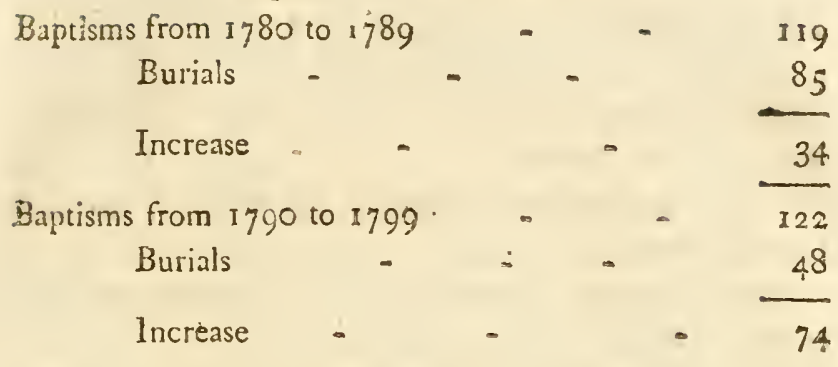

These parishes enjoying the right of commonage over iooo acres of grool land, and joining Ashill, whose comthons are enclused; I was solicitous to compare the results; and it is to be noted, that for the last ten years, the poor in the two former have been permitted to pare turf for fuel, before which time they only cut whins.

First period. Necton - $\quad 246 \quad 88$

Hale

Average of the two

$\frac{\text { II }}{\frac{365}{182}} \quad \frac{34}{122}$

Second period, Necton

Hale

- A :erage of the two

First period

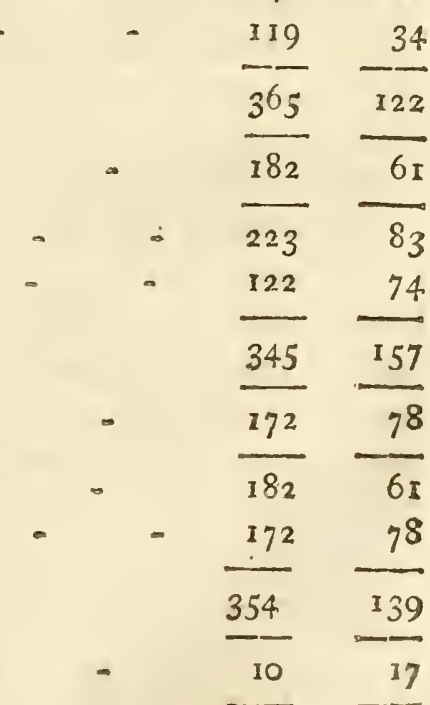

Second ditto

Average of the two

Baptisms in the second period less by ten.

Increase in the second period, more by seventeen. 
Ashill-10 years: two-thirds of the period of is s ears beforc enclosing $\}$ I $30 \quad 99 \quad 32$

Ditto of that since - $\quad$ - I72 $86 \quad 86$

Superiority of the last $\quad-\quad 42 \quad 1_{3} \quad 54$

With commons open at Hale and Necton, baptisms have diminislied.

With commons enclosel at $\Lambda$ shill, they have increased considerably.

With commons open, the increase, that is, the superiority of baptisms to butials, cquals one-tenth of the baptisms.

Witlı commons enclosed, this increase equals one-third.

KEMNINGHALL, I 799 .

2)antity.-About 1000 , or 1200 acres of common: 2500 in all the parish.

Rent. - Will be i $\delta$ s. an acre.

Corn. - If ill be all undes corn.

Slicep - W Wiil be decreaseci much.

Corcs. - iV ill be increased.

Rates.-About 5s.

The little commoners, as the common laid at a distance, complained that they should be obliged to sell their allotments: Mr. Goocis proposed that the whole parish should be included in the act for exchanges, to lay every man's ground near his housc; they consented, and done to general satisfacion.

\section{KETTERINGHAM.}

Baptisms. Burials.

Twenty-nine years, from I 1700 to 1728 - I18 $9^{2}$

Twerty-nine years, from 1729 to $1757 \quad-\quad 89 \quad 74$

Twenty-nine years, from $175^{8}$ to 1786 - $102 \quad 62$ Inhabitants 
Inluabitants in 1787

Houses charged to window tax

Fourteen single, fire double, one triple.

Acres

\section{Pasture \\ Wood}

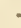

Soil, from sandy loam to wet clay.

$$
\begin{array}{r}
-1200 \\
-\quad 200
\end{array}
$$

Rent.-I2s. 6d.

Wheat.-I 75 to 200 acres; one half dibbled.

$$
\begin{aligned}
& \text { Course - } \quad \text { Turnips, } \\
& \text { 2. Barley, } \\
& \text { 3. Clover, } \\
& \text { 4. Wheat. }
\end{aligned}
$$

\section{LANGLEY.-ENCLOSED I 800.}

2uantity.-Five hundred and fifty acres of low common; sucne of it for the plough ; no open field.

Rent.-Quality price $7 \mathrm{~s}$. an acre. It yielded no rent before. Before enclosing, the peopie were told that to $200 l$. a year, icl. for common would be given; and they agreed, that if they contimued at their old rent, they would have nothing to do with the common, for they valued their rights at nothing. Rent now i2s.

Com.-No increase.

Cattle.-Six times as nuany as ever. Three hundred may be kept, instead of 40.

Sheep. - None before or since.

Porr.-Where wure 24 cottagers; 40 acres allotted to the commoners for tring, in regular cuttings: a very good improvement for them, as it is under direction by the act. They used to beg for straw, \&c. and ofien lost their cows; and went begging to get others; deriving very littlu bencfit. Sir T. Beauchamp, the lindlord, lias agreed also to mark out some lots of marsh land for such as can keep 
cows, by which means they will be in much easier crcumstances; and all tenants to himself; none pay more than 2!. 2s. rent for their cottage: nor are they charged with any expenst of the act or enclosing, if their rents did not exceed 5 l. betore the enciosure.

In examining this enclosure, Mr. BurT ON pointed out nany cotcages, with goud gardens annexed, and various small grass tields enclosed, to ail who kept cows; Sir T. BEAUCHAM p's order being at all times to furnish land to such as are able to get a cow. They have each a piece near the river, assigned for mowing fodder for their corvs-too much cannot be said in favour of that system.

EAST IEXHAM AND GREAT DUNHAM.-ENCLOSED I795.

Quantity - 2500 acres in the two parishes. Whole year and half year land.

500 common

3000 in all.

Rent.-Before enclosing, Dunham I4s. or I $5^{\text {s. and }}$ Lexham ios. Quality price, Dunham I8s. Lexham ifs. Course-Five shitits. Now the same in Dunham. Cọn after wheat.

Corn.-Greatly more.

Shcep.-Increased.

Cows.-Dimirished for many small proprietors; there were 5 r rights.

Improvement.-Clay and draining.

Tithe-Remains subjeet.

Expenses. - I' wo thousand two hundred pounds, includ. ing every thing.

$P$ cor.- I welve pounds a year allowed for fuel; an allotment ploughed, and sowed with whin seeds: part let. Employmunt much increased.

IYTCHAM. 
IYTCHAM.ENCLOSED $175^{8}$.

Quantity. - Above I 700 acres half year land,

$\begin{array}{rrr}\text { Farms.- No. 1. } & - & 1000 \\ \text { No. 2. } & - & 200 \\ \text { No. 3. } & - & 300 \\ \text { No. 4. } & - & 100 \\ \text { No. 5. } & - & 100 \\ & & 1700\end{array}$

Besides some smaller.

Poor.-The commons, except a small one given in liew of sheep shackage, were not enclosed, but left as they were. They are fed by trarkesmen and small occupiers, but not by the poor, whose chief benefit is fuel.

Population.-Forty-two years before the enclosure. Baptisms in 42 years before the enclosure - $\quad 3^{67}$

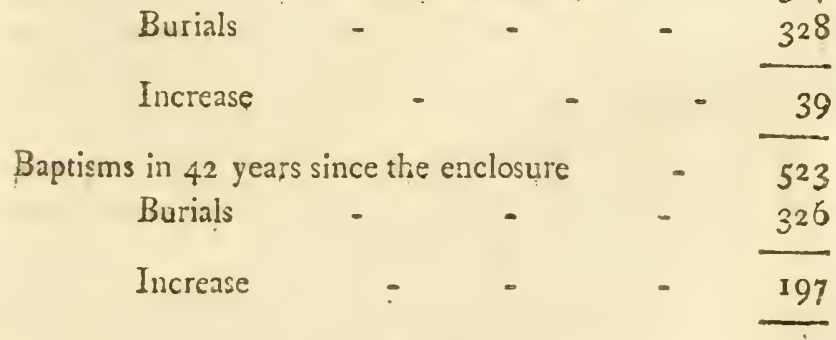

I. DHAM.

The commons were enclosed in 1801 : all cottagers that claimed, had allotments; and one for fuel to the whole; but the cottages did not belong to the poor; the allotments in general went to the larger propi ietors, and the poor consequently were left, in this respeet, destitute: many cows werc kept before, few now. All the poor very much against the measure. 
Mi. CUBIT, of Catfield, thinks, that where enclosing has converted land to arable, the poor get as much by gleaning as they did by the common: the high price of catcle has lessened the number of their.cous: gecse and fuel have been of late their chief advantage; nor does he remark, that those who support themselves by commons, are richer, or better off than others depending on the labutr of the farmers.

\section{IARHAM.-ENCLOSED 1793.}

2uantity.-Near 4000 acres in the parish; 1000 turf and fen; not 500 acres of old enclosures.

Rent.--Before the enclosure, between I 1001 . and 1200 .; - now twice as much.

Corn.-Very greatly incrcaced.

Cous. -Lessened consicicrably; for there were many renters of 101.121 . or ${ }^{5} 5^{l}$ a year, who loaded the commons with cattle.

Shecp.-As many now as before.

Poor.-An allotment of 205 acres of turf moor for fuel, and feeding cows, \&c. for which they pay, as a regula-

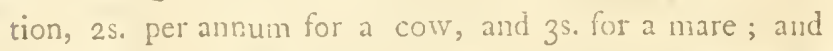
in this maniner 30 are supported hetter than they were before the enclosure. This measure has been so favourable that the poor have not suffered at all.

Rates.-Before the enclosure they were from is. to 2 s. Since, 6d. to 8d.; except the late scarcity, in which $3^{\text {s. }}$

Improvement.-In the Fen the improvement has been very great, by means of paring and burning; upon which ahey sow cule for sheep feed; but some hawe seeded it. Then oats, producing 10 to it combs per acse: after ahis, somc have sown wheat; and others gone on wich two or three more crops of oats, and have, by over cropping, hurt the land, and done themselve's no good. The fen soil is not grod and solid, but rather loose and frothy. 
Much of the upland is on a chalk bottom, on which sainfoin has been trierl: $\mathrm{Mr}$. WIrIEARLs says it has not anstrered; if forced by manuring, the same efforts would make the land prọduce corn.

Expcnsis. -28701 .

MARSHLAND, SMETH, AND FEN.

The act passed about seven years ago, for the drainage of the Fen, and the division and allutment of both.

A. R. P.

The Smeeth common I 585 I $O$

The Fin

$4757 \quad 3 \quad 0$

634300

Belonging to 528 common-rights. Besides this, there were drained, also of private propesty belonging to

A. R. P.

\begin{tabular}{|c|c|c|c|c|c|}
\hline General Brown & & - & - & 592 & $I$ \\
\hline Mrs. PATRICK & & - & $=$ & 40 & 0 \\
\hline Mrs. ALLXN & - & & - & 28 & 3 \\
\hline Dr. Hokne & - & & - & 15 & 2 \\
\hline MIr. HARDY, \&C. & & - & & II & 2 \\
\hline
\end{tabular}

And in another Fcn, Well-Moor:

Mr. TownLEY

Acres.

Mr. HOWEL

163

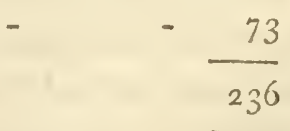

The Lords of Manors had one-twentieth, and the clergy half tithe, or 2s. 6d. an acre for five years: then subject to tithe. 
There has been raised by the Commis-

$$
\text { L. s. d. }
$$
sioners - - - 29,000 00

And it will demand 10l. a right more, or $5,280 \circ 0$

$f_{0} \cdot 34,280 \quad 0 \quad 0$

Sixty-five pound a right in all; 55l. a right for drainage; and sol. for act, Commissioners, Sxc.

For each right the alloment in the Fen is from 12 to 35 acres, in the distant and lower part: and $6 \frac{x}{2}$, for a mile and a half from the mill; and on the Smeeth, from $2 \frac{x}{q}$ to 3 .

Some of the latter lias sold for $5 \mathrm{cl}$. an acre; and much woulk sell for $70 l$, and even more. Rights sold three or four years agro, from 100l. to 125 l. each.

The Smeeth would, under the hammer, let at 3 l. an acre ; and the Fen, at 25 s.

This great tract of land was, in its former state, worth little: the F'en not above Is. an acre in reed, being two or three feet deep under water: the Sinceth was often under water, in parts to the amount of half; and then at the Mid. summer after rotted the sheep that fed it.

The first crop takith on the Smeeth, a strong clay soil on silt, has been chiefiy mustard; the crops great (see that article); wheat by some; and oats by others: the lase were great crops, of 16 or 18 coombs an acre; and would have been 20 , or more; but the bulk of straw too great. I found the country in a blaze, burning the oat stubbles, to sow cole for seed, about Michaelmas, on one earth.

Above 30,0001 . a year is added to the produce of the kingdom, by this most beneficial ursdertaking.

The poor people who turned cows, geese, and ducks upon the common, without possessing rights, have suffered, as 
in so many other cases; and it is to be regretted, that some compensation is not in all such cases provided by the act. There cannot be a doubt, that the immense system of labour created, is worth far more than such practices; still many individuals are injured, and without any absolute necessity for being so.

$\mathrm{Mr}$. CoE, of Islington, is one of the greatest undertakers in the cultivation of this Fen: he has 400 acres of it, and has already cultivated the whole of that tract. His method has been to pare and burn, at 30s. an acre for some; but paid too much; now 2 is. an acre paring, and 6 s. burning. But after this operation he found it too soft and rotten to go on with horses; he therefore breast-ploughed, and sowed cole seed; the crop very great, but killed by the frost: he then breast-ploughed again, and sowed oats; both thess ploughings at 2 Is. an acre: the crop from 15 to 18 combs an acre: he intends on 40 acres of this stubble to sow rye-grass to feed, that the land may be trodden, and consolidated: on the rest he will plough, and sow oats: some intend wheat, at Candlemas: he this year sowed 12 acres at that time, and got $g$ or 10 coombs an acre.

I viewed a fine piece of cole in the Fen belonging to Mr. J. Thisteton, which had been gained without burning, by tillage; but examining the surface, I found it in so loose and puffy a state, and so like bears' muck, that if it he nor very severely trodden, it will yield bad corn: another piece near it, after burning, more solid.

Crossing by the six-and-twenty foot road, a bridge now building, I caine to a piece which had been broken up by the Rev. Mr. Ashmole, by paring and burning, and sown to mustard: this failed; it was then tilled, and sown again; but again failed; and presented only a furrow of cears' muck; but examining the bottom, found a much 
more solid peat under the furrows: this furro:w should have been burnt, and the next would then have yielded good crops of any sort.

$A$ rast inprovement on such a $F \mathrm{cn}$, would he to pare and burn, and sow chicory, and feed, and trample well for two years, to consolidate; then to break up for cole, and after it corn.

The fen of Downhan, Outwell, Wimsbotsham, and Stow, under an act for draining, four years ago, extending to Old Podyke; and they are now at work.

The traet on to which Stowbridge leads, and marked in the new map as fen, is under cultivation.

\section{MARSHAMT.}

Enclosed in the same bill with Heveningham.

Quantity.-The common 5 or 600 acres; and so bad as not to be a great object; but the half year lands several hundred acres.

Tithe.-Remains subject:

POPULATION.

Baptisms from I 780 to 5789

Burials 195

Increase

Baptisms from 1790 to 1799

Burials
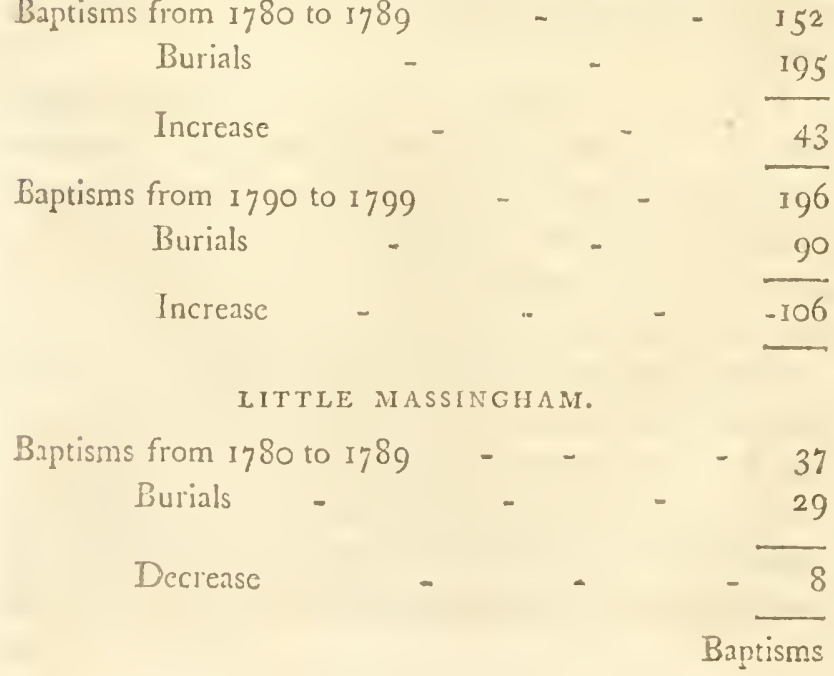
Baptisms from 1790 to 1799 - $\quad 26$

Burials - - _ .

Decrease _ $\quad$ - $\quad-\quad 8$

This account appeared to be so singular, that I looked back in the register, and finding the period from 1740 to 1749, well kept, and entered, I noted it.

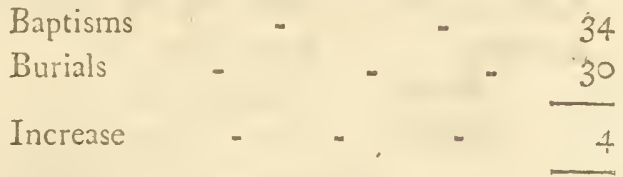

Mr. MORDAUNT, the rector, was not at home, nor Mr. Godfrey, one of the three farmers in the parish, or I should have inquired into the circumstances which have had this effect. It is an arable parish of dry land, and very well cultivated.

MATTISHALL, I8OI.

Nine hundred acres of common: average 20s. They suld land to pay the expenses, 35 l. per acre: subject to tithe; but for five years to half tithe.

\section{METHWOLD UNENCLOSED.}

It is a vast parish, containing, probably, not less than 12,000 acres. 'There is a very great common fen; but situated at such a distance, that many poor people who would otherwise use it do not, except for fuel. Here is an immense claak-pit, of hard building chalk, called clunch; in and about which are many contagers; but there are only three cows kept among them. I know no parish that calls for enclosure more than this. 


\section{MILCHAM.}

Arable

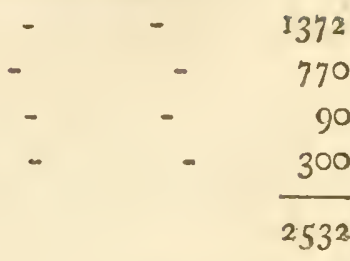

Pasture

Wood

Common

372 Acres.

770

90

300

$253^{2}$

Rent, arable and pasture, 15 s. in 1788 .

Eand-tax - $€ .18 i$ 8s.

Houses

Double

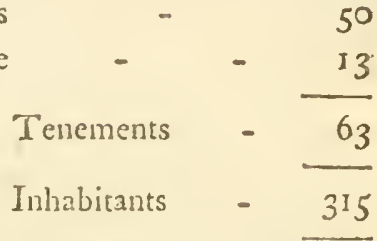

Maintenance of the poor to Launditch House of Ind dustry $\mathrm{f}_{0} 793^{\mathrm{s} .}$

Course.-I. Turnips,

2. Barley,

3. Seeds, one or two years,

4. Wheat; and some add,

5. Barley.

Produce, wheat 5 to 6 coombs.

Barley and oats, 8 coombs. NORWICH.

Poors rate in St. Andre:w's parish, which is very nearly in the same ratio as all the rest : it is one half the rent. The more wealthy persons are rated for stock, in whish $50 l$. is accounted equal to rl. of rent.

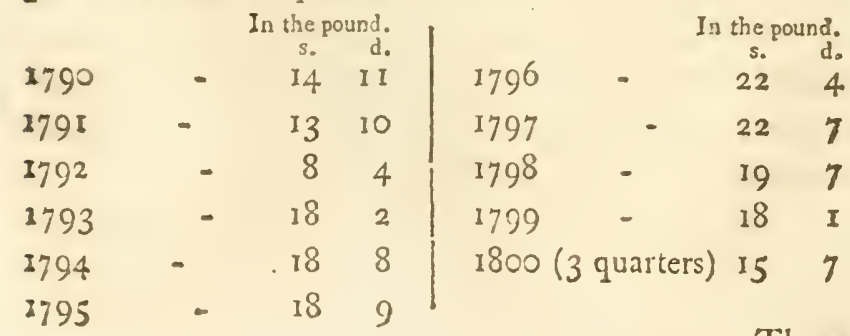


There appears, however, to be some difference in the patishes: it is calculated that ód. in the pound, in the whole city, raises 500 . Now, in the Annual General State of the Court of Guardians for 1799, the rates are set down at $18,405 \mathrm{l}$., deducting fom which $1722 \mathrm{l}$. for arrears and empty houses, there was raised 16,6831 . which makes, at $6 \mathrm{~d}$. producing $500 \mathrm{l}$. the rates to be that year $16 \mathrm{~s} .8 \mathrm{~d}$. in the pound, instead of $18 \mathrm{~s}$. $1 \mathrm{~d}$.

\section{POPULATION.}

Births from 178 I to 1789 , average

Ditto from 1790 to 1799

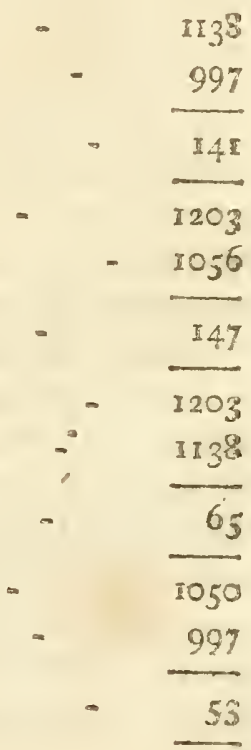

Decrease - $\quad \frac{945}{1403}$

Deaths in the first period

Ditto in the second

\section{Decrease}

Average deaths, first periou

Ditto births

\section{Annual loss}

Average deaths, second period

Ditto births

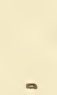


that flourishes. They have a large yarn trade, however; which muks the transter of the fabrics elsewhere.

Account of empty louses returned to the Court of Guardians, and arrears of rates:

Year ending April r, I79 I

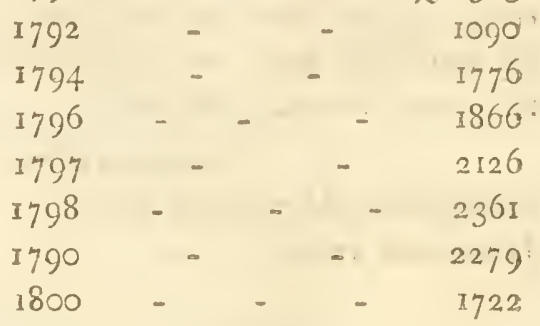

This circumstance does not explatin the difficulty.Rated houses are not probably in question: I applied to several persons who knew the city well; but they were not acquainted with such a number of little houses untenanted, as would account for a great decline in population.

There is one great encouragement to manufacturing; which is the cheapness of labour: I was assured by seved ral persons, by one in particular, remarkable for accuracy (Mr. SwrFT), that on an average of all the trade of Norwich, a weaver does not earn more than 5 s. a week the year round; yet, in some works, and at some seasons, he will get a guinea or more. This is very low; nor does any thing enable hin to support his family, but his wife, if she weaves, earning 4 s. In flourishing fabrics no such wages are heard of.

Proportion of the Sexes.

Baptisms of males from I 78 : to I 789 , eight years,

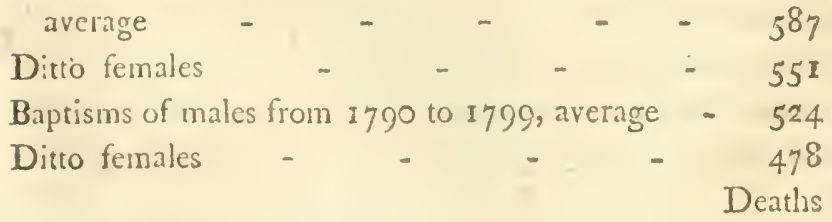


Deaths of males from 178 i to i 789 , eight years,

\begin{tabular}{|c|c|c|c|c|c|}
\hline average & - & - & & - & $5^{8} \cdot 3$ \\
\hline Ditto, females & - & - & - & - & 619 \\
\hline Deaths of males from & I 790 to & I799, & average & - & 511 \\
\hline Ditto, females & - & - & - & - & 53 \\
\hline
\end{tabular}

Average baptisms in the first period:

$\begin{aligned} & \text { Males } \\ & \text { Females } \\ & \text { Less by }\end{aligned}$ -
Second period. Nales
Females
Less by

These are or may be the number of weavers that enlist a) go elsewhere, to leave the sexes equal. Average deaths in the first period:

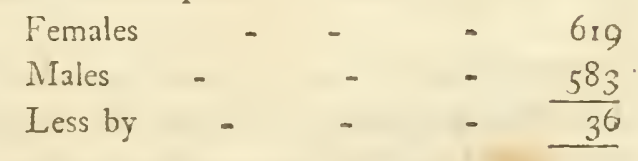

Average, second period:

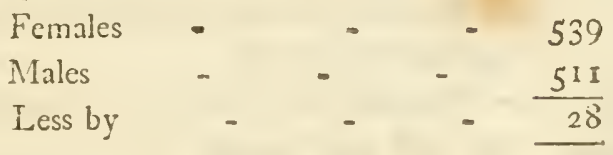

If many young weavers had emigrated, or enlisted, in a greater proportion than females go to London, \&xc. it might be seen in this comparison. If $5^{8} 3$ give a diminution of $3^{6}$, then $5^{\text {I I should diminish }} 3^{1}$, but it is only 28; had they emigrated more than common, this number would have exceeded 3 .

But there is one circumstance which throws snuch uncertainty on the inquiry, which is the number, an increasNORFOLK.] 
ing evil evcry where, of sectaries: at Norwich they are very numerous; several of them have buryinggrounds. There will te no judging of any of these circumstances with tolerable accuracy, till returns are made from all descriptions of persons. Mr. EAstLand does not conceive that Norwich is less populous than it was, excepting the immense number of recruits it has furnished; and sulstitutes for the militia. The amount of arrears and cmpty houses returncd to the Court of Guardians, lec thinks may be probably a tolcrable rule for marking this point; as there is a practice of rating houses of very low rent, dorn even to 20s. or zos. if they stick out a broont, or a plate of apples to sell, considering them as shops.

\section{NORTHIVOLD}

Act passed, r796.-In : 800 , the award, map, and Commissioners accounts, dated November I, 1798, not given in.

Quanity.-Five thousaud acres in the parish: of which $1500 \mathrm{fen}, 550$ ancient enclosure, not subject to the act; the remainder, ahout 3000 , open arable fields.

Lord's Allotment.--Ouse-twenticth of the commons.

Tithi.-Remains subject.

Soil.-The open field arable, a sort of sandy loam: much sand, and some gravel.

Rent.-Before the enclosure, average not exeeding 9 s. the statute acre: now it is 13 s.; some up to 15 s. ; of the I 500 acres of fen the worst at 6s. ; the best of the common up to r6s. Valued rent of the whole parish, houses included, 3374 .

Corr1. - The enclosure will undoubtedly increase the product very greatly.

Ceurse.-1. Fallow for turnips, or wheat; 2. Barley; 
ut oats; 3. Land for shackage; no seeds: now four shifrs.

Improvement.-Much has been and will be clayed, and the success very great: clover introduced and wheat on it, and the crops bear quite a new face: Dr. Hinton has had seven comb an acre of wheat. In all respects the improvement very great indeed. 'The fen is not cultivated, for the drainaze depends on Bedford Level; and it is not dry enough to pare aud burn. In I799, they were drowned so late as May.

Shecp. - There were once 3000 very bad and ill-fed sheep, with numbers dying for want of food; now there are not more than 1 roo kept, but they are far more valuable, from being better fed; though no change in breed.

Cows.-There wcre about 240 or 250 kept in a wetched manner, wandering the day through half-starved: now much lessened; perhaps half.

Rates.-Average of three years, to Michaelmas 1799, 2s. 3 d. in the pound. In 1800 , 4 s.

Pcor.-There were 72 commonable messuages. They are supposed to have received land to the amount of 81. IOs. per annum, for each right. The value of a common messuage, about five years before the enclosure, was I 10 guineas. Now, the house and allutment would sell for 340!. These are freeliold; but for copyholds, the value less. They may, on an average, be reckoned, rent of habitation, 3l.; allotment, 81. Ios. ; total, 1 Il. IOs. ; and value, $300 \mathrm{l}$. Besides this allotment, each has $5 \frac{3}{4}$ acre of fen set out for fuel, supposed to yield 12,000 turfs yearly, for one hearth, the calculated consumption. The ancient cottages, of 20 years standing, that liad no common rights, were favoured with a right of turbarv over $\mathrm{I}_{3} 3$ acres, subject to the controul of the fen reeves, to cut each 800 turfs. There might be about 20 cottagers, who without a right 
kept half-starved cattle, geese, \&c. which were subject to be driven, and fined. These are all at an end; and the loss is not what might be supposed, for they were not profitable speculations by any means. The allotments of 81 . 10s. are from four to six acres of fen, near the town, subject to inumlations; the remainder in value in high fen, $4^{\frac{x}{2}}$ miles distant from the village; and this circumstance proves a great hardship to them: the lands which would have suited them have been allotted to the great proprictors; all they can do is to mow it: thus in the winter they have no dry land on which to put their cattle. The allotments of fen ground for fuel, to common-rights, cannot be separated from the houses, neither let nor sold from them, by a clause in the act of parliament.

POPULATION.

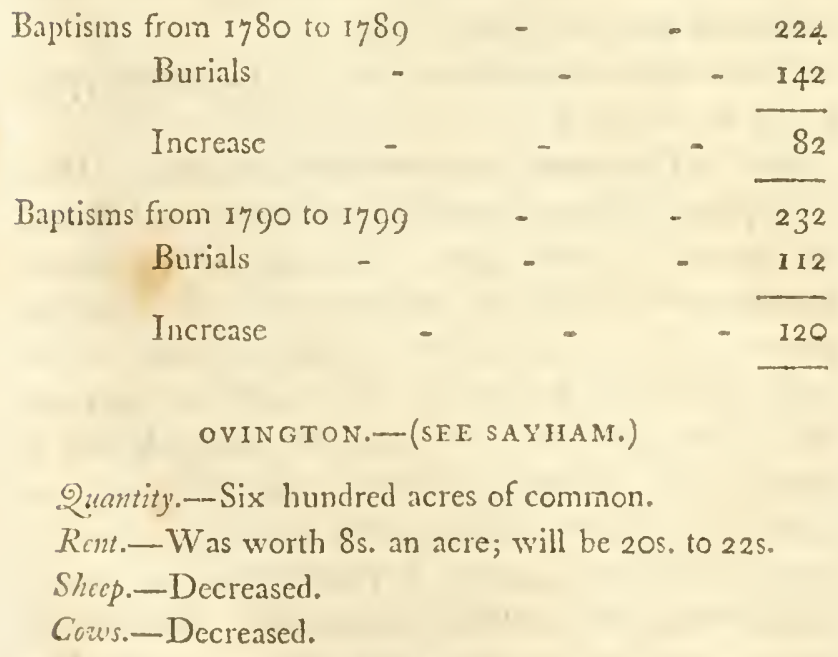

OXBOROUGH.-ENCLOSED 1723.

2uantity.-About 2000 acres in the parish. 
Rent.-Now near gool. a year. The award and all the documents relative to the enclosure being lost, the Rev. Mr. White, the rector, to whom I applied, and who was so obliging as to give me such information as was in his power, could not satisfy various of the inquiries.

Population. - For 20 years past :

Baptisms from i 780 to 1789

Burials

Increase

2

Baptisnus from I 790 to I 799

Burials

74

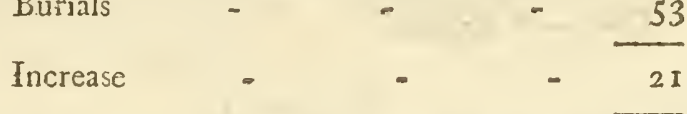

The people are certainly very much increased, and more than any account of this sort would shew: for the last seven or eight years the Roman Catholics are much increased; these bury, but do not baptize in the church.

In 1782 an enumeration taken:

Inlabitants

Houses

Charged to window tax Families

Souls, per house

Baptisms and burials for 7 years, 1780 to $1786, .44$ Average

One in 39 born-one in 39 buried.

\section{PLUMBSTEAD.}

2uantity, - About 600 acres of common. No half year land.

Rent.-Common worth $12 \mathrm{~s}$. and will be worth 25 s.

Corn.-Greatly increased.

I 3

Shecp. 
Sheep.-Decreased.

Cows.-Much the same.

PORINGLAND AND FRAMINGHAM, 1800.

Quantity.-One thousand one hundred and forty acres of common. Known for many years to be fed only by asses, and the worst of live stock : never paid (except by fining) one shilling. It is bad land; not worth more than Ios.

Tithe.-Commuted by a corn rent; which, on the commons and waste lands, sinall equal one-tenth part of their improved annual value.

Shecp.-Decreased.

Coius. - A decreasc.

\section{RANIVORTH.}

Baptisms from I780 to I790
$\begin{gathered}\text { Burials } \\ \text { Increase }\end{gathered}$
$\begin{gathered}\text { Baptisms fron I 790 to } 1799 \\ \text { Burials }\end{gathered}$
Increase

RINGSTEAD.-FNCLOSED I 78 I.

2uantity.-Two thousand six hundred and ninety-seven acres.

Soil.-Sandy loam.

Rent.-Now near 1 5s. an acre round, which is considerably more than double what it was before.

Course.-Five shifts at present; before irregular.

Corn.-The produce of corn more than doubled.

Shcep.-As many ; not more; but they were wretchedly kept before the enclosure. 
Cows.-More ; and more cattle of all sorts.

Tithe.-Remains subject.

Rates._Of late about 2s. 6d. in the pound.

Poor.-Fifty acres were allotred for cutting whins, and they are restricted to cut in regular crops; much more than wanted; so that others take for various uses. A fair equivalent was given to common-right houses. Very few little proprietors, like those at Heacham, adjoining.

Improvement.-Mr. STYLEMAN, after grubbing the whins, ploughed 100 acres of heath, quality at 4 s. an acre, and sowed cole, which killed many wethers by the murrain, which arises sometimes from feeding cole. After this, he summer-fallowed for wheat, which gave seven coombs an acre, and sold for 9301 .

POPULATION.

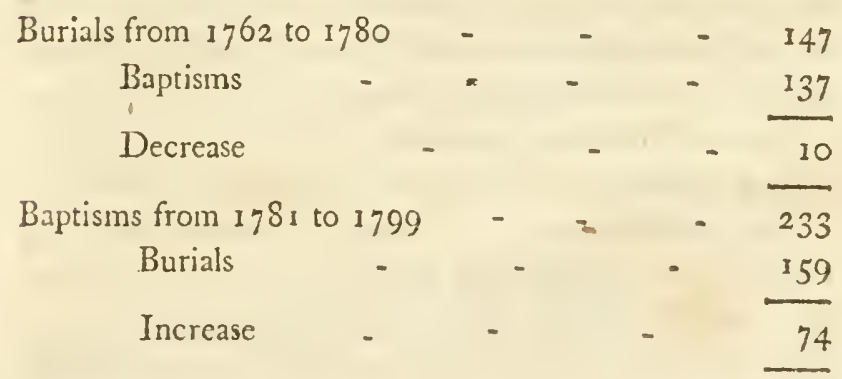

SALT HOUSE AND KELLING.-ENCLOSED I 780.

2uantity.-About 1200 acres of hearh. I 500 half year land.

2700

Soil.-Much black sand on a gravelly bottom; but some better land.

Rent.-The heatl yielded little or nothing; and the half year land was from 7 s. to IOs. an acre; it is now $15^{\text {s. }}$

$$
\text { L } 4 \text { Improis. }
$$


Improvement.-The rent now made by the heath is chiefly by culivating parts of it, for the assistance of the rabits, that are upon the remainder: before the enclosure the poor cut whins and flags every where; since, they are restricted to their own alloments. Mr. GIRDLESTONE, who is lord of the manor, and has a considerable property here, manages his warren by thus improving parts. He ploughs, and leaves the furrow two years to rot, then clays it 50 loads an acre, and so load's of muck, works it for tumips, which are good, worth 4Os. an acre; these are sowed with sheep and cattle. Sows oats next, which, in a season not tos dry, yield ten coombs: with these he lays dowa to grass for as many years as it will stand, for the rabbits; these new lays cnable ilum to give milk, and bring up their young; when grown, they teed upon the ling, thus giving value to all the res", and in this way is worth 20s. an acre: but would not let to a farmet, by itself, for more than 5 s. or 6 s.

Corn.-Very much increased.

shaep.-Not so many kept as before the enclosure.

Cuws.-Much more cattle kept. Cow's are increaseò, yet the farmers graze more than dairy; and the tread of freat cattle is wanting in foeding off the tarmips.

Poor.-To every commonable right house unde: rol. a year, there is a right alloted of kecping a cow, and two heifers, or a mare and a foal, and of cutting fuel; between three ald four hundred acres being allotted for this purpose. This common is not orerstocked, and the poor are much better off than they were before, as they have it to themselves, all great commoners being excluded; hut boing invested in the chu,ch-wardens and overseers, as well as in the lord of the manor and the rector, there are seme abuses which might have been avoided.

Titlie -Remairs sulject: pays $\mathrm{s}^{\mathrm{s}}$. an acre. 
Experses.-About 15001 .

Present General State. - A very large part of the parish, from being left in warren, has, to the eye, the same dreary, uncultivated, barbarous state, as so many other common heaths in the neighbourhood. Those animals are never found but in deserts, and it seems to have been a strange exertion to have gone to parliament for powers to leave any part of a parist in such a state. The soil is certainly not good; but turnips worth 4os. and ten coombs an acre of oats, are proofs that the land might be profitably cultivated in an alternate husbandry of sheep-walk and corn. Their manıer of breaking up and leaving to rot two years, explains the failure; this has been tried in various parts of the kingdom; and almost every where, whether it fails or not, proved unprofitable. It should be pared or burnt for turnips or cole, and laid down to grass; burnet, chicory, cocksfoot, Yorkshire white, and a little ray, and being well loaded with sheep as long as it would last, and clayed or not, would prepare for one crop of corn to lay down again. But the notion that the land is good for nothing Eut rabbits, makes it so.

POPULATION.-SALT-HOUSE.

Baptisms twenty ycars before the enclosure - $\quad 164$

Burials

Increase

Baptisms twenty years since the enclosure 128

Burials

Increase

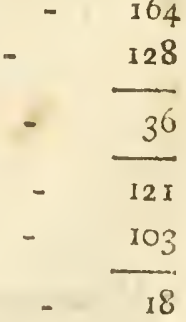

This is a singular instance; for population has unquestionably declined, as far as this document proves any thing, and considerably too, whether the increase or the baptisms be confided in. 


\section{KEXXING.}

Burials twenty years before the enclosure

Baptisms

Decrease

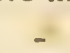

-

$-$
- $5 j$

Burials twenty years since the enclosure

Baptisms

Decrease

The two parishes together.

First period. Baptisms-Salt-House
Kelling

Second period. Baptisms-Salt-House - I2I

\begin{tabular}{lll}
\multicolumn{1}{c}{ Kelling } & - & $\frac{61}{182}$ \\
$\begin{array}{c}\text { Burials-Salt-House } \\
\text { Kelling }\end{array}$ & - & $-\frac{103}{106}$ \\
Increase & - & $-\frac{169}{13}$
\end{tabular}

Whatever the cause be, it has, therefore, operated on both parishes. 
SAYHAM AND OVINGTON.-ENCLOSED ISOO.

Quantity.-One thousand six hundred acres of common; no half year land.

Soil.-A marley clay bottom at 12 to 18 inches, over it a vegetable mould. Very superior land: friable loam.

Rent.-The value nothing; for it was so overstocked, that though the land is very fine, yet it would have answered much better to have paid a good joist price for putting cattle out, than keeping them gratis on the common: notwithstanding this circumstance, however, and the fact that the common was of no value to the public, yet it cer. tainly yielded a rent to the landlords of the enclosed property, probably to the amount of 8 s. an acre, or $6_{4}$ ol. a year. After cnclosure, worth 2 is. an acre. The Commissioners, in setting out 5 ol. a year directed by the ast for the poor, finding that the rents of land were rising, sold off a part they had intended for that purpose, for about $250 l$. and letting the remainder by auction, it produced, on a 2 I years lease, 981 . I 3 s. As this rent arose from the competition of the farmers, it offers a curious anecdote touching the value of land; not, however, to be separated from the price of corn.

Course.-Mr. Crowe, who has a large portion of the common, ties his tenants to either, 1. Tumip; 2. Barley; 3. Clover ; 4. Wheat; or, I. Turnip; 2. Barley; 3. Grassseeds two years; 4 . then two crops of corn or pulse.

Corn.-An immense increase.

Sheep.-There will be fewer sheep kept ; they often rotted before; now none. There was a walk on one of Mr. Crow E's farms for 36 score ewes, on this common and that of Ovington, and the two tenants, for the last cleven years, did not make a shilling profit, such were the losses. The 
tenant of the park farm has bought 300 ewes in one ycar, to make up these losses.

Cows.-Very few cows were kept, except by copyloold tenants: but it is suppoced that there will be fewer; but a very great increase in grazing beasts.

Tithe.-Remains subject.

Ratcs.-About 3 s. in the pound.

Expcnses.-3600l. on Sayham only, which was roop acres of the 1600 : land was to be sold for paying it: it fell short 500 . collected by a rate.

Poor.-An allounent of not less than 50 l, a year, for distributing to the poor in coals, was ordered by the at? it let for 981 . There were 100 commonable right houscs. "They used to sell a cottage of 31. a year, with a right, for 8ol. For each, four acres were allotted: and the cottage, with this allotment, would now sell for I6ol. And what is rery remarkable, every man who proved to the Commissioners, that they had been in the habit of keeping stock on the common, was considered as possessing a common-right, and had an allotment in licu of it. Nor was it an unpopular measure, for there were only two people against it from the first to the last.

Finces. - A citch, five feet wide and four feet deep, at 2 s. for seven yards; with a dead hedge and quick. Sixteen rod, at seven yards, cost 20s. for deai fence: quick, 5s. a 1000, and 80 laid into a rod. The best fence is white thorn and sweet-briar al:ernate; the latter protects the former, while it is young, and the quick killing it when grown, remains an excellent fence at a good distance.

Improcement.--The husbandry of breaking up the common, is to plough once for pease, oats, or cole; the two former all dibbled. Then clay 60 loads an acre of 24 bushels; and fallowed for turnips; and then the common

husbandry. 
husbandry. It may be calculated that the first year there were 600 acres of oats, and 600 of pease.

$$
\text { L. s. d. }
$$

600 acres of oats, are i 5 coombs, some broke

up this year 25. This is gooo coombs at

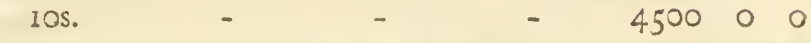

600 acres of pease at 5 , are 3000 coombs at

345

For the first year - $\quad \$ .660000$

No cole would be sown, but they camnot get all ready in time for onts and pease.

\section{Second year.}

400 acres of cole, at 6 coombs, 2400 coombs

at 30 s.

óo acres of wheat, after pease, at $\&$ coombs,

4800 at 24 s.

600 acres of turnips, at 3 l.

$$
\begin{array}{rrr}
5760 & 0 & 0 \\
1800 & 0 & 0 \\
\hline .11,160 & 0 & 0
\end{array}
$$

Third year.

400 acres of wheat, 6 coombs, 2400 coombs

at 24 s.

- 288000

600 acres of turnips, at $3^{1 .} \quad-\quad-\quad 180000$ 600 acres of barley, at 10 coombs, at 32 s.

after turnips fed

$\frac{3600 \circ 0}{E .8,2800}$

And this prodigious product will arise in three years, from the culture of a common which most certainly never produced 5ool. in any one year, reckoning at the highest which such indefinite returns as that of an unlimited common cin be estimatedat. 
POPUI.ATION.

\begin{tabular}{|c|c|c|c|c|}
\hline \multicolumn{2}{|c|}{ Baptisms from 1780 to $17 S_{9}$} & - & - & 182 \\
\hline Burials & - & - & - & 178 \\
\hline Increasc & - & - & - & \\
\hline Baptisms from 1790 to & 1799 & - & - & \\
\hline Burials & - & - & - & 6 \\
\hline Incrcase & - & - & - & \\
\hline
\end{tabular}

SEDGFORD.-ENCLOSED I795.

2uantity.-About 4000 acres.

Soil._Sand; loamy sand; and some sandy loam on marle.

Rent.-About IIs. an acre, which is more than double what it was before the enclosure.

Ceurse-Before enclosing, the management was quite irregular. Now it is in fuve shifts: 1 . 'Turnips; 2. Barley'; 3. and 4 . Secds; and 5. Wheat, pease, or oats, according so soil.

Corn.-A great dcal more than ever.

Sheep.-.More, and better than before.

Corws.-Fewer.

Tithe.-. Remains subject.

Rates.-Are 23. to 2s. Gd. in the pound.

Porr.- The real peor did not suffer by the enclosure; but the allotments to common-right houses, which before kept two cows, amounted only to half an acre, in lieu of shackage, and the common of above 100 acres.

Improvement. - The method Mír. Durscate took to improve his waste was, after stubbing the whins, to plough and sow oats, which yielded a good crop; he then fallowed and worked it well for wheat, which crop was very baj. He then clayed it well, and sowed turnips, which 
silich were very fine, but from a tinge of black sand in the soil, stock did not prove on them. Then barley, which looked beautifully in the spring (1800), but fell off in the drought, and proved a bad crop, though much in bulk.

SHARNBOURN.-ENCLOSED ABOUT 30 YEARS,

\&uantity:-Something under rooo acres.

Corn.-Very much increased.

SHARRINGTON.

Quantity.-Common $-\quad-\quad 200$ acres.
$\begin{array}{r}\text { Half year land } \\ \text { Whole year ditto }\end{array}$
$\begin{array}{r}570 \\ 890\end{array}$

Rent.-Increased full one-third. The quality value of the common was 16 s. an acre.

Common Rights. - 37 ; and 3 acres of average value were assigned to each cottage-right house, to enable the cottager to keep a cow : their cattle before were starved, by the farmers superior stocking.

Corn.-Increase in the proportion of I5O additional acres cultivated; and the inprovement of half year land converted to whole year.

Shcep.-Much the same.

POPULATION.

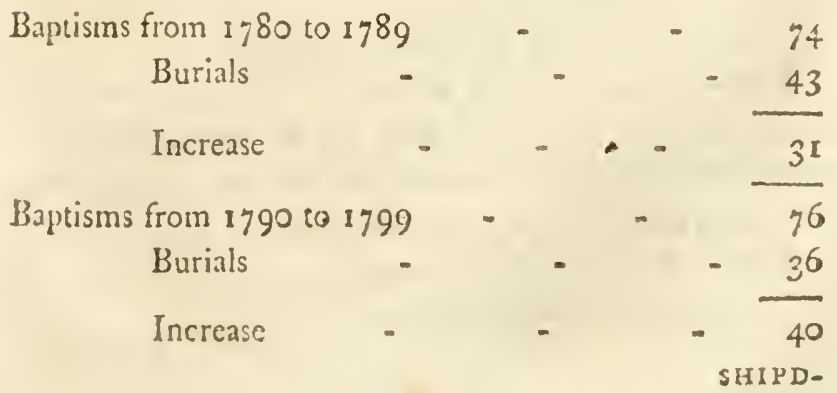


SHIPDHAM-NOT ENCLOSED.

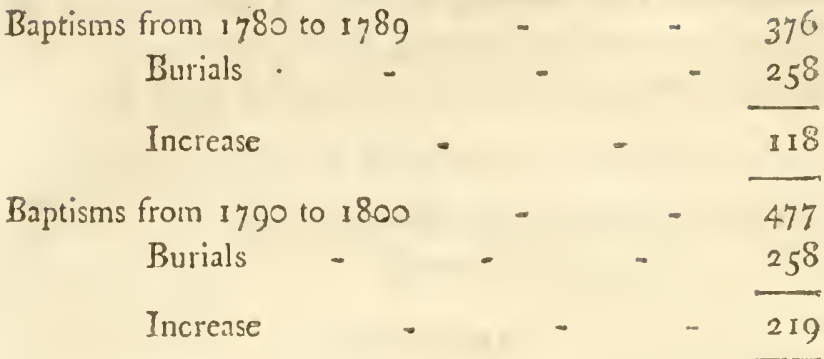

HINGHAMI-ENCLOSED.

Baptisms from I 780 to 1789
Burials
Increase
Baptisms from I790 to I799.
$\begin{aligned} & \text { Burials } \\ & \text { Increase }\end{aligned}$

SHROPHAM, I 798.

Quantity.-About 800 acres common: some half year land.

Rent.-Will be about I4s. : was before only 4 s.

Corn.-Will be greatly increased.

Shcep.-Decreascd.

Cou's. - There will be as many as before.

Poor.-About 50 or 60 acres for fuel: very few kept cows; and will keep better than before: severallittle proprietors of two or three acres, and will now have double allotments added, and be better abie to keep.

Rates.-About 4s. in the pound.

Tithe.-Land allotted for tithe. 
SHOULDHAM AND GARBOISE.-ENCLOSED I 794.

Quantity.-Whole year lands

820 acres.

Common fields, commons, and waste - $475^{\circ}$

5570

Tithe--Impropriations : temain subject.

Por.-Two allotments at Shouldham, of $\mathrm{S}_{2}$, and 13 acres, for fuel: what they have is good, but not in the former plenty; this, however, is not their great complaint, but the deprivation of keeping live stock: they used to have cows, mares, geese, ducks, \&c.; ; but now nothing; and their language is (I talked with several) that they are ruined. About 40 poor people kept cows at Shouldham; not all with what was esteemed a right; but if the commons were drove, the fine was small: those cottages that had riglits and allotments, are now let mercly as houses, and the allotments laid to the farrs. The account a farmer gave me was, that many poor kept corvs before; now, nor more than one or two. It is sufficiently evident, therefore, that tisis enclosure classes with those which have been, in this respect, injurious to the poor. At Garboisethorpe, the pour before the enclosure kept about 20 cows; now none.

Course- The former hushandry was:

$$
\begin{aligned}
\text { 1. Fallow, } & \text { 3. Barley, } \\
\text { 2. Whea:, } & \text { 4. Oats, pease, barley. } \\
\text { Now-1. Turnips, } & \text { 3. Clover, } \\
\text { 2. Burley, } & \text { 4. Whear. }
\end{aligned}
$$

Corn.-The quantity raised, very considerably increased in both parines.

Sheep.-About the same number kept as before at Shouldhan : 3 or 4 co fewer at Garboisethorpe.

Cows.-At least 50 fewer than before, at Shouldham. AIREOLX.] 
Rent. - The old rent at Shouldham was about $1300 \%$

Rates.-At Shouldham, Is. 6d. to 2s. in the pound be-

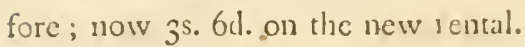

Soil.-At Shouldham, mucl, good bam on marle; and in the vale an extraordinarily fine sandy soil of great depth.

SHOTTESHAM ST. MARY, AND SHOTTESHAM ALL SAINTS, 1781 .

Quantity.-In all 3561 acres: ahout 314 acres of common enclosed by the act.

Remt.-It was gool land; about 12s. an acre, quality price; now abore 20 s.

Course.-The greatest part $(3-4$ this) grass; the arable in-1. Turnips; 2. Barley; 3. Clover, wheat.

Corn.-Increased proportionably.

Cous.-Not diminished; cattle in general very much increased.

Sheep.-Increased.

Poor - A common of $4 \delta$ acres of good grass allotted to

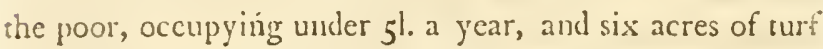
for fuel; also another common of six acres for the same purpose. To each cottage a right of keeping a cow, not merely common-right houses, but to poor inhabitants indiscriminately.

An account of the number of cows kept in 1792 , by poor people:- In 1792, I I cows; two occupiers of 7 l. each, keep two, or 4 ; in all 15 .

Notc-before the enclosure, only four cows were kept by poor people in Shottesham.

By half a right since the enclosure, they can keep a bud; a colt not exceeding 12 months, or an ass, or three geese, a gander, and their followers. A whole right is a cow, a 
horse, or double the others. In 1800 , increased and increasing : great competition.

Before the enclosure, cottages let from 40 . to 3 l. Now Mr. Fellowes has not increased the rent of any (all at 4OS.), but the rent of others is increased 20s. a year more than before the enclosure. It has upon the whole been very beneficial to the poor; and all were pleased; their share of 60 acres in 300 was uncommonly large. No poor person here, if he can, and will pay, but may be supplied with milk. There are six additional rights, which produce as many guineas a year, laid out in improving the common, by keeping open the drains, carting on the earth from them, and mowing rushes.

Tithe.-Remains subject.

Rates.-About 1795, they were at gd. in the pound; the year ending Lady-day, at rack rent 2 s. in the pound. In 1789 , I Id. in the pound; paid off 701 . for the purchase of the house, besides turnips. Now 4s. in the pound.

Mr. Fellowes' father (and himself continued it) took care to have no children bound to weavers, which has been a principal cause of preventing poverty being an increasing inhabitant of these parishes. Another cause has been, Mr. FELLowes having established a poor-house for all the Shotteshams, for the reception of very old and very young people; but which takes in none that can maintain themselves upon the sum which it would demand to kecp them in their own cottages: this has also had a very good effeet. Another plan that has been very successful, has been a steady determination in Mr. FELLOWES to get children, whether from the house or from cottages, to be put out for a year in farmers' services; he absolutely requires the attendance of all the farmers for that purpose, and on the day fixed, the children of a due 
age are brought out one by onc, and offered to be let: if refused without a premium, los. is offered with her or him; if no offer, 15 s. then 20s. and so on till some farmer agrees: as it does not suit Mr. Fex. Lowes to take them, he takes the burthen of any cripple, or other child that is particularly objectionab!e, and is himself at the expense of procuring them a situation without a premium.

Earnings in the house:

Lady-day 179 S to Ladly-day 1799 , by thirty peo- $\mathcal{L}$ s. is

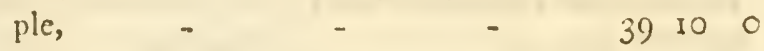

All very young or very old.

Lady-day 1788 to Lady-day 1789 , by twenty-

six people, - $\quad$ - $\quad 29$ ro 0

The old to the young, as three oll to four young.

In 1794 each poor person in the house cost, exclusive of their earnings, 2s. Sil. per weck.

In $178+$ each cost $2 \mathrm{~s}$, per week.

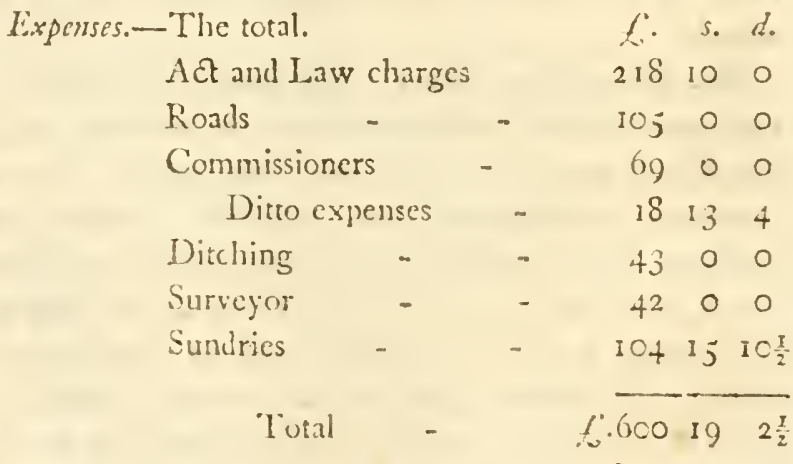

And yet this enclosure was opposed in Parliament. 
POPUI.ATION.

In Odtober $\eta_{j} 63$, Sto Mary and St. Martin, an accurate account :

St. Mary, including St. Botolph 190 souls.

St. Martin

68

All Saints

372

In 1782 ,

St. Mary and St. Martin All Saints

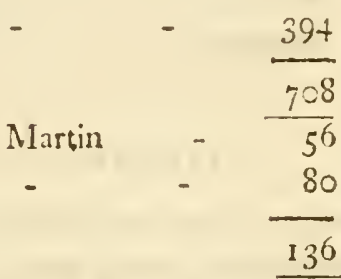

Now they are certainly increased.

This great attention to getting the children of the poor into servicc and liabits of industry, has had a very considerable cffect in keeping lown rates, which usually rise in proportion to negligence. The expense of these premiums is puid by the rate, and cqually horne consequently by the whole farishes.

\section{SHOTTESHAM ST. MARY.}

Twenty years before cruclosing: Baptisms from 1760 to 1779 Burials Increase

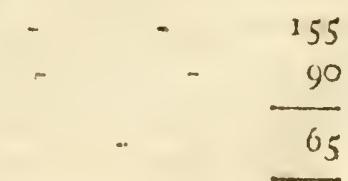

Twenty years since enclosing: Baptisms from 1780 to 1799 Burials Increase

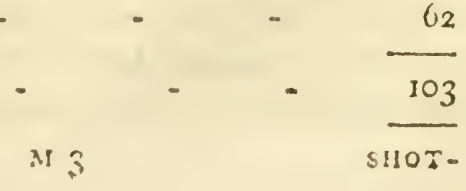


SHOTTESHAM ALL SAINTS.

Tikenty years before enclosing: Baptisms from 1760 to 1779

Burials 233

Increase 187

\section{Incense}

Twenty years since enclosing:

Baptisms from I 780 to 1799

Burials

$\begin{array}{r}-\quad \begin{array}{r}13 \\ 213 \\ -\quad \\ \hline\end{array} \quad-\quad 00 \\ \hline\end{array}$

Increase

$$
\text { SNET TISHAM.-ENCLOSED I } 762 .
$$

Quantity.-Five thousand acres in the parish.

Soil.-Various; sand, sandy loam, \&rc. on marle and stone and gravel.

Rent.-About 4000 .; but in a valuation in 1801 , has been at least doubled; since the enclosure perhaps much more.

Course.-The husbandry is six shift: 1. Turnips. 2. Barley. 3. and 4. Seeds for two years. 5. Pease. 6. Wheat.

Corn.-Very greatly increased.

Sheep.-Increased certainly.

Corus.-Increased; neat stock also much; many bullocks fattened in marshes $o_{1}^{4}$ en to the sea, before the enclosure.

Tithe - Free of all tithes.

Rates.-On an average 2 s. in the pound.

Expenses.-2200l.

- Psor.-The poor had an allotment of 90 acres for cutting flag, which they make little use of; 1 did not sce one stack on it: no right of common on it: there are ten little proprietors of commonable-right houses, who have 
$\hat{3}, 4,5,6$, or moje acres of land, keep cows, and are in comfortable circumstances.

Population.-No register kept for many years previous to 1760 ; I can therefore only give the last twenty, as if no enclosure had taken place.

Baptisms from I 780 to 1789

Burials 218

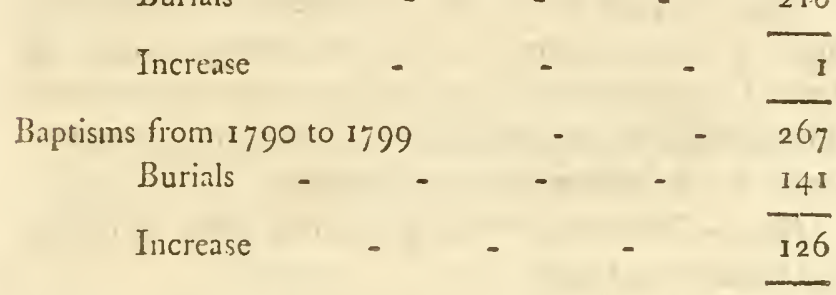

SPROWSTON.

Quantity.-Eight hundred acres in common; no half vear land.

Rent. - Worth 6s. raised to 145 .

Corn.-Great increase.

Sheep.-Decreased.

Cows.-None; nor will there be any.

$$
\text { TACOLNESTON-ACT } 1778 .
$$

Quantity.-Six or 700 acres: with Thorpe 1000.

Soil.-Pretty good mixt soil.

Rent.-Quality 155. to 20s. but now let higher.

Corn.-All to corn, and fences well got up: a valuable improvement.

STIFFKEY AND MORSTON.-ENCLOSED 1793.

2uantity.-About 3400 acres, and 1200 of salt-marshes. Very little common. Value about $\mathbf{4} 400 \mathrm{l}$. 
Tithe-Remains subject. Glche of two parishes laid together to one parsonage. Livings consolidated.

Olject.-The object of the enclosure was chiefly to lay the land together, and to extinguish rigluts of shackage, \&c. The common did not contain above 30 acres, and therefore was a very small object.

Rent.-Lord Townsuend advanced his farms 2.401. a year, on 1900 acres, for the expense of $115 \mathrm{cl}$. his share of the enclosure, besides the tenants doing the fences: at least rocol. a year anded to the whole rental. The marshes are valuabic only as a sheep-walk at certain times, for the spring tides overfiow them.

Poor.- The cottagers that kept cows, asses, or horses, had allotments of land.

Sheep.-More, and of a far superior quality.

Cosus.-More kept now than before; for one of the farms, thic pasture of which was at a distance before, is now become a dairy one.

Experises.-12s, an acre, exclusive of fences, which were done by the owners or tenants.

Improviment. - It has been a very capital one in cvery sespeet, and the inanners of the people much ameliorated -less wandering and idleness. The improvement is the more remarkable, as the usual object in Norfolk enclosures (commons) was almost wanting.

Corn.-Being half year land before, they could raise no turnips except by agrecment, nor cultivate their land to the best advantage: they raise much more corn than beforc.

STOKE.SBY.-ENCIOSED I 72.2.

This was an enclosure of about $35^{\circ}$ acres of marsl common, which is on the river leading to Yarmouth: I walked three miles from Acle, and crossing the ferry, made 
made inquiries for some person who could give me information, but all were long since dead: I was assured that three or four acres were laid to each common-right house, besides an allotment in common of eighteen acres of marsh for the poor that had no cottages of their own, which remains so at present. All those allotments, however, for rights, have heen sold long ago, as the whole parish is now the property of one person. By means of the common left, there are i 7 or I 8 cows now kept by the poor people, who buy hay or other winter food. Poor rates about 4 s. in the pound. The parish register at $\mathrm{Yar}$ mouth.

SWAFHAM.-NOT ENCLOSED.

Ten years, from 1780 to 1789 :

\begin{tabular}{llll} 
Baptisms & - & - & 619 \\
Burials & & - & - \\
Increase & - & & 489 \\
\hline
\end{tabular}

Ten years, from 1790 to 1799 :

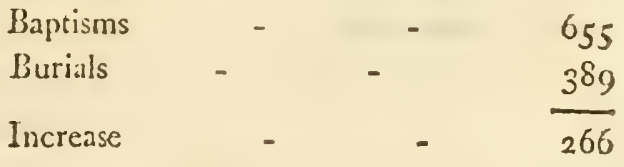

Rent. - The rental in Swafham in 1795 .

Land at 16 s, an acre f. 3108

Besides above 2000 acres of common.

Houses

Stock in trade and mills _ _ $\quad 1875$

Rectory, tithe and glebe - $\quad 387$

Vicar

$$
\frac{-150}{6.5^{6}+0}
$$


Number of inhabitants in Swafham in

$$
\begin{array}{cccr}
17 S_{2} & - & - & 1877 \\
1792 & - & - & 2031 \\
\text { number from Jan. } 1782 \text { to Dec. } 1791 & 1954 \\
\text { baptisms cach year } & - & - & 63 \\
\text { Burials ditto } & - & - & -
\end{array}
$$

Mean number from Jan. 1782 to Dec. 1791

Average baptisms each year $\quad$ - $\quad 63$

Baptisms, one in $3^{\mathrm{T}}$.

Burials, one in $43 \frac{1}{2}$.

Died from 1784 to 1794 - cleven years, 484 , or 44 average:

Of which under I year

At I ditto - 30

2 to 4 - -23

$5109-12$

10 to 19 . - 20

20 to 29 - $\quad 42$

30 to $39 \quad-\quad 25$

40 to $49 \quad-\quad-39$

50 to $59 \quad-\quad-33$

60 to $69 \quad-\quad 57$

70 to $79 \quad-\quad$ - 42

So to $89 \quad-\quad$ - 19

484

From December 1798 to February 1799 ,

$\begin{array}{rlr}\text { These died, I } & \text { of } & 82 \\ I & \text { of } & 99 \\ I & \text { of } & 95 \\ I & \text { of } & 78 \\ I & \text { of } & 89 \\ \text { I } & \text { of } & 83 \\ I & \text { of } & 73 \\ \text { I } & \text { of } & 77\end{array}$


ENCLOSING.

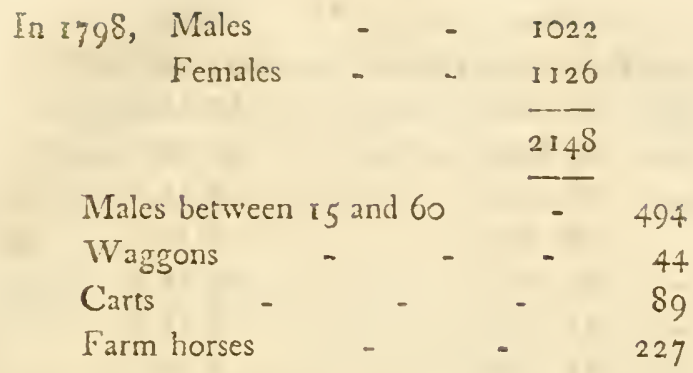

Price of the best wheat and barley at Swafham market, on the market day after Christmas, as ascertained by a corn rent paid by the rector to the vicat.

Wheat.

\begin{tabular}{|c|c|c|c|c|c|}
\hline 1750 & - & E.13 & o & o & per last. \\
\hline 1751 & - & 16 & ○ & 0 & . \\
\hline 1752 & - & Is & 15 & 0 & \\
\hline 1753 & - & 14 & ० & 0 & \\
\hline $175+$ & - & 12 & 0 & 0 & \\
\hline 1755 & - & 11 & 0 & 0 & \\
\hline 1756 & - & 21 & 0 & 0 & \\
\hline 1757 & - & 18 & 0 & 0 & \\
\hline $175^{8}$ & - & II & 0 & 0 & \\
\hline 1759 & - & 12 & 2 & 6 & \\
\hline 1760 & - & 32 & $\circ$ & 0 & \\
\hline 1761 & - & 12 & 5 & 0 & \\
\hline $17 \sigma_{2}$ & - & 16 & 0 & 0 & \\
\hline $176_{3}$ & - & 15 & 0 & 0 & \\
\hline$=64$ & - & 21 & o & 0 & \\
\hline $17^{6} ;$ & - & 19 & 10 & 0 & \\
\hline 1766 & - & 15 & 0 & 0 & \\
\hline 767 & - & $2 I$ & $\circ$ & 0 & \\
\hline 1768 & - & 16 & 10 & 0 & \\
\hline 1769 & - & 16 & 10 & o & \\
\hline 1770 & - & 19 & 0 & 0 & \\
\hline $177^{1}$ & - & 21 & 0 & 0 & \\
\hline 1772 & - & 24 & 10 & 0 & 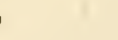 \\
\hline
\end{tabular}

Rariey.

f.6 ○ $\circ$ per last.

700

6150

800

600

5100

9100

8100

550

5100

5150

5 I5

1000

700

9. 00

10100

700

9100

700

7 I 50

9100

10100

12100 
Wheat.

$173-6.23$ o o per last.

ITit 2500

$1775-18100$

$1776=1800$

1777 - 2000

$1778-2000$

$1779-1300$

1780 - 2500

$17 \delta_{1}-2000$

$178=\quad 2600$

$1783-23100$

1784.2400

1785 - 1900

$1786 \quad-17100$

$1787-2100$

$1788-22100$

$1789 \quad-2600$

$1790-23100$

1791 - 2100

$1792-1900$

$1793-2200$

$1794-25100$

$1795-5500$

$1796-2800$

5797 - 2000

$3798-21100$

1799 - $4^{8} \circ 0$

$3800-66 \circ 0$

1801.3700.

$180 z-26$ 10 0
Barley.

f. II 10 o per last.

II 150

II 00

7150

9100

9100

7150

800

750

$1+00$

I 3150

10100

10100

1050

1000

9100

II 150

II 5.0

12100

1300

I 500

14100

1700

II 60

10100

12100

2800

380 ;

2000

I) 100

Until 1792 the last contained 2 I coombs; since that $\therefore m c, 20$. 
THE HEATH.

There is no clay under it, that has yet been discovered: a deep sand; and $i t$ is questioned whether it will answer enclosing: the town of Swafham feeds it, and cuts fuel; and has a shcep-ivalk over it. It contains about 2000 acres.

TERRINGTON, ST. JOHN'S, AND ST. CLEMENT'S.ENCLOSED 1790.

(9) $u$ antity. - Lands allotted, 868 acres, all a salt-marsh comnon, embanked from the sea. One hundred and eighteen commonable rights on it.

Improvement. - The tract was worth less than nothing: being injurious by the commoners' cattle being often swept away by the tides; when embanked, it was valued to the poor-rates at 25 s. an acre, and is let from 20s. to 40 s. ; average, 30 s.

Produce.-From y ielding nothing, it is now all ploughed and cropped with whear, oats, cole seed, and some beans. None of it laid to permanent grasss.

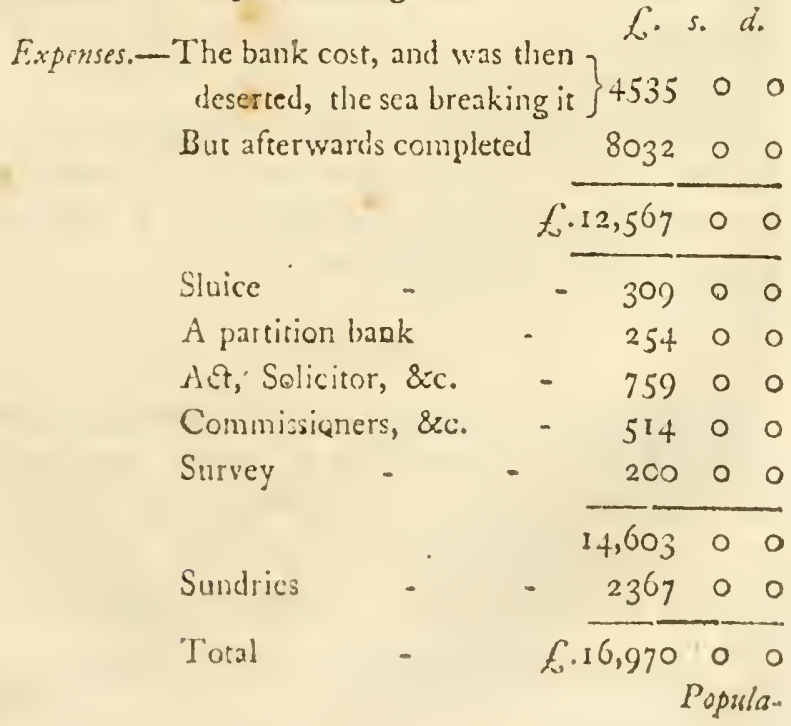


Popriation.-Ten years before embankment : Baptisns from 1780 to 1789

Builals

Increase

Ten years since the embankment:

Baprisms from I 790 to 5799

Burials

Increase

This account is surprizing, if we look to the balance; that near gco acres of waste should be brought into operose ziilange, and have no effect, or rather a bad one on populution, seems extraordinary. It could not result, I should suppose, from the profligacy introduced by the bankers, though it might be something, for that cause could not, one would suppose, be more than temporaty, cven if the effef was certain. Has it been caused by removing so much further the cffed of the tide in ameliorating the armosphere of this low trat of country? However, the comprarison must not be estimated altogether from the balance, as stated above, because men leave a parish, and are buicd elsewhere; the cinristenings are a better rule, gerhaps, and these have increased.

THORIE ABBOTS.

Here Mr. Pit th has $5^{6}$ acres of common, and determining to improve it as quickly as possible, advertised for hbourers, and had above 40 people at work: he ditched and hollow-drained the whole in six weeks; and has now clayed it 80 loads an acre. Quality price about I4s. an acre. 
TITCHWELI.-ENCLOSED I 756.

- Quantity - A small conmon, and much half year land. Soil.-A good loam.

Corn.-Greatly increased. The half year land was in very irregular manargement; now in six shifts.

Sheep.-More than doubled.

Cattle.-Neat cattle trebled. The whole parish could not muster more than 25 cows before the enclusure; now one farmer has wintered 100 beasts.

Tithe.-Remains subjeet.

Rent.-Three hundred acres of salt-marsh were embanked by the act, and raised from Is. 6 d. to at least 20 s.

POPULATION.

Baptisms from 1780 to 1789

Burials

Increase

Baptisms from I 790 to 1799

Burials

Increase

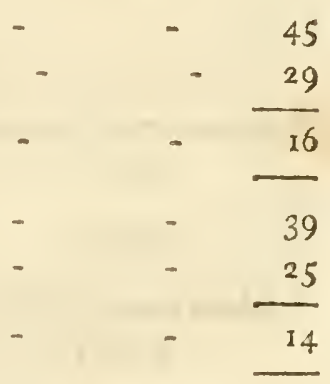

THORNHAM.ZENCLOSED 1794.

Quantity.-Two thousand one hundred acres; of which a ling common of 300 acres.

Soil.-Sandy loam.

Corn.-Much more produced than before the enclosure.

Shecp.-Before enclosing there was but one flock in the parish, of about 300 ; now not less than 900.

Cows.-Rather lessened; but not amongst the poor.

Tithe.-Renains subject.

Expenses.-Twclve shillings and sixpence an acre. 
Poor.- The common-right houses had an allotment of three roods, in lieu of slackage; and the common marsls stinted: they had also 29 acres of the ling common allotted for fucl, on which each poor person, and the occupiers of a common-right house had a right to cut 60 whits faggots; so that they are in a much better situation than before.

Baptisms from $1780101789 \quad-\quad \quad$ - $\quad 205$

Burials

Increase

Baptisms from 1790 to 1799

Burials

Increase

12 I

Increase

THOR:HAGE.

Baptisins from :;80 to 1789

Burials

Increase

Baptisms from 1790 to 1799

Burials

Increase

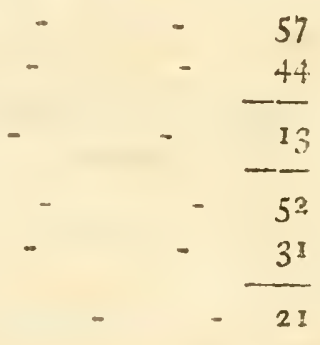

WEST TOFETS.

Three thousand and sis acres.

Mr. Galiway

Lord PeTRE

Rated at

Inhabitants

Cottages

Poor-rates, 1801
2804 acrcs. 202 actes.

f.590

6.1

- $\quad 13$

- $£ .86 \circ 10$

UPTON: 
UPTON.

2uantity.-800 to 1000 acres of common, no half year land; but great advantage by laying properties together.

Rent.-By giving contiguity, land of 5 s. made worth 20s. The common was under water; now drained by 2 mill, and worth I8s. to 20s. per acre.

Corn.-Will be increased.

Shecp.-None before; but there will be some.

Cows.-Very few ; but there will be a great increase of grazing.

\section{POPULATION.}

Baptisms from 1780 to 1789 - $\quad 100$

\begin{tabular}{|c|c|c|c|c|}
\hline Burials & - & - & - & 49 \\
\hline Increase & - & & - & $5^{\mathrm{I}}$ \\
\hline Baprisms from 1790 to & 1799 & - & 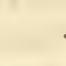 & 79 \\
\hline Burials & 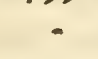 & & - & 44 \\
\hline Increase & - & & - & 35 \\
\hline
\end{tabular}

WALSHAM ST. IAWRENCE.

Baptisms from 1780 to 1789

Burials

Increase

Baptisms from I 790 to $\mathbf{7} 799$

Burials

Increase

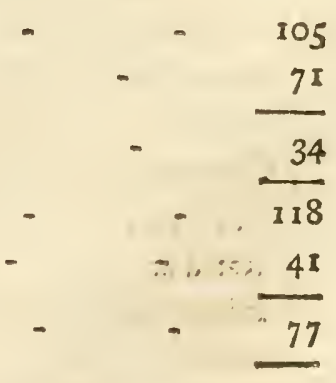

WAI- 
WALSHAM ST. MARIES.

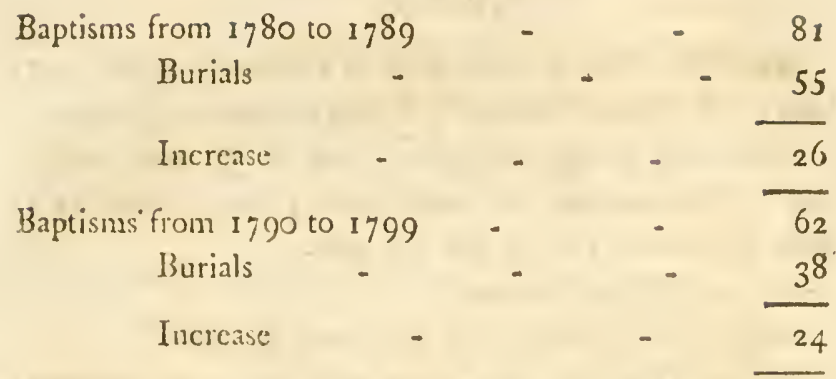

About 2000 acres in the two parishes. They are going to enclose the common, and half year lands.

WALLINGTON, ELLOW, AND NORTH COVE, 1797.

2uantity.-Four hundred and twenty acres of common: no open field.

Rent.-Before enclosing, the common was woth nothing: now I 4 s. an acre.

Corn.-Ihree hundred and twenty acres ploughed.

Sheep.-Tliey kept very few : but now will keep many.

Cows.-Much increased.

- Tithc.-Remains subject.

Rates.-An Incorporated hundred.

WALPOLE.

In 7770 , W $\mathrm{W}$ alpole, St. Peter, and St. Andrew.

Pasture land

Arable

Common, or waste, about
4130 acres. 2050

$-2500$

In the occupation of 103 persons, at the yearly

rent of

Assessed to the lank-tax, at
L. 4760 2907

Farmers 
Farmers and their wives and children 275

Servants

160

Labourers, and wives and children $8 \mathrm{r}$

Poor maintained by the parish $\quad 22$

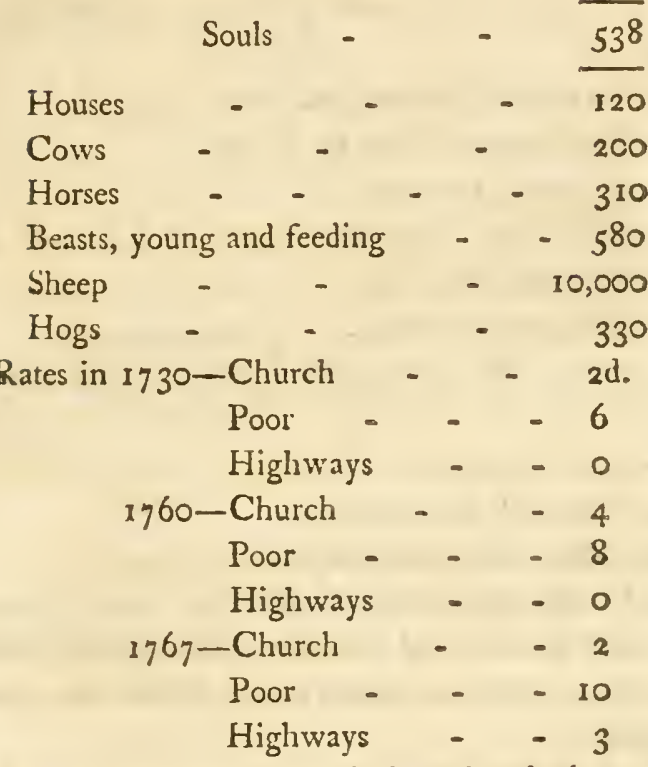

Quantity.-One thousand three hundred acres of salto marsh were embanked and enclosed in 1789 .

WHEATING.-ENCLOSED I 19 SO.

2uantity.-About 4500 : common 400 acres.

Improvement. - The chief object was laying property in the former open field together: there were 50 allotments of the cominon to commonable rights, eight acres eacn.

Corn.-Not increased; by reason of a large po tion lawned and planted by a nobleman who resides here.

Sheep.-Are better than before the enclosure; but not so many by some hundreds.

Corws.-Greatly lessened. 
Poor.-Much better off in every respect since the enclosure.

$$
\text { WINFARTHING.-ACT } 17 \delta 1 \text {. }
$$

2unitity.-Abour 600 acres of heath and common: no open arable.

Soil.-Like that of Banham, but hardly so good.

Rent.-Quality price, from 7s. to 20s.

Corn.-All turned to arable.

Shcep.-Six to 700 sheep were kept, and lessened to 300 ; but of a much better sort.

Corws.-The same as before.

Improvoment.-All clayed, and hollow-drained where wet.

Tithe.-Remains subject.

Rates.-Two-and-sixpence to 3 s.

Expenses.-Something under 2000 l.

Poor.-Twenty acres allotted for fuel; many allotments to little people; and they are well content; and have kept them : thcy have much hemp, wheat, \&c. and well managed.

An account of the number of baptisms and burials in the parish cluurch of Winfarthing, for forty years last past :

Burials from 1762 to $1780 \quad$ - $\quad$ - $\quad$ - 335

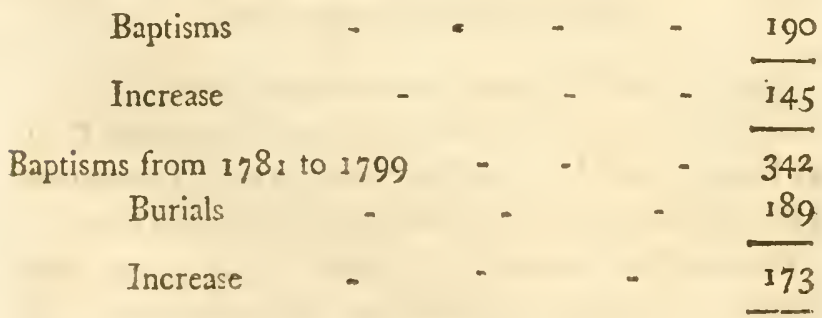

WRENNINGIHAM.-ALLOTTED IN 1779

Diantity.-T wo bundred and sixty acres.

Rent. 
Rent.-Before 15 s. an acre; now 20s. the whole parish. Tithe.-Free: an allotment in land, 37 acres.

Poor.-Twenty acres for fuel allotted.

Corn.-A great increase.

Expense.-About 6201 .

$$
\text { WOODBASTWICK, i } 176 \%
$$

2uantity.-About 300 acres of common.

Rent.-Worth above 14s. an acre at present.

Course.-1. Turnips; 2. Barlev; 3 . Clover; 4. Wheat. Shecp.-Decreased.

Cows.-Lessened.

WOODRISING.-ENCLOSED ONLY PARTIALLY'.

Baptisms from 1780 to 1789

Burials

Increase

Baptisms from 1790 to 1799

Burials

Increase

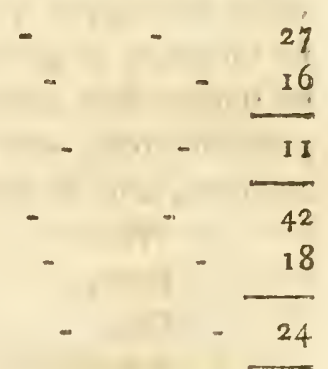

\section{GENERAL OBSERVATION.}

Mr. Burron, of Langley, on all wet commons, recommends to under-ground drain before breaking up; and where level, to clay it also. To be began at Midsummer, then left to March, when it should be ploughed and oats dibbled: and if it was left a year or more for grass to get up, it might be the better. After the oats, if not clayed before, clay it: if it was clayed, scale in the stubble atier harvest, and plough three or four times for oats', to be sown broad-cast. After that, fallow for turnips, and pursue the common husbandry, which would want no muck for a few years. 
In fifteen enclosures, in which Mr. Burton has been Commissioner, there are 10,800 acres of common land; about half converted to arable, and proper for the five-shift husbandry. One thousand acres for wheat, producing 5000 combs, at 24s. $6000 \mathrm{l}$; 1000 barley, 8000 coombs, at I2s. 48001 ; 1000 oats, second crop after wheat, 8000 coombs, at 10s. 40001 . ; 1000 acres turnips will feed 500 bullocks or cows, which will pay for the turnips only, 5l. a head, or 25001 ; and 1000 acres of grass, with the offal turnips, will feed 4000 shecp in winter, and fattened by a part of the new lay grass, "to be off by June. The shecp, for the turnips and grass, will pay $3000 \mathrm{l}$ : there remain 5000 acres of pasture, which will support 500 bullocks, bringing them forward for turnips, to $3^{1}$. per head, or $1500 l$. : and there may also be summer-kept 4000 shecp, which, with wool and profit on carcass, will pay 20001 . And, besides all this, 200 cows, at 61 . or 12001.

$\begin{array}{llll}\text { Wheat } & - & - & 6000 \\ \text { Barley } & - & - & 4800 \\ \text { Oats } & - & - & 4000 \\ \text { Bullocks } & - & - & 2500 \\ \text { Sheep } & - & - & 3000 \\ \text { Bullocks } & - & - & 1500 \\ \text { Shcep } & - & - & 2000 \\ \text { Cows } & - & - & 1200 \\ & & \\ & & \end{array}$

There are 800 acres more unaccounted for: 5000 acres of arable will take 200 horses to till it, wanting each four acres arable and pasture; 400 of this for corn will give 10 coombs a horse, for 30 weeks, or 2000 coombs, at eight coombs an acre; 250 acres for the 2000 coombs: 150 acres remains for hay, which producing 200 tons, will, 
will, with the barns, maintain them the winter; and the 400 acres of pasture will support the 200 horses, with mares and colts, in summer. The improved rent on the 10,000 acres, is for a lease of 14 years, $7725 \mathrm{l}$. The tithe, for 14 years, abou: I gool. a-year. Capital to stock, and improvement, about 10,000l. being additions to farms adjoining. The interest $5 \mathrm{col}$. Labour for said lands, including harvest, $5000 \mathrm{l}$. Seed corn, $2200 \mathrm{l}$. Wear and tear; the blacksmith will be about gool.; wheel. wright, about rool.; carpenters, Iool.; small seeds, 300 . ; poor-rates, on an average, at $5^{\text {s. }} 103 \mathrm{Il}$. $5^{\text {s. ; }}$ capiral for 5000 acres of pasture, 600cl.; interest, 3001 . Contingencies, \&c. may be estimated at Ioool.

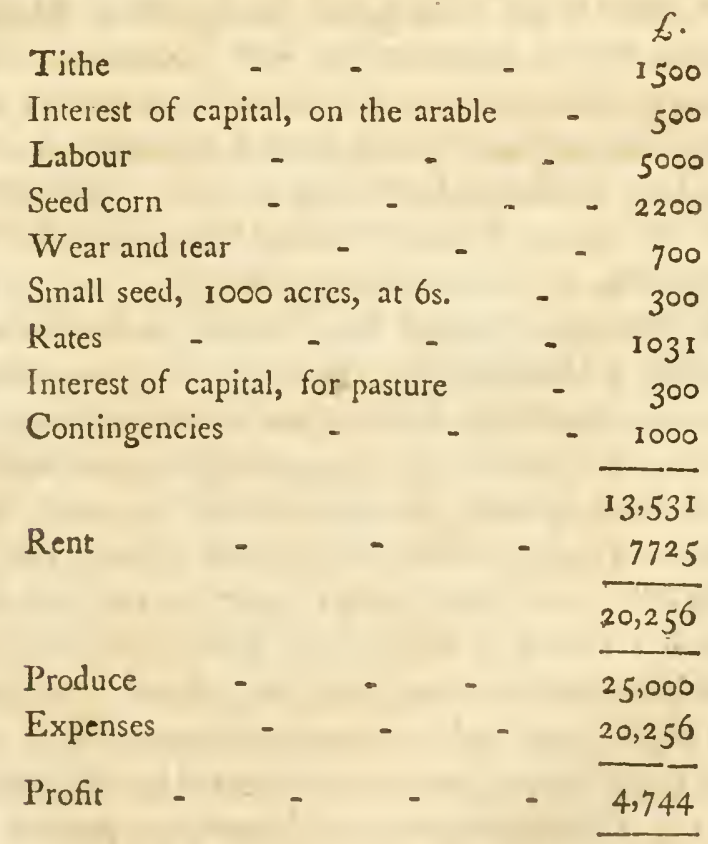

This calculation, which does Mr. BuR T on credit, sets in a very clear light, the immense advantages which have resulted 
resulted from the enclosurcs in which he has been employed.

In all the enclosures in which Mr. Algur las been concerned as a Commissioner, it has not been the practice to put poor men to the proof of the legality of their claims, but the mere practice, and if they have proved the practice even of cutting turf, it has been considered as a right of common, and allotted for accordingly.

In the several parliamentary enclosures of Snettisham, Ringstead, Heacham, Darsingham, Sharnborne, Fring, Sedgford, Thornham, Tichwell, and Hunston, which are all in Mr. Styleman's vicinity, the effect has been, at least doubling the produce: many of the farm-houses were before in the villages, and the distance to the fields so great, that no improvements were undertaken. The houses are now on the farms, and the improvements very great. In respect to the rent, the first leases were at a low rate, from the allotted lands being in a most impoverishcd condition : but on being let a second time, where that has taken place, the rise has been considerable.

In enclosures, in which Mr. Gooch, of Quidenham, has been a Commissioner, claying found of great advantage upon fresh land; it divides and mixes well with the decaying turf. Mr. Gooc H recommends one earth for oats, by all means dibbled; then a second crop harrowed: then turnips and barley, or oats laid with sceds; clover, trefoile, and a little ray, or better no ray. Leave it a year, and then clay, if a deep loose bottom, Ico loads; but if shallow, neat brick-earth or clay, about 6o. Ieave it with the clay on it a year, and it incorporates immediately.

In the cnclosures, particularly remarked by $\mathrm{Mr}$. BRADFIELD, of Heachan, two methods have been pursued, but that intelligent farmer recommends on dry lanu', after grubbing the whins, to plough and dibble in oats; then to clay 
or marle on the oat stubble, and summer-fallow for wheat; after that, to take turnips, and follow the four-shift husbandry, of 1. Turnips; 2. Barley; 3. Clover; 4. Wheat; which he thinks better for keeping land clean, than letting seeds lie two years.

\section{FENCES.}

In these several Norfolk enclosures, the fences consist of a ditch four feet wide and three deep, the quick laid into the bank, and a dead bush hedge made at the top.Expense :

s. $d$.

Digging, banking, and planting - $\quad$ - $\quad$ I 3

Bushes, a load 20s. does near 30 rods - $\quad$ I 3

Quick - - - $\quad$ - $\quad$ - $\quad 06$

The Banham and Carleton enclosures are well grown, and the fences excellent; but this much depends on good care and attention; for if the banks are made too steep, or neglected, they slip down, and gaps are the consequence.

Mr. ReEve, of Wighton, in forming new fences, gives a complete summer-fallow to the lines where the quicks are to be set, and dresses the land with a good compost: and instead of Jeaving the bank in a sharp angle at top, he flattens it, to retain the moisture.

Mr. HrLl remarks, that in making new fences, a southerly aspect, in strong land, will be a fence four years sooner than a northerly one; but on light sandy land, the north best, for the sake of moisture; on mixed soils, he prefers the cast and west. 
Mr. Coke has moveable gates and posts, if they may be so called, to place in rows of hurdles : they are a very useful contrivance; set down expeditiously, and moved with great ease. 


\section{CHAP. VII.}

\section{ARABLE LAND.}

WE arc now come to the grand object of Norfolk husbandry: in all the other branches of agriculture the county is not conspicuous for singularity of system, but in the management of arable lund much indeed will be found interesting.

SECT. I.-OF TILLAGE.

Ir would be easy to expatiate on every branch of this subject largely, but as much, in that case, would be inserted in this Report, equally applicable to almost every county in the kingdom, the writer will confine himself to the observations he actually made in Norfolk.

Ploughing.- There is a great difference in ploughing in West Norfolk; on some farms I have remarked the furrow to be cut flat and clean, but on others wrest baulked, by tilting the plough to the left, which raising the share fin, makes that inequality, and is partly the occasion of my having found so many ploughs at work which would not go a single minure without holding.

In East Norfolk the ploughmen, to prevent the soil when moist from turning up in whole glossy furrows, which they term "scoring," tie a piece of strong ropeyarn round the plate or mould-board, which by these means is prevented from acting as a trowel upon the soil. Marsiall. - I found this the practice at present, lut 
was informed that it was not so generally wanted as formerly, which they atuibuted to better constructed plats, or inould boards.

Depth.-Mr. Thurtell, at Gorlstone, near Yarmouth, has a great opinion of deep ploughing; three or four inches are a conmon depth about him, but when land is cleau he always ploughs five, and sometimes six or seven; he is careful, however, not to do this on foul land; he has no apprehension of breaking the pan, having many times gone depth enough for that without any inconvenience, and as to bringing up a dead soil, he has not seen any ill effects from it : his land is a good sandy loam, on a clay, marle or gravel.

Mr. EvERIT, of Caistor, is of a different opinion; he is not fond of deep ploughing; he thinks four inches deep enough; his ideas on this subject, however, seem to have been chiefly the result of a trial made by his father, who broke the pan by trench-ploughing a piece of land, which has ever since been full of charlock, \&rc. The difference of their soils will not account for this opposition of sentiment: Gorlstone is a very good sandy loam at 205. or 25 s. an acre, though certainly inferior in depth 'and goodness to the land at Caistor. In discourse with these two gentlcinen on this subject, Mr. Everit remarked to Mr. Thurtell, that if he ploughed deeper than common, he ought to add manure proportionably to the quantity of soil stitred; an old idea of mine, and I remember well, combated by my friend ARBUTHNOT.

Mr. FrAncis, of Martham, ploughs four or five inches deep.

Mr. Cubit, of Honing, on a fine sandy loam, always as shallow as possible; and at East Ruston, where the soil is cxccedingly good, the same: he thinks the smaller quantity of muck by this means answers. 
They do not plough four inches deep at Scotto; Mr. DYBLE remarked, that a piece was there ploughed five or six inches deep, and damaged for seven years : three inches enough: the soil much of it a fine sandy loan, manifesting no want of depth.

Mr. Palgrave, at Coltishal, applies deep ploughing in one case with singular judgment: he brings by water from Yarmouth, large quantities of sea ouze, or haven mud, this, on dry scalding gravels and sands, he trenchploughs in without fear of burying, and finds, on experience, the effect very great, forming thus a cool bottom, so that the surface burns no more.

Mr. JoHnson, of Thurning, thinks that it is common to plough too shallow; nor does he believe that any mischief results from depth. He has made a ditch one year, and thrown it down again the next, and the benefit was seen for seven years, without the soil being acted on by draining, or wanting it: nor is he nice to have his muck ploughed in shallow, having no fear of burying it. By ploughing a good pitch for turnips, they come slow to the hoe, but when they do get hold, thrive much faster than others.

Mr. REEve, of Wighton, is an advocate for deep ploughing; he goes five inches deep; if I did not $I$ should get no turnips.

Mr. DuRsgate approves of deep ploughing; remarking, that he breaks up his ollonds deeper than most people.

Mr. WILLis olserving the marle on his land was sunk below the common parh of the plough, turned it up again by going a deeper pitch, and found it to answer nearly as well as a new marling; and he suffered no inconvenience.

The two furrow work about Holt, \&xc. is to turn a furrow on lay or ollond; the plough then returns and throws it back with the untouched land that is under it, 
into the former open furrow, and overlapping that, rests on the baulk left beside it.

Mr. Money Hill, in breaking up the strongest land he has, ploughs deeper than on the lighter, that is, four inches, and on light three and a balf, and on that depth drills on flag; it twitch in the land, ploughs only three and a half: if beyond the usual depth, would hurt the crop and give weeds. Waterden, a thin and flinty soil. Mr. Hill's father lived for many years at Gateson, and was succeeded in the farm hy Mr. PARKER. Mr. Hill's 'ast crop yielded 400 lasts of corn, above $25^{\circ}$ of which were barley. He generally ploughed four inches deep, and never more than four and a half. Mr. PARKeR in the first year ploughed the second barley earth seven inches deep, sowing about eight score acres (the common quantity twelve scure). He sold that year but twenty lasts: the seeds also were worse than usual: the wheat that followed, good; but in general, he had indifferent crops for tourteen or fifieen years.

In March he applies what he calls onc-furrow work to a foul stubble, if he has such by chance; the land side horse (chat on the left hand) always, after the first furrow, returns in it; it is left open; harrowed down with a heavy harrow; then the weeds gathered and burnt, and the next ploughing given across.

In June 1776 , being as Wallington, adjoining Marshland, I found the high broad ridges begin, which thence spread over a great traet of country, nearly perhaps across the island; and many of the furrows were then twelve inches deep in water : but at present I was informed that much more attention is paid to taking water off.

Tiam, \&c.-Mr. 'Thurtell, through the summer, ploughs with three horses two acres a day, one always resting: this, from finishing sowing spring corn to the end 
end of turnip tillage. There is no doubt of their ploughing with ease an acre in four hours and a half.

In the clays of Marshland all are foot or swing ploughs; never more than two horses used: they do an acre a day, and in summer one and a half at two journeys.

At Hemsby, each pair of horses two acres a day, at two journeys.

Thirty years ago the common price of ploughing was 2s. 6d. an acre in every part of Norfolk, except Marsh-

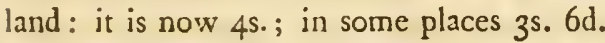

These notes of the quantity ploughed per diem, might be multiplied in every part of the county; the farmers in every district of it, get more land ploughed in a day by their men and horses, than on any similar soil in any other part of the kingdom : not altogether to be attributed to the inerits of the plough, though it is certainly a good one; nor to any superior activity in the horses: the cause is more in the men, who have been accustomed to keep their horses and themselves to a quick step, instead of the slow one common in almost every other district.

Harrowing.-This operation is no where better performed than in Norfolk, where the farmers are very attentive to finish their tillage in a very neat manner. In no other county with which I am acquainted, have they the excellent practice of trotting the horses at this work, which gives a fineness and regularity in burying small seeds, not to be attained with a slow regular motion of the harrows. They harrow from 12 to 15 acres with a pair of horses once in a place per diem. The practice of walking the horses up hill, and trotting them down, in the same place, is an excellent one. 
SECT. II.FALLOWING.

THE grand fallow of Norfolk is the preparation for tutnips, which will be mentioned under that article. The common summer-fallow takes place on strong, wet, and clayey soils; upon which, however, turnips are too generally ventured. One fault in the husbandry of the county, and of Norfolk farmers when they move into very different districts, is that of being wedded too closely to practices which derive their chief merit from a riglt application to very dry or sandy soils.

Mr. Overman, whose husbandry merits every attention, having taken a farm of Mr. Coks, at Michaelmas 1800 , and the outgoing tenant possessing a right to sow some layers which were very full of spear-grass, \&c. Mr. Overman gave him, to the surprize of his neighbours, 5l. ros. per acre to desist; not that he might himself sow those fields, but for the sake of completely fallowing them. Some I found had undergone the operation, and werc clean; others wcre in it, and almost green with couch. He destroys it by mere ploughing and harrowing, without any raking or burning; conceiving that by well-timed tillage, any land may be made clean; and that on these sandy soils, a July earth in a hot sun will effect it: but whenever or however done, his object, whether with much or little tillage, is sure to be answered; and as the successive cleanness of the land depends on its being once got perfectly free from weeds, his great expenses, he expects, will in the end prove the cheapest way of going to work. He gives four earths in all; the first before winter, only two inches deep; another in the spring; the third two, or two inches and a half deep, in July, in a hot time; the fourth after harvest. 
1803. - He now tells me, that the land I saw full of couch, is at present as clean as a garden.

Mr. Pit ts, of Thorpe Abbots, remarked to the the great consequence, for the destruction of weeds, of ploughing a summer-fallow just before, and also directly after harvest.

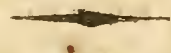 \\ SECT. III.-COURSE OF CROPS.}

If I were to be called on to name one peculiar circumstance, which has done more honour to the husbandry of Norfolk than any other to be thought of, I should, without hesitation, instance this of the rotation of cropping.

I should not hazard, perhaps, too bold an assertion, were I to declare that, till the accession of his present Majesty, there were to be found few just ideas on this subject, in the works upon husbandry of any author pieceding that period: if any thing tolerable occurs, it is mixed with so much that is erroneous, that credit cannot be given even for what is good. The fields of the rest of the kingdom presented a similar exhibition: right courses liardly any where, perhaps, no where, to be found. But in West Norfolk, the predominant principle which governed their husbandry at that period; as well as ever since, was the carefully avoiding two white corn crops in succession. Turnips were made the preparation for barley; and grasses, that for wheat, or orher grain.

I have viewed various parts of the county, at different periods in the last thirty years, and have found these ideas steadily adhered to.

\section{COURSES ON SAND, AND ON TURNIP LOAMS.}

Some of the finest rye I have any where seen, was on Mr. Bevan's farm, in 1802 , after two successive years NORFOLK.]

of 
of sowing cole, eaten off with sleep. The rye put in on one earth ; there are thirty acres of $\mathrm{it}$, and fourteen of then on a black sand.

Mr. BRADFIELD, of Knattishall, tenant to Mr. BE$\mathbf{v A N}$, pursues regularly this course of crops:

$\left.\begin{array}{l}\text { 1. Turnips, } \\ \text { 2. Barley, } \\ \text { 3. Seeds, } \\ \text { 4. Sceds, } \\ \text { 5. Wheat, } \\ \text { 6. Turnips, }\end{array}\right\}$

I. Turnips,

2. Barley,

But if seęds fail, changed to

3. Vetches,

4. Turnips,

5. Barley,

L6. Turnips;

by which means, in the sixth year, the variation ceases, and it comes, as in the other, to turnips again. The system, however, is open to two great objections: in the fourth year, he has no summer food for sheep ; and, what is as bad, he doubles his quantity of turnips; he also loses wheat in the course. To have two successive years of vetches, appears to be a hetter system, and a much less in. terruption, or rather none at all. If the first vetches are to be fed, grass-seeds might be sown with them for the second year, and this would save the expense of seed vetches and tillage for that year.

In 1802 , the barley crop is generally very fine; yet in the whole line from Holkham to Toffts and Thetford, I remarked many pieces which in colour were too yeilow for Norfolk management in a good year. I have some suspicion that it luas been caused by the very high prices of corn inducing some farmers to be wo free with their land, and varying from the course of shifis, which, in steady times, they adhere to more exactly.

Mr. Fow EL, of Suetterton:

1. Turnips, drilled at eighteen inclies,

2. Barley, ditto at nine,

3. Seeds,

4. Seeds, 
5. Pease, drilled at twelve inches; or wheat at nine, \&c. and this is the rotation of the vicinity. Wheat, pease, oats, or rye, the fifth year; if rye, a bastard fallow for it: the second year, seeds.

In general about Hingham :
I. Turnips,
I. Turnips,
2. Barley,
2. Barley,
3. Clover,
3. Clover,
4. Wheat,
4. Pease,
5. Wheat.

Nearly the same around Attleborough.

About Watton:
I. Turnips,
3. Clover, \&c.
2. Barley,
4. Wheat.

Mr. BlomfieId, at Billingford, in one field near his farm-yard:

I. Winter tares, and then turnips,

2. Barley;

and the crops always good.

Mr. DrAKE gets better turnips after wheat, the stubble ploughed in, than after pease.

Mr. WRIGHT, of Stanhow, never takes barley or pease after wheat, though his soil is a good loamy sand: he thinks that no district where this is the practice deserves the reputation of having the true Norfolk husbandry.

Mr. Drozier remarked, that upon the sandy land of Rudham, and that vicinity, the greatest improvement perhaps would be, to lay Jown for eight or ten years to repose, the land from turnips and corn, which would so freshen it as to render it productive perhaps in the stile of the first breaking up; but common grasses wear out, and will not pay the present rents after two years: they sow trefoil and ray. 
Sir MORDAUnT Martin's coursc is a five-shifs:
I. Turnips,
6. Turnips,
2. Parley,
7. Barley,
3. Clover,
8. Trefoil and ray,
4. Wheat,
9. Pease,
5. Potatocs, mangel wur- IO. Potatoes, mangel wur- zel, or vetches, \&rc. zel, vetches, \&cc.

Mr. Overman, of Burnham, has found, from many observations, that pease do not succeed well if sown oftener than once in twelve years. Whacre he has known them return in six or eight years, they have never done well.

Mr. Overman ploughed up a layer of four years, and drilled wheat on it. Then ploughed for winter tares. Ploughed the stubble once for a second crop of wheat, which I viewed: a very fine produce, and as clean as a garden. Three crops of great profit on only three ploughings, and yet the land kept perfectly clean. Not a little résulting from four years sheep feeding without folding from it.

His common course:
I. Turnips,
8. Barley,
2. Barley,
9. 10. Seeds two years,
3. 4. 5. Secis three years, II. Pease,
6. Wheat,
12. Wheat.
7. Turnips,

But with the variation of having part of the twclftin under pease on the three years layer, and also some tares. This course is partly founded on the experience of pease not doing well, if sown oftener than once in twelve years. Mr. Coke:
I. Turnips, 4. Seeds,
2. Barley, drilled at $6 \frac{3}{4}$ inc. 5 . Wheat, drilled at 9 inc.
3. Seeds,
6. Turnips, 
7. Barley, drilied at $6 \frac{3}{4}$ inc. 10 . Pease, driiled at $g$ inc.
8. Seeds, or tares at 6 ,

9. Seeds,

II. Wheat, drilled at 9 inc.

Mr. PURDIs, of Eggmore, a very uncommon variation worn the general husbandry:
I. Turnips,
4. Seeds,
2. Barley,
5. Tares,
3. Seeds,
6. Wheat.

Upon a large part of this fine farm the former rotation included a summer-fallow, which afforded (broken at whatever time) little food for live stock; tares now occupy the place, and support immense herds of cattle and sheep. What a noble spectacle is this fa! $m ! 300$ acres of turnips, 300 of barley, 600 of seeds, 300 of tares, and 300 of wheat: I 800 acres arable, the crops luxuriant, and much the greater part of the farm very clean; all of it except the layers; on which, however, some thistles, so difficult to extirpate.

Mr. Thurteli, near. Yarmouth, is in the four-shift, returning to turnips always after the wheat, for he thinks that nothing is so bad as saking a fifth crop.

At Caistor, in Fleg, the land excellent; they are in the five-shift of East Norfolk, that is,
1. Turnips,
4. Wheat,
2. Barley,
5. Barley;
3. Clover,

with two variations practised sometines by Mr. EVERIT, at the Hall farm.

I. 2. Cole seed instead of turnips and barley, taking

3. Wheat, two years,

4. Barley; but not a great crop; and then turnips again.

The other is, to substitute pease instead of clover, fol- 
lowed by wheat, and then in the four-shift, to come again to turnips.

A remarkable circumstance in the rotation of crops liere is, that spring corn will not succeed well after wheat which follows cole seed: they will give an excellent summerfallow for this crop; spread 14 loads of tine dung per acre, and sowing wheat after the cole, get the finest crops, yet if barley or oats follow, the produce is seldom tolerable; oats better than barley, but neither good.

Some farmers at Hemesby, and among others $\mathrm{Mr}$. FERRIER, on his own property :

r. Turnips,

2. Barley,

3. Seeds (clover once in I0 or 12 years),
4. Wheat,

5. Pease, or oats,

6. Wheat.

It may easily be supposed that the wheat of the fourth year is much better than that of the sixth. The course cannot be defended even on Hemsby land, and the wheat stubbles were some of them not so clean as they ought to be.

At Thrigby, Mr. Brown, \&c. is in the Fleg fiveshift; barley after the wheat; with the variation, to avoid clover every other round, of sowing half the barley with other seeds, and dibbling pease on the other half.

At South Walsham, Mr. SYBLE, and others:

x. Turnips,

2. Barley,

3. Seeds, one or two years,

Wheat,
. Burley,
5.

The variation of the seeds is to prevent clover coming two rounds together, as the land here, as elsewhere, is 
sick of it. Upon a part, white clover, trefoil, and ray are substituted, and left two years; about one third of the wheat is on a two years layer. If the clover be a good crop, the wheat is better than after the other seeds. The barley after wheat (if that followed a two years lay), is better than after turnips. But Mr. Srgle, if the land is foul after the first wheat, is sure then to take turnips. Sometimes pease on a two years lay, and then wheat; but Mr. Syble does not like pease, from their being so liable to failure. He is of opinion that the husbandry of Fleg and Blowfield wants variation, from having been kept too long in a regular course. One which has succeeded with him, is to sow barley after pease or vetches, in which way he has had great crops.

At Repps and Martham the common Fleg five-shift husbandry; that is, barley follows wheat; clover and other sceds alternate, and the wheat as good after one as the other.

At Ludham, the common five-shift.

At Catfield I found a variation; here the course is a sixshift husbandry:
I. Turnips,
4. Clover, \&c.
2. Barley,
5. Wheat,
3. Clover, \&c.
6. Barlcy.

Mr. CUBIT practises this in common with his neigh bours; the seeds riffed the second year before harvest, that is, rice-baulked, raftered, half ploughed: some scaled, a clean earth, as thin as possible; the management $\mathrm{Mr}$. THURTEZL reprobated for his soil: and what is singular, they seem to do it with equal reference to dibbling and broad-casting.

At Honing the same as at Catfield. All around North Walshain the same; and thence to Preston, Cromer, and 
Aylesham, in general the same husbandly. If secds fail, some scale the stubble in, and licep it for pease.

Mr. Margateson, of North Walsham, assurcl me, that he considered the four-shift husbandry of turnips, bad; clover, wheat, as the best of all management, if the land will bear it; but clover has been sown so long in East Norfolk, that it is sure to fail in that rotation.

Mr. Dyble, at Scotter, is in the six years course, which is also common through the country.

Mr. Repton, at Oxnead, has been, from the year. 1773, regularly in the sis-sinift husbandry, of
I. Turnips,
4. Sceds-ollond,
2. Barley,
5. Wheat,
3. Seeds-hav,
6. Barley;

which is common throughout the country. I took an account of several of his fields; and found but few variations: accidentally, wheat occurred on the first, instead of the second year's layer. Sometimes the barley omitted after the wheat. In a few instances, pease on the ollond, or hay and wheat, \&xc. after the pease: but the variations few ; so as to shew clearly the established rule.

Mr. Rezve, of Heveringland, in the five-shift; the seeds two years.

Mr. BIRCHAM, at Haclford:

1. Turnips,

4. Ciover, and other secdo

2. Barley, aiternately,

3. Clorer, and other seeds 5. Wheat, alicrnately,

6. Barley, oats, or pease.

But if land be out of condition, Mr. BirchaM's method to recover it, is to take,
I. 'Turnips,
3. Turnips,
2. Barley,
4. Barley,

The same six-shifts at Haydon. 
Mr. JoHnson, of Thurning, thinks that the common course of,
I. Turnips,
4. Seeds,
2. Barley,
5. Wheat,
3. Seeds, two years
6. Barley;

which, is the usual system about him, would be improved by the following variation:
I. Turnips,
5. Seeds,
2. Barley,
6. Pease,
3 Seeds,
7. Wheat,
4. Seeds,
8. Barley;

in which the land would have rest for fecding, three years in eight, instead of two in six, as in the other.

Mr. England, at Bingham :
I. Turnips,
4. Seeds,
2. Barley,
5. Wheat;
3. Seeds,

never adding barley after the wheat. Sometines on tender land, not equal to wheat, drills pease on the ollond, and then, if the land be clcan, takes barley, or even wheat, but not without rape cake.

Mr. ReEve, of Wighton:
I. Turnips,
5. Wheat, drilled,
2. Barley,
6. Turnips,
3. Trefoil, white clover, 7. Barley, and ray,
8. Clover,
4. Ditto,
9. Wheat.

Every idea of this most accurate farmer, merits much atrention; and this course among the rest : whenever red clover is left a second year, it disappears, and the land is principalIy covered with ray grass: query-if it is not much better, when red clover is the object, never to leave it two years: this is an improvement in Mr. REeve's intention, but it has not yet been his general practice. 
Mr. Rieve mucked a barley stubble for vetches, ploughed once for that crop; and then drilled wheat on one other ploughing. The stubble clean as a garden.

Mr. M. HILL:
I. Turnips,
6. Turnips,
2. Barley,
7. Barley,
3. Seeds,
8. Seeds,
4. Seeds,
9. Pease, or tares,
5. Wheat,
10. Wheat.

Mr. M. Hill has now ( 1802 ) on his farm a very fina field of wheat, drilled on the flag of a four years laycr: he remarked it as an instance of confidence in his landlord (Mr. COKE), not to luave broken it up sooner at the end? of a lease.

The same farmer sows cole after winter verches fed off; eats it off at Michaelmas; sows rye for spring feed; eats that off, and tills for turnips, getting four green crops to feed on the land in two years. Excellent husbandry.

Mr. Henry Blythe, of Burnham, is in the fiveshifts; the seeds for two years.

The following detail of all the courses pursced by Mr. Dursgate, on his fine farm of Summerfield, is, in my opinion, a most satisfactory account of Norfolk liusbandry, shewing the very considerable exertions made in this county for the great objects of keeping land clean and in heart: the particulars merit a close examination!. These fields contain near 1050 acres.

$$
\text { No. x.-Fring Break. }
$$

1797 Summer-fallow.

${ }^{3} 798$ Wheat, manured with half a ton of rape-cake per acre.

1799 Turnips, mucked, and fed with sheep.

isoo Barlcy. 
580r Clover and ray, mowed.

1802 Ditto, fed with sheep.

No. 2.-Upper-end of Cow-close.

I797 Half summer-fallowed. Half vetches, fed by sheep.

$\$ 798$ Wheat, rape-cake on one-half of it, one-quarter of a ton; on the other half, one-third of a ton.

1799 Turnips, mucked, and fed with sheep.

1800 Barley.

180 I Trefoil and ray, half of it mowed.

1802 Ditto, fed with sheep.

No. 3.-Fox Close, new broken up fox-cover.

1797 Oats.

1798 Wheat.

1799 Turnips, drawn.

I800 Barley.

1801 Trefoil and ray, fed with horses.

1802 Ditto, fed with horses and sheep.

No. 4.-First Burnt Stock.

I97 Turnips, one-quarter of a ton of rape-cake per acre, fed with sheep.

I798 Barley.

I799 Turnips, mucked, and fed with sheep.

1800 Barley.

I80 I Trefoil, fed with sheep.

1802 Ditto, ditto.

No. 5.-Church-Hill.

1797 Pease, barley, and vetches.

3798 Turnips, mucked, and one-quarter of a ton of rape-cake per acre; fed with sheep.

1799 Barley.

3800 Clover, mowed. 
I80 I Clover, fed with shecp.

I802 White pease.

No. 6.-Black Hurn.

- 797 Ollond, two vars, fed with sheep.

₹798 Turnips, mucked, and fed with sheep.

1799 Barley.

1800 Trefuil, mowed.

380 r Ditto, fed with sheep.

1802 Vetches.

No. 7.-First part Cow-close.

1797 Wheat.

1798 Tumips, one-quarter of a ton of rape-cake per acre; fed with sheep.

1799 Barley.

I 800 Trefoil, fed with sheep.

Isor Ditto, fed with horses.

${ }_{1802}$ White pease.

No. 8. - Stack-yard Breal.

\797 Turnips, mucked, and fed with sheep.

1798 Barley.

1799 Clover and ray, morvn.

I 800 Ditto, fed with horses and shecp.

1801 White pease.

1802 Wheat; one-third of a ton of cake per acre.

No. 9.-New-pit.

I797 Turnips, half mucked, and on the other half a quarter of a ton of cake per acre, fed with sheep. 1798 Barley.

7799 'Trefoil, ray, and white clover, fed with sheep.

3800 Ditto, fed with sheep.

1801 W'ite pease.

1802 Barley. 
No, ro.-Hiliy-piece.

$\$ 97$ Turnips, one-quarter of a ton of cake per acre, and fed with sheep.

1798 Barley.

ฐ99 White clover and ray, fed with sheep.

1800 Ditto, sheep fed.

I80 I White pease.

1802 Barley.

No. I I.-Pound Close.

1797 Turnips, mucked, and sleep fed.

1798 Barley.

I799 Trefoil, white clover, and ray, sheep fed.

1800 Ditto, sheep fed.

I80 I Vetches.

1802 Barley.

No. 12.-First i9 Acres.

I797 Turnips, mucked, and sheep fed.

1798 Barley.

r799 Clover and ray, mown.

1800 Ditto, sheep fed.

I80I White pease.

I802 Wheat; one-third of a ton of cake per acre.

No. I3.-First I 4 Acres.

I797 Turnips, mucked, sheep fed.

I798 Barley.

1799 Trefoil, white Dutch, and ray, sheep fed.

1800 Ditto, sheep fed.

1801 Vetches, soiled.

1802. Wheat, part mucked, the rest one-third of a ton of cake per acre. 
No. 14.-Second 14 Acres.

1797 Turnips, mucked, sheep fed.

1798 Barley.

1799 Trefoil, ray, and white clover, sheep fed.

1800 Ditto, sheep fed.

180 , White pease.

1802 Wheat; one-third of a ton of cake per acre.

No. 15.-Lady Summersby Break.

I797 Barley, after mucked turnips, and sheep fed.

ryg Clover, ray, and white Dutch, mown.

1799 Ditto, sheep fed.

I800 Pease.

180 I Wheat; one-third of a ton of cake per acre.

1802 Turnips, mucked.

No. 16.-Saffron-row.

I797 Barley, after turuips, one-quarter of a ton of cake per acre, and fed with sheep.

1798 Trefoil, ray, and Dutch, mown.

2799 Ditto, sheep fed.

1800 Forty acres of it summer-fallow; II of it pease.

I80 I Wheat; one-third of a ton of cake per acre.

1802 Turnips, mucked.

No. 17.-Thoroughfare.

1797 Barley, after turnips, mucked, and sheep fed.

1798 Clover, ray, and Dutch, mown.

1799 Dito, sheep fed.

1800 Pease.

1801 Barley.

I802 Turnips, mucked.

No. 18.--Second Burnt Stock.

1797 Barley, after wheat.

I 798 Trefoil, ray, and Dutch, sheep fed.

1799 Ditto, sheep fed. 
$\$ 800$ Trefoil, and then bastard summer tilth.

I80I Wheat; half of it tathed; half of it manured with cake, one-third of a ton per acre.

1802 Turnips, one-quarter ton cake.

No. I g.-Eleven Acres.

1797 Trefoil, ray, and Dutch, sheep feed.

2798 Ditto, sheep fed.

I799 Ditto, ditto.

s 800 Vetches, soiled.

iso: Barley,

1802 Turnips; one-quarter of a ton of cake per acrs.

No. 20.-Brick-kiln Breck.

I797 Clover, ray, and Dutch, mown.

1798 Ditto, sheep fed.

I799 Ditto, 20 acres of it sheep fed; 33 ditto, bastard. fallow.

1800 Wheat, ploughed up I5 acres, and sowed Tar. tarian oats.

z SOr Turnips, mucked; and part of it one-quarter of a ton of cake per acre; sheep fed.

1802 Barley.

No. 21.-Black Hurn, adjoining.

1797 Barley, after turnips, one-quarter of a ton of cake per acre; sheep fed.

1798 Trefoil, ray, and Dutch, sheep fed.

1799 Turnips; one-quarter of a ton of cake per acre; sheep fed.

1800 Whear, drilled, one-quarter of a ton of cake.

180 I Turnips, inucked; sheep fed.

1802 Barley.

No. 22.-First part Long Snelling.

$\$ 797$ Trefoil, ray, and Dutch, sheep fed.

1798 Ditto, sheep fed. 
1799 Half vetches, soiled: half summer-fallow.

1800 Wheat; one-thirl of a ton of cake per acre.

ISO: Tumips, mucked part; part caked, one-quartes of a ton per acre; one-half drawn; one-half sheep fed.

ISO2 Barley.

No. 23.-Seventeen Acres.

1797 Trefoil, ray, and Dutch, sheep fed.

I 798 Ditto, siseep fed.

I 799 Suminer-fallow.

1800 Wheat; one-third of a ton of rape-cake per acre.

180 I Turnips; one-fourth of a ton of ditto, sheep fed.

1802 Barley.

No. 24.-Paddock.

I797 Trefoil, ray, and Dutch, sheep fed.

1798 Ditto, sheep fed.

I799 Summer-fallorv.

I800 Wheat; one-quarter of a ton of cake per acre.

I80 I Turnıp, mucked, sheep fed.

I802 Barley.

No. 25.-Home Break.

1797 Trefoil, ray, and Dutch, one-half fed, one-half mown.

1798 Ditto, sheep fed.

1799 IV heat; forty acres of it manured with one-quarter of a ton of cake per acre.

1800 "Turnips; forty acres, one-quarter of a ton of cake; twenty acres mucked.

1801 Barley.

1802 Clover; forty acres mown; twenty acres fed horses.

No. 26.-Ling Piece.

I797 Layer, second year sheep fed.

I798 Summer-fallow; clayed. 
I799 Tartarian oats.

1800 Turnips; one-quarter of a ton of cake per acre.

I80 I Barley.

1802 Trefoil, mown.

No. 2\%.-Second Nineteen Acres.

1797 Trefoil, ray, and Dutch, sheep fed.

1798 Summer-fallow.

1799 Wheat; one-quarter of a ton of cake per acre.

1800 Turnips; ditto, sheep fed.

i801 Barley.

1802 Clover, mowed.

No. 28.-Fourteen Acres adjoining.

1797 Clover, ray, and Dutch, mowed.

₹798 Ditto, nown.

I799 Tartarian oats.

x800 Turnips; one-quarter of $a$ ton of cake per acre: sheep fec.

801 Barley.

1802 Trefoil, sheep fed.

No. 29.--Second Long Snelling.

1797 Layer, second year sheep fed.

1798 Summer-fallow.

1799 Wheat; one-quarter of a ton of cake per acre; on the other halt, one-third of a ton.

1800 Turnips, mucked; sheep fed.

isor Rarley.

1802 Trefoil, mown.

A finer detail of courses, or of great exertions in excellent management, has not often been seen.

A singular management he has practised, has heen that of breaking up a one year's layer, and sowing turnips, to the quantity of from twenty to fifty acres in a year, feeding them off with sheep, and then drilling wheat on one earth. 
Part of one of Mr. Dursgate's fields was summerfallow and part pease; the whole then sown with wheat, which was better after the pease than after the fallow; the crop was damaged by the wire worm, against which he has found fallowing no security.

Mr. Rishton, at Thornham, the old four-shift, of
I. Turnips,
3. Secds,
2. Barley,
4. Wheat.

Clover, one round, and other seeds the ncxt.

At Holm, on rich loam :
1. Turnips,
4. Clover, and tempered,

2. Barley,

5. Wheat,

3. Clover and ray-grass, 6. Barley.

Mr. Strleman, at Snettisham :
I. Turnips,
4. Seeds,
2. Barley,
5. Pease,
3. Seeds,
6. Wheat,

Mr. Goddison, at Houghton, and the farmers generally, are in the five-shift husbandry.

The same at Hillington.

Mr. BEck, at Riseing, the same. The seeds two years; and clover in alternate rounds. The fifth year some take wheat, some pease, and then wheat; but the land thus getting foul, Mr. BECK lias not practised it of late years. When he has taken turnips after pease, he has fed them off in time for wheat, on one earth broad-cast on fourfurrow work.

The old four-shift at Grimstone.

The same to the cast of the Ouze around Downham, for some miles; sometimes the seeds arc left two years, but in general only one: the course, however, is not by all adhered to, for some sow barley after wheat-some few beans. Mr. SAFFoRy thinks that the grand point now in Norfolk 
Norfolk husbandry is a due change and variation of crops, as beans, carrots, \&rc.

At Watlington the same four-shift course: if clover fails, pease, and then wheat.

Mr. Rogerson, at Natborough, on very poor sand, the five-shift, the seeds lying two years: but on the worst land, instead of wheat in the fifth year, rye, barley, vètches, pease, or Tartarian oats. He had no wheat this year (1802).

About Wymondham:

1. Turnips,

2. Barley,

3. Clover ; or clover, trefoil, white clover and rays one year.

4. Wheat,

5. Barley, but with exceptions. If the seeds fail dibble pease sometimes, and take wheat after.

At Besthorpe:
I. Turnips,
4. Wheat,
2. Barley,
5. Barley;
3. Clover, \&c.

but Mr. Prieste leaves oút this last crop.

Mr. Twist, at Breteuham:
I. Turnips,
4. Ditto,
2. Barley,
5. Rye, on one or on
3. Trefoil and ray grass, three earths.

At Acle, on some of the finest wheat land in the county:
I. 'Turnips,
4. Wheat,
2. Barley,
5. Pease,
3. Clover,
6. Wheat.

At Halvergate also, very fine land in the same course. If clover follows once in four years, it is sure to fail. Thirty years ago, a course I met with in Fleg hundred was: 
1. Turnips,

2. Barley,

3. Clover and ray,
4. Ditto,

5. Buck-wheat, or pease,

6. Wheat.

It was renarked more than thirty years ago, near Norwich, that the crops of barley, after tursips fed liste, were generally bad, which led to a practice that deserves not ing: buck-wheat was substituted, which succeeded well, and was followed by wheat; an observation very applicable to Swedish turnips ai present.

\section{COURSES ON STRONGER LAND.}

At Thelton, Mr. Havers, on his drier soils:

r. Turnips,

2. Barley,

3. Clover, once in eight years, the land being sick of it,

4. Wheat, dibbled.

But on heavy land:

I. Summer-fallow,

2. Barley,

4. Wheat, dibbled,

5. Beans.

3. Clover, once in eight years,

On either soil, in the intermediate course, trefoil, ray, and white suckling, substituted for clover; sometimes left two years, and then pease on the lighter land, and beans on the heavy - wheat following.

Mr. DraKe, of Billingford, on heavy land:
I. Summet-fallow,
4. Wheat,
2. Barley,
5. Beans or oats.

3. Cloyer,

But as the land is sick of clover, he does not sow it oftener than once in eight or ten years; using white clover the intermediate round.

On his light land, the common four-shift husbandry. Mr. PrtTs, at Thorpe Abbots, on gravel: 

1. Turnips,
3. Secds,
2. Barley,
4. Wheat, barley, or pease.

But on heavy land:

I. Suminer-fallow,

3. Seeds,

2. Barley,

4. Wheat.

Some put in pease or beans on the seeds, and then wheat. Mr. Mildred, on the Duke of NorFolK's beautiful farm at Earsham, near Bungay; on his lighter land, the four-shift husbandry; but on the heavy:
1. Summer-fallow,
4. Wheat, dibbled,
2. Barley,
5. Beans or oats, the for-
3. Seeds, mer dibbled.

His seeds for change are trefoil and white clover: he does not like ray grass, therefore sows as little as possible.

Mr. Burton, of Langley, summer-fallows the strong land at Hempnal, for barley and wheat alternately; taking beans after either, and wheat after the beans.

On the sandy and gravelly loams of the hundred of Loddon, the four-shift husbandry; but as the land is sick of clover, they sow it but once in eight years: sow white clover and trefoil instead of $i t$.

Mr. SALTER, near Dereham, on land so wet as to require much hollow.draining:
I. Turnips,
3. Clover,
2. Barley,
4. Wheat.

But it does not keep his land free from charlock.

I 776 , at Walpole :
1. Fallow,
4. Beans,
2. Wheat,
5. Wheat.
3. Oats,

Mr. FORBY's, at Fincham, on strong land:

I. Cabbages, dunged for, and worth, on an average, 5l. per acre;

2. Barley, $9 \frac{1}{2}$ coombs; 
3. Clover, mown twice, produce threc tons;

4. Wheat, dibbled, $8 \frac{3}{4}$ coombs; has had ten round:

5. Oats, fifieen coombs.

A bout Harleston, on their good loams of 20s. or 25 s. an acre, on a marle bottom, they pursuc pretty mucl? this rotation :
I. Fallow,
3. Beans,
2. Whear,
4. Wheat.

With this variation:

I. Fallow,

4. Beans,

2. Wheat,

5. Wheat.

3. Clover,

The beans all dibbicd, one row on a furrow; threc bushels of Windsor ticks per acre: they used to manure for the wheat after them, but of late have got much into the pradice of manuring for the beans, which las succeeded far better, not only for the beans, but witl: the wheat also. They most approve of ploughing the land for beans in the autumn, and leaving it in order, well water-gripped, for planting, after harrowing, the end of February or beginning of March, on this stale furrow. Crop, from eight to twelve coombs an acre. Dibbling is 6s. 6d. an acre, and hand-hocing, twice, 10s. -5s. each time. They harrow, and roll in the clover on the wheat, in the spring.

Mr. Salter, at Winborough, applied summer-fallowing, the first year of his taking his farm, much of which consists of various loams and sands, on a strong marley and clayey bottom, and abounding with springs; but after that, he has never fallowed, and never will.His expression was, "a man is a madman that summerfablows." He is very regularly in the four-shift course of:
I. Turnips,
3. Clover,
2. Barley,
4. Wheat. 
If clover fails, or on Fands where he expects it to fail, svinter tares or pease, instead of it. His wheat, on layers, all dibbled, and the turnips fed by sheep on the land; on the wettest soils, kept on them only by day, and Jaying on grass-land at night.

At East Biiney, Brisley, Gressenhall, Stanfield, Betdey, and Mileham, being adjoining parishes, the common course is:
I. Turnips,
4. Wheat,
2. Barley, and some add,
3. Clover,
5. Barley.

Also:

I. Summer-fallow,

2. Whicat,

5. Barley,

3. Oats,

6. Clover,

4. Turnips,

7. Wheat.

The Rev. Dixon Hoste, on some of the strongest and most tenacious land $I$ have seen in Norfolk:

I. Turnips,

6. Barley, drilled,

2. Barley, drilled,

3. Clover,

7. Tares, \&c. as the land is

4. Wheat, drilled, sick of clover,

5. Turnips,

Recurring thus but once in eight years, the clover stands.

At Goodwick, and the neighbouring heavy land parishes, the four-shift husbandry; the turnips on nearly flat lands! There are, however, some summer-fallows for wheat, in which case the course is:
I. Fallow,
2. Wheat,
3. Turnips,
4. Barley,
5. Clover,
6. Wheat.

Mr. Porter, at Watlington, on strong land:
1. Fallow,
3. Beans,
2. Wheat,
4. Wheat. 
One-fourth fallow. If fallow is had recourse to, how much better to introduce it thus:
I. Fallow,
4. Wheat,
2. Barley,
5. Beans,
3. Beans,
6. Wheat.

\section{MARSHLAND.}

At Wiginhall, St. Maries:
I. Summer fallow,
3. Beans,
2. Wheat,
4. Wheat.

This by good farmers; but some go on:
5. Oats,
6. Barley, or big.

On Governor Benrinck's estate, in Terrington, by Mr. William Arton, a tenant:
I. Wheat,
4. Potatoes,
2. Oats,
5. Wheat.

3. Wheat,

Will any reader believe that this note could be madie it: the county of Norfolk?

Another field of the same farm:
1. Wheat,
3. Oats,
2. Wheat,
4. Potatoes

Another :

7. Fallow,

4. Wheat,

2. Oats,

5. Spring wheat.

3. Wheat,

Bravo! for Marshland lads!

Other curious courses, from the same book:
I. Wheat,
I. Fallow,
2. Wheat,
2. Oats,
3. Oats,
3. Wheat,
4. Potatoes,
4. Wheat,
5. Wheat.
5. Wheat.

I. Fallows 

ז. Fallow,
4. Wheat,
2. Oats,
5. Barley.

3. Wheat,

At Walpole:
I. Summer-fallow,
3. Oats,
2. Wheat,
4. Wheat.

Also:
1. Oats on grass,
4. Wheat,
2. Cole,
5. Fallorr.
3. Oats,

Another:

I. Summer-fallow,

5. Wheat,

2. Wheat,

3. Oats,

6. Barley or oats,

4. Beans,

7. Clover,

8. Wheat.

Mr. Siwayne:

I. Fallow,

4. Beans,

2. Oats,

5. Wheat.

3. Wheat,

Adjoining Marshland Smeth, to the North, \&c. old land:

I. Summer-fallow,

2. Whear,

3. Beans,

Also:

1. Cole,

2. Cole seeded,

3. Wheat,

Mr. SafFory's fen farms at Denver Welney, Forilham, Downham, west side:

1. Pare and burn for cole for sheep; the crop worth 3os. to 40 s.

2. Oats, fifteen coombs,

3. Wheat, seven coombs,

4. Summerland cole for sheep, 25 s.

5. Oats, fifteen coombs,
4. Oats,

and some,

5. Wheat.

4. Beans,

5. Oats or wheat. 
6. Laid to ray, one bush, white clover 8lb. red ditto, 81b. for three years, fed in general with slieep and beasts, some mown $I_{2}^{\frac{T}{2}}$ load an acre.

Sometimes red clover only for one year, ploughed up, and wheat dibbled.

\section{OBSERVATIONS.}

One olservation on the Norfolk courses occurs, whicl the practice of Mr. Purdis, of Eggmore, I think, justi. fies:-he was long in the common system before he struck out a variation; and he was induced to it, partly from a conviction that the land generally wanted a change: the want of variety in the courses of the county, is the circumstance that I wish to allude to. For 60 or 70 years, the variations have, upon the whole, been very few : all have begun with turnips, followed by barley; then seeds, in which alone have occurred the chief variations, and those, by force of necessity, from failures. If there is a deficiency, I think it will be found in not having some substitutions of crops for so regular a routine. Mr. PuRDis introducing tares, appears a good idea: pease have been taken by some other farmers; but Mr. OverMan's curious observation, that they will not succeed, if taken oftener than once in I I or 12 years, should be a caution. Chicory, followed by winter tares, amongst which some scattered plants rising, would be of no consequence, but rather an advantage, deserves attention. Upon very poos soils, this plant is essential to profit.

Another crop. I shall take the liberty of naming for loams, is the bean. The notion, in Norfolk, that this is adapted only to strong soils, is very erroneous; it is more profitable on good sands, and pretty good sandy loams, than it is on clay; and would yicld great crops on soils, wherein it is never found in Norfolk.

Carrots also descrve attention; for turnips have been repeatcd till the land is sick of them. 
SECT. IV. - TURNIPS.

IT is proper to begin with the crop which, in Norfolk, is made the basis of all others.
I. Course,
I0. Drilling,
2. Soil,
II. Consumption,
3. Tillage,
12. Preservation,
4. Manuring,
13. For seed,
5. Sort,
I4. Is the land tired?
6. Seed,
15. Swedish Turnip,
7. Steeping,
8. Hoeing,
16. Inuportance of the culture.
9. Distempers,

1. Course.-At Massingham, on the first improvement above sixty years ago, it was common to take two crops running to clean the land, and it answered greatly: $\mathrm{Mr}$. CAR's barley, after the preparation, was greater than ever known in the common course: he had $6 \frac{1}{2}$ quarters per acre.

Mr. Burton, of Langley, considers a wheat stubble as the best for turnips.

2. Soil.-Norfolk farmers are so wedded to turnips, that they sow them almost indiscriminately on all soils. Perhaps, the heaviest land I have yet seen in the county, is at Goodwick, on the farm of the Rev. Dixon Hoste: and I was petrified to see his turnips on such a soil, as well as his neighbours, on broad flat lands: it is true, he has hoilow-drained well and carcfully; but the very texture of the soil is adhesion itself, and greatly retentive of water; so that carting to remove the crop, is very hazardous; the consequence is, a barley crop inferior to the land; certainly, in many cases (even in this fine barley year, 1802), not more than the half of what would have followed beans or tares, well managed. 
In discourse with Mr. Joknson, at Kempston, I found that he consilered cultivation and turnips as synonimous: no farming without turnips:-What, Mr. Jounson, on wery wet, stiff, tenacious, poaching soils? - " How are you to keep stock without them?" And, in Norfolk, they may be said to know nothing of the Northumberland culture, the only system that can make the crop advisable on such land.

The universality of this culture in Norfolk, whatever the soil, is singular; but the most extraordinary feature is, to see so many on the Marshland, clay the ridges almost flat; they are carted, or rather poached off, for cows and sheep.

The stronger, heavier soils of the southern parts of East Norfolk, will not bring turnips frecly without marle, which acts by rendering the soil more friable. This is an observation of an ingenious writer; but, at present, marled or not marled, all is under turnips.

The universal system in Norfolk, whatever may be the soil, of sowing turnips, and cultivating them on flat, or nearly flat lands, must, without hesitation, he condemn. ed: hollow-draining can never be praised too much; but there are districts, the soil of which is so tenacious, that no drains can make the husbandsy admissible. Mr. FOREY's cxperiments on cabhages, very carefully made, and accurately reported, bear irmediately on this point, were they necessary to establish it; but, in truth, few experiments are wanting to prove the point : for the many bad or inferior crops of barley 1 saw in 1802, a very great barlcy year, on such soils, would alone convince me that the turnip culture, in such cases, is mischievous. The difference between siz or seven coombs of barley, and eleven or twelve, would buy lintseed cake for the consumption of straw; or pay the loss of fattening hogs for 
the same purpose. Straw must be converted into dung: these methods make better dung than turnips; nor are these the only resources.

3. Tillage.-About Watton not less than four earths given. The seed harrowed in-no drilling practised.

Mr. MONey Hill, of Waterden, scarifies his turnip fallows in March, April or May, as it may happen; the scarifier attached to a frame on two wheels, made for that purpose, to save the carriage of the drill machine; but the second time of going over the land he fixes it to the frame of a roller, to which are added irons pierced for that purpose, the roller breaking any clods that contain the roots of the twitch grass, and freeing it to be taken up by the shares, or afterwards by the teeth of the horse-rake, the teeth of which are freed by working in the common manner of other couch-rakes, through a frame of wood.

A practice of Mr. ThuRTeil's on a pea stubble, which he has followed many times, is to scarify direct!y after harvest, and then throw it into four-furrow work for winter; in the spring takes off one bout from the ridge, then harrows well across, and leaves it for weeds to vegetate. Good.

Mr. BRown, of Thrigby, ploughs five izches deep for turnips; his first earth taking up the stubbles deep; and the first stirring scrapes the bottom.

Mr. Parmenter funds scuming a practice of great utility on a foul curnip fallow.

Mr. Bircham, at Hackford, scuffles his fallows much to his satisfaction; not to save ploughing, but additionally.

To these notes I could have added others; for the practice of adding the operations of the scuffer to those of the plough, is gaining ground in the county, but has not yet been so long established as to enable many to speak with sauch decision.

4. Manuring. 
4. Mamuring.- The practice of manuring for the turnip crop is universal in Norfolk. Before the culture had been for a long period general, good crops were sometimes gained without, but for many years past none are to be procured except on new land, without much attention to this necessary branch of the management. The more common method is, to cast the yard dung of the preceding winter into heaps, which are turned over and carted on to the turnip land before the iast earth is given. There are variations in every step of the business, but these, where important, will be noted either in the present section, or in the chapter of manures.

Mr. Thurtell is of opinion, that on heavy land, autumn may be a very good time for carrying on muck for turnips, but on his light land he always scales it in before the seed earth, which is given deep enough to bury it properly. Mr. THURTELL mucks all his turnips from Yarnouth.

Mir. Syble, of South Walsham, informed me that the farmers in that vicinity were, not many years ago, in the practice of carrying out dung for turnips at Michaelmas, but they have left it off; as neither the turnips nor the barley proved such good crops as with other management.

Mr. Layton, of East Norfolk, and his neighbours, were in the practice of ploughing in the dung very shallow by the last carth but one, to harrow well for mixing with the soil, and then to plough and sow.

Mr. M. Hill applies twelve loads per acre of yarddung or compost; sometimes turns it in by the seed earth, but when work is forward, scales it in, and leaves the land ready for the seed earth. He prefers, when it can be done, to lay the dung on in November, on the wheat stubble, and plough it in; this keeps stiff land open, and he thinks undoubtedly the best practice: the pulverization is such, 
such, that an carth may be saved by it, and, it ensures, a greater certainty on cold wet land. This can only be done to the extent of what is made by six weeks feeding in Oetober and November, after the horses are taken in; and this long dung is undoubtedly best for wet land, and as good as any other on all soils at that season. The turnips also come sooner to the hoe, and are less eaten by the Ay. But if long muck be spread just before sowing turnips, the fly is increased, owing to the dung being not well buried.

Mr. Core's turnips were putting in while I was at Holkham, and I found the business perfectly arranged for an equal and steady employment of all the teams and hands: three men filled the dung-carts, of which there vere four; three drivers; ten horses in the carts; three men spread the dung, one throwing out roughly, and two with forks breaking the pieces and distributing equally. Five ploughs were at work; these followed by a light roller; then the drill plough; and after all, a pair of light harrows; thus 18 men and boys were employed, and 24 horses and mules. Six acres a day finished, upon which 60 loads of dung spread; the drive not a short one. The men out at four in the morning from their own houses, to the ficld at five, and finish at two; brenkfast in the field: in the afternoon the ploughmen take care of the horses, and the carters in the hay. The ploughs work the same hours, but out an hour later, and home an hour later, as they turn in all the dung carried out: ten loads an acre.-For his application of oil-cake, see Manuring.

5. Sort.-Inquiring of Mr. BurTon, of Langley, if he cultivated Sivedish turnips, he replied that the green round turnip stood the frost so well, that Swedes were not wanted for that object, and the produce much larger, and much more certain. The sort most general, is the large globe white.

6. Seed.-Mr. SAlter, on his various loams, some of which 
which are wet and unkind for this crop, sows a quartet of a peck: I viewed all his fields, to the amount of about 80 acres, and the plants were in most of them very thick, but not too thick with harrowing: gives $8 \mathrm{~s}$. an acre for two hoeings: he had seventeen hoers at work.

At Hillington, from one to two pints an acre, but more on chalk.

7. Stceping. - Mr. SALTER, of Winborough, triec? steeping the seed in lintseed oil, \&c. and drying it with flour of brimstone, hut the fly ate all.

George Earl of ORForD for several years used Mr. WINTER's process for steeping turnip seed in train oil 12 hours, and was of opinion that it was beneficial against the Aly: but if heavy rains fall after sowing, the effect lessens.

Mr. SHEPHERD dresses all his turnip seed with train oil and sulphur; three pints of the oil and one pound and a half of sulphur to a bushel of seed: dresses the seed with the oil by thorough mixing in a tub, and drics it with the sulphur, keeping it 12 hours bcfore sowing: he has tried it repeatedly, and in comparisons, and is firmly persuaded of the bencfit, from the supcriority of the dressed seed in crops attacked by the Aly, not only in experiments side by side, but also in saving crops when t rnips have in general been destroyed.

It has been found that steeping old seed in water, and then drying in the sun, has brought it up sooner than sowing dry.

8. Hocing.-Upon land which is exceedingly given to charlock and wallock (Raphanus \& Sinapis), Mr. DursGATE lias hoed by the day instead of paying by the acre, to have the greater security of thorough cleaning; or in other cases paying an extra price per acre.

The turnips in Norfolk are universally twice hoed; the operation is every where well done, except, I think, in 
one respect, that of being set out too thin, which with dashing hoers is a common evil.

9. Distempers.-Mr. Cox e having heard that ducks had been used to clear turnips of the black canker, tried them on a field of 33 acres : he bought 400 rlucks; on the 16 th of July they were turned in; having water at one corner of the field, and in five days they cleared the whole completely, marching at last through the field on the hunt, eyeing the leaves on both sides with great care, to devour every one they could see.

The anbury, or external knots, each cointaining a small worm in the centre, depends on soil, and most of the soils in Norfolk are subject to it till they have been marled or clayed, which is an almost sure preventative.

I0. Drilling. - The application of this mode of culture to the turnip crop has not yet made any considerable progress in the country; nor are the opinions of the farmers settled upon the question of its propricty.

Mr. FoweL drills his turnips for bullocks at 18 inches, but for sheep at 12. I viewed several of his crops, and found them very regular; the drillings well joined, and very straight. Four strokes of the drill sow an 18 feet ridge; without a marker ; the horse led by the lines of the furrows: He gives 3 s. $6 \mathrm{~d}$. for hoeing the first time, and $2 \mathrm{~s}$. $6 \mathrm{~d}$. the second.

Mr. BlooMfield, at Billingfold, has this year (1802) very promising turnips on a bad black gravel soil, which he enclosed and broke up from the heath. His culture is, to set out the ridges of two feet from the flat, with a double breast plough, and to lay the muck in the furrows; he then sows broad-cast, and splits down the ridges with the ground wrest of a double breast plough without its breasts, harrows across, and the turnips come up regularly on flat land in rows at two feet. The bailiff thinks that on this poor soil they should have had no turnips in the SORFOLK.] 
common mode of cultivation; and that in this method 10 loads of muck are equal to 14 used in the common way.

Mr. CoKe, at Holkham, sows none broad_cast ; all are drilled.

Mr. Repton, at Osnead, driils turnips at one foot, and prefers the method.

Mr. ENGLAND, of Bimhan, tried the drill last year, but he found the plants too thick in the rows, and has observed the same in some other cases; they are then difficult to hoe.

Mr. REEve, of Wighton, drilled them fo: two years at II inches and a half, but has left off the practice.

Mr. Henry Blythe, of Burnham, though a very. staunch friend to drilling corn, from i 2 years experience, does not drill turnips, finding that they are not so easily hoed.

Mr. Strueman. at Snettisham, drills them at 12 inches, and he thinks they hoe better than broad-cast crops, and that the produce is greater.

Mr. Bloomfreld, of Harpley, finding that his turnips were very apt to fail, like those of his neighbours, on a chalk soil, varied his husbandry; he spread the muck, and then sowed the turnip seed, and ploughed them in together, by two furrows meeting, but not lapping the one on the other, and the seed coming up along the cemtre of the flat ridge thus formed, before winter he ploughs between, to earth them up powerfully, for preservation against the frost. The success has been great, and much exceeding the common practice on that soil. Mr. Goddison favoured me with this account-Mr. BLOOMFIELD not at home.

Mr. Priest, of Besthorpe, has this year turnips drilled at 18 inches, with Cooke's machine: I viewed the crop, and admired their rcgularity and size, for so unfavourable 
a year ( $1 \mathrm{SO} 2)$; they were first hand, and then horse-hoed; the rows 18 inches asunder: hand-hoeing performed as easy as in broad-cast crops.

Mr. Twist, of Bretenham, has seen drilled turnips, but did not like thern well enough to adopt the practice, though a great driller of corn.

I I. Consumption.-Mr. BEvas has for some years pursued the comınon practice of drawing half his crop alternately by stitches, and carting them to his yard or to layers, for cattle; and feeding the other half on the land by sheep; he has long suspected that he lost by it: this year his barley is so inferior to what it ought to be, as to afford entire conviction of it; and he is determined never more to repeat it. The sands of Riddlesworth are not rich enough to bear this treatment.

Mr. DRAKE, of Billingford, carts off his turnips with quarter-carts, the horse and one wheel going in the furrow, and only one wheel on the land, and that on the crown of the ridge. 'The mischief thus done, he says, is less than in any other method he has seen. The soil strong and wet.

Upon good land Mr. CoKE draws half and feeds half; but on the weaker soils feeds all.

It is common with many farmers in West Norfolk to draw out the largest roost for carting home to bullocks, and for feeding the smaller ones in the field by sheep. Carting damages many; but there is a great advantage in leaving the small ones, which resist the frost the best.

Mr. Mitches, of Houghton, having a great superfluity of turnips, in April, 179 I (a circumstance not uncommon in Norfolk), used a rool for cutting them into four quarters; it was a broad knife, crossed at right angles, with a handle ahout three feet long; women used it, and the expense was but a few shillings per acre. 
1 have known crops carted, at a great expense, into ditchss to rot.

Thirty years ago, three rookls of turnips would fatten a beast of 45 stonc, or six Norfolk wethers, in East Norfolk.

In 1770, I found the general method of consuming the crop, from Norwich to Yarmouth, to be drawing every other land for beasts, and cating the other half on the land by sheep.

At Thelton, the soil not being generally adapted to sheep, the crop is consumed by bullocks in the farm-yards (par yards).

Many drawn also at Billingford and Thorpe Abbots, as well as through all that country, sheep not being a common stock.

Mr. Thurtell, near Yarmouth, draws about onethird of every field for bullocks, kept loose in the yard; of tying up in stalls, his expression was, it is done with! ten beasts at liberty, make as much manure as thirty tied up: not that they may not fat solsething faster; the difference, however, is small, if there be sheds around the yard: if he fatted a beast on a bet, it should be tied up. The remaining two-thirds of the turnip crop are eaten by bullocks, and fat sheep in the field; and, in this consumption, he is in the Fleg system of drawing, and carting enough to spread a fair portion of the field cleared for the yard fatting; and the whole of the turnips consumed in the field, are pulled and thrown. This method is now common in Fleg, and the best farmers have an high opinion of it: the stock do better, and less offal is made, than where the roots are not drawn. Mr. Everit, of Caistor, is in the practice, and thinks, that to pull and throw, though in the same field, will make the turnips go further by one-fifth, and the. stock doing better at the same time. One-horse carts the best for this work. 
Mr. FerRIER, at Hemsby, carts his whole crop to the par yard, the roots being first tailed in the field. At Hemsby, \&c. in Fleg, 30 great cart-loads an acre; and single roots as much round as a middle sized man's body.

They have heen sold at Ormsby, to the Yarmouth cowkeepers, at 7 1. 7 s. an acre. A price fixed by appraisement, at Michaelınas, to incoming tenants, often 41 . 35 s. He has known 36 large loais an acre; and 24 lb. a turnip, and quite brittle, no flockyness.

Mr. HoRnARD, of Ludham, draws all his crop; he throws on his layers, on the wheat stubbles, and on wheat. He eats all his crop abroad, none in the yard or stalls; but the bullocks are brouglit home at night to hay or straw. The expense is something, but not heavy, as two horses, with one lad, will cart 30 or 40 acres in a season; the fields, lowever, within a furlong: some farmers do the same, though they have to cart a mile and a balf.

At Catfield, and, in general, through all Happing, they draw all the turnips; and think that an acre thus managed, goes as far as five roods fed on the land: they are carted to bullocks in yards, or thrown on ollonds, or wheat stubbles: it is not uncommon to throw on wheat in February 2nd March, and it is seldom hurt, if not done too late; but if in April, damage ensues; if a dry time succeeds, and the land not in good heart, it is generally injurious.

In South Erpingham the same practice; at Coltishal, all drawn, and thrown on wheat stubble, or eaten in the yards.

At Oxnead, all drawn for feeding on the ollonds, \&c. till Christınas, or till too jammy, that is, too much trodden from moisture, then into the yards. But Mr. REPTON stcams them, nixing turnips and their liquor with chaff, cut by horse work, and giving it with much success to young cattle, \&c. 
Mr. REEvr, of Heveringland, draw's the largest turnips, and throws them on o!londs, or wheat stubbles: he has tirown sometimes on wheat, and if the land be light, it allswers very well.

Mr. Bircham, of Reepham Hackford, reckons that 20 acres of iurnips will muck in the consumption, 20 acres of ollond, especially if thrown for shecp; and leaving enough for eating on the land; so that if more was left, the barley would not be the better, but, from its bulk, perhaps worse. In drawing the large turnips, they go only in the furrows, picking up all that are broken by horses or wheels, using small carts with two horses; often drawing in this manner, more than haif the crop.

Mr. JoHnson, of Thurning, used to be very fond of par feeding bullocks, but has left it ofl for two or three years past, now feeding them on the land: he draws part, and feeds part, picking out the great turnips; by which means he improves 40 acres of land, by growing 20 of turnips; prefers throwing on wheat stubble to jamm it in for barley, which answers better than haulming.

In feeding turnips by sheep, Mr. JoHnson remarks, that it is right to begin at the poorest end of a field, or where the worst crop is, as the flock, by falling back, will double dress it. Hay is beneficial to give to sheep while at turnips; but they will fatten without it.

Mr. JoHnson remarks, that it is wrong to top turnips for fatting beasts; the top being beneficial, if freed from slime and rotten leaves.

Mr. ReEve, of Wighton, feeds on the land by sheep: of all practices he most condemns drawing turnips; it is a heavy expence, and all to do mischief: far better to buy oil-cake.

Mr. M. HILL wishes to feed on the land all that is possible; draws no more than for converting straw to dung. 
Mr. DURSGATE is such a steady friend to feeding turmips on the land by sheep, that he would not have a bullock on his farm, except for the purpose of treading his straw into muck. He would have no straw eaten. In drawing a crop for beasts, he takes all, and manures with rape-cake, to supply the loss to the barley.

At Thornham, \&c. some farmers pick out the large surnips for carting to beasts; others draw alternate lands.

About one-quarter, or one-fifth of the crop drawn a Holm, for bullocks.

Mr. Sty LeMan, at Snettisham, feeds all his turnips on the land with sheep; and therefore sells most of his bullocks in aurunn!.

Much the greater part at Hillington, fed on the land by sheep.

12. Prcservation.-Tlie Rev. Dison Hoste practised a method, with this intention, that answered well; he took the coulters out of his ploughs, and then ploughed in the turnips; and they held good through a very bad March.

The Rer. Mr. MunNing has published his method: it is drilling at eighteen inches, and two feet, and plough ing furrows between, to bury them as well as may be effected. This method has been practised with great success, by Mr. Repton, at Oxnead, and other farmers.

I3. Seed.-Much attention is paid by farmers who raise their own seed, to the chuice of roots for that purpose, selecting such as are clean in the crown and neck; the footstalks of the leaves rising from a thin clean neck, and not from conglomerated protuberances, or coarse rough necks; and if, after some years attention, the turnips come too fine and delicate, they let the roots run to seed, without any transplantation, which correets that tendency.

14. Is the land tired of turnips? -Mr. THURTELL is confident that he has no land tired of turnips; nor has he 
ever seen any: the oftener he sows then, the better the husbandry, and no declension, on that account, in the crops hitherto perceived.

Mr. Everit, of Caistor, in Fleg, has no idea of iand being tired of turnips in that hundred: he thinks they will bear repeating better than any other crop,

Mr. SybLE, of South Walsham, is of a contrary opinion, and thinks that land becomes, from repetition, tired of turnips, as well as of clover: and he grounds the idea on the great failure of the crops which have been experienced for seven or eight years past. From that time, to twenty years ago, he remembers them nearly a certain crop; but not so now; being often lost. This has caused him to vary his practice, and sow on a wheat instead of a barley stubble, which promises better; the crops so arranged as to throw one turnip year equally far from another.

Mr. Francis, of Martham, conclucles that land tires of turnips, from the circumstance that more seed is now necessary than used to be commonly sown; formerly, he never sowed more than one pint and a half; now, always three pints, and yet they are not so certain as they were then.

Mr. Cuвiт, of Catfield, never observed that any land was tired of turnips; and he thinks the crops would be better if they followed wheat, than following barley succeeding wheat, though they would then come round once in five years.

Mr. Сuвıт, of Honing, never heard of land being sick of turnips in the six year husbandry.

Mr. Margateson, of North Walsham, has some doubts on this point: he sows three pints of seed, because now more subject to the fly than formerly; and he has re. marked, that when by accident there has intervened more 
years than usual between the turnip crops, they have been the better; and are always best on new land.

Mr. DYBLE, of Scotter, it may be supposed, admits no such fact as land being tired of turnips; for he positively asserted, that he never lost a crop in his life; but never gives any of the tillage while the land is the least wet; it cannot be too dry for turnips.

No land tired of turnips at Oxnead.

Upon this question Mr. BIRCHAM remarked, that 40 years ago, they could get almost as good turnips without eung, as they can now with it; but still muck will do the business well.

Mr. JoHnson, of Thurning, remarks on this point, that he gets to the full as good turnips as his father did. He never sows less than three pints. However, one observation of his looks like the land being tired, for he remarks, that turnips, in his proposed course of eight years, will come better from the sowings being longer apart.

Mr. ENGLAND, of Binham, has no other idea of land being sick of turnips, than what results from the fact, that this crop was to be gained twenty years ago without dung, but not so at present.

Mr. REEVE, of Wighton, agrees in the idẹa of his neighbour, and makes a point of manuring all he sows.

Mr. M. Hil L is clear that the land sickens of turnips, and that they are less in size every seven or ten years. His bailiff has been in the farming line fifty years; in dis. course with him on the subject, he assured me, that there was no sort of comparison to be made between the crops at present and those formerly raised: he has known two eurnips as much as a man could throw over the side of a cart. But he thinks the crops of corn better now; and he is also sure, that more sheep are kept now than in the former periods, notwithstanding the walks being broken up. 
Mr. Henty Blythé, of Burmam, or his neighbours, cannot get any tumips without inamuring.

Mr. DursGate never found any inconvenience from turnips being sown too often. At Sedgford he has often had them two years together, and the second better than the first. He does not admit, therefore, that land is sick of tliem.

Mr. CoKe is clear, that at Holkham, if turnips are sown oftener than in common, they fail, as the land is sick of them.

Mr. Fowel is clear that turnips have rotted much more for the last 10 years than they did 20 years ago, which he suppoes to be caused by a cliange in the seasons. But he cannot by any means agree with those who assert that the turnips in Norfolk are inferior to what they for merly wore, from long repetition; he is clear that they are just as good as ever.**

From these actes it appears, that opinions valy, and I wish the rcader to have the ideas of the farmers, rather than any general notion of my own, formed from those opinions-stich mighi be erroneously given. I make it a rule to let the county speak for itself on every point.

15. Sivedish Tumips.-Mr. WALKER, of Harpley, in Norfolk, has culitivated them for some years, with great success: generally has from 20 to 30 acres; feects them off with shcep and bullocks, and can depend on them, when common turnips are alt rotten. His crop in $18 c 0$, not.withstanding the drought, was very fine.

M.. OrenMAN, of Burnham, had in ISoc a fiell of this plant, and among them a mew-comer, the root somewhat resembling them, but the leat much more like a

* In the neiglibouring county, the Duke of GR A F T O N has made the same pbservation. Turnips were cultivated at Euston as early as at Rainham, yet His Grace is clear, that for the last ţo or so years they have not declined at 2!!, 
common turnip; and it buries itself in the ground more than any other, but the size inferior. It afterwards proved good for nothing.

Mr. Coke, of Holkinam, has 30 acres this year-has cultivated them several years, with the greatest success, and esteems them as a very valuable aç̧uisition.

Mr. Bevan sowel them in 1792 , at the same time with common turnips, and the crop was so inconsiderable as to prove the time quite improper. 1802.- - He has sorved this plant since repeatedly, and at the right season in May and June; but the Aly has always eaten it, so that he has never had a crop.

Mr. Fowel, of Snetterton, has sowed Swedish turaips for seven years successively, but has never had a crop: the fly ate all.

Mr. M. HIII, this year (1SO2) sowed Swedish turnips twice, and both sowings were taken off by the fly.

Now (1803) sowing Swedes and tankard turnip together, to draw the latter for autumn use.

Mr. Syble, of South 'Walsham, had last year a crop of these roots, which came to a good size; as heavy nearly as common turnips, but they were so hard that no stock which he tried liked them. They were white fleshed. Swedes, in East Norfolk, in the opinion of Mr. PALGRAVE, rather coming in: Mr. BaRTLET GURNEY has them at North Reps, and a few at Coltishal.

Mr. Bircham, of Hackford, has tried them, but did not succeed; he believes they were not sorvn early enough.

I saw a piece on the farm of Mr. REEVE, of Wighton.

Mr. H. BLythe, of Burnham, had a field of them last year, and found them of great use in the spring: this year he has ten acres.

Mr. WILLIs, of Choseley, has a few acres, 
Sir Mordaunt Martin, of Burnham, a promising crop.

Last year Mr. DURsGate had very fine Swedish turnips, sowed in May: he approves much of them.

In Mr. MACKIE's nursery, at Norwich, they are much infested with insects: a species of aphys.

Turnip Cabbages. - More than 30 years ago, Mr. HowMAN, of Bracon Ash, cultivating this plant, observed that those which were left in the seed bed, came to much the larger size. The same remark has been often made on the great common cabbage. In consequence of that observation, $l$ then recommended the practice of sowing cabbages where they are to remain; but know not that it was adopted by any person except the late Mr. BAKEIVELI.

16. Importance of the culture.-The general feature of the wet districts of the kingdom, is that of cleaning land which has hecome foul by the culture of white corn, by meaus of a summer-fallow; but in sandy and other dry countries, and more especially in Norfolk, the same object is attained by the turnip husbandry; and the great additional advantage secured of supporting great flocks, and herds of sheep and cattle. The system is, at present, pretty well known in most parts of the kingdom; but no where practised on such a scale and so universally as in Norfolk. The difference berween a barren fallow and an ameliorating crop, which admits so much tillage and successive hoeing, is generally known and admitted; and to expatiate on the importance of cattle and sheep in manuring, would be idle; but (confining our. selves ti) Norfolk) it merits inquiry, whether the practice, so common, of cultivating this crop on nearly all the soils in the county, whether sandy and dry, or heavy and wet, 
be so really advantageous, as to justify its recommenda. tion generally to the kingdom at large.

From all I have at various times seen in Norfolk of this custom, and 1 have often viewed the conduct of the farmers in winter, on strong, heary, wet lands, I must freely confess that it is carried too far. The reader should keep in his mind one material circumstance, that the tillage of the county is very generally performed on flat, or nearly flat lands, stitches, ridges, or by whatever name they are called: high and arched lands are unknown, and the Northumberland culture of drilling on narrow ridges, no where practised. Hollow-draining is the only dependence, and excellent as that husbandry is, it will not prevent much poaching, either by eating on the land, or carting the crop off.

Every degree of treading, poaching, or kneading in the spring, or when the spring is approaching, is on these soils pernicious: drying winds must follow before the ploughs can get to work, and then the furrow cuts whole, and what is called livery, soon becomes hard and tenacious, so that a very favourable succession of moderate showers and fair weather must ensue, or the tillage will be either disturbing hard clods, or poaching in the mire. On such soils, and in such seasons, to give the turnip land only one furrow when nearly dry, and dibble in beans, would be far preferable, than against circumstances to determine for barley: and in conversation with several good farmers on sowing turnips on really wet lands, I have heard the an admit that it is bad husbandry: a dead fallow would be betler; but we are tempted against our judgments.

When we speak therefore of what only deserves the title of true Norfolk husbandry, we ought always to confine the remarks to sand or sound loams. 
It is not merely a question between turnips and fallow, but beans should be more generally adopted: they are coming in, but move slowly.

\section{SECT.V.-BARLEY.}

Norfolk is the greatest barley county in the king dom, this grain forming the chief dependence of most of the farmers, in all except the very wettest parts of the district.

The notes taken may be thus arranged:
I. Course,
7. Drilling,
2. Tillage,
8. Dibbling,
3. Time of sowing,
9. Produce,
4. Sort,
10. Awns,
5. Seed,
II. Malt.
6. Depth,

I. Course--Mr. HAYER's bailiff assured me, that he gets as good barley on a fallow without muck, as he does after turnips on the same strong land that was well dunged: a good crop ten coombs; rarely less than eight in any management. The husbandry is well conducted. After harvest the fallow is laid on to ten-furrow ridges, so that in spring they have only to plough and sow: to scarify and sow would be better, the horses going only in the furrows.

Mr. Pitts, of Thorpe Abbots, also gets much better barley on a fallow without manure, than after turnips well manured for, if the land be heavy.

Mr. CuBit, at Catfield, and his neighbours, get more barley after wheat than they do after turnips drawn; but 
ene cleanest and the best coloured is after turnips; and they find that the barley after wheat, in a six year's shift (the seeds lying two years), is much better than in the five slift, in which the seeds remain but one year.

Mr. Cuвiт, of Honing, also gets the hest crops of barley after wheat, but attributes it to the pulling and throwing turnips on the wheat stubbles; but he remarks, that the throwing business seldom answers, except in very dry weather.

Mr. Reptos, at Oxnead, generally gets better barley after wheat than after turnips, but the latter all drawn.

Mr. Johnson, at Thurning, gets as good barley after wheat on four earths, as after turnips.

Mr. EverIT, of Caistor, in Fleg, observes, that if turnips are fed off by sheep early, that is, by December, then the barley is much better than what is gained after wheat; but if the turnips are fed in the spring, in March for instance, the barley after wheat beats it.

Mr. Franeis, of Martham, upon the whole, has rather better barley after turnips than after wheat, but the latter the greatest bulk: the turnips carted away.

Mr. PARMENTER, of Aylesham, has compared the barley after turnips fed on the land, and carted off; and the superiority of the former is very great, greater than he should have imagined; of course ho has many doubts on the common practice of carting off for bullocks.

Mr. STYLEMAN has observed a manifest superiority in his barley, from giving the sheep laay while feeding the turnip crop.

2. Tillage.-About Watton all is put in on two earths and an half; the first clean, the second two furrow work, or ribbling, and the third clean burying the seed. No one-horse ploughs. But if the turnips are very late on the ground, then only one carth, and the sced harrowed in. 
Through East Bilney and the adjoining parishes, they give two clean earths, and an half ploughing; some three clean ploughings: if the turnips are late, but one, and harrow in the seed.

Mr. SaLter, of Winhorough, always gives three clean carths for his barley, and will not admit any iclea of lessening this tillage: finer crops than his farm exhibits (1802) were never seen: I guessed them at 35 or 16 coombs an acre; and he has had above 20 . He puts all in with onehorse ploughs.

A bout Hingham they plough the turnip land wice clean and one half ploughing: no such thing as ever sowing on a stale furrow. Some plough in the seed, and a few har. row it in.

Mr. Bevan, upon trying the dill husbandry, some years ago, and being well satisfied with it, adopted the one-horse ploughs for that purpose, and they answered very well, doing an acre and a half a day; after which he used the scuffler, one man and three horses, doing seven or eight acres a dạy; being induced by the good crops which his tenant, Mr. BRADFIELD, gained in that manner; and he prefers scuffling, as being cheaper. The crop comes up equally, and he conceives that if the drill is superior, it must arise (not from the seed being deposited at an equal depth, because the same object is attained in other methods, bur, from the seed being crowded together as in cluster sowing, which has, in certain experiments, proved highly beneficial. Of course this applies to the present Norfolk practice of neither horse nor hand looeing being applied in the drills.

At Thorpe Abbots, they generally give three clean earths to their turnip land for barley.

At Hemsby some farmers give four. There are some also that put it in on one, but the crop is not so good. 
At Repps and Martham, three earths for barley, whether after turnips or wheat. Mr. FRANCIS is very careful not to touch the land till it is dry in March, and thinks that all winter ploughing is mischievous. He has tried putting in barley on onc earth, but never knew it answer. At Ludham, three earths to turnip-land, for barley; but Mr. HornARD, this year, put some in on two, and never had a better crop. He ploughs it in with one-horse ploughs, and now has a double plough for the same work, which answers bette;.

At Catfield, three or four earths to turnip-land, for barley. Mr. Margateson, at North Walsham, three and four on wheat stubbles, sometimes five. He, in common with the practice of the country, ploughs in the seed after turnips, and harrows in that sown on whear stubbles. Here and there are one-horse ploughs, but not common.

Mr. Parmenter, of Aylesham, puts in with onehorse ploughs.

Mr. Dyble, of Scotter, sometimes three earths, but oftener four, and has given five after turnips, and also after wheat.

At Oxneal, Mr. Repton, four or five earths for turnip.land barley.

Mr. Bircham, three earths.

Mr. ENGLAND, of Binham, if his turnip-land is quite clean, rarely more than two earths to prepare for the drill, but three if wanted.

Mr. ReEve, of Wighton, this year (1802) scaled some of his turnip-land in January, and left it till the beginning of March, then harrowed, and gave a stirring earth; rolled it with a light roller, and left it till the end of March, or the first week in April, and after the first shower, harrowed and drilled direelly; the soil stiff and NORFOLK.] 
stubborn (what a Norfolk sand-farmer assigns these crso piessions (o); the crop very great.

Mr. CokE, at Holkham, gives threc clean earths, invariably.

Mr. Moner Hril, three earhs-part with one-horse ploughs, the rest drilled.

Mr. Henry Blythe, of Burnliam, drills his barley on two earths, after turnips; sometimes on three.

It is common about 'Thornham to plough for barley thrice, if broad-cast; twice for the drill; Mr. Rrsuton thrice.

Mr. Stylemas, at Snettisham, if his turnips are late on the land, ploughs but once for barley, rolls and drills, and gets as good crops as any : but on the land fed early, ploughs thrice. It depends on the seasun, which shall prove the best crop.

Mr. Porter, of Watlington, ploughs his turnip-land once, for barley drilling, and gets as good crops as with more tillage.

3. Time of sowing.-GEORGE Earl of ORFORD, tried at Houghton, some experiments on sowing barley nuch earlier than common, which were interesting. The soil, sand. In $1785-23$ acres, after turnips fed off: sown Feb. 7 ; sharp frosts, with and without snow, followed, and the seed laid five weeks before it appeared. Produce, five quarters one bushel and one peck per acre.

In $1786-14$ acres, sown the 8th of February; produce, four quarters seven bushels and one peck.

In $1787-30$ acres, sown the 6th, \&c. of February; produce, five quarters one peck.

$\mathrm{Mr}$. CoKe is a friend to early sowing; he would wish always to begin by the 2oth of March, and finish by the $15^{\text {th }}$ of April, and never be a moment later than the 20 th.

$\mathrm{Mr}$, 
Mr. Overman thiinks the best season for soiving barley, is from the Ist to the 20 th of April: it will vary with seasons; but about that period the genial warmth of the earth will, on an average of seasons, take place. He has not made observations on the foliation of trees with this view.

Mír. England, of Binbam, as early as possible in April.

Captain BeAcrer, at Hillingdon, the earlier the better: this year (1802) some the last week in February; and though it was cut iny the frosts, and looked for a time badly, yet lie never had a better crop.

When the buds of the oak are breaking, a few days before the expansion of the leaves, no time should be lost in getting in the seed-barley: a rule in East Norfolk.From mid April to mid May, their general time.- $M r$. Marshall.

4. Sort.-Mr. Bevan has cultivated Egyptian-barley two or three years; it bears sowing a month later than the common sort, and produces two coombs per acre more, but of a coarser sample. He has this year 20 acres of it, the crop good. Seed, two bushels and a half per acre.

Naked barley was tried by Mr, Overman, of Burnham, on comparison with common, and produced scarcely half the crop.

5. Seed.-Mr. SALTER, on lieavy land, four bushels broud-cast.

At Thelton, three to four bushels; six pecks and a half, drilled.

Mr. ThuRteld, near Yarmouth, ten pecks, drilled at six inches: if he thinks hoeing may the wanted, then at nine inches.

Mr. EvERIT, of Caistor, in Fleg, three bushels to three and a half. 
Mr. Syble drilled three bushels; four sown. Mr. FrancIs, of Marthain, four bushels; turnip-land requires rather more than on wheat stubbles.

Mr. HoRNARD, at Ludham, sows four bushels.

Mr. Cusit, of Catfield, \&c. three bushels and a half.

Mr. DyвzE, of Scotter, sows three bushels and a half; drills two.

Mr. Palgrave, at Coltishall, two bushels drilled, four broad-cast.

Mi: RfPton, at Oxnead, drills two bushels and a half an acre; not at all agreeing to any thin sceding land in the drill husbandry.

Mr. REEvE, of Heveringland, drills at six inches, 10 to II pecks.

Mr. BrRCHAM, at Hackford, three bushels broad-cast.

Mr. Johnson, at Thurning, drills four bushels, the rows at four inches and a half.

Mr. ENGLAND, of Binham, finds that II pecks are the best quantity drilled.

Mr. ReEve, of Wighton, 10 pecks, rows six inches and three-quarters.

Mr. Overman drilis on light land three bushels. Mr. CoKE, at Holkham, the same.

Mr. Henry Blythe, of Burnham, drills nine to ten pecks.

Mr. Styleman, of Snettisham, drills six pecks.

Captain BeAcher drills two bushels and a half, at six inches three-quarters: broad-cast on marmy land, four bushels.

Mr. Beck, of Castle Riseing, drills ten pecks.

Near Downham, broad-cast, two bushels to four.

At Wathington, three bushels. About Wymondham, three to four bushels.

Mr. 
Mr. TwIsT, at Bretemham, drills two lushels: sows three pecks to three bushcls broad-cast.

6. Depth.-Mr. Hzath, of Hemlington, had some barley this year drilled three inches deep, aidd the crop suffered. Mr. Syble, of South Walshain, had part of a crop drilled at one inch and a half, and part at two inches; and the former was evidently the best. Mr. HoRNARD, of Ludham, ploughs it in broad-cast, two to three in, hes. Mr DYBLE, of Scotter, thinks it cannot be too shallow, if huried.

Mir. Palgrave, at Coltishal, one inch to one and a half, drilled.

Mr. Repton, at Oxnead, drills two inches deep.

Mr.BirchaM, at Hackford, Mr. JoHnson, at Thurning, and Mr. ENGLAND, at Binham, two inches and a half.

Mr. REEVE, of Wighton, not more than two inches: in most cases not so much; but if the weather be dry, deeper.

Mr. Overman drills his barley one inch deep. Mr. CoKe, at one inch three-quarters.

Mr. M. HILL, two inches.

Mr. Rishiton, at Thornham, one inch and a half deep.

Mr. Styleman, of Snettisham, thinks this a point of great conscquence; drills two inches and a half deep.

Mr. PORTER, at Watlington, two inches.

Mr. Priest has found that in both drilling and broadcasting, the shallower barley is put in, if it be but buried, the better.

7. Drilling.-Mr. Fowel, of Snetterton, puts in his barley at nine inches on one stale furrow, and thinks it a great improvement, as well as saving. He used to follow the common method of ploughing thrice, but prefers his present inethou greatly. He pens his turnips for sheep, 
across the ridges; then works the land in the same direction witli Cook's scarifier; and ploughs as soon as the close is fuished, with the ridges, leaving it till seed time : Jarrows, and drills, at nine inches, on this stole turrow. The soil is a good sankl, but light. He sows the grassseeds after the harrow's, and before the drilling. The success answers every expectation: his crops, which I viewed, were fine. Hc has twenty acres, half drilled at nine inches, and half at six inclues three-quarters, for comparison. This marked variation from Norfolk management camo from Suffolk: he has a relation near Ipswich, where spring ploughing is going out of fashion amongst the best farmers.

For barley, several farmers have remarked, that the grcat saving by the use of the drill, is forwarding business: the common praclice has been to give three earths; but by means of the drill, one is saved ; this a material object, as the farmer gets sooner to his turnip-fallows. A bout half a bushel of seed is also saved. As to crop, the butk is reckoned less than from broad.cast sowing, but the corn as much, and of rather a better quality. They have not observed any difference in ripening. Seeds are sown broad-cast? and luarrowed in; no horse-loeing in this case. This management depends on the land being clean. Whon barley is sown broad-cast on two earths, it is harrowed in, and does not come so regular, not being put in at an cqual depth.

I have rarely seen the drill so superior to the broad-cast, as in a large ficld of Mr. BEvAN's: in 1802 , the crop drilled was not only considerably superior to the broadcast, but vastly freer from weeds; especially poppies, which had damaged the broad-cast much; as neither had any hoeing or weedirir, this effect is remarkable, and what I cannot account for, nor could Mr. Bevan. The whole after turnips; one-half fed, one-half carted, alternately. 
Mr. Havers, at Thelton, drills barley, and has this year a very fine crop, in that method,

Mr. PitTs, of Thorpe Abbots, drills barley on the flag, one earth on white clover, and trefoil layers; by this means he gets it in much earlier than common, which, on a burning gravel, he finds of great consequence; otherwise the crops are apt to go off in July, however weil they might look in May and June.

Mr. Thurtell, near Yarmouth, has for two years drilled much : he drills on the second earth on his turnip land; saving the third, usually given for broad-cast barley: the rows at six inches.

Mr. Heath, of Hemlington, gets very fine crops, by drilling on two ploughings.

Mr. Syble, of South Walsham, approves much of the husbandry, and intends practising it more, but will give the three earths, which he thinks necessary. He has this a year a very fine crop drilled, which I viewed; the rows at seven inches.

Mr. Petre, at IVestwick, drills at nine inches, with Cook's drill, and thus gets his best crops: cight to ten coombs.

Mr. DYBLE, of Scotter, this year ( 1802 ) drilled some barley on three earths, saving one, and these were his best crops, by two coombs an acre; the rows at six and nine inches; but he prefers seven.

Mr. PALgrave, at Colcishal, gets as much barley from two bushels drilled, as from four broad-cast.

Mr. REPTON has, from much experience, an high opinion of drilling barley. He began in April, 1790, when he drilled 46 acres, with 30 coombs 3 bushels of seed; saving 15 coombs I bushel, which, at I is. 6d. was 81. 6s. 3d. Twice horse-hoeing the nime inch rows, 21.

$$
\text { R } 4
$$$$
\text { 5s. Net }
$$ 
5s. Net saving by drill, 61. Is. 3 d. Produce, 427 coombs, but five acres were destroyed by the wyer worm: per acre, nine coombs one bushel and a half: and if the five acres be deducted, ro coombs one bushel and a half per acre. Sowed broad-cast, 38 acres, with 38 coumbs of seed: produce, $321 \frac{1}{2}$ coombs; or eight coombs two bushels per acre: from tlat time he went on drilling, being convinced of its superiority, and has now no sown barley. Thomas Fox, his bailiff, remarked this year (1802), that in a field where was both drilled and broadcast, that the straw of the latter was faint, and the ears short; but that the drilled straw was stiff, and the ears long. Would you drill, if you had a farm of your oun? His answer to me was, I really think I should. He approves much of dibbling whear.

Mr. ReEve, of Heveringland, drills his barley at sir inches, and finds the crop better than broad-cast.

Colonel Buller, at Haydon, drills all his barley, and finds that it beats the broad-cast out and out.

Mr. Johnson, at Thurning, drilis all on three clean earths, the rows four inches and a half, with AsHBy's drill, which he thinks a very good one, though it is no: easy with it to make sostraight work as with Coon's : answers much better than broad-cast: the straw stiffer, and the crop larger.

Mr. EnGLAND, of Binham, drills ali.

Mr. ReEve, of Wighton, all; the rows at six inches three-quarters; but thinks six, if the land is good, would be better.

Mr. M. Hruc drills nearly all his barley at six inches, three bushels of seed an acre; when he sows broad-cast, three and one-quarter: daes not hoe. Sows clover, 2xc. the day after. In 1802 , he had two coombs an acre more 
from covering the seed with one-horse ploughs, five fur, rows to a yard, than from the drill.

Mr. Cone drills at six inches threc-quarters, and gets immense crops : finer barley cannot be seen, than I viewed on his farm in 1800,1802 , and 1803 .

Mr. DuRsgate drills all inis barley at six inches threequarters.

Mr. Rishton, at Thomham, drilled all ; some at six inches three-quarters, and some at nine inches.

Mr. Styleman, at Snettisham, drills all his barley on his large farm of about 2000 acres; the rows at six inches three-quarters, and nine inches; and he thinks, upon the whole, that his best crops are at nine inches. Drilling much superior to broad-cast : he has this year part of a field drilled, and part broad-cast; the former, the best crop, and even the labourers confess it. The broad-cast has a weak faint straw, on comparison with the drilled barley; and Mr. STYleman attributes this superiority to the uniform depth of the drilled seed.

Mr. Beck, of Castle Riseing, drills at six inches and a half, except on his very sandiest soil, on which he ploughs in with one-horse ploughs, to bury the seed deeper than the drill.

Mr. Edw. Scot t, of Grimstone, on a farm of only 200 acres, drilled his barley in $180 \mathrm{r}$, and it turned out much to his satisfaction.

Mr. Porter, of Warlington, drills all his balley; and hoes all at 2s. 6d. 10 4s. an acre, covering the clover seed: the operation does much good to the crop: he had this year 13 or 14 coombs an acre: 17 loads from four acres: from another four acres 16 loads: from five acres reaped 10 loads, each from five to six score sheaves.

Mr. PORTER, of Tottenhill, this year drilled I $g 0$ acres 
of barley; some at six inches, some at nine, and thinks nine (especially on a wheat stubble) the best.

Mr. Rogerson, of Narborough, was amongst the earlicst drillers in Norfolk, and on a very large scale, especially for barley; but this year ( 1802 ) I found he had put in all his crop with one-horse ploughs, preferring this method, after long experience: he never lad a better crop.

Mr. PrIEST, of Besthorpe, drills his barley at nine inches, and horse-hoes it if he lias not sown grass-seeds; and he has observed an evident benefit from the operation. His threshers admit that drilled corn is fuller bodied than broad-cast. At Shropham he tried seven, eight, and nine inches distance of rows, and nine proved the best.

Mr. TwIsT, of Bretenham, drills all his barley, and has much better than when he sowed broad-cast.

8. Dibbling.-Mr. Dr A ke, of Billingfold, dibbles barley on his lighter land on one earth; onc row on a furrow, and then sows a cast and harrows; and this he thinks pays hetter than wheat on land much subject to poppy, in which he has had wheat that cost from 20s. to 30 . an acre weeding and yer a bad crop; but of barley never gets less than nine coombs an acre, and the land clean.

Mr. Rerton, at Oxnead, has tried dibbling barley, but gave it up, as it would not answer.

9. Produce.-In a tolerable season the poor sands in the south west part of the county, of the rent of 5 s. will produce five or six coombs an acre; and in a good, that is in a wet season, six to eight: the hetter soils in the same district, intermixcd with the preceding, give from six to ten, which is not an uncommon crop in a wet year. The richer lands, from Quidenliam, by the line of separation on the inap, and from Swafham, by Castleacre, to Holkham, are very fine barley lands, and yield great crops, not, 
however, without a mixture of inferior soils of several varieties. It is in West Norfolk, as in many ocher districts, the best land is where the soils change; between chalk and clay, hetween sand and clay, \&c. there is usually a breadth of mellow loam of good quality. The crops of barley are generally good on tolerable lind. Dividing West Norfolk into two districts, one of 5 s. and the other of IOs.; the first rusing in tracts to 7 s. $6 \mathrm{~d}$. and falling to 3 s. $6 \mathrm{~d}$. : the other rising to 15 s. and falling to $8 \mathrm{~s}$. ; and I should average the barley of the former at six coombs, and of the latter at ten. I have considered this point under many corrections, and do not think it far from the truth: and I am of opinion that if the land was managed in an inferior stile, the poorer districts would not produce four: nor the richer more than seven.

The greatness of Mr. SALTER's barley (ISO2) may be easily conceived from this circumstance : he set 18 men to mow 18 acres, they worked all day, 22 men all the next day, and 18 men till nine o'clock the third day. There were about 120 loads of it, forming a stack 28 yards long.

They have a whimsical term about Holkham to denote a good crop; they call it hat barley: if a man throws his hat into a crop it rests on the surface if good; but falls to the ground if bad. "All, Sir, is hat barley since the drill came."

About Watton seven coombs on an average: I saw much in a good season that produced ten and twelve.

Average at Langley, on fine loamy and gravelly sands, ten coombs an acre.

Caistor, and average of Fleg, eleven coombs; sixtecn have been known.

Hemsby, five quarters; but some light land and open freld: sixteen have been known. 
Thrigby and Fleg, in general nine to ten coombs.

Martham, nine coombs; and of late more.

In 1793 a great crop in East Norfolk.

The same in 1800 ; Mr. Francis, of Martham, had that year:

$$
\begin{aligned}
& \text { Coombs. } \\
& 54 \text { acres of wheat, which yielded } 460 \\
& 63 \text { barley, } 823 \\
& \text { I4 oats, } 187 \\
& 6 \text { pease, } 63 \\
& \$ 37 \quad 11 \frac{3}{5} \text { coombs per acre, } \quad \$ 534 \\
& \text { Barley } 13 \\
& \text { Oars } 13 \frac{\pi}{3} \\
& \text { Pease } 10 \frac{x}{2}
\end{aligned}
$$

which, combined with the high price of the year, and here not a bad harvest, gave a good farming account.

Carficld and Happing, in general nine to ten coombs.

Happsborough and Walcot, fourteen coombs.

Horing, nine to eleven coombs.

North Walsham, eight to nine coombs.

Scotter, eight coombs.

Around Coltishal, ten coombs.

Mr. KePTon, at Oxnead, favoured me, from his books, kept with uncommon accuracy and care, with an account of his crops from 1773 :

Acres. Produce per acre.

$$
\text { Coombs. Bushels. }
$$

$\begin{array}{rrrr}1773 & 113 & 7 & 1 \\ 1774 & 84 & 7 & \text { I } \\ 1775 & 74 & 7 & 3 \\ 1776 & 99 & 8 & 0 \\ 1777 & 73 & 7 & 3\end{array}$


BARIEY.

Acres. Produce per acre.

Coombs. Bushels.

$\begin{array}{lrrr}1778 & 77 & 8 & \text { I } \\ 1779 & 73 & 8 & \text { I } \\ 1780 & 93 & 8 & 2 \\ 1781 & 99 & 10 & 0 \\ 1782 & 116 & 7 & \text { I } \\ 1783 & 98 & 7 & 3 \\ 1784 & 81 & 9 & 0 \\ 1785 & 90 & 7 & 3 \\ 1786 & 91 & 8 & 3 \\ 1787 & 107 & 9 & 2 \\ 1788 & 100 & 9 & 3 \\ 1789 & 94 & 9 & 0 \\ 1790 & 85 & 8 & 2 \\ 1791 & 90 & 9 & 3 \\ 1792 & 71 & 8 & 3 \\ 1793 & 90 & 9 & 0 \\ 1794 & 79 & 8 & 0 \\ 1795 & 90 & 9 & 3 \\ 1796 & 90 & 7 & 2 \\ 1797 & 84 & 9 & 0 \\ 1798 & 90 & 8 & 3 \\ 1799 & 91 & 8 & 3 \\ 1800 & 94 & 9 & 3 \frac{1}{2} \\ 1801 & 94 & 9 & \end{array}$

I8or Book not made up.

Average of the whole, $8 \frac{1}{2}$ coombs.

On the lighter soils at Heveringland, seven or eight coombs; on the better lands, nine or ten.

At Causton, the soil a good barley land, and the produce averages ten coombs.

Mr. BIRCHAM, \&c. at Hackford, ten coombs.

At Haydon, eight coombs.

At Thurning, \&zi, seven to eight coombs. 
At Bumham Westgate, eight coombs. Mr. M. Hrz varies, from difference of soil, eight to ten and a half; most on the lightest land.

Mr. Coke, at Holklıam, nine coombs.

At Holm, eight to ten coombs, and some more.

At Snettishan, eight coombs.

At Houghton, eight coombs.

At Hillingdon, from five to twelve coombs.

The vicinity of Downham, eight coombs.

At Watlington, ten coombs.

About Wymondham, nine coombs.

Harvest. - "When wet in the swath, it is not turned in East Norfolk, but lifted; the heads or ears raised from the ground wih a fork or rake, admitting air underneath the swaths."-Mr. Marshall.

It is the present practice of a large part of the county, especially where large farms prevail, to stack the com, particularly barley, in the fields where it grew: evidently to save time in the harvest period.

On a great Norfolk farm I found the work in carting a very heavy crop of drilled barley, the bulk of which I guessed at four waggon loads an acre, going on in this manner: Four putting in; four pitching totwo waggons; four loading; six women raking; two boys leading the horses; six men driving away; fourteen at the stack, eight of which, in two parties, wcre forking in holes and from a scaffold, as the stack was high; ten waggons and thirty horses. From eleven o'clock in the inorning to night they cleared, by estimation, twelve or thirteen acres. The drive about half a mile. The expense is heavy. Each man (1800) had in money and beer about 7 l. for the harvest; if we call this five weeks, it is near $5^{\text {s. a day per }}$ man; hawkey, \&x. \&c. will make it up 5 s. 


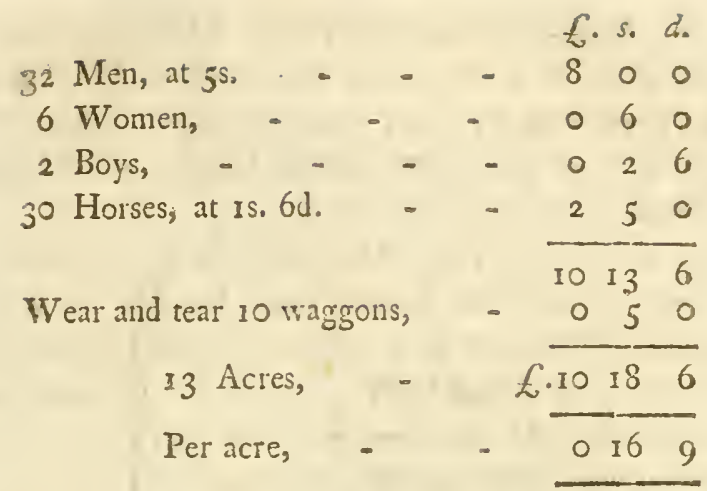

I conceive that with one-horse carriages this might have been done much cheaper.

I found Mr. BuRTon's fields, at Lângley, clearing under the following arrangement:
2 Pitchers,
2 Drivers,
2 Loaders,
4 Waggons,
2 Rakers, 10 Horses,
4 Unloading,

and cleared 12 acres of batley a day ; 36 loads; from onequarter to three-fourths of a mile distant, and some even a snile.

Mr. EvERIT, of Caistor, in Fleg, assigns ten acres per man: Mr. Francis, of Martham, the same.

Mr. BiRcham's arrangement on his farm of 720 acres arable, for a gang:
2 Pitchers,
3 Waggons,
2 Loaders, 5 At the stack,
2 Rakers, boys, 7 Horses.
2 Drivers,

Mr. JoHNSON, at Thurning, I4 to 16 acres per man.

Mir. Dursgate, I4 acres per man.

Mr. Styleman, I 7 acres per man.

At Houghton, 20 acres per man.

Mr. Priest, at Besthorpe, ro acres per man.

10. Awns. 
10. Ainns.-To free barley from the awn, in years of crops when it is very tough and adhesive, Mr. REvan has a horse rode by a boy repeatedly over the floor when six to eight or nine inches deep in barlcy, and it is found effectually and cheaply to free it.

II. Malt.-In i 800 Mr. Gilpin, of Heachan, a consideralle maltster, bought some beautiful barley that had not received a drop of rain, and trying a small parcel of it, found it malted badly: he tricd a most uncommon experiment, and founded upon an idea very contrary to all common ones on the subject: he kiln-dried it by a gentle heat, watering it lightly with a watering-pot twice or thrice, six hours intervening; dried it : after which operation it malted well, every grain sprouting, and no malt could be finer. Hence observes the very intelligent geritleman* from whom I had this account, it is evident that a good shower of rain in harvest, or a sweat in the stack, is beneficial to the maltster.

By the same gentleman it was remarked to me, that malt keeps better with the comó in it, screening when wanted.

The best trial is to swim it in water; all that swims is good malt; what sinks, is barley rather than malt.

SECT. VI.-CLOVER. SEEDS.

I PURSUE the general rotation in treating of these crops. seeds, as they are usually called, are universally sown with barley that succeeds turnips.

Thirty years ago they had for some time found their clover crop failing, from its recurring too often; this

* Maxsy ALLEN, Esq. of Lynn, 
caused the variation of substituting trefoil for one round, and the clover being sown but once in nine years, the evil was removed:

I found the same account every where in the South of the county, that the land (whatever the soil) was what they call sick of clover. Formeriy it was sown every fourth or fifth year; but now if it returns so often it fails, for acres together: thev therefore sow clover in one round, and then substitute white clover and trefoil, adding a little rav-grass, but as little as they can help. Whether the wheat is as good after these seeds as after clover, is rather an unsettled point. In discourse with Mr. BurTon, of Langley, a most intelligent observer, upon this question, he said, that he himself got as good wheat after white Dutch as after red clover, but that he believed the true change for the soil would be to sow no seeds at all; and he shewed me a large field of red clover, part of which was very regular and good, and part inferior: the former was in a course where no seeds had been sown, and the latter where Dutch and trefoil were introduced: a strong confirmation of his remark.

Mr. FowEL, of Snetterton, six pecks of ray, six pounds of clover or trefoil, four of white clover, for two years. I recommended him to try chicory, as well as to substitute cocksfoot for ray.

The land around Hingham is tired of proaucing this crop, and causes the varration of sowing ray, trefoil, and white clover: but-Mr. Meath has sown no ray of late years, for he has found it inju'e the land, so that he never observes such goor! wheat after it as after other grasies.

About Watton, if clover alone, ten or twelve pound; but if on land which has been found apt to fail, eight pound of clover; six or eight of trefoil, and half a peck of ray: but Mr. Robinson has a bad opinion of ray, espeNORIOLK.] 
cially on heavy land. When corvs are to eat clover, they reckon a small mixture of ray beneficial, to prevent horing. Clover is very apt to die in the winter; they have repeated it so often that the land is sick; this has occasioned the substitution of trefoil, rày, and white clover.

Upon the various soils near Derelian, towards Bilney, and the adjoining parishes, ray is nuch sown, yet does badly. The opinion in favour of it lessens gradually; they admit that after Midsummer it is good for nothing.

All over Earsham hundred the land is sick of clover, so that it will not stand if sown oftener than once in eight or ten years. White Dutch, trefoil, \&c. are substituted, but the wheat is not equally good after them.

Over the hundred of Loddon the same remark is applicaile; they use as little ray-grass as may be.

Mr. Thurtell, near Yarmouth, ventures clover not oftener than once in eight years; substitutes white Dutch, trefoil, and ray-grass; but he thinks that land tires of these seeds as well as of clover, and therefore on a portion of his land omits all, and sows pease. Nows clover twice - sceds once.

Mr. Everit, of Caistor, sows clover but once in eight or ten years, either substituting white Datch and trefoil, or baulking it of seeds eitirely: he mows clover twice for hay, and the wheat is the better for such moving; remarking at the same time, that when he has soiled a part of a field of tares and left the rest for wheat, that crop has been better after the laticr than after the former: a sure proof, he observed, of the benefit of shading the ground.

Mr. FERRIER, of Hemsby, finds no difference in his wheat, whether it follows clover or other seeds.

Mr. Syble, of South Walsham, thinks that nothing prepares for whent so well as a good crop of clover.

Mr. Francis, of Martham, has found, in common with 
with his neighbours, that the land is sick of clover; when he baulks it by substituring pease, then the four-shift hus. bandry instead of their usual Fleg five-shift, turnips coming after the wheat. Having no marsh or meadow's, he always keeps a layer two years, which is convenient also for throwing turnips: puts in wheat equally on one earth.

Mr. HoRnARD, of Ludham, is not ready to admit that the land of this couniry is so tired of clover as many are ready to assert; and he instances the case of a field which to his knowledge has been 28 years in the common course, sown once every five years; there is nothing particular in the soil, and the last crop is as good as any former one.

In Happing hundred I find the approach of a change in practice: they admit at Catfeld, that if clover recurs too often the land will not yield it, but their method is not an alternate substitution of other seeds, or baulking the land for a round, but to take a six course shift instead of a five, and mixing white clover and trefoil and ray, by which two precautions they succeed well. The clover is often mown twice for want of hay, fel the second year; it is of great importance, for there is no natural grass in the whole hundred, or next to none; all arable and commons. Such as sow their land in five-shifts, cultivate vetches for soiling their teams.

Mr. WIsEMAN, of Happsborough, relies chiefly on white clover, preferring it to any other: sows nineteen pound an acre, though twelve the common quantity; it makes the best of lay, and he gets two waggon loads an acre.

Mr. CuBit, at Honing, ten pound of red clover, three or four pound of white, and on the stronger soils a quarter to half a peck of ray-grass, for two years; the first year 
lie mow's once, and fects the second growth; the second year feeds all: on strong land he ploughs after the first feeding of the second year, and sows buck-wheat to plough under for wheat; but on light land he riffes the lay, or else scales it thin; after harrest harrows well, ploughs clean, and dibbles wheat. Red clover never fails with him, if sown only once in six years.

Mr. Margateson, of North Walsham, very rarely misses of clover in the six-shift husbandry; if it does fail the loss is great, for he thinks trefoil very uncertain for hay; when it does happen, the clover of the next course is sure to be good. The first growth of the first year is always nown; the second fed, as well as the second year. There will in the second year be as much grass upon one acre mown only once the first year, as on three acres that were nown twice: this is a remarkable obscrvation, and goes directly to the point of mowing or feeding new lays of permaneitt grass.

Mr. Dyble, of Scotter, does not find that land sickens of clover in the six-shift husbandry; sows clover-suckling and ray for two years.

Mr. Palgrave, at Coltishal, has sown his seeds on the barley, after it was up, but it did not succeed for want of rain. He sows only red and white then, and after liarvest, the ray, on the first rain coming; loy this means it is backwarder when the clover is mown: in the conmon management, the ray is in seed when the clover is in blossom, whiclu damages the hay, besides the laud being loaded with perhaps a sack an acre of the seed, which hurts the clovers of the second year. On the whole, however, he hates ray-grass, and has for three years omitted it; but candilly owns that his success has not been good.

Above thirty years ago, clover from Norwich to Yarmouth, was very generally mown twice; and as general an 
opinion, fuunded on much experience, that the wheat following was better than after feeding.

Mr. Layton, of East Norfolk, was clear from numerous observations, that clover mown twice for hay, gave better wheat than clover fed, by the difierence of a small coat of dung : the soil sandy. He attributed the effeet to covering the soil from the sun.

"In East Norfolk it is universally made into large cocks, as soon as it is weathered enough to prevent its damaging in these cocks; in which it frequently stands a week, or perhaps a fortnight. The leaf and the heads are thus saved before it becone too crisp; but heavy rains do.it injury in this state."-Marshall.

The trifolium procumbens, called red suckling, culivated about Norwich for the profit of the seeci, as it yields a large quanticy: said not to bave any merit comparable to clover or to tref́oil.

Mr. Repron, at Oxnead, twelve pound of clover, three pound of white suckling, and half a peck of raygrass; clover will not stand the second year, but the white and the ray succeed.

About Aylesliam the land is sick of clover.

Mr. REEvEs, of Heveringland, changes his rounds from clover to trefoil and suckling; when it fails, takes pease.

Mr. Birchan, of Hackford, finds that clover fails if sown oftener than once in twelve years: he was in the four-shift course, but the land grew quite sick of clover: now in one round are substituted one peck of trefoil, two pecks of ray, and three or four pound of white Dutch. Whether these, or clover and ray, they are all for two years.

Mr. Johnson, of Thurning, finds that clover has long worn out the second year, but now half of it is lost even the first. His substitutes are white suckling, black non- 
such (trefoil), and ray-grass. He does not like trefoil, but ray-grass much: it makes the best of hay, and if kept fed very close, it is good all the summer, carrying much stock, which secures corn. He conccives tliat clover itself is not so good as ray, as he remarks that catile feed dorvr? the borders when turned to clover much sooner and closer than they do when in ray-grass fields. After drilling his barley he harrows, rolls, and sows one bushel of ray, seven pound of clover, four pound of white. Mows the first growth, feeds the second, and the second year.

Mr. England, of Binham, red clover, one round, and trefoil and white the other; ray-grass, one peck witl either: if any thing like a failure, which thus rarely bappens, takes it up the first year, instead of leaving it two.

Mr. REEve, of Wighton, alternate rounds; clover, one course, and trefoil, white and ray, the other; but both for two years, if they will stand: intends the red clover only for one year. He has a great opinion of raygrass, thinking it the best grass they sow, and gets as good corn after it, as after any other. He finds that trefoil stands a drought better than either red or white clover.

Mr. M. Hrls, glb. of clover; 3lb. of trefoil; 6lb. of white Dutch; and from one-quarter of a peck to two pecks of ray: but his land is very sick of clover. He leaves the layer two years, breaking up part by a bastard fallow, and leaving part for one earth on the flag. In the consumption, prefers mowing one year and feeding the second. He has made observations on the comparison of mowing and feeding, and thinks the difference not striking in the wheat; but has remarked, that sceds broken up the first ycar after mowing, have yielded as good wheat as the second year's seed, though manured. This is curious; but, quere, whether the clover did not predominate in one case and the ray in the other? 
In some cases, when his seeds fail, he lets his two years layer remain three, breaking up the failing land for other crops: and he remarks, that the fields which are thus left three, and, even in some few instances, four, instead of two years, he breaks up with a much better prospect of success, than if they had been laid only the usual time.

Time of souing.-Mr. PuRDIs, of Eggmore, was recommended by a friend, whose management he had seen and approved, to sow his seeds at twice: half of each sort (white and red clover, and ray), at the time of sowing barley; and the orher half before the rollers in going over the young crop: and this practice he intends to pursue in future. He thinks it will give them a better chance of succeeding. He has 600 acres of seeds: he sows the great quantity of I 4 lb. an acre of white clover, Slb. of red, and one bushel of ray-grass. The last he esteems much in spring; and when an observation was made against it, said, that in April and May he had 3000 sheep that found the excellence of it.

In I $7 \delta_{4}$, registering the husbandry of the spirited cultivator of Holkham, it is remarked, that "those who have been conversant in the husbandry of old improved countries, know that a common complaint is the failure of red clover. It has been sown so repeatedly, that the land is said to be surfeited with it. In the same district it comes to nothing on the old improved lands, yet yields immense crops on any accidental spot, where never, or rarely sown before." The cbservation is so common, that no doubt can remain of the fact ; howerer, it may be attributed to certain methods in management pursued in this county. Pease and tares had been tried as substitutes, but they arc tillage crops, and what these thin soils, harassed with the plough, want, is rest. Mr. CoKE turned his views to a different and better quarter, to other artificial grasses, 
which would answer the same purpose as clover and raygrass. i had recommended to him, on a former occasion*, trefoil, white clover, cow-grass, rib-grass, and burnet. Mr. CoKE applicd them with no inconsiderable sagacity to the present purpose, and that the experiment night not be delusive, tried them spiritedly upon 30 acres in the middle of a large piece, haid with clover and raygrass. The quantities of seed he has found will vary according to circumstances; but in general,

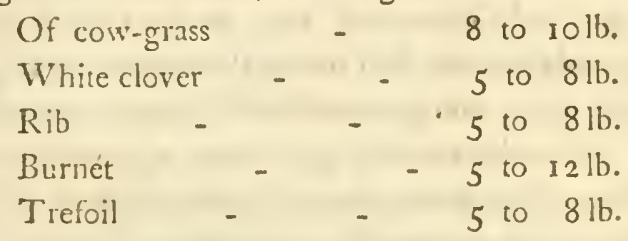

according to the price, and also the intended duration of the lay. The success of the first trial induced him to lay do: $\mathrm{n}$ a yet larger space the second year. And the third (with the barley of the last spring), no fewer than 22.2 acres: this is, in truth, doing justice to a new husbandry. Mr. COKE has found that those seeds fill the land completely with plants, which are abiding two, and even threc years; and how much longer they may last, is more than he can pronounce, as their appearance is yet as good as ever. I rode over all the pieces, and never saw a finer or more regular plant than they cxhibited. And he has, on several occasions, remarked, that sheep. give a preference to these grasses, whencver sorwin in the same field with clover and ray.grass."

In regard to the continuance of these trials, some of the pastures now remain, and are as fine as the soil will yield: thick, clean, and sweer.

* It was on finding a second crop of turnips in succession on the lawn facing the south front, as a preparation for grass; naming those plants, which were accordirgly sown, and have ever since succeeded well; and now form a vers fine turf. 
Mr. Coke considers hard stocking the seecis as the best preparation for wheat, and the safest means of saving the expense of oil-cake.-Sound doctrine, adds Mr. M. HiLl. Mr. H. Blythe, of Burnham, finds his land sick of red clover, and therefore sows it in alternate rounds with ray, and also with the trefoil and white clover of the other round. Rests two years, feeding most of the layers through both.

Mr. Wright, of Stanhow, does not like white clover; he thinks it a bitter food, and that sheep do not cat it kindly; so that while much food seems to be on the ground, stock do badly. This is an uncommon opinion, but I remember Mr. BAKEwELL staring the same idea.

Mr. DuRsgate finding his land sick of clover, sows it alternately, a round with, and a round without, substituting white clover and trefoil; ray-grass with both : no doing without that; all other seeds should come but once in ten or twelve years.

Mr. Rishton, at Thornham, clover one round in the four-shift husbandry, and other seeds alternately: finds little difference in the wheat.

Mr. Styleman, at Snettishan, sows secds for a two years lay; clover, $12 \mathrm{lb}$. one round, and in the nest, trefoil, 6:b. white clover, 4lb. and half a bushel of raygrass: in which system clover stands.

Ac Hillingdon the land is sick of clover, and therefore thie seeds are varied alternately by trefoil and white Dutcl. $8 \mathrm{lb}$. of red clover, $4 \mathrm{lb}$. of trefoil, or white, and one-quarter or half a bushel of ray : variation, 8lb. trefoil, $4 \mathrm{llb}$. of white, with the ray. If it is good enough to come to the scythe, it is all mown the first growth.

At Grimstone it is no wonder the land is sick of clover, for they are in the four-shift husbandry: they vary it with trefoil and white Dutch alternately. 
Alt round Downham the land, in some measure, sick of clover; and in that case, their variations are vetches, and by some, potatoes. Also sowing white clover, trefoil, and ray grass, leaving it two or three years, and breaking up for pease.

At Besthorpe, tired of clover; change it for trefoil, if it stands, mow the first growth for hay, and the second often for seed.

In Marshland I saw many very fine crops of pure red clover, and the malady, of the land being sick of it, is un. known. Mr. Dennis, of Wigenhall, St. Maries, sows it on his wheat in the spring, earing of the crop and harrowing well, before and after sowing the clover, and is sure to succeed: mows it twice for hay, and the best of all their wheats succeed-gets six coombs an acre.

From the preceding notes it appears, that one of the greatest difficulties which have for some years been found in the Norfolk husbandry, has been the failure of clover. I have often heard this, as a general fact, denied by men whose practice ought to have taught them hetter: in the common management there can be no doubt of the fact, and it well deserves the serious consideration of the farmers of this respectable county, whether there may not be devised some methods, beyond those already tried, to correct the evil.

An observation I made, during nine years that $I$ was in the constant habit of viewing the farm of Mr. ArBUтнNot, in Surrey, may here merit some attention. When he began to farm, the land was sick of clover, insomuch, that it was almost sure to fail, from having been, perhaps for a century, sown every four or five years. My fricind adopted the course of -1 . beans; 2 . wheat; 3 . clover, in which it occurred once in three years, and 
st:e farmers predicted an absolute failure: I viewed three courses, and better crops, of pure red clover, were never gained. He began with ploughing treble the depth of that to which the land had been usually stirred, and he manured very amply for every crop of beans, partly with night soil, from London. In what degree the success arose from depth of tillage, and in what degree from a variation in manuring, cannot be ascertained; but the experiment proved that these agents were equal to the cure of the malady.

Some farmers in Norfolk, as appears in the Notes upon Tillage, have moved out of the common sphere, and ventured to plough deeper than their predecessors; nor have they found any inconvenience in so doing. It merits consideration, whether this practice will not prove in some measure a remedy to the failure of clover. As to manuring, and especially in great variations, the means are generally limited, and a change in this respect, however desirable, is rarely in their power.

The only effective remedy hitherto practised, is tlat of omitting clover altogether, for one or two rounds, which points out the great importance of introducing as many new artificial grasses as possible.

\section{RAY-GRASS.}

Mrr. Salter, of Winborough, on varions loams called heavy, and some are so, sows but little.-Tie can't soiv too iittle; perhaps none would be better.

Mr. M. Hil L thinks that the common prejudice against ray-grass arises from a mistaken practice; approves the use, but not the abuse of it. Whenever it is sown for feeding, he particularly recommends the bare feeding in the spring; if suficred to grow more than two inclies long, it will imperceptibly rise and run to bent, and then only it is injurious.

Walking ovc: Mr. Money's farm at Rainham, with 
Mr. Hill; I-remarked, that ray had been sown with clover, on a soil perfeelly adapted to the latier plant; and conlernning the practice, Mr. Hill agreed, and made an observation that deserves noting: ray is sown with the clover, and if from a bad delivery of the seed, from the wind driving the lightest further, or from any other cause, some of the land misses its plant of ray ; the clover in such spots is much more vigorous; a sure proof of the exhausting quality of the ray.

Mr. CoKE, on his fine farm at Holkham, used to sow ray-gras, with sainfoin, but has left off the practice, and in general sows as litte as possible of the grass, being con. vinced that it exhausts; his corn is not so good after it, as where it has not been sown.

Mr. Overman had half a field sown with ray, trefoil and white clover; the other half with the two latter plants only. When the whole was broken up for wheat, the crop was much the better where no ray had been sown: the difference so great as to be visible at the distance of balf a mile.

Mr. HAvER's bailiff observed to me, that the less raygrass is sown the better, as he never found it kind for wheat: pease do better on it.

\section{BURNET}

Whas introlaced at Stokc 35 years ago, as I then registered, with great success; but it never made any progress, though it yielded luxuriant fcol for many horses in February.

The reputation of this plant made so mucin noise in the workl, that Mr. CoKe formed an experiment at Holkham, to exarrine carefully its merits, and, with the spirit that characterizes his husbandry, sowed 40 acres, mixing a small quantity of white clover and rib-grass with it.The result was as decisive as can be imagined; the freld has been fully and incessantly stocked with sheep, and was 
constantly pared as close to the ground, as a favourite spot in a pasture is by horses.

Mr. BEvan has found burnet to be the most wholesome fool for sheep, in a wet spring, and a certain remedy for the flux.

I 802 . He continues of the same opinion, and is never without 20 acres of it.

\section{COCKSFOOT.}

Sir Mordaunt Martin, in 1788 , observing, by an experiment, that this grass grew four inches in less than three days, determined to attend more particularly to it: he remarked, that when sheep were let out of a fold, they ran over every thing, to get at a baulk that was full of it, and there ate it in preference to other grasses. In some parts of Norfolk it is called cow's grass, from their being very fond of it. He began to cultivate it in 1794. It grows at Midsummer, in a drought, when every thing else is burnt up. He sows it with nonsuch, instead of ray-grass, and finds it much more profitable.

Mr. Overman, observing the eagerness with which sheep, when let into a field at Burnham-inarket that had some cocksfoot grass in it, ran over ray-grass, and every thing else, to get a bite of this plant, thought it worth cultivating, and sowed about an acre, on the dry gravelly part of his farm, just above the marsh. This spot was the only one, in a large field, that did not burn in the severe drought of 1800 , and conviniced him of the excellence of the grass.

This genleman, shewing me a beautiful crop of drilled wheat, which could scarcely be estimated at less than four quarters and a half per acre, pointed out a part of the field, superior, if any thing, to the rest; and said it was an experiment on the cocksfoot grass: he had found it an excellcnt plant for sheep, but having examined the roots, perceived them to be so strong, that he had some suspicion they might 
might exhaust the land, and therefore sowed this piece for a trial: the result has satisfied him that all apprehension of the kind was ill founded, and he intends substituting it for ray-grass.

Observation.-I have cultivated this grass on a large scale for many ycars, and liave found it of great use. It is a most valuable plant when kept close fed.

\section{CHICORY.}

Through all the southern district of West Norfolk, in which are great tracts of poor sand, the layers quite contemptible, I was petrified to see spontaneous plants of luxuriant chicory, pointing out what nature is ready to perform, were she assisted by adapting the plants to the soil. Here are thousands of acres which would, without other expense than that of a few shillings per acre in seed, be doubled and trebled in value; and were such layer fed by sheep, without folding from it, the succeeding crops of corn would be as supcrior to the present products, as the number of sheep kept would exceed the present stock. If such lands are so open, that folding is really necessary, let it be where the flock is fed on the layer, and this would open the farmers' eyes to the vast importance of changing their grasses. The common mellilot is another plant luxuriantly indigenous on the same poor soils; yields sced plentifully, is much affected by sheep, and would work great improvements, though not equal to chicory: but nobody makes the trial of either, though I have incessantly, for twelve years, been urging the farming world, in the Annals of Agriculture, to open their eyes to the value of these and other native plants, far exceeding that exhausting one of ray-grass.

Crossed a large field of turnips, of Mr. Twist, at Bretenhain; a miserably poor crop, with spontaneous plants of chicory, seeded, three feet high, and, had it been cut at the proper ages, would have out-weighed any of 
the turnips it grew amongst, though; I suppose, hoed off when the turnips were set out.

Mr. BEVAN sowed an acre of poor sand, worth not more than 2 s. 6 d. rent, with chicory, in 1793 , and the next year it produced $\eta$ l. ros. in seed.

In company with the Member for the County, at Sivafham, on the Igth of June, we could get nothing but salt butter. I hope the farmers there have found out that chicory is not worthy of attention.

Observation.-I have taken several opportunities of recommending this grass in Norfolk. On large tracts of poor land in that county, I am confident it would increase the produce ten-fold, and it well merits trial on every soil in it. The objection, which has been founded on its not being easily extirpated, is of no importance, for tares should be sown after it on some soils, and turnips on others, in which systen its destruction is unquiestioned.

SECT. VII.-WHEAT.

THus is in general the crop for which seeds of various sorts are the preparation. The notes may be thus arranged:

x. Course ;

2. Tillage;

3. Sort of Wheat;

4. Time of sowing;

5. Quantity of seed;

6. Steeping;

7. Dibbling;

8. Drilling;

9. Depth;

10. Sown with turnips;

I1. Feeding;

12. Hociag
3. Tathing, or feeding turnips on wheat ;

14. Mildew;

I5. Smut;

16. Roots of wheat;

17. Reaping;

18. Stubbles;

19. Produce;

20. Profit, compared with that of oats;

2I. Price. 
Course:- The Rev. Mr. Hos re, on the strong soils of Goodwick, which require hollow-draining, pluughs up his second years' clover lay after the first crop, a clean earth; harrows well, then cross-ploughs clean, and harowing again, gives a third earth, and tresh harrowing tor drilling the seed; throwing the surface into stitches or lands, just of the proper breadth for one movement of the drill plough, the horse treading only in the furrows. "Two clean earths and much harrowing, therefore, are incurred for the sake of drilling: and Mr. Hoste is clear, that on his stiff land it cannot be drilled well on a single earth, as in the Holkham district.

Mr. Overman, of Bumham, shewed me a field of very fine wheat, perfectly clean, drilled on a six years layer; he remarked, that it was laid down positively free from spear-grass, and when that is the case, you will find it clean after six years, as well as after cwo.

Mr. Francis, of Martham, when he keeps a layer two vears, puts in wheat equally on one carth: he has set it in the same manner on a three years layer, the clop very fine, and got great oats after it.

Tillage.-One of the most semarkable circumstances of the Norfolk husbandry, and the most difficult to account for, is the system, very common, of ploughing a lay intencied for wheat, three or four times, beginning in June or July. In Suffolk, and in other well cultivated counties where the soil is good, no preparation for wheat is better than clover ploughed once at sowing time. In this country, on our goods lands, we never think of giving incre tillage, and get as fine crops as can be seen: now, the necessity of tearing a loose soil in pieces, the fault of which is too great looseness, while no such necessity exists on much stiffer soils, appears to be quite a paradox. I macle particular inquiries of $\mathrm{Mr}$. COKE on this point, and found 
that he hid tried it experimentally several times, on clover and ray-grass lays two and three years old, and that the superiority was regular and great in favour of the tillage I have described. Such being the case, all we can do is to reason ûpon it, and reconcile it to principles; for agriculture can never become a scicnce while irreconcileable fasts exist.

There appear to be three ways of accounting for it:first, by supposing the land, from laying so long, abounds with the red or wyer worm, and that the ploughing and harrowing given to prepare the land, destroy or check them so much as to lessen greatly their depredations: the second, that the ray-grass, if ploughed but once in this loose soil, where tillage is given very shallow, is not destroyed by one ploughing, but rather encouraged to vegetate stronger, as if horse-hoed; and by its growth checks the progress of the wheat: lastly, we may conjecture, that, on these light soils which have been surfeited with ciover, the plant of that grass is thin and weak, and nearly voorn out in two or three years: the consequence of which is, the ray-grass and weeds only remaining, which every one knows afford litte manure in their roots to the wheat, which red clover does very amply. In this case, more good may result from destroying them by tillage, than can arise from turning them under at one ploughing. But, in richer soils, when ummixed with ray-grass, it is exceedingly great, and proves a most ample manuring. The effect we are considering, may be partly owing to all these reasons. With such consileration, is the luusbandry good? I shall not hesitate in declating against it : any circumstance that drives a man to give such summer tillage, in order to loosen a soil, the principal faule of which is too great friability; and the characteristic of its improvement, giving it tenacity hy clay, and the treoding and kncading Norros:-..] 
of bullocks and sheep, in the winter feeting of turnips; any such system is repugnant to that just theory which is the child, and ought to he the parent, of prackice: it results from, and ought to regulate it. To sec wheat thriving admirably on stiff soils with one ploughing, and to be rold that four are necessary on light ones, is a contradiction to common sense. And yet the fact certainly is so, while an old ray-grass layer is alone in question. How avoid the evil? By diblling pease upon the lay on one ploughing, and taking the wheat after the pease. I have little doubr of this avoiding the mischief. Another mode is, to follow Mr. Coke's husbandry of grasses, to the exclusion of ray, in which method, I an of opinion (barsing the red worm), that one earth would give better wheat than more. And his own course of crops, alrealy inserted, proves that this method will do. For, however useful, and even necessary in some cases, ray-grass may be, never let it be forgotten, that it is comparatively an exhausting plant, and not the best preparation for com.Either of these modes is consistent with the nature and character of the soil, the great feature of which, is the want of tenaci:y; but the practice now pursued, coincides with noother idea but the want of friability. - Note, in 1784.

Nothing is morc injurious, in Mr. Thurtell's opinion, than to give any previous tillage, commonly called a bastard fallow, to a layer for wheat: this husbandry, once so common, he says, is quite done with.

It is, however, almost universal in the northern part of Happing hundred, to Nortls Walsham, and also abous Aylesham.

Mr. Cusit, of Honing, set wheat on the flag for many years, but found it better to rise baulk or riffle, and the crops cleaner. He sets about half his crop.

Mr. Margateson, of North Walsham, breaks up 
the ollonds of the second year, by rifining before harvest; he harrows down, and ploughs as fleet as he can; after that, a full pitch for dibbling; he is clear that this is the best way for the wheat, but as certainly a loss in the barley crop; for the previous tillage has brought the flag into such a statc, that the wheat exhausts far more of the benefit than when set on a whole furrow.

In gencral, they riffe the second year's lay before harvest at Westwick, \&c. for dibbling; but some on one furrow; and many this year; the dry weather having prevented some breaking the lays.

Mr. Dyble, of Scetter, has made the comparison of riffing a layer for dibbling wheat, and leaving a part unbroken for dibbling on whole furrow, and found the former best by a coomb or six bushels an acre; and the barley fullowing, is as good, if the flar was not too much broken for the wheat; this, however, partly admits the evil.

Mir. Palgrave, at Coltislual, grets the best whent by dibbling his lajers on one earth; if it could be duilled, would be equal, if not superior, but it will not drill well; he has trench-ploughed for it with two ploughs, but the soil was thin, and it did not do wcll. It is remarkable, however, that among his tools I espied a skim.coulter plough of Ducket's, iaid by and never used: it is on the large construction, for four horses; but the hint of the skim surely invaluable. More wheat is put in on wholc furro:v, than on broken layes; all of which are of two jears.

Mr. Reptox, at Oxnead, riffies his ollonds before harvest, then, howcver, crosses and harrows, and works well, as it shoull be loose for dabuing.

Mr. BrRCHAn, at Retpham, sometimes rifles layers for wheat, but only on the stionger lands: on light 
lands, dibbles in on whole furrow: sometimes he dibbles on riffled land; but intends, in future, to put all such in by the drill.

Mr. Jounson, of Thurning, puts in lis wheat generally by dibbling on a whole furrow ; tempering was the practice, but it is left off by the best farmers.

Mr. ENGLAND, of Binham, drills all his wheat on thie flag, and prefers it to tempering; and this not only liere on a soil comparatively light, but also at Hindringham, where it is more stiff. Fie ploughs his ollonds direely. after harvest, to give time for the weather to pulverize the surface; but if there be not time for this, effeets it by harrowing and rolling, \&xc. Direclly after the plought, he goes with a heavy two or three horse roller to press the flag firm; and weights Coor's machine, which so does well in cuery case he wants it for: Mir. ENGLARD is cleally against the pradice of tempering light lant, which often brings poppies, that would not otherwise appear. Tempering is now done only by oid fashioned farmers, and for the sake of four-furromed work.

Mr. REEve, of Wighton, whose farm is in such order, that much attention should be paid to his practice ard opinions, always drills on whole furrow, if the land be clean: he had this year a rematkable experiment on this point; trying part of a field on one earth, and part of it tempered, and the former was the better crop, by at least two coombs an acre: and whencver he has made the comparison, he has alwaýs found the result the same. There is no difficulty, he cbserves, in drilling on whole furrow; immediately after ploughing, he rolls down the flag with a heavy roller; then leaves it two or three weeks, the longer the better, as a stale furrow much cxcceds a fiesh one; then harrows wice lengthways and wice across, after which it is in due orde: for the machire. 
M.-. M. HiLl's system jist the same as Mir. REEvE's ; he adinits all the preceding pradicc.

Mr. Henry BLsthe, of Burnhan, drills all on the Alag, or one furrow, before Michaelmas, but never after; then on tempered land. He finds no diffoulty in drilling on whole furrow; he rolls after the plough, and harrows, then drills, and covers with the harrow.

Mr. DuRsgate, of Summerficld, whose great success in hushandry gives much weight to the opinions he draws from his experience, is not partial to putting in wheat upon ollond, except it be done very early ; before Michaelmas it docs well, but should never be ventured after; all then sown or drilled, should be on tempered land.

Mr. StyLeman, of Snettisham, who puts in his wheat on pea stubbles, ploughs the layer in February; rolls the end of that month, or the beginning of March; and harrowing to a tilth, dyils the pease; hand-hocs them; ploughs the stubble once, betwcen three and four inches decp, scarifies, harrows, and drills wheat.

Mr. Goddison, at Houghton, tempers about half his lavers, and kceps the rest for sheep food.

At Hillingdon the layers are sown for two years, but if they fail, they are broken up for wheat at ous year; sometimes for pease.

Mr. DENNis, at Wigenhall, in the clays of Marshland, sows his wheat on ten-furrow ridges, thinking six-furrow work a loss of land.

Sort.-There is a notion ahout Ridilesworth, that red wheat will not do on black sand; white succecding much better; on this account I found the distinction made on Mr. Bevan's farm.

Mr. Salter, of Winborough, sows red whicat only; white sorts do not succeed so well on the heavier soils. It goes by the name of the old red. 
Mr. M. Hits prefers the red chaff, red wheat, to the white; less likely to grow in harvest; but white better sample and price.

Time of sorsing.-Mr. RoBrnson, of Watton, an intelligent attentive farmer, of 30 years experience, is clear that on their soils, which are not light, the sooner the wheat is sown, the better the crop.

Mr. Mason, of Necton, is a great friend to carly sowing: he has put wheat in even in harvest time; old secd, kept in the siraw and threshed just before sowing; and his success has proved the efficacy of early sowing. He has had it green in August, and not the worsc; but in general, he reckons September the prime season: he sows old wheat to chuse, and does not steep, nor has he been troubled with the smut.

At East Bilney, and the adjoining parishes, they think they never sow wheat on havy land too soon: but on light soils, and all given to red wecd, a month after Miclaclmas; nor is such land able to carry through forward crops.

Mr. Salter, of Winborough, begins dibbling immediatcly after harrest, using old wheat.

Mr. Whiting, of Fring, is a great friend to early sowing of wheat. In 1799 , he drilled on the 27 th of August, and this harvest got the crop up before any rain fell; while nine-tenths of the wheat through the whole neighbourhood, is growing in the shocks, or in the ear, as it stands. He would wish always to have his seed in the ground within the month of September. The crop abovementioned was one of the very best he has ever had.

Mr. OverMan wishes to have all his wheat in on lays by Old Michaelmas.

Mr. M. HiLl prefers from the ist to the 2oth of Osto. bei, and never wishes to be later on the flag; but on the tempered land, no objection to a fortnight later. 
In $1782, M r$. Coke made an experiment, to ascertain whether the time of sowing wheat in Norfolk (November and to Cirristmas) was not too late, by sowing a large fiela the last weck in September, which was a month earlier than any near it. The wheat flourished away very fincly through the winter; but the farmers predicted that it would not prove well in the spring. The fad turned our so, for when much poorer winter-looking crops began to rally, and spread upon the land in April, this went off, and gave at harvest a very light produce.

In general, the farners in East Norfolk begin the mid. dle of Oetober, and continue till December; sometimes to Christmas: but for dibbling, at Michaelmas.

Mr. Burton, of Langley, begins wheat-dibbling a week before Michaelmas, and continues till three weeks after: early sown gencrally the bcst, and it saves half a bushel of seed.

Mr. Margateson, of North Walsham, reckons the best time to begin is at Michacimas; and to finish in two or three wceks; some are earlier, but they are apt to suffer.

Mr. ENGLAND, of Binham, as carly as he can in October.

Mr. Dursgate, of Summerfield, puts in no wheat on ollond after Michaelmas: all frem that time on temperce land: seasons may prevent it, but he would wish to have all his ollond wheat in by that time. But on turnip land, it may be put in to Christmas.

Mr. Martin, of Tottenhill, drilled wheat in Februnry, and the crop good.

Quantity of secd.-About Watton, dibbled six or seven pecks. Mr. Robinson, if he sows before Michaclmas, two bushicls; afterwards, two and a half.

Mr. SALTER, at Winborough, near Dercham, four T 4 bushcis 
bushels broak'-cast, dibbles ten pecks to thrce bushels. At Wissen, ten pecks dibbled, three bushels broad-cast.

At East Bilney, and the adjoining parishes, two and a half to three.

Mr. Havers, \&c. at Thclon, dibbles six or seven pecks, early ; but eight later.

Mr. Burton, of Langley, seven.

Mr. Thurtell, near Yarnouth, seven to eight, dibbled.

At Caistor, in Fleg, six or seven pecks, dibbled.

Mr. FERRIER, at Hemsby, six pecks.

Mr. Brown, at 'Thrigby, begins with six pecks, and finishes with eiglit, dibbled.

Mr. SYbLe dibbled two bushels early, but more late.

Mr. Francis, at Mastham, dibbles two bushels: the quantity sown is ten to twelve pecks.

Mir. Cubit, at Catfield, \&zc. dibbles from six pecks to two bushels, according to time, early or late.

Mr. Margateson, of North Walsham, two rows on a flag, and three or four kernels in a hole, which is about two bushels an acre. He was once vely attentive to the droppers-they put in six pecks, and he never had a betrer crop: but it is good to allow for carelessness. He sows very near three bushels.

Mr. Dybe, of Scotter, two to two bushels and a quarter, whether dibbled or under furrow.

Mr. Resves, of Heveringland, drills, at six inches, seven to eight pecks.

Mr. BIRCHAM, at Hackford, on summer-land, one bushei and a half; in dibbling, five pecks.

Mr. Johnson, of Thurning, dibbles three bushels. Many here have lost by too thin a plant, half the wheats being under-seeded.

Mr. ENGLAND, of Binham, seven pecks, early; eiglıt 
late. In a favourable year, has had a great crop from six.

Mr. REEvE, of Wighton, on whole furrow, two bushels; on tempered, seven pecks.

Mr. M. Hill, at first eleven pecks; later, a peck more.

Mr. Henry Blythe, of Bumbam, drills seven to eight pecks an acre; the common quantity, broad-cast, ten to twelve.

Mr. DuRsgate begins with six or seven pecks, and never more than eight.

Mr. Styleman, of Snetisham, six pecks, drilled.

Mr. GODDIson dibbles and sows two bushels to ten pecks.

Captain BEACHER, at Hillingdon, nine or ten pecks, drilled at nine inches.

Mr. BECk, of Castle Riseing, drills from six to eight pecks.

Mr. DennIs, of Wigenhall, in the clays of Marsliand, five to six pecks, broad-cast.

At Watlington, two bushels.

About Wymondham, dibble in six to eight pecks; broad-cast, three bushels.

Mr. Overman, seven pecks, drilled.

Steeping.-Mr. Roвinson, of Watton, for many years has had no other smut on his farm than what has been caused by accidentally sowing a head-land, or finishing a corner of a field with dry seed; but if siceped, the prevention infallible. His method is, to steep it in a brine made with common salt, of strength to hear an egg, for twelve hours, and then to dry with lime.

Mr. Dover, of Hockham, had great plenty of plseasants, but lost them all, without knowing to what cause to altribute their disappearance: he found out, howcver, 
that it was entirely occasioned by his using arsenic in stceping his wheat-seed. Mr. Algur confirmed it, by observing, that he once found a covey of partridges dcad or dying, from tise same cause.

Mr. SAlter, of Winborough, dresses with salt and lime, without steeping, and never has the smut: it is only to be concluded that he has always sowrs clean seed.

Mr. M. Hill slakes the lime with salt, clissolved in a small quantity of water; dips the wheat in a skep, in plain water only, lavs it on the floor, and incorporates it with the salt and lime: dries with lime. Inquiring of lim whecher he had ever tried this method with very black wheat, as I conceived in such a case it would fail, he said that he had not.

Mr. OverMan stirs his seed well in pump water, then lays it in a heap to drain, and adds half a pound of salt to cvery bushel, stirs it well together, and dries with lime: this he finds sufficient against the smut. Whence I conclude that his seed is always free from that distemper, or assuredly he would find the process to fail, for he does not leave it any time limed.

"The salt is dissolved in a very sinall quantity of water; with this salt the linse is slaked, and with this saline preparation, in its hottest state, the wheat is candied, having previously been moistened for the purpose with pure water." This was the practice in East Norfolk, reported by Mr. MARSHALl. It is not very gencral at present, but pursued by many.

Dibbling. - Mr. DENTon, of Brandon, sets all his wheat, and nearly all his oats, and his neighbours very generally do the same-one row on an eight-inch flag. I observed, however, that many of their rows were nine inches, from the men, I suppose, carrying a wider furrow than directed. He prefers this practice to drilling, which 
has been tried, and is yet done by some. In his. farm in Burnt-fen, he sets every thing. The drill roller has beets "ried there, but it would nor do: the horses drawing by too great a puschase, tread in too much, and the roller drives the furrows.

At Oxborough, and its vicinity, great tracts are dibbled with wheat, oats, pease, \&c. and found to answer much better than drilling, which has been tried. They put in but one row on a fiag of whear, six pecks an acre, and hoe well : the result very beneficial.

Mr. SAFFory, of Downham, diblling a field adjoin. ing to one of Mr. CREAsY's, which was drilling at nine inches, borrowed the drill for two lands, for comparison. Those lands and Mr. CREAsY's field were mildewed, bu: the dibbled crop escaped.

About Old Buckenham, muchs wheat set, and generally one row on a flag, which they plough as narrow as they can, and put in six pecks of seed: this practice they find better than two rows. There is drilling, but Mr. ALGUR, \&c. prefer secting greatly. Many oats also dibbled.

"Dibbling peuse, practised time immemorial near Attleborough; but that of wheat, introduced by a labourer, James Stone, of Deepham, about the year 1760 , did not become very common till about the year r $770 . "-$ Marshall.

Twelve years ago, and how much sooner I an not well acquainted, they had, both in East and West Norfolk, discovered that this practice was not to be pursued under the notion (very common soon after its introluction), of saving seed: the usual quantity was risen to two bushels and a quarter and two bushels and :a lsalf per acret, and this both between Norwich and Y'.trmouth, and also around Houghton. Mr. LAYTON romaked, that suting 
las failed in many instances, in proportion to the saving of seed.

Mr. ROBINSON dibbles all his wheat on liyers, and is clear that he gains a coomb an acre more than he did broad-cast, with his land at the same time cleaner.

Sir Thonas BeEror, with almost all the vicinity, diubles every thing : drilling is known, and some few practise it; but the other method answers much better.

Mr. Fezzowes, of Shottesham, dibbles all, but ncither wheat nor oats late: only while the season suits: for wheat late in the season, when the land is wet and cold, he thinks the water lodges in the holes and perishes the grain. There are drills; but not one acre so put in in twenty.

Mr. SAlter, of Winborough, dibbles all his wheat on layers, or on whatever land is proper for the practice, and what deserves paricular attention, all is done by women, with only one confidential man for superintending them: he gives ros. 6ci. an acre for two rows on a flag. He thinks that women dibbic better than men, from being more obedient and manageable. This practice descrves universal initation: his women also reap whear.

At East Bilney, Brisley, Gressenhall, Stanfield, Beteley and Mileham, much wheat is dilibled; also some oats and barley.

Most of the wheat about Hingham is dibbled, as wcll as both pease and oats. They pay 9s. and even Ios. an acre for it. Generally two rows on a fag, but on land much subject to poppy only one, for the benefit of handhoeing.

Mr. BURTon thinks, that on reduced land the best of all is to dibble one row and put in the same quantity of seed: it beats the drill: he drill rolls at five inches; no red weed; only nine-inch furrows, and good room for a hoe. 
Not so much dibbling as before. A new drill is in use; four inches for barley; it has cups and pipcs, but not Cook's; price 30 guineas.

At Thelton and the vicinity, some farmers so much ap. prove this method of putting in wheat, as to practice it even on summer fallows; they pass a heavy roller over the land, which prevents the moulds filling the holes of the dibbles.

In Ioddon hundred there is much wheat dibbled, one row on a flag.

Mr. Thurtell dibbles, as general in his neighbourhood, two rows on a fiag; if hand-hoeing be necessary, one row; but in that case some few drill at nine inclies. Mr. ThuRtels would prefer dibbling one row. Ife has tried putting the seed in by spike rolling; but he thought it made the whent root fallen, which he attribured to the seed being too shallow. Nothing in his experience so good as dibbling; but drilling does well.

At Caistor, \&x. in Fleg, three-fourths of the wheats are dibbled two rows on a flag. One bushel of seed would do, in Mr. Everit's opinion, but as it depends on the droppers, they put in from six to seven pecks. He made a comparative experiment in dibbling: the common way 1s, so to spread the two rows on a flag, that they are apt to be too near the seams. He made the dibblers keep their hands as close logether as they could work them, sctting the two rows very near cach other in the centre of tho fiag. The resule proved the excellence of the practice, for the crop was beautiful.

Mr. FERRIER, of Hemsby, two rows on a lag, and as close as he cars get it donc.

Mr. BRown, of Thrighy, thinks that there are five times as many aures of wheat and pease dibbled in Fleg as ats sown broad-cast. He remarked, that their landis, 
though they contain so much sand, will not do well if wheat is put in in the wet; pretty dry weather does much hetter.

Mr. Syble, of South Walsham, this year (1802) dibbled 60 acres; Mr. HeATH, of Hemlington, the whole of his crop on a farm of 500 acres. Mr. Francis, at Martham, all for some years past.

There is a great deal dibbled all through Tunsted and Happing hunlreds; and also through all North and South Erpingham : it rather declines about North Walsham, for want of good droppers.

Mr. PETRE dibbles about one-fifth of his crop, amounting to 100 acres; sume drilied, and the rest sown; the best ears from the dibibled, but the drilled good.

Ahour Norwich they have dibbled one row on a flag; but not putting in the same quantity of seed. They generally prefer two rows, and nine pecks an acre: $\mathrm{Mr}$. Crow never saw a good crop of wheat in his life that was thin: this remark has thorough good sense in it, and he further notices, that if there is any mildew stirring, it is sure to atrack such a crop severely.

Drilling has been tried about Blowfield, Acle, \&c. but dibbling preferred by many as superior. I hey put in two rows on a flag, and find it the best practice of all.

Mr. DyBLE, of Scotter, dibbles much of his wheat, and has compared it with broad-cast in the same field, which it exceeded sufficiently to give him full satisfaction.

Dibbling common about Aylesham, but does not increase.

It increases about Reepliam.

The cleanest crops at Haydon are those which are dibbled on a whole furrow. Ten shillings to ten shillings and sixpence an acre. 
Mr. Johnson, of Thurning, thinks dibbling so excellent a practice, that equal crops are not to be gained in any other way; but three grains should always be put in every hole; for on various examinations he has found, that a single kernel in a hole has almost always produced a faint ear, scarcely ever a good one.

Mr. Risuron dibbled his wheat when put in on a whole furrow, but would not have done it, only his men not skilful enough with the drill for that work.

Much dibbled and well done at Holm.

Mr. Goddison, at Houghton, dibbles from 20 to 30 acres every year. But of all ways which he has tried of putting in wheat upon tempered land, he is inclined to prefer that of spreading the muck, then sowing broad-cast, and ploughing both in together into six-furrow ridges. He drills none.

Very little dibbling at Castle Riseing: Mr. BEck was in the practice, but left it of for drilling.

Dibbling well known all over Marshland.

Mr. Porter, at Watlington, dibbles much, and thus gets his best crops, rather better than by the drill: but as he loes not drill ridge work, his best land may be dibbled.

Dibbling very general about Wymondham, at 9s. to Ios. 6d. an acre.

Mr. PrIEst, of Besthorpe, dibbles his lavers, if they do not plough well for the drill. He this year compared one row on a flag with two, and the former had the best ears, and was the stouter crop. He scarified the single rows, but being clean did not liand-hoe.

The greatest part of Mr. Twis T's farm at Bretenham as rye land; but he has some wheat land; he had 40 acres dibbled in autumn iSOI; and he dibbles much rye. He has 50 acres of drilled wheat this year, and the best crop he bad. 
Leaving Holt in the way to Holkham, came to foürfurrowed work wheat stubbles.

Drilling.-More than thirty years ago Mr. Fellowes, at Shottesham, drilled wheat at eighteen incles, the rows equi-distant, which produced equally with the common crops of the country.

Mr. Dalton, of Swafham, has drilled hargely at Bilney; but his success for the two last years has been so bat? that he leaves it off, convinced that the broad-cast answers better. If he drills carly, the poppy gets greatly a-licad; if late, the frosts turn the drilled wheat out of the ground; by ploughing the seed in he avoids the latter evil.

Mr. Repton, at Oxnead, dibbles his wheat, as he cannot drill it on one furrow.

Mr. ReEves, of Heveringland, drills at six inches.

Many drill about Reeplam; the practice answers best on ligist land; and Mr. BIRcham is of opision that the layers should be broke previously for it.

Mr. JoHnson, of Thurning, drilled forty acres of wheat, two years ago, on a whole fallow: the crop very good.

Mr. ENGiAND, of Binham, drills all at ane inches.

Mr. ReEve, at Wighton, at nine inches: he thinks dibbling a great improvement on the broad cast husbandry, but that drilling exceeds it; and he never sarv greater burthens of wheat than what has been produced by drills at nine inches. He had this year four good waggon loads an acre, from land so managed. I viewed his stubbles, and found them beautiful spectacles of masterly manageinent; I rote cross and cross a field of nine acres, and do not think nine weeds were to be found in them: and all bis wheat stubbles, on examining the intervals, I found in a perfecliy friable and puicerized state.

Mr。 
Mr. M. Hris drills all his wheat with Cook's machine, at nine inches; scarifies twice in March or April; no hand-hoeing, but all weeded. Quantity of seed three bushels, but the first put in before Michaelmas less.

Mr. Coke, at Holkham, drills all his wheat at nine inches: hand hoes twice, and uses Cook's fixed harrow once.

Mr: Henry Buythe, of Burnham Westgate, drills all his wheat. Hearing much against the practice, he made an experiment for his own convietion, by sowing five acres broad-cast on four or six-furrow ridges, in an 80 acred field, drilled with Cook's machine, and at harvest he reaped one acre of the broad-cast, and threshed the produce immediately, which was seven coombs three bushels; it was a good wheat year, and on his best land: he then took half a land adjoiningg of the drilled, which measured three roods and 34 perches, and threshing it also immediately, the produce per acre was eight coombs three bushels, three pecks and a half, or per acre five bushels more than the broad-cast; besides which, the saving of seed was about three pecks. This convinced him that the drill method was the best, contrary to a prevailing opinion at that time.

Mr. Dursgate drills all; some at nine inches, and some at six 3 -fourths; hoeing twice at 4 s. and weeding. I viewed his stubbles, and found them very clean.

Mr. Risuton, at Thornham, drilled all at nine inches, and was well convinced of the superiority to broad-cast.

Mr. Styleman, at Snettisham, drills ail at nine or twelve inches; hand-liocing once or twice, as wanted.

Mr. Goddison, at Houghton, puts in some wheat with a drill harrow, which marking channels, the seed is sown broad.cast. I did not see the tool. 
Mr. EEACHER, of Hillingdon, drills at nine inches, and hand-hoes.

Mr. Beck, of Castle Riseing, drills at nine inches, and hand-hoes twice, at Is. gd. or 2 s. each time.

Mr. Porter, of Watlington, drills his wheat on layers, if on the flat, but not on ridges: he has 100 acres of wheat, and half of it drilled: dibbles much, a practice he luas a very high opinion of, but thinks lie gets nearly as much by the drill.

Mr. PrIEsT, of Besthorpe, dills on strongish land at nine inches, and intends trying at twelve this year; but if the furrows on hayers do not whelm well, but stand on edge, he then dibbles, as the drill does not work well. Fe scarifies in March, and if necessary hand-hoes, if nor, horse-hces twice, if he has the opportunity. Success much depends on the ridges being well formed for a bout of the machine, and they ought to be rolled and harrowed, and bef́t some time for tine air to pulverize, before drilling.

"Scarning-Sihool Farm, Aug. 10, 1802, " DEAR Sir,

"In compliance with your desire and iny promise, I will endesvour to describe, as accurately as I can, the inethod I uscd in drilling the field of wheat which you saw, when you did me the honour of calling upon me at Scarning.

"The field consists of about twelve acres, and is a mised soil: last year it grew clover and ray-grass after borley, and as soon as the first crop of clover was reaped, and the second crop fed off with sheep and cows, I broke it up in order to temper it for wheat. It was ploughed twice and scufted twice, which, with wany harrowings, brought 
brought it, by the beginning of Octcher, into a high state of pulverization: in this state I began my operation by rolling such a quantity as might be sufficient for two days work. The surface then heing as flat as po-sibie, I set out the work thus: in the mildle of the field (which was fixed upon because no side of it was straight) I e€t up two sticks, in order to draw a line as straight as possible to direet the drill. My drill is a small barrow with two hoppers or boxes, one on each side the wheel, and is pushed forwards by a man. In the line thus formed by the sticks the barrow was lirected, depositing the seed from the hopper on the right side of the wheel upon the flat work. Immediately after the barrow, at the distance of ahout ten yards, followed a plough to cover up this line of seed, by turning the mould of a fieet furrow upon it: when the barrow; followed by the plough, had reached the end, the man with the barrow tuined towards the left hand, and at the distance of one yard from the line of seed already deposited, dropped from the barrow another line of seed paraliel to the former: now a second plough followed him as hefore, whilst the first plough, which had covered the first line of seed, was backing its own furrow. The barrow-man, arrived at the end of the second line of sect, turned to the left as he had done before, and dropped a third line of seed one yard from the first and parallel to it, and was followed by tise first plongh, whilst the second was backing its own furrow. In this manner I worked, my barrow depositing lines of seed, at one yard distance from each other, and my two ploughs alcenately covering the lines of seed, and backing each its own furrow, till 1 had completed my unorning's worh, at the end of wnich yuu will observe, that excepte the work of the barrow, 1 had merely set out the tops of the forr-furrow work of aucrut two acres of land, and there remaned the batks to be 
split. 'This was the operation of the afternoon: for whilst my double barrow was directed upon a balk, depositing seed in the furrows from the two boxes on cach side of the wheel, a double breasted plough, drawn by two horses, split the balk, covered the wheat so deposited, and completely made up the four-furrow work which had been set out in the moming. The next day I repeated the work precisely the same as the day before, by setting out fresh work from a line formed by two sticks, as at first set up across the field, in a direction parallel to the first line dratvn, and at such a number of yards from the last line of seed dropped, as I thought would afford work for the day. Thus was the whole of the twelve acres laid into four-furrow work, with three rows of wheat upon every stitch, at the distance of nine inches between the rows, and eighteen incles for the furrows, with no more than five pecks of seed-corn'per acre, and performed by three men, two ploughs, and four horses, in a morning, and two men, one plough, and two horses in an afternoon; and the whole two acres were finished in a day. I rolled it afterwards to please the eye, level the work, reduce the depth to which the seed was deposited, and afford mould in the furrows to support the wheat on the sides of them. As soon as the wheat came up I cleaned the furrows by a plough with expanding wings, drawn by one horse. In the spring I contrived to fix upon this plough two scarifiers, and taking off the expanding wings, I used it to hoe the furrows, and at the same time scarify two rows of wheat, one on each side of the furrow: afterwards I put on the expanding wings, and substituting hoes for scarifiers, I by one operation of this plough hoed the furrows and two rows of wheat, and at the same time moulded. them up: this operation was performed twice.

"Thus, Sir, have I given you as clear an account as 
I am able, of the manner in which I drilled (if I may be allowed the expression) the wheat you saw.

$$
\begin{aligned}
& \text { "I am, Sir, } \\
& \text { "Your obedient Servant, } \\
& \text { "sT. JOHN PRIEST," }
\end{aligned}
$$

From the preceding notes, it appears that drilling wheat has made a remarkable progress in Norfolk. In the north western districk, amongst the great and intelligent farmers who have rendered their county famous, it is become so cstablished a practice, that it no longer adinits any question of its utility, on a soil like theirs. In some smaller cases, dibbling is prefersed; nor has it been sufficiently ascertained which of these methods will give the grenter crop. The inquiry, however, is not of consequence in North-west Norfolk, for they have no population equal to dibbling becoming general: and a circumstance which tends much to inpede this lusbandry, is the imperfeet manner in which it is performed, for the sake of making great earnings; this has, in many instances, given a preference to drilling.

Depth.-Mr. 'THurtell, near Yarmouth, has found two inches, which are commonly half way through the nag, to be the best depth in dibbling.

Mr. Everit, of Caistor, in Fleg, thinks that the deeper it is dibbled the better; two inches, to chuse.

Mr. Syble, of South Walsham, finds two inches, in dibbling, the best depth.

Mr. MARgateson, of North Walsham, prefers one inch; and three or four kernels in a hole.

Mr. DYRLE, of Scotter, remarked, that there is never any fear of the seed being dibbled too decp, even if through the flag: they plough only three or four inches.

Mr, Jalgrave, at Coltishal, dibbles two inches. 
Mr. Reptow, at Oxnead, dibbles one inch.

Mr. Bircham, at Hackford, two inches and a half.

Mr. Johnson, of Thurning, two inches; rathermore than half through the flag is best.

Mr. England, of Binham, two inches and a half, on a flag.

Mr. Rishton, at Thornham, one inch and a half.

Mr. STYLEMAN thinks the depth a matter of great importance; he drills two inclies and a half deep, by weighto ing Cook's macline, and using two horses; if only one, he should be of extraordinary strength.

Mr. Porter, at Watlington, two inches.

Mr. PrIEsT, of Bestisorpe, thinks, that if wheat be not buried from one inch and a half to two inches, it is apt to be root-fallen.

Mr. M. HILI one inch and a half; but by no means more.

Mr. OVERMAN drills his wheat one incl and a half deep on sandy soils, rendered light by cultivation; but on layers once ploughed, one inch only.

With turnips-Mr. W ALKER, of Harpley, some years ago, introduced and practised a husbandry in which he was entirely original. I viewed his farm, while these ex. periments were going on, for two successive years. In order to give a greater degree of stiffness to his sandy soil, he thought of putting in wheat without any ploughing at all, immediately before sowing. He began with six acres of turnips, hoeing in the wheat seed at the second hoeing of the turnips: these were eaten on the land by bullocks and sheep. The wheat proved good, and answered expectation. The next year he did the same on 35 acres: this also succeeded; but the best wheat was where the turnips were eaten in the driest weather. The following year he extended the culture to 70 acres, which also succeeded 
succecded to his satisfaction. The year following, he had roo acres. Upon the whole, the culture produced not better than the common crops, but equal. The most adverse circumstance is a wet season for eating the turnips, but at the worst, it can amount to no more than the loss of the seed. The course in which he practised this masagement, was,
1. and 2. Ollond,
4. Turnips,
3. Oats,
5. Whear;

his seeds being sown alone on the wheat stubbie ploughed once; he has tried sowing both in autumn and in spring; both succeeded well, but the autumnal rather the best: upon his farm of 600 acres, the saving in horses has been unquestionably five: the three earths for barley, in a busy time, were entirely saved.

Feding.-Mr. SALTER, of Winhorough, whose crop I found extraordinarily great, this year fed all his wheat -twice; and he says, that if he had not done it, it would all have been laid.

Mr. Coke-Do you feed your wheats? - Never, Never, Never!

Mr. M. Hill-Never!

Hoeing.-Not one farmer in twenty hoes any wheas about Aylesham.

Mr. England, of Binham, scarifies early in April; and hand-hoes twice at 2 s. each time per acre.

Mr. ReEve, of Wighton, hand-hues once or twice, as wanted; at 2s. each time: but if the land be clean, once at 2s. 6d. with the use of the fixed harrow, answers every purpose. His stubbles beautifully clean.

Mr. Henry BLythe, of Burnbam, hoes his drilled

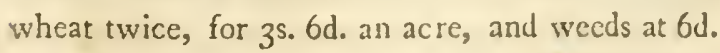

Drilled wheat in all the north-west angle of Norfolk, hand-hoed; but some do it not at Hillingdon. 
On the clays of Marshland, where there are other signs of bad management, they are much pestered with red weed, May weed, clivers, \&x. they are forced to weed much; Mr. Dennis, of Wigenhall, has paid a guinea an acre for it: he hoes all his dibbled wheat.

Tathing.-This is a singular husbandry, which I did not meet with till I entered Fleg, from Yarmouth. It consists in carting turnips on to wheat in February and March; they call it to pull and throw on wheat, eating them on that crop by sheep and bullocks, if sheep are kept; but if not, by bullocks alone. Mr. Everit, of Caistor, assured me, that the wheats thus treated, are the heaviest crops they gain; it makes the straw as stiff as reed. It is not practised as a preventive of the crop being root-fallen-for that is little known here; when finished, the field is harrowed, and if necessary, hoed.

Mr. Ferrier, at Hemsby, and his neighbours, are in the same pradice; and sometimes do it too late; with cows and bullocks.

Mi. Brown, of Thrighy, contines this practice to land that is light, and subject to red ween?; never later than March, and then wishes for some showers directly after: he finis that this practice does not make the wheat too rank, but the contrary, by stiffening the straw. The practice pretty general in Fleg; and some, but not so much, in Blowfield hundred.

Mr. SYBLE does it like his neighbours, here and there, on a piece given to poppy. The same rule at Repps and Marham; but some doubt whether it answers: Mr. Francis has been caught sometimes by drought, and he has seen others. He remarked that the open fields give as good wheat as the enclosures, yet never have turnips thrown on them. He thinks it better to throw turnips on wheat stubble, treading all weli down for barley. 
Mr. Hornard, of Ludham, on his light soil is in this practice: he had two pieces under the same circumstances, one tathed and the other not, and the former was the best crop; on an average of seasons, he thinks it certainly does good. He was the first here that practised it 28 years ago; but had seen it near Norwich: he has continued it ever since; begins in February, and continues through March; he has no sheep, but if he had, would do it with bull :cks also.

On his light land, Mr. CuBit, of Honing, has carted muck on to his wheat in winter, throwing turnips afrer for shecp: he has done it for bullocks, but sheep answer the purpose micli better.

About North Walsham, the practice of throwing turnips on wheat, is known, and that is all: Mr. MARGATESON does not approve of it with bullocks; he has done it, and mischief was rhe result; but with sheep only, it is good husbandry wih those who keep a sufficient number.

Mr. Petre, of Westwick, keens i 7 score sheep, and is in this husbantry: his bailiff, Crowe, informed me, that he practives it on ligin land with much success.

Mr. Dyble, of Scotter, has known it done now and then, but it is no general practice hore; nor does he approve of it.

Mr. Repton, at Oxnead, has tried it, hut the crop was damaged by the jamming, and he left it off.

Mr. Johnson of Thurning, never does it; but once saw it at Edgfield, and it was thought to answer.

Mildecu.-Mr. FrANCıs, of Marthan, remarked, that if wheat there be thin or backward, it is very liable to the mildew.

Mr. Margateson, of North Walsham, could never observe that thinness was the cause of mildew; but that 
the berberry bush will occasion it, he has ascertained by abservations that could not deceive him.

'The lisht soils of Saxethorpe, are very subjest to the mildew, and about Reepham, fine barley land the same. Mr. PARMENTER, of Aylesham, a considerable miller, has, howevcr, had some of his finest wheats from Saxethorpe.

The Rev. Dr. BAKER, at Causton, observes, that the wheat in that parish is so subject to the mikiew, that he has found on various occasions, oats to be a more profitable crop; he has known from 16 to 18 coombs of oats, where more than seren of wheat could not be expected, and that, probably, much damaged by this distemper. The soil is very fine barley land.

The mildew is so mischievous at Hillingdon, that some farmers do not sow wheat at all; Captain BEACHER, Steward to Sir M. Folkes, has not sowu any for three years past : as it is not here the custom to cut early, upon account of this distemper, no wonder it should make such havock.

"This distemper has been accurately traced from a point across a field to a berberry bush in a hedge. Several similar instances; and Mr. MARshall produced the distemper by planting a small bush in the middle of a large piece of wheat; all clean, except a stripe where the berberry mildewed the crop."

The parish of Elsing is well known for the wheat that grows in it being very liable to the mildew, arising (as evcry person in it knows) from the number of herberrybushes which abounded in the hedges, till much attention was given to extirpate them; and still, arising from the same cause, on the lands of those who are careless in this business. At Harpley-lam, a hedge of Mr. Jorn BLomFIELD's !ad been cleared, and the wheat consequently safe from this cause; but this year (1SO2), obscrving a 
streak of mildew in his wheat, he examined the hedge, and found a stub, missed by the workmen when they were set to eradicate the plant, which had hirown out only two shoots, not more than two or three feet high, and from that point the streak of mildew took its course. I had this from his own mouth.

Smut. - Very little smut is known in Fleg. Mr. Brown adds salt to sea-water, to make it swim an egg; skims off the cosh (husks) carefully, as they find that harbours smut if there be any; he only wets the wheat by dipping in the basket; dries with lime slaked with sea water.

Many farmers about Houghton are troubled with the smut, but Mr. Stanton, of Darsingham, sows only old wheat, and never having been known to have any smut from such seeding, others are getting into the same practice.

Captain BEACHER, at Hillingdon, always sows old wheat, and never has any smat: no brining or liming, as that injures old seed. He has sown old and new seed in the same field, and had the smut in the latter, but not an ear in the former.

Red Worm-Often makes great havock in the vicinity of Watton and Hingham, as well as the cock-chaffer grub in grass-lands; but they have encouraged rooks every where, with some effect: and sea-gulls fortunately resort very much to lay their eggs on an island in Scoulton Meer, and rear great numbers of young, undisturbed, as they arc known to feed only on worms and grubs, no seeds having been found in their crops. They come the end of March, and migrate in July.

Roots.-Mr. Thurtell has traced the fibres of the roots of wheat, five feet deep, on the side of a marle pit: also the root of a turnip, drawn by hand, two feet and a lalf in length, in a light soil. 
Reaping.-Mr. Syble, of South Walsham, cuts very low, and consequently does not haulm the stubbles; which he thinks a very inferior practice, if a farm is kept clean.

Mr. Parmenter, miller, at Aylesham, a considerable farmer also, and a very intelligent sensible man, remarked to me, that the farmers let their wheat stand ton long before cutting. They were apt to have a notion, that when millers gave this opinion, it was speaking for their own interest: but he cuts his own wheat hefore it is ripe, and would do so on the largest scale, if he was not a miller: the quality is far superior, and the crop just as goorl.

"Mowing las teen practised at Hainford; the crop very clean, and dead ripe. The gathercrs followed the scythe, and the waggon the gatherers. Secured, at a trifling expence, without any risque from weather." - Marshall.

Mr. M. HiLl prefers cutting green, and never began harvest but he wished he had began three days sooner.

Stubbles.-Mr. BurTon, of Langley, always haulms his whear stubbles, for littering the yards; and it is the common management in Loddon hundred: by this means he finds he can support his farm in heart, without buying dung. At first coming, he bought barrack muck, at $j^{\text {s. a }}$ load, laying on eight an acse : threc years of this brought his farm into such a state, that he discontinued it.

Produce.-About W atton, three quarters, on an average.

The finest wheat I saw in thirty miles, was a small broad-cast field at Tofts, of Mr. PAYNE GALWAY's; it promised to yicld five quarters an acre. Tofts is in a very poor district, but I have often remarked, that if a good piece of land is found in such, it is usually uncommonly good.

At Langley, \&rc. average seven coombs. Caistor, and average of Fleg hundred, seren to cight coombs: fourteen have been known, and were reaped by J. HUNTING. 
Don, Esq. at Somerton, last year; he had 32 coombs on two acres and a quarter.

Hemsby, eight coombs: fourteen have been known.

Thrigby, seven coombs.

South Walsham and Blowfield, seven coombs.

Martham, seven coombs.

Catfield and the vicinity, seven to eight coombs.

Happsborough, Walcot, and Barton, nine coombs.

Honing, scren. North Walsham, six to seven.

Westwick, six.

Scotter, six. Mr. DybLe, seven. As the average barley is but eight, the wheat seems high for a sandy loam, a good bariey land; but drawing the turnips, and throwing them on the ollonds for wheat, explain it.

Around Coltishall, six coombs.

Mr. Repton, at Oxnead, favoured me with an accurnte account of all his crops for some years back.

Acres. Produce per acre.

Coombs. Bushels.

$\begin{array}{llllll}1773 & - & 77 & - & 3 & 3 \\ 1774 & - & 50 & - & 5 & 2 \\ 1775 & - & 46 & - & 6 & 2 \\ 1776 & - & 56 & - & 5 & 2 \\ 1777 & - & 30 & - & 6 & 3 \\ 1778 & - & 71 & - & 5 & 1 \\ 1779 & - & 50 & - & 6 & 0 \\ 1780 & - & 61 & - & 5 & 0 \\ 1781 & - & 53 & - & 9 & 0 \\ 1782 & - & 46 & - & 7 & 2 \\ 1783 & - & 47 & - & 6 & 3 \\ 1784 & - & 50 & - & 5 & 3 \\ 1785 & - & 58 & - & 7 & 0 \\ 1786 & - & 59 & - & 8 & 2 \\ 1787 & - & 42 & - & 8 & 0\end{array}$




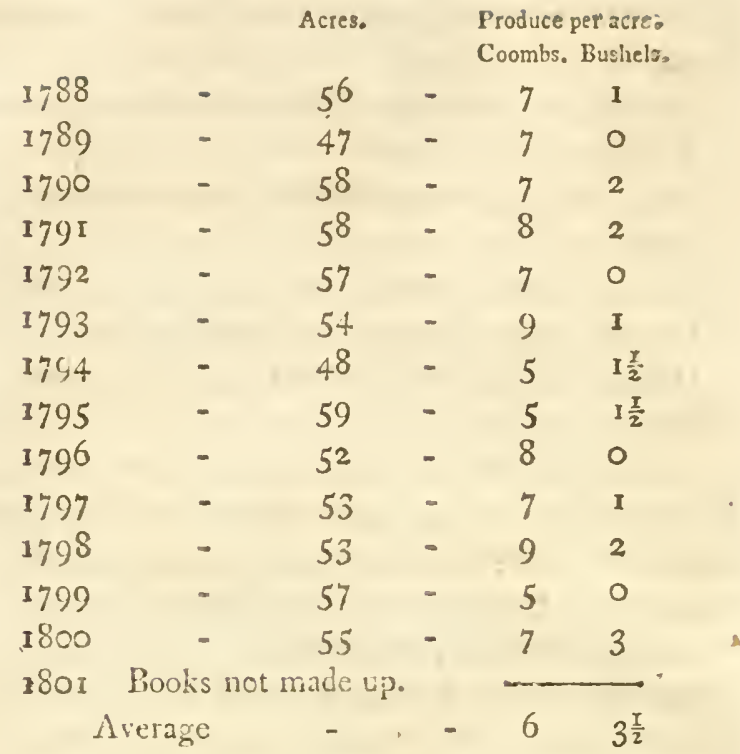

On the pocrer soils at Heveringland, not much wheat is sown; the best of it, frve coombs: on their better soils, six to seven.

Mr. B̈rchan, at Hackford, Reepham, \&c. seven coombs.

At Haydon, five coombs. At Thurning, better than five. Mr. CoKt, at Hollham, six coombs.

Mr. M. IILL, average of last twenty-one years, sis coombs.

At Burnham Westgate, five coombs.

At Holm, some very rich land, eight to twelve; some. times more.

At Snettishan, six coombs.

At Houghton, five coombs.

At Hiilingdon, not four coombs, on an average-nuch damaged by the mildew.

Abuut Downham an? the vicinity, seven coombs.

At iVarlington, seven coombs. 
At W igenhall, St. Mary's, the average, five coombs per acre; sometimes not more than ten to twelve bushels. If shis is true, it stamps their husbandry sufficiently.

At $W$ alpole, five coombs the small acre; more than three roods. By another account, five and a half.

Near the Smeeth, seven to ten coombs.

About Wymondham, five.

General average of the county, six coombs.

Profit, compared with Oats. - Mr. Fellowes, of Shotsesham, remarks, that oats pay betrer than wheat, in many cases even which are supposed to be particularly faxourable to wheat, as in clover lays. He has found it more profitable to plough a clover lay late in autumn; but before much wet comes, and to leave it till she spring, and then, as early as may be, harrow in oats or baricy, on that stale furrow, and the crops have beer so great, as to pay better than wheat; but oats better than barley. This secms to be, among ofliers, one proof that wheat has been too cheap.

Price.-In discourse with Mr. PARMENTER, a miller of Aylesham, on what ought to be the price of wheat, re. ference being hal to the farmer and to the poor, he gave it as his opinion, shat 30 . a conmh, on the average of samples, would be that fair price for all parties. He remarked, that the very high prices we have seen, were not advantageous to millers, by reason of the great capital demanded, and from a want of proportion in the price of bran. When wheat was 4 l. a coomb, bran was not higher than Is. a bushel. Within four vears lie has bought a great deal of wheat, as he shewed ine by lis books, at 2Is. and $22 \mathrm{~s}$. bran at $6 \mathrm{~d}$. and $\eta \mathrm{d}$. 
SECT.VIII.-RYE.

UPON the light sands of the Soutis-western distrie, this is a common crop, and follorvs the seeds gencrally upon a bastard fallow. The quantity of seed usually two bushels, and the produce more uncertain than with whent, for this plant is very liable to be damaged by frosts. The culture ought to lessen evcry where, except perhaps in mountainous districts, since wheat has been found to produce, on poor sands, as many bushels per acre as rye.

Mr. BEvan's rye, in 1802 , was sown in February, by which means it escaped the severe frosts which did so much mischief to this crop in June. I have rarely seen finer crops.

Colonel Cony had once six quarters per acre, at Runcton.

There is a practice in the South-rwest district, whichi has merit-that of ploughing up the rye stubbles in harvest, and sowing one or two pecks of seed additional per acre, with intention of burying the scattered grains, and thus having a crop of spring food for sheep. The tillage has its use for the following turnips, consequently the cxpence merely consists in the small portion of seed added,

SECT. IX.—OATS.

THIs is by no means a favourite crop in Norfolk, where, if the land is in order, they greatly prefer barley; and if it is not in order, they are too good farmers to sow any corn.

Mr. HiLs, at Waterden, in common with the generality 
rality of his neighbours, buys all the oats he consumes; he can grow as much barlcy per acre as of oats, and is at the same time a more certain crop.

Upon the good barley sand, for some miles around Holkham, the farmers think oats a so much more exhausting crop than barley, that they buy all their oats at Wells; carrying wheat, barley and pease thither, the waggons bring oats back.

Mr. Denton, of Brandon, dibbles oats with great success; puts in more than a coomb per acre of seed, observ ing. that he did not approve of adopting any method as a way of saving seed.

Admiring a very fine oat-stubble at Mr. Francrs's, at Martham, and inquiring the preparation, he informed me that wheat preceded, the stubble of which he scalcd before Christmas, ploughed it across thin, and then a full pitch for the seed oats. The wheat was on a two year's layer.

"The surface of a piece of ground, sown several days with oats, but which were not yet up, was run, by hcavy rains, into a batter, and baked to a crust: the owner ploughed the ground, notwithstanding they had begun to vegetate, under a flect furrow. The success was beyond expectation."-Mr. Marshall.

Seca.-Mr. Fel lowes, of Shottesham, has found, from many observations in a long and attentive experience, that the more oat-seed he sows, the better is the crop. This he finds to take place as far as seven bushels an acre, and even to eight.

On strong land at $W$ issen, five bushels broad-cast. Mr. SALTER, SiX.

About Watton, four bushels; some five.

About Bilney, four and five.

At Thelion, four to five bushels.

Mrr. Everit, of Caistor, in Fleg, fure to six bushels. SORFOLK.] 
Mr. Syize, of South Walshan, five bushels.

Mr. Cubit, \&co. at Catfield, five to six bushels.

Mr. REEves, of Heveringland, drills at six inches, three to four bushels.

Mr. RE七vE, of Wighton, three bushels, drilled: of Tartarian four bushels.

Near Downham, four bushels.

At Watlington, six bushels. Mr. Porter there harrows in, because no drill cups will deliver enough.

About Wymondhan, four bushels.

Produce.-At Thelton, ten coombs an acre common, and even more: some twelve to fourteen coombs.

On the fine loany and gravelly sands of Langley, \&c. average II coombs.

Caistor, \&cc. in Fleg, and the average of the hundreds, fourteen coombs: twenty-four have been known.

Hemsby, tweive coombs: twenty have been known.

Thrigby and Fleg, twelve coombs.

South Walsham and Blowfield, fourteen coombs.

Martham, eleven coombs.

Catfield and Happing, twelve to fifteen coombs.

Honing, eleven to fifteen coombs.

North Walsham, ten to twelve coombs.

Coltishal, twelve coombs: but few sown.

Mr. Repton, of Oxnead, favoured me with an accurate account of his crops for many years :

Acres,

$\begin{array}{rrrr}1773 & 10 & 14 & 0 \\ 1774 & 14 & 15 & 0 \\ 1775 & 20 & 11 & 0 \\ 1776 & 9 & 15 & 0 \\ 1777 & 26 & 13 & 2 \\ 1778 & 12 & 11 & 0 \\ 1779 & 14 & 11 & 0 \\ 1780 & 15 & 10 & 3\end{array}$

Produce per acre.

Coombs. Bushels. 
Acres. Produce per acre.

Coombs. Bushels.

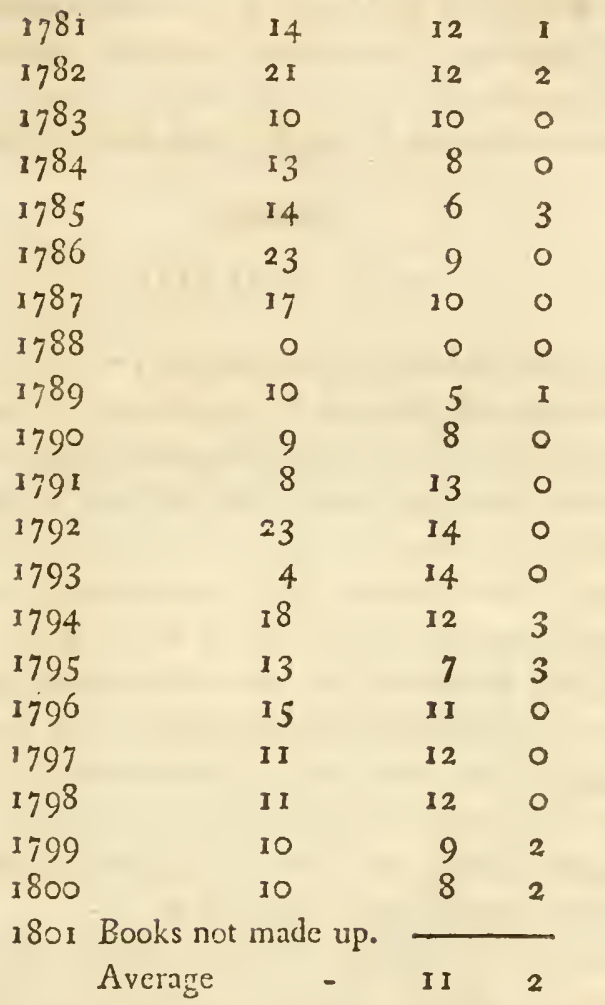

On the light soils at Heveringland, eight to ten coombs: on the better land, twelve coombs.

Mr. Bircham, at Hackford, fifteen coombs: has had twenty-six coombs one bushel, on old land that had had vetches only.

At Thurning, eight to ten coombs.

Mr. REEvE, of Wighton, has had twenty-five coombs an acre of the Tartarian.

At Snettisham, ten coombs.

The vicinity of Downham, ten to sixteen coombs.

At Watlington, fourteen coombs. 
About Watton, average ten coombs. At Wigenhall, St. Nary's, six or seven coombs. At Walpole, twelve coomhs. Another account, twelve to fourteen coombs; on fallow, sisteen coombs.

Near the Smeeth, thirteen or fourcen coombs.

\section{SECT.X.-PEASE.}

Mr. Overman, carrying me into a crop of broal-cast pease in his reighbouriood, desircl me to exanine the strongest tufts to be found, to shew that the poppics, so far from being destroyed, were erect and ready to force themselves through when the pease fall, theugh overtopped at present. He remarked, that the common observation, that pease are apt to foul land if weak, and clcan it, if stont, was erroneous: if red-weed or spear-grass are in the land, no crop will destroy them; and if they are not in the land, the pease camot gencrate them.

Mr. OvERMAN, from various observations, is of opinion, that if pease are repeated oftener than once in eleven or twelve years, hey are very ap: to fail.

Mr. SYELE, of South Walsham, has found that pease are a very Lincertain crop: this is known to all farmers; but he has remarked further, that they will not bear repeating. If sown often on the same land, they are almost sure to fail.

Mr. Everit, of Caistor, has this year (1802) a vast crop of pease, which I viewed with pleasure; he lays them at tivelve coombs an acre at least: they followed whent; and his renark was, that they had sluded the ground so completcly, that he had no doubt of very fine wheat after them again.

Mr. Fowez, of Snetterton, ploughs such of his laycrs 
as he intends for pease, in December or January, and solls and harrows before drilling on this stale furrow. His mode of drilling this crop, is to have two rotvs at five inclies, and intervals of fifteen inches for horse-hoeing. I vierved his crops, they were very well hung, that is, loaled with pods, but too many poppies for a driller. Horsehoeing, in this system, he finds far more effective than the hand-hoeing ha gave to equi-distant rows at twelve inches. For this drilling, he made a new beam to Conk's machine.

Mr. REEves, of Heveringland, drills his pease at nine inches; and highly alproves the methoul.

Mi. Jomnson, at Thurning, drills all at nine inches.

Mi. Strieman, at Suettisham, drills all; some at nine and some at twelve inclies: hand-hoeing, once or twice, as wanted.

Mr. Rogerson, of Narborough, drills all that he does not dibble.

Mr. M. HrL drills at nine inches on the flag, scarifies twice, and weeds; and prefers that practice to all others.

Pease are very generally dibbled at Theiton; crops, cight to ten coombs per acre.

Wherever found, thence to Yarnoutl, and my route through the Flegs, Blowfield, Stc. \&cc. to North IValsham, dibbling very general : about the latter town, few, but what there are, dibbled: they do not hoe them. The pea stubble reckoned kind for whent.

Few pease are dibbled on ollonds at Scotter; but some are; and Mr. DYBLE remarked, that pease cannot well be dilbled too decp.

Mr. Repton, at Oxnead, dibhles with great success: lie had this year (1802) seventy loads from twelve acres.

The maple grey is a great favourite at present in Fleg hundred. Mr. Tutific, of Southwood, selected them from a sample that came into the country, and cultivating 
them carefully, they have established themselves very gew nerally; they produce ten or twelve coombs an acre, on land that would not give five or six of the old sorts; the straw is not so long as some oiher sorts, but long enough for shade, which Mr. Brown, of Thrighy, holds to be a grcat point in a pea crop.

Mr. Dursgate finds the pearl pea to ripen a fortnight sooner than other sorts: but this year the frost damaged his crop.

Seed.-About Watton, two bushels.

About Dercham and to Bilney, three bushels.

At Thelton, grey pease dibbled, two bushels.

Mr. SyвLe, of South Walsham, dibblesthree bushels.

Mr. Cubiт, \&c. at Catfield, four bushels, whether dibbled or broau-cast: a thick crop they consider as a great object in preparing for other corn.

Mr. Repton, at Oxnead, dibbles, four bushels, two rows on a flag.

Mr. REEvEs, of Heveringland, drills at nire inches, ten pecks.

Mr. ReEve, of Wighton, four bushels of the large pea, drilled.

Mi. Henry Blythe, of Burnlıam, drills, ten pecks.

Mr. BEcK, of Cistle Riseing, drills, ten to twelvo pecks, at nine inches, and hand-hues.

About Downham, two bushels and a half to three bushels.

At Watlington, four bushels.

Produce.-At Langley, \&c. when the year is favourable, the average produce is eight or nine coombs.

At Caistor, and average of Fleg, eleven coombs: fifteen coombs have been known.

At Hemsby, Mr: FERRIER hạs known fourteen coombs. 
At Catfield, if good, ten coombs.

At Thurning, six coombs.

At Sisettisham, when no failure, eight ccombs.

About Downhim, guod, seven cocmbs.

At Walington, if good, ten coombs.

SECT. XI.-BEANS.

ON the stronger land about TVatton, the failure of common red clover, from lung repetition, has had one very good effeet, that of inducing some farmers to plant beans. They plough the barley stubble once, and dibble in one row of horse-beans on every furrow, keep them clean by hand-hoeing, and sowing wheat after; get excellent crops, oftentimes better than after any other preparation.

I viewed carefully a small field of wheat at Scarning, belonging to Mr. NELson, of Dereham, half of which followed beans and half potatoes: the superiority of the former considerable. The Rev. Mr. MunNings and the Rev. Mr. Priest were with me, and were entirely of tle same opinion.

Beans are in common cultivation at Thelton: Mr. HAvERs's are dibbled in rows along ridges seven feet and a half, or ten furrows wide, on which eight rows. $\mathrm{He}$ plougbs the land early in autumn, and (after the frosts) in the spring only harrows, and plants immediately; two bushels of seed an acre, at the expense of 4 s. and 2 s. $6 \mathrm{~d}$. in the pound for beer. Hand-hoes two or three times, at 8s. or Ios. expense; no horse-hoeing: he gets ten or twelve coombs an acre. There cannot be better management than avoiding spring tillage, on heavy land.

MIr. HAVERS, and his neighbours, having kept their $\times 4$ beans 
beans clean by heeing, plough the stubble once, harrow, and drill or dibble in the whear seed.

Many are also cultivated at Billingford, where they are in the same system: Mr. DRAKE avoids spring tillage, ploughing before Cluristmas; has a set of seven small har. rows, which dropping into every hollow, prepares well for the dibbles; rows at nine inches: he hand-hoes twice, keeping them quite clean. I viewed his crops and found them perfeetly so, and very fine, equal in appearance to five or six quarters an acre; yet they seemed too thick, and not podded so low as they would have been with more room.

Mr. Pitrs, of Thorpe Ablots, has this year (1802) drilled beans with Cook's machine, at I2, I8, and 24 inches, and he thinks the 24 promise to be the best crop. They have been horse and hand hoed, and kept quite clean. All will be eight coombs an acre at least.

Mr. KlRrich, at Harleston, lays his manure on for beans, and then drills wheat, getting great crops.

Mr. BALDWIN, near Harleston, drills many beans, and. gets great crops, as well as of wheat, after then.

Through the hundred of Loddon the beans are all dibbled, one row on a flag, and all the farmers sow wheat after them, finding it the best preparation for that grain.

Mir. Burton, of Langley, whose knowledge of husbandry is extensive and unquestioned, upon the strong land at Hempnal has always had excellent wheat, perhaps the best, on bean siubliles.

At Langley and the vicinity, average produce ten coombs. Mr. Bunton never less than that crop at a mediuin; this year ahove twelve.

At Seething and Muntham many beans, and great crops: wheat after them. Here are exccllent farmers.

Admiring the fine sandy loarns at Caj'tor, in Fleg, and combining 
combining the circumstance of soil with the small variation of their crops, I proposed to Mr. Everit the culture of beans: he said that he had tried them, and they would not do; they run away to straw, and will not pod well.

Mr. Ferrier, of Hemsby, has known them tried; but they would not do.

Mr. Syble, of South Walsham, sowed five acres, and they ran away to straw, and yielded very little corn.

These articles of information were rather discouraging, but having heard that Mr. Christmas, at Billockby, had made some experiments on beans, I called on him; unfortunately he was from home, but I examined his bean crop. Passing to Ludham, the ninth mile-stone is against the field, which I note, that others may, if they please, examine the field. It is a large field dibbled one row on every flag: the soil fair Fleg land, but rarher stronger than the very pale lands: the crop had been hoed, but not sufficiently, for they were rather foul : the conviction on my mind that the country will do for beans, was compleat: I guess the produce ten coombs an acre. They are rather low than high. There is a large pit of clay marle in the field.

Through the Flegs, Walsham, Blowfield, and Happing hundreds, I have been calling out for beans, and surprized at finding only one crop; but at last, at Happsborough, I found that Mr. WISEMAs had them for three years, and with good success, getting 14 or 15 coombs an acre, though in no better mode of culture than that of spraining the seed in every other furrow, and hand-hoeing them swice. He got as fine wheat after them as the best in the country. Inquiring how he cane to make such an experiment, I found he had been in Kent, and seeing the effee? of beans there, induced him to try them.

Mr. BirchaM, at Hackford, tried beans three or four tincs, 
times, and left them off hecause he could not get wheat after them; but did not hoe: could not. I advised fresh trials in the horse-hoeing system.

Mr. Srylenan, at Sr ttisham, has had two crops of beans on a scrt of march, stiff and strong soil. His ma. nagement of the second crop, shich l vicwed, was to plough a wheat stubhle in autunn, leave it well waterfurrowed, and in the sipring to dibble in the seed.

Mr. Prifst, of Besthorpe, has drilled beans with Cook's macine at 13 inclses; five cuonbs of seed on 17 acres; the crop a fair ons: the field yielded dibbled barley the year before, on a layer. The beans were once horsehoed, oxce hand hoed, and once weeded; designs to scuffle the stubble for wheat.

At Wigenhall, St. Mary's, in Marshland, they plough in the wheat stubbles in autumm, and stirring in the spring, sove cvery third or fourth furrow with two bushels of Inorse beans an acre; hand-hoe the rows once, and plough sometimes berween them. Last year (1801) they got ten coombs an acre, but the averige not above five or six. They burn the straw in overs, \&ic. For the following wheat they plough once, and harrow in the seed; and if the weather is good, twice: this they reckon best on account of the white snail, a slug which abounds on bean stubbles: ir eats the young plant of wheat the moment the sced shoots, and sometimes destroys the crop ; steeping in arsenic no prevention-they eat the sced itcelf also, by some accounts, but this is doubtul. Their best wheats follow bcans: the fallowed crops never average five coombs, but those on bean stubbles do. Such is Mr. Jennis's account.

Mis. Cof, of Ilington, has gencrally one-sixth of his arable in bcans; in auturnn he ploughs the wheat stubble, and again at Candlemas, and hatrows in two bushels and a 
half of sced per acre; some he dibbles, and hand-hoes in either case twice, at 5 s. and 4 s. an acre, and reckons a fair crop at six coombs; he takes wheat after them on one earth, and generally good; the best, if it escapes the slug, which in a wet season attacks the wheat in autumn: it is about an inch long, the size of a tobacco-pipe, and of a bluish white colour.

In going round from Islington by Tilney and Terrington to Lynn, I saw many crops of broad-cast beans full of weeds.

Mr. Thorp, on Governor Bentinck's estate, sows beans in furrows; keeps them clean, and gets fine wheat after.

1776. At Walpole, drilled in every third or fourth furrow, and kept clean by both horse and hand hoeing; four quarters sometimes gained. Mr. CANHAM, of Southry, near Downham, had 60 acres thus cultivated in 1769, which yielded five quarters and an half round: in 1770 I viewed the wheat after them, and found it as clean and as fine as any after fallows. He has ofien had five quarters an acre after beans.

This husbandry continues: in 1802 I found the same; and I am sorry to say without improvement.

Produce at $\mathrm{W}$ alpole six coombs.

Many are dibbled in rows, and kept clean and well managed; Mr. Philtp Griffin cuitivates them in this manner.

Mr. Swayne, of Walpole, gets the best wheat after beans, if it escapes the slug : if the land is lightish, it is common to put them in in every third or fourth furrow, for ploughing between; but on strong clay it is difficult to get the plough in. Some dibble in, but others object to it, on account of their not being sufficiently buried. It 
is more common to sow from two to three busiacls brosd. cast, and plough them in; but they hand-hoe all twice. The crop in general six to seven coombs; last year ten.

In the old lands adjoining the Smectl, the hest farmers sow them in every third furrow, but slovens at random; the rows ploughed and clcaned yield by far the best crop, even to ten or twelve coombs per acre in good years: broad-cast six or seren.

Some beans in the vicinity of Downham broad-cast, and a few farmers hoe: some furrowed and ploughed between, produce seven or eight coombs.

Mr. PORTER, of Watlington, sows them in every third or fourth furrorr; if the latter, he ploughs between the rows; if the former, he hand-hoes. Has dibbled some, and they answered well; he left a wheat stubble till the spring, then set two rows on cvery other furrow, and handhoed: got ten coombs an acre; and eight or nine coombs of wheat after them: afier beans, always as good as any other whent.

In discourse during this joumey with Mr. Mingay, of Thetford, on the subject of beans, he mentioned that on his farm at Ashfiell, in Suffolk, he has a field of seven acres and a half, which has been thus cropped:

1797 Beans.

I 798 Wheat.

I799 Beans.

1800 Theat.

isor Beans (Mr. MiNGAY's; and he sold Irol. worth from the seven acres and a half.)

1802 Wheat; estimated by the bailiff at from ten to twelve coombs an acre.

Soil, strong loam on clay marle.

Observation.-The not extending the culture of beans is a great deficiency in the husbandry of Norfols. In the 
Fich land of the eastern district there can be no question; but they ought to be much increased in that of various loams, wherein turnips are often found on land improper for that crop. But this plant would form a valuable acquisition where none are to be found in the good sands of the North-western district, because beans are, in general, found only on clays, or strong loams; the notion is general, that such only are well adapted to the culture; but on all the betrer soils of the last named district they would thrive to great profit, and prove a valuable variation in their course of crops. I have seen very great crops in Suffolk on rich sand, and without doubt they would do equally well in the neighbouring county.

\section{SECT.XII. - BUCK-WHEAT.}

Mr. Francis, of Martham, has sown buck-wheat after turnips, and got eight or nine coombs an acre, and wheat after the buck: the reason of this uncommon course was, hecause part of the field was coleseed, and it brought the whole into wheat; the crop nine or ten coombs an acre.

Mr. CuBit, of Honing, finds that nothing cleans land so well for wheat as sowing buck; he gets seven or eight coombs an acre; but oftener ploughs it under, putting a bush under the beám to sweep it down for the plough $1-a$ poor succedaneum for the skim coulter. He finds it as good as a mucking; but this only on strong land. He sows it on a second year's layer, as soon as barley sowing is over, from the $1^{\text {th }}$ to the 2oth of May; about the 1st of August ploughs it under, harrows well in September, then throws on the seed, and ridges for wheat: always good crops. 
The same practice takes place about North Walsham, and it is reckoned by some, on the heavier soils, as good as half a mucking; but Mr. MARGaTEson remarks, that if done on light sand it makes it too loose and puffy.

Mr. PETRE, of Westwick, sows some on ollond, for a crop, and then sowing wheat, is sure of a good produce.

Mr. DrbuE, of Scotter, has a good opinion of ploughing in green crops: he once in a first year's layer ploughed in the secund crop of clover, spreading no muck there, the rest of the field mucked, and the wheat was as good as the rest.

It was much cultivated when I was at Aylesham, 32 years ago; they ploughed three or fourtimes for it ; sowed the beginning of July five pecks an acre: the average crop four quarters an acre: sometimes they got six. Esteem it as good as oats for horses. Wheat always succeeded it, and rarely failed of producing good crops: sometimes they ploughed it in on cold springy land, using a small bush faggot before the ploughs, to lay it in the right direction for turning in: it answered for two crops better than dung.

Mr. Repton, sows buck on ollonds, and plouglas it in for wheat: it answers well.

Mr. REEve, of Wighton, has ploughed buck in for manure, but thinks his land hardly strong enough for this husbandry; but on any piece subject to wild oats, by sowing buck after barley, on four earths, and ploughing it in at the beginning of August, in full flower, he has freed land from that weed most completely.

Mr. STYLEMAN, at Snettisham, has this year ploughed in huck for manure; it was sown the middle of May, and ploughed in in full blossom the middle of August; stirred in September, and is ready for the wheat-seed earth. 
He lias practised the husbandry before, and received material benefit from it.

Mi. Thorp, on Governor BentincK's estate, in. Marshland, last year ploughed in buck as a manure for wheat, and it answered greatly, improving the crop as far as it extended to an inch : and this year he repeated it, fortunately; for in such a drought as succeeded he had not been able to have ploughed the land at all.

At Felthorpe, buck is considered as superior to all orher crops with which to sow grass-seeds-it does not rob them -it shelters better than any other from the sun-it is late sown, and consequently offers an entirespring for a second or third destruction of weeds : these are valuable circumstances, and merit the attention of those who wish to vary the methods of laying down land to grass.

\section{SECT. XIII.-TARES.}

THE culture of this plant has increased very consider. ably in Norfolk of late years. Within my memory they are multiplied at least tenfold.

Mr. Overman begins sowing winter tares about Michachmas, once more iefore Cirristmas, and sometimes twice and thrice more, with spring tares for succession. After mowing he does not plough the land; but runs sheep over it till wheat sowing.

But the cultivator who has made by far the greatest exertions in this husbandry that I ever met with, is Mr. PURDIs, of Eggmore, who has 300 acres every year, seeding no more than is necessary to supply himself: they are fed by his slieep; used in soiling his numerous horses; and inmense quantities made into hay. His crops of 1802 I 
viewed with much pleasure, and found them very greas indeed. In such an extent they are necessarily sown $2 t$ different seasons for succession, both winter and spring. Some he has dibbled; but intends drilling many in future.

Mr. M. HıL only winter tares for soiling his horses.

Sowing tares for summer feeding sheep, Mr. HENRY BLYTHE remarks, is an absolutely new improvement in the husbandry of West Norfolk, and he thinks it a very great and important one; he does not know who first introduced it: he is largely in the practice himself, sowing both winter and spring sorts, and in succession.

Mr. Dursgate is in this husbandry.

I found Mr. HART, at Billingford, feeding off his spring tares, the winter ones, first growth, being done: the sheep were in pens moving regularly forward; brought in at night, and in the day on the layers: a piece of 20 by 30 yards given every day to 400 brecding ewes. They draw back on the cleared land, not resting on the unfinished tares. They were sown on a two years ollond, and as fast as cleared, the land was tompercd for wheat. Winter tares fed off in May in the same field, are now. in August, a fine crop again for the sheep, when they finish the spring ones.

SECT. XIV.-CABDAGES.

THE Rev. J. ForBY, of Fincham, was a most successful sultivator of this plant. Two acres produced 28 tons per acre, carried off the land, a strong wet loam on clay; two aljoining acres of turnips were fed off with sheep: the whole sown, after three earths, with oats, to the eye perfectly equal, and the whole produce 90 coombs, or 12 quarters per acre. Seeds took well, and he cut nine tons 
of hay. No manure for cither cabbage or turnip. Cabbages never exhausted his land, which always worked better for barley or oats than his turnip land. No cattle could do better than his cows when on cabbages, and the cream and butter free from any disagreeable taste. The seed was always sown as early in the spring as possible, on land well sheltered, dunged, and dug. The moment he perceived the fly on the young plants, he sowed the beds with woodashes, which instantly destroyed the fly, and so far from hurting the plants, that it was astonishing to see low they were invigorated by it. They werc planted out the third or fourth week in May. Mr. Forby always mucked the land intended for the crop soon after Michaelmas, which he found far preferable to doing it just before planting. In a very severe frost which destroved all the turnips, Mr. ForBY's cabbages escaped, and were of immense use.

Subsequent to this communication he further informed me, that he had never seen any piece of land at Fincham planted part with cabbages and part with turnips, where the former did not exceed the latter four-fold at least. Doubts having been expressed whether they did not impoverish the land, he fomed an experiment upon a course of crops to ascertain that point, by a rotation which would prove it, if the fact were so. The land middling, let at I2s. an acre. He spread I 4 loads per acre of dung on a wiseat stubble, and ploughed it in soon after Michaelmas. Three ploughings more were given, and cabbages planted in June: then oats: then wheat. No person in the parish had cleaner oats or wheat, nor any such large crops; I 5 coombs an acre of oats, and six coombs one busleel of wheat; and two years in five, I 9 coombs an acre of oats, and nine coombs one bushel of wheat. No sheep or caule NORFOLK.] 
fed on the land at any time, nor other dressing given, except the third year, as above, for the cabbages.

This gentleman tried the red garden cabbage, and found them very hardy, and come to 14 lb. but they denand more. time for growing than grecn sorts: of which those streaked with red veins are best, and most dirable. He hung those up for seed for two months after. Christmas. Did not approve of setting the stalk only, as the side branches were apt to break off; each good plant yielded rlb. of seed : he dried it on hurdles raised on stahes: and if the ground was fine under them and dunged, is became a seedbed.

Mr: Coke has cultivated the large catrle cabbage 13 or 14 years, and got very fine crops, whicin yielded more food than turnips, on good sands: he has had up to 20 acres per annum. He sowed the seed in February, and transplanted as soon as the plants were large enough, continuing till the beginning of July. Manured as for turnips, ro loads per acre. The expense the same as that of turnips.

Mr. REEve, of Wighton, has every year a few acres, to use in frosty weather, finding a load of great use for his cows in the morning: he sows the seed in February, and plants in June, the rows three feet by two and in half: he. is clear that an acre produces double the food of an acre of contiguous turnips; and does not observe any defect in the barley that follows.

Mr. Rishton has culivated cabbages, and has known as good barley after them, though carted off, as after turmips fed late on the land. His method of culture was to sorv the seed the first week in February, once to remove the plants, and set them out by the 4 th of June: hand. hoed theri, earthing up: then ran the double earth-board plough botween the rows, and the hand-hoes after to draw the ear still higher up. He planted by a marking rake, with 
with three teeth, at three feet asunder, drawn along and across the lands, and set the plants at the intersections.

Mr. Fowel cultivated Scotch kale in 180 r. The seed was sown in a bed in April, and transplanted the middle of June, in rows at three feet, and the same distance from plant to plant, on three acres. They were kept clean by hand-hoeing, and fed off by sheep. They yielded abundance of food; but he thought the sheep did not take kindly to them; the use, however, was very great, as his turnips rotted. This year he intended a crop, but the seed was bad and failed. The barley was as good as after turnips.

In 1784 , I remarked in the Annals of Agriculture, vol. ii. p. 365 , the great superiority, on my own farm, of borecole, \&c. drilled and left without transplanting, to that which was transplanted, and thence recommended the practice; which was, I believe, the first public hint given of it.

\section{COLE-SEED.}

Mr. Everit, of Caistor, in Fleg, alwavs liand-hoes his cole-seed once, with seven inch hoes, giving the same price (6s. 6d. an acre) as for the two turnip hocings. The benefit is very great, not only in cleaning the land, but also in the growth of the plants: they stand the winter much better than unhoed crops, spreading on the ground, instead of rumning up, and being exposed and cut by frosts.

Cole-seed, in the fens of Marshland, on paring and burning, runs to thick stalk, and that quite brittle, and is excellent for stock; but at Walpole it is inferior. 
SECT. XV.CARROTS.

IT is a remarkable circumstance, that carrots should have been an article of common cultivation, in a district of Suffolk, for more than 200 years, and yet that so valuable a crop should not, in all that time, have travelled into this neighbouring county, where there are such great quantities of land so perfeetly adapted to the husbandry.

Forty years ago, Mr. Fellowes, at Shottesham, cultivated carrots with much success: he gor 600 bushels per acre, which were used for horses and cows: the former never did better, and the butter from the latter, of superior quality.

They were pretty much cultivated more than thirty years ago, between Norwich and Yarmouth-nearer to the former; the farmers trench.ploughed for them, and sowed in February; hoed in two months after; thrice in all, at a guinea an acre, and barley succeeded.

Mr. Woodbine cultivated carrots at Packsfield, near Rainham, a farm of Marquis Townshend's, success-

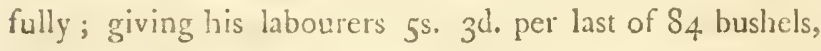
for digging, topping, heaping, and loading: he tried them in fatting 30 hogs; and weighing one fairly chosen, and again after twenty 28 days, found he had gained three stone Ilb. paying 2s. a week. They were sold to drovers for the London market: he then put up 40 more, giving some pease with the carrots, which made better flesh.

Mr. Forby, of Fincham, for some years kept carrots without suffering from the severest frosts, by forming a platform of earth, six inches above the level and two feet and a half wide; on this a sprinkling of dry straw, and then a row of carrots, with their tops all on, and turned 
outwards, the tails lapping over one another; so that the width covered with carrots was about two feet; the small ones topped and laid in the midlle: on every two or three rows a little dry straw, and thus to the height of four feet, the tops well covered with dry straw; another row parallel, with room for a person to walk between: these alleys at last filled with straw, and the outside guarded with bundles of straw, staked down, or set fast with hurdles, to prevent the wind blowing the straw away.

But the person who made the greatest exertions in this husbandry, was Robert Billing, a farmer at Weasenham, who had them on a scale of 20,30 , and 40 acres per annum, during four or five years; gained some premiums from the Society for the Encouragement of Arts, and published a pamplilet on the subject.

\section{SECT. XVI.-MUSTARD.}

MUCH cultivated from March to Wisbeach, and about the latter place. A good crop will yield five or six coombs per acre, and it sells at from 8s. to 2 Is. a bushel. It is, after being in full blossom, subjeet to a $\mathrm{Hy}$, which damages it greatly.

In the newty-inclosed lands of Marshland Smeeth, mustard is the chief crop. They ploughed the old grass of that rich common once, and afrer one or two harrowings, sowed a quarter of a peck of seed per acre, from Candlemas to the end of March; land-hoed the plants once or twice, as wanted, thinning and scting them out at nearly equal distances. 'The crop is reaped the beginning of - Seprember, and tiea in sheaves, leaving it three or four days on the stubble: it is stacked in the field, and these stacks are called pies. If it gets rain in the field, it turns grcy, and 
loses half its value. The Suseeth is now full of these stacks, and the season has proved highly favourablc. It is threshed in the autumn, being left for a swcat, which improves the colour. A good crop, such as they have got this year, amounts to six or seven coombs an acre, and the present price at Lynn is 20s. a bushel. From this account it is not surprizing that the Smeeth of 1500 acres, letis at 31 . The price, however, is sometimes so low as 7 s. 6al. to Ios. a bushel. They intend, according to the common practice near Wisbeach, \&cc. to sow four crops in succession; the second is usually as good as the first: and after four years mustard, a crop of wheat, then fallow.

In old cultivated lands, four or five coombs a good crop.

SECT. XVII.- HEMP AND FLAX.

Mr. Algur, of Buckenham, had a three-acred piece under this course for many years:

I. Hemp, dunged for,

2. Wheat;

and the wheat was alivays very good; more apt to be too great than too small a crop. Most of the cottagers in that vicinity have a patch of hemp, which is a great relief to them: it is very profitable, and finds the families much employment.

As an instance of the inefficacy of the bounty, $\mathrm{Mr}$. ALGUR, though long a hemp-grower, never applied for it.

This culture, in the vicinity of Diss, has greatly declined; there is scarcely one-tenth grown of what there was some years past : this is chiefly attributed to the high price of wheat. Forty stone from the break, an average crop; bunching and heckling now 20d. a stone, and a 
good hand will do one stone and a half in a day. The spinners earn from 4d. to 8d. a day.

Mr. RaInbearD, Governor of the House of Industry of Forehoe, cultivates hemp every year, to supply a part of what is manufactured in the house ; and in the watering of it, has a contrivance which $I$ do not remember seeing elsewhere, by means of which it is deposited in the pit, without any necessity of a single person being wet, a pretence in common for making the farmer's tap bleed pretty freely. The pond is an old marle pit, with a regular slope from one side (where the hemp is prepared) to the depth of eight feet on the other side : on the slope above the water, the hemp is built into a square stack, upon a fráme of timber, of such a height as will float and bear a man without wetting his feet: this is slid down upon the frame into the water, and when floating, drawn away, a person on the opposite bank drawing the floating stack to the spot where it is to be sunk, and on which it is built to the requisite weight.

He finds it does soonest at bottom, and would not object to sixteen feet depth of water.

By means of this very useful contrivance, he can put in a waggon-load in an hour.

The sheaves are taken out in the common manner, sheaf by sheaf: here wants a further improvement, easy to be effected.

In the parish of Wyndham, a farmer had, about seven years ago, some land (four acres and a half), dunged and ploughed, and designed for fallow for wheat; Mr. RAINBEARD seeing the field, advised him to sow hemp before taking wheat, which he did, on one acre and a half; he bought the hemp at 81.83 . an acre, as it stood, and the farmer sowed the whole with wheat; and the crop was so much cleaner and better after the hemp than after the fill- 
low, that the farmer told Mr. RAINBEARD that he lost $20 l$. by not following his advice upon the whole piece. Account seven miles round Diss, Lopham, \&ic.

EXPLNSES :

Rent

Tithe

Rates

Ten pecks of seed, at $\mathrm{rs} .6 \mathrm{~d}$.

Sowing

Three earths

Five harrowings

Ten loads of farm-yard dung

On an average, sells as it stands (hemp selling from the break at 6s. 6d.) for $£ .880$ Expenses

Profit

Suppose the crop 40 stone, dew-retted:

Pulling and spreading, turning and tying - 150 Breaking, Is. $3^{\text {d. a stone - } \quad 2100}$

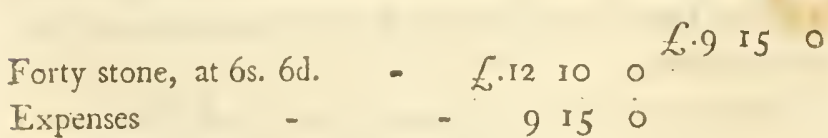
- $\quad 9$ I5 0

Profit

Price of hemp, from the break, in s. $d$.

1789 Hemp bought at - 50 per stone. 1990 Dito $\quad-\quad 56$ 


$$
\begin{gathered}
\text { FEMP AND FLAX. } \\
\text { s. d. }
\end{gathered}
$$

I 79 I Hemp bought at - 5 o per stone. peracre. I792 Ditto - $\quad$ - $\quad £ .4150$ 1793 Ditto - $\quad$ - $\quad$ - 6000

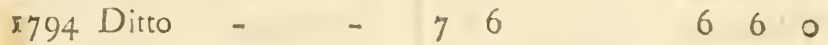
1795 Dirto - - 70770 I796 1) - 36 itto 790 1797 Ditto - $\quad 70770$ $179 \delta$ Ditto - $\quad-60660$ 1799 Ditto - $\quad 60700$ 1800 Dito - $\quad 80990$

The difference of price between dew and water-retted used to be reckoned 2s. a stone; but is now full 3 s. on the average.

Forty stones of hemp from the break wiil make 40 stones of tow, it being weighed from the break at $14 \frac{\mathrm{T}}{2} \mathrm{lb}$. to the stone, and that of tow is only rolb. At 6s. 6d. a stone from the break, it is worth 8 s. the stone from the heckle. The bunching is valued at $8 \mathrm{~d}$. a stone, and the heckling Iod. In the House of Industry they have a very simple machine for buuching: men, by turning a winch, move semi-circular cogg'd wheels of iron, which lift, every moment, one of four perpendicular beaters, and let them fall on the hemp coiled under them to receive the stroke.

Estimation of the quantity of hemp raised in the hemp district of Norfolk.

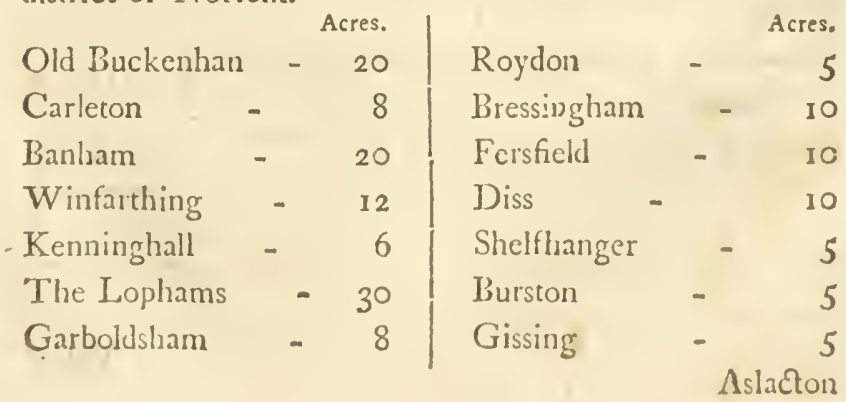




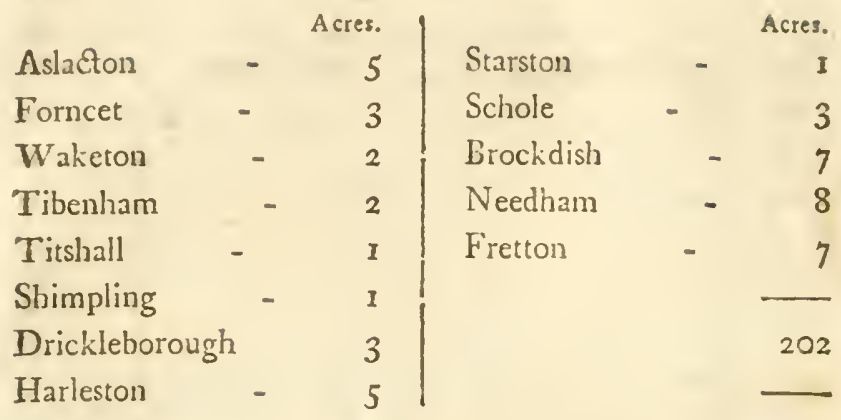

It may amount to about 200 acres.

Mr. Geo. Eaton, linen-weaver, informed me, that about Diss there is not so much hemp grown as before the price of wheat was so high, by a third or fourth. It is affected also by the high price of turnip seed; for the cottagers, \&c. sow turnips on their hemp grounds, and if seed be high, they let them stand for a crop, instead of sowing hemp every year in the conmon mainer. The necessity of manuring for every crop of hemp, impedes much the increase of it under any circuinstances.

\section{ACCOUNT OF AN ACRE.}

Rent, tithe, and rates

Manuring 20 loads

Five earths

Harrowing

Seed, ro pecks, at 2 s.

Pulling

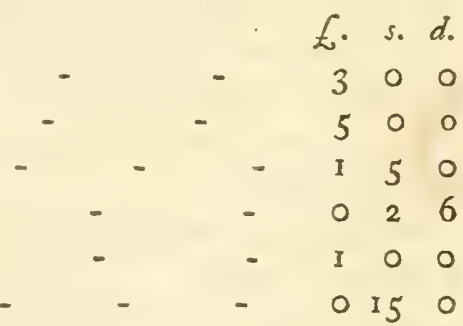

Dew-retting spreading, 2s. 6d. turning, 4s. 6d. $\} \circ \mathrm{I} 20$

$$
\text { getting, } 5^{\text {s. }}
$$

Breaking 40 stone, at $14 \mathrm{lb}$. is. $6 \mathrm{~d}$.

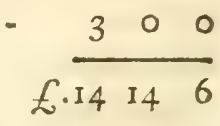


Value then, 8s. 6d. a stone

1700

Expenses

14146

Profit

L.2 56

Bunching and heckling, Is. 6r. on 40 stone 300

$$
\text { f. s. } d \text {. }
$$

Value then 40 stone, at IOs. 6 d. 2 I 00

Expenses

Profit
I7 146

$2 \cdot 3 \quad 5 \cdot 6$

Spinning to clews, at 8d. per stone, 6s. 8d. 1368

Half bleaching, 40 stone, at 2 s. Id. (chiefly $\} 468$

Winding on bobbins, 40 stone $\quad$ I 00

Weaving, 40 stone - $\quad 800$

Bleaching the cloth (nearly all labour), $\quad 3 \quad 6 \quad 8$

Total culture and manafacture of every acre $f .47 \quad 14 \quad 6$

A good spinner earns $8 d$. a day.

A middling one, 6d. a day.

A bad one, or child, 4 d. a day.

The weavers, 7 s. to I 4 s. a week.

Women ditto, ros. or 12s. One girl, 12s. bat an extraordinary instance.

The price of dew-retted hemp has risen from 6s. 6d. to 8s. 6d. in two years. The war increases the demand for their linens, while the culture of the raw matcrial falls off: this obliges them to mix Russian flax with it, the warp of one sort, the woof of the other: but nothing equals their own hemp for duration and strength. The bounty 


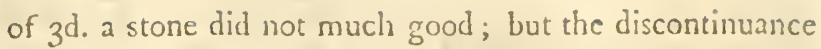
of it did mischief. Mr. EATON thinks, that if a bounty of 6d. were given, it would have a good effect when wheat is cheap.

Mr. Richardson, of Fritton.-Most hemp in Lophams, (iarboldsham, Kenninghall, Banham, Buckenbam, Diss, Bressingham, Palgrave.

The soil a rich mellow loam, on a clay bottom; worth

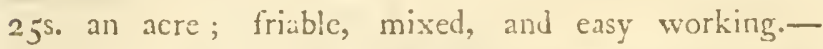
Manure, 20 good loads, a compost ; three or four earths given; the best time, the beginning of May; I 3 pecks of seed. No selection. They pull in 12 or 13 weeks from sowing; here they water-ret, in other places, dew-ret, the former best for fineness, but equal in strength: in the water, from three to five or six days; dew-retting, from three to six weeks. Dew-retted is seldom finer than $2 \mathrm{~s}$. a yard; water-retted, to 5 s. Showers, whether for water or dew-retted, arc necessary. As a crop, hemp is profitable, but yields no manure; Mr. Richardson has 100 acres of land that would do for it. On a layer it is good, but another crop first, and then without manure; an average crop, 40 stone: now at I2s. a stone waterretted; dew-retted, 9s. The common price of seven years, 6s. dew, and water-retced 8s. This price will not increase the culture, because wheat is so high; nor is protitable, for want of manure: if he ciid not want it for his fabric, he would not sow any.

Rent, tithe, and rates f. s. d. Seed, 13 pecks, at 2 s. Manure Three earths

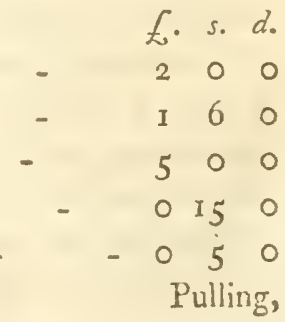


Pulling, retting, spreading, lifting, turning,

binding, and housing _ _ 3300

Breaking 40 stone, at Is. 6 d.

At 7s. 6d: it only pays

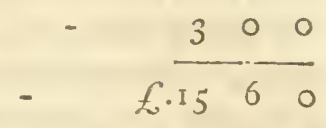

Mest is grown by cottagers in bits, roods, and half acres of land; few have so much as an acre: Russian hemp is fit only for coarse goods, being deficient in fineness, strength, and colour. A relation, at Lowestoff, made nets of it at the same price as Russian good hemp; but it would not last in salt water so long as the Russian; but Russian linen is far inferior in strength to our own homemade. They could always sell more home hemp sheeting than is possible to make, and those who cannot get it, and buy Russian, find a vast difference. But coarse sheeting is made of the refuse of all; fine sheeting, 3s. 6d. a yard, five-quarters wide.

If encouragement was given to the growth, it would be a very good thing for the poor; for it is of great benefit to them; and would answer better to them than potatoes: a rood pays their rent, and keeps them in employment. The $4 \mathrm{~d}$. a stone bounty was not worth going for ; to encourage it by 6 d. a stone, instead of 3 d. might do a little good. Mr. Richardson never claimed the 4 d. though he grew for three years. Not half the hemp raised now, that he rememhers, though the price is doublet. Where they used to have hemp, they now have wheat. And licte farmers had mose than large ones at present.

A small quantity is cultivated around Downham, by farmers who sell it to cottagers, at 5l. to Iol. an acre, as it grows: they sow wheat after it, and always have good crops: they muck for the hemp. 
The following is an answer I sent to some Queries transmitted to me on the subject of the increasing the grouth of homp.

The only account to which I can at present have recourse, to discover what is the import of hemp, is a detail of imports of merchandize from all the world, from the $5^{\text {th }}$ of January, 1792 , to the $5^{\text {th }}$ of January, 1793 , in which rough hemp is set down at 61 4,362 cwt., value 522,207 . Whether this jucludes the import for the Royal Navy, I know not, but in the following calculations, must presume that it does "include the whole. It makes 30,718 tons, at 17 . a ton, or 2 s. $1 \frac{1}{2} \mathrm{~d}$. a stone of $14, \mathrm{lb}$. from which price I conclude that this hemp is in its very earliest stage of dressing. Hemp sold in England, in 5796 , at 6 rl. ros. a ton.-Annals, vol. xxvii. p. 79.

'The hemp lands of the counties of Lincoln, Cambridge, Suffolk, and Dorset, yield nearly the same crops; from 35 to 50 stone per acre; 40 may be considered as an average crop; in which ratio it takes exactly four acres to produce a ton, and 120,000 acres for the quantity imported of 30,000 tons.

I cannot conceive that it is impracticable to add I20,000 acres to our hemp grounds, even in England alone; certainly not in England and Ireland together. But it would be impracticable to add a tenth part of that space, without giving a most decided and effective encouragement.

The former bountics per stone, had no effeet whateverthey did not occasion a single acre extraordinary to be sown; and I personally know, that many persons who cultivated hemp, did not even think them worth appiying for; the forms were so difficult and tedious.

I have not the ad to recur to, to know exactly their amount, but it was either 3 d. or 4 d. a stone; at the latter, 40 stone gave only I 3 s. 4 d. an acre bounty; totally insuf. ficient as an ericouragenent for an article which we know is not extended under a bounty of from eight to ten times

that 
that encouragement in the price of the commodity. The rise cannot be estimated at less, on an average, than 2s. a stone from the breaker. Yet this great advance does not extend the cultivation. In all these articles there is an apprehension of the price falling, if generally gone into. Two shillings a stone is a bounty of four pounds per acre-but being liable to a fall in price, it has little or no effect.

There are other circumstances which unite to prove, that a bounty, to be effective, must be very large. It would not be easy very greatly to extend the culture without ploughing up grass-lands for the purpose; nothing pre. pares for hemp so well as the land lying under grass; but landlords do not admit grass to be ploughed by tenants; and as the latter would reap all the profit, of course they would give no indulgence where they would. reap no advantage. This reduces the object to the grass-lands in the hands of the proprietors, unless the parties were enabled to divide the bounty.

The land which will produce profitable crops of hemp, is applicable to various other beneficial purposes; and to induce men who possess such land to vary from their common objects, would demand a very powerful impulse.

There seem to be but two ways to give this impulse; one by a general bounty per acre (per stone would be more liable to fraud) on all hemp that produced 35 stones and upwards per acre: the other, to dispatch intelligent persons through all the hemp districts, and others where the soil is rich enough, to form contracts with all persons willing and able to raise the commodity largely; engaging to take all they produced, not less than tons, at a given price, for tive years.

To engage for such a pcriod would be absolutely necessary, for undoubtedly a man would not plough up good grass for any inducement of a shorter duration.

I do not conceive that a less buunty than 5l. per acre would 
would have the desired effect; and the only limitation that would be admissible, would be to limit it to a certain sum, for instance, 600,000l.; and if the clainants exceeded it, then to be divided among them proportionably.

If the other method of contracting wese adopted, the price must, in negotiation, be raised, till it satisfied then of slove profits of the undertaking: IOs. or 10s. 6d. a stone might prove sufficient: and for five years al.o.

I an inclined to think that by either of these measures the requisite quantity of land might be brought into this cultivation; and it would have another beneficial effect, of adding to the culture of wheat-hemp prepares well for that grain, which is commonly sown after it.

The parts of the kingdom most fitted for the culture of hemp are, the rich lands of Lincolnshire; the skirts of the fens of Cambridgeshire, great part of the fens themselves; all the upland-lands enclosed in the fens; the coast lands of Essex and Sussex; the coast, and various other tracts in Dorset, Somerset, and Devon; and much of the convcrtible soil laid to grass in all the central counties. In Ireland, large districts in Limericl, Tipperary, Rosconmon, Meath, \&c."

Ireland producing much flax, is not a proof that it would do for hemp; as much flax is sown in the north of that kingdom on soils not adapted to hemp.

The private advantages which would result in Ireland from applying public money to the encouragement of the growth of hemp, would depend on its being a measure not of the moment. To induce them to break up their grassland for this object, and then by withdrawing the bounty leave them to common liusbandry, would be injurious, supposing them unwary enough so to be led astray.

In regard to pointing out individuals able to contract for the delivery of hemp, to the amount of 50 or 100,000 
acres; I could not name them. The proper way would be to take a journey into the right districts, and apply to great numbers, with powers to make such a contraet; a person weil skilled in husbandry, to explain the benefits, and answer objections and doubts; could by posting, traverse a great extent of country in a month, if he knew the right roads to take, and a good scattering of individuals to apply to immediately. Such an experiment would enable Government to ascertain pretty nearly what may be expeeted. I am of opinion that many thousand acres might thus be secured for sowing next spring.

As to giving any assistance by advancing capital, I do not conceive it to be in the least degree necessary. The culture is not expensive; and those men who possess or occupy the proper land, are generaily in sufficient circumstances for the undertaking. They want only a sure price for a proper number of years. Mlen who are in want of so small a capital are nor likely to effeet the business. But attention should be paid to procuring large cuantitics of seed, which individuals, in case of a great extension of the culture, might not be able to procure. From ten pecks to three bushels are sown per acre.

The plans above suggested would take effect upon a very large scale next year.

As there are many allusions to the old bounty in the queries, it is necessary to observe, that they require so many forms, and such delay in payment, that no extension would inake them answer. And if a bounty should be given per acre, though certain forms would be necessary, yet thesse should be as simple as possible.

One objection to a bounty is, that it would equally encourage and reward, at the expense of 5 l. per acre, all the hemp which would be culcivated though no cuch measure was adopted, as well as new undertakiugs, alone in HORFOLK.] 
contemplation. Contrading avoids this: it also adnits a progressive experiment in which to fecl your way; but a bounty plunges at once to the full cxtent of the measure. -A. Y.

\section{$F L \wedge X$}

Is much cultivated about Wisheach, and in tise cultivated parts to Downham, at Outwell, \&xc. Four actes one rood was this year sold as it stood, for the purchaser to be at all following expenses, for 161.5 s. 6 d. per acre; and as high as I 7 l. has been given.

\section{SECT. XVIII. -SAINFOIN.}

ONE of the most valuable plants that were ever introduced into the agriculture of this kinglom, and it may be asserted, witlout danger of contuadiction, that it has beeri too little cultivated in Norfolk, especially in periods winen the price of corn has been low.

In $1784 \mathrm{Mr}$. CoKE had 400 acres; an extent to which he carried this excellent grass, in order to be able to feed off all his turnips by the end of March, avoiding thereby the common evil of permitting then to run up to blossom, for supporting the flack in April, by which the succeeling barley is always matcrially damaged: lae found the object well answered. The hay was given in well contrived racks on wheck, so that both the hay and the sheep's heads while feeding, are under cover from rain. A space sown with winter tares received the sheep in May, if the layers were not ready for then.

The same excellent cultivator then made an experiment on this grass: ten acres weresown with an addition of white 
clover; ten with trefoil; ten with red clover; and ten with sainfoin only. The result was, that the white clover division turned out the best; the sainfoin alone the next best; then the trefoil, and the red clover much the worst.

Some years after that period he tried ray-grass, and approved of it much better than any other plant for this purpose, observing, that it kcpt down the blubber-grass, so apt to come with sainfoin: but from the time of the drill husbandry being adopted he has left off all additions: the regularity of the crop being so great that all spaces are filled, and the cleamness of the land being trusted to against the blubber.

Mr. ALLEN, at Stanlow, had very fine sainfoin on a rich loamy sand, on a clay marle bottom, worth 16 s. an acre. The common crop was two tons per acre.

In 1792, Mr. Bevan, at Ricklesworth, sowed two bushels an acre of sainfoin, and six pound of clover and trefoil, to give a crop the first year.

802. It got full of rubbish, did not answer, and was ploughed up after four or five years. The method he intends to pursue is, to turnip his land for two years, both fed off with sheep, and to lay down with buck-wheat in June; sowing four bushels of sainfoin per acre: he did this some years ago, and it is now the best sainfoin on his farm. He has now 28 acres under the second crop of turnips, to be thus laid down.

Mr. Bevan has sown sainfoin with rye to good effect. Mr. WARD, of West Harling, has done the same, and got fine crops.

Mr. M. Hill sowed sainfoin on a deep gravel, and it gave, in the third year, one load and a half per acre; from the repeated failure of sceds, he has been induced to lay down this spring 48 acres. The barley drilled first at six inches, 
inches, and then sainfoin at the same distance: three bushels an acre eacli: looks very promising.

The Earl of ALBEMARLE made an experiment which, though not in the bounds of Norfolk, is in sight of it, and therefore I shall mention it here: taking into his own hands an immense farm of 4000 acres, with 3000 sheep, and wishing to provide all sorts of food as early as possible, he ventured to sow a field, in extremely bad order, with sainfoin alone in June: the foulness of the land such, that his Lordship's hope was :rot sanguine. This was in 1801 , and the crop this year, 1802, was among the very finest he had ever seen, at least two tons and a half per acre. The result is remarkable, and will certainly bring to the reader's mind the husbandry of sowing sainfoin amorg couch in Gloucestershire, mentioned by Mr. Marshall.

Mr. OverMan, of Burnham, has broken up sainfoin layers, and suffered such losses by the red-worm, that he was fearful of sowing corn upon the last field he plougher. He therefore ploughed it before winter, and summer-fallowed it forturnips without manure. After these he sowed barley, which crop I viewed, and found very fine; not having suffered the least attack. He remarked, that the ploughing before winter probably contributed to the destruktion of the worm, as well as the summer tillage.

Mr. Overasan broke up another field by thorough fallowing for turnips; the crop very good: he then sowed pease; the crop middling: turnips again, bad: then barleg, which was much eaten by the red-worm. This followed by winter tares, now ( $1 \mathrm{SO} 2$ ) on the ground, and $a$ bad crop.

Mr. CoKE, of Holkham, pared and burnt a sainfoin lay, intending turnips, but changing his mind sowed wheat, and the red-worm ate half of it. This shews that this 
operation is not in all cases effective against that destructive animal.

At Holkham there is much gravel, in some places to the depth of above twelve feet, the surface a thin covering of sand; no clualk or marle beneath, at any known depth. I was solicitous to ascertain whether this soil would do for sainfoin: Mr. CoKE assured me that it succeeded very well on it; but it is to be remembered that the whole country has been marled.

Mr. Orerman and Mr. CoKe drill sainfoin before drilling barley, in the contrary direction to that in which the barley is to be drilled, the rows at six inches and three quarters. Seed three bushels an acre, and perfectly regular; much mcre so than the generality of broad-cast crops.

Mr. PItT's father and grand-father both tried sainfoin upon very deep and dry gravels; there are some pits 15 or 20 feet deep; but it did not answer.

It is much approved about Binham: Mr. ENGiAnD, in breaking it up, would summer-fallow for wheat, as after laying so long the land is generally foul.

Mr. H. Blythe, of Burnham, has a very fine plant three vears old, from drilling, three bushels of seed per acre, at sis inches three-quarter rows; it is common to sow from four to five. This field before produced little or nothing, and was over-run by rabbits and game. He gave a clean summer-fallow for drilled oats, and drilled the sainfoin across the oats.

Mr. Rishton, at Thornham, broke up sainfoin I I years ofd by a bastard summer-fallow for oats; the wyerworm ate up the crop: he then laid on 10 loads an acre of dung, and soved turnips, which came to nothing (eaten also I suppose by the worm); then barley, and got I 5 coombs an acre; then pease, 10 coombs an acre; and this year (1802) a great crop of wheat. 
Mr. Broomfield, at Harpley, broke up a sainfoin layer in $\mathrm{ISO}_{2}$, by one ploughing, and got a fine tilth for wheat by much scarifying.

Sir M. Folkes has given much attention to sainfoin, but not with success: he has prepared for it by two crops of turnips in succession, both fed on the land by sheep, yet twitch and blubber-grass over-ran the crop in a few years, and some in that case has been spoiled in three or four: he has been careful not to feed it with shcep; and he has harrowed it the third year severely, cross and cross, and from corner to corner, yet without destroying the blubber. By reason of this circumstance the culture does not flourish at all. When broken up it is fallowed for wheat, and the crop generally good.

\section{SECT. XIX.-IUCERNE,}

Was cultivated, very successfully, thirty years ago, by Sir JoHn TURner, at Warham, on a turnip sandy loam, of the rent of $7 \mathrm{~s} .6 \mathrm{~d}$. an acre: he sowed it broad-cast after turnips, and without corn. Every spring he harrowed it severely, till it carried the appcarance of a fallow; manuring, at the same time, with six loads an acre, of rotten dung. It was cut regularly every five weeks, and has been often known to grow from 22 to 26 inclies in 28 days. It maintained five horses per acre, from the middle of April to Michaelmas: this, at only 2s. per horse per week, is I3l. an acre-at 4s., 261.

Mr. Allen, at Stanhow, had drilled lucerne at one foot, which succeeded well on a good loamy sand, on a clay marle bottom.

Mro 
Mr. Fowell, of Snetierton, to Arthur Young, Esq.

I beg you will communicate to the Board of Agriculture, the following experiment, on feeding horses with green lucerne.

In the summer of 1797 , I fallowed a piece of land of seven acres, being part of a farm belonging to the Right Honourable the Earl of ALBEMARLE, situated in the parish of Snetterton, in the county of Norfolk, and in my cccupation. 'The soil a sandy loam, upon a clay marle bottom, worth to reni, about $15^{\text {s. }}$ an acre, exclusive of tythe.

The above land, in June of the before-mentioned year, was sown with turnips, which were well hoed; the following spring it was properly prepared, and the last week in Apil, was sown with six pecks an acre, of barley, and also with 2olb. of lucerne and 4 lb. of clover an acre, broad-cast, which were harrowed in with the corn. In the summer of 1799 , the grass produced by the lucerne and clover-seed, was mown and made into hay, and the after-grass fed with cattle. The following summer (1800) the clover disappeared, and left an abundant crop of lucerne, a part of which was given green to horses, and the remainder mown twice, and made into hay; but as no register was made, I cannot state any particulars.

In the summer of $180 \mathrm{I}$, I determined to keep an accurate account of a certain quantity, the result of which was as follows:

On the IIth day of May I began mowing 4 acres I rood and 24 perches of the ahove lucerne, which I liad purposely divided off, and applied it by feeding ten cartloorses, in a walled-in yard. There was neither hay nor 
corn given to the horses, except the first two weeks they were taken into the yard, when two precks of oats, with some.chaff, were allowed each horse per week, to prevent any ill consequences from the too sudden change from corn and hay to green food, and they were fed entirely from the aforesaid 4 acres I rood and 24 perches of lucerne, till the 2 ist of September following, making exaclly 19 weeks from the period of their first going into the yard. I cannot state with accuracy the quantity of work done during the above 19 weeks by the ten horses, but, as near as I can estimate, eight out of the ten went to plough or other work, nine hours every day (Sundays escepted), and were in excellent condition during this experiment. The yard in which the horses were kept, and which they never quitted except when at work, was littered with refuse straw from other yards, green weeds from borders or waste land, or any other refuse litter that could be converiently procured. The dung was turned over after the horses were taken from the yard, and afrer remaining about a month in heaps, produced 62 loads, at 36 bushels to the load. The grass had a slight top-dressing of peatashes the first winter, and has received no manuring since, except a small part, which did no material good. The first mowing commenced the ith May, when it was fiftecu inches high; second mowing Gh July; third mowing I 8 . h August.

I was induced to adopt the above method of summerfeeding horses, from the inconvenience I had previously experienced, from having but a small quantity of pasture land, and the consequent difficulty of preventing them from breaking the fences, and getting into and damaging the growing crops of cor:.

Calculation of the value of the 4 acres $I$ rood and 24 perches of lucerne, above-mentioned: 
Keeping Io horses 19 weeks, at 6s, per horse per week - $\quad$ - $\quad-£ .5700$ Sixty-two loads of compost, at 35 . per load -960

$6 6 \longdiv { 6 0 }$

Deduet $2 \frac{\pi}{2}$ coombs of oats, at i2s. $£$.I 100 Chaff - - - 060 Refuse straw and litter - $\quad 200$

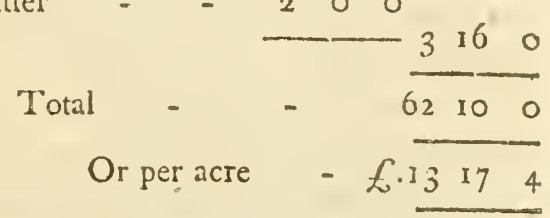

With the greatest respect, I remain, SIR, Your most obedient humble servant, RICHARD FOWELL.

Snetterton, near Harling, Norfolk, Ist Dec. 1801 .

I viewed the crop described in the preceding account, and found it very fine, regular and clean: Mr. FowelL had twelve horses soiling on it, and some pigs in the yard, which had nothing else, and which were in very good order. He has seven acres; has sown ten more with this year's barley, which I examined, and found it had taken perfectly well, and promised to be a fine crop: he intends eight acres more next year, meaning to mow it for liay. The ten acres are the half of a ficld, the other half sainfoin, for comparison. He thinks the luceme will beat the sainfoin.

Mr. Bevan sowed at Riridlesworth, in 1793 , thirteen acres broad-cast, with barley; seed tcn pounds an acre, and also six pounds an acre of red clover, on good sand, worth I2s. an acre. In 1794 he mowed half for soiling 
and half for hay; the latter two tons per acre; the lucerne wos predominant, rising four or five inches above the clover.

Mr. Bevan's is now nine years old, and is still very profitable, and had it not been attacked by the parasitical plant which infests it, would have been now in full perfection. He has sown twelve acres more, which is now in the second year, and promises to be vcry produchive. He approves highly of the culture.

Mr. Bkvan, in order to get rid of the parasitical plant which is so apt to destroy his lucerne, half ploughed it in the sprring of 1802 , and harrowed in spring tares, which gave him a very good crop: it did not damage the lucerne, and checked the weeds. A very good thought.

Sir Mordaunt Martin has cuitivated luceme $3^{6}$ years; has tried it, transplanted, drilled, and broad-cast, but, from much experience, finds the last by far the best way. Sows $161 \mathrm{~b}$, an acre; it has lasted 17 years, and when ploughed up, it was like ploughing horse-radisls. Three roods have given a good noon-meal to six horses, for seven years together, the racks being filled. Has had eight acres of it, but scalding in the summer, ploughed up six of them. He thinks a fair growth of it exceeds a crop of tares: has only gravel for it: it will not do on wet land.

The Rev. Mr. Crow, of Eurnham, has cultivated it for many years; and found that nothing could recompense the cxpense of cleaning the rows of the drilled, and if the alleys are very clean, then the lucerne is dirtied, so that broad-cast beats it greatly. It has lasted seven years; he has had four cuttings.

Mr. Priest, of Besthorpe, copied Mr. FownLL's example, and sowed three acres near his stables, broad-casthe has got a very fine plant: this the first year. 
SECT. XXI-MANGEL WURZEL.

Sir Mordaunt Martin has cultivated it from irs first introduction; and generally with great success. Has usually four or five acres. He has drilled it for the purpose of better cleaning; drills it with CooKE's wheat cups, so reduced by putty, as to sow half a peck an acre. But intends it, in furure, broad-cast, as the seeds are apt to be buried. Sow's about the middile of May, to the 2oth, being apt to run to seed if earlier. He is persuaded that an acre will carry more cow stock than an acre of turnips. It will keep loggs perfectly well, but better for large than young ones, - 3 apt to scour: if he wanted them for hogs only, he would still have them, as very beneficial for that stock. He usually sows it after barley. They keep in the same way as potatoes: his method is to open a furrow and fill it, and then turn two furrows over the roots, observing that the ridge thus formed, is left sharp to shoot water off. He has a very high opinion of them, and found that they will fatten a beast faster than any root he has tried: on this gravelly loam, they yield a much better crop than either carrots or parsnips.

1802. He has this year a flourishing crop. I was unfortunate in his absence when 1 called at Burnham.

SECT. XXI.-POTATOES.

THE quantity of potatoes in the south of Norfolk, is very inconsiderable; and in Fleg, I saw but a thin scattering of very small pieces.

Mr. 
Mr. Everit has found that they exhaust the soil more than any thing.

Mr. Cubit, at Catfield, had an acre two years ago, which produced 481 . at 6 s. a sack: the rest of the field was turnips; then wheat after the potatoes, and barley after the turnips, seeds with both; and now, where the potatoes grew, is a bed of rubbish, the rest clean.

Mr. REPTON has raised potatoes for the consumption of his farm; but not when he has any prospect of buying them, which he lias done at Is. 6d. to 2s. 6d. a sack. He steams them for young cattle, \&cc. laving a very com-. pletc apparatus for the purpose; boils five coppers, which steam 50 or 60 bushels a day, and answers well; ajso turnips, an! pours their liquor on to cut chaff, giving the whole mixed together; it answers extremely well; the cattle licking it up with great avidity, and doing perfectly well on this food.

This root is much in use amongst the poor at Thornham, \&c. their gardens are full of them.

A good many near and around Downham, and wheat after them; but Mr. SAFFORY sows barley, for he has found they make the land too light for wheat.

SECT. XXII.-OF THE DRILL HUSBANDRY.

THE introduction of this culture has given a new face to the fields of West Norfolk; and a new spliere of inquiry to the agricultural reporter. Some notes respecting this subject, have been introduced in the detail of particular crops; but more general observations have been reserved for this section. 
Mr. Drozier, of Rudham-To raise a great crop of wheat, how would you put it in-would you drill it? No. I would dibble. Mr. Drozier, last harvest, had dibbled and drilled; the dibbled beat. In 1800 he had sone drilled; but in $1 \mathrm{SO}_{2}$, I heard that he drilled again.

Mr. Haring, of Asla Wicken, put in wheat, dibbled one row on $a$ flag, and it beat the drill.

Mi. Holland, of Bircham, in I799, lost hals his crop of barley by the drill; and in I 800 , his drilled whear was much too thin: he then determined to drill no more. His stubble did not give any signs of bad management. He remarked, that he has seen no drilled stubbles that do not shew gaps much more numerous than ought ever to be seen,

Mr. Whiting, of Ering, has been long in the pracsice of drilling, which he prefers much to broad-cart sowing: drills all his corn. Has a high opinion of dibbling, and for produce, knows not which to prefer; but drilling admits the hoe, which is a matcrial point.

Mr. BRADFIELD, of Heacham, never drills. As to saving a ploughing by drilling barley, he will not admit it to be a saving; it is an earth that pays well. One-horse ploughs for putting in barley on one eartl, the best instru- . anent that has been invented. He also observes, that in a long course of experience, he had never seen a thin crop of wheat, but if any mildew happened, it was sure to be struck: drilled wheat is the thinnest of all, and most subject to mildew. In 1800 , all the drilled crops he viewed were much mildewed. His neightour, Mr. NorTON, had in 1799 , a very thin drilled crop; and in 1800 he drilled none.

In I792, I found the chief part of Mr. Overman's farm drilled, and in very beautiful order and cleanness; his stubbles 
stubbles carried unequivocal marks of good husbandry; He was then in the third year of his drilling; the experiments of the first encouraged him. In the second, his drilled pease yielded twelve coombs and a half an acre; the dibbled ten, and the broad-cast eight. In 1792, the thind year, all his pease, and the greatest part of his whear, were drilled, and superior to what he had broak-cast in 1792. He has attempted more than once to drill barley and oats, but was then convinced it would not do, and did not intend to try it any more; but he changed lis mind afterwards: he drills six pecks an acre of wheat; sows two hushels; he horse-hoes once, doing an acre per hour, if the furrows are long; and hand-hoes twice, each time at 2od. per acre. I vicwed his machine at work, drilling wheat; a suspended marker forns the line by which the horse walks: the boy who guides, does not leal, but rides upon him, and goes quite straight by seeing the mark always between the horse's ears. The man that bolds, direets the plough by the wheel mark; and as he holds for that purpose only one handle, the pressure is counteraeted by a leaden weight hung on the other handle. The work completely straight. He considers the saving of seed as something. In I 791, this saving, after paying all the expenses of hoeing, gave a balance of 281. 10s. yet the prices of corn were wheat, 24l. a last; barley, 11. IOs.; beans and white pease, 15 l. Women hand-hoe the whear at 2od. an acre; $3^{\text {s. }} 4 \mathrm{~d}$. for twice; and it is then earthed up by horse-hoeing. The rows nine inches asunder: By drilling barley he saves an earth; and thinks that the drill supersedes the use of one-horse ploughs. He never hoes it, but harrow's in seeds.

Mr. OVERMAN is a gentleman of such clear and intelligent 
gent abilities, that great deference ought to be paid to his opinion.

Putting some questions to him on broad-cast husbandry, his reply was: "Pray, don't ask me questions about :he broad-cast husbandry; for I wish to answer you from practice, and I have been so convinced of the superiority of the drill, that I have had no broad-casting for some years, and never shall again."

Sir Mordaunt Martin, Bart. at Burnham, lias practised the drill husbandry ten years, for barley, oats, and retches, for soiling, at six inches; but no hoeing: has had fouiteen coombs an acre, of barley and oats, and has had a last an acre of Tartarian oats, broad-cast. Has never observed that the drilled crops ripened more unequally than others.

Sowing on one earth in putting in barley, lie considers as belonging to the drill. Sir MORDAUnT is very well satisfied with the result of his experience; he sows the seeds broad-cast, and harrows. Barley tillage is, first to scale in the tath, harrow, and then plough deep. Then harrow once for drilling, and once after; then sow the seeds broad-cast, and harrow twice, and with the harrows drawn backwards, an iron being fixed for the purpose, by which means the seed is not drawn out of the ground.

In the period of Mir. CokE's broad-cast husbandry, Iy 8 4, I found that he had two years before carried eleven coombs and one peck of clean barley to markct, over 162 acres; and that year he had 300 acres, estimated by all who viewed it, part at twclve coombs, and the whole at ten.

In 1792 I was at Holkham, and found Mr. Coke then drilling on a considerable scalc. In 179 I he drilled 76 acres of barley, which produced 34 lasts 13 coombs three bushels, of nine coombs two bushels one peck per acre: 
93 acres sown broad-cast produced 44 lasts 18 coombs two bushels, or ten coumbs two pecks per acre.

As it was a common practice in the district of Holkham to break up a second year's layer (and sometimes of three years) at Midsummer, to give a bastard-fallow for wheat; a husbandry still common in Wiltshire, where they begin with raftering, it should seem that one great benefit of the drill is the saving this tillage on all light soils. But it oughi certainly to be remembered, that this saving belongs to the dibbling husbandry as well as to drilling.

It was with much plcasure I viewcd Mr. Coke's farm at Holkham in 1800 : every sort of corn was all drilled, and in a masterly manner. The wheat, however, not great that year, being apparently too thin; and I pointed out to Mr. Wright many gaps in the rows, of nine inches, a foot, and even two feet in length. If a general thinness is a fault, such gaps add much to it. I made the same remark in other person's crops. Mr. CokE's distance of row's nine inches; always hand-hocs twice at 1s. $8 \mathrm{~d}$.; 2s. and sometimes much more per acre.

Some of the crops were immense, particularly barley; and all the barley I saw was cxtremely good; one acre certainly produced, as MIr. WRIGHT, the bailiff, assured me, ig coombs one bushel.

Mr. CoKe had that year some drilled turnips, but bis broad-cast oncs far exceeded them: these were capital. In drilling corn, the distance for barley six inches; never hoed, but drilled after harrowing on the stirring earth; then the secds sown broad-cast, and harrowed again across. Thus the only advantages attending the drill in this crop, is-depositing the seed at a more regular deptls than the harrow will do, and saving an earth ploughed by one horse. And one man and one horse putting in an acre a day of barley, 
barley, will reduce the saving of the earth to something not very considerable on these soils.

The seeds of two years are once ploughed very carefully for drilling wheat, and this operation is trusted only to the best ploughman on the farm; that the furrows may be so evenly and neatly lapped together, as to enable the drill to be safely used longitudinally, which is Mr. CoKE's and Mr. Over ma n's practice both for wheat and barley. The wheat is hand-hoed twice, in March and April, at the expense of $4 \mathrm{~s}$. an acre; the barley not at all. The wheat is at nine inches, the barley at six and three quarters.

Several gentlemen present at the sheep-shearing at Holkham were of opinion, that in the district of that seat, extending one way to Hunstanton, another to Swafham, and East to Holt, I 5 acres in 20 of all the corn sown, were this year put in by the drill.

In $1792 \mathrm{Mr}$. Bev AN had made some experiments with Cook's drill, with DUCKET's, and with the drill-roller, and at that time much preferred the last.

1802. From 1792 to this time he has had no drilling; but this year hegan again.

Mr. BEvan, in 1800 , had six acres of wheat drilled at nine inches, in the middle of 50 acres; 44 put in with the Norfolk drill-roller. Those six acres were mildewed, and the 44 quite bright. The drilled appeared also very inferior in every respect. Mr. DAY, the bailiff's expression was, the broad cast will beat out and out.

In discourse with $\mathrm{Mr}$. BEvAN, in I $\mathrm{SO} 2$, after viewing the very fine and clean crops at Holkham, he said that he had for some years been in doubt upon the question; he had tried it several times, but the result was not favourable: but this year having been desired by Mr. CokE :o give it another trial, he had done it, and the barley MORFOLK.]

A a

drilled 
drilled was now certainly superior to the broad-cast. His neighbour Fow ELL, of Gastrop, drills every thing.

Mr. Fowell, of Snetterton, has drilled all his farm for twelve years, and has not the smallest doubt of the superiority of the husbandry to the broad-cast; not only in yielding superiur products, but also in being cheaper; he lays much stress on saving tillage, putting in lis barley and pease on stale furrows scarified: this is, however, clearly applicable to the broad-cast. He will not by any means admit that the scuffle, or the one-horse plough, will bury seed-barley at sa equal a depth as the drill. In Snetterton there are five farmers: four have drills; the fifth is a small one, for whom Mr. Fowell drills. They have come about to this husbandry wifin two or three years, from seeing Mr. Fowell's crops. In Harfham there is some drilling. Mr. Goock, at Quedenharn, drills all. In Illington there are two farmers, and both are drillers. In Little Hockham one, Mr. Kiтton, and he drills all, and scarifies a stale furiow for barley. At Wilby three farmers; and two, Mr. PALMER and Mr. Bowles, drill very well. At Gastrop, Mr. Fowel d drills all.

The Rev. Dr. Hinton, at Northwold, has made some intercsting comparisons: on a mixed loam he drilled, at twelve inches, with Coox's drill, one bushel, four quarts, and half a pint per acse; broad-cast one bushel and 29 quarts. Hand-hoed the drills thrice: ivceded the broadcast. The former produced 44 bushels two quarts; the latter, $3^{\delta}$ bushels is quarts: weight of the dirilled $62 \mathrm{lb}$. 2 oz. per bushel; of the broad-cast, 6 i ib.

He drilled barley at 12 inches, and hoed in clover seed 25 days after: the crop better than broad-cast, and the clover took well; winch, however, is not common, for is often fails thus put in. 
His drilled turnips were at least equal to those sown broad-cast.

Dr. Hintos does not drill spring corn, as it is not a practice, except out of course, on account of the seeds, which will not do in drilled crops: has been tried by others, and the crops failed; but for winter corn, better than broad-cast on sandy loams; but it will not do on strong wheat soils as a general practice.

Mr.SALTER, at Winborough, whose soil is a wet loam on a clay bottom, which requires dräning, does not drill, as he thinks his land too stiff and difficult for it ; but dib. bles largely.

In discourse with Mr. Salter, on the drill hus. bandry, and inquiring how far it could be made applicable to his difficult land (note, however, that he has several fields, the surface of which is an unquestion. ed sand, upon a strong under-stratum, yet called strong land fields), he gave it decidedly as his opinion, that it would not do: yet he understands drilling, and has practised it at Srarehill. He appealed to his vast crops of dibbled wheat, and immense ones of barley, this year, $\mathrm{ISO}_{2}$, promising nine or ten coombs an acre of the former, and fifteen, sixteen, and even more of the latter, and denanded whether drilling could, or did any where beat them? A respectable party of Norfolk farmers were present, and two drillers among them, but they were silent, and all equally struck with the uncommon crops we were then exainining.

The Rev. Mr. Munnings, at Gorget, is upon a most unkind sharp finty gravel; red gravels are usually good soils, but his are blachish, from a mixture of black sand; nearly tle worst of all soils: on this land he drills turnips at eighteen inches; also oats at niue inclies; pease at nine and twelve; and once he tried wilheat. 
Mr. MUNnengs drills his poor gravels with his barrow-drill. I viewed his turnips at eighteen inches: a very regular and well executed crop.

Mr. Hart, of Billingford, in 1802 , drilled turnips at six inches, cutting up in part of the field every other row, and in part cutting away two rows and leaving one: part also broad-cast, for comparison; done with Cook's machine, and part horse-hocd with his tools; part with $\mathrm{Mr}$. MUnnings' expanding hoe-plough. Last year he drilled all his barley, and it answered better than the broad-cast; and this year all his corn is drilled, except the allonds; these drill rolled, a practice pretty general here: but the small farmers dibble.

It is gradually coming in around Dereham, and dibbling rather going out, for want of dependence on the droppers.

I viewed Mr. Collison's farm at East Bilney, and found several crops drilled, which made a very fine appearance: one field of wheat by the barn promises to produce ten coombs an acre; some barley also very fine, and the crops in general clean: all at wine inches, and the wheat horse-hoed thrice; barley twice if no seeds, but with them not at all, as the seeds are covered by the harrow which follows the drill: Mr. Collison, however, has horsehoed in some seeds, and did not fail. He drills seven to ten pecks of seed-barley. Mr. Collisos prefers the drill very much: he forms his lands to be worked at a bout of the drill, the horse walking only in the furrows, and the same in horse-hoeing; a point he justly esteems essential for all heavy or ticklish land. I put the question home to an intelligent labourer who has worked 40 years on the farm, and he assured me that if he had a farm of his orn, he would drill all the wheat, and horse-hoe it likewise, for when land is bound in the spring, to break the surface makes the plants grow well; 
but as to drilling barley he spoke very doubtfully, but said it was less liable to be laid: and in a dry time it comes best drilled.

Drilling on light lands which are laid flat, is no difficult operation, but on strong, tenacious, clung soils, it is no such very easy matter, without much attention. The Rev. Dixon Hoste, however, at Goodwick, has effected it with a comnendable regularity: one method he practises, is that of drilling atliwart the ridges; to prepare which he sometimes trench-ploughs.

Drilling is very little practised in the neighbourhood of Norwich. Mr. Crowe had a machine of Mr. Cook's, which he gave to Mr. Sillis, of Hertford Bridges, but lse never used it. Mr. CrowE is so satisficd of the use of dibbling, that he desires nothing better.

Many driils in the vicinity of Thelton, a heavy land district, and much used of late.

Mr. KERRICH, of Harleston, drills or sets all his corn. Many drills in Earsham hundred; and several farmers drill for their neighbours at 2s. $6 \mathrm{~d}$. an acre. There is, however, as much dibbling as ever; the drilling having chiefly been substituted for broad-cast sowing.

Mr. BuRTon, of Jaingley, approves much of drilling, and has seen Cook's machine beat dibbling: he, however, does not drill himself, observing that he is absent too often.

Mr. DRAKE, of Billingford, near Scole, drills both wheat and barley, he has three fields of drilled barley this year, with part broad-cast; and the latter beats in all tnree: lis drilled wheat good, and he prefers the drill for that crop much more than for barley.

Mi. Thurtell, near Yarmouth, has for two years drilled almost all his barley, by that means saving one ploughing. 
No drilling in Fleg that I could hear of. Very little in Blowfiell and South Walsham, but it is coming in, and Mr. SYBLE is clcar that it will spread.

It cannot be said that drilling is quite unknown in the hundred of Happing, but I heard of very little, and saw none: a man last year travelled with a drill, for drilling at 2s. 6 d. an acre, and some farmers employed him. Some farmers use the drill roller.

Very little practised about North Walsham. Mr. MarGATESON approres much of Cook's dill. Mr. LubBock, of Lanmas, and Mr Repton, of Oxnead, are the only drillers; they practice it much.

Mr. Palgrave, of Coltishal, has drilled wheat, barley, and oats, for 17 years; has tried four and a half and six inch rows, but finds nine the best for all. The merit of the husbandry he thinks consists in the equal deptl at which the seed is deposited, and were this equally effected, does not conceive there would be any difference in the crops, whether put in by dibbling, drilling or broadcast.

Mr. Ref.ves, of Heveringland, has drilled most of his corn for three years, and is clearly convinced of the merits of the practice, and determined to continue it.

Mr. ENGLAND, of Biulam, has drilled all sorts of grain for five years past, and is perfectly satisfied with the practice; nor has he the least doubt of the superiority of it to the broad-cast method; there is little dibbling in his neighbourhood, drilling having superseded it.

Mr. REEve, of Wighton, has been a driller four years, and for all sorts of corn: he has no doubt, and makes not the least question of its superiority to the broadcast liusbandry. I viewed his stubbles with singular pleasure, and a more beautiful spectacle of cleanness I never beheld 
beheld_-absolutcly and positively clean; not a weed to be sees in those of wheat, commonly so foul.

Mr. M. Hill began drilling about five years since, and ever since practised it as his general system; and is clear in its superiority, for every thing except barley, at six inches; in that he has some doubis. He has tried it for turnips, but none at present.

Mr. HeNRY BuYThe, of Burnham Westgate, has drilled every sort of com for twelve ycars, beginning in 1790 with wheat, and has continued it ever since. He is well convinced of the superiority of this husbandry.

Mr. Dursgate, of Suminerfield, who, if not the greatest farmer in Norfolk, is nearly so, drills every crop except turnips, and of course las no doubt of the superiority of the method to the broad-cast husbandry. On his stiong land farm at Palgrave, however, the drill is not so universally used as at Summerfield, Sedgford, and Docking.

Mr. Rishton, at Thornluam, drilled all sorts of corn, and has no doubt of the method much exceeding the broadcast husbandry.

Mr. Styleman, of Snetrisham, was one of the first drillers in Norfolk: he began the use of Cook's machine sixteen or seventeen years ago, and has continued it regularly to the present time, keeping three machines in use. $\mathrm{He}$ is perfectly convinced of the superiority of drilling to the broad-cast husbandry.

Many farmess around Houghton drill much corn, and approve of it exceedingly.

Captain BEAcher, at Hillingdon, drills all : the practicc increases much, and promises to be universal.

Mr. BЕсK, of Castlc Riseing, drills largely, and has done so for seven years: the husbandry meets with his en-
A a 4
tire 
tire approbation. I viewed some of his stubbles, and found them very clean : on his sandiest soils, he, however, does not drill, hecause he cannot so put the seed in deep enough.

Drilling is a little practised about Downham, and is preferred by several farmers.

Mr. Porter, of Watlington, drills both barley and wheat, and this year all, except on strong land, and finds the crops a great deal better than broad-cast. He hoes all; thus covering the seeds amongst his barley; but they do not take quite so well as in the common way. He hoes, at the expense of $2 \mathrm{~s} .6 \mathrm{~d}$. to $4^{\mathrm{s}}$. an acre, once, and is clear that the benefit to the crop is very great : has had 13 to 14 coombs an acre, of balley.

Mr. MARTIN, of Tettenhall, this year drilled 190 acres of barley and 20 of wheat; is convinced of the superiority to the broad-cast.

Mr. Rogerson, of Narborough, was a very gieat driller, but not at present.

About Wymondham, drilling coming in, and has been so more or less for several years. Mr. WeLLs, of Hethel, letts his drill by the acre. Mr. CHURCH, of Flawdon Hall, drills all.

Mr. Priest, of Besthorpe, drilled largely for eighit or nine years, at Shropham, on sand, -nd continues the practice on strong land: he is much inclined to think that it is a superior method to the best broad-cast. He has drilled all sorts of grain.

Mr. Twist, of Bretenlan, drills all the corn he can, except rye; and has no doubt of its answering.

Observations.-From these notes it appears, that, notwithstanding some failures, and probably many prejudices, the drill culture has very completely established itself 
in West Norfolk, and is spreading into the other districts of that extensive county. The success appears, on the whole, to be very flattering.

But there is one singular circumstance which should, so far as Norfolk only is concerned, check the unlimited panegyrics sometimes too generally heard in conversation, and that is, there being, at least to my knowledge, but one farm (Mr. Hoste's) on strong or clay land, where this practice is thoroughly introduced. Suffolk affords multitudes; but Norfolk is at present our business; and here the farmers on strong land, have hitherto rejected it. This is remarkable, as I have heard some very able dritlers give it as their opinion, that this husbandry has greater merit on strong than on light land.

\section{DIBBLING.}

Mr. BuRTon, of Langley, remarked, that good as this practice was in some respects for the poor, there are inconveniences flowing from it. Girls, old enough for service, are kept at home by it. Gleaning is their employment in harvest, which gives them idle habits in the fields, then dibbling follows; and the girls lying about under hedges with the men, produces the natural consequences on their manners; bastardy flourishes, and maid-servants are uncommonly scarce.

Dibbling flourishes very greatly in Fleg, both wheat and pease, and oats.

Mr. HoRnard dibbles part of his crops, and soms part, and he is not jet convinced that the dibbled exceeds the sown. About Ludham, and through a great part of Happing, it is not so general as in Fleg. About North Walsham it is hy no means gencral, except for pease. 
MIr. PETRE, of Westwick, puts in about roo acres of wheat, of which he sows and drills 80 , and dibbles 20 .

Mr. JoHnson, of Thurning, makes the same observation on the ill effects of dibbling as Mr. Burton. The great girls do not drop so well as children, nor is the work so well done as formerly: they now drop between the fore-finger and thumb, which is much inferior to doing it between the fure and middle finger.

Dibbling is common around Wigiton, for wheat and pease; and Mr. REEve thinks it a great improvement upon the broad-cast husbandry, but that diilling is a step further.

There is at Snetisham much dibbling, pease and wheat on flag; and Mr. STYLEMAN thinks it never will be abandoned, as there arc seasons that do not suit drilling.

In Marshland, the practice obtains every where for wheat on clover, and some on clean stubbles; ros. 6d. an acre. It increases.

Practised about Downham, and with good success. Mr. Saffory dibbles all he can, and thinks it a great improvement.

SECT. XXII.-ON THE NORFOLK ARABLE SYS-

TEM.

For the last four or five and thirty years that I have examined West Norfolk with the eye of a farmer, the change in the tillage system has not been great. At that period the course was, I. Turnips; 2. Barley; 3. Grasses for two, or, in a few cases, three years; 4 . W'hite-corn; on the better soils wheat; on others, rye, \&c. The only change that has occurred has been in the grasses: the variation, 
riation, which I believe first took place from forty to fifty ycars ago, was shortening the duration, from three years to two: in both cases giving what may be callet a bastard fallow the last year, by a half-ploughing, soon after Mid. summer. Above thirty years ago, 1 contended, both in print and in conversation, against it, but was held cheap for entertaining any doubts of the propriety of the practice. I have lived, however, to see this change also in a great measure take place amongst the best farmers, who now give only one ploughing for the winter corn, whether wheat or tares; or in the spring for pease. That it is an improvement, cannot be questioned. The argu, ment for it, founded on the invention of the drill-roller, and on the introduction of the drill-plough, is good, but nor singular, as the practice of dibbling is likewise far more adapted to a whole than to a broken furrow : and for broad-cast common sowing, if we are able to cover the seed by harrowing on stiff soils, once ploughed, assuredly the same practice might be betier followed on sand. The other reason for the former system, spear-grass getting a-head in a layer, is quite inadmissible: for 1 must agree entirely with Mr. OVEKMAN, that no weeds, the seeds of which are not carried by the wind, will be found in a layer, if they were not left there.

The variations which have taken place in the crop put in upon layers, are neither great, nor are they peculiar to Norfolk: the principal one is taking pease on the flag, and then the wheat, \&c. an admirable systen, which has long been practised by good farmers in Suffolk, and I believe, earlier still in Kent. Mr. PURDIs's substitution of tares, holds on the same principle. Considering the very great value of white-pea straw, well got as shecp food (no where better understood than in Kent) there is 
no liusbandry better adapted to a sheep-farm, than this of pease or tares preceding the wheat crop.

A great and a very important change has, however, taken place in the application of crops to sheep instead of bullocks and cows. Formerly the farmers consumed much of their straw by cattle: now the best tread it all into dung.

Sheep are the inain grazing stock, and no more cattle kept than for treading, not eating straw, while feeding on oil-cake, \&c. This is an important chatrge, which has had considerable effect, and has depended not a little on the introduction of South Down sheep.

The grand object in the whole system, is the singular stcadiness with which the farmers of West Norfolk have adlhered to the weil-grounded antipathy to taking two crops of white corn in succession: this is talked of elsewhere, but no where so steadily adhered to as in this district. It is this inaxim which has preserved the effect of their marle, on thin-skinned wheat lands, in such a manner that the district continues highly productive, under an alınost regularly increasing rent, for more than 60 years, or three leases, each of $2 \mathrm{I}$; and by means of which great tracts have been marled a second, and even a third time, with much advantage.

This system has been that to which the title of Norfolk husbandry has been long, and is now peculiarly appropriated; and by no means the management of the very sich distric of East Norfolk, where the soil is naturally among the finest in the kingdom, and consequently where the merit of the farmer must be of an inferior stamp: barley there very generally follows wheat; an incorrect husbandry, deserving no praise. The celebrity of the eounty in general was not heard of, till the vast improvements of heaths, wastes, sheep-walks, and warrens, by 
enclosure, and marling took place from the exertions of Mr. Allen, of Lyng House, Lord Toirnshend, and Mr. MORLEY, which were in the first thirty years of the preceding century. They were happily imitated by many others; an excellent system of management introduced, and such inprovements wrought, that estates which were heretofore too insignificant to be known, became objects of public attention in the capital. The fame of Norfolk gradually expanded, and the husbandry of the county celebrated, before East Norfolk was heard of beyond the conversation of Norwich and Yarmouth.

Without a continuance of cautious management and persevering exertions, West Norfolk would again become the residence of poverty and 1 abbits. Let the meadows be improved; irrigation practised wherever it is applicable; the remaining wastes cultivated, and this district will become a garden.

Mr. MARshall, who considers the practice of East Norfolk as alone deserving the title of Norfolk husbandry, mentions 40 or 50 bullocks, on turnips, as a matter of exultation. In 1768, I registered the fact, that $\mathrm{Mr}$. Maliet, of Dunton, had 280 bullocks fatting on tur. nips, on a farm aluost wholly arable.

This ingenious writer appears, in various passages of his work, to consider East Norfolk as deserving the most attention. In this, I am sorry that I must differ from him greatly; and I think, that had he resided on the other side of the county, he would have adopted a different opinion himself.

"In West Norfolk, no general plan of management has yet (1780) taken place." "Viewing the state of husbandry in West Norfolk colle@ively, it is much beneath that of East Norfolk." In West Norfolk, the most steady and regular plan of management had then, and for 
many years taken place, that was to be found in the kingdom; and at that time, probably, for the soil, the

- best. It is to be regretted, that so very able a writer did not examine it with more attention.

There are some circumstances in the husbandry of Flcg, \&c. which deserve attention, hefore the merit of it can be duly appreciated. 1st, The soil is certainly amongst the fincst in the kingdom. 2d, They are within reach of marle, by water carriage, to every part of the district, comprehending, besides the Flegs, the hundreds of Happing, Tunsted, Blowield, and Souh Walshans: and they have, in addition, great plenty of a fine clay marle for variation, under many parts of the whole. 3ol, They have an enormous quantity of marsh and fen, and low rough waste, and rushy grounds, which yields a very considerable bulk of coarse hay and rushes, with which to make yard-dung, as well as to support great herds of cattle. Examine the map, and it will appear that near half the district is marsh, fen, and water. 'These are circumstances so favourable to the arable part of the country, that I am more surprized their products are so small, than that they are so great. In discourse with Mr. HoRNARD, of Ludham, on two years layers, he said, that he was forced to have recourse to them, for since the sea, eight or ten years ago, broke througls the Marram banks, and flowed over the top of the marsh banks, destroying the rushes and coarse fodder, it has made a difference to him of 60 to 70 loads per annum of jushes, that were four feet high: now he has none, and therefore must leave hislayers two years for want of manure. What advantages has West Norfolk to be contrasted to such a circumstance?

View the two districts in another light: I conceive that no farmers in England would make more of West Norfoll, than those of the district actually make at 
present. But I have little doubt that East Kent and Isle of Thanet men, would make 20 per cent. at least, more of East Norfolk than is at present made by the occupiers: they would not be long before they shewed what beans would do in such a soil.

\section{IMPROVEMENT.}

In discourse with Mr. BirchaM, at Hackford, on the public benefit of tillage; and the effeet of the landlords restraining their tenants from breaking up grass-land; lite asserted it as a fact, of which he had not the least doubt, that tillage, well managed, would support as much livestock on the seeds, turnips and straw, as the same land would do all under grass; consequently, the corn is alf gain to the public. I am certain it would: he spoke of moderate pasture, that keeps two heasts of 40 stone per acre in summer.

Great improvements have taken place in Earsham hundred, in twenty years. The unuber of horses much les. sened, by not ploghing so often for barley; scarifying instead of it, and even putting that crop in on one earth.Mr. PAUL, of Sharston, has even trusted to scarifying only, and thus got the best barley on his farm. Besides this practice, general managenent is better; and far more weeding done than formerly.

Mr. Thurtell is clear, that in five and twenty years past, the general avcrage produce is, at least, one-fourth more, probably one-thind.

Mr. FERRJER, of Hemshy, is sure, that in lusbandry there is grcat improvement in 30 years. The seeds were then left three years; and they did not raise lialf the corn that is produced now. Summer-fallows were common then; now, no such thing known, unless by chance, when no manure for turnips.

Mr. SybLe, of South Walsham, is clear that hushan- 
dry is much improved of late years: summer-fallowing, heretofore so common, is quite done away, yet the land cleaner. Small trifling enclosures are thrown together, the hedges and pollards grubbed, and the sun and air admitted. Dibbling has spread very greatly.

Mr. Palgrave, of Coltishal, has no doube of the improvement that has taken place in 17 years; every thing is better done, and business carried on with more animation: drilling is spreading, and dibbling increased.

Mr. Parmenter, of Aylesham, has not the least doubt of husbandry being greatly improved: more land in cultivation, and a greater expense in 'manuring, and every other article bestowed.

Mr. STYi.eMAN has improved his Ringstead farm from 5s. to I 5s. an acre. A farm in Snetrisham, which he has let, from $11 \mathrm{~s}$. in 1783 , to 17 s. in 1798 ; and has laid out, improved, built, and let seren farms, at a very considerable improvement; and this he considers as the most profitable object of a gentleman's husbandry. I viewed several of his new farms, and found the buildings on a rational scale; so small, yet convenient, that the expense was no formidable objection, even for sinall farms. He has also accommodated several tradesmen in the village, with closes of land for their horse or cow, for which they are glad to give a very high rent, even to 3 l. an acre: this should universally be done; and to the poor also, though at a lower rent.

This gentleman has no doubt of the husbandry of the vicinity being much improved in 20 years, exclusive of new inclosures: the crops were then disfigured by weeds, hut now, every man is ashamed to have such seen on his farm: drilling and dibbling have done much.

Mr. SAFFory, of Downham, lias no doubt of husbandry being much improved in 20 years; they plough better, 
better, manure more, and have carried all rough banks and hills on to their fields.

Upon the heavy lands of Goodwick and the ricinity, husbandry is very little improved in the last fifteen years.

Mr. HiLl thinks that the husbandry around Waterden las wonderfully improved in the last fifteen years. He attributes it chiefly to drilling, and the various conversations which have taken place upon that topic. Another essential point, is the increase of sheep; cows nuch lesscnerl, and consequently fewer turnips being drawn for them: if the two greatest blood-suckers of an arable farm are to be named (I use Mr. HrLL's terms), they are a dairy of cows, and the sale of lambs from a merely breeding flock.

Mr. Fowel L, of Snetterton, a very intelligent and ob. serving cultivator, is clear that the husbandry of all that vicinity is much improved in the last twenty years; for besides the introduction of drilling, the rotation is improved. At that time, if their seeds laid two years, they took two crops after them; a practice of some few now; but the better farmers, never more than one. Less tillage is now given, yet the crops greater; and thev are much improved in better exertions; in hand-weeding, \&c.

Mr. Robinson, of Watton, has no doube of lusbandry, in general, being very much improved in 20 years; in almost every circumstance. 


\section{CHAP. VIII.}

\section{GR $\Lambda$ SS.}

NO person can have been in Norfolk without quickly perceiving, that in this branch of rural economy the county has very little to boast. No where are meadows and pastures worse managed: in all parts of the county we see them over-run with all sorts of spontaneous rubbish, bushes, briars, rushes: the water stagnant: ant-hills numerous: in a word, left in a state of nature, by men who willingly make all sorts of excitions to render their arable land clean, rich and productive. To make many notes would be useless, for through nine-tenths of the county, they would consist of disgusting repetitions-the same objects continually recurring, to be condemned in the same terms.

Improvement.-It is, however, with great pleasure that I have it in my porver to mention under this head, one of the most original discoveries (for such I esteem it, in common with many excellent cultivators) that I have any where met with in the improvenent of grass-land. Mr. Salter, of Winborough, near Dereham, upon his large farm o above 800 acres, found 3 or 400 acres of old meadows en. tirely poisoned by springs, which, from every sort of impediment that negleck could cause, had formed bogs and moory bottoms, famous for rotting sheep and miring cows ; with blackthorns and other rubbish spread over large tracts. His first operations were, to grub and clear the land, and open all ditches to the depth of four or five feet, and to cut open drains in almost every direction for laying them dry; burning the earth, and spreading the ashes 
on the ground: so far, all was no more than common good husbandry; but he applied a thought entirely his own: as he found that the flinty gravel, marle, and other earths, but especially the gravel, was very beneficial to the herbage, he thought of sowing winter tares and white clover upon the places wherever any earth was spread, or any other operation had laid bare the surface, harrowing in those seeds. 1 had the pleasure of seeing several of these crops growing: the success has been uncommonly great; for the land thus sown not only has given large and very profitable crops of hay, but has also received a rapid improvement in the herbage; the cover and shade of the tares, so beneficial to all land, mellowed the surface, and seemed to draw up as well as protect such of the old plants as received improvement from the manure, and exhibited a much superior fleece of grass to any spots where this singular management had not taken place. So that nothing can be clearer, on viewing this large tract of meadow, than the superiority of the improvement resulting from the growth of the tares: the effect of the manure is much accelerated and rendered greater. The idea is certainly applicable to many of the grass-lands of the kingdom, especially such as are improving by the addition of chalk, marle, clay, loam, sand or gravel: 40 loads an acre of any of these bodies will much improve coarse or wet, or moory grass-lands; and then to add tares secures an immediate profit, and makes the manure work much sooner and more powerfully. He sows some so late as the middle of May. An idea here strikes me, which I shall venture to add; that if I was to scarify any mossy, hidebound or poor pastures, \&c. it should be with a drill scarificr, drilling in winter tares by cvery tooth of the scarifier, and I have no doult but the tares would take well, and effect a considerable improvement, even without manuring. 
nuring. Mr. Salter has practised the tare husbandry on meadows for 10 years, but his first beginning was 17 years ago, 2t Ellingham: the cockchafer-grubs had destroyed a part of a meadow; lie harrorved in tares and seeds, and the success was great.

Tare-seed running short, he this year sowed pease and oats mixed on some spots, and they do well ; and this husbandry he pursues, whether he intends mowing or pasturing.

I will venture to add, that if making known this single discovery had been the whole result of examining the county, the Board would nor have failed in the object of ordering the district to be reported.

Mr. Bevan's arable sand, at Riddlesworth, joining to his low boggy meadows, gave him the power of carring sand down hill at an easy expense; and thus he improved some parts of those meadows to great effect: from 100 to 150 loads an acre were spread at the expense of 41 . or 5 l.

f. s. $d$.

A team of five horses, 30 loads a day, and

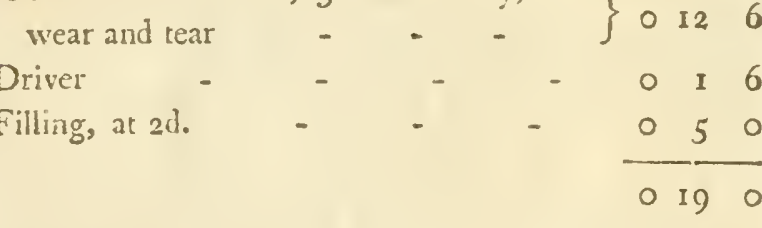

1802. It has answered very greatly: these meads were then not capable of irrigation, but one meadow has since been watered, and the water has taken much greater effect on account of the sanding, than if that operation had not been performed. The sand has all been laid on the most boggy meadows.

There is a great range of meadow and marsh all the way from Norwich to Yarmouth. Those at Thorpe are very good, and let at 5os. an acre; but at Whitlingham 
they are neglected, and therefore only 20 s. At Surlingluam are boggy marshes, and to Buckenham ferry, Rockland and Cautley, they are in a bad state, wanting much improvenent, by draining and embanking, and clearing from rubbish; these are not more ihat $\delta$ s. an acre. To Reedham better, and let at 20s. At Langley there are 600 acres newly enclosed, let at I2s. but will soon, from the improvements introducing by Mr. BURTan, steward to Sir Thomas Brauchans Proctor, be much alvanced. A circumstance not uncommon was found here: a great range of marsh, but with no safe means of com. munication with it. Mr. BURTON made a solid road banked and gravelled, above half a mile long, so traced as to communicate with all Sir Thomas BEAuCHaMp's allotment: a great and most useful work, equally well inagined and executed. Five miles of banking against the river, \&c. are also made: part drained by mills, and part by sluices. From Langley to Yarmouth the marshes are good; all 2os. and upwards, and some to 30 s.

At Dawling and Gestwick Colonel BuLler has from $\eta$ to 800 acres of pasture, which he esteems worth 30 . an acre, but let at about 2os. Some is let by Mr. CoussMAKER, a relation of the writer,' at zos. to $36 \mathrm{~s}$.

At Tasborough, between Wymondham and Stratton, some very fine well-drained meadows, with a ferrile aspect.

Mr. Jounson, of Thurning, classes with the very few in Norfolk, that have made any considerable exertions in the improvement of permanent grass; he lias converted 200 acres, which were rough, moory, and of small value, into a traet which does credit to his husbandry. He cut off the springs which poisoned them from the adjoining hills, by outside fences, acting as drains, which worked a vast improvement: moved great quantities of earth in

$$
\text { s. b } 3
$$


levelling inequalities, to the depth of five fect, to fice the land from water. Under-drained to a very great amount. 'The soil moory, and under it a gravel; part of it bog. Some parts were so bad, that no stock ever went upon it ; his predecessor let 15 acres for $5^{l}$. a year, clear of all town charges, and at that rent they were flung up, and let to another person at the same rent. At present these worst parts graze bullocks well, and are very valuable lands. These works, which were only preparatory to various other articles of good management, cost him, over a large part of the tract, rol. an acre. It is no easy matter to dwell sufficiently on exertions of this sort, in a county where they are so rare: the efforts of years, and the expense of thousands to the improver, are dispatched in a few lines--but let those who best know the deficiency of the county, estimate such works as they deserve, and hold in due honour and veneration the men who have thus laudably stepped beyond the common practice.

In these most meritorious works of this active farmes he has but one defect: a perennial brook runs througl his meadows, whicl he thinks erroneously would not be beneficial in irrigation: this will be his next undertaking: he will not continue to let it run waste.

Mr. Palgrave, at Coltishal, improved some meadows very capitally, by spreading sea-sand from Yarmouth, whicls killed all sedge and rushes, and brought up a fine sheet of white clover. The soil boggy. In I 780 they were valued at 7 s. 61. an acre, and lately by the same person at $3^{l}$.

Mr. Repton, at Oxnead, drained a large tract of meadows, and did all they would admit in good grass husbandry, but a water-mill belonging to his landlord is a nuisance to all such endcavours, and keeps the water so high that all excrtions are vain: when will landlords have 
just iủeas on this subject of mills? There is scarcely one to be found, but does mischief to an estate to ten times the value of the rent these wretched erections let at. $\mathrm{Mr}$. REPTON's father, on the same farm, improved a bog 25 years ago, as well as the mill would permit, laying a great dressing of gravel on a boggy part; but from being kept by the mill a saturated spunge, the gravel is now got down two fect deep, and overgrown with the spontaneous rubbish of the bog. If you will have mills, you must give up all ideas of true meadow improvement.

Mr. REEvE, of Wighton, may perhaps be considered as the prince of grass-land improvers in Norfolk: he has very few rivals that have come to my knowledge: one great improvement consists of 45 acres, effected wirhout irrigation; the other of 50 acres, by means of many exertions, finishing in.irrigation; the latter will be mentioned under another head. The former traet is situated between a line of chalk hill, on one side full of springs, and a mill river pent up on the other, so as to poison and turn to bog all the land below it : the springs from the hills thus meeting the soakage of the river, it may easily be supposed what the effect must be: the land was a quaking dangerous bog. His cure was effective, and such as could not fail; he tumed an arch, traced by a level, 160 yards long, for catching the soakage of the mill-pond, and continued it an open drain to the length of three quarters of a mile parallel, and near the river, gaining such a fall as now to keep the water in the drain four feet below the surtace of the land, in piaces where before it was never more than six inches. To cut off the springs from the clualk-till he run a deep ditch at the foot of the hill, varying in depth according to the level of the line, but effective in cutting off the springs.

In the parts where it must be of the greatest depth, as

$$
\text { s b } 4 \text {. }
$$


that of eight feet, he turns an arch of brick-work, as the expense of sloping down the sides would exceed it; and that the bricks of the wall against the hill may not impede the entry of the water, he has made them each with two open grooves for admitting it.

Hc has yet much to do to finish the improvement, as he intends carrying great quanticies of earth from the drains to spread on the boggy parts, to finish the consolidation, and improve the suil. From the harvest of 1801 to that of 1802 , he has had constantly at wo:k from 20 to 30 men, on this tract and that irrigated.

One of the richest traets of grass in Norfolk, is the district of marsh lying to the south of Lynn and east of the Ouzc. Sir Martin Folnes has there 700 acres, which let at $42 \mathrm{~s}$. an acre short measure, besides 2 s. tithe. The tenants are restricied from mowing two years together; a bad covenant; for mowing and fecding should be on distinct lands; and for cvery load of hay they sell, must bring three loads of muck. Some tracts in the liands of butchers are never nown, which has made them very superior to the rest. In general these marshes, like all others in the county, are hired by the upland sand farmers, and not stocked regularly, but merely as convenience occasions, to ease their farms. Tliey will carry, when so fed, a large beast to two acres, and a ferw sheep besides. They never have too much water, and can let in fresh water at pleasure.

\section{ROUEN.}

In 1792 , I found that Mr. BEvan had not read the Annals of figriculture in vain; he had a fine field of 28 acres of excellent roucn savcà for the cives and lambs in the spring.

I802. His present system of allotting ewes to different tups, in separate fields, prevents his being able to avail himself 
himself of this article of food, as every enclosed pasture is, from the $15^{\text {th }}$ of September to the $15^{\text {th }}$ of November, forced to be fed each with a lot for this purpose. But his opinion of the great value and use of rouen, is as complete as ever: the object of improving his flock, alone óccasions the change.

Mr. Mason, of Necton, near Swafham, keeps grass from the end of July, and does not turn into it at all, till early in the spring of the following year, when he puts in his fatting bullocks and sheep, which have had hay in the winter. The old grass nurses up a great bite of young growth, and both together carry on the bullocks well: and it is excellent for sheep; nothing at that season equals it.

Mr. Overman, of Bumbain, in I799, kept I 3 acres of grass, from Midsummer, an exposed piece, open to the sea and N. E. wind: turned into it 10 score and 16 ewes and their lambs the $27^{\text {th }}$ of March, and it kept them well a month. They would have been lialf starved without it; but were well supported, to the surprize of many who saw them feeding. The piece was equally tathed in cvery part.

Laying down.-Mr. CoKE, at Holkham, has laid down warious pieces with good success, and he is decicledly of opinion, that the best method is that of a fallow, till about the middle of August, and then sowing the seeds alone; keeping off all stock in the autumn, and sheep feeding for two or three years.

Mr. DEnn 1s, of Wigenhall, St. Mary, in Marshlınd, lays down with barley, or oats after fallowed wheat, sowing rolb. of white clover, rolb. of trefuil, and a sack of hay-seeds. Manures the stubble of the corn amongst which they were sown, in autumn. Shcep feeds the new lay the first year; and mucls better to observe the same for two 
or three years; by which means it comes to a good pasture soon; but if mown, it is a long time before it gets a good covering.

Break up.-Mr. REEve, of Wighton, broke up an old pasture in 1800 , for oats, which he dibbled in on the flag; he then scaled the oat stubble, and on a second earth, drilled in another crop of oats: the wyer worm did some mischief to both. He then laid on 60 loads an acre of marle, and so of muck, and sowed turnips, which are now one of the finest crops I have ever seen.

At Snettisham, 600 acres of common being enclosed by adt of parliament, much of it was broken up, in I801, for oats, by mere ploughing : they did not succeed at all. In 1 So2, they ploughed and took oats again, and the crop stili worse.

Mr. CRIsP broke up a four-acred field of old grass behind his house at Dereham; the four last crops in which, paid him rool. a year; one of which was coleseed; one wheat; another year hemp, and after it curnip seed; the former producing I49l. 12s.; and the turnip seed, 18 coombs, at $36 \mathrm{~s}$. a bushel, 12gl. 12s. It is now ( 1802 ) in wheat, and the crop very fine: he has railed off a walk around this field, and has laid it down to grass: such a piece of land affords cntertainment, and might yield instruction in experiments; - but who lias not a grass field to walk into, which alfords nothing of the sort?

Mr. SALTER, of Winborough, upon his finely cultivated farm of about 800 acres, of which he had permission to break up a large portion of old and iniserably bad grass, poisoned with springs, and over-run with bushes, and all sorts of aquatic rubbish, first surrounded every field with ditches five feet broad and four deep; then hollowdrained evcry acre completely; and broke up for a crop of dibbled oats; took a second crop of oats, and on the stubble 
spread roo loads of marle (called here, as every where in Norfolk, clay, and in much of it there is a large portion of clay), and then took turnips. His success was various; many oats lie lost by the wyer worm; and his first crop of turnips was, in some felds, very indifferent. In one large field the two crops of oats failed entirely, and the turnips the same. He has been there seven years: this year (1802) his turnips were the finest 1 had seen; serenteen hoers in one field; and all his corn an uncommon spectacle of greatly luxuriant crops.

He is of opinion that all the pastures and meadows of the farm ought to be broken up. I think he will make them excellent

Mr. Heath, of Hingham, in I795, broke up seven acres of old pasture; the soil, a turnip loam on a marle bottom, sowing oats, the crop 2 I coombs per acre.

1797 Wheat, much damaged by the wyer worm.

1798 Oats, 23 coombs.

1799 Oats, 2 I coombs.

1800 Barley, 16 coombs.

1801 Clayed near 100 loads an acre for turnips.

I 802 Barley, and the crop very great indeed.

Mr. Robinson, at Carbrook, in I795, broke up an old pasture, dibbling in oats, and got 17 coombs an acre.

1796 Oats again, 16 coombs.

I 797 Clayed for turnips.

1798 Oats, 15 coombs.

I 799 Clover.

I 800 Wheat, six coombs.

I80 I Oats, I6 coombs.

I802. Turnips.

Sir THOMAS BEEvOR broke up an ordinary pasture, and dibbled in pease; the crop five quarters an acre.Then he sowed buck-wheat; followed by wheat, which produced $^{-}$ 
produced six quarters an acre; succeeded by turnips, and baıley, with grasses.

The instances of the great profit of breaking up old grass, on whatever soil, and under whatever circumstances (but on dry land being every where superior to wet), should be combined with the arrangement of a farm in the course of shifts. Upon the poor sands of the southern half of Wcst Norfolk, say-grass and trefoil are their only dependence: their grand-mothers trusted to these plants, and the farmers of the present day do the same; after a year and a half they produce little; after two years, scarcely any thing. Thus the land does not get rest enough: when broken up, it has not been sufficiently impregnated with the dung and urine of sheep, and the crops consequently are poor.; but if the farmers were persuaded that their future crops would be exactly proportional to the stock kept, from the case of a layer of five years to one of 50 , they would set themselves to find more durable plants, and bring their waste arable under shifts that slould secure very different produeis.

The failures in this husbandry of breaking up, have all been for want of paring and burning. 


\section{CHAP. IX.}

\section{WOODS AND PLANTATIONS.}

THE modern spirit of planting took place as early in Norfolk as in any other county of the kingdom; and in some cases, upon a very considerable scale. The exerzions of Sir Robert WALPole, at Houghton, and of Lord Townshend, at Rainham, were followed by many other persons spread over the whole county. I have, on various occasions, noted several cases in planting in this county; but rather than transcribe here, I wish to refer the reader to Mr. Kent's Report of Norfolk, who has treated this subject in a satisfactory mauner.

There are some large woods at Billingford and Thorp Abbors, where hurdles and hoops are the principal object. Hurdles, r2s. the dozen. Admiral Wr at the former place, let at ros. an acre; and Marquis CoRnwallis 144 acres at the latter, at a ligher rent. The Billingford wood abounds much with hornbeam, which is made into hurdles, but is inferior in working to hazcl.

At Catfield, in Happing, there was a wood of 150 acres, belonging to the Earl of ABERGAVENNY, that was grubbed ten years ago, and it has produced very fine crops ever since; it was not, while a wood, let at above 5oi. a a year; the produce faggots.

Mr. Allen, at Stanhow, took potatoes for the first crop, 150 bushels an acre. Then carrots very fine; then Poland oats, a last ( 84 bushels) an acre. Fousth, winter tares. Fifth, turnips. The success on the whole very great. 
1 List of Trees planted at Holkham, from the year I 781 to I $80 \mathrm{I}$.

Acres planted- 718 acres, 2 roods, II perches.

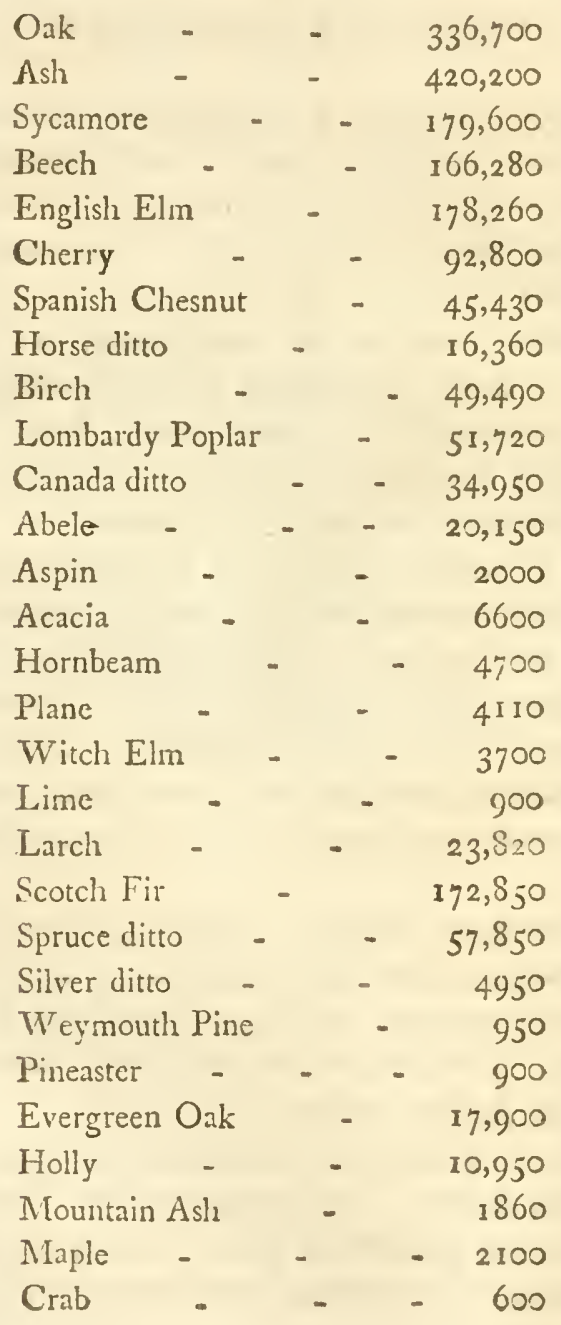


TOODS AND PEANTATIONS.

${ }_{3} S_{3}$

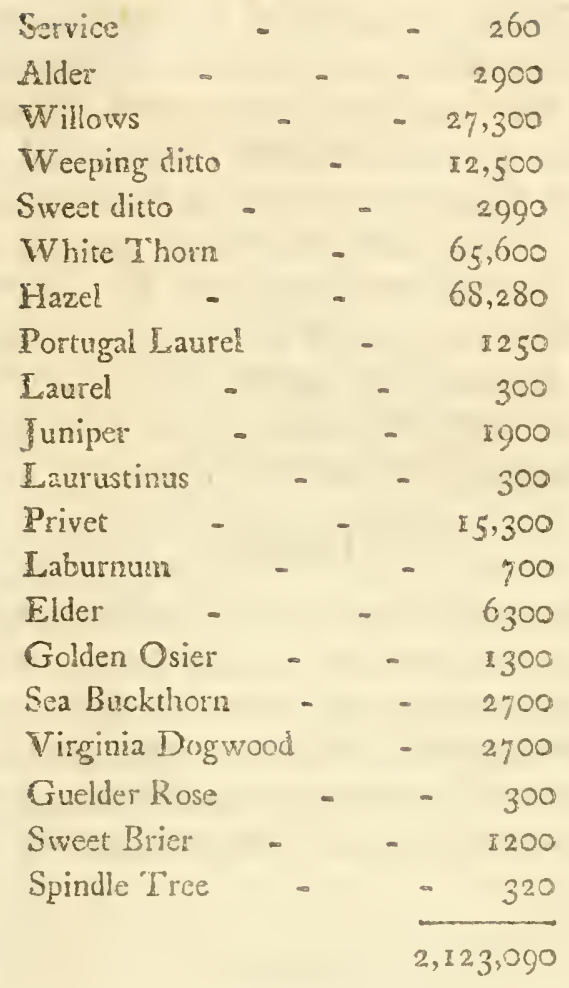

Mr. BevAn, at Riddlesworth, has planted 966,000 which have, at present, a very flourishing appearance.

Marquis Townshend has been long in the pradice of feeding cattle, sheep and deer, with the trimmings and thinnings of plantations: half an acre thickly planted thus fed 35 bullocks, 20 cows, 7 young cattic, 200 sheep, 200 deer two weeks, witis the assistance of three tons of hay, at 4 l. The browse saved seven tons, or 281 . Sheep are fond of the bark of Scotch fre and ash, as well as the trimmings of those trees, and it is a cure for the scour. The stock prefer ash, Scotch fir, and oak; but seen to dislike beech, birch, spruce, fir, and larch. 
Mr. Crowe, of Lakenham, is a great adrocate for trees in grass-land; he has a pasture with many large oak, ash, and other trees, with spreading tops, and he is fully persuaded that he has to the full as much, and as sweet grass under them, without waste, as if no trees were in the field. This is novel, and an idea I have not met with before; it deserves much observation: Mr. CROWE's rule is to admit air and light, for if the trees are close, or the branches hanging to the ground, in such case the grass becomes coarse and sour, and is refused by the sheep; but all is fairly and closely eaten under Mr. Crowe's trees.

\section{LARCH.}

Colonel Buller shewed me a circumstance relative to this tree, which merits noting: old sows, if allowed to get at them, will bark them for the sake of rubbing themselves in the turpentine : he lad some killed, in this manner, before he knew by what cause; when informed, he ordered the sows to be watched, and had it confirmed by his own view.

\section{OSIERS,}

Planted in small spots, and along some of his hedges, supplied Mr. ForBY with hurdle-stuff enough to make many dozens every year, as well as a profusion of baskets. The common osier cut at three years; the yellow bark at four. 


\section{$(385)$}

\section{CHAP. X.}

\section{WASTES.}

NOTHIN $(i$ can cause more surprize in the minds of many strangers on their frist visiting Norfolk, than to find, on entering the county by Brandon or Thetford, a long stage of 18 miles to Swafham, through a tract which deserves to be called a desert: a region of warren or sheepwalk, scattered with a scanty cultivation, yet highly inproveable. This is a capital disgrace to the county, and las been the result of an absurd prejudice in favour of these old heaths for sheep. They have been let for is. Is. 6 d. and 2 s. an acre for many years; have been valued at $2 \mathrm{~s}$. 6d. of late years, the best at $3^{\mathrm{s}}$. and $3^{\mathrm{s} .} 6 \mathrm{~d}$. and while left at such rents they are not likely to be improved. Something, however, has been done; better ideas are slowly creeping in, and some men have begun, though grod clay be not found on their farms. Chicory would treble the rent of these lands.

Mr. BEvan, after trying several methods of bringing old heath-lands into cultivation, gave the preference to the following: sow oats and seeds on one earth after the drill :oller; after hnvest feed hard with sheep for two years, in order to rot the old turf; then prepare it for cole-seed, by repeated ploughings and harrowings; feed off the cole with sheep, and prepare for rye, with which sow seeds again, and let it remain as a layer till it can be clayed or inarled with 60 loads per acre, when it may be brought into the regular shifts of the farm. This process will give

sOREOLK.] 
the old flag time to rot, and will not exhaust the soil, so frequently done with new lands.

1802. The crops on the fields thus managed have been very good, and are now great. He continues of the same opinion; paring and hurning he has not tried, but has advised a friend to comprare it with this method. Mr. Bevan now generally takes two successive crojs of cole, both fed off with sheep (the latter greatly superior to the first), and sows seeds with the rye.

I crossed 400 acres of thick fern, caller Eccles Common; half in that parish and half in Snetrerton: Lork ALBFMARLE has much property in both; and being a good farmer, it is to be hoped so fine a tran of land will not long remain in such a horrid state, exhibiting in its siontaneous prociuce, its great capabilities of yiekling corn and turnips most amply.

The commons are immense at Attleborough; "Turrmoor, Westear, Broad Moor, Fen and Row, Lyng, Bacon's Thorpe, Decoy, Bunrough; these are all above 100 acres, and some above 200, with many smaller; I was assured that they amount to hetween 2 and 3000 acres.

Mr. FARRow, of Shipdam, purchasing 200 acres of Sayhan common, under the aet of enclosure, pursued, in breaking up, the practice common in Norfolk. He took two crops of oats, and then clayted for turnips: some on this common, and on that of Ovington, have begurs with pease, and got very great crops ; then oats, and then clay for turnips: for two vears past the pease have answered better than the oats; the crops very large: the sccond crop of oats the best, and have produced in many instances 20 coombs per acre. I viewed various fields, both at Sayhan and Ovington, in $\mathrm{xSO}_{2}$, which promise that produce at least. I saw wheat also, which must be 12 or 13 coombs: barley exceedingly great. In a woici, all the products immense. 
immense. 'The barley follow's the claved tumips: Mr. FAR Row had 1 7 coombs an acre of halley big: with that crop clover: some with ray and trefoil.

Among the improvers of Norfolk, Mr. OVERMAN, of Bumham, ranks very high. When he first took the farm, the land surveyor employed by the landlord pronounced that it was a dangerous errot to think of wheat, as the soil was adapted only to rye and light oats. The great success he has had in raising very fine crops of wheat, proves that his husbandry has been conducted on sound principles.

Improvements on heath's and sheep-walks, which hring them from the state of desert wastes to be productive of corn and grass, are certainly in the very first class; but there are others which, though less striking, manifest abundance of exertion, vigour and perseverance. Mr. OyERMan took a farm of Mit. Coke, at Michaelmas, 1800 , which was, as I could easily jurlge from a part, the improvement of which was mot finished, in a very bad state: and this spirited farmer not being of a temper to dream over any thing, determined to bring the whole into orter as soon as possible: very little remained to do when I saw it in June 1802, and that little would be finished by wheat sowing. Eesides paying the outgoing tenant 5 l. ros. per acre for desisting from sowing the lays, and summer-fallowing lands which many would have sown, largely manuring, and other more common exertions, he is going to enclose the whole farm at his own expense, throwing down the old ragged fences, and arranging the ficlds anew according to his intended shifts: but planting quick he postjones, till all spear-grass and weeds are quitc destroyed : all corn sown is drilled, and as clean as a garden. He brings rape-cake in his own vessel; has a numerous flock of 
South Down sheep; and, in a word, will carry the productiveness of the land to its ultimate degree of perfection.

There are 600 acres of good land in Sparham-heath, that calls loudly for enclosure.

Sporle common, near Swafham, has much of excellent land.

South Creke commons, 1050 acres; four great farmers. and four sheep-walks; passed it by West Basham enclosures, where it is covered with thick fern, yet this is the worst land of the four. Mr. SMitu's common belongs to $\mathrm{Mr}$. CoKE, and is very fine land, worth zos. an acre, rent, tithe, and rates.

Mr. Crowe broke up a warren at Ash Wicken, of 300 acres, and re-laich it for a sheep-ivalk, with the greatest success,

Mr. ReEves, of Heveringland, broke up 165 acres, an ull sheep-walk, on a poor sandy soil: he began with turnips, claying and mucking for them ; the crop very good, and fed on the land by sheep: then be took oats, which were likewise very good: after the oats, wheat, and a fais crop: now turnips. The improvement great and profitable, and with this excellent farmer's management will be durable.

- One thousand sis hundred acres of wastes at Holt; they have talked for five years of enclosing, but nothing yes done.

Commons and mimproved marshes abound much in Fleg; but many are enclosing and draining: 400 acres of common, and as much open field at Hcmsby, and an $\mathrm{cm}$ closure just agreed upon.

In the parochial notes entered under the Chapter of Enclosures, are numcrous other cases, as well of wastes as of their improvennent.

CHA?. 


\section{CHAP. XI.}

IMPROVEMENTS.

TO examine the county of Norfolk with a single eye to this objeet, and explain in full detail the causes, progress, and consequences of the improvements which have taken place, woull demand at least a year's travelling, and would require a lasge volume to contain the notes necessary for such an unclertaking. The subject is of such importance as to demand, in every work that concerns the agriculture of this county, a particular attention. The methods more especially to be treated arc:

r. Draining,

2. Irrigation,

3. Manuring,

4. Paring and burning,

5. Embanking.

GECT. I.-DRAINING.

Mr. FreEMAN, of Swanton Morley, possessing a tract of meadows on the river, at Billingfold, poisoned by the water boing pent up by the mill at Elsing, and no fall to be gained on his side for draining it, laid a truck under the river, and, by permission, cutting a drain on the other side, gained a fall, and by it drained 120 acres, to his great profit, and also to lowering the soakage of his neighbours' meadow's. The improvement doubled at least the value of the land; the rruck delivers a good stream mow (in August).

$$
\text { c c } 3
$$


There are numerous facts which shew that water is, in certain cases, so confined within the earth, that if the reservoirs of it are pierced into, it has a force sufficient to rise to certain heights. At Finchain, a man complaining that his well was often dry, Mr. ForBY advised lim to bore at the bottom of it. The well was $2 S$ feet deep; and - on horing, the borer sudkenly dropped down to the head, and being drawn up, the water gushed after it, and has ever since ran over the top of the well.

The exertions which Mr. SALTER, of Winborough, has made in draining his freat farm of above Soo acres, have much merit. The first year of his coming he made a straight cut for the brook which runs through it, 342 rods in length of seven yards; i i 6 rods of open drains in the meadows; 2937 rods of ditching, five feet hroad and four leep; and 487 r rods of hollow-draining: these works he continued, and in 1801 did above 4000 rols of hollow-draining. In another fam he has at Carbrook, of 400 acres, he did in $1791-2,798$ rods of ditching, and 788 of draining; in $1792-3,37$ i of ditcling, and 1562 of draining; in $1793-4,571$ of ditching, and 897 of draining; in 1794-5, 201 of ditching, and 687 of draining; in all, 2941 of ditches, and 3931 of drains. His dains are in general 30 to 36 inches deep, some to four feet. He uses any sort of wood, chiefly the bushes that were a nuisaince to his fields, but of late has been forced to buy great đुuantities.

In this note of the excrtions of the master, it will be fair to minute those of one of his labourers, who did 1300 rods of hollow-drains between .Harrinnas and harvest.

I was rather surprized to find that this improvement was necessary on $W$ aterden farm, in a very liy country: but Mr. Hus, funding that the springs were injurious to much of his land, made ycry laudable excrtions in freeing 
his farm from then: He digs hollow-drains, from two feet and a half to four feet deep, filling them very carefully with stones, hand-picked from the heaps by women, to prevent any earth going into the drains and impeding the current of the water. The effects of the improvemear are great.

In going from Waterden to Rainham, passed by Sculthorpe Mill, and there enter a region that must make a farmer's heart ache. Of the nuisances that a country can be plagued with, certainly water-mills class very high in the black catalogue: for the sake of this beggarly mill, which apparently cannot be worth more than from 20 . to 30l. a year, here is a noble tract, from a furlong to a mile wide, of what, ought to be rich meadow, poisoned with water, and producing rushes, flags, sedge, and all sorts of aquatic rubbish. Who would not suppose the two sides of the river belonging to little proprietors, as beggarly as the mill, who could meet over their tankard to wrangle, but never ayree? No such matter. Marquis Townshend on one side, and Mr. Coke on the other. It would not be arniss to couple the two stewards of the estates up to the chin in one of these overflowing dykes, till they settled the matter, for the binefit of the public.

The Rev. Dixon Hoste, who has done much hol. low draining, twists three sticks or poles together, which he lays in at the hotton: of the drain, and then tills, six inches deep, with stones; as he has found, that when the drains are filled with stone only, they do not run quick enough. The smaller drains he digs 24 inches deep, and the leading ones 30 . The price $4 \frac{T}{2} d$. a rod for the one, and $5 \mathrm{~d}$. for the other.

Mr. HAvERs, at Thelton, drains attentively: the distance from eight to ten yards; the depth, in general, 30 inches, but of leading drains, 32 ; fills with hushes and

$$
\text { c. } 4
$$

straw; 
straw ; the expense 55. a score. He has tried the draining plough, at the depth of It inches; but the bailiff (Mr. H. not at home himself) thought that it did not answer. Mr. Smith, at the inn at Scole, has done much. On every farm the improvement is very great.!

There is some wer land in Attleborough; and to and around Hinglian, draining is well established and much done; but, strange to say, none on pastures, be they wet as they may.

About $W$ atton, much done, and the effect such, that one crop has paid the expense.

The father of the prosent Mr. KERRICH, of Harleston, began hollow-draining at Redenhall 27 ycars ago; his drains were filled with bushes, and they work now. He also drained much pasture land, which was the better for three or four years, but worse afterwards, by being too dry; moles and rats have now stopped many of the clrains, and done good by so doing. I had this fact from the present Mr. KerRich. Mich has been done by $\mathrm{Mr}$. PAUL, of Starston, who recommends greatly the culture of sallows in hedges, as that wood lasts longer in drains than any other, and is as good for the purpose as the hazel.

In Loddon hundred, Mr. CRICKMORE, of Seething, began hollow-draining above 20 years ago: he is an excellent farmer, and has been much imitated in this great improvement.

Mr. Burton, of Langley, has made great exertions in this husbandry at Hempnal, laying out $3 \mathrm{col}$. in one year.

Mr. Jounson, at Thurning, has inade a great improvement in draining meadows, described in the following cxiract from a leiter he favoured ne with:

"The track of land I took of the late Mr. ELwIN, is abou: 
about 26 score acres, consisting of five farms, jumbled together, for more than 80 years; three of them have not had a resident occupier during memory. The lands were chiefly small pieces and large borders; the meadows a long strip, of about nine score acres. It is not in my powver to represent the bad state the whole of the lands were in, nor can I give an exact account at what prices the work was done. The fences are chiefly drains for the land, which always should be the case, if possible. I began the work on the chief of the mearlows, the year before I took the farm: the account I annex was all done the first year of the lease, and I have since expended much on all the lands. I have always had more labourers than I wanted for harvest: I began the work in all directions, which made it look in a confused state. My neighbours said at the time, it would never be made a job of; but before the year was expired, Mr. DugMore, who knew the state the land was in, looked it over, and paid me the compliment of saying, it was the greatest and best work he ever saw in our county. In draining land, the main object is to form the main cut in the bottom; the fences for the next drains; then begin on the great springs, and see what effect they have: but draining small springs se'dom has any effect on the large ones.

s. JOIINSON."

Thurning, Jan. 31 , 1803 . 
Work done on the late Mr. Elwin's estate in Thurning, from Michaelmas 1796 to Michaelmas 1797 , by SAM. JoIINSON.

\begin{tabular}{|c|c|c|c|c|c|c|c|c|}
\hline 14 & at & 3 & 0 & per ro & & 2 & 2 & \\
\hline 99 & at & 2 & 6 & - & - & 12 & 7. & \\
\hline 401 & at & 2 & 4 & - & - & 46 & I 5 & \\
\hline 225 & at & 2 & 3 & - & - & 25 & 6 & \\
\hline 598 & at & 2 & 0 & - & - & 59 & 16 & \\
\hline 326 & at & I & 10 & - & $\because$ & 29 & 17 & \\
\hline $593^{\frac{1}{2}}$ & at & I & 9 & - & - & $5^{1}$ & 18 & \\
\hline 138 & at & I & 8 & - & - & I I & 10 & \\
\hline $348 \frac{x}{2}$ & at & I & 6 & - & - & 2 I & 2 & \\
\hline 28 & at & I & 4 & - & - & I & 7 & \\
\hline $18 j$ & at & I & 3 & - & - & II & II & \\
\hline 53 & at & I & 2 & - & - & 2 & 18 & 10 \\
\hline $5^{89}$ & at & I & I & - & - & $2 I$ & 18 & \\
\hline 500 & at & $I$ & 0 & - & - & 25 & 0 & \\
\hline $15^{2}$ & at & 0 & I I & - & - & 6 & I9 & 4 \\
\hline 15 & $a t$ & 0 & 10 & - & - & 0 & 12 & \\
\hline $66 ́$ & at & 0 & $9 \frac{1}{2}$ & 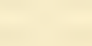 & - & 2 & 12 & \\
\hline I50 & at & 0 & 9 & - & - & 5 & 12 & \\
\hline IS64 & $3 t$ & 0 & 8 & - & - & 62 & 2 & 8 \\
\hline 2062 & at & 0 & 6 & - & - & 6 & II & \\
\hline $3^{6}$ & at & 0 & 5 & - & - & 0 & 15 & \\
\hline 119 & at & 0 & 4 & - & - & I & 19 & \\
\hline 187 & at & 0 & 3 & - & - & 2 & 6 & \\
\hline 920 & $2 !$ & 0 & 2 & - & - & 17 & 13 & 4 \\
\hline 68 & & & & & & & 10 & \\
\hline
\end{tabular}


Stubbing, clearing, levelling by the piece - $178 \quad 8 \quad 8$ Mould filled on three-whecl tumbrels by the day, on a valuation of Id. per load, 262 so 0 36,000 tumbrel loads: two tumbrel loads make one cart-load )

New barn, stables, bullock-houses, \&c. Twenty extra horses, keeping; 1200 loads town muck; rape cake; labour for extra $\} 120000$
jobs, \&c. f.2g6I I5 7

Mr. Priest, of Besthorpe, digs his drains 30 inches deep and seven yards asunder, price 6s. a scorc.

SECT. II.-IRRIGATION.

Thrs improvement is of very late standing in Norfo!k: the experiments made are $\mathrm{fcw}$, but they are interesting enough to promise a speedy extension.

In 1792 I found Mr. BEva.N liad made some progress in watering his meadows. In 1794 he had completed some. He purchased them at the rent of 4s. an acre only, and his tenant had now offered him 4QS. an acre rent, for all done 'That year he fed thom with ewes and lambs till the $15^{\text {th }}$ of May; the rushes wcre then swept over, and the produce of hay two tons per acre, though watered only for 48 hours the micldle of June, and cut the. I $5^{\text {th }}$ of July. The expen e of making then was 5 l. 10 s. per acre; the produce leaving $36 s$, per annum interest for that sum, or about 26 per cent, profit. 
1802. After some years experience of these mendows, Mr. Bevan found, contraly to his expectation, that the rushes would not give way to the water; and $\mathrm{Mr}$. Brooks, from Gloucestershire, viewing them, and having the favour of a visit from the Rer. Mr. WRIGHT, he einploycd Mr. BRooks to new form the works, by altering the direetion of the beds, and reducing them from ten and twclve yards to seven, and the immediate improvement made was very great: and he has also made several new meadows; the first done were 46 acres, and 14 more are now adding.

Mr. P. Galwar, at Toffrs, has watered 20 acres: having read Mr. WRIGHT's tscatise, he made application to that gentloman, who procurcel for him a man (Mr. Brooks) well shilled in the Gloucestershire method. I viewed the meadow which was fed. I have no doubt of the improvenent being exceedingly great, thougl the expense, by contract, was only 4 l. 4 s. per acre; but I have great doubts of the inethod followed. I think the beds or panes too flat, and that, consequently, the water has not a motion sufficiently nimble; and this, I conceive, results from the error of taking the water from a level of too small an elevation. Mr. Lucas has clowe a meadow of eight acres, still lower, at Lyndford, upon which the improvement, owing to the same cause, may perluaps disappoint him.

Having crossed the Bridgham river, going from Riddles. worth to Thetford, and observing that it brought down (in July) a most copious strcam, I made it a point to examine it higher up; and under the conduct of Mr. Fow ELI, of Snetterton, traced it from East Harling church to Bretenham, being throughout that line chiefly bounded by the property of Sir JoHn SEBRIght; generally on the left side, West Harling; but interrupted by the commons and 
some smaller properties in Bridgham, on the right side. How far this circumstance may operate in preventing a system of irrigation, depends on the rights of various persons, but this precluded, here is a very fine field for a capital improvement by watering; for some distance the stream is sluggish, and therefore may not give so good an opportunity as lower down, upon the lands between the Hall and Bretenham; but a large tract is evidently below the level, and consequently capable of a very important improvement. The rental of the West Harling estate, on old tenures, is 2387 . Roundham is a very fine farm of 1600 acres, including 500 of ling heath: it is 500 . a year at present; and contains much fine sandy loam.

1 crossed a fine stream at Chapel mill, in Gressenhall and Hoe, which runs to Wendling; another in Elmham and Beteleg; much water in August, and a falling valley with it, capable of much irrigation; but not a thought of it. At Billingford, it is a fine river: passed above three miles over Mr. BLOOMFIELD's farm, and again examined the river and meadows to Elsing mill: they are in a sad state for many miles, caused by mills keeping up the water as high as the adjacent lands, and in some places higher; ruining the lands, which it would convert to gardens, were the waters applied to irrigation instead of grinding. Messrs. BLoomfields made a weir of timber and stones to discharge the water at a certain height, sufficient for the mill, which l examined, and could not but commend; yet this work was opposed by the miller, and was near causing a law-suit. It is the same story over half the kingtom; and were the extent of the mischief known, would prove how necessary it is to apply other powers for this purpose. stcam, wiad, 2xc. rather than suffer 2 trifling rent of a mill, 
mill, to prevent fifty rimes the amount being gained by the improvement of meadows.

Mr. Bloomfifid, on the recommendation of his landlord, Mr. COKE, has irrigation in contemplation; he has a small stream at command, and has begun by a straight cut, which is thus to be applied.

Note, in I 792, the stream at Cley uffer's so fine an opportunity for watering, that I stopped my horse, repeatcdly, to view it with regret. Poor sand-hills might be converted to rich meadow.

The river at Bodney, and the poorer arable lands, which cone down helow the levels it affords for watering, struck me as offering an uncommon field for irrigation; which calls aloud for the exertion of that spirit which has just begun to awaken in Norfolk. The two streams between Swafham and Buckenham, join st Boiney.

Mr. ReEve, of Wighton, has made an exertion in irrigation that has uncommon merit. Having a long, rough, and very coarse meatow, of above 20 acres, through which a small stream russ, which is nearly dry in any time of drought, but has sufficient water in any other season, he cleared a straight channel for it through the centre of the meadow, and taking the necessary levels, threw it at pleasure into carricr trenches, under the two hedges that bound the meadow, and accompanied those trenches with drains: the first part he did, remains too flat; but as he advanced, he correeled that error, and raised the surface inio arched laids, ruming the carriers along the centre, from which the water flows down the sides to the drains. This part is very well done. The experiment having been lately finished, the full effect is not yet scen; but it is evident enough to determine, that the value of the meadow 
meadow is trebled. The expense of the first part was about five pounds per acre; but by filling up holes, taking up turf, and laying it down again, \&c. some of the latter part cost him, it is said, above 20l. per acre. Genslemen who attempt this improvement, cannot be too much impressed with the idea of the necessity there is, that water, applied in irrigation, should always be in nimble motion; the effect is greater and more certain: another circumstance, oftentimes not sufficiently attended to, is chat of the carriers being so levelled, that the water will flow over the edges in every part, by which means it is much more equally delivered than when let out by small cuts.

Mr. PURDis, of Eggmore, shewed me a mead of eight acres, which he had very lately renewed; employing Mr. Brooks, from Gloucestcrshire: upon examining the spot where it would be proper to fix the sluice for throwing the water of the river into the main carrier, the foundations of an old sluice were found, in a sound state; and the whole immediately renewed: on further examination, the carriers and drains in the meadow were all raced, opened afresh, and thus an irrigation formed upon very nearly the plan of olk? works, which had been utterly neglected for at least 80 years: upon further inquiry, it was found that this former irrigation was obscurely known to have existed, but no records gave any illformation of the time when it had been formed: it is extremely curious thus to trace tormer exertions in so cxcellent a husbandry, followed by so long a period of darkness and ignorance, as to suffer such immense advantages to sink into a state of neglect and ruin. Mr. Brooks approved the former mode of irrigation. I may observe upon it, that the water through- 
out the meadow flows through little cuts: not one carric: ovcrfows: equally varying in breadth as it advances, for the equal delivery, as explained by Mr. Boswell; the delivering trenclies are not on a very gentle, but on steep declivities: and the benefit is unequal: at the end of every little cut, there is a great bunch of grass, with spots on the sides, inferior: I pointed this out to the waterman, and he admitted the defect, observing, that those little cuts must, another year, be greatly multiplied. It ought to be appasent on the first view, that the equal distribution, by a universal overflowing, without any cuts for the purpose, must be superior. The coinpany with whom I viewed this and Mr. ReEve's meadow, I found strongly impressed with the idea of the great superiority of the water first taken from the river, and reasoned as if all the benefit arose from a deposition of certain particles, which being dropped, the water became of litthe value: these ideas, in certain cases and to a certain extent, are just; but they seem to be carried here much too far, and may have ill effects in causing a small value to be assigned to water taken at the second and third hand.

Mr. Brooxs forms his works by the eye, and without using a spirit level: the consequence is, that the distribution by overflowing is, in that manner, impossible to be attained.

The improvement, however, as in all cases of irrigation, is very great: the meadow had heen watered but three weeks, and the growth was very luxuriant; the benefit is unquestioned; and the exertion does great honour to Mr. PURDis, who has the merit of effecting a most valuable amelioration, which 80 many of his sleeping predecessors utterly neglected. 
April $\eta$ th, 1802 , he turned in his cows, and they found full feed during the rest of the month. May ist, shut them up, and in nire weeks cut two tons per acre, and thcy have been fed since: these meadows were full of the broad-leaved plaintain, which has disappeared, and are no:w clothed with good grasses.

I have rarely seen a finer opportunity for irrigation than at Hillingdon: Sir Martin Folkes and Mr. Coké have the stream as a boundary for two miles together. Captain BEACHER walked with me on the banks of it for a considerable distance: I found the declivity every where so rapid, that it cannot be doubted but that it may be carried over a large tract of poor arable slopes, to the effecting a most profitable inprovement. Nothing yet done: but this subject is well started in Norfolk, and the age of dreaming passcd. If these proprietors muddle themselves in the low flat lands, on the river banks, alreacty of a good, though inferior value, instead of running leveis as high as possible for floating the dry arable, they will make a shilling where they inight make pounds. For carrying irrigation to the highest improvement, the levels should be taken for two or three miles before a spade is in hand: and then, if there be some lousy miller below, he yelps at the undertaking. Three or four proprictors should unite, and buy, or burn, the mills, before they think of beginning.

Uncommon opportunity for it from Sedgford to the sea, through Heacham: two mills denote a fall of ten feet in three miles, besices the rapid motion of the water every where: after a long droughtic I found ample water in the stream for great improvements, and the circumstance of many dry arable fiekls under the level, will, by-and-bye, be found of great value. Mr. STYLEMAN has engaged Mr. Bkooks to make a trial.

NORFOLK.] Dd

SECT. 
SECT. III. - MANURING

Turs is the most important branch of the Norfolk improvements, and that which has had the happy efrect of converting many warrens and shcep-walks into some of the finest corn distriots in the kingdom.
1. Marlc.
I1. Ashes.
2. Lime.
12. Sout.
3. Gypsum.
13. Malt-dust.
4. Oyster-shells.
14. Buck-wheat.
5. Sea-ouze.
15. Yard-dung.
6. Sea-ivect.
I6. Lcaves.
7. Pond-weeds.
17. Burning stubbles.
8. Burnt-earth.
18. River-mud.
9. Stickle-backs.
19. Town-manure.
so. Oil-cake.

\section{MARLE.}

Thirty years ago, being in Norfolk, I was informed by the late Mr. CAR, of Massingham, that 25 years before that period, 70 loads an acre liad been commonly spread; after which, many farmers wied 30 more, but without success: his own practice was to lay on 35 to 4 o load, and in thrce or four years after, as much more, by which means he found that it incorporated better with the soil.

Thirty years ago the quantity spread from Warham to Holt, was 60 loads an acre, which lasted 15 or 16 ycars in perfection, then they laid on 25 or 30 loads more, which lasted ten or twelve years longer; repeating it still; so that previous to 1770 , that country had much of it been marled thrice at least.

Mr. BEvan marled (clayed, as it is called) his whole farm 
farm, from 60 to 80 loads per acre: I found his team at work at it, and measured thc carts: length, six feet; width, four feet; depth before, two feet; ditto behind, one foot; contents, 36 cubical feet; price of filling, 28 s. per 120 loads, filling and spreading, and pumping out water from the pit, if necessary; six horses, two tumbrels; four men fill 30 loads a day. The expense per acre for 60 loads :

Filling and spreading - $\quad \begin{aligned} & \text { E. s. } d \text {. } \\ & 0 \text { It }\end{aligned}$ Two days work of six horses, allowance of oats, two coombs a week, at Ios. which, $\}$ o 58 for two days Hay

Decline of value, 5l. 12s. 6d. per horse per annum, at such hard work, or $4 \frac{1}{2} \mathrm{~d}$. a day for 300 days ; and for six horses, 2s. $3^{\text {d. a }}$
day

Interest of his purchase, 301 . or zos. a year, $1 \frac{1}{4} d$. a day, and for $6,7 \frac{\pi}{2} \mathrm{~d}$.

Driver, at is. 6d.

Wear and tear of carts, and interest of first cost, 2 gl. say I gl. per cent. $3^{\text {d. a day }}$

Sundries, shoeing, harness, \&x.

Per acre for 60 loads

He scuffles the marle after spreading.

Examining a team (belonging to one of the tenants of Mr. Colnoun) at clay cart, I found the tumbrels four feet three inches long, three feet nine inches broad, and two feet three inches deep, consequently hold, if full, $35 \mathrm{cu}$ bical feet: the whecls five feet six inches high, and six inches broad : eight horses (sometimes nine) were employed; $\mathrm{D} \mathrm{d}_{2}$ 
four men filled, and did regularly $3^{2}$ loads a day, eiglst loads per man being the stint; the distance to the heaps 334 yards. Each load made eight heaps, and to discharge it the easier, there is a false tail-hoarl in the cart. The tumbrel does not separate from the shafts, as in our common ones in unloading; the shafts are fixed, and rise in the air, the traice horses drawing by the ends of the shafts, and the thill horse by short traices fixed at the other end of the shafts. The price given to fill and spread, 25 s. for 120 loads, or $2 \frac{x}{2} d$. each. I cxamined the heaps with particular attention, and guessed them at four bushels each, and then, asking the men their opinion, they also guessed the same. Surely it behoves the gentlemen and farmers of this country, to reconsider this business entirely ; for seven horses (and therc are often eight) to draw 32 bushcls of clay, secins preposterous; $4 \frac{1}{2}$ bushels a horse are a load, which, when you come to divide it, seeme such a system of tritling, as to be worthy only of children; but viewed in that bundie of logs called a tumbrel, with great lumbering wheels, the nuachiue and the load seem more congruous, and to the eye there appears something for the horses to draw; but calculation tells us there is nothing but a heavy, ill-contrived, unmechanical cart, lessening the power of the horses, till one draws not more than a man would push in a wheel-barrow. All this evil, and an enormous one it is, springs from this circumstance of uniting many horses in the same draught, to form a team, which is never analyzed and well examined, but you find it a barbarity worthy only of savages. Take a light cart, such as I use and have recommended, or even the little car of an İrishman; put one of these horses in it, and see if $4 \frac{\mathrm{T}}{2}$ bushels will be the load!! See if you are content with 9; try if you camnot carry 12 ; try again at $13 \frac{\pi}{2}$, or the treble of what your horse does at present!!! Thus one 
horse does the business of three. But drivers? Let us examine: I get but little there; but what do I lose? A man, at Is. 6d. a day, drives away 32 bushels; this is a fraction more than a halfpenny a bushel: a boy at $6 \mathrm{~d}$. with me drives away $13 \frac{x}{2}$; this is not a halfpenny. Here then is no loss in driving, with an enormous gain in team; and the measure of employing children to execute the work of men, is a parochial and national benefit, which wants no explanation. I need not observe, that with onehorse machines, of whatever kind, it is not necessary to allow a horse in the standing cart; the horse in 'an Irish car, or any other, if preparcl with that view, is attached in an instant, as quickly as you hook a traice-horse to a thiller. But in this point, an improvement which was introduced by Mr. Colnoun, deserves attention.

This is, a contrivance to draw the carts of any size out of the pits by means of a capstan; he uses large three-wheeled tumbreis, and to save the extra number of horses, which are used in common to get the loal out of the pit, he applies a boy and a horse to the lever of a cap. stan, and draws up the load with s.) little loss of time, that the whole operation takes but three minutes and a half, and with horses in the common way, three: if it demanded inore, the objection would go no further than letting there be an extra cart in the pit, which would prevent any waiting. Mr. Colnoun's are threc-ivheeled carts. By means of this machinery, the pit may be dug of any depth, without impeding the raising the load; a great advantage, not only to the men in filling, but also in the quality of the clay or marle, which is usually better at the bottom of a pit than in any other part of it. I measured the dejth of one pit, which was above 20 feet.

'I'le country about Snetterton was all marled many years ago; Mr. Fowell's firm, fitry ycirs past, and was

$$
D d_{3}
$$
done 
done by the landlord, who contrakted for the work, paying by the load; and this was the cause of an evil, felt to this day ; they laid on a great deal too much near the pits, and too little at a distance: the soil in the former situation now tills badly, insomuch that Mr. FoweLL wishes it had not been done at all. The marle is yellow, from the mixture of clay, but ferments strongly with acids.

All the country about $W$ atton has been marled (clayed, as they call it), and the general way has been to do it upon the first breaking up of all old grass. They take two crops of oats in succession, and then clay for turnips, 40 to 60 loads an acre.

Mr. Salter, at Winborough, in seven years has clayed, as it is called, 100 acres, at 100 loads an acre; a quantity which he thinks necessary on his soil, which is a wet loam, or springy sand, and also brick earth; but observed, that if so much was to be laid on the dry Norfolk sands, they would be set fast, and it would be many years before the clay would work.

All Mr. Johnson's farm at Kempston is marled: he approves of doing it at twice, rather than giving the full quantity at once.

The country about Thorpe Abbots, has, in general, been clayed; and on the gravels it answered greatly. But some being done on Mr. PITT's farm a second time, it did mole harm than good.

The hundreds of Loddon and Clavering have all been clayed. 1 observed many pits of clay marle every where. At Langley, they now bring white marle from Thorpe, near Norwich, by water; laying on 12 loads per acre, at

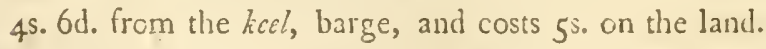

Caistor and the vicinity, has all been clayed, 40 loads per acre.

Mr. Everit marls from Wightlingham, at 5 s. a load, 
load, at the water-side, of two chaldrons; lays 16 chaldron an acre; carriage, three miles besides.

At Thelton, \&c. no old pasture is ever broken up without marling, called here, as every where in Norfolk, claying. Much done in the vicinity, especially in all the new enclosures; and the best praetice that of claying one year before breaking up. Without clay, the straw on new land runs up weakly and faint: this manure stiffens $i t$, and much increases the produce.

Mr. Thurtell, near Y'armouth, is decidedly against claying on a layer: he has found, that in this way, it is four or five years before it works well. He spreads it, to chuse, in the winter bcfore a turnip fallow, by which it is thoroughly mixed with the soil: he knows several practicat farmers of the same opinion.

At Hemsby they spread from 20 to 70 and 80 loads an acre, of their own clay marle; the latter quantities, if not done in the memory of man; hut for renewing 20; the effect lasting 30 or 40 years. Some white marle is brought by water from Thorpe, \&c. Mr. FERRIER' agrees with IVIr. Thurtelz, that it is best spread on a fallow; it works quicker and nixes better, than when on a layer.

Mr. Brown, of Thrigby, having a piece of land that he had over-clayed, ploughed it a little deeper, and it then did well. That parish was marled above 30 years ago from Thorpe; he now clays 35 to 40 loads an acre, and it does well.

At Martham they marle from Wiglutlinglıam; a keel

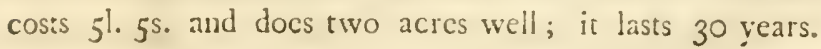
Mr. Francis has no clay on his farm; he lays on ro cart loads per acre of the marle, equal to 20 clualdrons: $6 \mathrm{~s}$. a load: spreads it to chuse on a fallow for turnips; does not approve of marling on layers, because it hurts them, otherwise it is a good method, and not ant to sink so soon.

$$
\text { D d } 4
$$


Ar Ludham they have it by water from Thorpe, Wightlinghan and Wrosham, at 4s. a chaldron; and lay from eight to ten cart loads an acre; it lasts 20 years. Mr. HORNARD spreads it on stubbles scaled: none better for it than a one year's layer that is to remain another.

He also lays it in summer on turnip fallows : first marls, then spreads the dung; scales in, and then deeper for the seed earth.

Mr. Cueir, \&ac. at Carfield, brings marte from Horsted, 20 miles, by water; costs at the staich $5^{l} .5^{\text {s. a }}$ keel of 36 chaldrons, 18 to 20 loads. He lays on seven or eight loads per acie, generally on a fallow for turnips: lasts 30 or 40 years. Mr. Cubtr has some land done 40 years ago, and does not yet want renewing.

Mr. Сивіт, of Honing, spreads eight or nine loads per

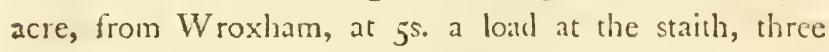
miles off: he would give 9 s. a load in his yard; no claymarle of their own, except at Happstborough. When turnips shew the anbury, it is a sure sign that the land wants marling.

They have white marle in North Walsham, and it is much used: Mr. PAYNe has done 40 acres in one year, 12 loads an acre: it lasts 14 to 20 years. It is common to make layers of mould, the marle on to that, and then the yard muck, and turn the whole over together: they also lay lime on mould, turn it over, leaving it some time, then muck on, and turn the whole over again; all chiefly for turnips, but some for wheat. Mr MARG ESON brings it five miles, from Oxnead and Lammas; lays on ten cart loads an acre: it lasts 20 years. If the land has nor been marled, or wants a renewal, the turnips have the anbury, which this manure prevents entirely.

All the country about Scotto has been marled; full of marle 
warle is the expression; ten loads an acre on strong land, and eight on light; and lasts above 20 years.

Good yellowish marle at Coltistal; they spread 12 loxds an acre, and it lasts 14 years.

Much at Oxnead, \&c.; Mr. Repton lays 20 small loads an acre: it lasts 20 years: a second marling answers wetl : the foulness of land shews the want of marling. He spreads on the layers, and thinks that the longer it is kept on the surface the hetter.

Mr. REEves, of Heveringland, who is a very attentive and spirited farmer, lays on 28 loads an acre of clay-marle, free of callow, which he reckons equal to 40 to take all as it comes; but as this demands a greater depth of pit, he reckons that it costs him gd. or Iod. a load.

Mr. BirchaM, at Hackford, from 40 to 60 loads: and the whole country there has been so marled; the white best by far, 10 loads as good as 40 of other sorts. It prevents the buddle (crysanthemum segetum) which, and sorrel, are the signs that land wants marling; when done, these plants disappear. Marle does a second time, but he has found that the best way of applying it then, is by composts with dung; on layers for wheat. Marle, Mr. BirCHAM has found bad for turnips, except when it is wanted to get a farm done as quickly as possible.

Mr. Johnson, at Thurning, clays, 40 loads an acre, which lasts 20 years: it is best on a layer, but hurts the grasses to the amount of half the produce: he reckons that the longer it is kept above ground the beiter. Much inarle ahout Holt.

All the land about Binhan is marled that wants it. Mr. ExGLAND lays on from 40 to 50 large loads an acre: it lasts 20 years; but this depends on soil. He thinks it best spread on ollonds, between the first and second year; but 
this must be governed by convenience. After a proper time a second marling is as good as the first.

Mr. HrLl's father marled 350 acres of the Waterden farm, at 80 loads per acre; he has done the rest of the farm himself, 35 per acie, and never exceeding 40 , thinking it much better to do it at twice than at once. The colour is yellow and white mixed; considers the yellow as best. Spreads it to choose on a one year's layer; and in winter rather than in summer; leaves it a year, and ploughs for the first time very shallow. The first turnips are not the better for it, but the barley great, especially when it comes to the bushel. His rule, in after-manuring is, to muck the first time, in preforence to folding. His father did one field, at the rate of 122 loads per acre, which was so over-dosed, that the land has not recovered it yet: the soil light. It has given but one good crop, which was wheat, nine coombs three bushels (old measure) per acre: every other crop has failed more or less. If Mr. Coke had not granted a second 2 i years' lease of this farm, the benefit, after much loss, would all have gone to others.

On Mr. Reeve's farm, at Wighton, I saw an extraordinary fine white marle, not as in common, in globules, but more resembling the equal consistence and texture of white butter.

In all the light lands of Norfolk, clay, as it is called, but which ought to be called chy marle, from the quantity of calcareous earth it contains, is preforred much to more chalky marls; and of all others, the hard, clualky, and stony marls are reckoned the worst: when these only (called also cork) are found under traćts of waste or poor land, they are not deemed improveable to profit. Mr. OVERMAN has made the experiment of such, and has 
found the benefit so great, that, direelly contrary to the common opinion, he prefers them. I saw such used in 1792, on a very large scale on in is farm. He spreads from 40 to 50 loads per acre. Such manuring prevents the anbury in turnips.

Mr. H. Bly тhe, of Burnham, has no doubt of white marle, on the sands of his farm, being better than clay; it works better and sooner, adding the expression, it will buy a horse, bcfore clay will buy the saddle.

Mr. Dursgate has found white marle more profitable than clay; working much sooner: nor has he any objection to that hard chalk called cork. Of white marle he lays on 50 to 60 loads an acre.

Mr. WRIGHT, of Stanhow, a very attentive and excellent farmer, has found, that the longer marle or clay is kept on the surface the better. He spreads it on a lay of one or two years old (the latter best), and leaves it a year; then ricebaulks the land, leaving it so for the summer; and it gives as much food as if it had not been stirred, and thus the marle works without being buried. He marls largely, yet is clear that it is an enemy to grass and tur. nips.

Cork has been used successfully at Ringstead.

Marle is found under all the country at Snettisham, generally white: the farmers lay on from 60 to 100 loads an acre.

Mr. Goddison, at Houghten, laid, in six months, $32 \mathrm{co}$ loads on 44 acres of very poor black-sand heath, and broke it up; the success great, and shall do as much more this year. He pays qu. a load, to a man who finds team and every thing.

Mr. Beck, at Castle Riseing, has clayed all his farm, 60 to 80 loads an acre, and covered the whole with Lynn inuck. 
muck. He thinks, lowever, that it is better to lay on less at first, and renew it by composts. He always lays it on ollonds, and leaves it ahove for a year.

Mr. SAFFory, of Downham, is for 40 loads an acre, and then repetitions, which is a far better system than much at first; and he would always spread it on a one year's layer, to be left another year: it then does not sink so soon. Not much done near Downhaın.

Mr. Porter, of Watlington, lays roo to I fo loals per acre of clay (marle) on to his gravels; and never found it too much ; the benefit of some, done thirty years ago, is to be seen now: spreads on a layer for the sake of frosts taking it: one acre done before winter, as good as two in, summer.

Mi. Martin, of Tottenhill, lays 100 load of clay per acre on black sand and gravel, at 25. per 120 in winter, and 30 . in summer.

About Wymondham, 60 to 100 loads of clay; $80 \mathrm{com}-$ mon; some chalky; some blue; and some yellow.

At Besthorpe, white, biue, and brown marle; all ferment in acids. Mr. PrIEsT, 64 loads an acre, at jos. per I 20 cubic yards; now, $35^{\text {s. }}$ to $36 \mathrm{~s}$.

\section{LIME.}

Mr. B1Rcram, at Hackford, has used lime at the same time with yard-muck, very successfully for turnips; three chaldrons, at 10s. or I is. a chatdron, spread out of the waggon on land, on which twelve loads of muck are spread: and when a piece has had part of it muck only, and the rest muck and lime, the eflect is seen to an inch.

Mr. SAFFory, of Downham, has, tried lime, sixty bushels 
bushels per acre, on his fen farm; but discontinued it, as it did not answer.

"In East Norfolk, lime is successfully used, even after marle. It is of the greatest efficacy on hot burning soils, and is perhaps the most effectual cure of scalds: hence considered as a cold manure."-Marshall.

\section{GIPSUM.}

Mr. ALten tried this manure, very carefully, at Stanhow, on clean clover.

Narch 3I. No. I and 4. No manure; produce average of the two, $38 \mathrm{lb} .6 \mathrm{oz}$.

2. Four quarts sifted coal-ashes kept dry, $50 \mathrm{lb}$.

3. Gypsum, one quart, $54 \frac{1}{2} \mathrm{lb}$.

The ashes, therefore, gave an increase of I I lb. rooz. and the gypsum of $16 \mathrm{lb}, 2 \mathrm{oz}$.

\section{OYSTER-SHELLS.}

In East Winch and West Bilney, and scattered for ten miles to Wallington, there is a remarkable bed of oystershells in sea-mud: the farmers use them at the rate of 10 loads an acre for turnips, which are a very good dressing; they are of particular efficacy on land worn out by corn. Mr. Forster several years ago laid 20 loads an acre on some worn-out land, and they had an amazing effect in producing grass, when laid down in seeds, giving a deep luxuriant hue like good dung: the benefit very great at the present time. They are found within two feet of the surface, and as deep as they have dug, water having stopped them at 16 or 18 fect deep. They are used again and again on the same land, and will the same effect. At East Winch, Mr. Crowe has acres together of this 
most valuable manure. They fall to powder on being stirred.

\section{SEA-OUZE.}

Mr. Palgrave, at Coltishal, uses much sea-mud, scraped up by the bear from the bottom of Yarmouth Haven: he lays on 40 loads per acre, and has thus manured 70 acres; the improvement very great. I found, on trial, that it is a calcarcous mud: on scalds, or burning places of sand or gravel, it forms a cold bottom, and is an effectual cure.

Fifty loads per acre, of sea-ouzc, have been used on the upland sandy loams of Warhan, with very great success: superior crops the consequence.

\section{SEA-WEED.}

What other mane to assign to a very singular manure on the coast at Thomhan, I know not. In the great and accurate map of the county, published by Mr. FADEN, there is a mark on the shore for what is called crabs, scalps and onk-roots. Mr. Risuron had the goodness to take me to view this spectatle, which is an extraordinary one: it is evidently the ruirs of a forest of large trecs, the stubs and roots remaining, but so rotten, that with a spade I dug: into the centre of many, and might luave done of all, with as much ease as into a mass of butter. Where the stumps are not found, on digging I turned up a black mass of regetable fibres, apparently consisting of decayed branches, leaves, rushes, flags, \&xc. ; to what depth this vegetable stratum extends is not known, but at some creeks on the very edge of the sea, at low water, there is a very fine soapy sea ouze, at two or llsec feet depth. The extent 
of this once sylvan region, which every common tide now covers, can scarcely be less, in one place oniy, than from 5 to 600 acres. There is not an appearance of any tree lying at present from the stump, as if blown down or left after falling, but rather that of a forest cut down in haste, the stems cleared and hurried away, leaving the branches to rot: but this is mere conjecture. It is remarkable that there is not, as I am informed, any mention of this ruined forest in the old historians of the county; nor does tradition offer the least conjecture or report on the subject. . Trees, roots, and stumps, are very common in hogs, wherever found; but here is not the trace of any thing like a bog, the earth is solid, and all a fine ouze or sea-clay.

Mr. Rishton viewed these relicks with the eye of a farmer; for experiment, he sent his carts down for some, and spread ro loads per acre of it, for turnips: it answered perfeely, and on comparison, equalled his yarddung: and also rape-cake. In another experiment, he manured two acres for wheat, with a compost, consisting of nine loads of this weed, and three chaldrons of lime, mixed; one acre with yard-muck; one acre, with tallowchandler's' graves, 16 bushels, and the rest of the piece with rape-cake. The graves were, in effeet, far beyond all the rest; between which the difference was not very perceptible. The expense only 1s. per load: but if a barge was floated to the spot, and anchored when the tide was in, for loading at low water, it might be procured at a much cheaper rate. This gentleman is going to quit his faral, but not before he has opened a real inine to sucl farmers as shall have the sagacity to dig in it : it appears astonishing that none of them should long ago have marle the same experiment, and consequently have profited by so beneficial a vicinity. 


\section{POND-WEED.}

Sereral persons in Norfolk are in the regular habit of clearing their rivers and ponds just before turnip-sowing: they cart them inmediately on to the land, and plough in as muck, and load for load they are equal to farm-yart. dung. Mr. Coke thus manures from 20 to 30 acres annually from the lake at Holkham.

Mr. Crowe, of Lakenlam, manures four acres annually for turnips with the weeds of a river that runs by his farm; the plants are chielly the Phelandrium aquaticum Es Sium nodiforum (waier-hemlock and water-parsnip). He lays 20 loads of 30 bushels per acre, and ploughs in direaly: are as good on sand and mixed loam as the best dung, but not equai on stiff soils.

Mr. Broomfierd, of Pillingfold, has been in the habit of manuring his turnip-land with weeds fresh from the river, and ploughed in quickly; they have answered as weil as yard-nuck.

\section{BURNT EARTH.}

Mr. SALTER, of Winhorough, whose fine farm offers many proofs of excellent management in every part, burns all the turf and rubbish which comes out of the numerous open drains he has made throughout his moory meadows, as well as the first spit of many hedge rows and borders: this he spreads on the grass, with earth from hills and rows. In his turnips, observing one part of a field finer than the rest, I found it had been manured with cottagers' ashes, who burn the parings of grass-land: these ashes never fail of giving great crops.

At Summer-green, in Dickleburgh, I observed a large heap 
ireap of burnt earth, the ant-hills, and inequalities in the common pared off.

\section{STICKLEBACKS.}

These little fisl, which are caught in immense quantitics in the Lymn rivers about once in seven years, have been bought as high as $8 ! 1$. a bushie!. The favourite way of using them now, is by mixing with mould and carrying on for turnips. Great quantities have been carried to Marham, Shouldham, and Beachamivell. Mr. Fulles there, is reported to have laid out 400 l. for them in one year: they always answer exceedingly.

Mr. Rogerson, of Narborough, lras gone largely into' this husbandry, laying out 300 . in one year, at from 6d. to 8d. a bushel, besides carriage from Lynn: he formed them into composts with mould, mixed well by turning over, and carried on for turnips: the success very great.

\section{OIL-CAKE.}

From 40 to 50 years ago this was a very common ma. nure in Vest Norfolk: 35 years ago I registered the husbandry of manuring there with oil-cake; then chiefly spread for wheat. Mr. CARR, of Massingham, tried it largely: he laid out 1400 . for one crop, in which he received very little benefit from the manuring: on another occasion his expenditure was for lintsced-cake, to fatten beasts, and the dung thus gained answered much better than buying rape cake. Ahout the sane period this manure was much used at Snetrisham, at the expense of 31 . 10s. to 4l. IOs. a ton, which quantity did for three acres; the beNORFOLK.]

Ee

nefit 
nefit there reckoned exceedingly great, but lasting only one crop.

At that period, from Holkham to Holt they spread one ton threc-quarters to three acres; bringing it from Holland and Ireland, but they found the Dutch cakes best, from not being pressed so much. It lasted strongly only for one crop, wheat; but of some use to the following turnips.

In 1784 I found $\mathrm{Mr}$. CoKE in the regular practice of using this manure, at $\mathrm{gl}$. per ton. He found it more forcing to a crop of wheat than either dung or fold; but the turnips after the wheat not so good as after dung spread for that crop.

At present (1803) it is S1. 10s. per ton, and he drills in with the turnip.seed a ton to six acres; and though when used in lumps, it may be better to sow it six weeks before the seed, yet, in his estimation, this is not the case when reduced thus to a powder.

In the district of Holkham rape-cake is very generally, perhaps I might say universally, used. They now spread a ton on three or four acres, usually sowing it (about clcven or twelve bushels to the acre) for wheat or turnips, or for both. Mr. OverMan has compared English, Dutch, and Irish cake; the latter he thinks the worst, and suspects from its breaking of a black grain, as well as from its want of that agreeable scent yielded by other cakes; that it has undergone in the manufacture some operation by fire. This manure is very effectivc.

The expense rising so high, induced $\mathrm{Mr}$. Coke, some ime ago, to recommend to Mr. Cook, the patentee of the drill-plough, to add to that machine an apparatus for sowing rape-cake-dust with turnip-seed; but his various engagements preventing the necessary attention, Mr.

Coze 
CokE has procured one from Mr. Burres, of Thetford, which worked while I was at Holkham, to the great satisfaction of every one who saw it, delivering a constant stream of powder so regularly, that no doubts were entertained of the great success of the invention. It contains alternate divisions, with large and small cups for the delivery of both cake and seed into the same drills. In this way a ton does six acres, instead of three or four in the common method. In a letter I afterwards received from this very able cultivator, he informed me that the experiment answered to his satisfaction.

Mr. HiLl, of Waterden, has much doubt of the benefit of this manure, and thinks that it is often used (the great expense of it considered) to loss. For the last three years it has decreased in goodness; by reason of the increased power of the mills; exertions caused as he thinks by the great demand. It should not be used in less quantity than two tons to five acres; and always for turnips it preference to wheat.

Mr. Jonnsos, of Thuming, finds that from one-third to half a ton per acre for turnips, will, in a wet season, beat every thing. It ought to be sown the first week in Nay, if possible; all ideas of putting it in at the same time with the seed, he thinks erroneous; he has seen it quite lost thus : in dry seasons it has no effect. Of this manure Mr. JoHnson uses much. He thus expresses himself in a letter he favoured me with:

- Rape-cale is an excellent manurc for turnips, and does not subject them to mildew; they will grow longer than from any other manire; the turnip that grows most after Michaelmas is always of the best quality. Malt combs quick to bring the turnip to the hoe; rape-cake clow; where both are used they should be sown together, 
but not at the same time; the rape.cake should be broken to the size of ivalnuts, the less dust the better, and should be sown in April or May, as near the second ploughing as conveniently can be done, to have a shower on it; the malt-combs should be sowed on the last earth, and harrowed in with the sced."

Mr. ENGLAND, of Binham, uses much rapc-cake, and this year his turnips, thus manured, are his best. The cake-dust should be scaled in, early in May.

Mr. REEve, of Wighton, uses large quantities of rapecake for his turnips, which in a wet season is an excellent manure. Nucked turnips come quicker at first than caked ones, but the latter exceed them afterwards: it is best applied three weeks or a month before sowing the secd, scaied in by the last earth but one: the deeper seetearth then deposits the manure in the centre of the furrow.

Mr. HenRy Blythe, of Bumham, has this year turnips for which he spread rape-cake, at the expense of $3^{\text {l. }}$ per acre, and the crop is not worth 20s.; but it answers in a wet season.

Mr. Syble, of South Walsham, feeds many bullocks with oil-cake, and. finds that one load of the dung is worth two of any other: this he thinks by far the best, and even the cheapest way of getting a farm into condition, and laughs at the idea of buying rape-cake for manure, when compared with this superior practice. It is expensive to men who put lean beasts to cake, but if they are what is called fat before cake be given, it answers well.

Mr. Bircham, at Hackford, has found that ro load of dung from cattle fed on oil-cake, will do as well as 16 loads from turnip-fed beasts.

Mr. Strleman, finishing his turnips before the grasses were ready for the sheep, gave oil-cake in troughs, with 
cut hay, to the amount of just 6d. a week for cake, on a pea stubble; a pond in the field: it continued four or five weeks, and turnips succeeded, which were the best on his farm, and a very great crop.

\section{ASHES.}

Mr. Salter, of Winborough, buys all the ashes he can get, of the poor people who burn fag parings, and the strength of them is very great on his heavy land; but on dry sand he remarks that they do little good.

Mr. Styleman, of Snettisham, has manured sainfoin with coal-ashes; 40 bushels per acre, and with great success.

SOOT.

Mr. Bircham, of 'Hackford, lays out from 70 . to Iool. a year in soot, sowing 20 bushels per acre on his wheat, in March or April.

\section{MALT-DUST.}

Mr. KERRICH, of Harleston, manures for turnips with 50 sacks of malt-dust per acre, at 1 s. 6d. and gets finer crops than with yard-dung.

Mr. M. Hill uses this manure; Io sacks per acre, at 3s. 6d. a sack.

\section{BUCK-WHEAT.}

Mr. Bevan has been in the practice some years of ploughing in buck-wlieat when in full blossom, as a unanuring for cole: the success to his satisfaction.

Mr. Salter has plouglicd it in as manure, fixing a

$$
\text { E e } 3
$$

bush 
bush to the beam of the plough, to brish it down for that purpose.

Upon a harsh stiff piece of marshland, at Warham, Sir J. TURNER sowed buck, and ploughed it in for wheat; it answered well as a manure, besides saving much tiilage. Sir Thomas BeEvor tried the same husbandry on strong clay, and got five-quarters of wheat per acre.

\section{YARD-DUNG.}

Through every part of West Norfolk, from Brandon and Thetford, to Snettisham and Holkham, the farm-yard dung, after foddering is over, is turned up in heaps in the yard, or carted on to heaps in the fields, where it is turned over for mixing: Mr. Dexton, of Brandon, has made an observation on this point, which has a tendency to at change of system. It secnis from the general practicc, that the gentlemen and farmers, for all are in the same husbandry, do not conceive that the sur and wind have any power of extracting those volatile particles which contribute to the food of plants; and the common way of leaving the heaps when carted on to the land for some time betore spreading, and again, when spreal, before ploughing in, shew that this is the case. Here, however, ! must make an exception of Mr. Coke, whose teams I sâw so proportioned, that the dung was turned in as fast as carried out, and very completely buried; but it was short.

The observation alluded to is this-Mr. Denton shewing me his beautifully improved warren farm at Feltwell, he remarked, how much better one half of a layer of seeds was than the other; occasioned by one part being manured with long dung, and the other with old turned-over hort dung. The soil, quite a sand: I observed the different 
appearance clearly. The best was that which was covered with the long inanure.

Thirty years aro they reckoned, near Holkham, that the wheat stubble ploughed in, was as good as a light coat of dung.

Mr. Bradfieln, of Kerattishall, Suffolk, tenant to Mr. BEVAN, carries the yard-dung long from the yard, without any turning or mixing, and spreads it about six weeks before sowing; ploughs it in fleeter than for the sowing earth, but not so fleet as what is called scaling; ploughs two or three times after the manuring.

Mr. Bloonfreld's bailiff, in the absence of his master, gave lis opinion in favour of rotten dung, rather than long and unrotted : however, this year, he says, they used the latter, and the turnips on bad land, justify an opinion different from his own.

The Rev. Mr. Priest, at Scarning, in 1801 , on a field that had been unkind for turnips, drew it into baulks, and laid long fresh dung into the furrows, then split the baulks, covering the manure, and drilled the turnips on the tops of the ridges; the crop proved the largest and best in the neighbourhood. His man, not satisfied with this method, and thinking that he could get a better crop, Mr. PRifs T permitted him to try : he laid the land on broadlands, and sprained the seed into every other furrow, but in such a manner, that it came a broad-cast crop and good for little; because his dung was not buried.

Mr. PRIEst, complaining to Mr. BIRCHAMr, of Reepham, that he had some land on which it was difficult to get turnips, had this answer- $P_{u t}$ on your dung in autumn, and your dificultics will vanish.

Mr. SALTER, of Winborough, pointing at some dung hills, observed, that he had now got a year's muck beforehand: over-year muck, he thinks, far preferable to long 
fresh, as the latter breeds insects, \&rc. and sometimes is hurful. We soon after entered a very finc field of turnips, the crop beautiful; and long dung lying about some of the best parts of the field: his theory was here evidently condemned by the appearance of the plants.

Mr. Havers, at Tl:elton, in common with his neigh. bours, keeps his yard-dung in hills, and composts, called sier-year muck: that is, kept over the year to have it old, and for use in succession, so managed.

Mr. DraKE, of Bilingtord, in the same vicinity, does not applove of over-ycar muck for heavy l.nd; but on light land, subject to burn short dung best: and he has obscrved, that when land has been over clayed, long dung helps it much.

Mr. Pitrs, of 'Thorpe Abbuts, carts clay marle on to heaps in the summer, to which he carries his yard-dung, turns over thrice, and spreads it for turnips, or wheat, or on young seeds, and he finds that on his burning gravels, it answers better than dung alone; though a second claying on the same land, will do more harm than good.

The farmers about South Walsham, \&c. mix dung and marle together. This Mr. SYBLE thinks a bad practise, as the marle will not suork in the land, after it has suorked in the dung.

Mr. Burton, of Langley, does not approve of overyear muck: the best merhod, he thinks, is to spread carth over the farm-yard before foldering begins, to let it be late before it is turnel up, to turn over the hill once, and in a month after to cart it for turnips. He never muc's for wheat: but very good to do it for winter tares, in order for having turnips jonmediately after; in this way he alivays gets good turnips.

"Mir. Thurtell does not approve of over-year muck; 
he carts it on to heaps as soon as his turnips are sown, to rest without turning till wheat-sowing; as all his turnips are manured from Yarmouth. He has accidentally carted long par muck for turnips, to finish a field, and they were certainly a worse crop: for wheat it may be different.Mr. ThuRTELL thinks the winter is the worst time of all for carrying out muck, whether from yards or composts; it slould be either in summer for turnips, or in autumn for wheat. He does not wis! any of his straw to be eaten; all trodder into muck.

Mr. EvERIT, of Caistor, never uses over-year muck: he carts from the yasd, late in the spring, forming heaps; in three weeks turns over, and in a fortnight more carts and spreads for turnips: when he has fallen slıort in quąntity, he has taken long and fresh dung, and has had as good turnips as after the short. Upon strong land, he lias known long fresh dung answer very well: the clief objection to it is the difficulty of turning it in. He was much pleased at the idea of the skim coulter.

At Hemsby, Mr. FERRIER, \&c. thinks short dung, from heing carted to a hill, best; but no over-year muck. Mr. FERRIER gives fifteen loads per acre to turnips, and six to wheat

Mi. Brown, of Thrigby, has carted long stable-muck in March, without any stirring, for turnips, and had as good crops as from hilled short muck; but in such cases gives 15 loads per acre, instead of 12 . If the same quantity, he thinks the rotten would prove the best. His obje tion to long muck is, the idea that seeds would be carried out which would not vegetate in time for the hoe to destroy them, such as docks and needles; and thesc, he imagines, are destroyed by the fermentation, when lilled, and for this purpose, the muck, by all good farmers, is

thrown 
thrown light on to the hills, without carting on to them.He never turns them over. Mr. BRown puts no value on the dung made by straw.fed heasts. He has also tried dung collected from commons, and found it of little or no service. He remarked also, that the dung witich in long snows has been deposited by sheep under hedges, has proved of very small use. Mr. Brown, and other good farmers in Fleg, are attentive, in carting out inuck, \&c. to make the drivers keep on the head-land till they come to the end of the land which is manuring, so as to make each ridge bear its exact proportion of damage, if any : for wast of this attention, if the men are left to themselves, they make roads across from the gate, in evcry direetion, to the great injury of the crop.

Mr. SybLE, of South Walsham, thinks over-year ciung a bad system: he is in the common practice of the country, but were he to farm a strong soil, he would carry out longy dung direetly to the land: and on all soils it cannot be too new, if it be in the right state.

Mir. Fraxcis, at Martham, no over-yeas muck, but in manuring fur wheat, some left was carried on for turnips, and there the crop not so good, though perhaps a fuller plant. He has tried long muck, fresh from the yard, and it does as weil as any, but nor quite so quick a growth for the first six wecks. He has no objection to the practice, but the diffculty of burying it. He likes the idea of the skin coulte. He carts on to heaps, and if tine team goes on, always turns the heap. He lays twelve loads per acre for turnips, and likewise eight for wheat. This large manuring, common in these hundreds, depends much on the quantity of marsh and fen land, abounding in all this country, and which commonly yields a great plenty of rough coarse fodler and rushes, for thatch and litter. 
At Ludham, 12 loads per acre of par dung, common. Mr. Hornard ofien lays on 20. He carts his muck to heaps, on moulds, not suffering the teams to go on to the hills. Some farmers turn it over. He never keeps it overyear. He lays some on for wheat, but for turnips in preference.

Mr. Cuвit, at Catficld, and others, carry out muck in frosty weather, on to mould heaps, and also when barley sowing is over. He has often carried out long fresh dung for turnips, and the effect has been very good, especially if the land has been at all strong or wet. The objections are, the difficulty of hoeing well, and the manuring being unequal, from some yards and parts of yards being better than orhers; whereas, in carting to hills, Mr. CuBIT takes from oxen and stables, alcernately, in order that the whole may be mixed and equal, when turned over.

Mrr. CUBıt, at Honing, thinks that for land on a wet bottom, long dung is good for turnips or wheat; but he carts on to hills, to have it as short as possible; for on light land he has known it fail, for turnips, when long.

'Throughout the hundreds of North and Sout' Erpingham, the same management prevails : all cart out and hill, and in general turn over.

Mr. Dyele, of Scotter, makes platforms of earth, then a layer of marle, and turns over, then adds muck, and turns again, whether for turnips or wheat. Has on many acres carted long fresh stable muck for turnips, ploughing it in at once, and gained fine crops if the season proved wet; but not in a dry time.

Mr. Repton, at Oxnead, thinks long dung the best for turnips; however, he seldom uses it; ibut when he has, the turnips have generally been the best. Carts his dung on to heaps of marle, and turns over.

Mr. JoHnson, of Thurning, thinks that muck wastes 
by keeping to an unprofitable degree, and that the more is is turned over, the worse: he has tried long muck, fiesh from the yard, for turnips, and got as good by it as by any other; and the barley also as good. The difficulty is to get it buried: he has employed hoys to tuck it in: he approves much of the idea of the skim coulter.

Extract of a Letter from Mr. JoHnson.--" Where lands are unkind for turnips, straw may be converted into muck with profit, by feeding the pirrs with pease in the yards; and the muck kind for turnips; the quality of the muck depends on what the animals is ted with; muck made from turnip-fed beasts is better for grass or wheat, than for turnips: if beasts have nothing but straw and turnips, it is not so kind for turnips as muck made in strawyards from other food."

Mi. England, of Binham, carts his yard-muck on to heaps in the winter, and turns up the rest in the yard, to get it rotten for the turnip-seed earth, and thinks it would lose its virtues if carried on long: on strong land it may do, carried on in winter, for turnips, and has clone it on such a soil with good effect. He has no doubt of the superiority of rotten muck for turnips, but is against kecping it over-year.

Mr. Reeve, of Wighton, carts his yard muck on to heaps, and turns them twice, to destroy the seeds of weeds, and the shorter the better, provided it be in a fermenting state: eight load of short are as good as twelve long; but o:er-year muck bad, as fermentation in that is over. He has tried long and fresh dung, but it has not answered so good a purpose. He lays on all his muck for turnips; none for wheat.

Mr. ReEve is clear that all straw should be trodden :nfo muck, and none eaten. He las kept a large dairy of coivs, 
cows, and thinks them the worst stock that can be on a farm, as turnips are drawn for them, instead of being fed on the land by sheep; and more straw is eaten by them, instead of being trodden, than by any orher stock. His expression was, "I would not have a mouthful eaten."

I have observed on many farms, the dung for turnips either not well turned in, or harrowed out again, and olien recommended the use of the skim coulter. I shoulk observe, however, that on Mr. CoKe's farm, his dung was very well tucked in; whether it would have been the same had it been long dung, is a question.

Mr. M. Hill remarks, that long muck is best, if laid on in November, for turnips the following year; especially on wet cold land: but short and rotten for summer manuring on the land that has had thrce earths. The difference, in this case, little in the barley atter the turnips, but much in the turnips themselves.

The Rev. Dixon Hoste, at Goodwick, prefers shore and rotten dung: dunghills for rotting seen in all that country.

The quantity per acre generally applied on the sand district, north of Swafham, is 10 cart-loads; and every man tills that quantity for a day's work. The price for

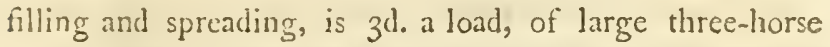
carts: three men spread; one to throw out, and two to break to pieces, and shake aboat equally.

Mr. Orerman desired me to remark a superiority of a part of a field of sainfoin: it was very visible. He coulci attribute it to nothing but that part of the field having been dunged trelve years before: the soil a sharp gravel, commonly thought to divour dung quicker than most other soils.

Mr. JURsGate carts his muck on to heaps, and then iurns over: he lias tried it long and fresh for turnips, but likes 
likes short much better: though roo loads carried out, be comes but 60 on the land. Mr. DuRsGate would not have a bulluck on his farm, except for trcading straw into muck: he would have none eaten.

Mr. Sryleman, of Snettisham, carts out his yardmuck on to platforms of marle, turns over, and lays it ors for turnips. He thinks long muck might do well for strong land.

Mr. SafFory, of Downham, turns over the dung in the yard, and then carts it for turnips, plougling in directly. He has seen very long fresh dung spread and ploughed in direetly for turnips, and it has answered well on strong, but not on light land. Soinc cart out of yards, and mix with mould.

Mr. Porter, of Watlington, turns over dunghills, to have the muck short for turnips, not liking long dung at all; it makes the land scald.

Mr. Rogerson, of Narborough, carts earth into his yards previously to foddering, and when it is done, turns it over for turnips.

Mr. Priest, of Besthorpe, forms his yard-muck intn a heap, and turns over: chuses to have it short: evein in this way he has boys to tuck it in.

Mr. Goddison, Steward to the Earl of CholmonDELEY, at Iloughton, considers rotten dung as necessary for wheat on light soils; and he prefers top-dressing wheat crops to ploughing in at seed-time: he also topfolds as mucls as he can do by Christmas, harrowing both across in the spring : but for turnips he has a high opinion of long-muck; he carries it out of the yard without any stirring over, and ploughs it in for that crop: little harrowing up; nor does it impede the hoe: it answers greatly, and the barlcy after has been much bet- 
ter than in any other way, insomuch, that if a fair comparative experiment were made, he would bet on long dung against short.

Mr. E. Scotr, at Grimstone, has carted out long muck from Christmas to Lady-day, and ploughed it in for turnips, and had none better: nor did he see any difference in the barley, but believes that it does not last quite so long as short.

" Muck from the straw which is trodden only, is, by some, thought to be better than that from the straw which is eaten by lean stock." A capital farmer much in favour of fatting pigs loose in a littered yard: "What a rare parcel of muck they make, compared with what neat beasts would have made from the same straw !"- Marshall.

Observations. - Many of the preceding remarks are extremely interesting. The negative of so many able and intelligent men against suffering any straw to be eaten, which is the common practice of the larger part of the kingdom, deserves much attention: and the consequent practice they are in of buying oil-cake, often to loss, that their straw may be trodden into dung by fatting beasts, is a perfection of management not often met with.

In regard to the question of long and short dung, opinions are evidently much divided; and though, in the common method of the county, short dung is preferred, here is enough said upon the merit of that which is used in a long state, to prove that the inquiry deserves morc attention than it has met with. Mr. Denton's experiment is remarkable, and the observations, founded on practice, of Messis. Bradfield, Brown, Syble, Francis, Dyble, RePton, Johnson, and Scotr, are all much 
to the purpose. Comparative experinents, very casy to make, would ascertain this point, which is certainly of considerable importance. A prevailing idea in Norfolk is, that long dung is best for strong land, and short for light soils: the general practice is that of spreading shors in all cases. But Mr. Denton's soil is sand *

\section{LITTERING.}

There is a singular practice at Itarmouth, which has been common time out of mind, of littcring all stock, such as horses, cows, \&c. with sea-sand. A number of Yarmouth one-horse or one-ass carts, are employed to bring sand from the shore for this purpose, and it is done the more largely, that the quantity of muck to sell to the farmers may be the greater. Mr. THURTELL manures all his turnips with this dung, and it is excellent. The sand ought to be ten' days or a fortnight under the horses and cows, being gradually drawn back with hoes, and fresh supplied: many thousand loads are thus made annually; and great quantities are taken into the country by the sailing barges called kucls. Ten large cart-loads per acre are a good dressing, as much as three horses can draw. It sells at 4 . a waggon-load in the town, and six of these loads do an acre. Mr. Thurtell brings it all winter long. He observes, however; that it is not clurable; the chief force of it is exhausted in the turnips and follorving barley.

Mr. Everit, of Caistor, manured a ficld with par yard-nuck for turnips, but falling short two acres, he finished that part with Yarmouth sand-niuck: the turnips

* Much information on this interesting question, is 10 be found in many Passages in the Annals of Agriculture.

were 
were equally good; but the barley on those two acres inferior to the rest of the field.

Mr. FERRIER's horses, at Hemsby, all littered with sand; and the manure very good.

\section{LEAVES.}

Sir Thomas BeEvor, more than 30 years ago, constantly swept and raked up all the leaves in his park to use for litter, at the expense of 6d. a load : the success, in adding to the farm-yard-dung, great.

\section{BURNING STUBBLES.}

1 found many oat-stubbles in the new enclosure of Marshland Smeeth burning, ready to put in wheat or cole for seed : the crops had been immense in straw, and reaped, and the land quite black with the ashes; but many parcially and badly done, not half burnt. Mr. JoHN 'THIsTLETON, of Walpole, had burnt his completely: I saw the fire spread over several in an unbroken moving wall of flame, and inust be to the utter destruction of many insects, and all grubs and slugs not buricd in the earth. Where stubbles are stout it must be excellent husbandry, and will remind the reader of burning straw in Lincolushire as a manure for turnips. - (See my Lincoln Report.)

Mr. Porter, of Watlington, has burnt oat-stubbles for sowing wheat, with much success: is now threshing to coombs an acre of wheat thus gained. Harrows fine after ahe burning : dibbles if strong land; drills if light.

\section{RIVER-MUD.}

Mr. Palgrave, at Coltishal, has used moory-mud, from the bottom of the river, mixed with lime and inarle,

$$
\text { If and }
$$


and spread upon the sandy uplands, and it produced a profusion of weeds, especially persicuria.

Mr. BrRcham has used the silt out of the brook at Reepham, for a moory meadow: it killed the rushes, and covered the land with white clover.

\section{TOWN MANURE.}

Mr. ReEves, of Heveringland, for five or six years kept one or two teams almost constantly at work bringing manure from Norwich, at the distance of eight miles, laying eight loads per acre: the expense heavy, but he thought it answered while the price was 4 s. or 5 s. for good stuff; bus the price rose, and the manure became adulterated.

Mr. Beck, of Castle Riseing, for seven years liept a team constantly at work, bringing Lym muck.

SECT. IV.-PARING AND BURNING.

Mr. Dr a Ke, of Billingford, broke up a rough coarse pasture; the soil poor, wet and hungry, on brick-earth, worth scarcely any shing, from the kind and state of its herbage; by paring and burning, 'at the expense of 2l. 12s. 6d. per acre; he then ploughed it as shallow as possible, hardly more than an inch and haif deep, and dibbled in oats, covering the seed with a very light harrow, bushed: the crop, which I viewed, vcry great indeed; it varied in parts of the field, but the produce must be eight or nine quarters per acre. He proposes to plough the furrow back in the spring a litile deeper, and dibble oats again; then to work it well for barley, laying down and claying on the layer. I remonstrated against these crops, but he urged the ne. cessity of the flag (as he calls it, though pared) rotting, 
and the tillage for barley, mixing the ashes well with the soil: as it is very thin skinned land, he will lay 80 loads per acre. He has hollow-drained part, and intends the rest.

On another piece of the same soil he has got turnips for the first crop. His oats, however, are worth at least 61. or 71 . per acre more than the turnips.

Mr. W YNEARIS, near Marham, on a common being enclosed, pared and burnt 200 acres for turnips and coleseed.

\section{SECT. V. EMBANKING。}

THE tract of land in Norfolk, between the rivers Wyne and Ouze, called Marshland, is one of the richest districts in the kingdom. It spreads also into Lincolnshire, and forms alogether by far the largest salt-marsh we have. As the sea still retircs from this coast, it is easy to perceive in what manner all this country has been the gift of that overwhelining clenent, which in other places encroaches so severely, and is, at high tides, restrained even here with so much difficulty.

The soil of the whole is the subsidence of a muddy vater, witin a considerable portion of what the waves, powerful in their agitation, wash from the bottom of the adjoining gulph, which forms the embouchure of two considerable rivers. It is a mixture of sea-sand and mud, which is of so argillaceous a quality, that the surface of it which covers the sarul, gives it the common acceptation of a strong clay country. Is its extraordinary fertility at all owing to the marine acid, with which every particle is impregnated? That cause has every whore on the cuasts 
of every part of these islands, as well as other countrics, some effect. If the sea leaves only a ruming sand, the saline particles are soon washed away or exhaled; the land may be barren, though never in the degree of vulgar conception. But when the sand is mixed with, or covered by a more retentive substance, such as an argillaceous or calcareousearth, then the particles, whether saline or mucilaginous, are retained, and the surface classes amongst, or rather is at the head of all, fertile soils.

I observed that the whole country has been a present from the ocean: this is olvvious from numerous appearances; but those who wish to know its history particularly, should cousult DUGDALE. I may remark, that there are ranges of banks at a distance from each other, which shew the progressive advances which industry has cffected, eager to seize the tracts which so dreaded an enemy relinquishes. One of these banks is called the Roman, which naturally brings to our mind the vast exertions which that people made in agriculture, wherever their vietorious eagles frew. The distance of this bank from the shore, if it realiy is Roman, and not a misnomer, is not so great as it would have been, had the sea in all ages been as liberal as it is in this. It probably varies considerably in this respect in different periods: at present it retires very rapidly, so that though Count BENTINCK's embankment has been finishec but a ferv years, there will be, in twenty years, a thousand acres more ready to be taken in, belonging to Mr. BENTriveK, the present possessor.

The mud deposited by the sea, is at first, and for some years, bare of all vegctation : the tirst plant that appears is the marsh samphire; by degrees grasses rise, which, from their appearance at the time I viewed them (October), and eaten close down by cattle, secmed to be the common ones 
of the improved salt-marsh, but not the diadelphia fanily, which come afterwards.

Long before it is raised enough by successive deposits of mud from high tides, it lets to the farmers of the con-

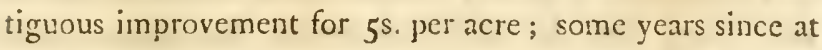
2s. 6d. Broken as it is by holes and little creeks of water, it lets, immediately after embanking, at from 20s. per acre; a few years ago to $40 \mathrm{Os.;}$ and $42 \mathrm{~s}$. at present. I onserved one or two pieces within Count BENTINCK's new bank, that were left in that rate for cattle, but in general they were under the plough, and the grass-fields laid down after a course of tillage.

The business of embanking to take in a new piece of marsh, is done sometimes at the expense of the farmers, who make the bank, to have the land rent-free for 2 I years. Adjoining to the Bentinck improvement, is a piece of 80 acres thus taken, but the bank very ill made, at no greater expense than 40 . a rod. Those constructed by landlords, were deficient in not having slope enough given towards the water. Count BENTINCF laid out his upon a scale never practised laere before; and his son, the present pos. sessor, has far exceeded it. The former extends about four miles, and adjed to his old estate, I000 acres. The base of the bank is about 50 feet. The slope to the sea, $3^{6}$ feet, forming an angle, as 1 guess from my eye, of 25 or 30 degrees. The crown is four feet wide, and the slope to the fields, 17 feet, in an angle, I guess, of 50 degrees; the slope to the sea, very nicely turfed. The first expense of this bank was 4 l. per rod, but a very high tide coming before it was finished, not only made several breaches, but occasioned an additional height and slope to be given to several parts, to bring it to the above dimensions, all which made the gross expense about 5 l. a rod. The whole cost something above $500 \mathrm{cl}$. 'the expense of

$$
\text { F } \mathrm{f}_{3}
$$


the buildings, and other things, amounted to as mucls more, for five new farms, with loouses, barns, and all necessary offices, were immediately raised; this was, however, going to a greater exponse than necessary, for the land would have let as well in two or three farms, as it did in five. Calculating the expense at 10,000 . and the new rental at roool. a year, it is just ten per cent. for the capital. The expenses certainly ran too high; for the value of the marsh, at $2 s .6 \mathrm{~d}$. an acre before embanking, reduces it to less than nine per cent.; after which, there is still to be deducted, the almost periodical repairs, which remarkably high tides still occasion, and which may be averaged at once in ten years. So that when we consider it not as a purchase of a new estate, but an agricultural improvement of a waste, the profit is not equal to whinat inight be made on other species of waste lands.

This is probably owing to the husbandry of these stiff wet soils being very ill understood, and mnnaged in a manner that is reprehensible in almost every particular.

Instead of a system of miserable tillage, with weeds the chief signs of fertility, the plough ought to be introduced only as a preparation for the most perfect grass system that can be devised. These lands, when well laid down, will fatten the largest bullocks and sheep in England, which is the right employment of them; and in which application they would be better worth zos. than in their present state $20 s$. Hence it should be an improving landlord's business to farm the marsh till he got it to a very fine grass, laid down himself, for I scarcely ever saw a tenant that would do that well. Ray-grass, and the weedy rubbish of a loft, which he calls hay-seeds, with, perhaps, some common clover, are what he has recourse to; and, under such management, the wonder is, that he ever gets a pasture worth even 20s. In all improvements, where 
the previous steps are very expensive, like embanking a marsh, draining a bog, \&ic. it is essential to profit, that the land he advanced to the highest perfection possible, as those preparations to culture cost no more for a great than a small rental.

Count BENTINCK had one idea in the execution of his work, which had considerable merit; he planned a navigation from a quay to each of his farms, over the whole estate, by a large ditch capable of admitting long-boats, some of which he actually built ready for the business: by this means the farmers would be able to carry their corn, or bring manure from Lynn, if they chose to do it, without the least land-carriage; but his death, which was occasioned by too assiduous an attention to building the bank, living in a tent, in a bad season, and aguish situation, without the precautions of adapting his diet to those circumstances-prevented the execution.

One circumstance of tolly in his neighbours, prevented the improvenent from being so considerable as the Count had planued. At the further extremity, towards the wisbeacl river, there is a common belonging to the parish of Terrington, to which the sea, by retiring, makes additions similar to those by which individuals have profited.

A continuation of his bank, in nearly a righit link to the Wisbeach river, would have taken in about 500 acres of that common. Mr. BENTINCK applied to the parish for their consent to do it, which would have heen the means of shortening his bank. Though several indiviciuals would have been glad of making use of so favourable an opportunity, the body refused their consent. They were even so preposterous in their opposition, that when he atterwards offered to be at the sole expense, provided they would give him a lease of 2 I years of the land recovered, they still $\mathrm{re}$ fused it. Upon which, he was obliged to follow the 11. Ff 4 regur:m 
regular outline of his own property. The motive of the parish for refusing their consent to a proposal so advantageous to themselves, arose from this circumstance. It is of great extent; the proprietors adjoining the common, make, at present, nearly the whole advantage of it; but when embanked and let, those at a distance would come in for their share, a jealousy of which, occasioned the failure of the scheme.*

The spirit and unliunited attention, even to the loss of his life, with which Count Bentinck planned and executed this great worl, ought to render his memory dear to every lover of aşriculture. His active mind had taken a strong and most useful curn towards that art ; apparent, not only in this great and successful project, but in the original invention of an admirable machine for drawing up trees by the root, which executed that difficult work wih expedition and cheapness. - Minute, in $17 \delta_{4}$.

Neru Embankment. - The men were paid 4s.6d. a foor of 400 cubical feet, but they find wheeling planks, barrows, trussels, \&c. \&c. When formed, the front slope is sodded, for which they are paid 4.s. a floor of 400 square feet, earning from 5s. 6 d. to 7 s. a day. And some small expense follows for beating it firmly down. The whole expense of bank, sluice, and all, 3300 . The quantity of land taken in, 273 acres of marsh, and 18 of bank. The previous value absolutely nothing; now, Mr. MAITLAND, steward to Governor BENTINCK, was at once offered 4 l. an acre for four years; or 3 l. an acre for six years. The former amounts to 43681 . in four years, or the whole expense, and 1000 guineas over. Some buildings, however, in this case, to be erected: the Governor

* This tract has been since embanked, and a!lotted by act of parliament, passed in 1790. 


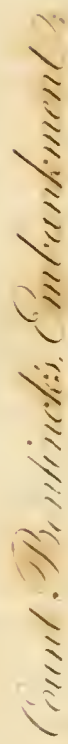

$\checkmark$

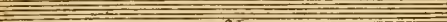

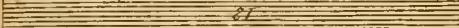

21

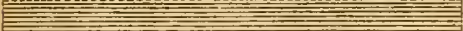

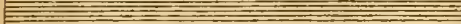

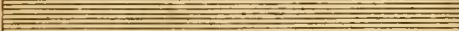

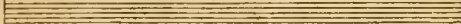

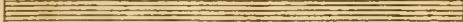

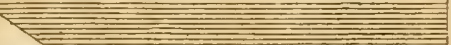

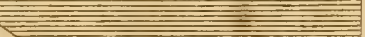

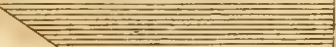

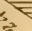

F

0

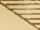

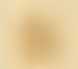




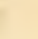


fet it to his old tenants at 40 . an acre, without any expense of building, a permanent rent, and under restrikions in cropping: confined to cole-seed and corn; of which, to take seven crops, laying down to grass with the seventh, to remain seven or fourteen years, and when broken up, to lay down an equal quantity of their old farms. This, upon the supposition of the grass failing, but if good grazing land, to remain unploughed. This system of cropping 1 must think mucin over-doing it, if rich grazing-land is the view. There is a great treasure in the land, and it should have no more tillage than necessary 10 prepare it for grass: if that grass does not turn out of a luxuriance and sweetness sufficient to carry a full stock of bullucks, then is the time for a tillage system; but I conceive that after seven crops of cole and corn it will not be found fine bullock-land. All ideas of the fertility being inexhaustible are idle and vain; you cannot make it bad land; but there is a great difference between common grazing pastures, like some in these marshes, and such as will carry an ox of 100 stone.

The Governor has the agreeable prospect of taking in 300 acres more in six or seven years. The space is fast covering itself with grass; and wants very little more than to have the cracks silted up*, which adds so considerably to the convenience and value of the land, that if this traet was taken in now, it would not let for more than 20 . an acre; but a few years hence it will be worth 40s. But to assist the operations of the tide, in thus silting up the creeks, much attention is necessary to accelerate the effect; and $I$ found Mr. MaItLAND engaged in this operation:

* It is proper to observe, that the effect of the water on this const, depusiting its sediment, is here called silting; which upon the Humber and the Trent, is termed warping; they are the same operation of Ndture. These waters are muddy to an extraordinary degree. 
where the sea-water remains in a creek after the tide rew tires, the creek will not sile up nearly so fast as when channels arc made for conveying it quickly away: by making stanks across the large creehs for giving a new direction ro some of the water, and cutting channels from hole to hole tor their drainage, this is effected. Mr. Matruane sisewed we the surprizing difference in the silting up of crceks without water, compared with those where it remains. The floorings, from which the bank was raised four spits deep, are now, in only two years, nearly silted up in some places, and in others, not more than a foot deep : by these attentions, regularly put in exccurion, the traet preparing to be taken in, will be ready many years sooner than it otherwise xould.

Ciovernor BENTINCK has a very attentive and understanding agent in Mrr. MAITLAND, as lis plans sufficiently prove. These are, to build a small house close to the new bank, for a steward, at an angle, to command a view both ways; and where one or two cortagers sloould he always realy for executing the works necessary in assisting the silting of the tides, and any little reparations, or sather precautions, that the banks may want; to make 2 road from the highway to the new bank; this is done. To build a granary on the sliore for the tenants to lodge their corn, for taking it by water to Lynu. And lasty, to plant the old hanks, rendered useless, unkess in the case of breaches, to suppiy the wast of wood on this estate of fertile land.

In ieģard to the cultivation of this fune estate, I wish I could add, that it is worthy of the soil; but this is far from reing the case. The tractaken in, in 1800 , was plongled direcily, and sown that year, part with cole for seed, and part with what; and in the spring of 3801 , part with oats. The cole-seed crops were great; and the wheat 
EMBANKING.

443

some of the best in the country. This year (1802) it is under cole, wheat, and oats again; the wheat and cole the best. It is let from al. 2s. to al. 12s. Gd. per acre: tithe, 4s. Gd. per acre; and rates, es. in the pound. The expense of the whole, 4000 l.

CHAP. 


\section{CHAP. XII.}

\section{LIVE STOCY.}

SECT. I.-CATTLE.

THE cattle predominant in Norfolk are Scotch, bought in every year from the drovers of North Britain. The quantity of these is very considerable indeed; as there is scarcely a farmer of any consideration in the county, that does not turnip-feed a lot proportioned to the size of his farm. The profit was formerly respectable, but it has been gradually lessening, by reason of the high price at which they are bought in. The breed is lessened in Scotland, and the drovers are more skilful than they used to be, in estimating what the demand will be from the state of the turnip crop, and they accordingly proportion their supply so exactly, that cheap lots are rarely procured. This circumstance has had some influence on the change that has taken place in the county respecting sheep. This stock has of late years been very greatly increased, to the diminution of bullochs, and has been effected by the superior profit derived from the South Down breed over that of Norfolks. The change has been of great importance to the farmers, insomuch, that they have by this means raised their profit, at the same time that their farms are in better heart: if they were in the liabit (could it be effected on a large scale, of which I have litte doubt) of treading their straw into dung by their far shecp, 
sheep, they would have still less occasion to buy bullocks.

Cattle in Norfolk of other sorts, do not offer much that is interesting : they have a breed of their own which possesses no qualities sufficient to make it an object of parricular attention.

I saw upon Mr. Money's farm at Rainsham, a Norfolk horned cow, which is undoubtedly 35 years old; she has not had a calf for about ten years; she is old to the eye, but in good condition, and no marks of extreme age, except a stiffness in her motion, and a halting gait, as if her feet were sore.

I viewed a dairy at Milcham, Mr. Carrington's, the only one left in that country of the true old Norfolk. breed of cows: middle horned; some rather shorter, and tending to the Alderney horn; colour red, in some not much unlike the Devon; as loose and ill made as bad Suffolks. Mr. Marshall gives a much more favourable idea of those of East Norfolk.

" Simall boned, short-legged, round barrelled, well loined, thin thighed, clean chapped; the head in general fine, and the horns clean, middle-sized, and bent upwards: the favourite colour, a blood red, with a white or a motsled face. The Herefordshire in miniature, except that the chine and the quarter of the Norfolk breed are more frequently deficient: no better flesh'd beasts are sent to Sinithlield. This quality of flesh, and fatting freely at an early age, do away every solid objection to their sizc ( 40 stone) and form. One of the best farmers in the district apprehended that the best cross, that of the Highland Scot, would not fat so casly: he is clear that a Scot does not fat kindly even at three years old, much less at two. at which age many humdred head of cattle are annually fatted in this county."--Marshall. 
Mr. Drxon Hoste's are hetween the Suffolk and the polled Scotch; came originally from the Duke of GRAFIon's; they milk very well; I 2 were in August, fatting two large calves, supplying the family with milk and cream, and giving 6olb. of butter per week.

About Attleborough, Hingham, and Watton, there are many dairies, but fewer coss than formerly: as the farmers have changed their system to grazing, there is some good fattening land all through that country.

Mr. CoKe, at Holkham, has had many bieeds; and he was once almost exclusively addicted to long horns. Some of FowLER's stock are now at Holkham: he has many Devons.

Mr. PURDis, of Eggmore, imported from Devonshire, in 1802 , above 40 cows and heifers, and two bulls of the true North Devon breed, from Mr. PEster. I viewed them with pleasure, and also 16 oxen of the same breed, which were ploughing for turnips. He works four to a plough, in yokes and bows; they moved fully as fast as the horses at plough in the same field. This gentleman was before in the long-horned breed, of which he exhihited two cows at Holkham; but the part of his stock which most attracied notice was a Galloway heifer, of a most beautiful form; of a singular disposition to fatten; much admired by every one who examined her.

Mr. Bircham, at Hackford, buys his bullocks in Oetober, and puts thom to turnips dircetly, thrown on the ollonds, but the beasts brought home at night to straw; continues thus to Lady Day; if turnips be done, he puts them to hay and oil-cake, or ground pease or balley; and he reckons that cake at 81 . or 91 . per ton, is equal to pease at I6s. per coomb : he has ferl with cakc when it was at 13 l. per ton. His son at Reepham, on 300 acres, keeps 40 bullocks, and 100 to I 50 sheep. 
MIr. PitTs, of Thorpe Abbots, is of opinion that cake at 10l. 1os. per ton, is a cheaper food than bean-meal at iss. per coomb. He gives meal with turnips, but with cake only cut hay.

In Happing hundred, some farmers feed with cake, but the number no: considerable: more do it in Fleg, but the practice by no means general.

Mr. REPToN, at Oxnead, feeds with cake, and has used much linseed jelly: he has gone to 13 l. 13s. per ton, for cake, but that price too high to answer, except in the manure alone.

Mr. Havers, at Thelton, has imported two bulls and several Devon cows and heifers: some are very beautiful, and must be estecmed a well-chosen selection: he has 26 in all: rears all the calves.

Mr. Francrs, of Nartham, thinks that his own home. breds do as well in grazing as Scots, but that it is different with such as are bought-it is uncertain. He turnips 40 bullocks a year; half in the yard, and half abroad; but the latter at home every night.

SECT. II.TSHEEP.

NoREOLK and Suffolk have for ages been in possession of a brced of sheep, of which the farmers were (as they generally are, whatever the breed) extremely provd; thinking that no other sort would suit their country. Of this breed, the district of Bury, in Suffolk, possessed the hest. They have often been described. I shall therefore only observe, that they are horned; bear clothing wool, the third in the kingdom for fineness: fleece, about $2 \mathrm{ib}$. shape 
bad, loins narrow, back-bone ligh, chines thin, legs long, pelt good, disposition very wild and roving, not hardy, though formerly thought so: rate of stocking half a sheep per acre. Mutton I81b. a quarter equal to any in the world in cold weather, and yields an uncommon quantity of high coloured gravy.

Mr. KENT thus characterizes them :- "When great tracts of heath-land were brought into cultivation, the Norfolk sleep gave great aid to the new improvement: hardy in their nature, and of an agile construction, so as to move over a great deal of space with little labour, folding became in high estimation. The turnip system enabled the farmer to improve his stock by better keeping, so that at this time they are become respectable and profitable in their return, and in as high estimation at Smithfield as any sheep whatever.

"I have no patience with the great farmer, in suffering himself to be lulled into so gross an error, as to prefer Lincolns and Leicesters; he will never be able to substitute any other sheep that will answer pemning so weil as the native sheep. It is a manifest incongruity, to cross a Norfolk with a South Down."

The following is Mr. Marsiall's account:-" The Norfolk breed of sheep, taken all in all, appears to be singularly well adapted to the soil and system of management prevalent in this county. They may be bred, and will thrive upon heath and barren sheep-walks, where ninetenths of the breeds in the kingdom would starve: they stand the foid perfectly well; fat freely at two years old; bear the drift remarkably well to Smithfield, or other distant inarkets; and the superior flavour of the Norfolk mutron is universally acknowledged; therefore the Norfolk husbandmen, in their sheep as well as in their cattle, have much to lose. The sheep appear to me, from a 
knowledge of different breeds, to be better adapted to the soil, situation, and system of management of the county at large, than any other breed at present existing in the island."

I proceed to the minutes $I$ have taken in the county at different periods; in all such cases the opinion of strangers must fall before the experiments of the natives: their practice, their opinion, are what County Reports should contain.

\section{BREEDS, CROSSES, AND VARIOUS CIRCUM- STANCES.}

The South Down breed is getting rapidly in possession of all the country from Swafham to Holkham; but from Brandon to Swafham many Norfolks remained: I observed, however, some mixture even in that district.

In 1784 , being at Holklam, I was informed and registered, that Mr. Coke " last April twelvemonth sold sixty Norfolk shearling wethers at Smithfield for $35^{\text {s. }}$ each : he has killed them at two years old of 3 olb. a q'aniter." At that time these were thought extraordinary circumstances.

I $S_{7}$, with one of the finest flocks in Norfolk, Mr. CorE is not so devoted to the black-face and leg as to hesitate at any experiment calculated to compare it with anvilier breed. He purchased a number of Leicester ewes of Mr. WALKER's breed, to whom he put one of Mr. BAKEwELL's tups: he is well satisfied of the advant.nge atrending this breed.

Mr. CoKE's flock of 160 New Leicester ewes, produced in 1802,100 lambs; his flock of 630 South Downs produced 830 lambs living in June. The same farm yields a most interesting comparison between NorNORFOLK.] Gg folks 
folks and South Downs: his former flock was 800 Norfolks, sELLING all the produce: he planted 700 acres, and now has 800 South Downs, KEEPING all the produce.

Mr. CokE's New Leicester hogs and theaves produced $8 \mathrm{lb}$. of wool each in 1802 , yet they luad been hard kept on seeds fed very bare.

Of all the crosses of sheep Mr. Coke has tried, none strikes him so much as that of a New Leicester tup and a Norfolk ewe: the change is almost total, to a degree that is cxtraordinary indeed. I viewed the hoggits of this eross, and found them enveloped in about $7 \mathrm{lb}$. of long wool; no horns; faces, some white; and the form surprizingly improved.-(Note, some years back).

In $\mathrm{ISO}_{3} \mathrm{I}$ found his opinion changed, from much experience; so that he prefers the cross of a South Down ram on a Norfolk ewe to that of a Leicester ram.

Mr. Hoste has had the same cross, and they come to $3^{2 l b .}$ a quarter, at two-shear. He put a Norfolk tup and a BAKEWELL tup at the same time to the same parcel of Norfolk ewes, and at St. Ive's fair sold the lambs fat at six or seven months old, and the BAKEwELLs brought just double the price of the Norfolks.

Mr. Coke, in April I799, sending Norfolk, South Down, and New Leicester three-shear wethers to Smithfield, that had been fed together, the return: $\mathcal{L} \cdot s . d$.

Average per head, Norfolks - - 300

Leicesters - - - - - - - 422

South Downs - - - - - - 372

Ditto, fleeces included, the otliers being in

their coats - - - - - 3153 And in May following above 100 going, the South Downs beat the new Leicesters by 2s. a head.

Mr. Money Hrll, at Waterden, with about 500 acres 
less land than at present, kept 27 score breeding Norfolk ewes, and sold the produce of lambs: now he has 35 score South Down ewes, and keeps their produce, selling his wool at 5s. a tod more than the Norfolk.

In I 798, Mr. Money Hill sold a flock of Norfolks, reckoned a very fine one, and they brought 34 l. Ios. a score, on the average. The next day he went to the South Downs, and bought 1000 ewes, at 3 Il. a score home: he culled 200 that were rather coarse-woolled behind, or not well made, which he sold for 4001 . to a neighbour. In 1799 he lett one tup for 100 . 10s. In 1800 he lett five at 5l. 5s. and eight at Il. I Is. 6d. 'In I 80 I he lett twelve for 237 . and one to various persons, sending 60 ewes, at ros. $6 \mathrm{~d}$. each, besides 40 of his own, being in all 50 guineas for one. In 1802 he lett ten for $254^{l} \cdot 3^{\text {s. }}$ His mode of letting is by a table of the number and price at which they are put up at austion. In 1802 he sold 157 culled ewes for 3681 .

Mr. Hill estimates the difference of stocking betwcen Norfolks and South Downs, at one-third in favour of the latter, in number, in better condition, and of greater weight both in wool and carcass; all fairly attributable to the superiority of the brecd, and free from any change of lessening cattle, \&c. When his flock was of Norfolks, scarcely one in a score had a whole fleece; but now they are South Downs, scarcely one in a score is broken. His flock at Midsummer: 700 breeding ewes, 660 lambs, 45 rams. The wethers are grazed off in the spring, the last lot going before the ewes lamb; sucls as are short of shearlings go in their wool: culled ewcs are sold in July, one, two, and three ycars old. Crones fed and killed in harvest. Mr. Hill thinks that South Down stock-shcep and hoggits are generaliy shorn three weeks too soon, when later there is more wool and better clipt: common

$$
\text { G } g 2
$$


time about the 2oth of Junc; would be better the roth of July.

In 180 I he gained the prize, a silver ladle, for the best South Down ram shewn at Swafham, given by the West Norfolk Agricultural Society.

Mr. Blythe, of Burnham, had, four years ago, a flock of between 5 and 600 Norfolks: he has now 1000 South Downs on the same land.

Mr. BLyтнe has double the wool from his land, stocked with South Downs, to what he clipped when under Norfolks.

March.27, 1799. Mr. OverMan took from turnips 24 two-year old Norfolk wethers, and Io South Downs of the same age, having always lived together from the time they were lambed, and two hours afterwards weighed as follows:

st. lb. st. lb. oz.

24 Norfolk, from the field, $2647 \frac{\mathrm{T}}{2}$ average I I I 15 Do. after fasting 28 hours, 257 I3 30 10 7

Difference, - $\quad \overline{058}$

10 S. Downs, from the fich, Io9 4 average 10 I3 0 Do. after fasting 28 hours, $106 \quad 2 \quad$ 10 $8 \quad 9$

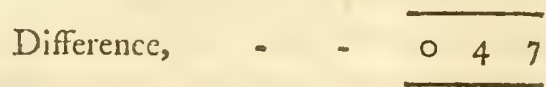

One of each lot slaughtered:

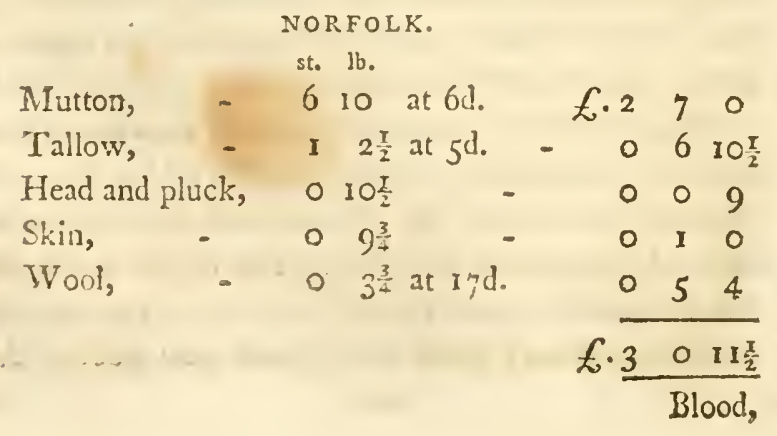




\begin{tabular}{|c|c|c|}
\hline Blood, & - & $\begin{array}{cc}\text { st. } & \text { lb. } \\
0 & 6 \frac{i}{4}\end{array}$ \\
\hline Entrails, & - & O II \\
\hline Loss, & - & 00 \\
\hline Live & & \\
\hline
\end{tabular}

SOUTH DOWN.

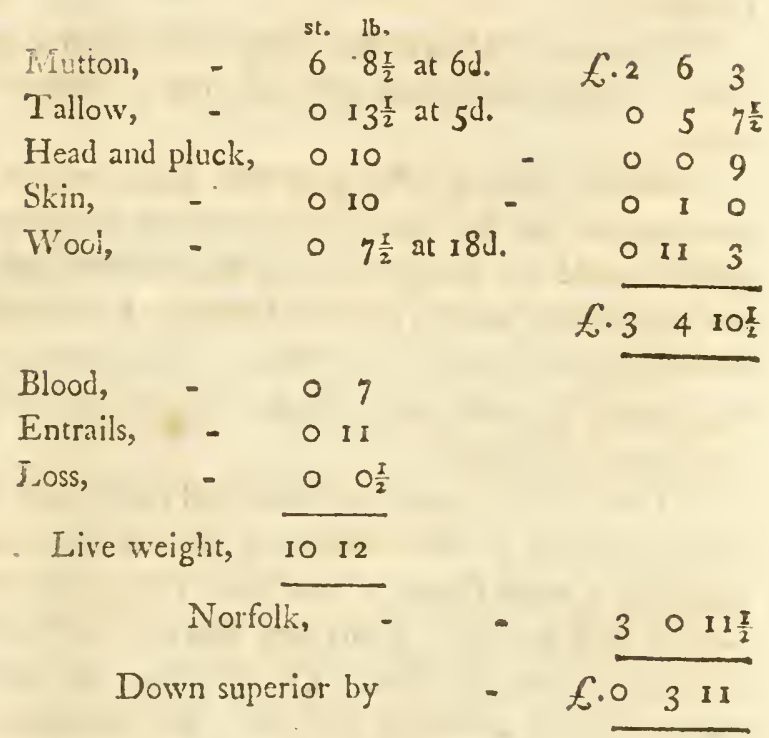

These Norfolk sheeep losing Ilb. roz. more of their respective weight (taken full and empty), is a strong cir. cumstance against them. The Downs are run much thicker on the land than the Norfolks.

Mr. Overman's 600 South Down ewes have this year (1802), 645 lambs.

Mr. PURD1s, of Eggmore, in November 1801 , on a farm of 1900 acres, had 70 score fatting sheep, 20 score South Down cwes and their lambs, and 15 score Leicester ewcs and their lambs; in all very near 3000 . Abour

$$
\text { c } 3
$$


one and a half per acre on a corn farm! full double the ratio of black-face stocking.

South Downs, in the Holkham district, 181b. a quarter, two-shear; and Norfolk about the same: Mr. CoKE 2 olb.

Fleece, South Down, three and a half on an average.

Norfolk, before, on the same land, one and threequarters.

Mr. Lovg, of Cranworth, bought in wether hoggits at 35 s. clipped them twice, and sold all at 4 l. without any refuse.

Screnteen years ago, being at Mr. BAKEwELL's, he mentioned to me the curious circumstance that Norfolk mutton would not keep so long as South Down, on the autherity of the butcher of Eton College; I immediately desired my late brother, then Fellow of Eton, to apply to the butcher for particular information, and his own account was as follows:

"The Norfolk mutton certainly will taint sooner than any in very hot weather; neither is there any sort (that I know) of a worse flavour at that time, though inferior to none in cool weather. Many very fine and fat Norfolks do not please on the table. The fat often runs away in roasting, if they are laid to a hot firc; and they rarely are so sweet as the South Downs. The latter are in hot weather, worth a halfpenny a pound more than the Norfolks.

"When both, are completcly fatted, it is hard to say (supposing the scason cool) which, upon an average, is fattest : the flavour too, in such a scason, I think is equal; and as to coarse meat, there is none in either sort. But if they are killed in cool weather, before they are very fat, the preference inust be given to the Norfolks, hecause the

* I printed this paper in the sixth volume of the Annals of Agriculture, but as it is a véry curious decision relative to Norfolk sheep, $I$ insert it here.

meat 
meat will in that case eat better, and there is a probability of much more fat within.

"With respect to profit to the feeder, if they are fed entirely with grass, and upon good land, my opinion is decidedly in favour of South Downs; or if they cat turnips in the winter, and after that are kept two or three months upon grass in the spring, it is the same. But if. they are half fat against winter, and are to be completed at turnips, I believe no sheep are more profitable than Norfolks, perhaps none so much so. But both sorts should be kept where there is both turnip and grass-land.

\section{" JQHN VYSE, butcher, Eton College."}

Mr. BAKEWELI observed upon this account, that the Norfolk mutton not keeping, conneels vcry much with the quantity, and perlaps the colour of the gravy. In all sorts of meat, that which is chosen for gravy, and which actually abounds with it most is the lean; and the freer from fat the better. That loose texture which is implied by the very circumstance of being full of gravy, is the cause of the meat tainting so soon, by the admission of air.

To this account there is one collateral circumstance to be named: the Wiltshire sheep have proved in various trials an unprofitabie breed, as well as the Norfolks; but it is remarkable that for turnips, no sheep are said, by many practical and experienced husbandmen, to pay better, if so well. In Hertfordshire nany who turnip-feed adhere to that breed, who admit the South Downs to be a superior sort for grass-feeding. I cannot but conceive that this whole comparative inquiry into the particular merits and demerits of the breeds of sheep, is yet in its infancy: certain important facts are gained; but when they are combined, and the causes to be assigned, we are still in great want of further observation and experiment. 
Mr. BAKEWELL, on the same occasion; gave as his opinion, that there is no comparison between the Norfolks and South Downs; that the latter are much better for any kind of food, for folding, or for any purpose, than the for. mer, except the flavour of the mutton.

Mr. Samuer Thorn, at Kimberly, buys wether lambs in August, at 12s. or I4s.; keeps them highly; winter-feeds on turnips; then on clover; turnips a second time; and sells, six weeks after Christmas, at 36 s. each : I79I. This was mentioned as a profitable system with Norfolks; but if wool makes the profit 25 s. they do not pay above 4 d. a week.

Experiment by Mr. Crow.-_" About Michaelmas I put ten Norfolk, ten Leicestershire, and ten South Down wether horgit lambs to turnips, that they might learn to eat them readily, and let them remain together till the 6th of November, when the ten Leicestershire, the ten South Down, and nine of the Norfoik (one having died) were numbered, weighed, and put each sort by themselves, into three pieces of wheat stubble, of one acre cacl, separated by hurdles, and I provided at the same timc three other pieces of the like size, and separated in the same manner, to shift them into. They were fed upon turnips, topped, and tailed, measured to them in bushel skeps, with great exactness, from that time till the $14^{\text {th }}$ March, and then weighed again. 


\section{LEICESTERSHIRE.}

Weight of each sheep, 6th

November.

No. Stone. Lbs. Oxs.

I. 4 I3 4

2. 5.44

3. 5.5 . 0

4. $5 \quad 7$

5. $5 \quad 8 \quad 0$

6. 5,90

7. 5 10 4

8. 600

9. 625

30. 640

Average weight 6th of November, about $5^{\text {st. }}$ glb. 3 oz. each.
Weight of each sheep, I $4^{\text {th }}$ March.

No. Stone. Lbs. Ozs,

I. 708

2. 690

3. $7 \begin{array}{lll}7 & 7 & 8\end{array}$

4. $6 \begin{array}{lll}6 & 12 & 8\end{array}$

5. $612 \quad 0$

6. 7.60

7. 7228

8. $7 \quad 90$

9. $7 \quad 7 \quad 8 \quad 8$

x०. 8 I 0

Average weight, I $4^{\text {th }}$ of March, about 7 st. 4lb. I oz. each.

Average increase of weight in eighteen weeks two days, about I st. 8 lb. I4 oz, each.

\section{SOUTH DOWN.}

Weight of each sheep, 6th of November.

No. Stone. Lbs. Ozs.

I. $413 \quad 0$

2. 50

3. 5 I 8

4. $5 \quad 2 \quad 12$

5. 5412

6. 5512

7. $5 \quad 7 \quad 0$

8. 570

$\begin{array}{llll}9 . & 5 & 7 & 4 \\ \text { 10. } & 5 & 8 & 8\end{array}$

Average weight, 6th of November, about 5 st. $4^{\mathrm{lb}}$. $5 \frac{\mathrm{x}}{2} \mathrm{Oz}$.
Weight of cach sheep, I $4^{\text {th }}$ of March.

No. Stone. Lbs. Ozs:

I. 6 I3 12

2. 6 II 8

3. 6 I3 8

4. . 7220

5. 694

6. $612 \quad 0$

$\begin{array}{rrrr}\text { 7. } & 7 & 2 & 0 \\ 8 . & 6 & 10 & 8\end{array}$

$\begin{array}{rrrr}9 . & 7 & 3 & 8 \\ \text { 10. } & 7 & 0 & 8\end{array}$

Average weight, 14 th of March, about 6st. 12 lis. $7 \mathrm{cz}$. each.

Average increase of weight, in eighteen wceks two days, about Ist. 81b. I I $\frac{\mathrm{T}}{2}$ oz. each. 
NORFOLK.

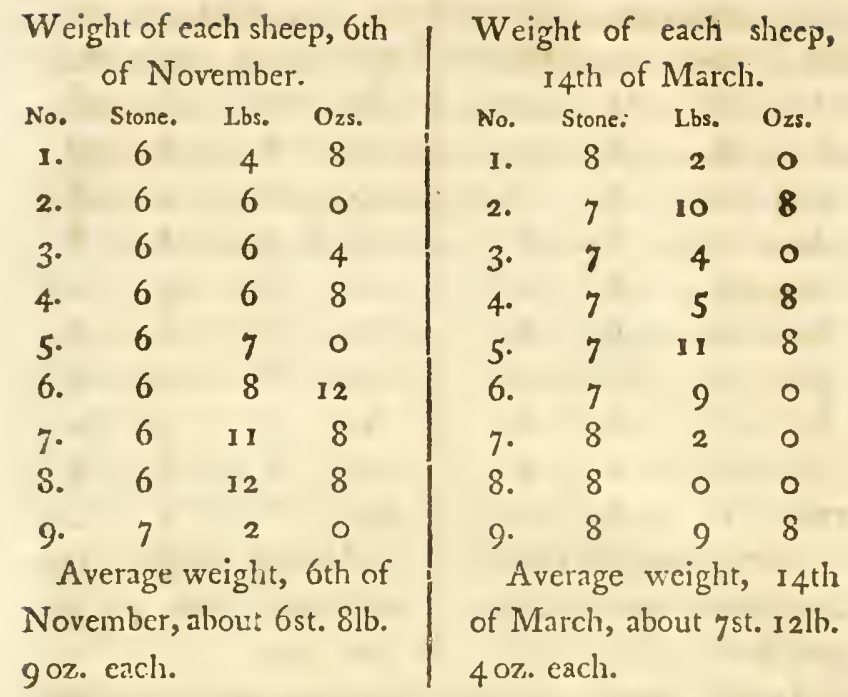

Average increase of weight, in eighteen weeks two

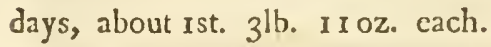

Quantity ate in eighteen weeks two days:

The ten Leicestershire ate 588 bushels of turnips.

The ten South Down ate 589 bushels of turnips.

The nine Norfolk ate 607 bushels of turnips.

The offal turnips were, at different times, collecred, measured, and deducted from the account of the quantitics given to them.

If nine Norfolk consumed 607 busisels, ten would, in the same proportion, have consumed above 674 bushels, or 85 bushels more than the South Down, and 86 bushels more than the Leicesters.

The Norfolk and South Down are about the same age; Leicestershire about six weeks younger.

I should 
I should have observed, they were both times weighed, after having stood some time in pens to empty themselves.

The Leicestershire and Norfolk were bred by $\mathrm{Mr}$. Coke, of Holkham ; the South Down by Mr. ELiman, of Glynd; and as they were all picked out for the purpose, I doubt not but you will allow they are prime stock of their kinds. The Norfolk were chosen out of about 700 lambs; the Leicestershire and South Downs, out of about 100 each.

South Downs are coming in about Watton: it is no sheep country; but on the commons Mr. Robinson. shewed me his own little flock, bought of Mr. BRADFIELD, of Knatishall, who parted with them because he thought they would not do for ling walks.

A Gentleman remarked on the Norfolk breed, that their pelts were more valuable than any other, being worth 4 l. 4 s. a dozen (179I) to the London butchers, owing to the singular quality of being separable into three flakes, or skins.

Mr. WRIGHT, of Stanhow, an excellent farmer, and very attentive to his flock, kept on 800 acres of very good land, four hundred breeding Norfolk ewes, 80 or 100 of which went to his marsh (exclusive of 800 ) in the spring, and stayed till after Michaelmas; three hundred ewes in summer ; one hundred hoggits ditto, on the marsh in winter. Little more than one-half a sheep per acre. Never sold wether lambs higher than $16 \mathrm{~s} .-$ (Note, some ycars past).

Mr. SALTER, of Winborough, keeps only Norfolks; whatever success may attend other breeds on dry land, he is sure they would not do with him: they would not travel through the mud of his gateways 
In I 192 , I found a South Down Hock, of 30 score, on Mr. BEvAN's farm, and having a tock of Norfolks on an adjoining farm at Knattishall, he had an opportunity of comparing the wool exactly: 34 score of Norfolks produced 43 tod at $28 \mathrm{lb}$.; and 34 score of South Downs produced 6I tod; which 6r, kept till November, became 64 , but the summer very wet.

South Down

Norfolk

Superiority, just $\frac{3}{4} \mathrm{lb}$. each
I $708 \mathrm{lb}$. - $\quad 1204 \mathrm{lb}$.

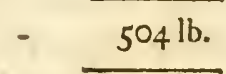

In I79I, the shepherd would not let his own Norfolk ewes take the South Down ram; but in I792, he was ready enough. He said, they would eat harder than the Norfolks; and would eat what the Norfolks would not: that they are more quiet and obedient than the Norfolks; so that he has done with them what he could not do with the Norfolks; fold them almost to an inch without hurdles.

A neighbouring farmer bought three rams of Mr. BEvAN, at $5^{\text {l. }} 5^{\text {s. each }}$; but afterwards repenting, because they would stain his fock, Mr. BEv a offered him $6 \mathrm{~d}$. a head, for all their lambs, more than he sold his Norfolks for, in the same flock, at Ipswich fair. The offer was accepted; the price proved 6s. 3 d. for the ewe lambs, and 9s. for the wethers. Mr. Bevan re-sold the ewes for 9 s. and the wethers for 1Os. 6 d. or 2 s. $1 \frac{\mathrm{T}}{2} \mathrm{~d}$. a head in favour of the half-breds.

When his sheep were Norfolks, he kept 500 ; but in 1794, he had 960 South Dorns. 
Produce of 116 ewe lambs, bred by Mr. BEvan, it Riddlesworth, 1792:

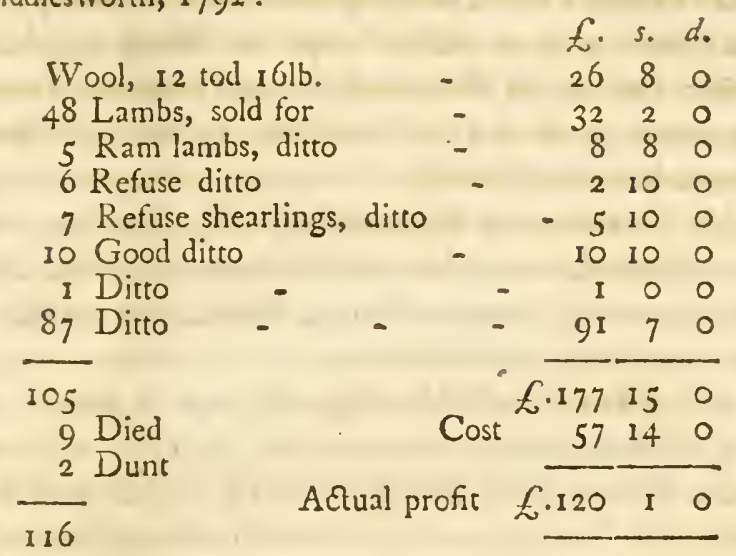

Mr. BevaN was early in trying South Down sheep, but finding them tender at lambing, went into a new Leicester cross: these he abandoned, and got back to South Downs, but still esteems them a tender breed, and that they ought to have yards sheltered and littered for lambing in bad weather; reınarking, that all the farmers he knows on the South Downs, have these yards for that purpose.

Mr. DRAKE, of Billingford, buys ewe-lambs in August, selling them that time twelvemonth, folding the whole year; a great improvement on his hot gravelly lands: wool included, he more than doubles his money.

Mr. Hart, of Rillingfold, all South Downs, except a few Leicesters. He and Mr. Bloomfield were gone, when I called, to Mr. Scr ACE's sale in Sussex.

Loddon and Clavering hundreds are no sheep coun: tries; there are a few, and South Downs and Leicesters have been creeping in.

In Fleg one scarcely sees any sheep: I was told that Mr. Chris rmas, at Billocby, has some Norfolk ewes, but the number inconsiderable. Bullocks the general stock. 
This year (1802), there were but two pens of Nor folk lambs at a fair in this neighbourhood; not many years since there were no others : at present chiefly half-bred.

Mr. Petre, of Westwick, keeps 17 score in a country where flocks are not common; he las some South Downs but more Norfolks.

Mr. Repton, at Oxnead, keeps fifty breeding ewes of the New Leicester kind, which answer greatly: Norfolks are so mischievous to fences, that he does not like to have any thing to do with them.

Mr. ReEves, of Heveringland, buys in lambs, and sells them shearlings from the fold. Tried half-bred South Downs from Mr. Dursgate, which paid him better than Norfolks, and he likes them so much better, as to intend continuing to buy this sort in preference.

Mr. BirCHA M, at Hackford, declares against having any favourites; he has generally bought Norfolks, and halfbred lambs; some few South Downs, but they did not answer : has had some Leicesters : any sort he can get worth his money. Little farmers who keep a few sheep, find the polled breeds very convenient from their quietness, and therefore prefer thein. Norfolk lambs bred near Cromer, were bought by Mr. G. Jones at 14s. were run on stubbles in the autumn, and put to turnips at Christmas, then to layers of the first year, probably as the best food for sheep, and sold shearling wethers at Michaelmas at

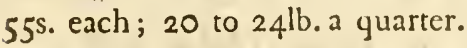

Colonel Buller, at Haydon, is convinced that Norfolks answer better than South Downs: shearlings come sometines to 20 and $25 \mathrm{lb}$. a quarter, and have had $19 \frac{1}{2} \mathrm{lb}$. of tallow; he has a breeding flock of 400: sold his wether lambs at 26s. and his ewe lambs at 24 s.

Mr. JoHnson, of Thurning, has 40 score of South Downs, which he has been rearing these six years, having bought many eives and got good tups. He has, how- 
ever, a good opinion of Norfolks, and will not be surprized to see them come into fashion again. In May 1792, he sold two shear Norfolks at Smithfield, for 3 l. each. He admits their rambling disposition, which is much against them; and he is clear that he cannot keep so nuany on his farm as of South Downs. The South Down wool is not, on good kcep, so good as Norfolk wool, but the fleece is heavier. Five years ago he got a lot of Yorkshires from the Wolds, white faces, polled, and the wool very coarse, but they throve wonderfully; never having liad any sheep that did better, insomuch, that he was sorry when he parted with them. Norfolks, he thinks, will bear folding better than South Downs. 'The latter will, however, come to hand rather sooner, but not on ling : has had three shear South Downs of 28lb. a quarter. Mr. Fohnson, shall you go back to Norfolks? - "Ccrtainly not, for my lands lie wide." I like this discriminating attention; it is a sign of accurate observation, and the balance is enough in favour of South Downs.

Mr. England, of Binham, got South Downs last year, and approves what he has seen of them: he thinks they may be run thicker on the land; and if as much profit is gained from five as from four, it is a better system.

Mr. ReEve, of Wighton, keeps only Leicesters: white he was in the Norfolk breed, his flock was 18 score breeding ewes: he has now 10 score Leicester ewes, and all their produce, amounting in the whole to never less than from 28 to 30 score, lambs included; but the account taken at any time of the year, the amount is 10 score more in number. He has had this breed six years, and prefers them to South Downs. Mr. ReEve's account is, however, candid, for he admits that they are apt to go barren; and the highest bred, the most so; clips $6 \mathrm{lb}$. on an average, ewe and hog: his Norfolk cwes 12 to 14 
to a tod. He letts from 35 to 40 tups annually, at from five to ten guineas, and a few from fifteen to twenty.

Mr. H. Blythe, of Burnhain, has been for three years entirely in the South Downs; clips 1000; a stock greater than ever he kept of Norfolks, the comparison fairly madie: his flock averaged $3 \frac{1}{2} \mathrm{lb}$. of wool this year; his Norfolks never exceeding $2 \frac{\mathrm{T}}{2} \mathrm{lb}$.

Mr. Dursgate has had South Downs six years, and is clear that, free from all change in husbandry, or other circumstance that would unfaisly affect the comparison, the number kept, compared with Ncrfolks, has been as five to four. The carcasses as heavy as the Norfolks; more wool, and at a better price. He does not fold; but the South Downs would bear it better than the Norfolks. At Palsgrave, he folds the South Downs, because there is a sheep-walk-a Norfolk flock changing gradually to South Downs.

Mr. Rishton, at Thornham, South Downs, and approved very greatly of the breed; from 250 acres of land, sold off a thousand pounds worth on quitting the farm.

Mr. Dodman, at Thornham, South Downs.

Mr. Strlemar, at Snettisham, keeps 2000 of various breeds, South Downs, New Leicesters, and half and half; in number considerably more than when, on the same land, he kept Norfolks : his farm may, and probably does, produce more sheep-focd than it did at that time; but he is perfeclly clear in the great superiority of the number, this circumstance dedueted, and that the profit is considerably greater. Clear also in the superior hardiness and kindliness of feeding of the new breeds. Of all cross breeds, he thinks the first cross of the Leicestcr tup on the Norfolk ewe the best, and that wool now ( 1802 ) sells at 4 6s. a tod; fleeces 4 lb.

Mr. Goddison folds Lord Cholmondeley's flock 
of Norfoik and South Down, all the year, except while in turnips; and Mr. BEck, at Massingham, who has 35 score "South Downs, folds them as regularly as any Norfolks.

At Hillingdon, all either Norfolks or half-breds, a Leicester tup on a Norfolk cwe. Captain BEAcher thiuks there are no sheep in the island which the Leicester will not improve. He has grazed many $W$ iltshires, and thinks them the best of all for cole-grazing in the fens.

Mr. BECK, of Castle Riseing, has had South Downs 13 years, beginning with some from Mr. TYRRELs, of Lamport, and has imported three or four times since. He has now 800 , and is quite convinced of their superiority to Norfolks: when he was in that breed he had not half the number; but after abating fully for improved husbandry, and every other circumstance, he is clear that there is a superiority of four to three. His fences are and must be bat, and in such a farm quietness is a vast obje $\tilde{\imath}$ : his farm 486 acres. He gained the first prize for ewcs both the last and this year at Swafham, and also at Holkham. I examined his flock attentively, and it certainly is a very beatitiful one. His wool now averages cight to a tod, equally of hogs and ewes: his Norfolks todded twelve: he is clear that, take the country through, they average half at much again as Norfolks. Before he took the farm there were go sheep on it, and a dairy of cows. What an improvement!

In the vicinity of Duwnham are found all sorts of breeds : towards ticc river, Lincolns and Leicesters; higher up, Norfolks and South Downs. Mr. SafFory likes the South Downs best, but thinks that if as much care and attention had been exerted to improve the breed of Norfolks as the South Dowas have experienced, they would by this time have bcen a very different sheep. Nor- 
folk three-shear wethers sold, in April last, at St. Ives, at 41. 45. 10 4l. 10s. cach.

Mr. Portek, of Watlington, keeps Leicesters, which he obtained from Mr. Fasset, Mr. CreasY, of Downham, and Mr. WILcox, of West Walton, near Wisbeach. Letts tups himself, from 7 l. 7 s. to 10l. 10s.: this year to the amount of 330 .

Mr. MART1N, of Tottenhill, keeps half-breds: Leicester tups on Norfolk ewes: sold lambs in $180 \mathrm{I}$, at 27 . a seore; this year his shepherd sold at 23 l. both ewes and wethers. His flock is subject to the rickets. He has much black sand; but unwilling to attribute the malady to soil, as this year he had not 10; but last year 120; and all circumstances of land and food the same. It attacks the lambs at six or eight weeks old.

Mr. Rogerson, of Narborough, keeps 7 co Norfolk ewes on 1200 acres, which he covers with Leicester pups.

Mr. Tw Is T, of Bretenhan, keeps 60 score of brceding Norfolk ewes on I 800 acres of poor land. He had a South Down tup some years ago, from Mr. $\mathrm{C}_{R} \circ \mathrm{w}$, but he could not perceive that the breed did better than Norfolks, though they stood the fold to the full as well.

Marshland.-Mr. Dennis, of Wigenlall, St. Mary, grazes only the best Lincoln wethers: he buys from May Day to Midsummer; keeps them over-year, clipping twice, average price 50 s. to 60 s. and se!ls at 655 s. to 75 s. getting $181 \mathrm{~b}$. in the two fleeces: his good land will carry six per acre, on an average, in summer; in winter, two on three acres, and these will quite preserve their flesh: if the season be favourable, will get something. He thinks that there is no other breed so profitable here; even a stain of the new Leicester is hurtful, as they will not stand the winter so vell. 
well. Sheep the chief stock, though some Lincoln bullocks. He never gives hay to sheep; nothing but grass; $32 \mathrm{lb}$. a quarter, his average of fat wethers.

Mr. Swayne, of Walpole, prefers the cross between Lincoln and Leicester: he buys them shearling wethers, about Lady-day; last year 3l. to 3l. IOs. each, but has had them at 36 s. and 38 s. He clips the best twice; three to a tod, which he likes better than heavier fleeces of sheep demanding more food. Some give 17 or $18 \mathrm{lb}$. of wool. At Michaelmas he culls the worst, or buys cole for them, if reasonable: sells all by Midsummer, making 8 s. or Ios. a head, when bought in high, besides the wool. Very few beasts.

I have heard it made a qucstion, who first introduced South Down sheep in Norfolk? When once an improvement has spread so much as to become an object of importance, there are genera!ly many claimants for the merit; and if such claimants are only heard of many years after, but little attention is due to them. With regard to the neighbouring county of Suffolk, I can speak with some accuracy, but should nor mention it on this occasion, were not the fait connested with the introduction into Noriolk. In May, $\tau_{\eta} \delta_{5}$, I published an account of an observation* I made in $17 \$_{4}$, the year $I$ brought them into suffolk from Sussex; and being printed at the time, the fact will admit no doubr. I recommended them strong-

* It was this : a South Down ram I had got from Sussex, broke, by accident, to a little Alock of Norfolk ewes, belonging to a tenant, the efiect of which was, his having seven or eight lambs entircly different from all the rest. His lambs were drawn tat by the butcher early in the summer; who, when he came first to mike choice, úrew every one of South Down breed bafore he took a single Norloik, Jeclaring, at the same time, that they were by much the fatcest in the fock. The farmer applied to me immediate!y to szre him a 1 am lamb. 
ly to every gentleman and farmer I conversed with on the subject, and, at my persuasion (as many well know), the late Mr. MAcro, of Barrow, purchased that flock which the Earl of ORFORD, after his death, bought and established at Houghton. Mr. Macro dicd in 1789.

In a paper printed in the Annals, in 1790, I remark: "I have had six and twenty years experience of Norfolk sheep, and once thought so yell of them as to carry them into Hertfordshire; but in the advance of my practice, I began gradually to doubt the superior merit of that breed. I thought, that of all the sheep which I had examined particularly, none promised to answer so well for the general purpose of the counties of Norfolk and Suffolk as the South Downs. I began the import in 1784 , and in 1990 had 350 . I had too much friendship for the late Mr. MACro, to advise him to try any experiment that I was not clear would answer to him. I repeatedly urged him to try the South Downs; he listened to me with attention for some time, but would not determine, till, having seen the number I kept proportionably to the quantity of land *, and at the same time with some Norfolks, it prover to hin that the South Downs were worth attending to, and the journey I persuaded him to take into Sussex, giving him an opportunity to converse with various noted sheep-masters there, he determined to make the experiment: he went over, previous to Lewes fair, and hought a flock of them. The lambs sold well at Ipsivich fair. Mr. Le Blanc, at Cavenham, also turned South Down rams to 700 Norfolk ewes: he found no difficulty at Ipswich; and his shepherd, after three years obstinate preference to Norfolks, gave up his old friends, and actually

* On 240 acres, 353 sheep, 45 head of caulle, 10 horses, and every yaar 70 acres of corn. 1790. Annals, vo!. xv. 
set South Downs for his shepherd's stock. Whether the breed should or should not, in the long run, establish itself, I have the satisfaction of feeling that I have done no ill office to ny brother farmers by introducing it. From the daily accounts I receive, I have good reason to believe that it will be established."

I may he pardoned, perhaps, if I here remark, that $\mathrm{Mr}$. LEBlanc, of Cavenham, and Mr. MAcro, of Barrow, being at Ipswich fair, and having felt, as well as other farmers, the great advantage that promised to result to the county from the introduction of South Downs, proposed a meeting of the farmers at the White Horse, to present me with a piece of plate, for doing what they thought a public good. A person came to me to tell me what they were about, and I went immediately and requested them to drop the design, which I effected with difficulty; at last they postponed it, as I urged that the result was too little known, and their experience too short to form a satisfactory idea. A farmer afterwards told ine that he heard of the intention, and that had it been brought forward he would have voted me an enemy to Suffolk, for endeavouring to change the best breed in England for 2 race of rats.

Mr. Crow, of Lakenbam, informed me, in 1800 , that five and twenty years before, he had a few South Downs at Ash Wicken, which he mixed with Norfolk blood, and has since mixed with new Lescester, and he thinks that between the three, lie has a breed better than eitlier of them, pure. 


\section{FOOD.-WOOL.}

Mr. JoHnson, of Thurning, remarks, that ling keeps sheep very healthy: he has a farm at Holt, where it abounds on the heath; and he loses four sheep at Thurning to one at Holt, which he attributes to the ling.

Captain BEACHER having 700 fatting shcep, and turnips running short, put 200 of them to oats (not ground); he found that the practice would not answer if nats were more than 6s. percoomb, and then not for longer than six wecks: they were fed on a pasture, and the improvement of it very great. He thinks grey pease, or beans would have answered much better.

Mr. Money Hill, from the observations he has made, is of opinion that the fleece l.cing very fine, cannot be regarded as a sign of a thriving disposition.

Mr.Hill's prices:

$\begin{array}{llll}\text { I799 } & 48 \mathrm{~s} . \text { a torl. } & 180 \mathrm{I} & 48 \mathrm{~s} . \\ \text { I } 800 & 5^{2 \mathrm{~s} .} 6 \mathrm{~d} . & 1802 & 5^{\text {Is. } 6 \mathrm{~d} .}\end{array}$

Arrangement of Mr. Bevan's flock of 45 score South Downs: the tuns are put to the ewes about the tently of September, for two months, being fed on the layers and pastures, and are folded on the old layers for wheat: after wheat-sowing thcy are foldcd on the pastures and layers till the time of yeaning, during which they lie on the pastures without fold, and have cumips thrown to them, with plenty of good hay. The fattering shecp are on turnips and hay from Michacimas to the end of March, followed by the hoggits. In April the couples go to cole-seed in hurdles; from cole to rye, from rye to the new layers, if forwasd enough, otherwise to the water-meadows, till the beginning of May, and from thence to the new laycrs, bcing still in hurdles, with a good deal 
of room to fall back, and continue so on the layers till ahout the Ioth of June, when the ewes are washed for clipping, and until the lambs are wcaned: the ewes then go to fold with the shearlings on the fallows intended for turnips, and the lambs are put to fresh grass reserved for that purpose: all the sheep on. turnips and cole laving hay, they consume about 25 tons. The general winter provision is 80 acres of turnips, 20 of cole, and 30 of rye, for the spring * : the latter, after feeding, stands for a crop. He values his turnips on the average at 30 . per acre, and cole at 25 s. After turnip-sorving the flock is folded on old layers for rye, till the end of August, when the ewes intended for breeding are put to grod pasture till the tups are let in.

I SO2.-The tups now put to the ewes about a week later, and the lambs not weaned till the latter end of June. Provision this year, 100 acres of turnips, 30 cole, 30 rye, for 25 score breeding ewes, 15 score hoggits, 20 tups, Io score fatting stock; 51 score in all.

Sale of Cull-lambs, Euves, and IVithers.

1796, Sold at Kenninghall Fair, July 18
1797,

* Mr. Bevan ploughs in his rye-stubbles before the shocks are carried to turn in the scattered seed, harrowing in half a peck of cole-seed for sheepfeed in the spring, and finds it of very great service. 
PRICE OF WOOL, PER TOD OF 28 ii).

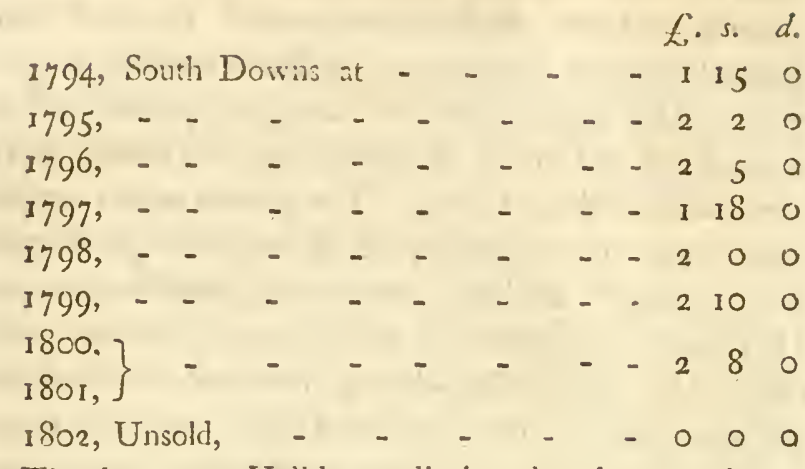

The shearers at Holkhain, clip in a day about 23 shearling wethers, or 20 larger sheep.

Mr. CRow, at Lakenham, 643 sheep and lambs, on $3^{2}$ acres of very good turnips, and $9 t$ acres of grass and 60 acres of stubbles for the winter.

Mr. Purdis, of Eggmore, has two shepherds' boarded houses on wheels; they contain a bed, and a stove for heating milk, so well contrived that it is heated in ten minutes: he has found the advantage in lambing time so great, that he has no doubt of loaving saved a great number of their lives, and recommends it strongly to his brother farmers.

Mr. Hill, at Waterden, has a sliepherd's liouse on: wheels, for lambing time, and hinted that it was furs: used at Waterden.

Mr. Coke readily assits net only his tewants, but other neighbouring farmers, in sorting and selecting rheir Soutl Down ewes, \&cc. and distributing them in lots to the rams, according to the shapes and qualicies of each. He puts on his shepherd's smock, and superintends the pens, to the sure improvement of the flock : his judgment is superior and admitted. I have seen him and the late Duke of BED- 
FORD thus accoutrel, work ail day, and not quit the business till the darknoss forced them to dinner.

\section{FOLD.}

I found in 1792, at Mr. BEvan's, what I had often recommended to the public; a yard well fenced in for a standing fold, in sight of the shepherd's windows, for littering and folding in bad weather. 1802, he continues the practice, and is well persuaded of the great advantage: he thinks it is indispensable, and means in future to have his flock in for yeaning, whether the season be good or bad; and has always 15 or 20 load of hay stacked in it for them to help themselves: he finds this not attended with any waste.

Near Brandon there is a practice introduced about ten years ago, said to be from Kent, which is, to fold their flocks for five or six hours in the middle of the day in hot weather.

In laying out the enclosures of the farm of Waterden, from 15 to 50 acres each, much attention was paid in the arrangement to have every field of the farm to open into a lane, that leads through the whole, so that by dividing the flock, for stocking, according to varying circumstances, Mr. Hill can keep at least one-fourth more than when all the breeding ewes and lambs were in one flock, and the food dirtied by driving to fold: by this means there is not a bent on the farm, the stocking being equal. He is not, however, entirely without a fold; when the lambs are weaned (usually about old Midsummer) the ewes are folded for about two months, principally to prevent their breaking pasture, when the lambs are taken from them: and while thus folded, he finds that it takes one-half more land to feed them, than if they were left allotted, as through the rest of the year. That folling lessens the value of the lambs, 
lambs, le las not a doubt, and that considerably ; they do not bring so high a price as others not folded-this is not opinion, but fact. The ewes are also in doubly better condition from lying still and quiet. That the teat/2 will, in certain cases, be unequally given, he does not deny; but it is not difficuit to remedy this by the lung-cart; to fold a lot in its own lay, is also a remedy, and is the only sort of folding he can approve. Where there are downs, heaths, or commons, the case is different; there folding may be necessary without question. In regard to the effeet on wool, Mr. HiLl is clearly of opinion, that folding does not render it finer-it makes the fleece lighter, but never finer.

Folding is generally given up by all who have Soutls Downs; not because they will not bear it, for they bear it better than any sheep in the isiand, but because the stock is so valuable, that it is worth the farmer's attention to contrive, by every means, to keep as many as possible.

One circumstance, though a small one, deserves mentioning, for the use of those who form separating sheep-pens : Mr. HiLl's, at Waterden, have sliding-gates from one to the other, he remalked, that when a pen is full of sheep, the gate cannot be opened with convenience; but by their sliding in the fence, this is avoided.

Mr. England, of Binham, does not fold, conceiving it to be merely robbing Petcr to pay Paul. When not folded, sheep do with less food, and as to the common objection, of their drawing under hedges for shelter, in storms, \&xc. so much the better; it is what they ought not to be prevented from doing. Tlie tathe is much more than lost in mutton.

Mr. REEve, of Wighton, never folds: folding from layers, upon fallow, is only robbing one field to enrich anothicr. Hc is clear in this point; and also in the fact, 
that if sheep (whatever the breed) are driven by foul weather to a hedge, there is the proper place for them, and not by penuing, left to abide the beating of the storm.

Mi. H. Blythe, of Burnham, sometines folds, but never from choice, but solely by reason of the openness of his farm; nor does lie approve the practice. And he expiained a point, in his manuring for wheat, which comes home to the question:-he never sows tempered land with wheat, without either oil-cake or muck, except on picces from which the shcep were not folded while feeding the laycrs.

Mr. DURSGATE remarks, that folded sheep certainly demand more food than those which are not folded; 2 quarter of a ton of rape-cake is equal to the fold; and the flock, without any doubt, suffers more than that value by folding. In short, folding is to gain one shilling in manure, by the loss of two in flesh.

Mr. Goddison folds Lord Cholmondeley's flock of Norfolk and South Downs: and Mr. BEck, of Massingham, who has 35 score of South Downs, folds.

Mr. BECK, of Riseing, does not fold; and he is very certain that if he did fold, he could not kcep any thing like the number of his present flock.

As I rode across a layer of 40 or $5^{\circ}$ acres, on $\mathrm{Mr}$. OvERMAN's farm, I observed a great difference in the verdure, to a line across it, the appearance of one side of that line being so much superior to the other; and on my remarking it, I was informed that it was an accidental experiment, which was well work attention: there was no other difference in management, to make one part of that layer better than another, except the sheep that fed it heing from one part of it folded on another arable ficld during the summer; but from the other part they werc not folded at all, but left in the layer night and day. The difference 
difference was very considerable, and might have been discerned half a mile off. This experiment made $\mathrm{Mr}$. Overman give up folding, except when his flock was in a salt-marsh; and Mr. TUTTLE, a neighbour, asserted, he would never fold at all had he no marshes. Nor does Mr. Etheridge, of Stanhow, fold. These facts should be combinei with another, that of heaths and shecpwalks, that have been fed with shecp for centuries, but those sheep constantly folded on other lands, are so far from improving, that they are to all appearance as poor as they could-have been at any former period.-Note, some years past.

Mr. Stylgman, at Snettisham, turned his flock loose, and without folding, in 20 acres of ollond every night, for the same period that would have folded it in the common manner. 'The sheep did much better than they would have done had they been folded; the face of the herbage materially improved during the period, and upon ploughing it up for wheat, the crop was equal to what it would have been with folding, and shewed, by a regular verdure, that they had distributed the manure equally in every part.

Mr. StYleman conceives that lambs sell $3^{\text {s. a head }}$ lower on account of folding, than they would do without it; but this is only his opiaion. He thinks also that the ewe is much injured.

Mr. PITts, of Thorpe Abbots, finds that no mucking, on his burning gravels, will do so much good as the fold, and especially on a white clover and trefoil layer for barley.

\section{DISTEMPERS.}

Wisen I had formerly the pleasure of being at Houghton, I have often urged Lord Orford to break up a 
heath of black sand, but his Lordship informed me, that the farmers were clear that if he did it, his lambs would be ricketty, by feeding on the turnips or grasses. Mr. GoDDIsON has, however, laid on 3200 loads of clay on 4.4 acres of it, in six months, and broke it up: he got great turnips on it, and this year very fine barley, two londs and a half per acre, in the straw. As to the rickets, he cannot assert that there has been none, but quite inconsiderable, not ten affected in a large flock. On this distemper lie observes, that the only danger is while the ewes are in lamb; and that after lambing the malady is not acquired.

On a ground noted for causing this distemper, the soil a black sand, heath, but marled and cultivated, a farmer accidentally removed part of his flock during the months of October and November; the flock then noved escaped the rickets, but those left had it. In consequence of this the trial was repeated next year, and the effect the same. It should seem from this case, that the distemper is taken only in the autumn, at whatever time it may appear, and if so, there is very little difficulty in avoiding it.

Mr. Coke's receipt for dressing his flock previous to. winter, against lice and ticks:- Tivo pounds of tobacco, two pounds and a half of soft soap, one pound of white inercury, ground to powder: boil in eight gallons of water one hour. Part the wool down each shoulder, and the breast of the sheep, and twice along each side, into which pour-it. This quantity enough for 60 sheep.

Mr. Overman, as soon as his flock is sheared, dresses his lambs to destroy ticks and lice. He boils a pound of arsenick and a pound of soap in about six gallons of water, and then adds 26 gallons more water: in this he dips the lambs, and finds it effective in the destruction of all the vermin: without this precaution they are propagated a. fresh from the lambs to the ewes.

Mr. 
Mr. M. Hril has experienced a distemper among lambs which, from the description, should scem to be a species of rickets. "In I 799 all were quite healthy; but in 1800, 140 lambs fell lame in the knees and hamstrings, and wasted away much. In 1801 the same. In 1802 no such appearance; all healthy; the only difference in the management, and to which he is inclined to assign the cause, was putting the tups to the ewes the loth of September in 1798 , and 1801 and in the intermediate years, on the 7 th of October. I inquired if they had fed on different lands, or if he had broken up any black sandy heatls? No such thing. In $1 \mathrm{SO}_{3}$ quite healthy.

\section{SECT. III.-HOGS.}

THE breed of hogs in Norfolk do not demand any particular attention, though a useful pig if well supported: their most usual colour black and white, \&xc. \&c. : carcass long, but wants thickness; legs the same, or at least not short: good breeders.

I found Mr. Salter, of Winborough, fatting 180 pigs in August, by throwing down pease in a well littered yard, and says the pigs lose none at all: they have the run of a meadow, and he is clear, from long observation, that they fatten much better and quicker than if confined. He assigns II score of pease for fatting 200 , more or less; and considers it as a profitable application of the crop: he buys them all. He has compared stye-fatting and loosefatting, and decidedly in favour of the latter.

Mr. Havers, at Thelton, has the Suffolk breed, and has also Berkshires; but finds the cross between them better than either separate. 
I found a new piggery building by Mr. HAvers, at Thelton, in which the most singular circunstance is the sties for fatting, being single, for one hog, and so narrow that ise canrot turn himself; a range of these on one side and a space for cistern on the other, the whole near the new dairy-perhaps, rather too near: a degree of vicinity is necessary for the milk and whey to fow to the cisterns, but the air around a dairy should be preserved quite uncontaminated.

Mr. Wiseman, at Happsborough, having occasion to wean some pigs much too young, from the death of a sow, or some other cause, tried boiled pease for them, and the success was so great, that he would never enter largely into breeding or fattening hogs without a furnace and copper for hoiling whatever corn might be given.

Mr. JoHnson, of Thurning, fattens with boiled barley, and by this means madẹ one so fat that he was blind from excess of far.

M. REEVE, of Wighton, every feature of whose husbandry merits attention, condemns a dairy stock as unprofitable to a farm, in respect of manuring : he once had a large dairy, now only 26 cows, and a principal motive for keeping so many, is the right application of it to supporting a large stock of swine.

\section{SECT.IV.-HORSES. OXEN.}

1792. MIr. Overman's, arable, 523 acres: he keeps 2 I horses.

In the district of Holkham, 20 to 500 acres in one farm, 16 to 500 acres. The larger the farm, generally the smaller the proportion. 
At Snettisham, 30 years ago, 16 horses necessary for 500 acres of arable land.

In Happing hundred, five per 100 acres.

Mr. H. BLythe, 30 to 1000 acres of sand, and chalk, drilled.

Mr. ReEve, of Wighton, 700 acres, 22 horses; not four per 100: drilled.

Mr. Dursgate, at Summerfield, 1050, and 31 horses. At Sedgford, 1240 acres, and 36 horses; very nearly all in tillage, and all drilled.

Mr. Styleman, of Snettisham, four to IOO acres; not the more for drilling.

Mr. Pow ELL, of Broomsthorp, near Fakenham, with ${ }_{5}$ Suffolk horses in his stable, used but one load of hay last winter. He feeds wich cut straw and oats, and has no racks. Uses BURRELL's chaff-cutter, paying 2 s. for 20 coombs.

Mr. Burton, of Langley, never lets his horses remain in the stable at night, always turning thern into a well-littered warm yard, contiguous to the stable. This is the practice of the farmers in the angle of country formed by Woodbridge, Saxmundham, and the sea.

Two and thirty years ago, Mr. R AMEY, of Yarmouth, was in the regular practice of soiling, which has not since been followed to any thing like the extent to which it ought to be every where carried. The second week in May he began on clover for 20 horses and 7 cows, 5 calves, and his hogs, and found seven acres sufficient for them till the wheat crops were cleared: reckoning the horses and cows at 2s. 6d. a week, the calves at Is. $6 \mathrm{~d}$. and nothing for hogs, it amounted to 9l. 2s. 1d. per acre. A tenant fed stock to the same amount in an adjoining field, and when Mr. RAMEY had eaten 5 acres, this man had eaten and wasted 30 . 
Mr. Ferrier, of Hemshy, is very sensible of the importance of soiling: his team had not been out all summer when I was with him in September.

Mr. Francis, at Martham, in common with every good farmer in the neighbourhood, uses tares for soiling horses, but thinks clover better, and much used every where.

Mr. JOEnNON ${ }_{3}$ of Thurning, soils on clover, in preference to vetches.

Mr. ENGLAND, of Binham, has tares enough for baits ing his teams: does not sow turnips the same year after them.

Nr. Priest, of Besthorpe, cuts all the hay he uses, for eight horses and fourteen bullocks, and has no.doubt of its answering greatly.

Mr. M. HiLl, does the work of 1300 acres with forty horses, but he has 200 of pasture.

$\ln 1784, M r$. CoKe worked 12 oxen in harness for carting, and found them a very considerable saving, in com? parison with horses.

1803. Mr. COKE gave them up some years past, from the difisculty of shocing them, hut more from the inveterate prejucices of the men against them. He was not, however, convinced that the practice might not in many cases be profitable.

Mr. DREw, of Bexwell, tried oxen, and gave them up from heing troublesome in a waggon. Mr. Clark, c! Denver, used them many years, bur gave them up at last.

Mr. Bevan hat them for a few years, and then gave them up.

M. PURDIs, of Eggmore, works 32 Devonshire oxen in yokes and bows, four to a plough. I saw them at work, and was much pleased to see them step out so nimbly, as to be fuily equal to the horses ploughing in the same field,

NORFOLK.]

I $\mathrm{i}$

in 
in point of movement: they plough an acre and an half in one journey. Mr. PURDIs thinks the saving will be considerable, as he has procured 40 heifers of the same breed for his regular supply.

Mr. M. HILl uses two pair of short-horned oxen, which, walking well, plough two acres a-day ; each pair an acre in five hours and an half. He is of opinion, that on farms that employ 22 horses, it would be more proficable to have 16 horses and 8 oxen; but he cannot recommend? them for nearly the whole strength; as in hay and harvese it is necessary to be very nimble, the horses in empty waygons trotting fast; this cannot be dione with oxen.

Mr. Havers, at Thelton, works Devon oxen for earting, and approves of them much.

Mr. Thurtell, near Yarmouth, a few years back, worked bulls; he had two pair, and two of them ploughed as much land as two horseș: he has a great opinion of them, and would recommend to any abtive young farmes going into business to employ them in preference $\%$ horses. 


\section{CHAP. XIII.}

\section{RURAL ECONOMY.}

\section{SECT. I. L L BOUR.}

THE circumstance in rural economy, which for many years distinguished Norfolk in a remarkable manner, was the cheapness wherewith the farmer carried on his business. This arose not only from a low price of lahour, but also from a much greater activity and spirit of exertion amongst servants and labourers, than was to be found in almost any other county of the kingdom. This spirit is scill highly commendable here, but by reason of the scarcities throwing the mass of the people on the parish to be supported by rates, it has suffered considerably.

In 1767 , I registered the price of labour in West Norfolk at Is. a day in winter; in spring, rs. 2 d.; for the harvest, 2l. [2s. 6 d. to 3 l. with meat, drink, and lodging, and lasting from one month to five weeks; hoeing turnips, 3s. and 2s. ; ploughing, per acre, 2s. $6 \mathrm{~d}$.

Holkham, 1792.-In harvest, 51. 5. generally five weeks.

Threshing wheat; Il. Is: a last. barley, 9s. ditto.

Thatching stacks, is. a yard, running measure, length of stack all widths on an average. 
AT BRAMMERTON, $17 \% 0$.

\begin{tabular}{|c|c|c|c|c|c|c|}
\hline For the harvest, with & h boar & & 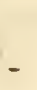 & $\begin{array}{l}£ . \\
2\end{array}$ & $\begin{array}{l}\text { s. } \\
2\end{array}$ & $\begin{array}{l}d \\
0\end{array}$ \\
\hline - - Hay time, & - & - & - & o & 1 & 6 and beer. \\
\hline - - Winter, & $-\quad-$ & - & - & 0 & I & o and ditto. \\
\hline Mowing grass, per a & acre, & - & - & 0 & $\mathbf{I}$ & 6 and ditto. \\
\hline Hoe turnips, & - & - & - & o & 4 & 0 and $2 s$. \\
\hline Clay, per I20 loads, & - & - & - & 1 & 5 & 0 \\
\hline First man's wages, & - & - & - & 10 & 10 & 0 \\
\hline Second, ditto, & - & - & - & 6 & 6 & 0 \\
\hline Lad, $-\cdots$ & - & - & - & 3 & 0 & 0 \\
\hline Dairy-maid, - & - & - & - & 4 & 4 & 0 \\
\hline Others, $\quad-\quad-1$ & : & - & - & ? & 0 & 0 \\
\hline
\end{tabular}

In the Holkham district, winter and summer, is. 6 J. Odd men in harvest, 2s. 6d. and ${ }_{3} \dot{s}$. Regular men, 21.25. and board for the harvest.

Snetterton, Szc. in winter, 1s. 6d. $\}$ no beer.

At Hingham, summer and winter, is. 8d.

The harvest 42 s. to 50 s. and board, generally for a month.

A custom is coming in around Waterden, \&rc. of allowing board-wages to farm servants, instead of the old - way of feeding in the house; Ss. a week are given;

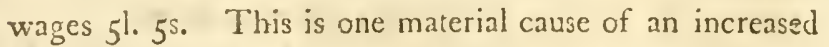
negleet of the Sabbath, and looseness of morals; they are free from the master's eye, slecp where and with whom they please, and are rarely seen at church. A most pernicious practice, which will by-and-bye be felt severely in its consequences by the farmers. Mr. Hill feeds his servants in the old way.

The price is raised at Waterden 6d. a day, in the last swo vears, and the work worse done. Last winter $2 s$. a day, 
a day, and the same in summer. But Mr. Hitr intends next winter to reduce it to is. gd.

At Winborough, in winter, 1s. 8d. ; in sunmer, 2s. ; for the harvest, 5 os. gloves, and is. hiring, with board: reaping wheat IOs. $6 \mathrm{~d}$. an acre, or $2 \mathrm{~s}$. $6 \mathrm{~d}$. a day, and board.

Through Loddon hundred, 45s. for the harvest, and board; and allot twelve acres per man; some four load an acre, all three, of spring corn, and two of whear: dibbling wheat, 10s. 6d. In winter, 1s. 63.; sumner, 2s., which was lately is. $6 \mathrm{~d}$.

In Fleg hundreds, winter and summer, Is. 6d. a day, allowing bread-corn at $6 \mathrm{~s}$. a bushel: harvest, 50s. and board.

At Marthain, dibbling wheat 9 s. an acre; pease, $8 s_{.}$; bread.corn at 6 s.

In parts of Happing hundred, 2s. winter and summer: harvest, 21. 12s. 6d. and board.

At Honing, harvest 50 s. and board; winter, is. $4 \mathrm{~d}$. and Is. $6 \mathrm{~d}$. a day; summer, 2s. but wheat at $j^{\mathrm{s}}$. a bushel to the men.

At North Walsham, ros. a week, winter and summer.

Scotter, Is. 6d. and beer to harvest; then 42 s. and board.

Reepham, \&c. in winter, Is. 6d. to Is. 8d.; in sum. mer, 2s. ; in harvest, all included, 4s. $6 \mathrm{~d}$.

Thurning, 2s. to harvest, for which 71 . without board.

Binham, 2od. to 2s. in winter and to harvest, when 52s. 6d. and board, or 61. 6s. withour.

Wighton, harvest $61.6 \mathrm{~s}$. and sixteen acres a man; six, wheat, and ten spring corn.

Thornham, Is. 9d. to 2s. the year round, except harvest, then 21 . I2s. 6d. and board; 61. 6s. without: filling marle cart, 28s. per 120 loads. 
At Snettisham, 10s. 6d. a week, winter, and to hay and turuip hoeing; in harvest, 61. 10s. without board. Hóeing turnipstwice, 6s.; mowing grass, 20d. to 2s. 6d. ; filling marle, 25s. per 120 loads; 12 s. for small low carts half loads.

At Houghton, in winter, 103. 6d.; in summer, 12s.; in harvest, 50s. to 60s. and board.

Ar Wigenhall, in Marshiand, the average price of reaping wheat, I2s. the statute acre,

Labour, at Lynn, is sunk by the peace:-Sailors wages, from 4 l. IOs. a month, to 50 s.; and that of cornporters, from $I \frac{x}{2} d$. a sack to $I d$.

Ar Walpole, in Marshland, 6s. to 7s. a day, general in harvest: some, this year, gave 9s. and 10s. a day: 2s. 6d. after Michaelmas, till seed time is over; 2s. all winter; 2s. 6d. after May-day.

Near Downham, in winter, 20d. and beer; summer, 2s. ; hay-time, 3s. 6d.; mowing grass, 2s. to 45 .; mowing barley, 5s.; reaping oats, 10s. to 16s.; wheat, 10s. to. 125.; in harvest, by day, 6 s.

At Besthorpe, Is. 8d. in winter; 2s. at hay, and after

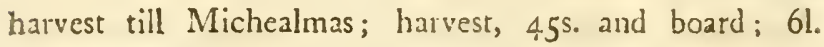
without. No malt.

RUNCTON.

1770.

1803.

Harvest, 21. 2s. and board. 21. 12s. 6d. and board. Hay, - Is. 6d. and beer. 2s. and beer. Winter, Is. $2 \mathrm{~d}$. and beer. 1s. gd. and beer. Reaping wheat, $4 \mathrm{~s}$, to $6 \mathrm{~s}$. $\quad 7 \mathrm{~s}$. to $8 \mathrm{~s}$.

Reaping oats, 4 s. 5 s.

Mowing barley, 1s. 6d. 2s.

Mowing grass, 2s. 3 s.

Hoeing turnips, 4s. and 2s. $\quad 4$ s. 6d. and 2s.6d.

'Threshing wheat, 2s. a guvarter. 3 . 
1770.

1803 .

Threshing barley, Is.

Is. $6 \mathrm{~d}$.

'Threshing oats, $8 \mathrm{~d}$.

Is.

Head man, I2l.

I21.

Next ditto, gl.

gl.

Lad, $\quad 5^{l}$.

61.

Dairy-maid, 4l. ros.

41. 10s.

Others,

31.

31.

AT SNETTISHAM.

I 770 .

Five weeks harvest and board,

1803.

$$
45^{\text {s. to }} 5 \text { os. 2l. } 12 \text { s. } 6 \mathrm{~d} \text {. }
$$

In hay time, a day, 1s. 6d. to $2 s$.

2s. 6 d.

In winter, 1s. 2 d.

Is. 9 d.

Reaping, 5s. per acre.

I2S.

Mowing barley, is.

2 s.

Mowing grass, artificial, Is. to 2s.

$2 s$.

4s. 6d.

Hoeing turnips, 4s. and 2 s.

Filling and spreading marle,

$$
25 \text { s. per } 120 \text { loads, } 28 \text { s. to } 30 \text { s. }
$$

Thresling wheat, per quarter,

$$
\text { Is. } 2 \text { d. to } 1 \text { s. } 4 \text { d. Is. } 8 \text { d. to } 2 \text { s. }
$$

Threshing barley and oats, $8 \mathrm{~d}$. $8 \mathrm{~d}$. to rod.

Threshing pease, Is. $3^{\mathrm{d}}$.

$8 d$. to rod.

Head man's wages, IOl. to 121 .

Next ditto, gl.

Lad, 4 l. to 7 .

i il. to i 5 l.

7l. to 101.

4l. to $\eta$ l.

Dairy-maid, 5l.

sl.

Other ditto, 3l. to 4 l.

3l. to sl.

Women, in harvest, Is. and board,

Is.

in hay, gd. and beer, in winter, $6 d$.

Is. No beer.

$8 d$. No beer.

$$
\text { I i } 4
$$

$\mathrm{Mr}$ 。 
Mr. Henry Blythe assures me, that labour, in the vicinity of Burnlaum, nearly doubled from I795 to 1801 : to sacisfy me of this fact, he laid his books before me, in which the fact appeared clearly; and this has taken place on his farm, not at all by any extraordinary works done on it, but merely by the rise of prices: it is not, however, to be accounted for merely by the ise per week, but the men will not perform what they formerly did, and more must, therefore be kept for the same work.

The labour of a sand farm, of 1000 acres, near Holkham, 820l. last year.

Mr. Marshall takes every opportunity, in his work, to note the great activity of the farm workmen, in the dispatch of business in this county, much exceeding any prher. The observation is pointedly just; insomuch, that there could hardly be a greater improvenent than to introduce their system, in this respect, in many other counties, equally adapted to it ; but managed, at present, at a far greater expense.

Recapitulation.-General average in harvest, 2l. 8s. 3d. the month, and board; in summer, Is. Irda a day; in winter, Is. 8 d. a day. 


\section{$(489)$}

\section{CHAP. XIV.}

\section{POLITICAL ECONOMY.}

\section{SECT. I. - ROADS.}

DURING the long period in which Norfolk was content with the reputation given to her roads by the observation of CHARLES the SECOND, without having recourse to the assistance of Parliament, in the establishment of turnpikes, her ways were bad enough, though not so bad as in heavier soils: she has, however, in the last 20 years, made considerable exertions-turnpike gates are erected in all the principal communications; these are kept in good repair, and the roads, in general, must be considered as equal to those of the most improved counties.

In the line from Dereham, 30 miles to Harleston, the direction is diagonally across all the Norwich roads, yet I found this road as good as a turnpike.

\section{SECT. II.-CANAIS.}

VERY little has been effected in Norfolk by means of canals; merely artificial; but some rivers have been ren-

- That Norfolk ahould be cut into roads for all the rest of England. 
dered navigable, which add considerably to the communications of the county. The Little Ouze is navigable to 'Thetford; the Yare to Norwich; the Waveny to Bungay, and the Bure to Aylesham; a small branch of the Great Ouze to Narborough. More considerable exertions are rarely found in counties merely agricultural. Without coal-mines, or a great demand for coals, lime, \&c. and the estabiislument of immense manufactures, canals are too precarious a speculation for the ready advancement of great subscriptions.

SECT. III.-FAIRS AND MARKETS.

THE principal fairs are those of Harleston, St. Faith's, Hempton, Kenninghall, Harling, Causton, Kipton, Swafham, and Thetford, for wool.

As to markets, there are but three considerable oncs in the county, Norwich, Yarmouth, and Lymu: these are plentiful: Norwich approaches to Bath itself, and Yarmouth is most plentifully supplicd. The rest are very inferior.

In the district of Holkham, a circumstance has taken place, which I cannot but consider as an extraordinary proof of the spirit of exertion which pervades this county.

Mr. Overman, of Burnham, has a small ship, which he keeps constantly employed in carrying his corn to London, in bringing rape-cake for manure from Holland, London, Hull, or wherever it is to be procured best, and at the cheapest rate. When his farm does not in this manner produce employment, he sends her for coals; or deals, 
or on any service which times and markets render eligible: and this speculation answers well. $\mathrm{He}$ conceives that drilled corn, kept perfeetly clean, is a better sample than the common run of broad-cast, and lie finds it difficult to get, in the country, a price proportioned to the merit of his productions; and to send the corn by sea to London, does not cost so much as land-carriage to Lynn would do. Entering on a new farm of Mr. CoKE's, a year and a half past, and finding many hurdles necessary, he sent his ship to Sussex for a lading of hurdles: there, made much better, of riven oak, and at the same time lighter than others to be had in Norfolk: they cost him 3s. 6 d. each, and will last 20 years. Common wattle hurdles cost IS. is. Id. besides long carriage, and will not last above two years.

Mr. Money Hill, of Waterden, has also a sloop of 50 tons, which goes to sea, with two men and two boys: he built her, and the employment is the same as $\mathrm{Mr}$. Overman's. Mr. Davy has likewise one. They have not yet brought manure from London; though probably tallow-chandlers' graves, woollen rags, and various other articles, would answer as well as rape-cake, at the present price of 7 l. to 81 . per ton. 
SECT. IV.-THE POOR.

An establishment at Snettisham, which has been found of the greatest use to the poor, and has answered every expectation, is a subscription water-mill: it cost 800 . and a miller is employed, at 20s. per week, to grind, at 4d. per bushel, for all persons, whencesoever coming. 

PROGRESS OF LABOUR, \&cc. \&c. IN SUNDRY PARISHES, 1793. Communicated by Sir Thomas Beeroz, Batt.

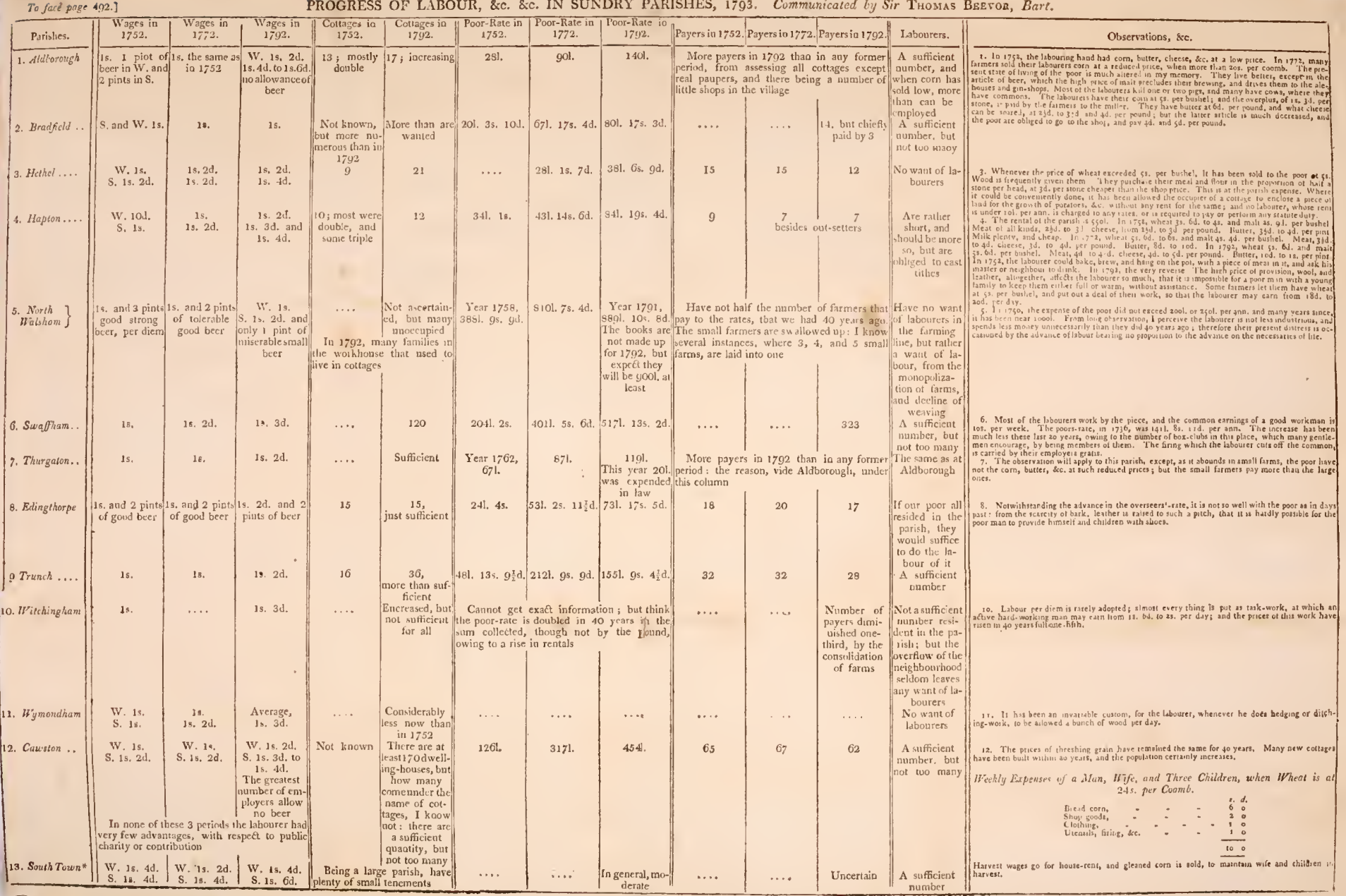


The necessary and unavoidable expenses of a labourer and his wife, without any family, for one year, calculated at the price of flour $4 \mathrm{~s}$. and meal 3 s. per stone, and the other articles at present price, $1799^{*}$.

Coltage rent f. s. d. f. s. d.

One peck of coals per day, 20 weeks, or I 40 days, at $\left.3 \frac{\mathrm{T}}{2} \mathrm{~d}.\right\} 2$ ○ 10

Half a peck per day, 8 weeks, or $5^{6}$ days

\}$\circ 8 \quad 2$

A quarter of a peck per day, 24 weeks, or rather 169 days $\} 0124$

Soap, 4 ounces per week, at $2 \frac{\pi}{2} \mathrm{~d}$. which is per annum - $\} 01010$

Oil or candles; at 6d. per week, for 20 weeks

O 100

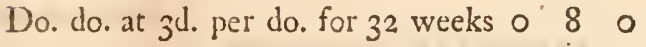

Shcemaker, one pair of shoes, one pair.of highloos, and mending $\} \circ \begin{array}{lll}16 & 0\end{array}$

Stockings, two pair - $\quad 050$ Hat - - - 020

Slops, jacket, \&zc. - - 090

Breeches - - - 050

Twashirts - . . . 0 10 0

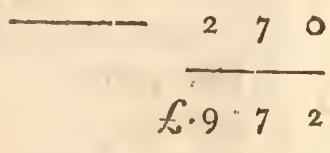

* Communicated by ara active Magistrate.

Amount 
Amount brought forward - $\quad 972$

Woman's apparel - $\quad$ - 1150

Sixpence per day, for food for each person - 1850 Sixpence per do. additional food in the harvest month, perman - _ _ _ \} 3140 Expense of tools f.30 92

In the above account no allowance is made for the wear and tear of the furniture, and sunJry small articles used in the house.

EARNINGS.

f. s. $d$

Harvest, 4 weeks - $\quad 4146$

48 weeks, at 8s. per week - 1840

Woman's glcanings - $\quad 0140$

48 weeks, at Is. per week $\quad-280$

$£ .26 \quad 0 \quad 6$

HOUSES OF INDUSTRY.

MITFORD AND LAUNDITCH.-MINUTE, I792INCORPORATED 1776.

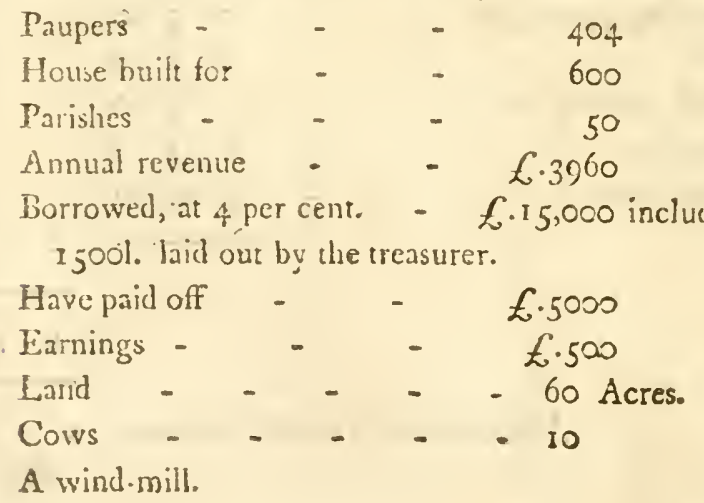


THE POOR.

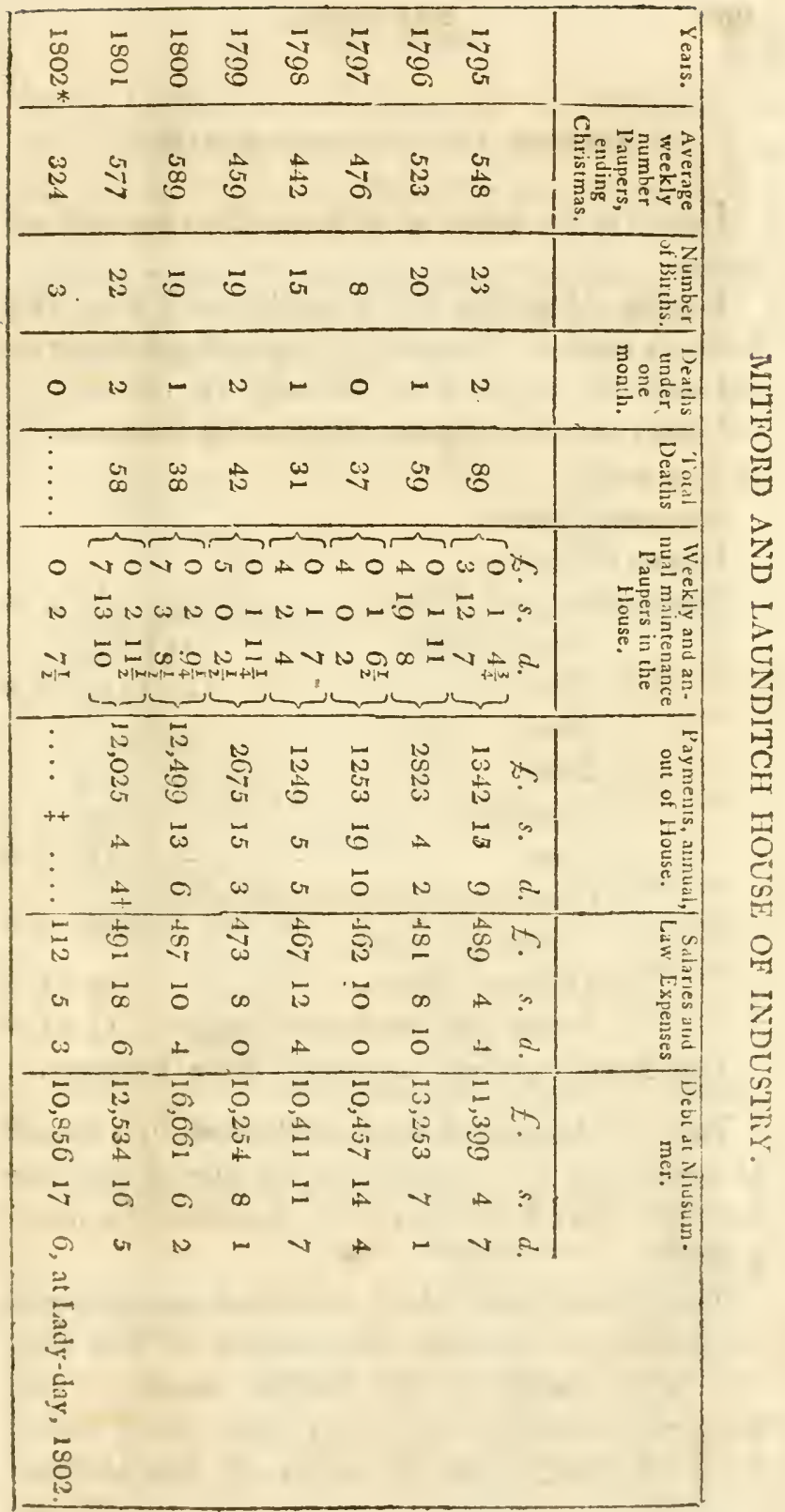

- Christmas to Lady-day.

+ Unly three quarters of the year to Michaclmas.

: In the parishes. 
MITFORD AND LAUNDITCH. - I 802.

Paupers in the house, 2d of Aug. 1802: 244 old and young.

Earnings-Upon the 2 Ist of June last there were in the house 52 paupers: 86 women; 4 boys and girls above 16 , and under $18 ; 25$ above 10 , and under $16 ; 48$ above 5 , and under 10; and $3^{8}$ under 5.-Earnings then about 81. or gl. a week.

Poor-rates lowered.

Income uncertain.

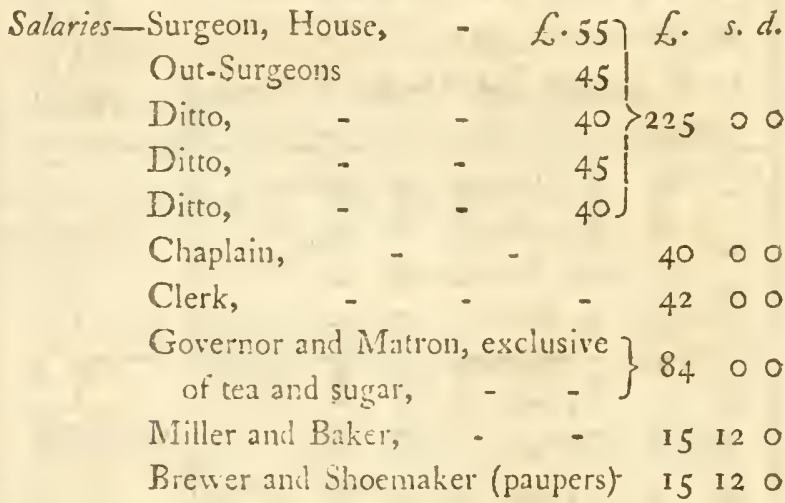

Debt remaining 9000l. and 15021 . to the Treasurer.

Poor-rates higher or lower. - Each parish, by a late act of parliament, pays acconding to the number sent into ahe house-have been much lower than those not incorporated.

The circumstances which occasioned an application to parliament, to enable the parishes to keep their own poor, paying to the standing cluarges of the house-a proceeding quite new, were these: several gentlemen thought that the parish of East Dereham 
were a burthen to the corporation. It was agreed between the gentlemen who took the active part for a new act, and the gentlemen of East Dereham, that that parish should by the new aet maintain their own poor, and accordingly a clause was inserted for that purpose, and Dereham has built a workhouse, and inclosed ten acres of the common waste for their own poor.

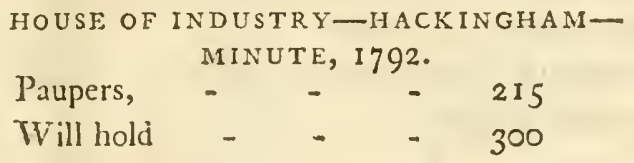

Expense of building, 25 years ago, $7000 \circ \circ$ All paid off, and a balance in hand of $5^{15} \circ \circ$ Parishes, $4 \mathrm{I}$

Poor-rates lowered one-eighth.

Annual income, - - $1866 \circ$ Spin wool; some hemp.

Annual earnings, Salaries, Surgeon,

Chaplain,

Clerk,

Governor,
$-$

$-$

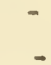

$-$

$\begin{array}{ccc}250 & 0 & 0 \\ 105 & 0 & 0 \\ 30 & 0 & 0 \\ 30 & 0 & 0 \\ 40 & 0 & 0\end{array}$

and $\frac{I}{2} \mathrm{~d}$. per Ib. on all wool spun, which is I2l. morc.

Baker 6s. a week and board.

FOREHOE HOUSE OF INDUSTRY, BUILT 1776 .

Average number of Farnings. Paupers. $\quad$. s. $d$.

From Midsummer, 1788 to $1789, \quad 306 \quad 53^{2} 192 \frac{1}{4}$

\begin{tabular}{lllll}
1789 to 1790, & 256 & 471 & 4 & $8 \frac{1}{2}$ \\
1790 to 1791, & 239 & 390 & 12 & 0 \\
1791 to 1792, & 220 & 436 & 15 & $5 \frac{3}{4}$ \\
1792 to 1793, & 206 & 357 & 14 & $4 \frac{1}{2}$ \\
1793 to 1794, & $\underline{243}$ & $\underline{366}$ & 099 \\
\hline
\end{tabular}

MORFOLK.?

15 $\mathrm{k}$

Average 
Average number for 6 years, from I 788 to 1794 ,

Average earnings for each pauper per year, $\quad$ I 149
Ditto for
ditto per week,
008

In the above earnings are included all the servants' labour, for which they are not paid.

Sixty acres of land farmed.

Income, till I796, fixed at 28881. per annum, from iwenty-three parishes.

Income.

No. in the House.

1796. Lady-day, f.1084

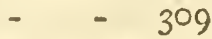

Midsummer,

- 1445

- $\quad-244$

Michaelmas,

- 1807

Christmas, - - 1807

- $\quad-224$

£.6143

Average, $\frac{269}{26 I}$

1797. Lady-day, $E \cdot 1084$

Midsummer, - 722

Michaelmas, - 722

Christmas, - $\quad 722$

$\overline{f \cdot 3250}$

I798. Lady-day, $\overline{\AA \cdot 903}$

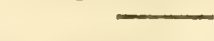

Midsummer, - 903

Michaelmas, - 722

Christmas, - 722

$\frac{722}{E \cdot 3250}$

- $\quad 242$

- $\quad 234$

- $\quad 237$

- $\quad 270$

Average, 245

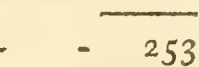

- $\quad$ II 7

- $\quad 224$

Average, 235 
1799. Lady-day, $£ .903$

Midsummer, - 903

Michaelmas, - 722

Christmas, - $\quad 1084$

$$
f \cdot 3^{6} \text { i2 }
$$

I800. Lady-day, $\overline{f .1807}$

Midsummer, - $253^{\circ}$

Michaelmas, - 2530

$$
\text { Suppose }-\frac{2530}{f .9397}
$$

- $\quad 242$

$-\quad-233$

$-\quad-240$

- $\quad 284$

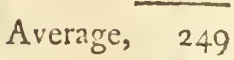

- $\quad-\quad 315$

$-\quad-\quad 334$

Suppose * - 334

Suppose - 334

Average, $\quad 329$

A different arrangement must be made, in order to add the earnings, and deduct the allowances paid out of the house, as in these respects the year's accounts are made up at Midsummer.

Parochial income for the year,

Average Persons. ending Midsummer, I797, $£ \cdot 5420$

$$
\begin{aligned}
& \text { Earnings, }-\frac{378}{£ \cdot 5798} \\
& \text { Allowances, }-\frac{\frac{1131}{£ \cdot 4667}}{£ \cdot 3250} \\
& \begin{array}{l}
\text { 1798. Parishes, }- \\
\text { Earnings, - }
\end{array} \\
& \text { Allowances, } \frac{-\frac{347}{1.3597}}{£ \cdot 25^{85}}-244
\end{aligned}
$$

* These three articles, of course, not made up; there is very little doubt but the sum is exaclly, and the number very nearly stated.

$$
\text { K k } 2
$$




$$
\begin{aligned}
& \text { I799. - Parishes, - } .6 .3250 \\
& \text { Earnings, - - } 355 \\
& \text { f. } 3^{605} \\
& \text { Allowances, - } 913 \\
& f \cdot 26 g^{2}-236 \\
& \text { 1800. Parishes, - - } 6143 \\
& \text { Earnings, - - } 46 \mathrm{I} \\
& \text { E. } 6604 \\
& \text { Allowances, - } 3210 \\
& \overline{E \cdot 3394}-293
\end{aligned}
$$

In order to compare the dear and cheap years, we should take the average of 1798 and 1799 as cheap, and of 1797 and 1800 as dear. 1798 and 1799 .

$$
\begin{aligned}
& \text { Parishes, - } \begin{array}{l}
£ \cdot 3250 \\
\text { Earnings, }
\end{array} \\
& \text { Allowances, }-\frac{35^{1}}{£ \cdot 3601} \\
& \\
& \qquad \cdot 2639-240
\end{aligned}
$$

1797 and 1800. Parishes, - $f .5781$

$$
\begin{aligned}
& \text { Earnings, } \frac{419}{\mathscr{L} \cdot 6200} \\
& \text { Allowances, } \frac{-2170}{£ \cdot 4030}-{ }^{267} \\
& \text { ANNUAL. }
\end{aligned}
$$


ANNUAL EXPENSE, PER HEAD.

$$
\text { fo. s. } d \text {. }
$$

₹797.-242 persons cost 4667 l. which is

perhead, per annum, - - - 1958 $1798 .-244$ persons $25^{8} 5^{1}$. which is per

head, per annum, - - - - 101110 1799. -236 persons 26921 . which is per

head, per annum - - $\quad$ - 118 I 1800.-293 persons 3394 . which is per

$$
\begin{array}{r}
\text { head, per annum, - } \\
\text { Average, } \\
\text { HOUSEKEEPING. } \\
\text { 1798. The expense, } \\
1800 . \\
\hline
\end{array}
$$

EARNINGS.

E. s. $d$.

1797. - 242 persons earned 3781. which

is per head, per annum, - - 1 II 2 1798. - 244 persons earned 347l. whicl

is per head, per annum, - $\quad$ - I 85 1799. -236 persons earned $355^{\text {l. }}$ which

is per head, per annum, - - $~ I 10$ I 1800.-293 persons earned 46rl. which

is per head, per annum, - _ _ I II 5

Many are old and decrepid, and many are children. 
MORTALITY.

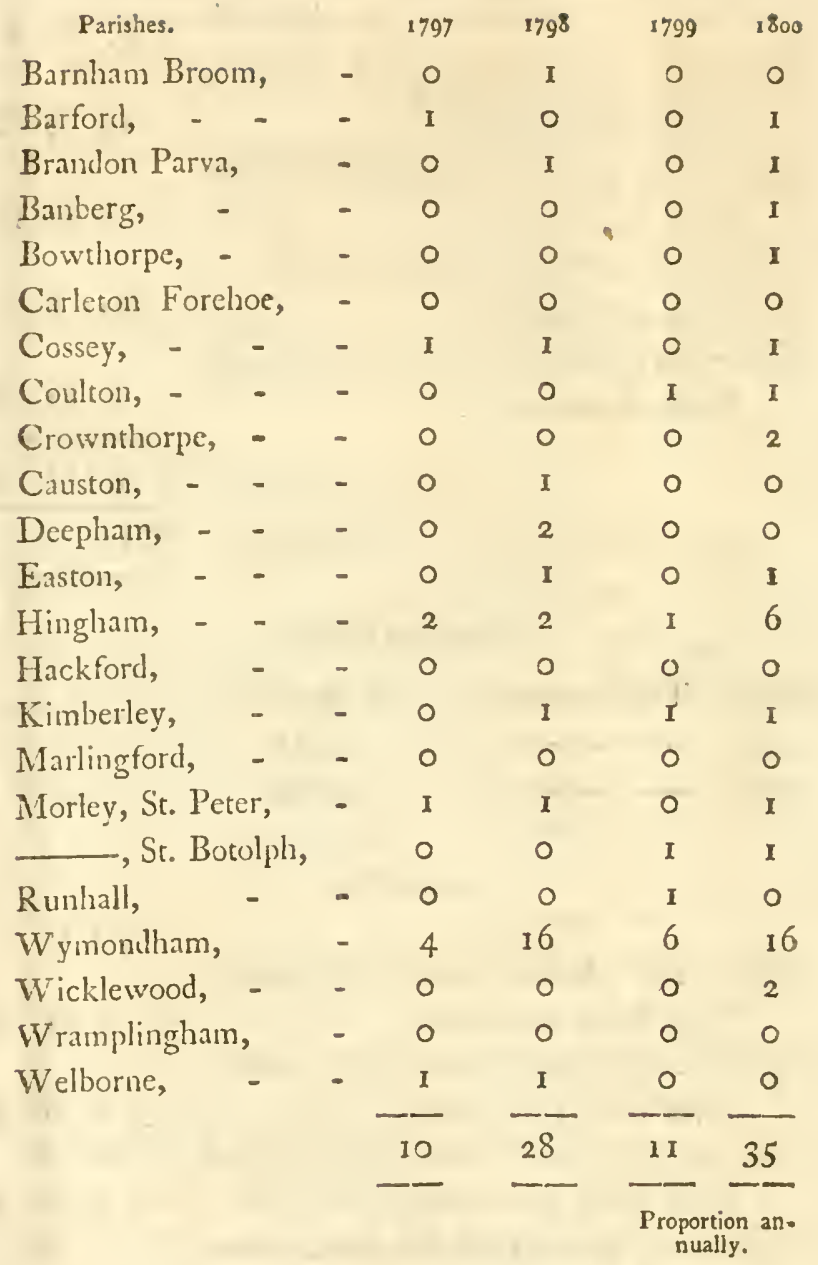

In I797, of 242 persons, 10 died -1 in 24 - I798, of 244 persons, 28 died $-I$ in 9

- I799, of $23^{6}$ persons, 11 died -1 in 20

- 1800, of 293 persons, $35 \mathrm{died}-\mathrm{I}$ in 8

A. HOUSE 


\section{A HOUSE OF CORRECTION.}

That at Wymondham is one of the best managed in the kingdom. I viewed it with much pleasure, for the extreme cleanliness throughout; and in the persons of the prisoners, as well as in every other circumstance, is highly worthy of praise. The carnings shew how well it is conducted.

I 797- - April to July, earnings of $19 \mathrm{pri-}$

$$
\text { f. s. } d \text {. }
$$
soners, exceed their maintenance by - $\begin{array}{lll}7 & 2 & 2\end{array}$

July to September, of $15, \quad-\quad-5148$ Septemiber to December of 15, - -1067 2798. - December to April, of 21, - - 11182

April to June, of 14 , - $\quad$ - $\quad-892$

June to September, of I I, - * - 278

September to December, of I2, - - 4I3 2 1799.-December to March, of I5, - - 10 I 3

March to July, of 14 , - - - 9185 July to O\&tober, of 12, - _ - 256

Oetober to January, of 24, - - - - 34 I And the proportion of their carnings which the prisoners receive for themselves, has, in some cases, amounted to sums which have established them in industrious callings, such as from 4 l. to $9 l$. One Brown had the latter sum, witl which he set up as a basket-maker, and is now in good business, and with a good cliaracter. The main hinge upon which this turns, is the employment being the hemp manufacture; bunching, heckling, and spinning hemp, are, by far the most profitable occupations they can be put to. 
SECT. V.-COMPARISON OF TIMES.

THE Board of Agriculture having, in consequence of a requisition from the Corn Committee of the House of Comnons (1804), procured returns from the several counties, of the expenses on arable land in 1790 and 1803 , I am permitted to insert here the result of their inquiries for the county of Norfolk, which will be found in the following 'Tables. 
505

\begin{tabular}{|c|c|c|}
\hline $\begin{array}{l}n \\
\text { st, }\end{array}$ & $\begin{array}{r}\text { Pric } \\
\text { Har } \\
180\end{array}$ & $\begin{array}{l}\text { ve in } \\
\text { vest, } \\
04 .\end{array}$ \\
\hline ek. & PerW & Veek. \\
\hline$d$. & s. & $d$. \\
\hline . & 35 & \\
\hline & 24 & \\
\hline 6 & 24 & . \\
\hline & 24 & \\
\hline & 24 & $\ldots$ \\
\hline 6 & 18 & $\ldots$. \\
\hline & 16 & $\ldots$ \\
\hline 6 & 13 & 4 \\
\hline$\cdots$ & 27 & $\cdots$ \\
\hline & 13 & \\
\hline $6^{*}$ & 10 & $6 *$ \\
\hline$\cdots$ & 30 & $\ldots$ \\
\hline ... & 39 & $\ldots$ \\
\hline . & 28 & $\ldots$ \\
\hline$\cdots$ & 30 & $\ldots$ \\
\hline & $1 \%$ & $6^{*}$ \\
\hline • & 30 & $\cdots$ \\
\hline & 37 & 6 \\
\hline 6 & 24 & $\ldots$ \\
\hline$\cdots$ & 34 & $1 \frac{\pi}{2}$ \\
\hline & 33 & \\
\hline 6 & 12 & 6 \\
\hline - & 12 & 3 \\
\hline & $12 *$ & 6 \\
\hline & 28 & 9 \\
\hline & 25 & $\therefore$ \\
\hline & 39 & . . \\
\hline & 18 & ... \\
\hline & 24 & $\ldots$ \\
\hline $2 \frac{3}{4}$ & 24 & 4 \\
\hline \multicolumn{3}{|c|}{$41 \frac{1}{4}$} \\
\hline
\end{tabular}




\begin{tabular}{|c|c|c|c|c|c|c|c|c|c|c|c|c|}
\hline \multirow[b]{3}{*}{ Communication. } & \multirow{2}{*}{\multicolumn{2}{|c|}{$\begin{array}{c}\text { Price is } \\
\text { Winter, } \\
1790 . \\
\text { Per Werk. }\end{array}$}} & \multicolumn{2}{|c|}{$\begin{array}{c}\text { Price in } \\
\text { Witster, } \\
1804 .\end{array}$} & \multicolumn{2}{|c|}{$\begin{array}{c}\text { Price in } \\
\text { Su numer, } \\
1790 .\end{array}$} & \multicolumn{2}{|c|}{$\begin{array}{c}\text { Price in } \\
\text { Summer, } \\
1801 .\end{array}$} & \multicolumn{2}{|c|}{$\begin{array}{c}\text { Price in } \\
\text { Harvest, } \\
1790\end{array}$} & \multicolumn{2}{|c|}{$\begin{array}{c}\text { Frice in } \\
\text { Harvest, } \\
1804 .\end{array}$} \\
\hline & & & PerWe & & PerW & Veek & Per We & Teek. & PerW & Veek. & PerW & Veek. \\
\hline & & & s. & & s. 1 & d. & s. 1 & $d$. & s. & d. & $s$. & $d$. \\
\hline 1. Samuel Tayje & 7 & & 10 & & 6 & & jo & & 21 & & 35 & \\
\hline 2. $\mathrm{M}$. & 7 & $\cdots$ & 10 & & 9 & & 12 & & 13 & & 24 & \\
\hline 3. Fic & 7 & & 9 & & 8 & & 10 & & 16 & 6 & 24 & \\
\hline 4. $\mathrm{Her}$ & 7 & 6 & 10 & 6 & 0 & & 12 & & is & & 24 & \\
\hline 5. St. & 9 & . & 10 & & iv & & $1 i$ & & 21 & & 24 & \\
\hline 6. $\mathrm{An}$ & 7 & $\ldots$ & 9 & & 8 & & 10 & & 14 & 6 & 18 & \\
\hline$\therefore$ W & 8 & & 10 & 6 & 12 & & 15 & & 12 & & 6 & \\
\hline 8. Th & 7 & 6 & 10 & 6 & 10 & 6 & 13 & 0 & 10 & 6 & 13 & 4 \\
\hline 9. W & 7 & 0 & 10 & $\ldots$ & 9 & & 11 & & 24 & & 27 & \\
\hline 10. $\mathrm{Ba}$ & 7 & & 10 & .. & 8 & & 12 & & 10 & & 13 & \\
\hline 11. Jo & 6 & & 9 & & 9 & & 12 & & 10 & $0^{*}$ & 10 & 6* \\
\hline 12. $\mathrm{Tl}$ & 8 & $\ldots$ & 12 & & 10 & & 15 & & 21 & $\ldots$ & 30 & \\
\hline 19. Jat & 7 & & 13 & & 8 & & 15 & & $2 !$ & .. & 39 & \\
\hline 14. SI & 7 & 6 & 9 & 6 & 8 & 6 & 11 & & 24 & & $y$ & \\
\hline 15. $\mathrm{He}$ & 7 & 6 & 9 & ... & 9 & $\ldots$ & 12 & & 8 & & & \\
\hline 10. $\mathrm{Ed}$ & 7 & ... & 9 & $\ldots$ & 8 & & 10 & 6 & $10 *$ & & 12 & $6^{*}$ \\
\hline 17. Da & 7 & .... & 10 & & 9 & & 12 & & 21 & & 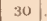 & \\
\hline 18. W.I & 7 & ... & 10 & & 9 & & 12 & . & 27 & & 7 & 6 \\
\hline 19. J & 6 & . & 10 & & 7 & & 12 & & 13 & 6 & 4 & \\
\hline 20. $I_{1}$ & 7 & & 10 & 6 & 9 & & 15 & & 23 & & 34 & $\mathrm{j}$ \\
\hline 21. II & 7 & . & 10 & & 8 & & 12 & & 21 & & 33 & \\
\hline 22. Richa & 7 & . & 9 & & 8 & & 10 & 6 & 10 & 6 & 12 & 6 \\
\hline 23. John & 7 & & 9 & .. & 8 & & 10 & 6 & 10 & & 12 & 3 \\
\hline 24. & 7 & & 10 & & s & & 12 & $\ldots$ & $10^{*}$ & & $12 *$ & 6 \\
\hline & 7 & & 10 & & 9 & . & 12 & & 20 & & 28 & 9 \\
\hline 26. William Palgrave & 8 & & 10 & & 9 & $\ldots$ & 12 & & 20 & & 25 & \\
\hline 27.) & 7 & & 9 & & 8 & & 12 & & 24 & $\cdots$ & 39 & \\
\hline 28. Juha. & 7 & & 10 & & 9 & $\ldots$ & 12 & & 15 & .... & 18 & \\
\hline 29. John Keddle...... & 7 & & 10 & & 8 & ․ & 12 & & 18 & & 24 & \\
\hline & 7 & $2 \frac{2}{4}$ & 10 & $\mathrm{Ot}_{4}^{1}$ & 8 & 8 & 121. & $\ldots$ & 17 & $2 !$ & 24 & 4 \\
\hline Per Cent. & $\cdots$ & +33 & & & & $3 S_{4}^{3}$ & $\frac{74}{4+1}$ & & & 41 & $\overline{\frac{1}{3}}$ & \\
\hline
\end{tabular}

NORrOLK.]

- Denotes with board. 


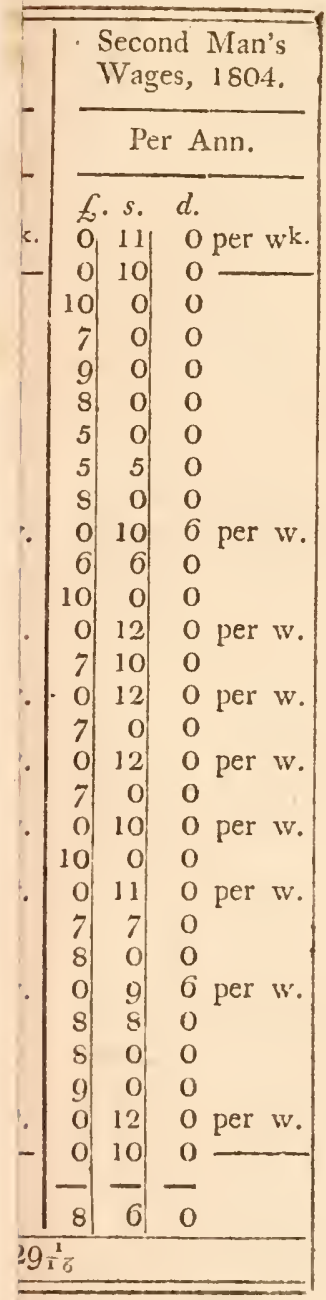

inds for 10 l. Ios. being in 


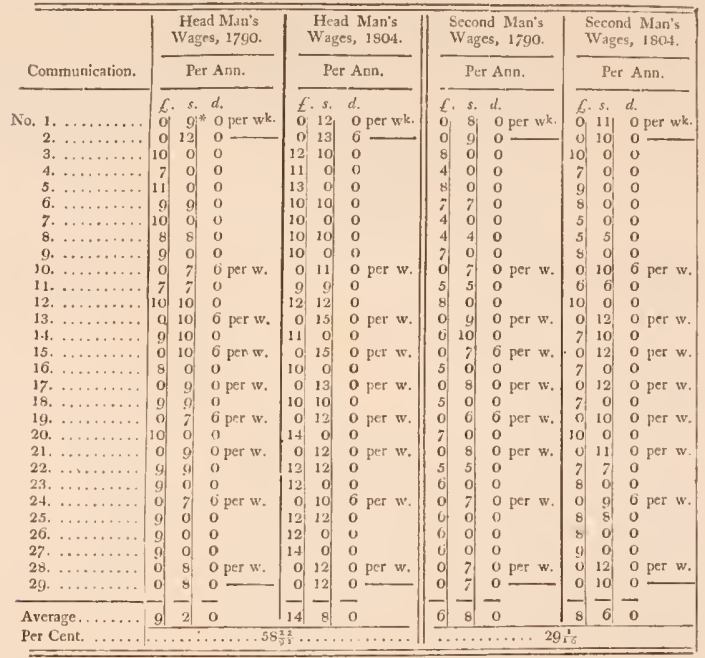

- The shillings per week are reckoned as poundi, to form the average. thus, 10s. 6d, per weck stands for 10l, Jos. being in the sime proportion.

$\mathrm{Am}$ 


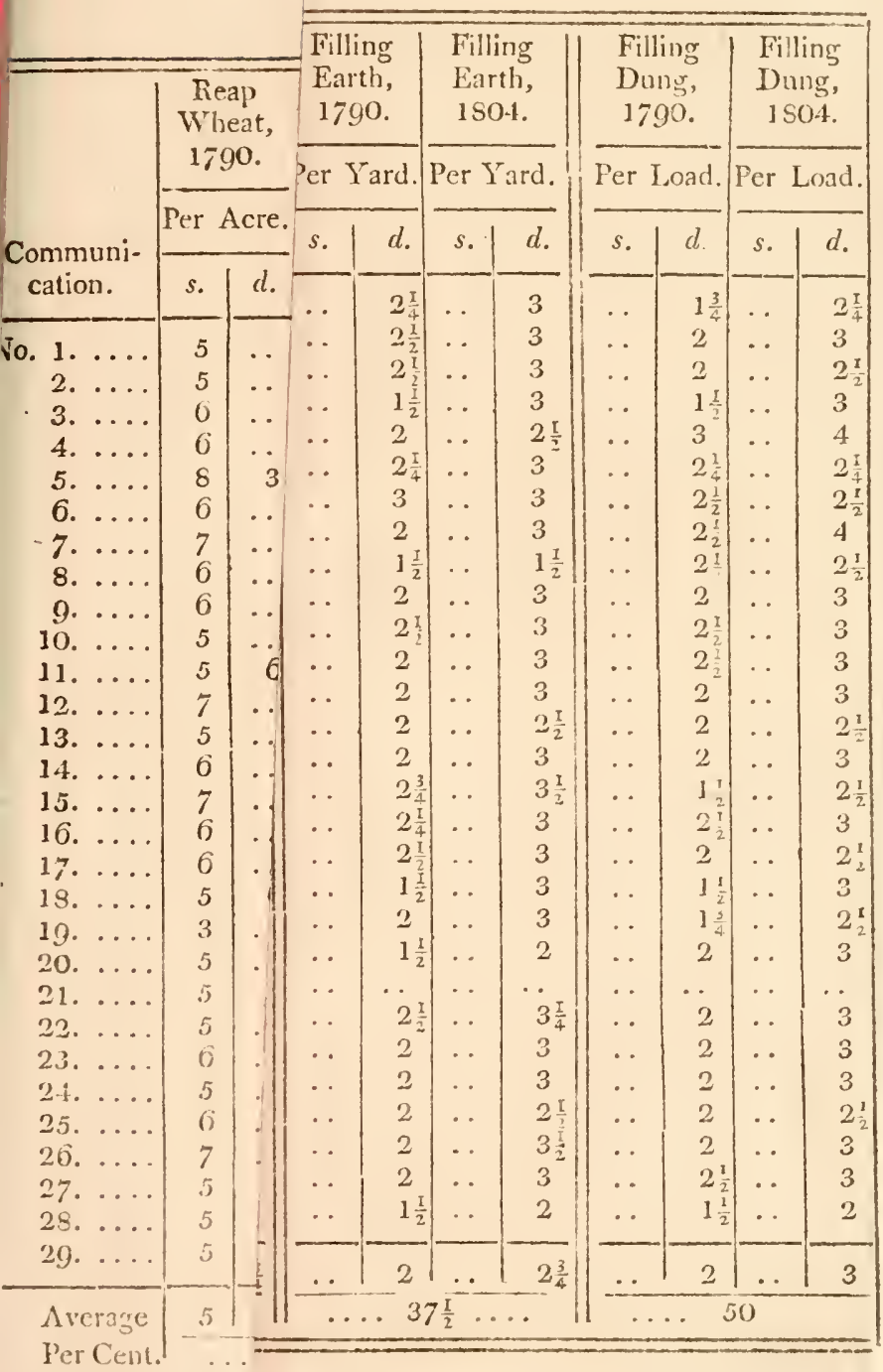

XORFOLK.] 


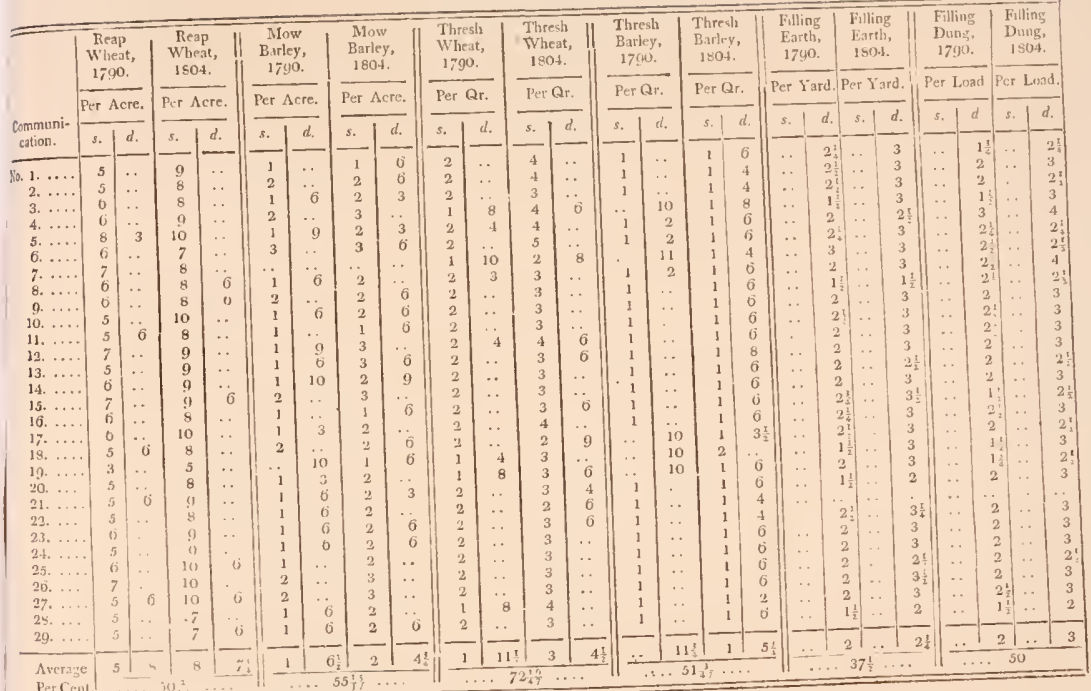




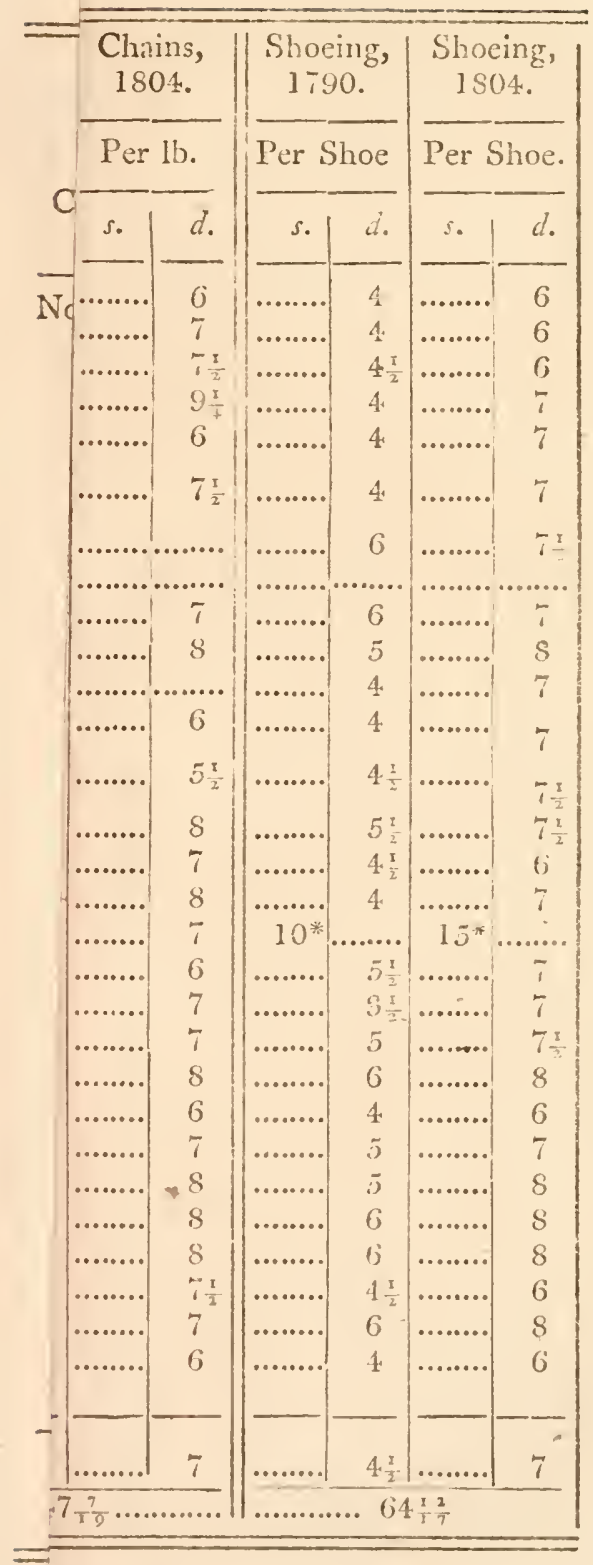

as 4d. to Gd. 


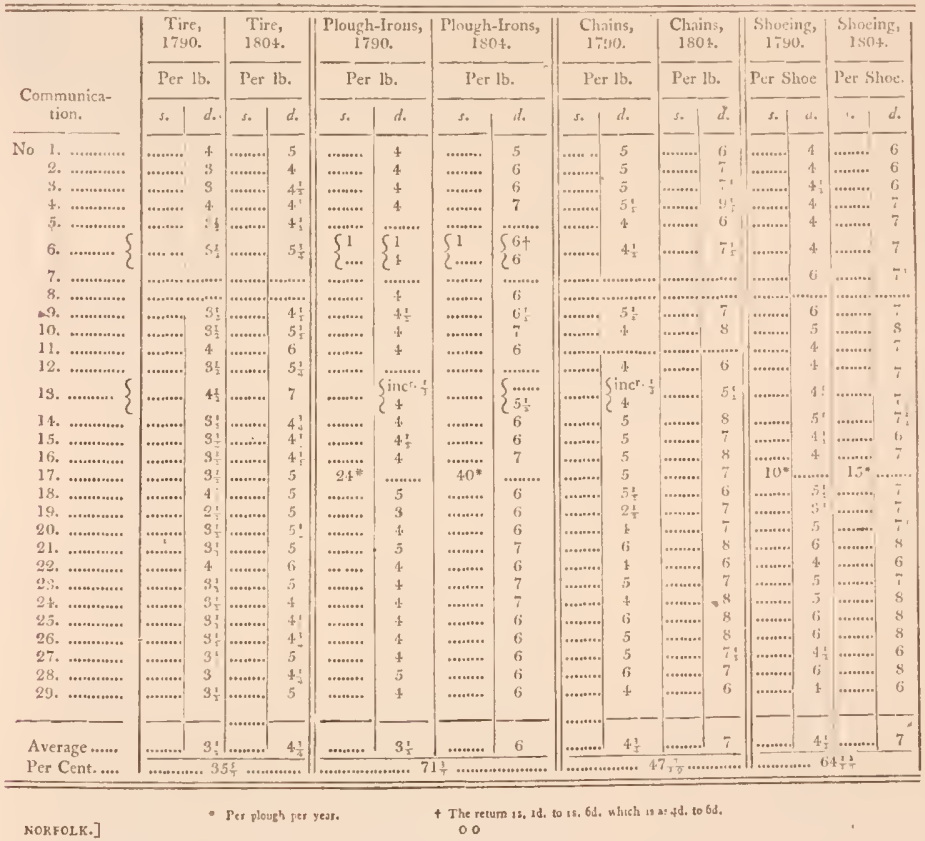


509

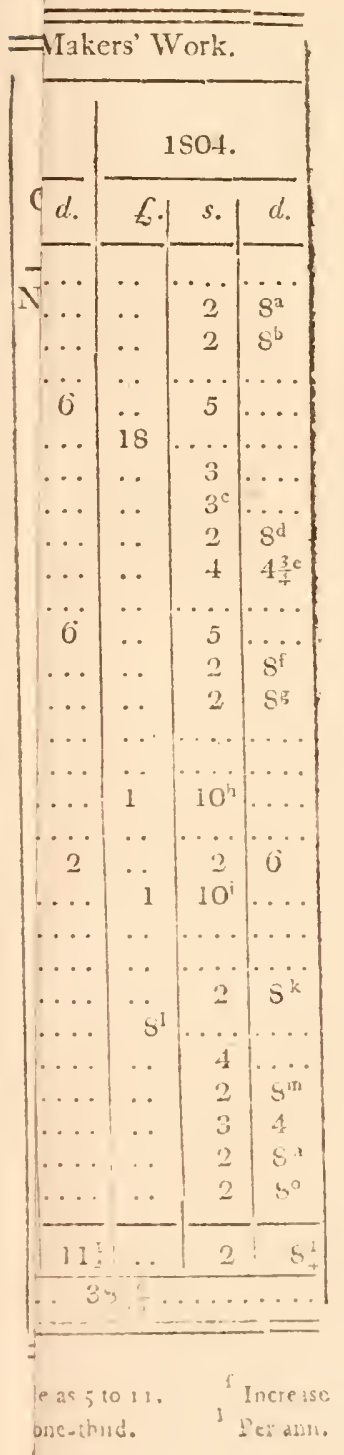




\begin{tabular}{|c|c|c|c|c|c|c|c|c|c|c|c|c|c|c|c|c|c|c|}
\hline \multirow{3}{*}{$\begin{array}{l}\text { Communi- } \\
\text { calion. }\end{array}$} & \multicolumn{4}{|c|}{ Carpenter. } & \multicolumn{4}{|c|}{ Mason. } & \multicolumn{4}{|c|}{ Thatclier. } & \multicolumn{6}{|c|}{ Collar-Makers Wark. } \\
\hline & \multicolumn{2}{|c|}{$\begin{array}{l}\text { By Day, } \\
1790 .\end{array}$} & \multicolumn{2}{|c|}{$\begin{array}{l}\text { By Day, } \\
1804 .\end{array}$} & \multicolumn{4}{|c|}{$\begin{array}{c}\text { By Day, By Diy, } \\
17 y 0 . \\
1804 .\end{array}$} & \multicolumn{2}{|c|}{$\begin{array}{l}\text { By Day, } \\
1790 .\end{array}$} & \multicolumn{2}{|c|}{$\begin{array}{l}\text { 5y. Day, } \\
1804 .\end{array}$} & \multicolumn{3}{|c|}{1790.} & \multicolumn{3}{|c|}{150.} \\
\hline & s. & $d$ & s. & d. & s. & d. & $\therefore 1$ & d. & s. & $d$ & s. & $d$. & E. & s. & $d$ & 6. & (5. & d. \\
\hline No. 1..... & 1 & 10 & 2 & 6 & 1 & 10 & 2 & 6 & 2 & & 3 & & $\cdots$ & & & & $\cdots$ & \\
\hline 2. & 1 & 8 & 2 & i & 2 & 5 & 3 & 9 & 2 & S & 3 & 9 & $\ldots$ & 2 & & .. & 2 & $8^{i}$ \\
\hline 3. . . & 1 & 8 & 2 & 4 & 2 & 8 & 3 & 9 & 2 & 8 & 3 & 9 & .. & 2 & & .. & 2 & $8^{6}$ \\
\hline 4. ... & 1 & 8 & 3 & + & 2 & $\ldots$ & 2 & \pm & 2 & $\ldots$ & 2 & 4 & $\ldots$ & ... & $\cdots$ & .. & $\ldots$ & \\
\hline $5 . \ldots$ & 1 & 8 & 2 & 4 & 2 & $\ldots$ & 2 & 6 & 2 & $\ldots$ & 2 & $i$ & $\therefore$ & 3 & 0 & .. & 5 & \\
\hline 6. .... & 1 & 9 & 2 & 2 & 3 & 9 & 2 & 2 & 3 & & + & & 12 & $\cdots$ & $\ldots \ldots$ & 18 & $\ldots$ & \\
\hline 7.... & 2 & 3 & 2 & 8 & 2 & 3 & 2 & 8 & 2 & 6 & 2 & 6 & .. & 2 & $\ldots$. & .. & 3 & \\
\hline 8. ... & 2 & 3 & 3 & i & 2 & . & 3 & $\cdots$ & 2 & $\ldots$ & 3 & $\cdots$ & .. & 2 & $\ldots \ldots$ & .. & $3^{5}$ & \\
\hline $9 . \ldots$ & 1 & 8 & 2 & 9 & 1 & 8 & 2 & 9 & 1 & 8 & 2 & 9 & .. & 2 & $\ldots$ & .. & 2 & $8^{d}$ \\
\hline 10. & ] & 8 & 2 & 2 & 1 & 8 & 2 & 2 & 3 & $\dot{0}$ & 3 & 2 & .. & 2 & & . & 4 & $4 y^{2}$ \\
\hline $11 \ldots$ & 1 & 8 & 2 & $\ldots$ & 3 & 0 & 4 & 2 & 2 & 0 & 3 & & . & & & $\ldots$ & & $\cdots$ \\
\hline 12. . . & 1 & 8 & 2 & 4 & 2 & $\ldots$ & 2 & 6 & 2 & $\ldots$ & 2 & 6 & . & 3 & $i$ & $\ldots$ & 5 & \\
\hline $13 . \ldots$ & 2 & ... & 3 & . & 2 & .. & 3 & $\cdots$ & 2 & $\ldots$ & 3 & $\overrightarrow{0}$ & . & 2 & $\ldots$ & .. & 2 & $51^{\circ}$ \\
\hline 14. . & 1 & 8 & 2 & ij & 1 & 8 & 2 & u & 1 & 5 & 2 & u & .. & 2 & $\ldots$ & $\ldots$ & +2 & se \\
\hline 15. . & 1 & 0 & 2 & 6 & 1 & 6 & 2 & 0 & 1 & 6 & 2 & 6 & . & .. & 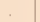 & & . & \\
\hline 16. .... & 1 & 6 & 2 & 3 & 1 & $s$ & 2 & 3 & 1 & 9 & 2 & & . & $\ldots$ & $r_{1}$ & & & \\
\hline $17 . \ldots$ & 1 & 10 & 2 & 3 & 2 & $\ldots$ & 3 & $\ldots$ & 2 & i) & 3 & 0 & 1 & 1 & 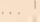 & 1 & $10^{n}$ & \\
\hline $18 . \ldots$ & 2 & 8 & 2 & 4 & 1 & 8 & 2 & 4 & .. & $\ldots$ & .. & & .. & $\ldots$ & $\cdots$ & . & . & . \\
\hline $10 . \ldots$ & 1 & 2 & 2 & i & 1 & 2 & 2 & 0 & 1 & 2 & 2 & 0 & . & 1 & 3 & & 2 & 0 \\
\hline 20. .... & 1 & 6) & 2 & G & 1 & 6 & 2 & ij & 3 & i & 3 & 6 & 1 & 1 & $\ldots$ & 1 & $10^{\prime}:$ & \\
\hline 21.... & 1 & 8 & 2 & 3 & 1 & 8 & 3 & 3 & 3 & 0 & 2 & 8 & & $\ldots$. & $\ldots$ & & .. & . \\
\hline$\not 2 . \ldots$ & 2 & $\therefore$ & 3 & & 2 & & 3 & $\ldots$ & 1 & 9 & 2 & 0 & . & $\ldots$ & $\cdots$ & - & . & \\
\hline $23 . \ldots$ & 1 & $?$ & 2 & 3 & 1 & 9 & 2 & 3 & 2 & 9) & 2 & 3 & & 2 & .. & 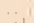 & 2 & 5: \\
\hline 24. . & 1 & 8 & 2 & 3 & 1 & 5 & 2 & 3 & 2 & 6 & 3 & 2 & 4 & & & $s^{1}$ & & \\
\hline 2.5. . & 1 & 8 & 2 & 2 & 1 & 8 & 2 & 2 & 2 & $\cdots$ & 3 & & . & 2 & & . & 4 & \\
\hline $20 . \ldots$ & 1 & 8 & 2 & 6 & $i$ & $y$ & 2 & 6 & 1 & 8 & 2 & (i) & . & $\because 1$ & & . & 2 & $3^{m i n}$ \\
\hline $27 \ldots$ & 2 & .. 1 & 3 & 4 & 2 & $\ldots$ & 3 & 4 & 2 & 6 & +1 & 6 & . & 2 & & & 3 & 4 \\
\hline 28. & 2 & ... & 2 & 6 & 2 & . & 2 & 0 & & $=$ & .. & $=$ & .. & 2 & & & 2 & $s^{\prime \prime}$ \\
\hline $20 . \ldots$ & 3 & & 2 & 0 & 2 & 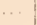 & 2 & 6 & 1 & 0 & 2 & o & .. & 2 & & & 2 & so \\
\hline Avcrage & 1 & (1) 1 & 2 & $\therefore$ & 1 & 11 & 2 & $s$ & -2 & & 2 & 11 & . & 1 & $11^{11}$ & & 31 & $\mathrm{~s}$ \\
\hline & & . 30 & & & & & & & & & & & & & & & 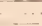 & - \\
\hline
\end{tabular}




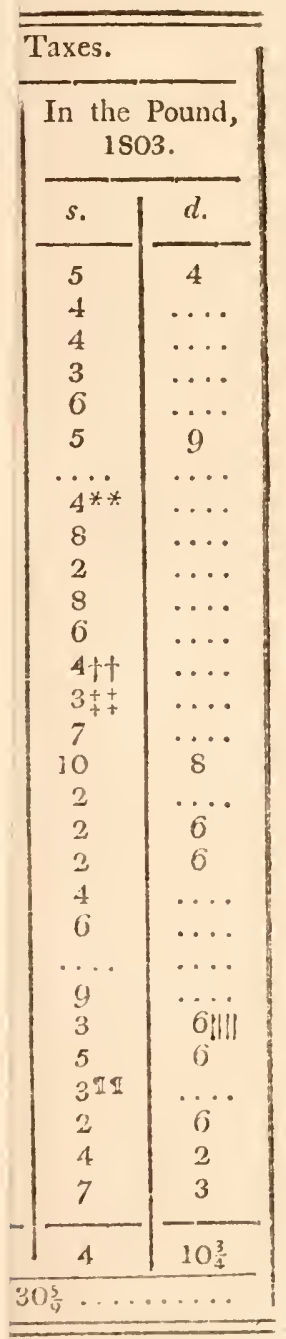

I I 18. to 15s. 6u.

hH linuse of lodest:? 


\begin{tabular}{|c|c|c|c|c|c|c|c|c|c|}
\hline \multirow{3}{*}{$\begin{array}{c}\text { Communi- } \\
\text { cation. }\end{array}$} & \multirow{3}{*}{$\begin{array}{c}\text { Wise of Rent, } \\
\text { from } 1790 \text { to } \\
1804 .\end{array}$} & \multicolumn{4}{|c|}{ Tithe. } & \multicolumn{4}{|c|}{ Parish Taxes. } \\
\hline & & \multicolumn{2}{|c|}{$\begin{array}{c}\text { Per Acre, } \\
1790 .\end{array}$} & \multicolumn{2}{|c|}{$\begin{array}{l}\text { Per Acre, } \\
1803 .\end{array}$} & \multicolumn{2}{|c|}{$\begin{array}{c}\text { In the Pound, } \\
1790 .\end{array}$} & \multicolumn{2}{|c|}{$\begin{array}{l}\text { In the Pound, } \\
1803 .\end{array}$} \\
\hline & & s. & $d$. & s. & & s. & d. & s. & $d$. \\
\hline 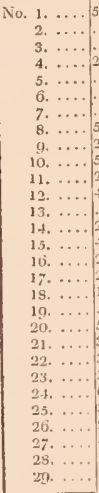 & 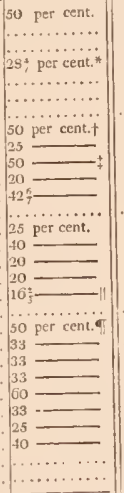 & $\begin{array}{c}3 \\
3 \\
3 \\
2 \\
3 \\
2 \\
\ldots \\
4 \\
2 \\
3 \\
3 \\
2 \\
\cdots \\
2 \\
3 \\
3 \\
1 \\
2 \\
\ldots \\
2 \\
\cdots \\
4 \\
3 \\
3 \\
3 \\
3 \\
4 \\
2\end{array}$ & \begin{tabular}{|c}
$\ldots$ \\
$\cdots$ \\
6 \\
$\cdots$ \\
$\cdots \cdots$ \\
$\cdots$ \\
$\cdots$ \\
5 \\
$\cdots$ \\
6 \\
3 \\
$\cdots$ \\
9 \\
6 \\
6 \\
$\cdots$ \\
3 \\
$\cdots$ \\
$\cdots$ \\
$\cdots$ \\
6 \\
$\cdots$ \\
$\cdots$ \\
6 \\
2 \\
$\cdots$ \\
\end{tabular} & $\begin{array}{r}4 \\
5 \\
5 \\
4 \\
4 \\
3 \\
\cdots \\
5 \\
4 \\
4 \\
4 \\
4 \\
\cdots \\
4 \\
6 \\
4 \\
1 \\
3 \\
\cdots \\
4 \\
\cdots \\
6 \\
4 \\
4 \\
5 \\
5 \\
7 \\
3 \\
\cdots \\
\end{array}$. & 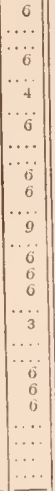 & $\begin{array}{c}1 \\
2 \\
3 \\
1 \\
3 \\
3 \\
\ldots \\
2 \\
6 \\
2 \\
4 \\
3 \\
3 \\
2 \\
4 \\
4 \\
1 \\
1 \\
\cdots \\
1 \\
4 \\
\cdots \\
4 \\
3 \\
3 \\
3 \\
2 \\
2 \\
3 \\
\end{array}$ & $\begin{array}{c}9 \\
6 \\
\ldots \\
6 \\
\ldots \ldots \\
\ldots \ldots \\
\ldots \\
\ldots \\
\ldots . \\
\ldots \\
6 \\
\ldots \\
\cdots \\
6 \\
\ldots \\
2 \\
\ldots \\
8 \\
6 \\
3 \\
\cdots \\
6 \\
6 \\
2 \\
5 \\
6 \\
6 \\
7 \\
\cdots \\
\end{array}$ & $\begin{array}{c}5 \\
4 \\
4 \\
3 \\
6 \\
5 \\
\ldots \\
4 * * \\
8 \\
2 \\
8 \\
6 \\
41+ \\
3 \\
7 \\
10 \\
2 \\
2 \\
3 \\
4 \\
6 \\
9 \\
9 \\
3 \\
5 \\
359 \\
2 \\
4 \\
7 \\
\end{array}$ & $\begin{array}{c}4 \\
\ldots \\
\ldots \\
\ldots \\
\ldots \\
9 \\
\ldots \\
\ldots \\
\ldots \\
\ldots \\
\ldots \ldots \\
\ldots \\
\ldots \\
\ldots \\
8 \\
\ldots \\
6 \\
6 \\
\ldots \\
\ldots \\
\cdots \\
6 ! i i l \\
0 \\
\cdots \\
6 \\
3 \\
3 \\
\end{array}$ \\
\hline & & 2 & $10^{2}$ & 4 & 0 & 3 & 9 & 4 & $10 \frac{3}{2}$ \\
\hline
\end{tabular}

$14^{4.10} 185$

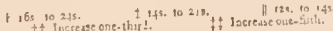

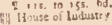
$\because v$ Insiene one-hisf. 5q Inerease 20 pei
noRfolk.] 


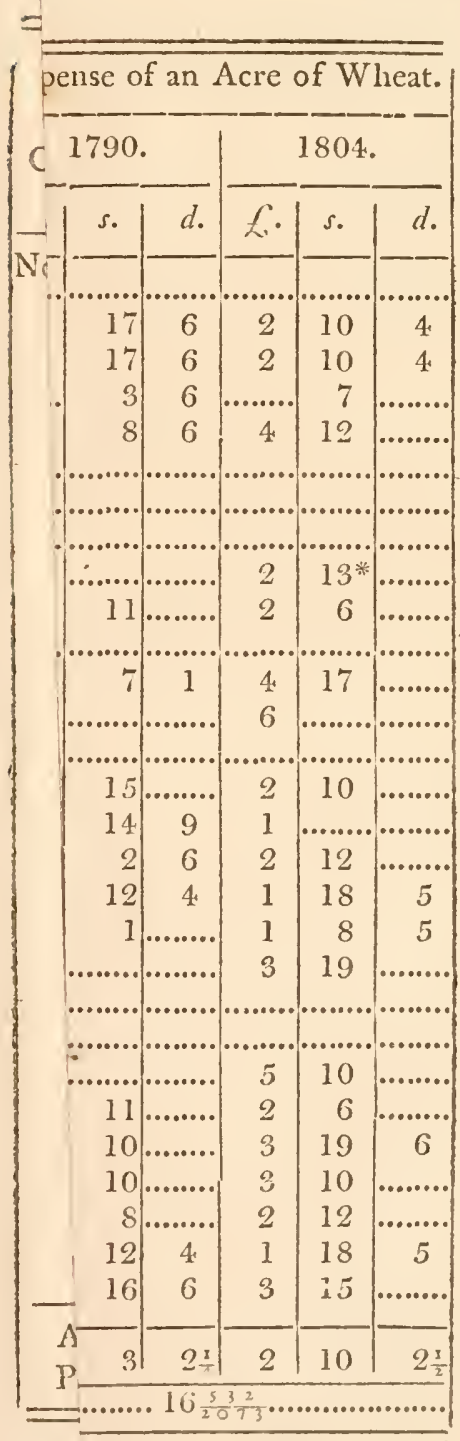




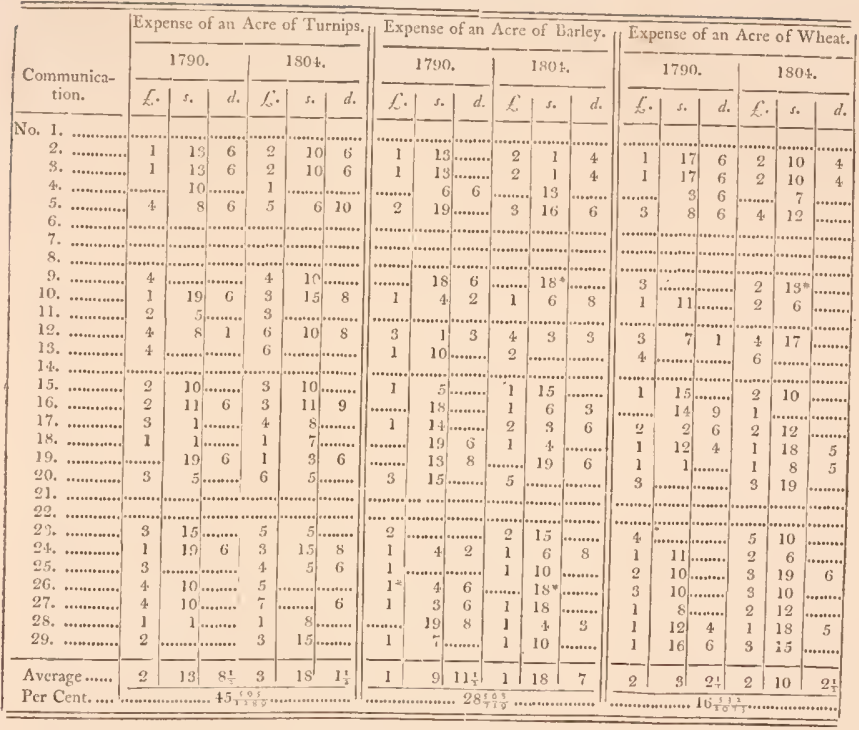

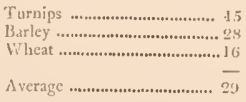


MANURE.

\begin{tabular}{|c|c|c|c|c|}
\hline \multirow[b]{3}{*}{ Communication. } & \multicolumn{4}{|c|}{ Expense of Manure. } \\
\hline & \multicolumn{2}{|c|}{1790.} & \multicolumn{2}{|c|}{$180-1}$. \\
\hline & $s$. & $d$ & s. & $d$. \\
\hline T. 1......... & 1 & 6 & 2 & .. \\
\hline $2 . \ldots \ldots \ldots$ & 2 & 6 & 4 & .. \\
\hline $3 . \ldots \ldots \ldots$ & 2 & 6 & 4 & . \\
\hline $4 . \ldots \ldots \ldots$ & 2 & 6 & 6 & . \\
\hline $5 . \ldots \ldots \ldots$ & . & .. & . & . \\
\hline $6 . \ldots \ldots \ldots$ & . & $\ldots$ & .. & . \\
\hline $7 \ldots \ldots \ldots$ & 2 & 6 & 2 & 9 \\
\hline 8. ....... & 2 & 6 & 4 & $\ldots$ \\
\hline $9 . \ldots \ldots \ldots$ & 2 & 6 & 3 & 4 \\
\hline 10. . . . . & 2 & $\cdots$ & 4 & $\cdots$ \\
\hline $11 \ldots \ldots \ldots$ & 2 & $\cdots$ & 4 & 6 \\
\hline $12 . \ldots \ldots \ldots$ & . & $\cdots$ & . & .. \\
\hline $13 . \ldots \ldots \ldots$ & 1 & 4 & 3 & .. \\
\hline $14 . \ldots \ldots \ldots$ & 2 & 6 & 3 & . \\
\hline $15 . \ldots \ldots \ldots$ & 3 & $\cdots$ & 6 & .. \\
\hline 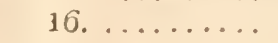 & 2 & 6 & 3 & 7 \\
\hline $1, \ldots \ldots \ldots$ & 2 & 6 & 2 & 9 \\
\hline $18 \ldots \ldots \ldots$ & 2 & 6 & 3 & $4 \frac{r}{2}$ \\
\hline $19 . \ldots \ldots \ldots$ & $\cdots$ & $\cdots$ & $\cdots$ & $\cdots$ \\
\hline $20 . \ldots \ldots \ldots$ & 2 & 6 & 4 & 4 \\
\hline $21 . \ldots \ldots \ldots$ & $\cdots$ & .. & . & $\cdots$ \\
\hline $22 \ldots \ldots \ldots \ldots$ & . & . & . & .. \\
\hline $23 . \ldots \ldots \ldots$ & $\ldots$ & . & . & .. \\
\hline $24 . \ldots \ldots \ldots$ & 1 & 6 & 6 & . \\
\hline $25 \ldots \ldots \ldots$ & 2 & .. & 4 & 6 \\
\hline $26 . \ldots \ldots \ldots$ & . & $\cdots$ & $\cdots$ & $\cdots$ \\
\hline $27 \ldots \ldots \ldots$ & 1 & 6 & 4 & 6 \\
\hline $28 . \ldots \ldots \ldots$ & $\therefore$ & . & $\cdots$ & $\cdots$ \\
\hline $29 . \ldots$. & 2 & 6 & 3 & $7 \frac{1}{2}$ \\
\hline Average.. & 2 & $4 \frac{1}{4}$ & 4 & 2 \\
\hline Per Cent. & $\ldots$ & .76 & $\frac{12}{83}$ & $\cdots$ \\
\hline
\end{tabular}


EXTRACTS FROM THE LETTERS ACCOMPANYING THE PRECEDING RETURNS.

\section{COMMUNICATION, No. 8.}

\section{PARISH OF GORLSTON.}

I could grow wheat in 1790 at 40 . a quarter, with a greater profit to myself than I can now at 60s. a quarter, and other grain in proportion. I am confident, if something is not done by the Legislature, to enable the farmer to carry on his business with spirit, it must ultimately be a very great injury to society. I assure you, a great relaxation in improvement has taken place in this neighbourhood, in consequence of the low price of grain. 
COMMUNICATION, No. 11.

PARISH OF HEVINGHAM.

Annual disbursements on the average of three years preceding the building of the Buxton House of Industry, amounted to

Disbursements from October 10, 1802 , to October 10,1803 .

Out-door relief to aged and infirm - $\quad 124511$ to sick put out to service $24 \quad 4 \quad 8 \frac{3}{2}$ Extra iniscellaneous parish charges - $\begin{array}{lll}7 & 7 & 2\end{array}$ In-door expenses for provisions

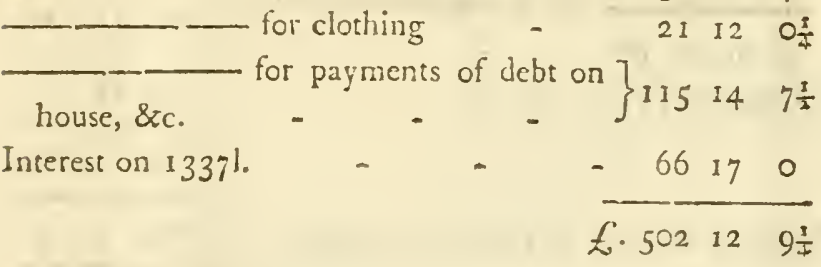

Receipts by rate, at 6 s. $6 \mathrm{~d}$. in the pound $£ \cdot 502$ I2 $9 \frac{\pi}{4}$

Debt on house, Exc. Paid off

Total unpaid f. $1337 \circ 0$ $-\frac{11514 \quad 7 \frac{1}{2}}{541221}$

Joseph Alderson, Visitor. Thomas Rackham, Guardian. To Mitr. Fohn Refion, Oxneat. 


\section{PARISH OF BUXTON.}

Annual disbursements on the average of $\mathcal{E}$. s. $d$. three years preceding the building of $\mathrm{I}_{370} 3 \quad 7 \frac{3}{4}$. the Buxton House of Industry, amounted to

Disbursements from OEzober 10,1802 , to

$$
\text { Oezober 10, } 1803 \text {. }
$$

Out-door relief to aged and infirm -

$$
\text { to sick }
$$

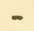

- II7 55

put out to service to clothing boys and girls

$\begin{array}{lll}19 & 15 & 3\end{array}$

Extra miscellaneous parish charges

In-door expenses for provisions

for clothing for payments of debt

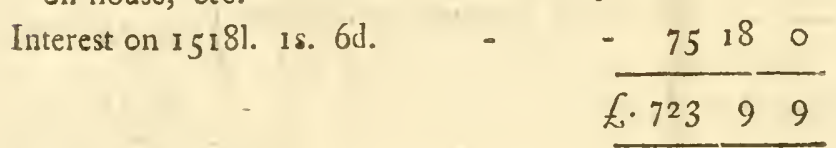

Receipts by rate, at I 7 s. in the pound

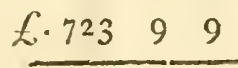

Deht on house, \&c. $\mathscr{E} \cdot 1518$ I 6

$$
\text { Pail off - - } 116132 \frac{3}{4}
$$

Total umpaid f. I40I \& $3 \frac{3}{4}$

Josepit Alderson, Visitor. WM. Jeweli, Guardian.

'To Mr. Folin Repron, Oxncad. 


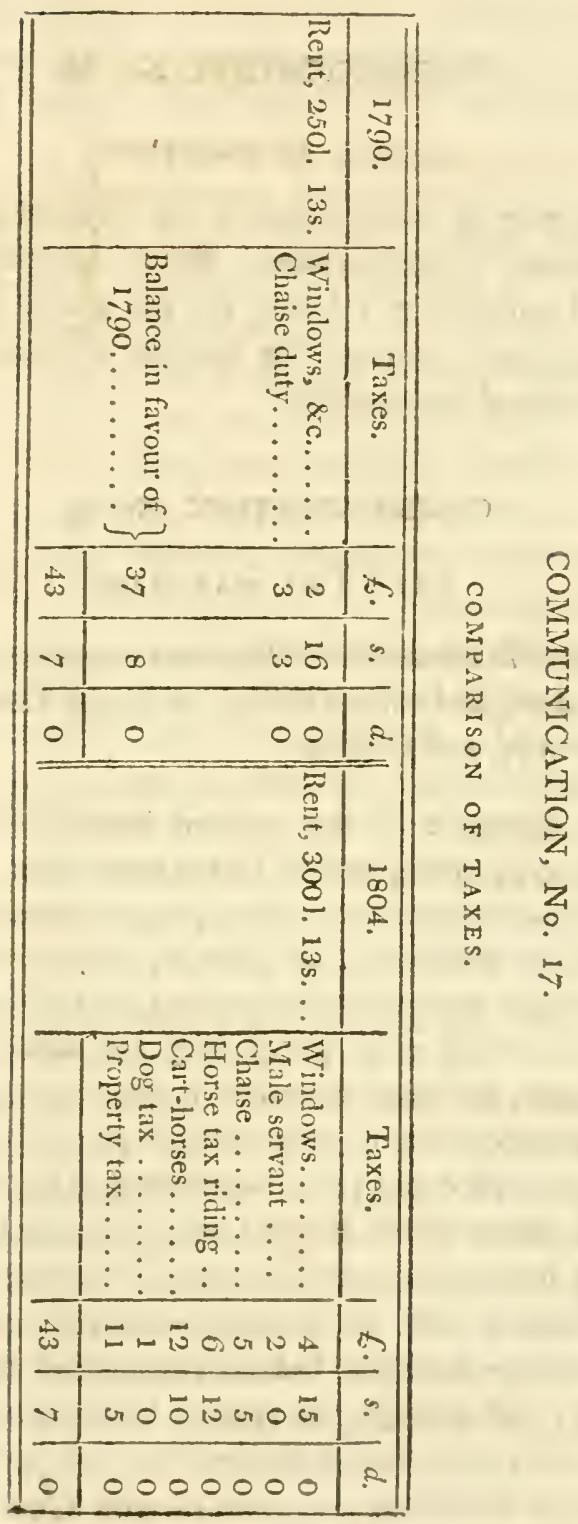


COMMUNICATION, No. 28.

\section{PARISH OF WIGHTON.}

One material circumstance is not inquired after, viz. the increase of assessed taxes. By the establishment in I790, I paid 261. 7s.; I now pay 471. 4s. 6d. exclusive of the property tax, and the increase of taxation upon every article of consumption.

COMMUNICATION, No. 29.

PARISH OF MARSHAM.

Remarks to be annexed to the Statement respecting the Rates of Labour, and various Charges on Arable Farms, in the year 1790 , and in 1804.

The difference in the price of labour, between the year 1790 ana 1804 (which I have taken from my farm expenditcie books in those years), cannot be attributed to the price of bread corn; as I find, by reference to the receipt-book in the former of those years, that my wheat was sold at an average of $3^{\text {l. }}$ per quarter, and harley at 11.4 s. per quarier; but must be traced to other causes; one of which I conceive to be from the high price of bread-corn in the years 1800 and 1801 , which otliged the employers of workmen in all the different trades connected with the farming interest, to give a considerable increase of wages, to correspond with the parish allowance granted by the magi trates to those who had no employment during that scarcicy; and although the price of bread-corn is roduced considerably more than half since those years, the other necessaries of the poor are, since the year 1790 , increased 
nearly double in their price, as grocery of all kinds, shoes, the little malt they are enabled to purchase, \&c. that the bhourers enjoy but little benefit from their increase of wages.

There is but litte work done by the day in the Norfolk harvests. The usual method has beew, engaging a proper quantity of labourers, in proportion to the number of acres of corn, allowing five acres of winter corn, and ten acres of summer corn, to a man's share, and giving them such sum, with board and lorlging, to finish the harvest; which, if the weather be favourable, is ended in four weeks; frequently, when the havest is early, and the weaticr good, in three, having the assistance of the cavters and plouglimen kept on the farm. The difference of wages 1 find, by my boks, to be one-third increased since rlie year I790; in which year I gave Il. I3s. per Inan; the last harvest 2l. Ios. per man. The increase of wages I attribute to the recent practice of the large occupiers of lands in this county griving 7 l. per man, the labeurers finding their own victuals, drink, and lodging; their wives rot liking to have the trouble and fatigue of providing provision in their houscs, which has comprlled those who adinere to the oll custom to give the increased price. The day-labour I have stated.

It is usual in this county, where labourers are emploved as carters or ploughmen, and have the care of a tean of horses during the year, to give them the harvestwages equal to those retinined for that purpose, with their board. This is prudent, as, being so engaged, they have an interest with the re $t$ in culling the harvest as soon as possible; which, if continued at their common wages, in all probability the business would be retarded.

The alvance in the price of threshing, between she two years in question, may be attributed to the same

$$
\text { ss } 4
$$

catises 
causes as the advance of other labour connected with the farm, with the general objection labourers now have to that employment, whose capacities are adapted to any other method of obtaining a livelihood; and many will go niles for employment, sooner than thresh corn.

There is no doubc but the great increase in the price of blacksmiths' work, since the year I790, may be accounted for from the dearness of foreign iron, which was then sold at 1 l. $3^{\text {s. per }} \mathrm{c}$ (vt. ; is now at rl. Ios. per cwt. Coals enhanced is. per chaldron; and the advance of journeymen wages, which has been in proportion with other labour.

A very material charge on arable farms (not noted in the Statement), since the year I790, is the advance on wheelwrights' work, which has been greater in proportion than any other, owing to the increase in the price of timber, ash-timber, which is materially useful in their employment, having had a rise from 21. 5s. per load, wlich was then the general price, to $5^{l}$. per load, the present onc, and other timber in the like proportion; the advance in the price of their working tools, and the additional wages given to their mon.

In this county, thatchers are seldom employed by the day, only on sinall breaches that cannot be conveniently measured. The price, per day, for man and labourer, is advanced, since the year I7 Measured work, in that year, was charged at $4.5 .2 \mathrm{~d}$. per square of 100 feet, and Is. per square for materials: it is now 5s., and 2s. for materials. Hay and corn ricks are usually done by the square yard: in 1790 it was $0 \frac{3}{4} d$. per yard; in $18 \times 31 \frac{1}{2} \mathrm{~d}$. Here seems to be a greater advance than in any other labour connected with the farmer; which may be supposed to have its cause from few learn- 
sing the business; as it does not give constant emploxtment disroughout the year, there is not an inducement.

Collar-makers' work is, since the year-1790, increased at least one-third, from the advance of leather, hemp, iron' and the addition to the journeymen's wages. The usual method of repairing harness is, for the farmers to have them done at their own houses, the collarmaker charging is. per day; for labour, per man, the employer boarding them, and finding food for their liorses; the collar-maker charging for the materials used, which they always take with them.

The difference in the expense of preparing and raising an acre of turnips since the year 1790 , is chiefly owing to the advance on manure. Flag and turf ashes, which, in the neighbourhood of large heaths and commons, is eagerly sought for for that purpose, and carried to a considerable distance, is enhanced in its price, from Is. per cart-load to $4 \mathrm{~s}$.; Io loads of which is the usual quantity used per acre. Stable-dung, and street-muck, as it is usuaily termed, collected in large towns, has had nearly the same advance. Malt-dust, or cooms, as they are provincially called, have had an equal rise, from is. $6 \mathrm{~d}$. per sack to $3^{\text {s. }} 6 \mathrm{~d}$. This, in different parts of the county, is frequently used as a manure for turnips. The carriage is certainly a considerable saving; and where no ither can be procured, it is necessary to use it, as the turnip requires always to be manured for; but I must confess it never met my approbation, when recourse could be had to any other.

The little difference in the raising the barley-crop between the years in question, as described in the Siatcment, is merely the alteration in the expense of tillage; as barley in this county is rarely manured for, being sowert after 
after wheat or turnips that has the preceding year had that operation.

Wheat-The expenses of raising of which (as it is usual to manure for it in this county), has had the same additional charges as the turnip crop, from the great rise of inanures. Soot, a manure frequently used for that purpose, is sold at double the pricc it was in the year 1790, being then 61. per bushel, now 1s. Rape, or oil-cake, an excellent manure for culd wet lands, has since that tinte sold at the same proportional advance.

The reater will perceive, on consulting the preceding table of the expense of cultivation, that the onjent is incompletely ascertained. Some correspondents returned only the amount of lahour; others exclucied reut and rates; others omitte! seed, Erc. The returns from some other counties were still more deficient. To remedy the omissions, the Board ordered a second letter to be written, requesting an answer to the following question: That ar: the charges upon 100 acres of arable land, under the following distinet heads?

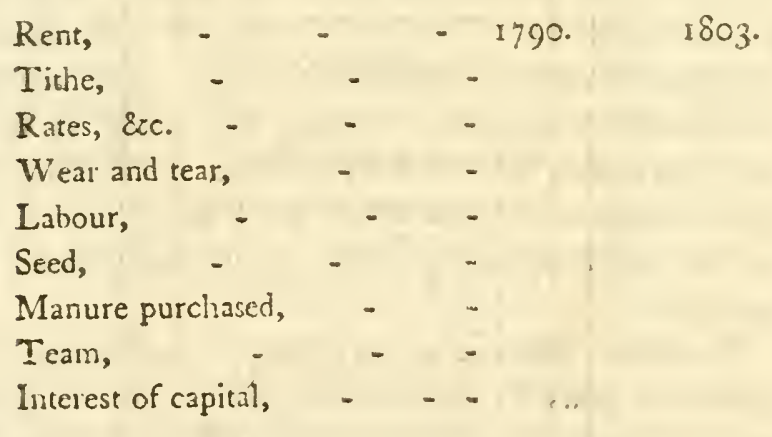

The following tables contain the result of these inquiries for the county of Norfolk. 


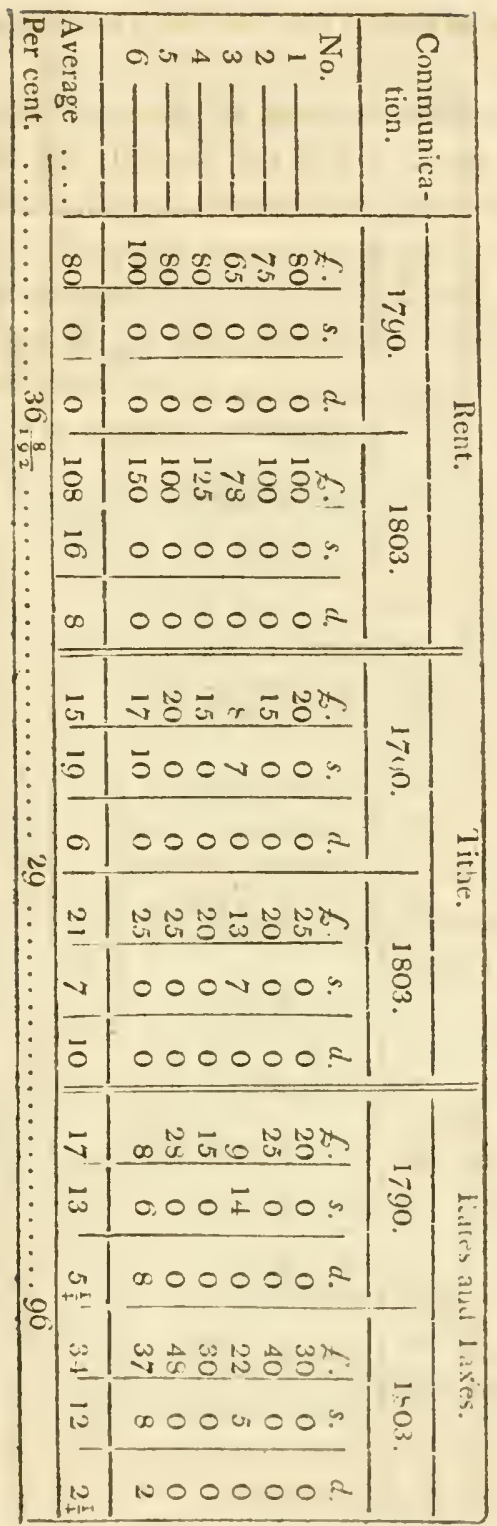




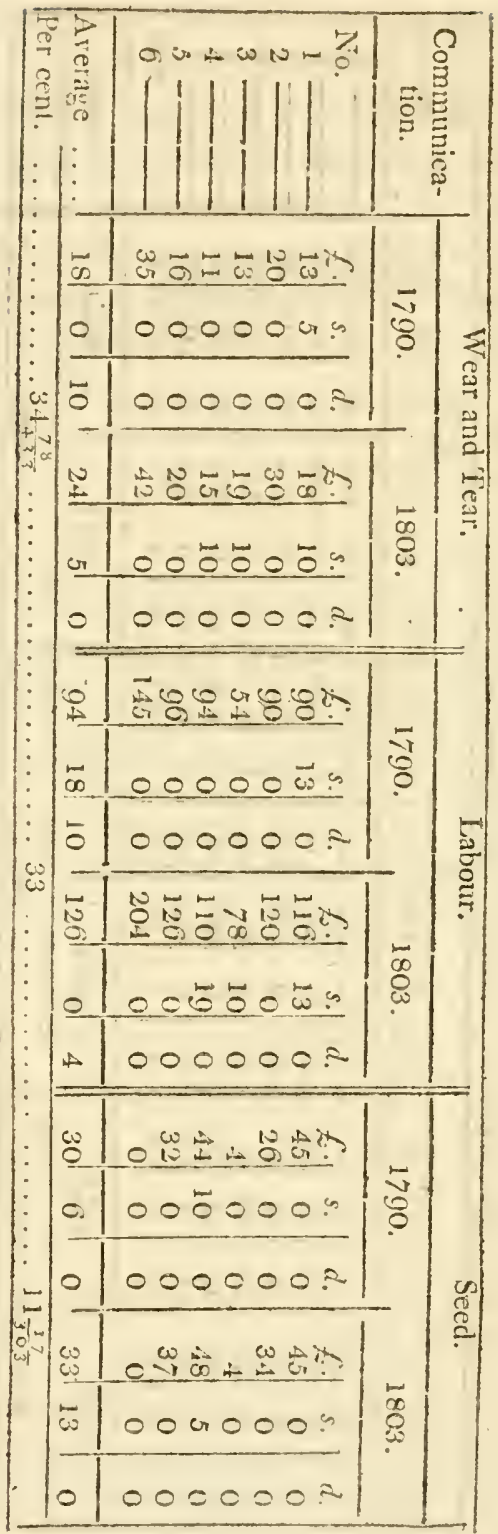

Commu- 


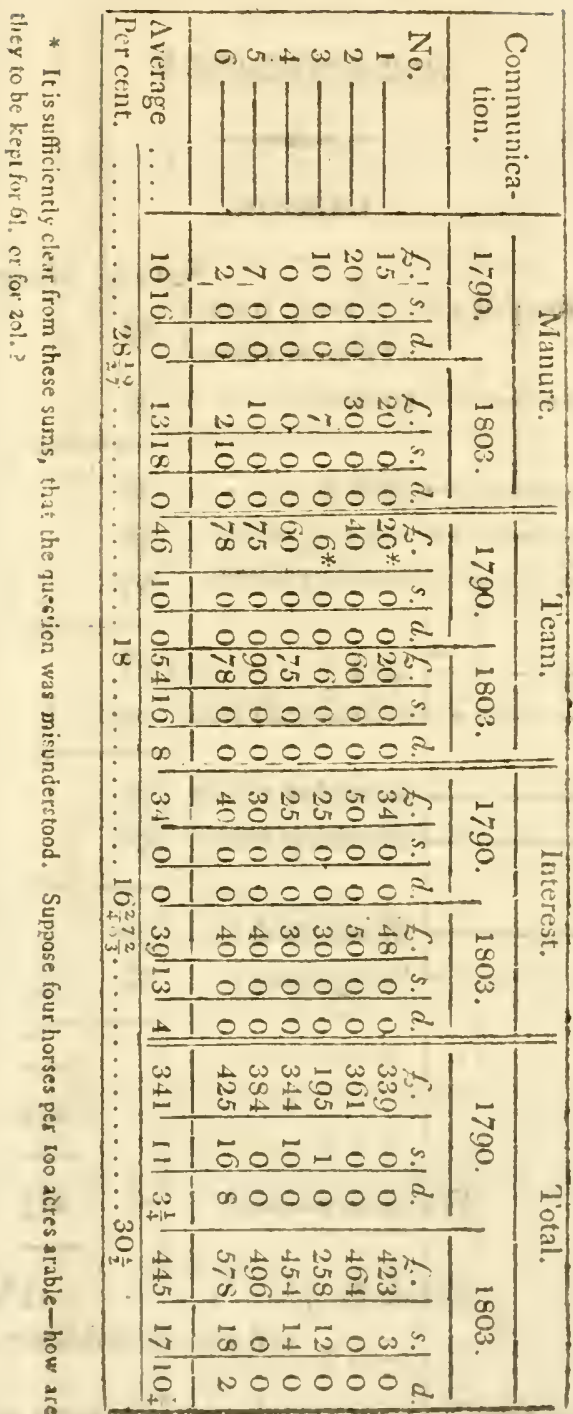




\section{RECAPITULATION.}

\section{LABOUR.}

Rise in the price in winter, from

Per Cent. Average.

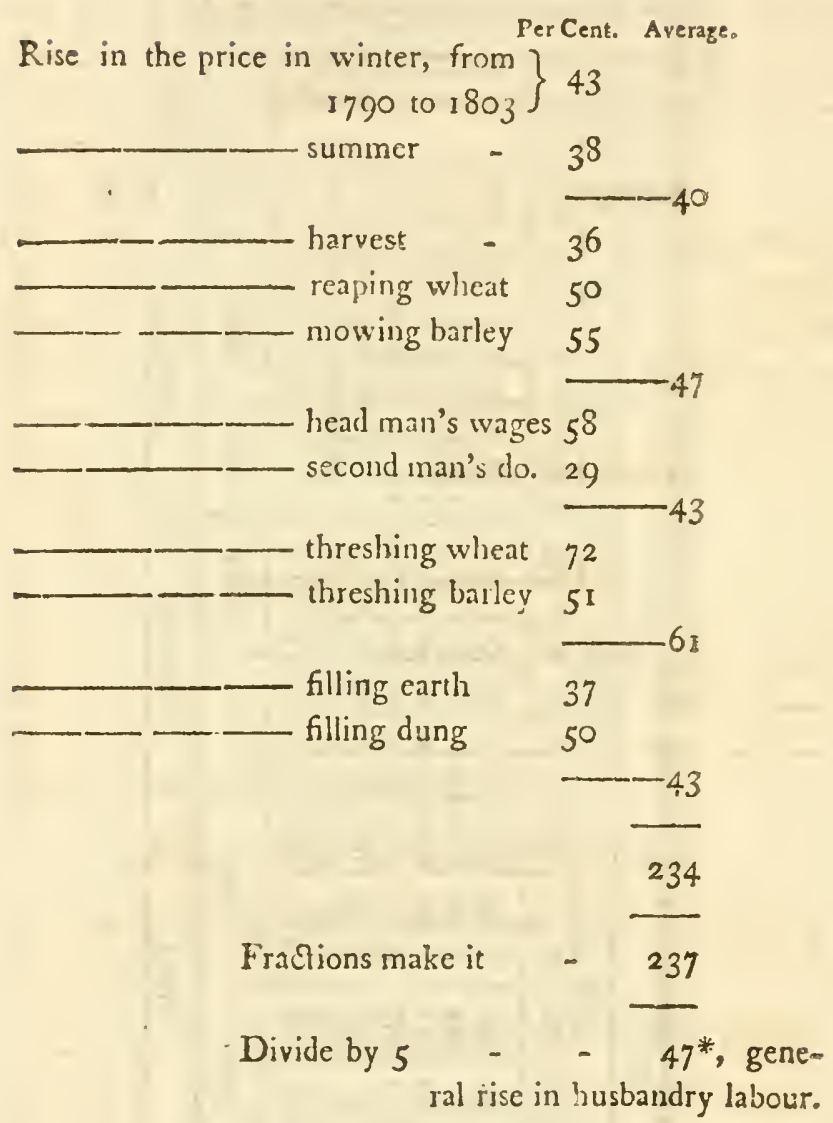

* This may not militate so much with the result of the second series of labour as some may at firse sighs imagine. This table resulting from very different data ; the five different divisions of labour being considered as equal in amoune. To vary the caiculation, without authority in the papers for sodoing, would be wking too great a liberty. 
ARTISANS.

Ser Cent.

$\left.\begin{array}{c}\text { Blacksmith-Rise in the price of tire, from } 1790 \\ \text { to } 1803\end{array}\right\} 35$

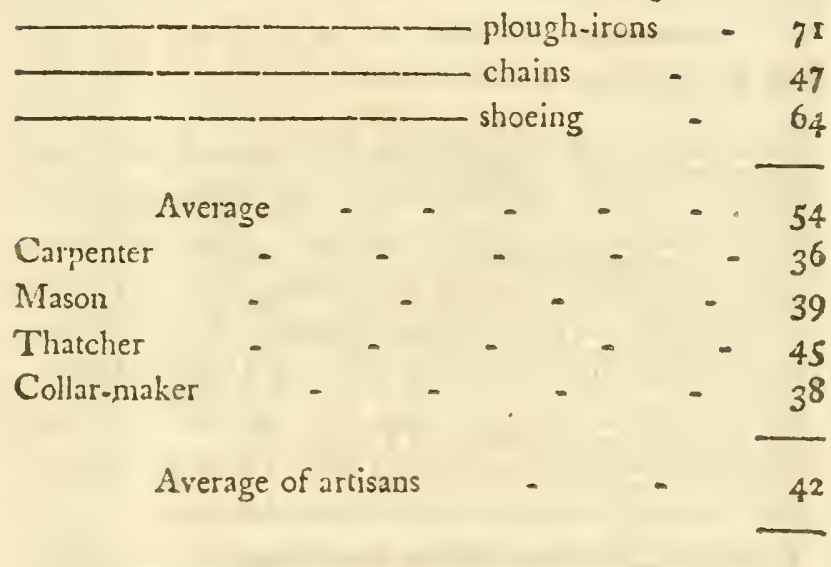

RENT AND TAXES, \&c.

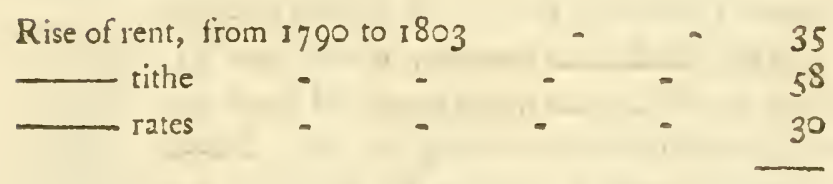

\section{CULTIVATION OF ARABLE LAND.}

Average rise on an acre of turnips, barley, and wheat 29 Average rise by the tables for 100 acres
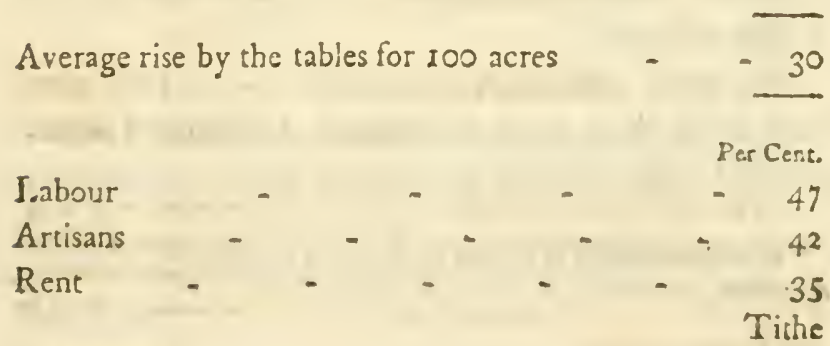


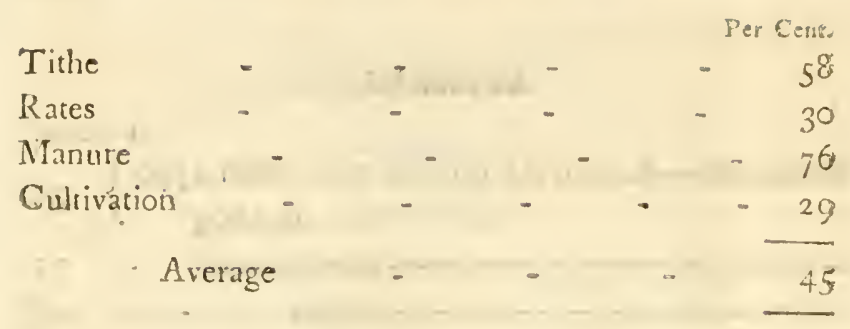

In remarking on the picceding particulars, I am, in the first place, to note, that the Board is not in the lcast committed in drawing any of these averages. That Body simply ordered circular letters to be written; and every reply stands distinctly on the personal authority of the writer. There ends the auchority of the papers as I received them. The calculations, to draw them into one view, I have made, for the satisfaction of such readers as might wish to know what such a general result would be.

It does not, however, follow, that, supposing the authority of the letters correct, the averages would be the same, when a certain rise per cent. is deduced from them.

In this sketch, for instance, which gives 45 per cent. every one of the seven articles should be of equal importance, which is far from being the case. Manure, which, if bought, stands so high in the list, may in fact be the lowest, and, in bad times, perhaps is so *: Artisans count for one, as well as labour and rent; but that article is of far inferior importance to either. The same may be said of tithe and rates.

The same observation is applicable to the particulars from which these sums are drawn. In that of Labour, servants' wages count with summer and winter labour;

* If purchased manure be left out, the average of the other articies would be 40 per cent. 
and filling earth and dung the same; but it is sufficiently obvious, that, in fact, no such proportion holds. In the article of Artisans, if the particulars are examined, there will be found a still greater disproportion in their importance to the farmer. If these circumstances be not kept in the reader's mind, he must necessarily be deceived.

In order to attain a nearer approximation to the real fact, or to ascertain that the view of the subject now given be indeed accurate, it may contribute to the reader's satisfaction to combine the results of the two series of replies; to take the proportions of the expenses to each other from the second letter, and the rise per cent. from the first; these proportions not appearing in the first correspondence.

The average expense of 100 acres in 1790 , returned as above, is:

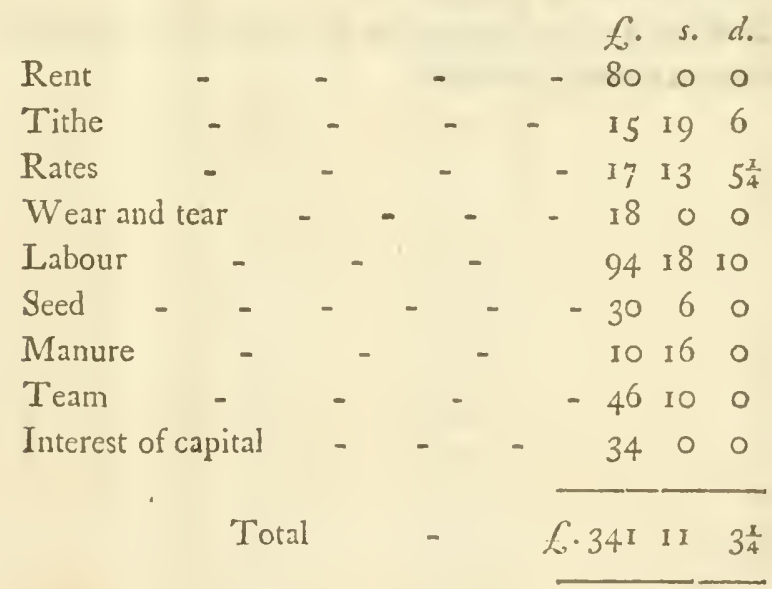

Now, if the rise upon these be estimated from the first series of letters, viz. Rent 35 , Tithe 58, Rates 30 , Wear and Tear 42, Labour 47, Manure 76, and taking the advance in the articles, Secd, Tcam, and Interest, from NORFOLK.] 
the answers to the second letter (not having place in the first), the result would stand tinus:

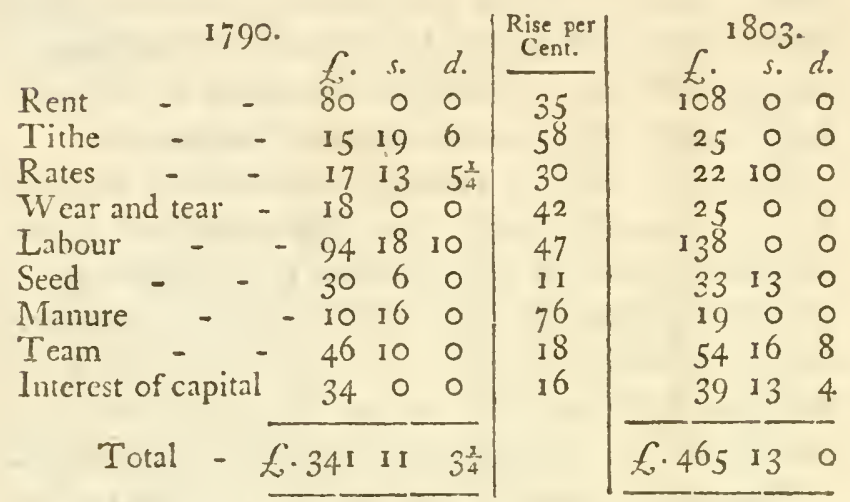

Which is a rise of $36 \frac{22}{34}$ per cent.

And this I take to be as near the truth as these data will permit an estimate to arrive. 


\begin{tabular}{|c|c|c|}
\hline \multicolumn{3}{|c|}{ :upations. } \\
\hline & $\begin{array}{l}\text { rade, Ma- } \\
\text { ctures, or } \\
\text { dicraft. }\end{array}$ & $\begin{array}{l}\text { In all other } \\
\text { Occupations. }\end{array}$ \\
\hline Bloti & 183 & 2334 \\
\hline Brotl & 237 & 1955 \\
\hline $\mathrm{Clac}$ & 1158 & 6024 \\
\hline Clav & $43 S$ & 2302 \\
\hline Dep & 784 & 35.99 \\
\hline Diss & 999 & 4803 \\
\hline Ears & 6.53 & $48+6$ \\
\hline Erpi & 1666 & $10,1.13$ \\
\hline Eyn & 636 & 4969 \\
\hline Fleg. & 337 & 3110 \\
\hline Fora & 1923 & 4200 \\
\hline Free & $8+17$ & 4388 \\
\hline Gall & 605 & 3530 \\
\hline Gree & 1877 & $58+5$ \\
\hline Grin & .125 & 2501 \\
\hline Guil & 1331 & 2837 \\
\hline Hap & 396 & 3656 \\
\hline Hen & 461 & $1 S 08$ \\
\hline Holı & 856 & 3396 \\
\hline Hur & 236 & $2 \$ 52$ \\
\hline Lau & 766 & 6513 \\
\hline Lod & 477 & 2790 \\
\hline Mit1 & 1003 & 4812 \\
\hline Shrc & 683 & 3952 \\
\hline Sni & 360 & 3576 \\
\hline Tav & 486 & 3550 \\
\hline Tun & 839 & 5314 \\
\hline Wal & 197 & 2203 \\
\hline Wa: & $1160^{\circ}$ & 378 \\
\hline Yar: & 1399 & 13,431 \\
\hline Thic & 307 & 1730 \\
\hline $1, y n$ & 2103 & $780 j$ \\
\hline Nisl: & 12,207 & 21,157 \\
\hline & $\cdots \cdots$ & 22 \\
\hline & 39,181 & $\mathrm{I}(\mathrm{j0} 0,313$ \\
\hline
\end{tabular}


SECT. VI.-POPULATION OF THE COUNTY OF NORFOLK, ASCERTAINED IN CONSEQUENCE OE THE ACT $11 \mathrm{GEO}$. 111 . 1800 .

\begin{tabular}{|c|c|c|c|c|c|c|c|}
\hline \multirow[b]{2}{*}{ Hundreds. } & \multicolumn{3}{|c|}{ Houses. } & Fersons. & \multicolumn{3}{|c|}{ Ucotyations. } \\
\hline & Inhabued. & $\mid \begin{array}{l}\text { By how many } \\
\text { Familes oucu- } \\
\text { i ed. }\end{array}$ & Uniphabited. & & $\begin{array}{l}\text { Chiefly em- } \\
\text { ployed in Agri- } \\
\text { culture. }\end{array}$ & $\begin{array}{l}\text { In Trade, } \mathrm{Ma}_{1} \\
\text { nutiatures, or } \\
\text { Haidicraic. }\end{array}$ & $\begin{array}{l}\text { In all other } \\
\text { Occupiatiosis. }\end{array}$ \\
\hline 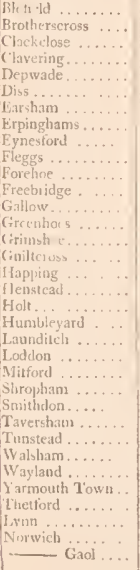 & $\begin{array}{r}557 \\
505 \\
1910 \\
758 \\
1070 \\
972 \\
1046 \\
3253 \\
1432 \\
739 \\
1509 \\
3308 \\
1065 \\
2628 \\
7545 \\
743 \\
878 \\
627 \\
1139 \\
537 \\
1385 \\
879 \\
1312 \\
1002 \\
1004 \\
721 \\
1617 \\
567 \\
739 \\
3081 \\
483 \\
1065 \\
8010\end{array}$ & $\begin{array}{r}700 \\
655 \\
2403 \\
919 \\
1441 \\
1424 \\
1384 \\
3984 \\
1453 \\
911 \\
1903 \\
3030 \\
1335 \\
3121 \\
903 \\
1017 \\
1043 \\
791 \\
1537 \\
769 \\
1792 \\
905 \\
16301 \\
1439 \\
1255 \\
10113 \\
1750 \\
691 \\
9414 \\
3541 \\
513 \\
2137 \\
9093\end{array}$ & $\begin{array}{r}22 \\
15 \\
32 \\
6 \\
7 \\
11 \\
20 \\
50 \\
39 \\
9 \\
27 \\
40 \\
15 \\
86 \\
8 \\
14 \\
10 \\
13 \\
48 \\
7 \\
21 \\
12 \\
13 \\
4 \\
45 \\
12 \\
53 \\
15 \\
13 \\
78 \\
49 \\
47 \\
74\end{array}$ & 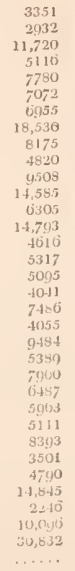 & 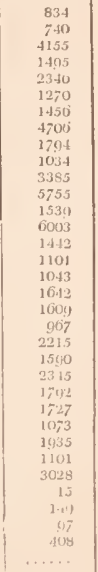 & 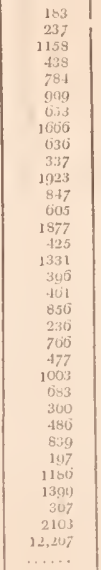 & 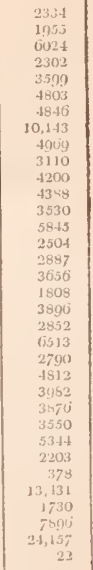 \\
\hline & 47.617 & 57.430 & $15 \div 3$ & 27.3 .371 & 01.711 & 34,181 & 160.313 \\
\hline
\end{tabular}




\section{$\left(53^{1}\right)$}

\section{CHAP. XV.}

\section{OBSTACLES.}

\section{ROOKS.}

" SELDOM attempted to be shot in East Norfolk, where a notion prevails, and is, perhaps, well founded, that rooks are essentially useful to the farmer, in picking up worms and grubs, especially the grub of the cockchafer, injurious to meadows and marshes."-Mr. Marshall. Confirmed in the following note of Mr. Jonnson, of Thurning.

I cannot but notice two growing evils with us, of which but little notice is taken:-1st, the number of insects in the lands, owing to the loss of rooks, by felling so many rookeries, and not taking care of what are left; $2 \mathrm{~d}$, the increase of mice, and, were I to give my opinion as to quantity and damage done, but few would give credit to it: I have, at different tinnes, had five mice killed to every coomb of corn moved off the stacks in the sumner season, and sometimes double that quantity; besides being on every other part of the premises, corn and grass pieces not excepted. Some are driven into the barns and stacks in wet seasons; but when wheat stands long on the shock, we are sure to have most mice in our barns and stacks, except where they are driven away by some other vermin :- -in iny inemory there were 20 grey owls, where there are now one, and though the country was in a rougher state, we had not so many mice, the owls prey 
very much on them, and in wet weather they are more exposed to the owl than to any other vermin. The grey owl is destroyed by the game-keepers, and by felling the pollards. I have seen a young hare in their nests, but never saw a young pheasant or partridge:-the white, or church owl, are not so destruclive to game; and were there places made within side the top of one end of every barn, like a box, for them to pass through as they come into the barn, they would there make their nests, and become more numerous, and be of great service.

\section{S. JOHNSON."}

THE END. 


\title{
LIST OF PUBLICATIONS
}

\author{
or \\ THE BOARD OF AGRICULTURE,
}

Which may be had of the Publishers of this Volume.

Report of the Committee of the Board of Agri- $f_{\text {. s. }} d$. ture on the Culture and Use of Potatoes, 4to. 050 Account of Experiments tried by the Board of Agriculture on the Composition of various Sorts of Bread, 4to.

Letter from the Earl of Winchilsza, on the Advantages of Cottagers renting Land, 4to. - 0 I 0 Communications to the Board of Agriculture on Subjeets relative to the Husbandry and internal Improvement of the Country. Vol. I. 4to. Ditto, Vol. II.

Ditto, Vol. III.

Elkington's Mode of Draining, by Johntane, $8 \mathrm{vo}$

A General View of the Agriculture of the County of Argyll, by Jorn Sirrif, D.D. one of the Ministers of Campbeltown, 8vo. - O 6 o of Clydesdale, by John NaE-

SMITH, SVo. - - - $\quad-0_{0} 40$ of Fife, by Jom Thompson, D.D.

Minister at Markinch, 8vo. - - o 6 a of Hertfordshire, by the SECRE-

TARY of the BOARD, 8VO. - - - 060 of Kent, Ly Johs Boys, of Bet-

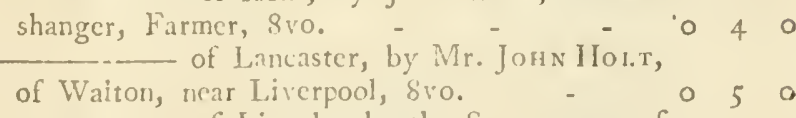

the BOARD, Svo. of Middlecex, by John Middie-

ros, Fsq. of West Barns Farm, Mleiton, and of Lambeth, Surrey, Land Surveyor, 8vo. o 


\section{(2)}

A General View of the Agriculture of Mid-Lothian, $f$. s. $d$. by George Robertson, Farmer at Granton, near Edinburgh, 8vo. of the County of Norfolk, by $\mathrm{N}_{\mathrm{A}}^{-}$.

thaniel Kent, Esq. of Fulharn, Middlesex, 8 vo.

$$
\circ 60
$$
of Northumberland, Cumberland, and Westmorland, by Messrs. Bailer, Cul. LEY, and Pringle, 8vo. of Nottingham, by Ro в e RT Lowe, Esq. of Oxton, 8vo. - of Perth, by James Robertson, D.D. Minister at Callander, 8 vo. ○ $\$$ $\circ 40$ 060 Rev. Robert Douglas, D. D. Minister at Galashiels, svo. of Somerset, by JoHn Bilirings. 060 LEY, Esq. of Ashwick Grove, near Shepton Mallet, Sio. of Stafford, by W. Piтt, of Pende060 ford, near Wolverhampton, Svo. - - 056 of Suffolk, by the SECRETARY of
the BOARD, 8vo. - - - o 56 of Salop, by the Rev. Joseph PLym-

LEY, M. A. Archdeacon of Salop, in the Diocese of Hereford, and Honorary Member of the Board, Svo.

of Yorkshire (the West Riding)

by Robert Brown, Farmer at Markle, near Haddington, Scotland, svo. - - 1 - 060 __ of Yorkshire (the North Riding)

by Joms Tuke, Land Surveyor, 8vo. - o 76 


\section{A CATALOGUE}

or

AGRICULTURAL SEEDS, Sic.

SOLD BY

\section{THOMAS GIBBS AND CO.}

Seedsmen and Nurserymen to the Board of Agriculture,

Corner of Half-Moon-Street, Piccadilly, London :

IV ho also Sell every Article in the Nursery and Seed Line; and with whom Bailiffs, wanting Places, leave their Address, and particulars of Situations in which they have previously leen.

Barley. Isle of 'Thanet.

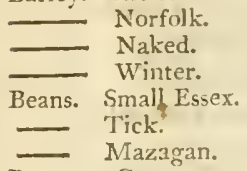

Broom. Common yellow:

Buck, or French wheat.

Burnet.

Cabbage. Gibbs' true drumhead, for cattle.

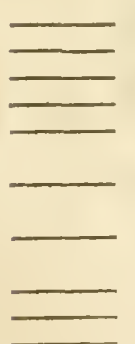
Scotch.

American.

Large red.

Long-sided.

White turnip above ground.

Purple ditto ditto, or kohl rabi.

White turnip under ground.

Tall green borecole.

Tall purple ditto.

Siberian hardy sprouting.

Carrot. Large thick orange, for cattle.

Canary.

Clicory.

Clover. Common red.

Perennial, or cow-grass.

- White Dutch.

- Yellow, trefoil, nonsuch, or black grass.
Clover. Malta.

- Providential.

Flax, or linsced.

Furze.

Grass. Meadow foxtail.

— Meadow fescue.

- Sheep's fescue.

- Hardish fescue.

_ Purple ditto.

- Float ditto.

- Crested dogstail.

- Rough cocksfoot.

— Tall oat-grass.

- Yellow ditto.

- Meadow ditto.

_- Swect vernal.

__ Common ditto.

- Marsh ditto.

- Compressed ditto.

- Annual ditto.

- Common ray-grass.

Peacey ditto.

_ Improved perennial do.

_Timothy. Yorkslure.

With many other sorts.

Hemp. Russian. English.

Honeysuckle. Frencl.

I.etuce. I arge Coss.

l.estily. Snall.

1.estils. Sirate. 
Lucerne.

Mangel wurzel.

Maw-seed.

Medicago, various sorts.

Millet. Red. White.

Mustard. Brown.

Oats. Farly Essex.

\section{- Dutch brew. \\ - Tartarian. \\ - Poland. \\ - Potatue. \\ - Planders. \\ - Caspian. \\ _ Black.}

Parsley. Plain.

Parsuip. Large thick.

Pea. Marlborongh grey.

- Large grey rouncival.

- Iarly white.

- White boiling.

- Pearl.

- Blue Prussian.

- Maple.

Potatoes. Ox-noble.

- Iate champiou.

- Large red.

- Nicholson seedling.

- Bomb-shell.

Rib-grass. Iambs-tongue, or Upright plantain.

Rape, or coleseed.

Rye.

Sainfoin.

Saridella.

Tares. Spring.

Winter.

- White.

- Perennial.

Trefoil. Birdsfoot.

Common, various soris.

I'urnip. Early stone.

White Norfolk.

- Norfolk bell.

- Stubble.

$\longrightarrow$ Green top.
Turnip. Red top.

Large yellow.

Globe.

White tankard.

Green ditto.

Red-top) ditto.

Large Dutch.

'I'rue yellow Swedish, or ruta baga.

White Swedish.

Vetch, Kidney.

Clickling.

_ Pale-flowered.

_- Everlasting.

Great wood.

Six-flowered.

'Tufted.

Bush.

Hoary.

\section{Sainfoin.}

Red-flowered.

Biennial.

Bastard.

Broad-podded.

Rough.

Single-flowered.

Narbonne.

Flat-podded.

Hairy ditto.

Narrow-leaved.

Streaked.

White-flowered.

White-seeded.

Horse-shoe.

Milk.

Liquorice.

Weld.

Wheat. Red Lammas.

- Common white.

White hedge.

White Siberian.

Fogyptian.

Sicilian.

Round African.

Zealand.

Calue.

Woad.

Dantzick.

Yarrow.

I'rinted by B. N'Millan,

Bow-Sircet, Covent-Gatden. 

UC SOUTHERN REGIONAL LIBRARY FACILITY

A 000031383 


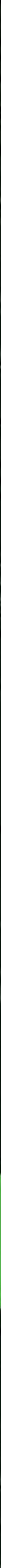

